\title{
Permian Brachiopods
}

\section{of West Texas, I}

\section{G. ARTHUR GOOPER}

and

RICHARD E. GRANT 


\section{SERIAL PUBLICATIONS OF THE SMITHSONIAN INSTITUTION}

The emphasis upon publications as a means of diffusing knowledge was expressed by the first Secretary of the Smithsonian Institution. In his formal plan for the Institution, Joseph Henry articulated a program that included the following statement: "It is proposed to publish a series of reports, giving an account of the new discoveries in science, and of the changes made from year to year in all branches of knowledge." This keynote of basic research has been adhered to over the years in the issuance of thousands of titles in serial publications under the Smithsonian imprint, commencing with Smithsonian Contributions to Knowledge in 1848 and continuing with the following active series:

$$
\begin{gathered}
\text { Smithsonian Annals of Flight } \\
\text { Smithsonian Contributions to Anthropology } \\
\text { Smithsonian Contributions to Astrophysics } \\
\text { Smithsonian Contributions to Botany } \\
\text { Smithsonian Contributions to the Earth Sciences } \\
\text { Smithsonian Contributions to Paleobiology } \\
\text { Smithsonian Contributions to Zoology } \\
\text { Smithsonian Studies in History and Technology }
\end{gathered}
$$

In these series, the Institution publishes original articles and monographs dealing with the research and collections of its several museums and offices and of professional colleagues at other institutions of learning. These papers report newly acquired facts, synoptic interpretations of data, or original theory in specialized fields. These publications are distributed by mailing lists to libraries, laboratories, and other interested institutions and specialists throughout the world. Individual copies may be obtained from the Smithsonian Institution Press as long as stocks are available.

\section{S. Dillon Rupley Secretary \\ Smithsonian Institution}


SMITHSONIAN CONTRIBUTIONS TO PALEOBIOLOGY • NUMBER 14

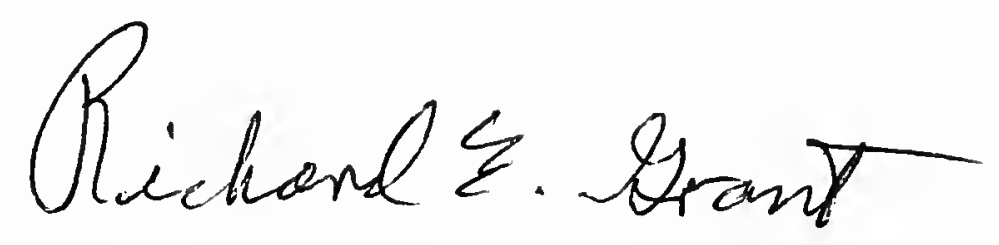

\title{
Permian Brachiopods of West Texas, I
}

\author{
G. Arthur Cooper
}

and Richard E. Grant

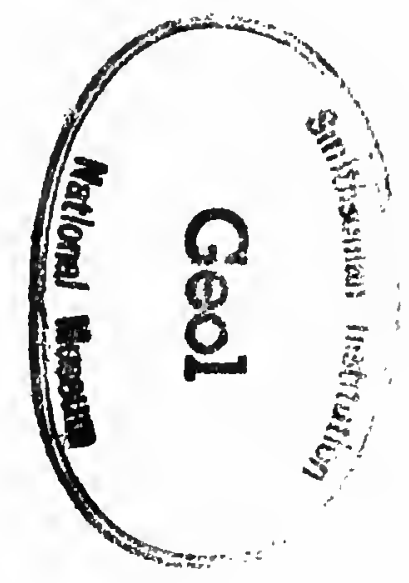

$$
\begin{aligned}
& \text { ISSUD } \\
& \text { CE6 } 2910
\end{aligned}
$$

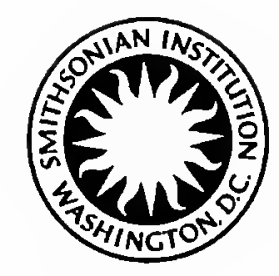

SMITHSONIAN INSTITUTION PRESS

City of Washington 1972 


\section{A B S T RA G T}

G. Arthur Cooper and Richard E. Grant. Permian Brachiopods of West Texas, I. Smithsonian Contributions to Paleobiology, number 14, 231 pages, 39 figures, 23 plates, 1972. - The first of a projected six-part monograph on the brachiopods of the reference area for the North American Permian in the Glass, Guadalupe, Diablo, Delaware, Hueco, and Chinati Mountains of West Texas and adjacent New Mexico, this introductory volume recounts the history of geological work in the area, the development of the stratigraphic framework in the Wolfcamp, Leonard, and Guadalupe Series, and the basis for age assignments. It also explains field and laboratory techniques for collecting and preparing silicified fossils by means of acid, and it presents detailed measurements and lithic descriptions of the stratigraphic units in each mountain range in terms of the current nomenclature. The paleoecologic implications of the various rock and fossil types are interpreted, and the problems concerning large scale conglomerates, bioherms, and shell heaps are considered. The faunal composition of each stratigraphic unit in each mountain range is set forth as documentation for a local zonation of the brachiopods, intra-regional correlations, and age determinations with reference to the worldwide time scale for the Permian. There are brief accounts of each locality from which fossils were obtained. The full locality listing and the literature cited for the entire monograph are included in the present volume. Plates and line drawings illustrate the techniques of collecting and preparing fossils and the nature of certain stratigraphic units and lithic types; they diagrammatically depict numerous cross sections and correlations. Detailed maps indicate the exact positions of collections of fossils in the Glass Mountains. Taxonomic descriptions will appear in subsequent volumes.

\footnotetext{
Official publication date is handstamped in a limited number of initial copies and is recorded in the Institution's annual report, Smithsonian Year.
}

Library of Congress Cataloging in Publication Data

Cooper, Gustav Arthur, 1902-

Permian brachiopods of West Texas

(Smithsonian contributions to paleobiology, no. 14)

Bibliography: v. 1, p.

1. Brachiopoda, Fossil. 2. Palcontology-Permian. 3. Palcontology-Texas. I. Grant, Richard E., joint author. II. Title. III. Scries: Smithsonian Institution. Smithsonian contributions to paleobiology, no. 14

QE701.S56 no. 14 [QE796] $560^{\prime} .8 \mathrm{~s} \quad\left[564^{\prime} .8^{\prime} 097649\right] \quad 72-4218$ 


\section{Contents}

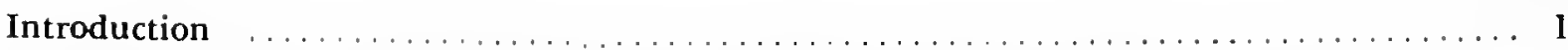

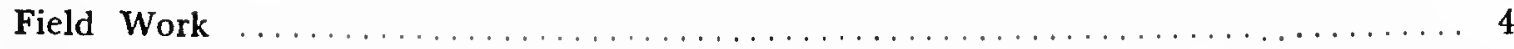

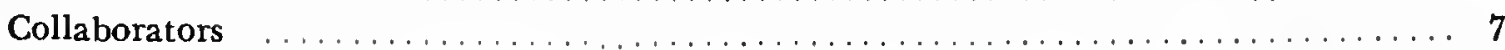

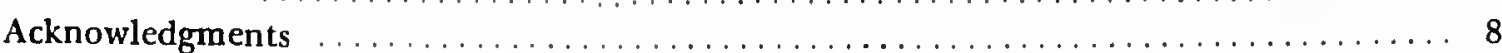

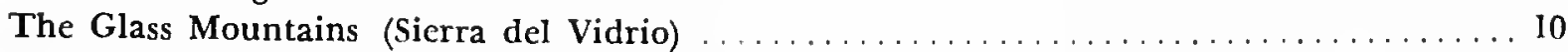

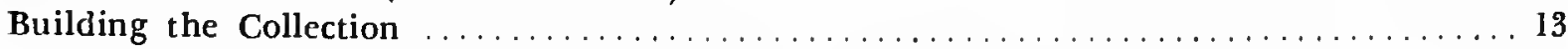

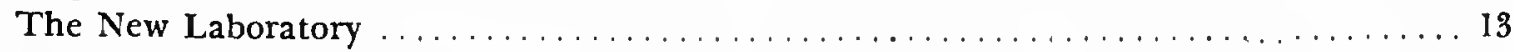

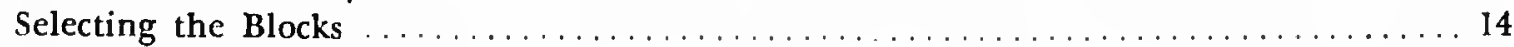

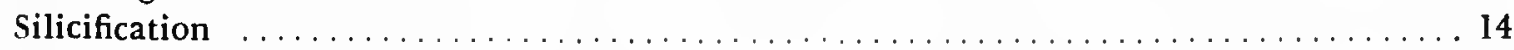

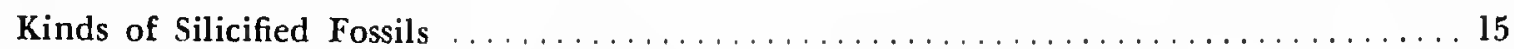

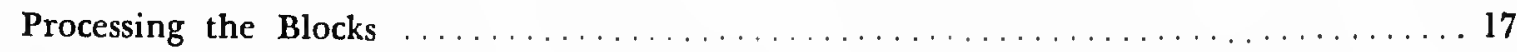

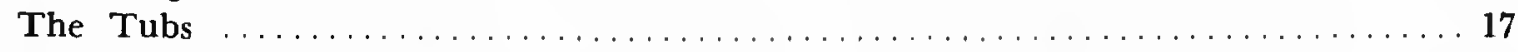

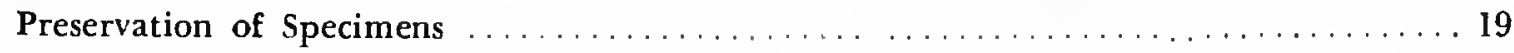

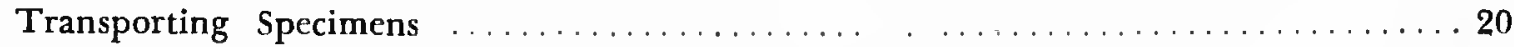

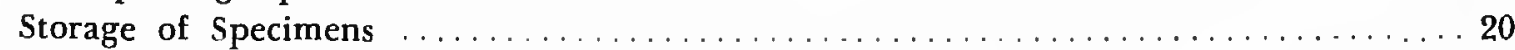

Collections Supplementing the Glass Mountains Specimens................. 20

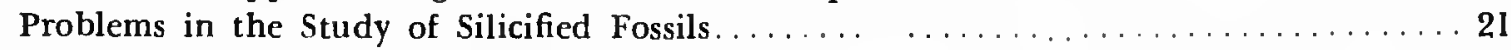

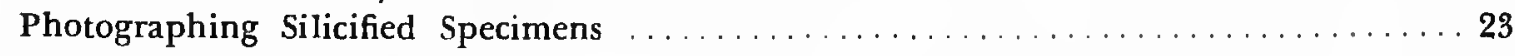

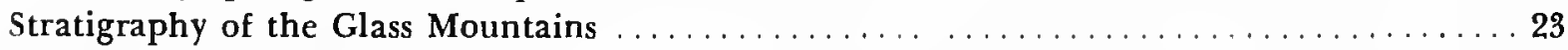

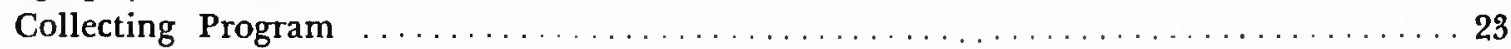

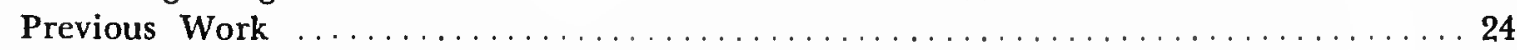

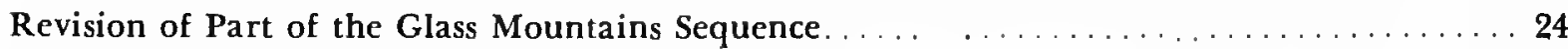

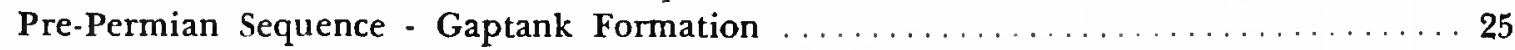

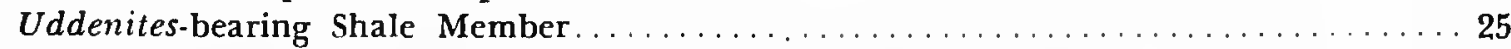

Uddenites-bearing Shale Member Northeast of Wolf Camp Hills ............. 28

Other Gaptank Localities........................................ 29

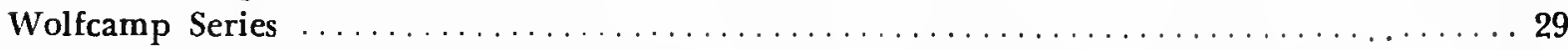

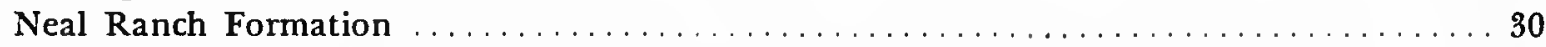

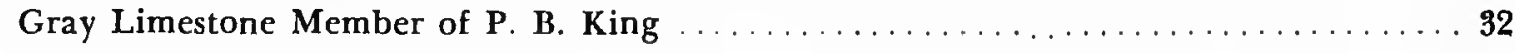

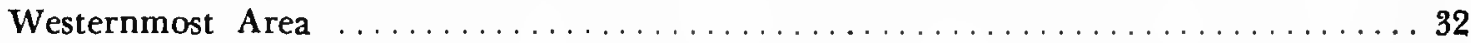

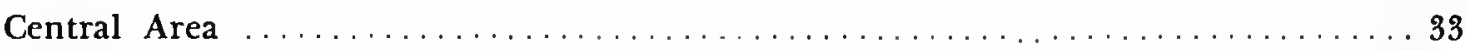

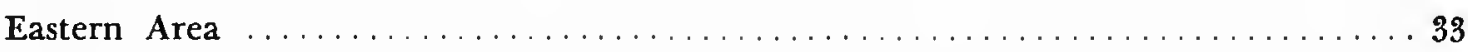

Relationship to the Uddenites-bearing Shale Member.................. 33

Dark Shales with Scattered Limestone Layers .... ...................... 34

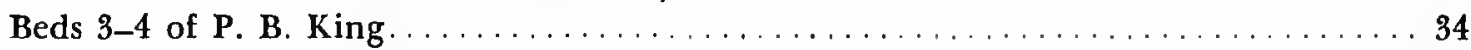

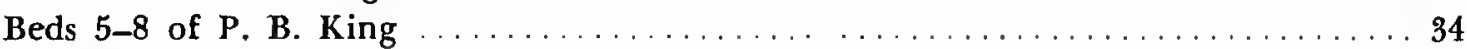

Biohermal Limestone, Shale, and Cobbly Conglomerate $\ldots \ldots \ldots \ldots \ldots \ldots \ldots \ldots$

Area West of North Tributary ............................... 35

Shale and Thin Limestone Sequence (Section above Bed 14 of P. B. King) $\ldots \ldots \ldots \ldots 36$

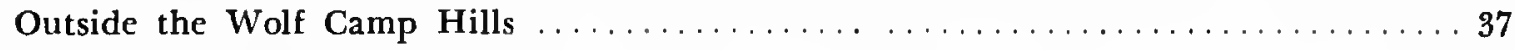

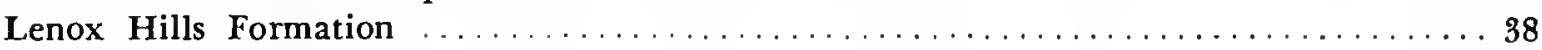

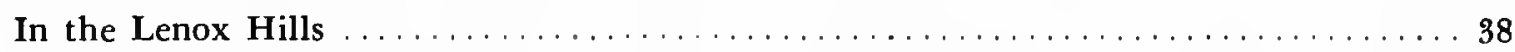

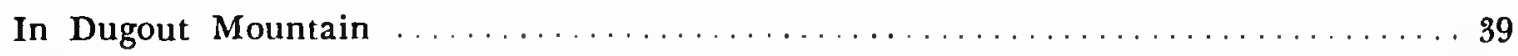

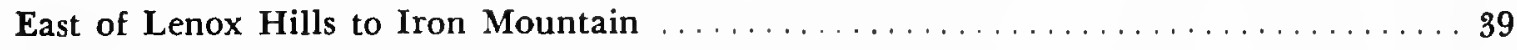

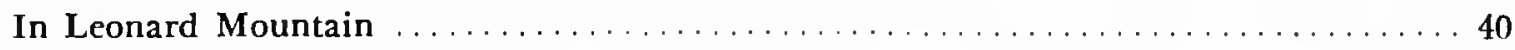

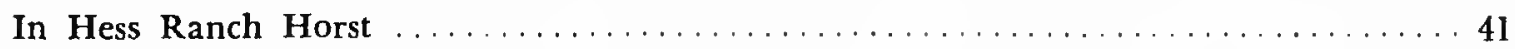

Immediately North of Hess Ranch House $\ldots \ldots \ldots \ldots \ldots \ldots \ldots \ldots \ldots \ldots \ldots \ldots$

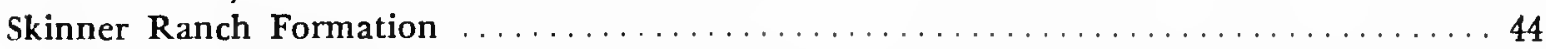

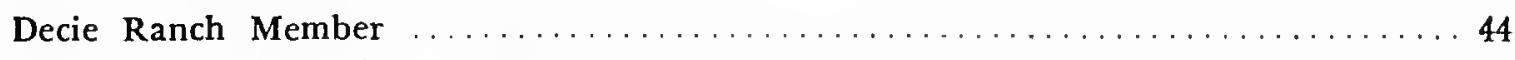

In Dugout Mountain ..................................... 44 
Wolfcamp Series-Continued

Skinner Ranch Formation-Continued

Decie Ranch Member-Continued

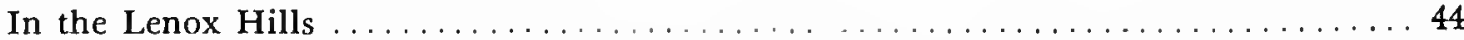

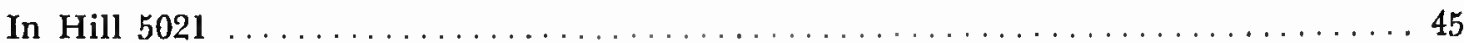

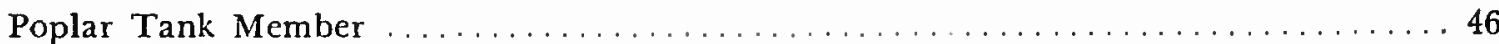

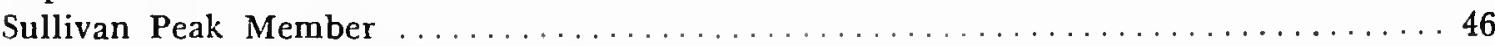

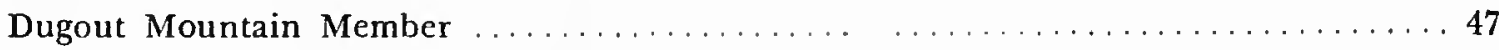

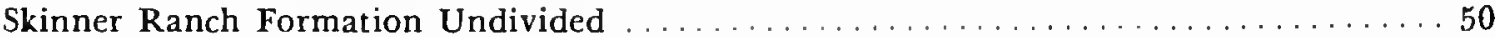

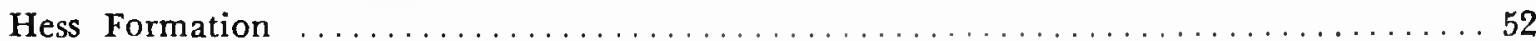

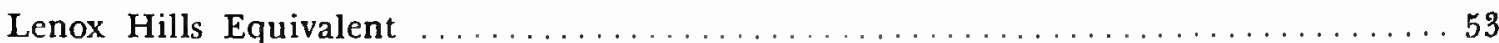

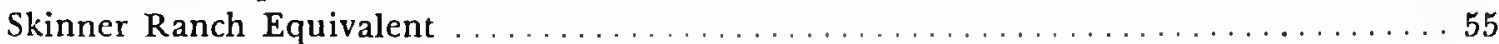

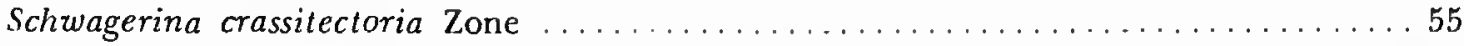

Fossil Bed of P. B. King (= Taylor Ranch Member) $\ldots \ldots \ldots \ldots \ldots \ldots \ldots \ldots \ldots$

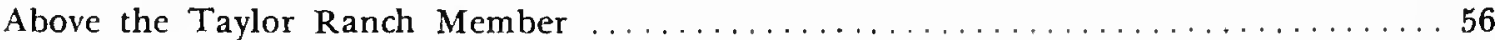

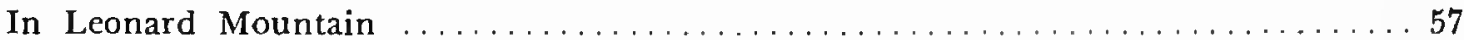

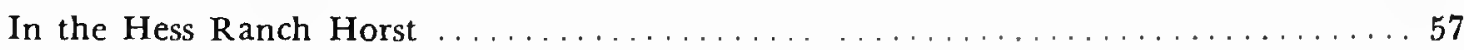

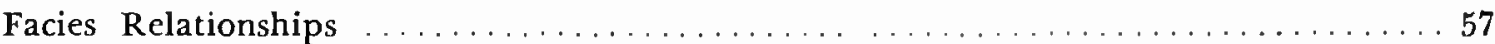

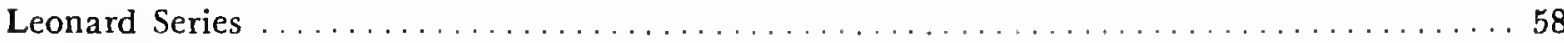

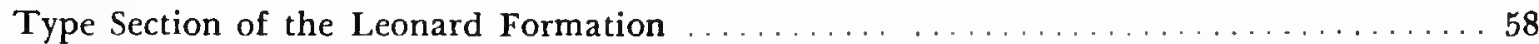

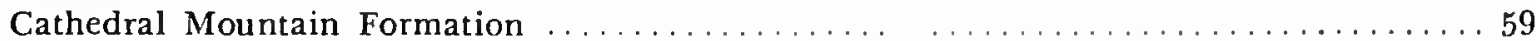

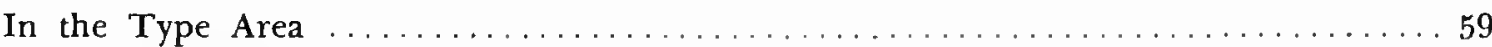

Leonard Limestones of P. B. King in the Lenox Hills .................60

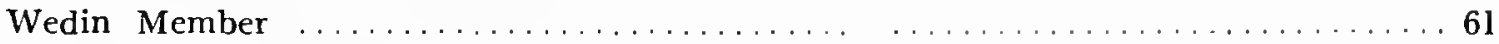

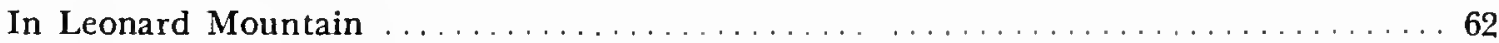

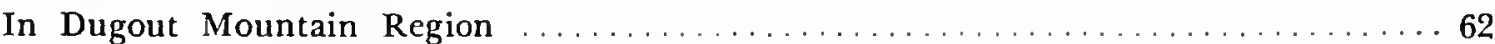

In Old Word Ranch $(=$ Split Tank Area $) \ldots \ldots \ldots \ldots \ldots \ldots \ldots \ldots \ldots \ldots \ldots \ldots \ldots \ldots \ldots$

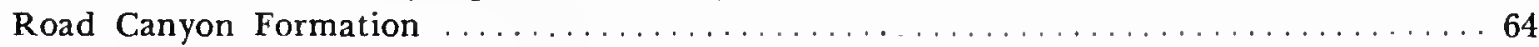

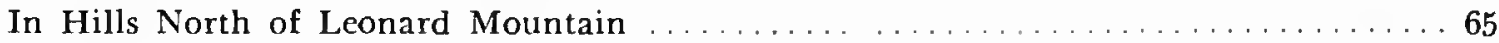

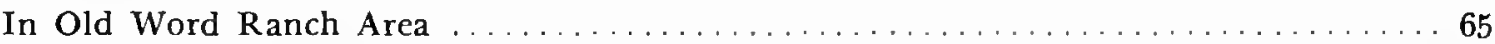

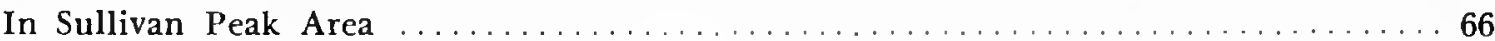

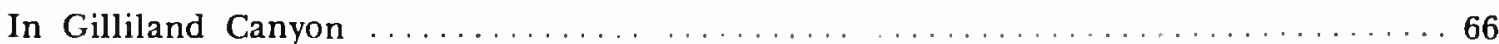

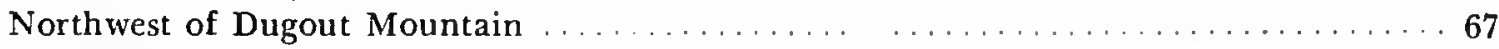

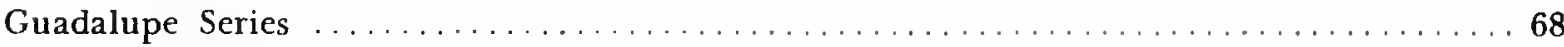

Word Formation $\ldots \ldots \ldots \ldots \ldots \ldots \ldots \ldots \ldots \ldots \ldots \ldots \ldots \ldots \ldots \ldots \ldots \ldots \ldots$

China Tank Member (=Second Limestone Member of P B. King) . . . . . . . . . . 69

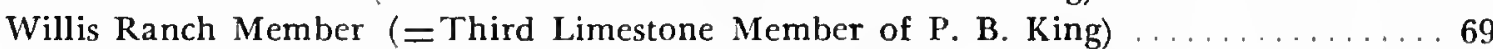

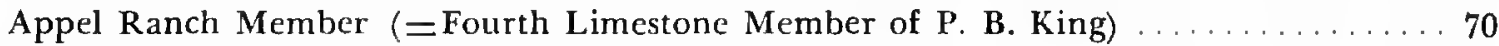

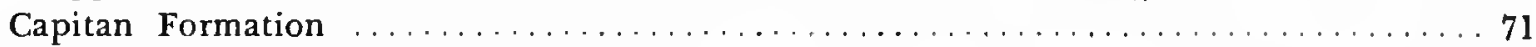

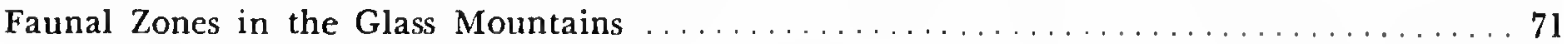

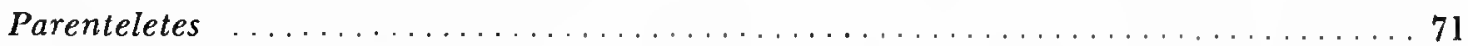

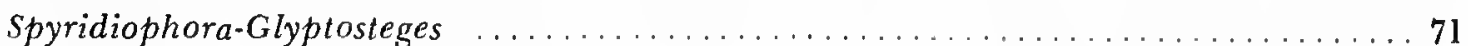

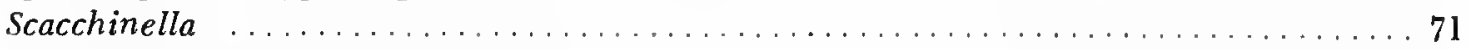

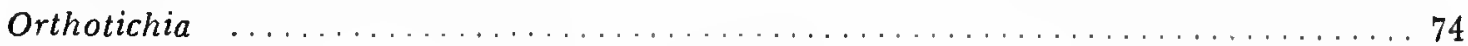

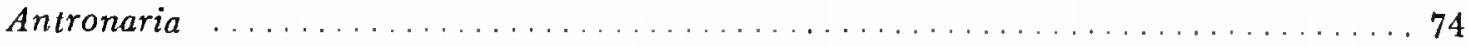

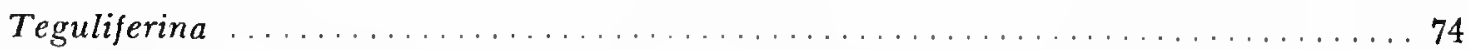

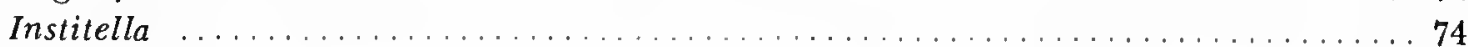

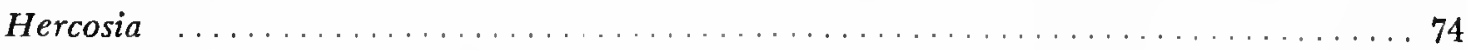

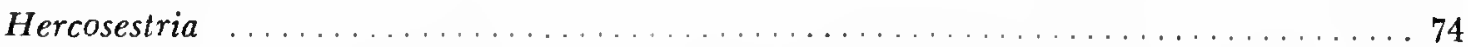

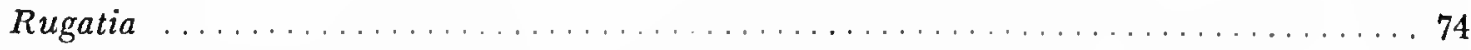

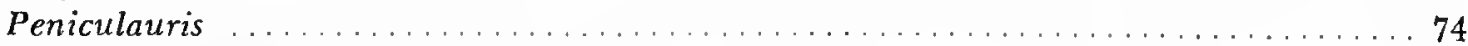

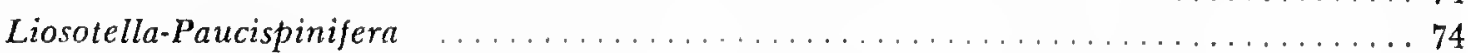

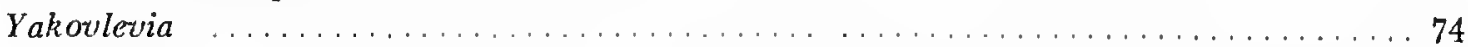

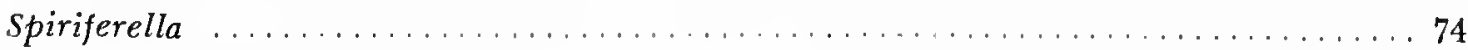

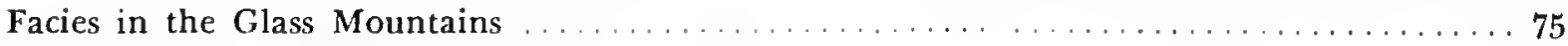

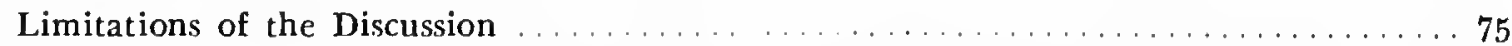

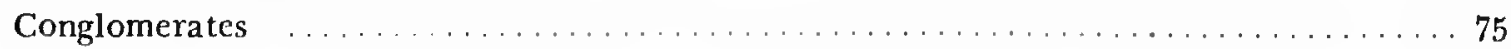

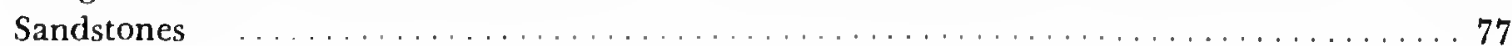


Facies in the Glass Mountains-Continued

Shale

.

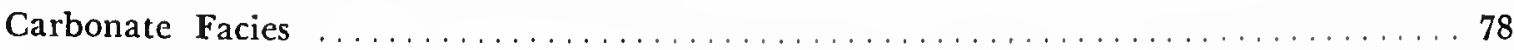

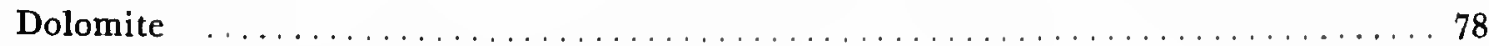

Limestone $\ldots \ldots \ldots \ldots \ldots \ldots \ldots \ldots \ldots \ldots \ldots \ldots \ldots \ldots \ldots \ldots \ldots \ldots$

Organic Accumulations in the Glass Mountains $\ldots \ldots \ldots \ldots \ldots \ldots \ldots \ldots \ldots \ldots \ldots \ldots \ldots \ldots$

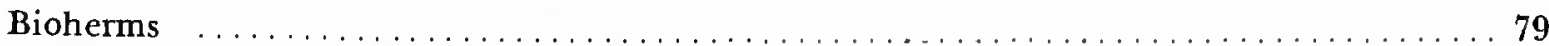

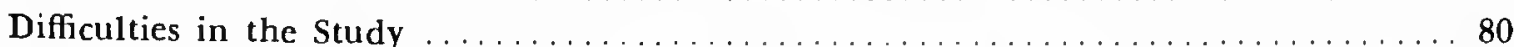

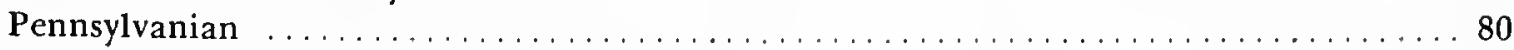

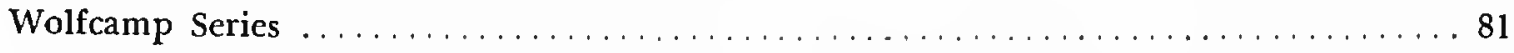

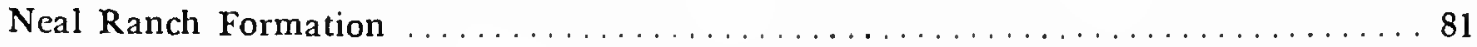

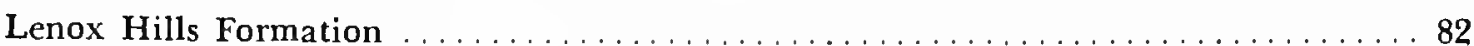

Skinner Ranch Formation $\ldots \ldots \ldots \ldots \ldots \ldots \ldots \ldots \ldots \ldots \ldots \ldots \ldots \ldots \ldots \ldots$

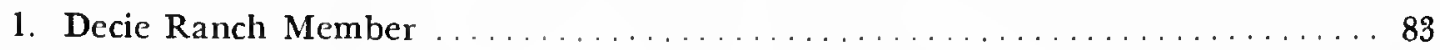

2. Poplar Tank Member $\ldots \ldots \ldots \ldots \ldots \ldots \ldots \ldots \ldots \ldots \ldots \ldots \ldots \ldots \ldots \ldots \ldots$

3. Sullivan Peak Mernber ... .......................... 83

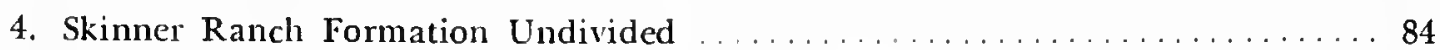

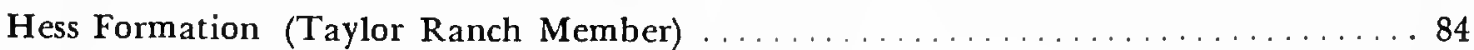

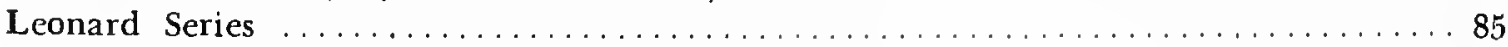

Cathedral Mountain Formation (Wedin Member) $\ldots \ldots \ldots \ldots \ldots \ldots \ldots \ldots \ldots$

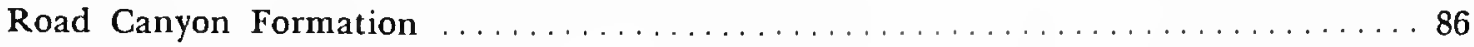

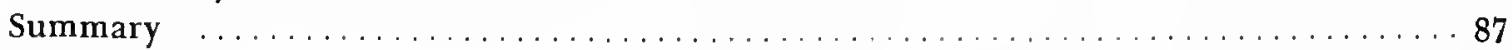

Shell Heaps $\ldots \ldots \ldots \ldots \ldots \ldots \ldots \ldots \ldots \ldots \ldots \ldots \ldots \ldots \ldots \ldots \ldots \ldots \ldots$

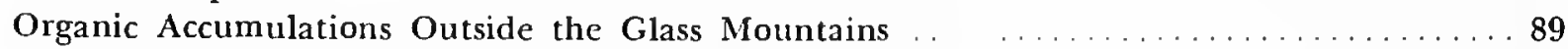

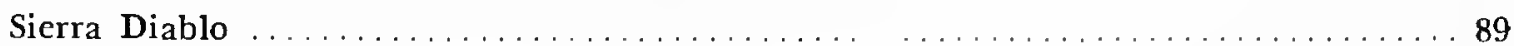

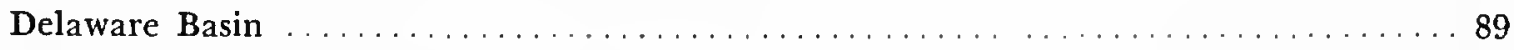

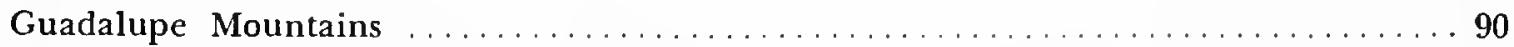

Chinati Mountains ................................. 90

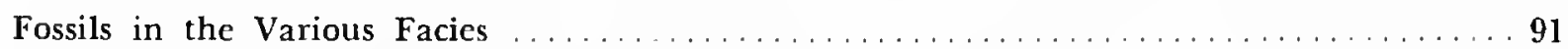

In the Conglomerates $\ldots \ldots \ldots \ldots \ldots \ldots \ldots \ldots \ldots \ldots \ldots \ldots \ldots \ldots \ldots \ldots \ldots \ldots$

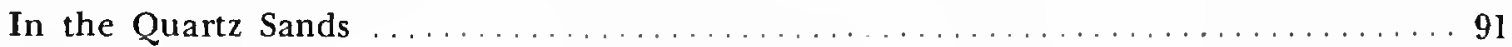

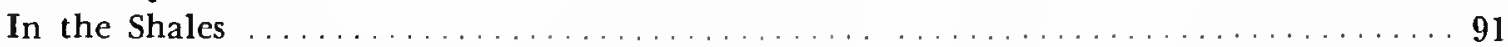

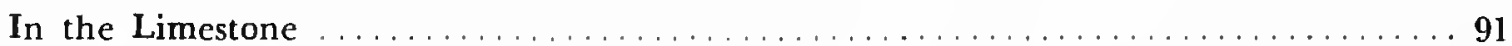

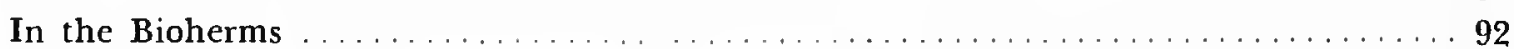

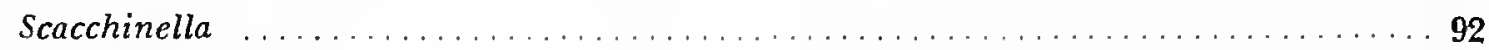

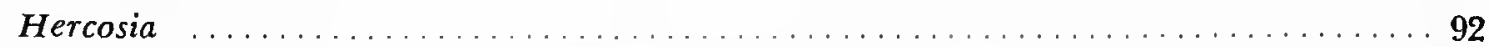

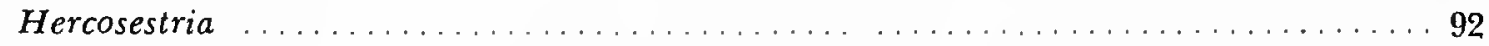

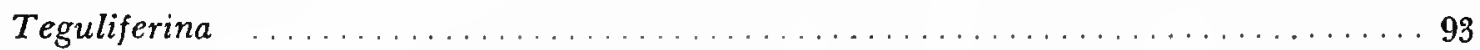

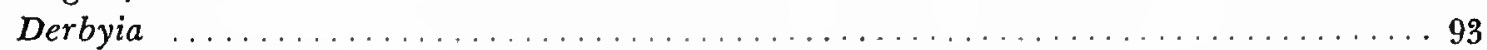

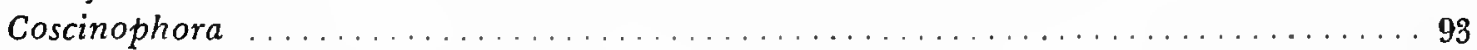

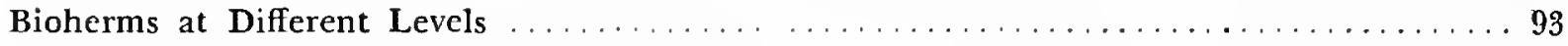

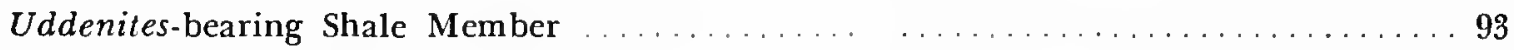

Neal Ranch Formation $\ldots \ldots \ldots \ldots \ldots \ldots \ldots \ldots \ldots \ldots \ldots \ldots \ldots \ldots \ldots \ldots$

Lenox Hills Formation $\ldots \ldots \ldots \ldots \ldots \ldots \ldots \ldots \ldots \ldots \ldots \ldots \ldots \ldots \ldots \ldots \ldots \ldots$

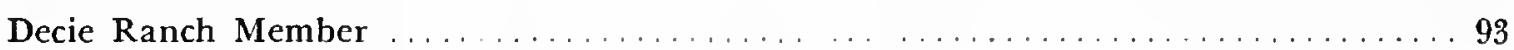

Sullivan Peak Member ................................ 94

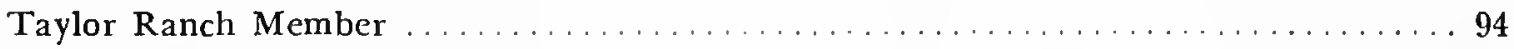

Cathedral Mountain Formation $\ldots \ldots \ldots \ldots \ldots \ldots \ldots \ldots \ldots \ldots \ldots \ldots \ldots$

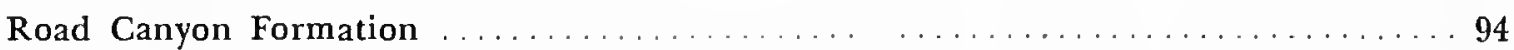

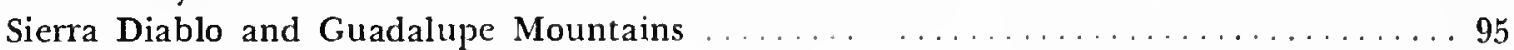

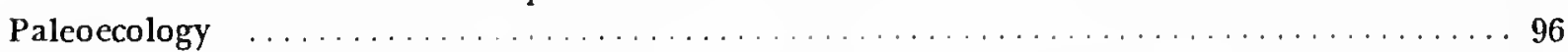

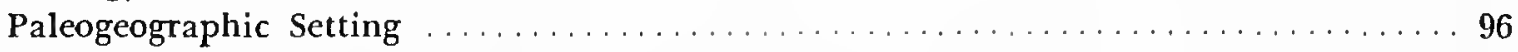

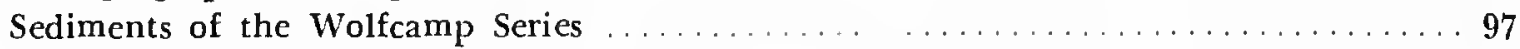

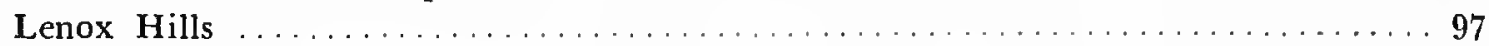

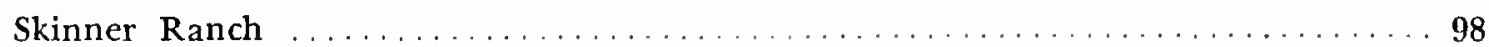

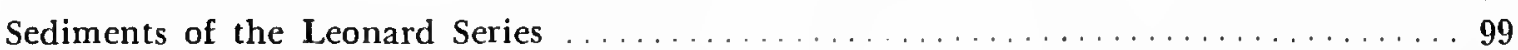

Cathedral Mountain . . . . . . . . . . . . . . . . . . . . . . . 99

Cathedral Mountain in the Split Tank Area ...................... 99 
Paleoecology-Continued

Sediments of the Leonard Series-Continued

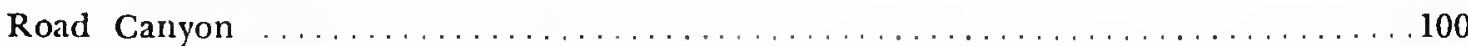

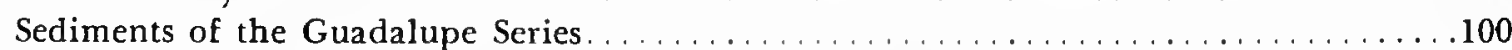

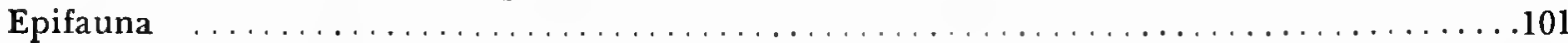

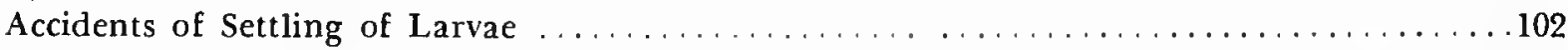

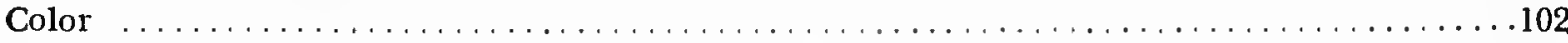

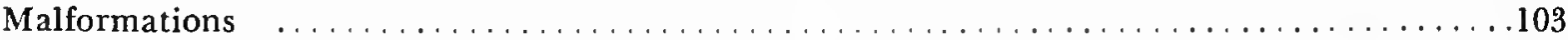

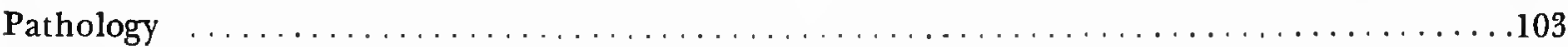

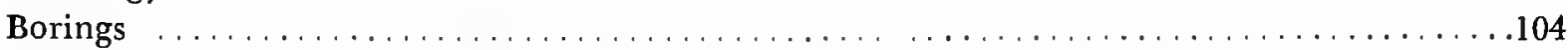

Faunas and Correlations of Glass Mountains Formations $\ldots \ldots \ldots \ldots \ldots \ldots \ldots \ldots \ldots \ldots$

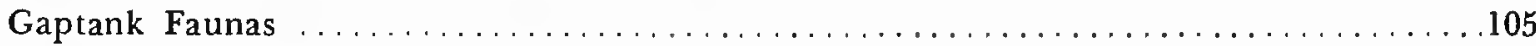

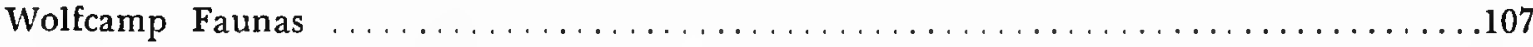

Uddenites-bearing Shale Member $\ldots \ldots \ldots \ldots \ldots \ldots \ldots \ldots \ldots \ldots \ldots \ldots \ldots \ldots \ldots \ldots$

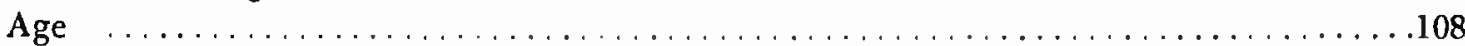

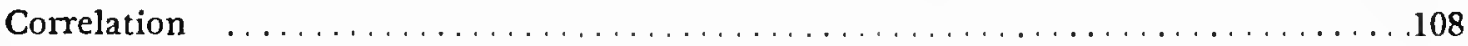

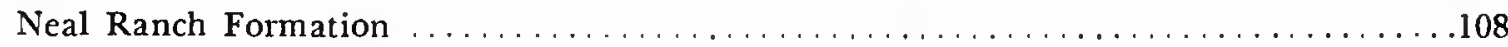

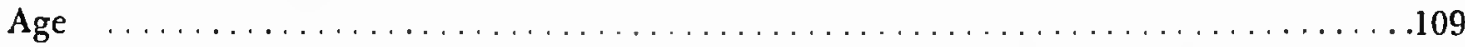

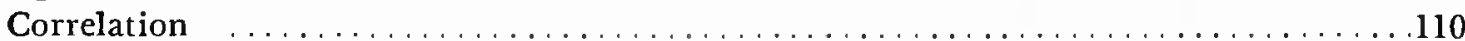

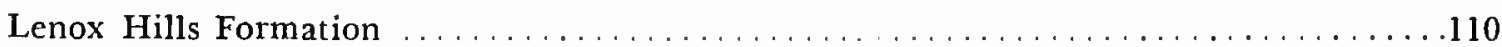

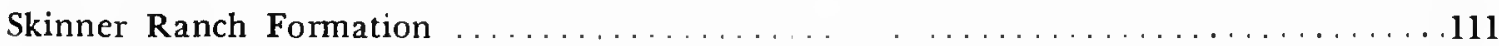

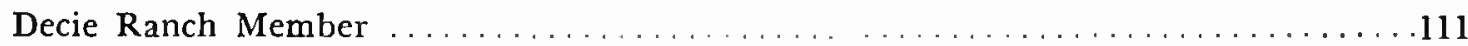

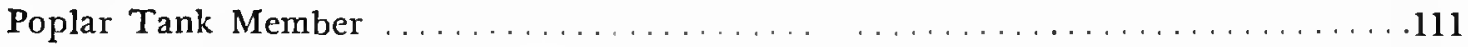

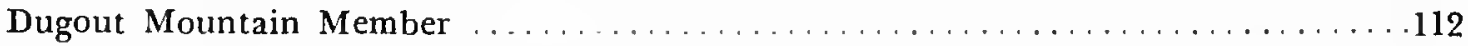

Sullivan Peak Member ...................................112

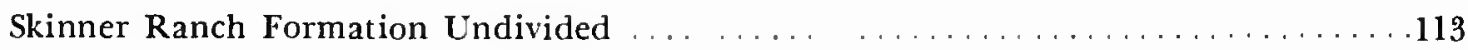

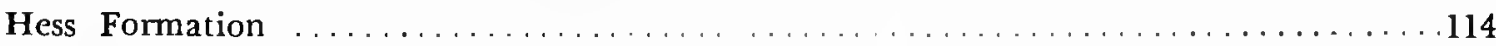

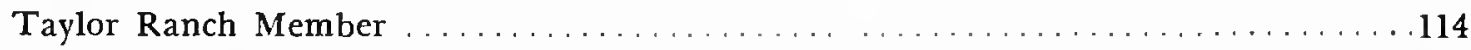

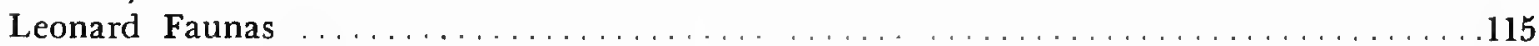

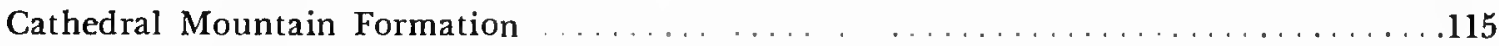

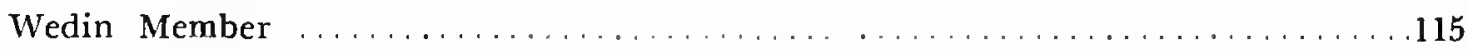

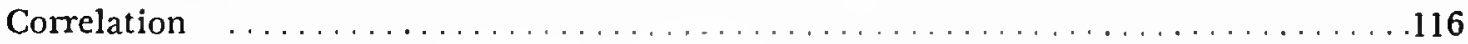

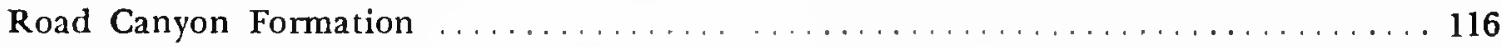

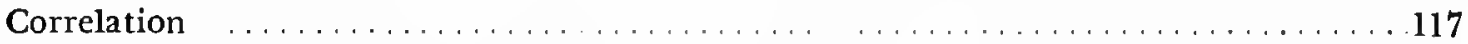

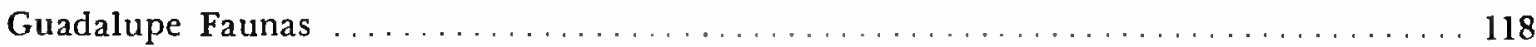

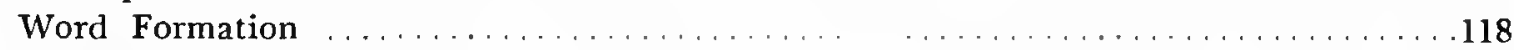

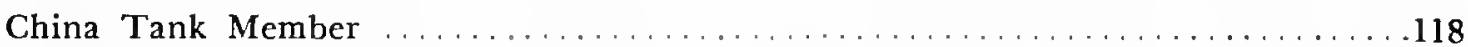

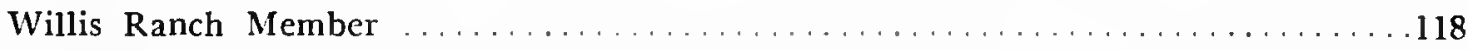

Lenses Between Willis Ranch and Appel Ranch Members $\ldots \ldots \ldots \ldots \ldots \ldots \ldots \ldots 18$

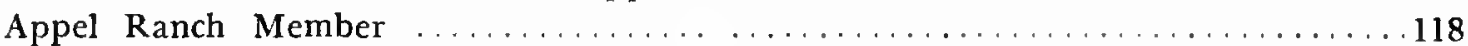

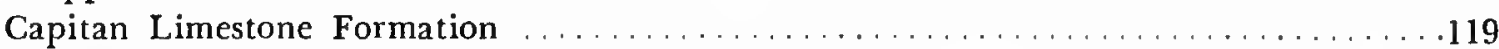

Stratigraphy and Fossils of Other West Texas Areas $\ldots \ldots \ldots \ldots \ldots \ldots \ldots \ldots \ldots \ldots \ldots$

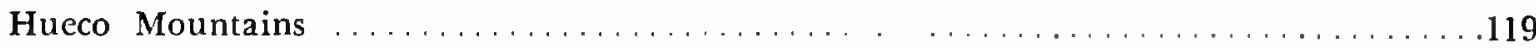

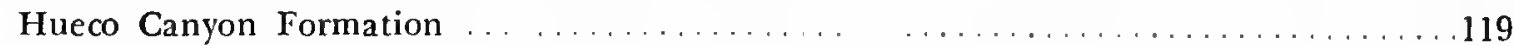

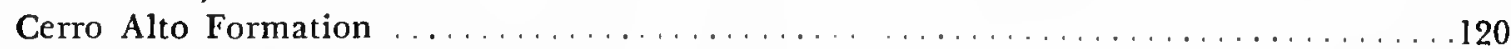

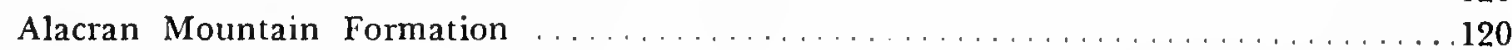

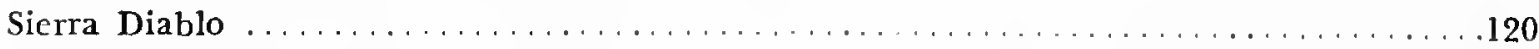

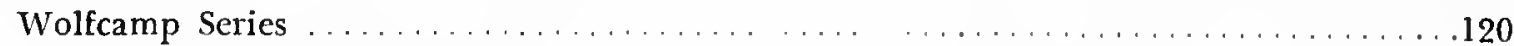

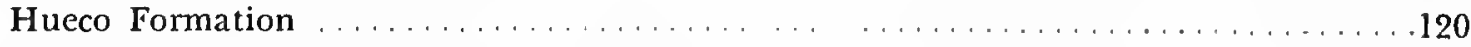

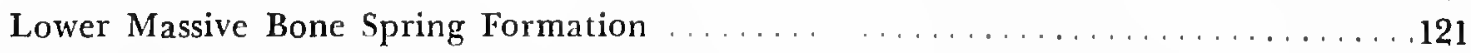

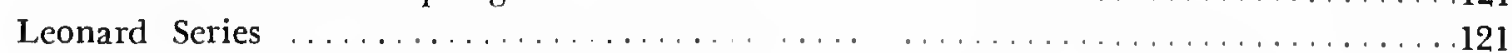

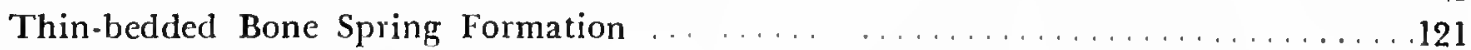

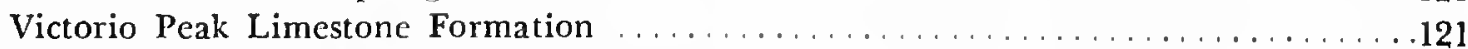

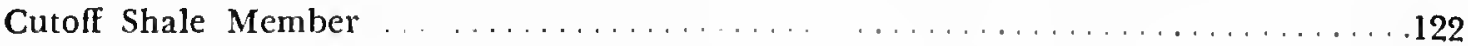

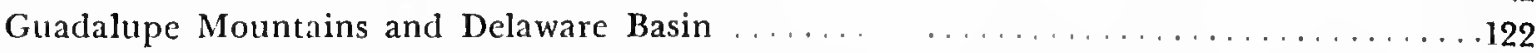

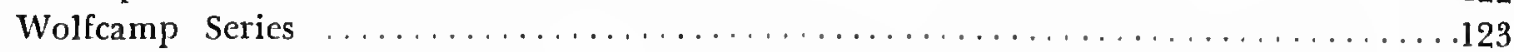

Leonard Series . . . . . . . . . . . . . . . . . . . . . . . . . . 123

Guadalupe Series . . . . . . . . . . . . . . . . . . . . . . . 123 
Stratigraphy and Fossils of Other West Texas Areas-Continued

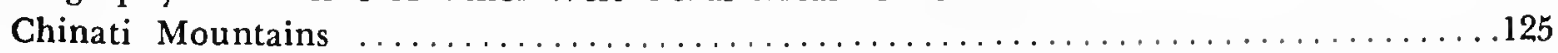

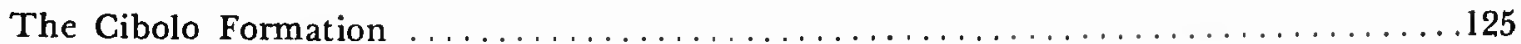

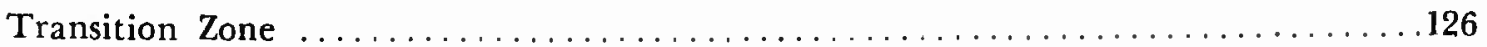

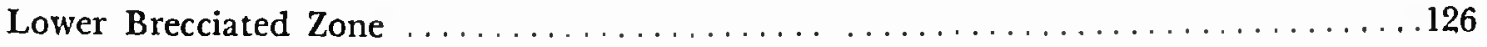

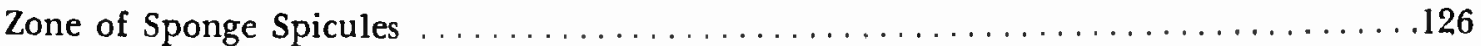

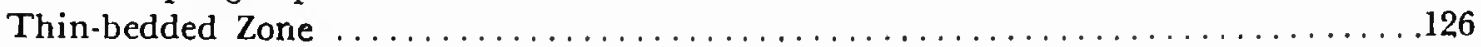

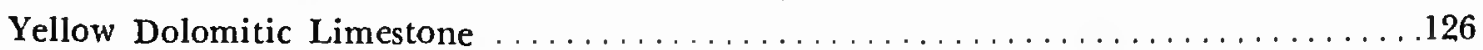

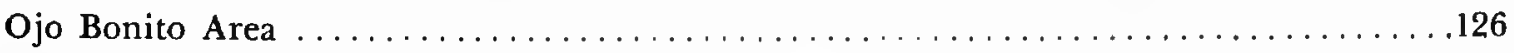

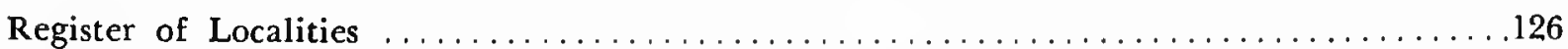

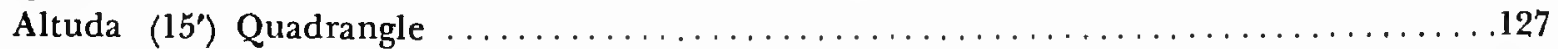

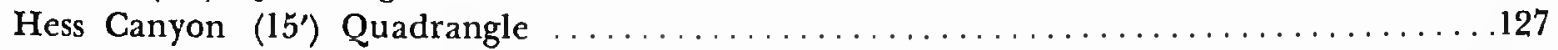

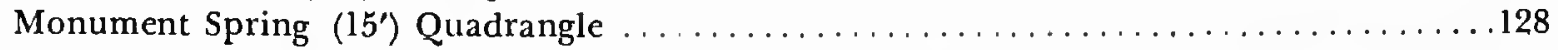

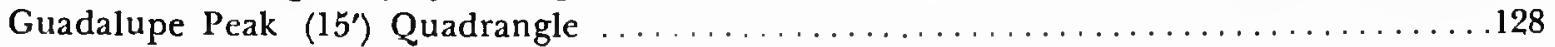

Van Horn $\left(30^{\prime}\right)$ Quadrangle . . . . . . . . . . . . . . . . . . . . . . . . . . . 128

Location of Canyons in Carlsbad Caverns West (15') Quadrangle ................ 128

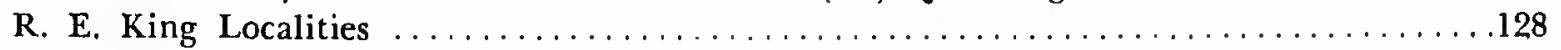

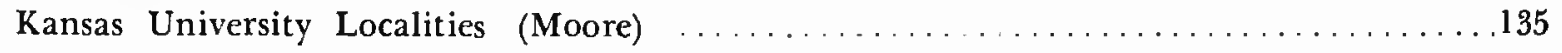

United States Geological Survey Localities (USGS) $\ldots \ldots \ldots \ldots \ldots \ldots \ldots \ldots \ldots \ldots \ldots \ldots$

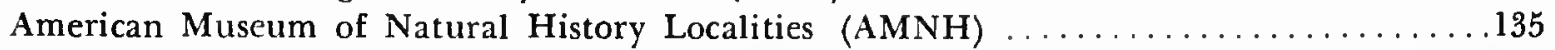

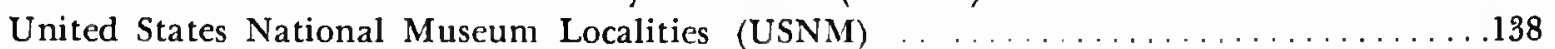

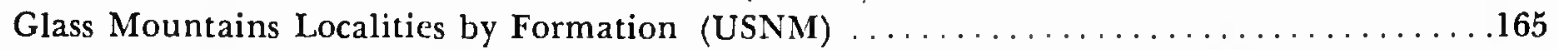

Guadalupe Mountains and Sierra Diablo Localities by Formation (USNM) . . . . . . 166

Chinati Mountains Localities by Formation (USNM) $\ldots \ldots \ldots \ldots \ldots \ldots \ldots \ldots \ldots \ldots \ldots$

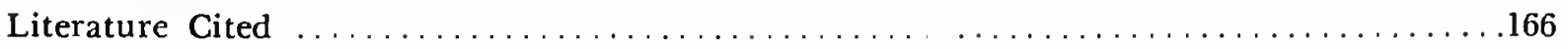

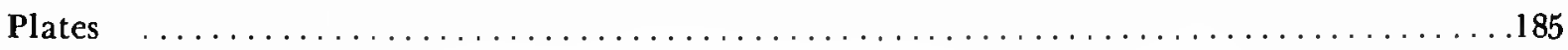

\section{FIGURES}

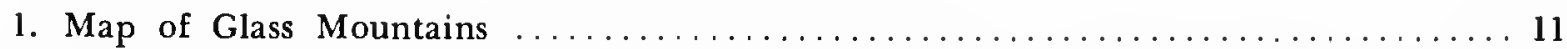

2. Diagram of riker mount for delicate specimens $\ldots \ldots \ldots \ldots \ldots \ldots \ldots \ldots \ldots \ldots \ldots \ldots \ldots 20$

3. Diagram to show etching of block to produce perfect specimens $\ldots \ldots \ldots \ldots \ldots \ldots \ldots 22$

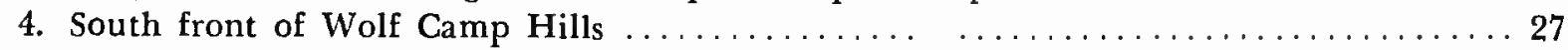

5. Sections of Neal Ranch Formaion of P. B. King compared with those of Jarvis, Ross

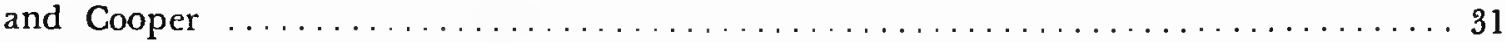

6. Section through Hess Ranch Horst $\ldots \ldots \ldots \ldots \ldots \ldots \ldots \ldots \ldots \ldots \ldots \ldots \ldots \ldots \ldots \ldots$

7. Section through Wolf Camp Hills and Hess Ranch Horst $\ldots \ldots \ldots \ldots \ldots \ldots \ldots \ldots \ldots 42$

8. Section 0.5 mile north of Hess $\mathrm{Ranch}$ house $\ldots \ldots \ldots \ldots \ldots \ldots \ldots \ldots \ldots \ldots \ldots \ldots$

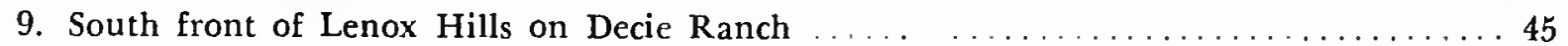

10. South front of spur on west side of road to Sullivan (Yates) Ranch on Decie Ranch,.. 46

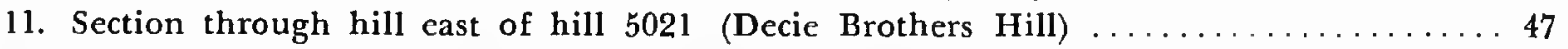

12. Cross section of hill west of hill 5300 (closed 5250 -foot contour) ..........48

13. Diagram showing probable correlation of Dugout Mountain Member within Skinner

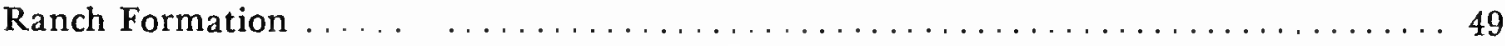

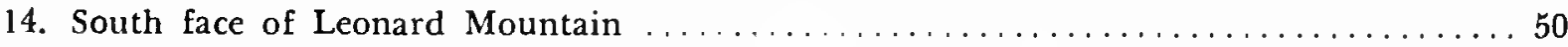

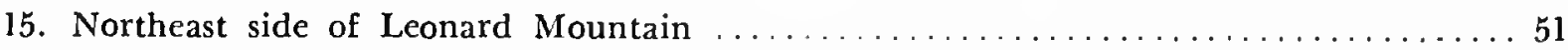

16. Correlation of Lenox Hills Formation in Hess Ranch Horst with same formation in

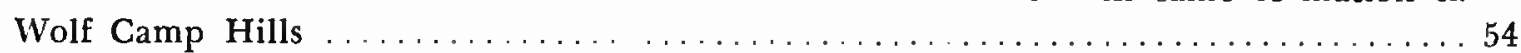

17. Section through Wolf Camp Hills to Old Word Ranch $\ldots \ldots \ldots \ldots \ldots \ldots \ldots \ldots \ldots \ldots 7$

18. Section through Leonard Mountain $\ldots \ldots \ldots \ldots \ldots \ldots \ldots \ldots \ldots \ldots \ldots \ldots \ldots$

19. Comparison of Ross's members of Leonard "Formation" with Skinner Ranch and Cathe-

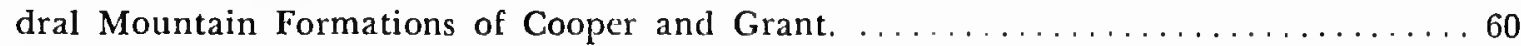

20. Section through hill 5250 (closed contour) just west of hill 5300 to Sullivan Peak .... 61

21. Section through Dugout Mountain to hill with Capitan Formation in northwest corne1

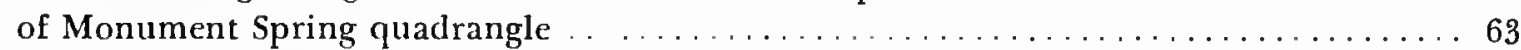

22. Section of Cathedral Mountain Formation 0.5 mile east of Split Tank ..........64 
23-25. Revised geological maps: Dugout Mountain area; Lenox Hills area; Leonard Moun. tain area $\ldots \ldots \ldots \ldots \ldots \ldots \ldots \ldots \ldots \ldots \ldots \ldots \ldots \ldots \ldots \ldots \ldots \ldots \ldots, \ldots \ldots \ldots$

26. Diagram showing facies in Glass Mountains $\ldots \ldots \ldots \ldots \ldots \ldots \ldots \ldots \ldots \ldots \ldots \ldots$

27. Paleogeographic setting of West Texas Permian $\ldots \ldots \ldots \ldots \ldots \ldots \ldots \ldots \ldots \ldots \ldots$

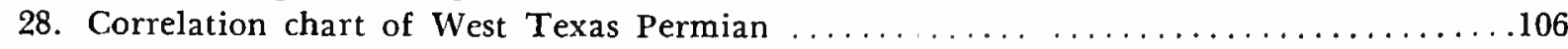

29. Localities in area northwest and west of Dugout Mountain including part of Sierra

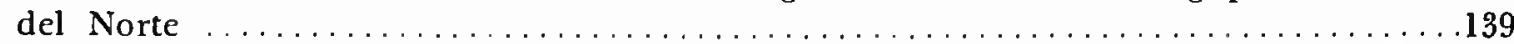

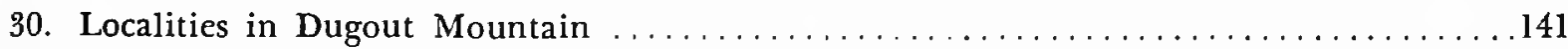

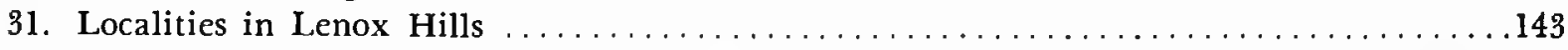

32. Localities between Sullivan (Yates) Ranch road and Iron Mountain .............144

33. Localities on Leonard Mountain . . . . . . . . . . . . . . . . . . . . . . . . . . . . . . . . 146

34. Localities on Leonard Mountain and hills to north $\ldots \ldots \ldots \ldots \ldots \ldots \ldots \ldots \ldots \ldots \ldots 148$

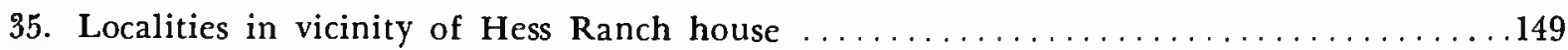

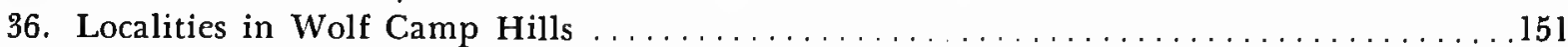

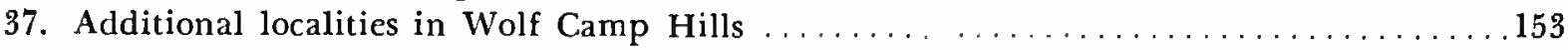

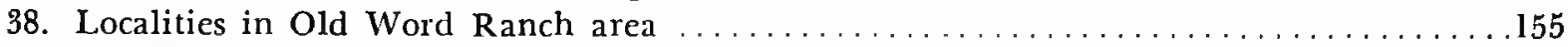

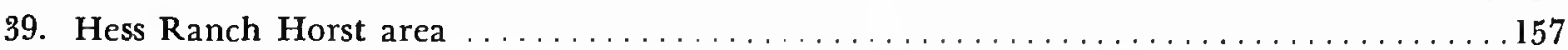

\section{PLATES}

1. Acid laboratory, National Museum of Natural History; immersing limestone block; profile of Wolf Camp Hills from southwest; Sierra del Norte from east; Sullivan Peak

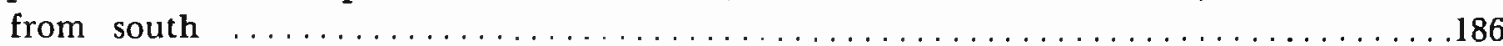

2. West side of Leonard Mountain; south face of Wolf Camp Hills; east end of Lenox

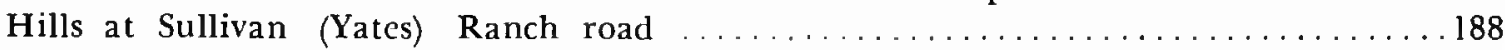

3. Hess Ranch Horst from west; Hess Ranch Horst from east; Lenox Hills conglomerate at Leonard Mountain; Road Canyon Formation southeast of Sullivan Peak ........190

4. The "Uddenites saddle"; Uddenites-bearing Shale Member, Wolf Camp Hills; mosaic in Neal Ranch Formation, Wolf Camp Hills; Neal Ranch Formation and Lenox Hills

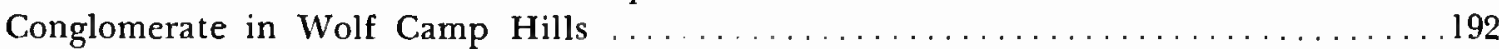

5. Bioherm with Coscinophora in Sullivan Peak Member, Dugout Mountain; Neal Ranch Formation, west end of Wolf Camp Hills; Road Canyon Formation south of Sullivan

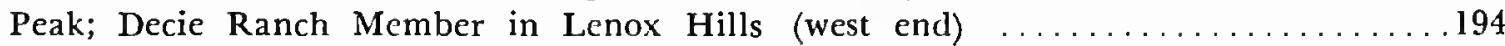

6. Southwest face of Leonard Mountain; Skinner Ranch Formation (Sullivan Peak Member) on southwest side of Dugout Mountain; east side of Leonard Mountain . . . . . 196

7. Wedin Member southwest of hill 5300, Lenox Hills; clay slide; panorama of Lenox Hills

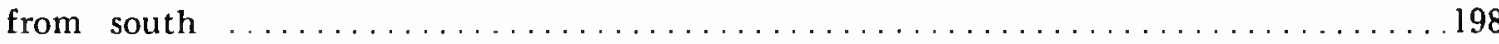

8. Hess Formation east of Hess Ranch house; south face of Leonard Mountain; panorama

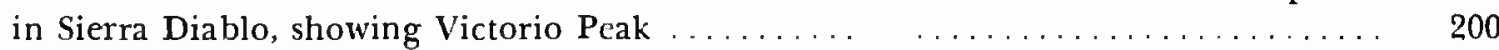

9. Taylor Ranch Member south of Old Word Ranch; Poplar Tank Member in hill 4801; Decie Ranch Member in Lenox Hills (west end); blocks wrapped for shipment . 202

10. Hill 5021 (Decie Brothers Hill); same from south; west knob of same; Decie Ranch

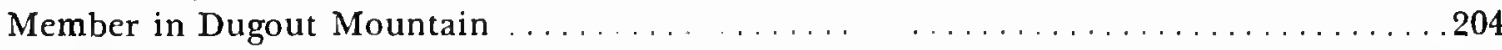

11. Conglomerate in Sullivan Peak Member in hill 4801, Lenox Hills; Scacchinella bioherm on Lconard Mountain; polished section of biohermal limestone from Neal Ranch Formation, Wolf Camp Hills; conglomerate in Sullivan Peak Member, hill 4801, Lenox

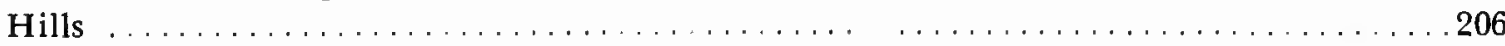

12. Giant crinoid stems in Sullivan Peak Member; Lenox Hills Formation at south end of Lenox Hills; hill 5060 in Wolf Camp Hills; small pebble conglomerate in the Cathedral Mountain Formation near Old Word Ranch site .. . . . . . . . . . . . . . 208

13. Hill 4861; conglomerate with Perrinites in same; thin-bedded limestone in Road Canyon Formation at Old Word Ranch site; east face of Dugout Mountain ...........210

14. Type section of Willis Ranch Member in Road Canyon; Appel Ranch Member on Appel Ranch; sandy Willis Ranch limestonc in Gilliland Canyon; bench capped by Willis

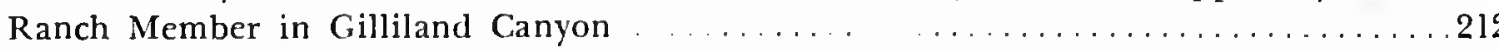

15. Appel Ranch Member north of Appel Ranch; Road Canyon Formation in hill 5453; foothills of the Sierra del Norte showing location of hill 4861; Sullivan Pcak with lens of Willis Ranch Member (USNM 73lu) in foreground 
16. Bioherm in Gaptank Formation south of Arnold Ranch; bioherm in Sullivan Peak Member in hill 4801; bioherm in Neal Ranch Formation in Wolf Camp Hills; bioherm ir Road Canyon Formation in hill 5779, north of Skinner (Iron Mountain) Ranch ......216

17. Hercosia bioherm in Cathedral Mountain Formation southwest of Old Word Ranch site; massive bioherms in Road Canyon Formation south of Sullivan Peak; bioherm in Road Canyon Formation north of Leonarcl Mountain; Coscinophora in preceding bioherm.. 218

18. Hill 4801 in Lenox Hills; bryozoans in bioherm in same; large bioherm in same; large crinoid stems in large bioherm in same ............................. 220

19. Bioherms in Skinner Ranch Formation, south side of Leonard Mountain; Heliospongia in bioherm in Taylor Ranch Member northeast of Hess Ranch house; hill 4752 on Montgomery (Conoly Brooks) Ranch; Scacchinella bioherm on north side of Hess Ranch

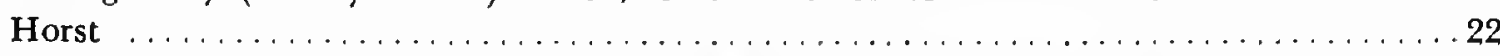

20. Road Canyon Formation at USNM 702c; Scacchinella bioherm in Lenox Hills Formation on southeast side of Leonard Mountain; bioherm with Collemiataria, 0.5 mile east of Split Tank; bioherm in Cathedral Mountain shale near Old Word Ranch site ........224

21. Geopetal structure in bioherm of Road Canyon Formation at Old Word Ranch site; bioherm in Poplar Tank and Sullivan Peak members in hill 5300; profile of Lenox Hills from southwest; Dugout Mountain from northeast; Hess Ranch Horst from south .... 226

22. Bold face of El Capitan, Guadalupe Mountains; Hegler Member in Delaware Basin; Lamar Member on D-Ranch; bioherms in Cibolo Formation, Chinati Mountains...... 228

23. Cibolo Formation along Sierra Alta Creek, Chinati Mountains; biohermal limestone with Scacchinella on same creek; bluff on same creck showing thick "Breccia Zone" of Udden; Rader Ridge in Guadalupe Mountains 



\section{Permian Brachiopods of West Texas, I}

\section{G. Arthur Cooper and Richard E. Grant}

\section{Introduction}

The Permian rocks of West Texas and nearby New Mexico are regarded as the standard to which all correlations in the Permian of North America are referred. The reason for this importance is partly historical: the presence of the Permian in North America was recognized first in the Guadalupe Mountains (Shumard, 1859, 1860); and the Guadalupian fauna was monographed at an early date (Girty, 1909). The continued increase in intensity of study of the Permian of this area, however, is due to the excellence and completeness of the exposures and the great abundance of many different kinds of fossils.

Monographs on many groups of fossils from the Texas Permian recently have been published, making this fauna one of the best documented in the entire Paleozoic. Among these, in addition to Girty's, are Miller and Furnish (1940) on the ammonoids, Batten (1958) and Yochelson $(1956,1960)$ on the gastropods, Newell and Boyd (1970) on some of the bivalves, Finks (1960) on the siliceous sponges, and R. E. King (1931) and Stehli (1954) on the brachiopods. King's (1931) Glass Mountains monograph documented 185 species in 47 genera of brachiopods, a large enough fauna to give the impression that nearly every significant brachiopod was known.

G. Arthur Cooper and Richard E. Grant, Department of Paleobiology, National Museum of Natural History, Smithsonian Institution, Washington, D.C. 20560.
It was with this impression in mind that Cooper made his first trip to West Texas to obtain representative specimens of some of these well-known fossils for the national collection. The process of etching limestone samples in acid, however, freed enough new material to suggest that further research along these lines would be fruitful.

After the first sample taken in 1939, it became apparent that the Glass Mountains were a veritable treasure house that exceeded by far the richest Permian deposits known-even the remarkable Sosio Limestone of Sicily. Sampling in one year usually yielded clues to sites for a further enriching of the collection or it led to the need for more specimens from old localities. For example, the discovery of the Siphonosia pedicle valve led to three additional samplings (about 24 blocks) of USNM locality $721 \mathrm{u}$ in order to produce the two brachial valves now in the collection. These were needed to complete a generic description. Such collecting yielded generous, often overwhelming, suites of the commoner species, but it also revealed rarities that could have been obtained only by chance, or not at all, by any other method of collecting.

The same may be said for the stratigraphy. Originally there was no intention to make any re. vision of the formations as laid out by the King brothers. Theirs was a remarkably complete and excellent piece of work, but the present authors' and colleagues' persistent search for fossils from all levels and the scale of the collecting made it clear that some revision was necessary. 
We had not intended originally to redate any parts of the Pennsylvanian or Permian successions. Our complete corroboration of Robert King's Permian elements in the Uddenites-bearing Shale Member of the Gaptank Formation led us inevitably to the same conclusion reached by him, i.e., that this portion of the sequence is Permian. Our philosophy of dating parts of the section is not based primarily on newcomers in a sequence, as motivates some stratigraphers, but it is based rather on the preponderance of the faunal evidence.

It is unfortunate that our references to sedimentology must be generalized because this is a very important part of the picture of the Glass Mountains geology that bears on paleoecology. With the modern advances in sedimentology, this subject in the Glass Mountains will require a monographic treatment of its own.

Another modern approach neglected by us is a statistical study of the species. The collections are too large and our time too short to have adopted such methods for the approximately one thousand species described. Even with a statistical approach, the paleontologist is obliged initially to sort all of his collections into the units he believes are the proper and natural species. Because our sorts have been made with great care, we believe that most of our species are well and accurately defined. Doubtless, in some instances, the reader will differ with our choices. It is a question in any paleontological study as to how fine species should be drawn. If we have erred, hopefully it is on the conservative side.

Although this monograph is of gigantic proportions, it is doubtful that our sampling of the mountains is complete. The sixty or so square miles occupied by the portion of the Glass Mountains sampled by us contains many poorly accessible layers not yet visited. The limy lenses just above the Road Canyon Formation, for example, in the hills north of Leonard Mountain almost certainly will yield many new species when collected in detail. Furthermore, bioherms are faunally so varied that any new one discovered will probably yield new species. The Delaware Basin south of the Guadalupe Mountains offers great possibilities for collecting, as do the Sierra Diablo and Apache Mountains. We have not exhausted the Glass Mountains for future paleontological exploitation.

As noted above, our correlations are based on the preponderance of evidence as indicated by the brachiopods. These are our primary concern, and our dating and correlating are based on them. The appearance of a single genus in the column is not regarded of significance unless other geologic or faunal data give supporting evidence. In some instances our views are in accordance with those expressed by proponents of the fusulinids and ammonites, the two groups most used in correlating Permian rocks. In other cases, however, the brachiopod story does not parallel that of other animal groups. The fauna of the Uddenites-bearing Shale Member is an example. The ammonites and fusulinids, according to Ross (1963a), argue for a Pennsylvanian age, but the brachiopods indicate a Permian age. To cite another example, the Gray Limestone Member of P. B. King, Ross (1963a:6) contends that the fusulinids indicate a Late Pennsylvanian age, but the brachiopods clearly are Permian and so are the ammonites. Bostwick (1962) has anticipated the Permian age of the Uddenites-bearing Shale Member by his discovery of Schwagerina in this member.

Our work in the Glass Mountains is a demonstration of the value of extensive paleontological study in stratigraphy. Collecting in Gilliland Canyon we sampled the mapped Lower Word Limestone (=First Limestone of the Word of P. B. King) in an effort to fill in our knowledge of that part of the column. Abundance of Waagenoceras led to the suspicion that something was wrong. On dissolving several large blocks of limestone from the questionable bed (USNM 723t), we recovered an excellent Willis Ranch Member fauna. Other examples of such findings were the discovery of a Cathedral Mountain fauna in a conglomerate mapped as Word, the discovery of the Leonardian elements of the Road Canyon Formation, and the tracing of the Willis Ranch remnants in the Word Shale after the member had disappeared as a continuous carbonate layer. Lenses discovered below Sullivan Peak (USNM $731 \mathrm{u}$ ) and near the site of Old Payne Ranch (USNM 732s) indicate this level.

One problem has plagued us, as it has been worrisome to all paleontologists: What should be done 
about fossil names based on types now lost and with indifferent stratigraphic data? It is only natural that paleontologists rely on previous work, but when this reliance is without critical examination, misconceptions and errors can be perpetuated.

This situation is particularly true of the species from the Guadalupe Mountains described by B. F. Shumard. The specimens were collected by his brother G. G. Shumard on the expedition that set out to obtain water by artesian wells along the 32nd parallel under the direction of Captain John Pope, United States Corps of Topographic Engineers. These fossils were important because B. F. Shumard recognized them as Permian in age at a time when this period was poorly understood and uncertainly identified in the United States. In 1857 the Pope Expedition collections were presented by the Smithsonian Institution to the St. Louis Academy of Sciences (B. F. Shumard, 1858: 108, 113). Unfortunately, all of the specimens later were lost in a fire; thus, Shumard's types are gone. His descriptions are good, his illustrations of the few specimens figured are bad, and most of the described specimens are unfigured; and, finally, the locations are highly generalized and the stratigraphy restricted to presence in the "dark limestone" or the "white limestone."

Confusion is confounded by subsequent authors who have tried to interpret Shumard's descriptions and, in some cases, have established genera on Shumard's species. The case of Crania permiana Shumard, described in detail herein under Cyclacantharia, illustrates the point. Shumard's species, from the White Limestone (= Capitan Limestone) was identified by Girty from the Word Formation of the Glass Mountains. On the latter, R. E. King (1931) made the genus Prorichthofenia. Neither Girty nor King had any knowledge of Shumard's species other than his description. Inasmuch as two different genera occur in the White Limestone, it is now impossible to say what Shumard's species was and what King's genus really is. Under the circumstances, it seems best to retain the combination Prorichthofenia permiana (Shumard) in the literature as indeterminate.

The case of King's genus Uncinuloides is similar and was adjusted by Cooper and Grant (1962). It seems best to us to recognize these combinations as "literature names" rather than to indulge in guesswork regarding their anatomy, stratigraphy, and locality. Some of Girty's species are of this sort. His collections were derived from many sources, some of which had erroneous or careless locality descriptions and stratigraphic information. Many of his specimens came from float. We have been unable to establish with certainty the location of Comanche Canyon (USGS 3763) in the Glass Mountains. This leaves most of his Glass Mountain specimens without any sure stratigraphic or geographic data. Enteletes dumblei Girty and Leptodus americanus Girty have been widely identified, but the identifications are generally inaccurate and misleading. Productus meeki Girty from the Glass Mountains is a fragment having the body spine arrangement of Grandaurispina, but the shell outline is unknown as are its geography and stratigraphy. There is no value whatsoever in trying to save such names that are so equivocally based. It is far better to make a new name on accurately documented material. This at least assures future workers references that are reliable. In accordance with these views, we have not used some specific names, which, perpetuated, would make mischief.

In correlating we have not used early appearances as absolute criteria for age determination. The appearance of abundant Parenteletes and occasional Diplanus in bed 10 of P. B. King of the Gaptank Formation are definite Permian elements, which, taken alone, would suggest an Early Permian age for beds now regarded as of Canyon age. But these two genera are diluted by a host of characteristic Pennsylvanian types. The same is true of the bioherm (USNM 700g) south of the Arnold Ranch in rocks of Virgilian age. Here occur Scacchinella and Limbella, the former the most primitive species of the genus, the latter smaller than usual. Both attest to an early appearance relative to the Permian. All of these Permian precursors and others of certain Permian affinity occur commonly in the Uddenites-bearing Shale Member. Not only are typical Permian genera present, but many of those inherited from the Pennsylvanian such as Meekella, Hustedia, and Tropidelasma are Permian in their expression rather than Pennsylvanian. Thus, the evidence of actual Permian types and progressive Pennsylvanian forms gives the stamp of Permian. 
Rather than regard the Skinner Ranch Formation as Leonardian, we have placed it as the uppermost formation of the Wolfcamp Series. We do this not only because of the large number of Wolfcampian transients that finally rested there, but also because of the presence of distinctive persistent Pennsylvanian genera such as Kozlowskia, Fimbrinia, and Hystriculina. Most of the Pennsylvanian and Wolfcampian genera fail to cross the boundary into the Cathedral Mountain Formation of the Leonardian, or if they do cross, as Spyridiophora, Glyptosteges, and Torynechus did, it is evident they failed to flourish and died off early in the succeeding time.

Dating of the Road Canyon Formation has proved difficult because its fauna has not only many residual Leonardian elements, but also heralds of the Word Formation such as Echinosteges, Undulella, Paucispinifera, and Costispinifera. It also contains exotics difficult to date, such as Horridonia, Ombonia, and Tschernyschewia. Although Perrinites suggests Leonardian, the reported presence of Waagenoceras (Miller and Furnish, 1940: 173; Clifton, 1945; and P. B. King, 1931:139) and the few Word brachiopod genera mentioned above argue for a Guadalupian age. Our opinion as to its age is based on the overwhelming number of Leonardian forms and the termination of most of them in, or at the top of, the Road Canyon.

Paleoecology is a youthful subject now receiving the enthusiastic attention of many geologists and paleontologists. Some dangers exist in the present excitement. One of these is the ambiguity of views that may result in interpretation of an ancient environment of a stratigraphic unit based on its sediments as opposed to the reconstruction of the environment based on a study of the fauna. Large blocklike masses may be interpreted by the sedimentologist as exotic or moved blocks finally resting in deep water. The same block may be regarded as a bioherm, in place, replete with algae and shallow water fossils. In the Chinati Mountains along Sierra Alta Creek the brecciated beds of Udden are interpreted as reefs (bioherms) by us, but Rigby (1958) regards the same beds as reef slide debris. Sedimentological and paleontological evidence should agree where fossils are in growth position, but may not agree where they have been transported to form death assemblages. The fossils in many of the Glass Mountains bioherms and zotikepia are in natural growth position and, consequently, are reliable indicators of environment. See the section "Organic Accumulations in the Glass Mountains."

FIELD WORK.-Cooper's first visit to the Glass Mountains was in the fall of 1939, when he and Dr. Josiah Bridge of the United States Geological Survey spent five days collecting in the vicinity of Split Tank and on the south slopes of Hess Canyon (USNM 706). This visit was made for the specific purpose of obtaining specimens of "Prorichthofenia" and examples of the lyttoniidae, neither of which was represented in the collections of the United States National Museum at the time. The nine boxes of limestone lumps collected, totaling about 1800 pounds, were processed during the ensuing winter and provided the incentive for another collecting effort the following year.

Cooper spent two weeks, in the late summer of 1940, alone in the Glass Mountains and collected about 1700 pounds of small blocks to supplement those collected in 1939. By now the great possibilities of developing a fauna by etching were becoming evident.

In 1941, Cooper and Dr. Norman D. Newell, then of the University of Wisconsin and now of the American Museum of Natural History, spent one month in the area collecting large blocks. Although cooperation was necessary in the hard work of removing blocks, Newell and Cooper had different objectives. The former was interested especially in obtaining pelecypods, while Cooper wanted brachiopods. Blocks with conspicuous pelecypods were, therefore, sent to the University of Wisconsin. An understanding was reached between both collectors that good specimens of the desired phyla obtained in the etching of any of the blocks would be available to each other.

American participation in World War II, which began in late 1941, effectively postponed further work in the Glass Mountains for several years.

An extensive party was arranged for collecting in the Glass Mountains in 1945; this project was in cooperation with Dr. R. C. Moore, then connected with the United States Geological Survey as well as with Kansas University. Cooper was assisted by Dr. J. Brookes Knight, who was interested in finding blocks containing gastropods. The party 
spent one month working in all parts of the mountains and obtained more than five tons of blocks, the solid core of material around which the collection has been built.

In 1946 Cooper and Dr. Preston E. Cloud, then of Harvard University, spent two weeks in the Glass Mountains as an interval in a more extensive collecting trip with main objectives elsewhere. At this time localities, hitherto not extensively collected but from which the samples previously acquired showed promise, were revisited and larger amounts were taken. A field trip in 1947 made with Dr. Ellis Yochelson, United States Geological Survey, had the same purpose and was an interval in more extensive collecting farther to the west. In 1948 Cooper and Dr. Alfred R. Loeblich, Jr., visited the Glass Mountains for about two weeks, the chief object being to collect fossil sponges in which Loeblich was then interested. Another short visit was paid the mountains in 1949, again as an interval in a collecting trip with main objectives elsewhere. On this occasion Cooper was accompanied by Mr. William T. Allen, museum aide, and Dr. Alwyn Williams, a Commonwealth Fellow studying at the United States National Museum. A modest supply of blocks was obtained at this time.

In 1950 Cooper and Mr. Allen, accompanied by Dr. Harry B. Whittington of Harvard University, spent a month in the Glass Mountains. The time was chiefly devoted to collecting from Wolfcampian rocks in the Wolf Camp Hills. This expedition took more than 100 blocks.

In 1951 Cooper, Allen, and Mr. A. L. Bowsher, then of the United States National Museum staff, went to the mountains with the specific purpose of studying the stratigraphy of certain areas, particularly the Wolf Camp Hills and to collect goniatites needed to help date parts of the section. This party was successful in obtaining a large number of goniatites from several levels hitherto not collected; they also rediscovered an ammonite locality of Plummer and Scott, which is difficult to find because the old landmarks that had been used to identify it have long since disappeared.

In 1952 Cooper, Allen, and Bowsher on their way to New Mexico for a study of the Devonian and Mississippian joined Dr. N. D. Newell and party, who were camped at Pine Spring in the Guadalupe Mountains. Five days were devoted to making collections from the Cherry Canyon Formation, the Capitan Limestone and its equivalent, the Bell Canyon Formation. In the summer of 1953 Cooper, Allen, and Dr. Francis G. Stehli, then a graduate student at Columbia University, made more extensive collections in the Guadalupe Mountains and also spent 11 days in the Glass Mountains.

Trips prior to 1956 were primarily for collecting. Each succeeding visit was intended to make up a proved deficiency or failure on a preceding one or to follow a promising lead discovered in the course of prior sampling. The collecting naturally led to observations of the stratigraphy and, thus, constitute a test of prior mappings. After 1956 the visits to the mountains were made to test views on the stratigraphy as well as to collect in new areas. Again, laboratory reflections on the work of one season indicated significant areas for further study in the next.

In 1956, on the way to the International Geological Congress in Mexico, Cooper, Mr. L. G. Henbest of the United States Geological Survey, and Dr. C. O. Dunbar of Yale University spent several days in the Glass Mountains. While there they were joined by Mr. John Skinner and Mr. Garner Wilde, both of the Humble Oil Company. The party jointly studied Leonard Mountain and several other areas of uncertain stratigraphy. At this time the real nature of the Wolfcamp and Hess relationship on Leonard Mountain was established, and much of the rock mapped as Wolfcamp was proved to belong to the Gaptank formation.

In 1957 and 1958 Cooper and Dr. R. E. Grant, who was invited as collaborator, spent a month each year visiting new localities and correcting erroneous views on some of the old ones. Much time was devoted to a study of the Hess Ranch Horst and the related beds north of Hess Ranch and on the north side of Leonard Mountain.

The main objective of the 1959 trip by Cooper and Grant was to collect from the Bone Spring beds of the Sierra Diablo. Dr. F. G. Stehli helped the members of the party during their stay in these mountains, and some exceptionally fine blocks were taken. Some additional collections were made in the Guadalupe Mountains, and a one day visit was made to the Chinati Mountains. In the Glass Mountains on this trip some sampling was done 
in the First Limestone of the Word Formation of P. B. King, a horizon that had been largely neglected.

The expedition of 1961 was primarily to settle some bothersome problems of stratigraphy and to collect more from the First Limestone of the Word Formation, which had proved to be extremely rich. This expedition by Cooper and Grant also included another visit to the Guadalupe Mountains, again to collect additional blocks at certain key places in the hope of improving representation of some rare rhynchonellid and terebratulid genera and species hitherto represented by inferior or insufficient specimens.

The expedition of 1963 consisted of Cooper and Grant with the addition of Mr. John L. Carter, who had been engaged on National Science Foundation funds to run the acid laboratory and pick the residues. The object of this visit to the mountains was primarily stratigraphic. Many places were visited to test their stratigraphic level regardless of faunal content. Special emphasis was placed on investigation of the limestones of the Leonard on Dugout Mountain and a comparison of them with the numbered series of Leonard limestones in the Lenox Hills. Discovery of an interesting discrepancy between faunal zones and numbers resulted. In spite of the emphasis on stratigraphy, a large supply of blocks was taken on this expedition. In most cases single samples were all that resulted from many of the localities, but they helped to give more definite answers regarding age and ecology.

In April 1964 Cooper and Dr. J. T. Dutro of the United States Geological Survey visited the Glass Mountains for a few days on their return from a study of the Devonian in New Mexico. Their intention was to select some additional blocks from USNM 72lu in the hope of obtaining more specimens of some rare species (Siphonosia) from that level of the Cathedral Mountain Formation.

Grant and Cooper again visited the mountains for three weeks in late March and early April of 1965 with several objectives: to verify the age of the band of rock mapped as the First Limestone of the Word on the west side of Gilliland Canyon, which proved to have the fauna of the Third Limestone of the Word of P. B. King, to make additional studies of the Leonard limestones of the Dugout Mountain area, and to obtain a few blocks from selected localities.

In 1966 Cooper and his wife visited the mountains briefly to verify details of some of the bioherms and to consult with some petroleum geologists. At this time small collections of ammonites, fusulinids, and brachiopods were obtained from a number of new localities. The section up Sullivan Peak was also restudied.

In 1967 Grant and Cooper, accompanied by Dr. George A. Thomas of Australia and Dr. J. B. Waterhouse, then of New Zealand, spent several days acquainting these visitors with the section and collecting some areas hitherto not well studied. Prior to the arrival of Thomas and Waterhouse, Cooper and Grant measured and studied sections along the east front of the Sierra del Norte. An interesting development of the Road Canyon was discovered at this time.

A short visit was paid in 1968 to the northern part of the Delaware Basin to sample this area for silicified fossils. A few days also were spent in the Glass Mountains. On this trip Dr. John Roberts of Australia was a participant.

Following is a list of all the collections made for this program in West Texas:

\begin{tabular}{|c|c|c|c|}
\hline Year & $\begin{array}{l}\text { Number } \\
\text { of blocks }\end{array}$ & $\begin{array}{l}\text { Party (in addition } \\
\text { to Cooper) }\end{array}$ & $\begin{array}{l}\text { Approximate } \\
\text { weight (pounds) }\end{array}$ \\
\hline 1939 & $\begin{array}{l}9 \text { boxes } \\
\text { (small } \\
\text { lumps) }\end{array}$ & J. Bridges & 1800 \\
\hline 1940 & $\begin{array}{l}7 \text { boxes } \\
\text { (mostly } \\
\text { moderate- } \\
\text { sized small } \\
\text { lumps) }\end{array}$ & None & 1700 \\
\hline 1941 & $30+4$ kegs & N. D. Newell & 7500 \\
\hline 1945 & 360 & $\begin{array}{l}\text { J. B. Knight, } \\
\text { R. C. Moore }\end{array}$ & 10817 \\
\hline 1946 & 69 & P. E. Cloud & 5327 \\
\hline 1947 & 28 & E. Yochelson & 3527 \\
\hline 1948 & 64 & A. R. Loeblich & 9259 \\
\hline 1949 & 57 & $\begin{array}{l}\text { W. T. Allen, } \\
\text { A. Williams }\end{array}$ & 5093 \\
\hline 1950 & 107 & $\begin{array}{l}\text { W. T. Allen, } \\
\text { H. B. Whittington }\end{array}$ & 9148 \\
\hline 1951 & 40 & A. L. Bowsher & 4000 \\
\hline 1952 & 36 & $\begin{array}{l}\text { W. T. Allen, } \\
\text { A. L. Bowsher }\end{array}$ & 3600 \\
\hline 1953 & 33 & $\begin{array}{l}\text { W. T. Allen, } \\
\text { F. G. Stehli }\end{array}$ & 5994 \\
\hline
\end{tabular}




\begin{tabular}{|c|c|c|c|}
\hline & Number & Party (in addition & Approximate \\
\hline Year & of blocks & to Cooper) & weight (pounds) \\
\hline 1956 & 22 & $\begin{array}{l}\text { C. O. Dunbar, } \\
\text { L. G. Henbest }\end{array}$ & 2057 \\
\hline 1957 & 21 & R. E. Grant & 2390 \\
\hline 1958 & 40 & R. E. Grant & 5000 \\
\hline 1959 & 95 & R. E. Grant & 10552 \\
\hline 1961 & 102 & R. E. Grant & 14390 \\
\hline 1963 & 157 & $\begin{array}{l}\text { R. E. Grant, } \\
\text { J. L. Carter }\end{array}$ & 17000 \\
\hline 1964 & 13 & J. T. Dutro & 1400 \\
\hline 1965 & 56 & R. E. Grant & 6190 \\
\hline 1967 & 53 & R. E. Grant & 7670 \\
\hline 1968 & 74 & $\begin{array}{l}\text { R. E. Grant, } \\
\text { J. Roberts }\end{array}$ & 9900 \\
\hline & $\overline{1457}$ & & $\longdiv { 1 4 4 , 3 1 4 }$ \\
\hline
\end{tabular}

Collaborators.-As indicated earlier, this program had humble beginnings. It was not intended originally to monograph a fauna or revise stratigraphy of the Glass Mountains when the first collections were made in 1939. These, however, proved the potentialities of a study of the Glass Mountains fossils, and the collections of the next two years inspired the idea that a gigantic, fairly complete fauna could be obtained by dissolving Permian limestones. This meant that, not only the brachiopods, but all of the other groups obtained by the solution method also should be monographed. The method is the only one likely to yield a nearly complete fauna.

In accordance with this idea, the extensive collctions of 1945 suggested the possibility of enlisting the aid of a number of colleagues who were specialists in the various phyla represented in the Glass Mountains. At the outset, Newell and Cooper joined forces, but after the conclusion of World War II in 1945, Dr. J. B. Knight and others were invited into the program. The general scheme was outlined by Cooper and Knight (1946:625). This original plan, like most ambitious schemes, has since been greatly modified. The original personnel involved are represented only by Cooper, Newell, and Moore, with occasional others who can be induced to participate.

It was planned in 1946 that Dr. R. C. Moore would undertake description of the corals, bryozoans, and crinoids, each of them a gigantic task. Although corals are not abundant in the Glass Mountains, neither are they rare. The coral collection is large and includes many choice speci- mens. Bryozoans are legion; in places they make up a large percentage of the rock and can be found nearly everywhere in the area. They are obtained in absolute perfection of colonial form, but the inner details, revealed by thin sections, usually are sporadically preserved. Mr. Gary Gautier of Kansas University is now studying the Leonardian bryozoans. Crinoids are not common, but in places microcrinoids are numerous. Well over a thousand specimens have been taken, which are being studied by Dr. R. C. Moore and Harrell Strimple.

Dr. Porter M. Kier (1958:889; 1965:453-456) described and illustrated a new genus of echinoids and figured some of the unusual club-shaped echinoid spines common in the Word Formation (China Tank Member).

Under the original arrangement Dr. J. B. Knight was to have described all of the gastropods. These, however, were obtained in such numbers that he had to call for help. As a result, Dr. Roger Batten, American Museum of Natural History, undertook a study of the pleurotomariacean gastropods and published (1958) an extensive monograph on them. This is not his last work on the subject, because new specimens are frequently obtained. $\mathrm{He}$ is still at work on families not appearing in the aforementioned monograph. Dr. Ellis Yochelson, now of the United States Geological Survey, selected the nonslit-bearing snails, the Bellerophontacea, Patellacea, Euomphalacea, Trochonematacea, and several other groups. His studies have appeared as two monographs (1956 and 1960). These two large papers do not exhaust these nonpleurotomariacean groups of gastropods, and many species are yet to be described. Nevertheless, our knowledge of the gastropods of the Glass Mountains has been greatly advanced by these studies.

At first, all cephalopods were sent to Dr. Arthur K. Miller at Iowa University. These, except for the main body of ammonoids collected in 1951 and later, were described with his characteristic dispatch. The first of these was a description of some exceptional ammonoids from the Road Canyon Formation (Miller, 1945a) and the second described some of the nautiloids (Miller, 1945b). Further information on Glass Mountains nautiloids based on silicified specimens was published in Miller and Youngquist's (1949) monograph on the American Permian nautiloids. 
The Wolfcampian part of the large collection of ammonoids made in 1951, with later additions, and placed in the hands of Dr. A. K. Miller at the University of Iowa, was turned over to Mr. Richard W. Moyle, an Iowa graduate student who has prepared a monograph on them under the direction of Drs. W. M. Furnish and B. F. Glenister. Identifications obtained from Drs. Miller, Furnish, Glenister, and Moyle have been added to the brachiopod lists as a help toward stratigraphic orientation.

Drs. Furnish and Glenister are restudying all Permian ammonoids, including those collected from the Glass Mountains in preparation for a reevaluation of Permian correlations and a revision of many of the genera.

The pelecypods, of which there are hundreds from the Glass Mountains, are being studied by Dr. N. D. Newell of the American Museum of Natural History. Dr. Donald M. Boyd of the University of Wyoming and Dr. Bruce Runnegar, Queensland University, Australia, are collaborating with him.

In the original plan, no provision was made for study of the sponges, because few good specimens had been taken at that time. In 1948 Cooper and Loeblich made a special effort to obtain sponges and achieved considerable success. Because remains of these animals appear in most of the residues, the collection finally obtained is large. The Glass Mountains sponges, combined with those from the Guadalupe Mountains that belong to the American Museum of Natural History, as well as those of the National Museum of Natural History (under USNM numbers), were turned over to Dr. Robert M. Finks (1960), who published a large monograph on the silicious sponges. $\mathrm{He}$ is presently working on the calcareous sponges.

No definite plans have been made for the study of the trilobites, the collection of which is growing slowly. Dr. J. Marvin Weller (1944) described a number of specimens sent to him at an early stage of the collecting.

A few other Glass Mountains species have been described as special items. Dr. R. M. Finks (1955) described a Conularia associated with a sponge. Dr. Donald Fisher, New York State Museum, has the scaphopods and hyolithids. Dr. Allyn G. Smith, California Academy of Sciences, is describing the chitons, plates of which are common at some localities.

We have enjoyed substantial aid from three students of the fusulinids, to whom we have appealed for help from time to time. It has been our aim, as far as possible, to document our brachiopods with important occurrences of fusulinids and ammonites. Dr. Carl O. Dunbar of Yale University identified many lots from Gaptank, Wolfcamp, and Hess Formations. Dr. Charles A. Ross also identified a number of lots including those sent to Dr. Dunbar, from Wolfcampian, Leonardian, and Guadalupian rocks. Mr. Garner Wilde of the Humble Oil Company, Denver, Colorado, identified many lots and spent several days in the field with Cooper and Grant locating collections in important places. The names of many of the species identified by these experts are recorded with the brachiopod locality lists.

Acknowledgments.-In a project as large as this, with its ramifications and collaborators, thanks are due to many people for favors. Acknowledgments are owing for official encouragement and financial support, for permission from owners to work on the several private ranches that cover generous parts of the Glass Mountains and other areas, and to colleagues who have given favors, specimens, or other help.

First, we express our gratitude tol Dr. Philip B. King, United States Geological Survey, for help in locating the areas of best collecting at the beginning of the project.

This study never could have been accomplished were it not for the enthusiastic support of Dr. Alexander Wetmore, sixth secretary of the Smithsonian Institution. Dr. Wetmore took special interest in the work of dissolving the blocks and came often to see the growing collection. He authorized many field trips to the Glass Mountains and financed them from the Walcott Fund of the Smithsonian Institution-for all of which we thank him.

It is a pleasure also to record thanks to Dr. Wetmore's successors: Drs. Leonard Carmichael and S. Dillon Ripley, seventh and eighth secretaries, who also authorized the use of Walcott money for field work in the Glass Mountains. Other officials of the Smithsonian to whom thanks are expressed are Drs. A. R. Kellogg, A. C. Smith, and T. Dale Stewart, former directors of the National Museum of Nat- 
ural History, and the present director, Dr. R. S. Cowan. Drs. R. S. Bassler and W. F. Foshag, former head curators of the Department of Geology, approved all of the proposals for work in the Glass Mountains.

The United States Geological Survey has aided the project in many ways: chiefly by allowing free access to specimens in collections made by Geological Survey parties; by approving Grant's requests for field work in west Texas, and by providing vehicles for several of the collecting and study trips. In addition, the Geological Survey gave Grant official time and administrative and logistical support for a trip to the Salt Range of West Pakistan to gather comparative Permian material, a project that was an outgrowth of the west Texas project.

We thank three members of the National Museum of Natural History staff for their assistance in preparation of the illustrations: Mr. Jack Scott made about one-third of the photographs, including those of the Rhipidomellida, Strophomenida, and Spiriferida, amounting to more than 10,000 negatives; Mr. Andrew Wynne printed all of the negatives, those made by Scott and the many made by Cooper; Mr. Lawrence B. Isham made all of the maps accompanying this monograph and the drawing illustrating some details of anatomy of some of the specimens.

Acknowledgment is gratefully made to the $\mathrm{Na}$ tional Science Foundation for financial assistance, which permitted the attachment of Dr. R. E. Grant, as co-author, on an original grant (G-3805) for four years. Unfortunately, this period was not long enough, and the grant was renewed (G-18680) for two years. The new grant also permitted the addition of four successive helpers to care for and catalog the collection: Mr. George Hamilton, Miss Jane Goodwin (now Mrs. James Ferigno), Dr. John L. Carter, and Mr. Mohammad Ghahhari.

Mr. Leo Connors, museum aide, also assisted in the sorting of the collections and picked many of the residues. Dr. A. R. Loeblich, Jr., served as field collaborator in 1948 .

The good will of property owners in a study of this sort is essential. Happily we were permitted freedom on all of the ranches in the Glass Mountains, from Dugout Mountain to the Fort Stockton-Marathon highway at Gaptank. Thanks are due to Mr. John Catto and to Mr. Travis Roberts, owner and foreman of the Catto-Gage Ranch on which Dugout Mountain is located. The Decie brothers, Zennis, Zeb, and Zoye, have been most kind, cordial, and helpful throughout the many years of collecting and study. This is true also of the late Mr. Leonard Hess and Mrs. Hess, whose ranch includes part of Leonard Mountain, the Hess Ranch Horst, and other important places. Mr. and Mrs. Hess welcomed us and helped us in every way possible. Mr. W. R. Blakemore, II, of the Iron Mountain Ranch (Skinner Ranch of the Altuda quadrangle) has been most helpful with his permission and the use of a jeep, not only at Iron Mountain, but also on the Corn Ranch in the Sierra Diablo. Mr. David L. Allen now of Kyle, Texas, formerly foreman of the Iron Mountain Ranch, was also most helpful and cordial and took a keen interest in our work.

The Split Tank area is one of the key collecting places in the Glass Mountains. Mr. Carl Appel, owner of the Old Word Ranch on which the tank is located, gave permission to work in all parts of his ranch. Smithsonian parties were also welcomed when this property was leased by Messrs. Fenstermaker, Charles L. Thomas, and Weir Hall. The Wolf Camp Hills are one of the most interesting and geologically important parts of the Glass Mountains. Here Smithsonian parties were not welcomed by one of the lessees, and work there had to be discontinued for some time. Mr. Bill Neal and son, however, permitted parties to work there on several occasions and good collections and much information were taken from this place. The ranch farthest east visited by us is that of Conoly Brooks, who cordially gave permission for work to be done on his property and, on one occasion, came out to observe our efforts. Mr. and Mrs. R. A. Ligon of Nickel Creek, Guadalupe Mountains, gave permission to work on the former Hegler Ranch in the Guadalupe Mountains.

We are grateful to Mrs. Loraine Love Johnson and Mr. Russell White for their kindness in permitting us to work on their properties in the Chinati Peak Quadrangle.

Two men who helped us immeasurably in our work are Mr. J. N. Allebrand, formerly manager of the Parkway Hotel in Marathon, Texas, and Mr. Frank Wedin of Marathon. The former interceded in behalf of museum parties on several occa- 
sions and gave the use of the hotel yard for the storage of blocks and a place where they could be prepared for shipment. Mr. Wedin carted the plunder to the freight station. Mrs. Frank Wedin also helped with information on place names and historical information.

Mrs. Walter Glover of Pine Spring Camp, Texas, permitted us to work on her property and interceded in our behalf with other ranchers. We had the help of the officials of Carlsbad Caverns National Park on two occasions. We acknowledge the permission of Mr. Wallace Pratt to work in the McKittrick Canyon area, when he owned that beautiful place.

We thank Mr. J. C. Hunter of Abilene, Texas, for permission to collect in the vicinity of Guadalupe Peak and Mr. Noel Kincaid, his foreman, for help and information concerning the country around Guadalupe Peak.

To all of these men and women, we give not only our thanks but those of the Smithsonian Institution.

In the spring of 1965, Peabody Museum, Yale University, presented some blocks from the Glass Mountains that were no longer needed.

Dr. R. C. Moore transferred to the Smithsonian Institution 750 specimens of clean silicified specimens from the Glass Mountains from the collections made in 1945.

Mrs. Josephine W. Cooper, wife of the senior author, has helped the project in many ways: picking and sorting specimens, translating descriptions of genera and species described in Russian publications, cataloging many of the specimens, helping to solve bibliographic problems and to number the plates. Mr. George Reed helped with typing and checking generic names.

\section{The Glass Mountains}

(Sierra del Vidrio)

The fame of the Glass Mountains rests on the fact that they are composed of one of the most fossiliferous sequences of marine Permian rocks in the world. They are, therefore, well known to geologists and especially to the oil geologists who have studied them to obtain better knowledge of subsurface Permian. The mountains are reached easily by good roads from west, east, and north.
Their western extremity lies southwest of U. S. Highway 90, 236 miles southeast of El Paso, and their eastern end crosses U. S. Highway 385 about 33 miles south of Fort Stockton. The mountains trend in a northeast-southwest direction for about 35 miles, merging in the south into the Del Norte Mountains and in the east they pass under the Edwards Plateau. The Glass Mountains form the northwestern and western sides of the Marathon Basin, a lowland underlain by strongly folded Lower Paleozoic, Pennsylvanian, and Permian sediments.

The eastern face of the Glass Mountains is formed by steep slopes and in places bold cliffs. The relief along the mountain front is about 1,200 feet. Deeper in the mountains the relief is in places 2,500 feet above the village of Marathon, which lies on U. S. Highway 90 a few miles south and east of the mountains. The maximum elevation in the mountains is 6,523 feet on the western side of Gilliland Canyon, west of bench mark 4973. In most parts of the mountains in which the collections were made the relief is about one thousand feet or slightly more.

Although the Marathon Basin and Glass Mountains are in a semiarid region, the country has wide areas of grassland. Consequently, large ranches that have operated for many years are located in and near the mountains. Good ranch roads branch out through the hills and make most parts readily accessible. This is especially true of the mountain front and for four or five miles beyond it in the interior. Where roads are not available, it is usually possible to drive over the desert floor with an ordinary vehicle.

The Glass Mountains area is well depicted on three topographic maps. The extreme southwestern part appears at the northern end of the Monument Spring (15') quadrangle; the Lenox Hills area is shown on the lower third of the Altuda (15') quadrangle and the longest portion is in the middle part of the Hess Canyon (15') quadrangle. The contour interval is 50 feet, which permits the relief to be shown in considerable detail. A good geological map, using the above quadrangles as a base was prepared by P. B. and R. E. King and was published in 1931 (in P. B. King, University of Texas Bulletin 3038). Aerial photos also are available for these mountains. 


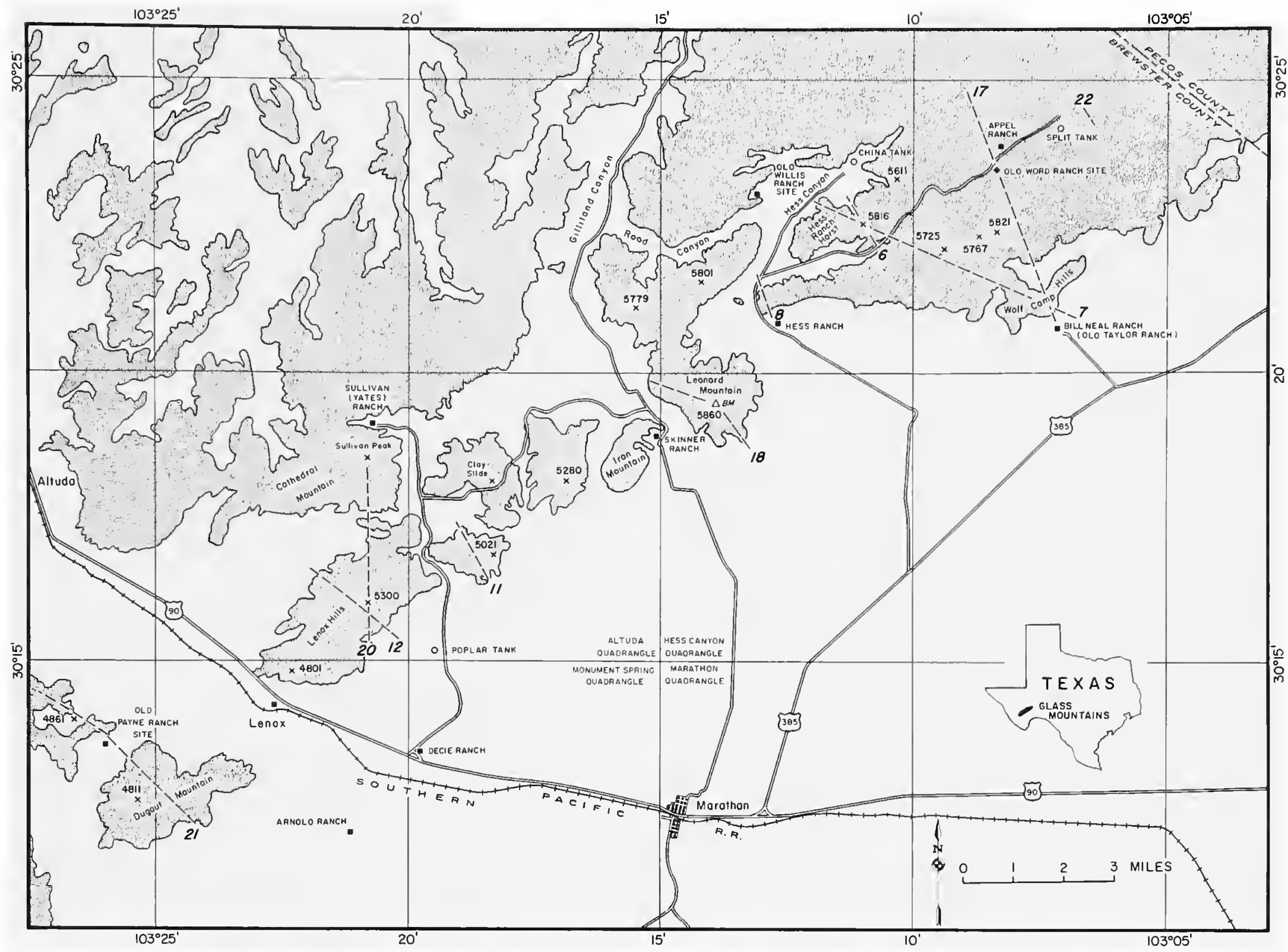

Figure 1.-Important geographic locations in the Glass Mountains (broken lines and italic numbers indicate cros-sections figured in the text; $B M=$ bench mark).

Many of the topographic features of the Glass Mountains have not received names, a fact that makes description of localities difficult; however, several salient points have been named and should become familiar to the interested geologist. On the Monument Spring quadrangle, Dugout Mountain (Plate 21: figure 4) forms an isolated cuesta on the western side of U. S. Highway 90 and is the western termination of the Glass Mountains. On the opposite side of the highway, the Lenox Hills (all in the Altuda quadrangle, Plate 21: figure 3) form foothills to the mountains. Although the name "Lenox Hills" actually refers to the hills adjacent to U. S. Highway 90, these foothills extend northeast to a conspicuous igneous plug called Iron Mountain. On the north of the Lenox Hills and separated from them by a broad valley is Cathedral Mountain (Plate 1: figure 3), a bold, scarp face capped by the thick Capitan dolomite.

The syenite plug called Iron Mountain is conspicuous because of its reddish-brown color and extremely rugged surface. Its igneous composition and consequent contrasting weathering form make it unique in the mountains and an excellent landmark. It divides the region roughly into two parts and occupies the extreme eastern end of the Altuda quadrangle. Important landmarks on the mountain front from Iron Mountain to Gaptank on the Fort Stockton road (U. S. Highway 385), all in the Hess Canyon quadrangle, are: Leonard Mountain (Plate 6: figure 3; Plate 8: figure 2) and the Wolf Camp Hills (Plate 2: figure 2). Leonard 
Mountain has the form of an arrowhead with the point directed to the southeast. This mountain is significant in having a stratigraphic section intermediate between an essentially limy facies on the east and a predominantly shaly sequence of Lower Permian rocks. On their north side rises the high and steep face of the main mountain mass, but it has not yet been given a name. Northeast of Leonard Mountain about 2.5 miles, lies the short chain of hills called by P. B. King (1931:56) the "Hess Ranch Horst" because it is an uplift of older rocks among younger ones (Plate 21: figure 5).

Several canyons permit access deep into the mountains, but not all of them have been named. From the Decie Ranch in the Altuda quadrangle the mountains may be penetrated on a road that leaves the plain and enters a canyon ultimately reaching the Sullivan Ranch (now Yates Ranch). Gilliland Canyon extends northward from Iron Mountain far into the mountains.

Hess Canyon is the most conspicuous valley on the western side of the Hess Canyon quadrangle, but it is unusual in containing a divide within it and in having two branches. Another canyon is also known to the ranchers as Hess Canyon. This one extends northeast from the south-flowing branch of Hess Canyon to the site of Old Word Ranch and the mountain top just beyond it. It is possible that this is the "Comanche Canyon" mentioned by Girty (1909:512) in his descriptions of fossils collected in the Glass Mountains by $R$. T. Hill. Mr. Leonard Hess, owner of part of the property on which this canyon is located, corroborated this supposition. This identity is also borne out by some of the species identified by Girty, which are known commonly only from this part of the mountains.

According to P. B. King (1938), the Glass Mountains were formed when the Marathon Basin originated. This resulted from a doming of the Edwards Plateau at its western side, where it reached the Cordillera. The stripping of the Cretaceous sediments of the Plateau exhumed the Paleozoic sediments beneath, creating a window, as it were, in the Plateau. Differential weathering in a semiarid climate left the resistant limestones and dolomites of the Permian in high relief on the northern side of the Marathon Basin and thus produced the Glass Mountains.
The Permian strata of the Glass Mountains are inclined to the northwest about 10 degrees, forming long dip slopes in places (Plate 21: figures $3,4)$, but in others, as on the northern side of the mountains in general, the slope is the old erosion surface on which the Cretaceous was laid. The Permian overlies the basin rocks unconformably, in places resting on the Pennsylvanian, but in others on klippen of the Devonian thrust over the Pennsylvanian. A detailed account of the geology and stratigraphy of the Marathon Basin was prepared by P. B. King $(1931,1938)$. The stratigraphy of the Permian of the Glass Mountains is fairly simple, but the facies relationships of the strata are extremely complicated.

The Permian of the Glass Mountains includes Lower Permian (Wolfcamp Series) at the base, comprising the Uddenites-bearing Shale Member of the Gaptank Formation, the Neal Ranch and Lenox Hills formations mostly of shale, followed by the Lenox Hills and Skinner Ranch formations of calcarenite and conglomerate. These are succeeded by the Leonardian Cathedral Mountain and Road Canyon formations, a succession of limestone and silicious shale. Many of the limestones of the Leonardian are sandy and conglomeratic. The Guadalupian Series of rocks that follows is generally without conglomerate and consists of the Word Formation, a thick silicious shale sequence with thick, sandy limestone wedges. This is followed by heavy, bedded dolomites representing the Capitan Formation. Inasmuch as silicified fossils occur from the Wolfcampian through the Word Formation, but not beyond, our discussion of the stratigraphy will include only the Wolfcampian, Leonardian, and Word formations, with an incidental comment on the Capitan.

As noted above, the stratigraphic section in which we collected is restricted; this is true also of the geographic area. We have not covered the entire area of the King map of the Glass Mountains, nor have we investigated the sections east of the Fort Stockton road (U. S. Highway 385). These do not contain silicified material and therefore were not visited. $T_{0}$ the rest we extended our studies to the eastern slope of the Del Norte Mountains in the area northwest and, for a few miles, south of the site of the Old Payne Ranch in the Monument Spring quadrangle. This area contains 
a good development of the Road Canyon Formation and a sandy manifestation of the Word Formation, both overlying a poorly exposed section of the Cathedral Mountain Formation. The latter is also sandy and conglomeratic but contains interesting faunas, especially the Perrinites in conglomerate. We made a brief survey of these formations in the Del Norte Mountains and Altuda Mountain, which lies to the north of the Old Payne Ranch. We did not trace the Cathedral Mountain Formation in its thinned manifestation more than a mile or two east of the Split Tank area.

\section{Building the Collection}

After the early trips to the Glass Mountains, during the period of collecting small pieces, we realized that an enormous treasure of fossils lies buried in these limestones. This led to the idea that the successive faunas of the various strata could be developed by dissolution of the limestones. It was also realized that continued collecting of small pieces would not yield significant results. By 1945 we decided to collect in quantity and to increase the size of the blocks. It seemed possible to obtain the faunal succession by this means and to amass a great collection of the various types of animals preserved in beeckite.

The program thus graduated from the dissolution of small scraps of limestone "on the window sill" to the purchase by the museum of a stone tub that would hold the larger blocks. Accordingly, a tub of some 90 gallons capacity was set up, and etching of the large pieces started. A short time later two porcelain tanks of the same capacity were added. The stone tub proved to be a problem because it was not fitted with proper fixtures for stopping the outlets. Nevertheless, it gave good service until one day, when unattended for several days, it released its virulent contents over the floor of its upstairs room. The active liquid leaked onto the exhibition floors below, but no harm was done. This accident warned that the locale for the work had been poorly selected. The result was the erection of a small building especially designed for dissolving blocks in acid. Here, two porcelain tubs were installed, and a third tub, much larger than the others, was added. The latter, composed of acid-resistant Haveg material, was designed to hold a block up to 400 pounds in weight. In addition to the three tubs owned by the National Museum of Natural History, two others, belonging to the United States Geological Survey, were installed in the room. With this increase in equipment, all the facilities for a large-scale program were at hand. In the 10 years following the erection of the "acid house," as this structure in the museum's east court was dubbed, approximately 30,000 pounds of limestone were processed.

In 1959, when it was necessary to make way for the erection of air-conditioning apparatus for the museum building and the new wing to be built on the east side, the program was interrupted only momentarily to transfer the acid equipment to the ancient and inadequate Escanaba Hall, where a small basement room was assigned to the work. Here, two tubs 2.5 by 4.5 feet by 20 inches deep were installed along with a smaller porcelain tub, 2 by 4 feet by 1.5 feet deep. The dissolution of blocks was thus carried on throughout the period of construction on the east wing.

The New Laboratory.-When the east wing of the National Museum of Natural History building was planned, provision was made for two acid laboratories, one for the museum and one for the Geological Survey. That of the museum originally was very spacious, measuring 80 by $19 \mathrm{feet}$, and is located on the ground floor on the north side of the building. The laboratory contained five tubs (now three) 4 by 2.5 feet by 18 inches deep.

Hoods are mounted over the tubs to bear off the noxious fumes. In the middle of the room there is a large, stainless steel washing trough. A drying oven completes the equipment. The tubs are drained as explained below and are emptied directly into the main sewer by rubber siphons into floor drains. There is no plumbing connected to the tubs, but faucets are mounted over them to facilitate filling the tubs with water and washing them (Plate 1).

In order to accommodate sedimentological work in 1967, the "acid room" was reduced to about half size, with three active tubs, the washing tank, and the drying oven. This is the equipment of the laboratory at the present time, when the need for extensive dissolution of blocks is much less than before. 
Selecting the Blocks.-In collecting blocks the selection of any piece for solution is made with considerable deliberation. At no time has the collecting consisted of random sampling, although some people believe that the results would have been the same. Each block selected was studied to be sure that it contained a minimum of chert, which is usually a dead loss and a danger to the more delicate material if it plunges onto a screen full of good specimens. Each block selected must contain signs of silicified shells on all six sides. It was necessary to trim some blocks to eliminate material of probable low yield. At USNM 706e, for example, many of the best blocks, when pried out of the ground from the parent ledge, proved to be about 2-2.5 feet deep but with only 1 foot of material at the top having a good concentration of fossils. Consequently, these blocks were trimmed by use of sledge hammers to eliminate the part without numerous specimens. The location of pieces meeting the specifications frequently took considerable searching. This care was worthwhile, in our opinion, because only a few blocks out of the hundreds dissolved (less than 1 precent) proved to be duds because of buried chert masses or poor distribution of, or lack of, specimens.

Once collected, the blocks were treated with considerable care, on the theory that they were irreplaceable. For shipment, they were jacketed in burlap sacks, which were elaborately sewed on and then reinforced with wire bands. Later it was found to be easier to wrap the blocks in burlap and encase them with steel straps applied by a banding machine. The reason for the banding and wrapping was to save the pieces in the event blocks did get broken during shipment. One or two blocks usually were broken in nearly every shipment, but the pieces were held together by the wrappings, and seldom was the broken block a complete loss (Plate 9: figure 4).

Blocks totaling 1457 in number and comprising sizes above 50 pounds were collected and processed. No quantitative data have been collected for the project as a whole. One large block, from USNM 706e and weighing 186 pounds, was studied quantitatively for an article published in Life magazine (22 June 1953). It yielded 30 pounds of insolubles, 5 pounds of which were clean, sugary quartz sand. The other 25 pounds were fossil shells, many of them complete, but many broken and of all sizes. Actual count of the larger shells was 3000; estimate of the smaller specimens indicated about 7000 (of brachiopods only; great quantities of bryozoa were not included in the count). Thus, the block had at least 10,000 useful specimens besides a great quantity of unusable debris. Not all blocks were that prolific, but some were more so. Blocks from USNM 702c, with their countless tiny specimens and lack of sand or other nonfossil insolubles, probably would yield far more specimens than the preceding. It is safe to say that no other form of collecting would yield so many good megafossils for so small a volume. The specimens were packed by current action into the small volume with an amazing economy of space.

Silicification.-No studies have been made on the physico-chemical causes for the silicification in the Glass Mountains. The subject probably is complex, and no single method of silicification will explain all of the occurrences. Several possible sources of silica that may have played a role in the silicification occur within the rocks. Some of the rocks are spiculite, and sponge spicules are a known source of silica (Pittman, 1959:132) for altering shells. Radiolaria also are present in some of the sediments. In addition to these sedimentary sources of silica, the region is one of volcanic activity. The Iron Mountain plug and its dikes probably account for some of the dolomitization and some of the silicification.

Silicification of the fossils is not uniform geographically, nor are all types of fossiles silicified. Generally it may be said that the region west of Iron Mountain contains less prolific occurrences of silicified fossils than that to the east and north. In the Lenox Hills the Decie Ranch Member shows much silicification on the outside of the blocks, but many specimens on the inside are marked only by patches of beekite on otherwise unsilicified shells. This is most unfortunate, because it has made diffcult the collecting of the remarkable gigantic fauna of this member. Most of the large Derbyia. Scacchinella, and Geyerella taken from that member and the higher Sullivan Peak Member were obtained by breaking the specimens out with sledge hammers, a method not productive of high quality material, especially of specimens with spines such as Scacchinella. The spines, bound to the matrix, 
cause peeling of the outer shell layers when the matrix is broken.

In the immediate vicinity of Iron Mountain, considerable dolomitization has occurred. In many places this has completely destroyed the fossils. In such areas, as that in the upper Cathedral Mountain and the Road Canyon Formations west of the divide and 3.5 miles northeast of Hess Ranch, fossils are almost impossible to extract. In the region around the Old Word Ranch house, Word dolomites yield good silicified material. Generally, however, dolomites are a loss for good fossils.

The Glass Mountains silicified fossils generally can be divided into two types of preservation: siliceous coatings and complete alterations to silica. USNM localities $706 \mathrm{c}$ and $702 \mathrm{c}$ are examples of the former method. At these places many of the specimens are coated by a thin film of silica, which, when unbroken, protects their interior from the acid. Crinoid stems and echinoid spines from the former locality that have been in an acid bath for more than three weeks may be broken after removal and may prove to have unaltered calcite in the interior. The inside is protected by the thin coat of silica. If these specimens have a small hole or crack in them, they often emerge from the acid bath as thin, hollow shells, only the delicate siliceous coating being preserved. At USNM 702c the larger spirifers are preserved in the same way, unbroken ones having unaltered calcite between the siliceous coatings. Some specimens that had cracks in them, however, have been reamed out by the acid and are recovered as the most delicate of hollow shells, the interior shell surface being represented by a thin layer that preserves all the details and the exterior surface as an equally thin and delicate sheet. Specimens preserved this way often must be filled with plaster of Paris to preserve them.

The other type of preservation is found at the Split Tank area and several other places. Here, many of the shells consist of a thick, single layer of silica, in some cases showing distinct beekite rings but, in others, just a bluish chalcedony-like silica. It seems evident that the calcite of the brachiopod shells has been removed and followed by deposition of silica. Shells of this type often are so coarsely silicified that the fine details of the anatomy and shell sculpture are destroyed. Nevertheless, the gross interior often is preserved in sufficient detail to permit adequate generic determination.

Kinds of SillcifiEd Fossils.-All kinds of invertebrate fossils are taken from the insoluble residues from all parts of the column in which silicification has taken place. Small protozoa are not common, but fusulinids are frequent to abundant. The smaller foraminifera seldom are found in a silicified state, although they have been diligently sought. They occur in countless numbers in some parts of the column such as the Neal Ranch Formation and in the Decie Ranch Member of the Skinner Ranch Formation. Foraminifera, ones with thin tubes that ramify over brachiopod shells, are common in most of the formations.

Sponges abound in many parts of the section and are often exquisitely preserved. They occur in especial profusion in several bioherms in the lower part of the Road Canyon Formation and in others in the upper part of the same formation. They also are conspicuous elements of the bioherms in the Hess Formation (Taylor Ranch Member; Plate 19: figure 2) at the level of the Sullivan Peak Member. Other bioherms yield sponges in considerable abundance such as those in the Neal Ranch Formation and in the Skinner Ranch Formation (USNM 705a) north of the Hess Ranch house.

Generally corals are fairly common, but they do not make much of a contribution to the strata. They are usually small solitary cups, but some colonial types appear in the Uddenites-bearing Shale Member and in the Neal Ranch and Hess Formations. Except for some fairly large heads of Syringopora-like corals in the former, they are seldom very large. Small colonies of Cladochonus and Thamnopora are conspicuous in some of the residues (USNM 702c). The corals, however, are not reef-building animals in the Permian of the Glass Mountains.

Bryozoans play a far greater role in contributing to the stratal construction of the mountains than do the corals (Elias and Condra, 1957). Some beds are composed almost completely of their colonies. Massive bryozoans are fairly abundant in most of the bioherms, but the fenestellids in some occurrences are still more numerous. In fact some of the bioherms (USNM 714w, 723v, 702un) are so rich 
that they may be called bryozoan bioherms (see "Bioherms").

Brachiopods are the most abundant of the silicified megascopic animals in the Glass Moutains, occurring in nearly all of the levels. They are also so common in some bioherms that their name is given to the bioherm; thus, the bioherms in part of the Decie Ranch Member may be designated Scacchinella bioherms and some of those in the lower part of the Road Canyon Formation may be called Hercosestria or Coscinophora bioherms (Grant, 1971).

Silicified Gastropoda, unlike brachiopods, seldom occur in great numbers. They are scattered sparsely through the faunas. Althougl sporadic in occurence, they display great generic and specific differentiation. Their variety is very great, although their numbers are small. A few locations in which they were found in abundance are known-for example, the "sponge bioherm" of USNM 703c in the Road Canyon Formation. They also were found in considerable variety and fair abundance in the sponge bioherms in the upper part of the Hess Formation (Taylor Ranch Member). The association of sponges and a variety of snails also was noted in the Guadalupe Mountains at the famous Cherry Canyon (Getaway Member) "sponge bed" at AMNH 512 (=USNM 728). A location abounding in snails but without the accompanying sponges was seen in the Cathedral Mountain Formation (Wedin Member, USNM 717e) on the north side of the Lenox Hills, and USNM 721 u produced an abundance of well-preserved gastropods.

Similar remarks apply to the Bivalvia, which occur in abundance in the sponge beds (USNM $703 \mathrm{c}$ and 728), but which are fairly scattered elsewhere. They do not occur in the variety of kinds that characterizes the gastropods, but any block from any level may yield a molluscan surprise. Most of the environments represented by the Glass Mountains strata were not favorable for Bivalvia. Fine muds and sands, the usual bivalve environment, are rare.

Cephalopods occur throughout the section. Nautiloids rarely are gregarious, but two such concentrations were seen (USNM 702a and 703a). Generally these are rare fossils and many are large. It is difficult to dissolve large nautiloids from the rock. A large silicified specimen that would have measured a foot or more in diameter was seen in matrix, but it had been the victim of a vain attempt at collecting and was so damaged as to make it unworthy of removal. Good silicified nautiloids are prizes, and every effort to collect them was made when they were encountered (Miller, 1945b; Miller and Youngquist, 1947).

Ammonites are far more abundant than nautiloids, but they are seldom well silicified and are most successfully collected by breaking them from the rock. One conspicuous example of silicified ammonites of high quality is that at USNM 703, described by A. K. Miller (1945a). They came from the upper part of the Road Canyon Formation. Most of the ammonites collected were picked up loose as limonitized fillings in the upper part of the Gaptank Formation (Uddenites-bearing Shale Member) or were broken from conglomeratic beds of the Gaptank, Neal Ranch, Lenox Hills, and Cathedral Mountain Formations. It is an odd fact that the best ammonites were taken from limestone conglomerates having a variety of ragged or rounded pebbles and also an abundance of plant seeds and fragments of wood. The ammonite bed near the middle of the Lenox Hills shale on Dugout Mountain is a conspicuous example (USNM 715). Another prolific ammonite zone in the conglomerate is at the base of the Lenox Hills Formation (USNM 707j) just west of the Devonian klippe at the Slick-Urschel Oil Company No. 1 Mary Decie-Sinclair Well. A still more striking one with large Perrinites is at USNM 732u in hill 4861, Dugout Mountain area. The ammonites found in conglomerates may represent dead forms floated into shallows or onto beaches. In this way they become mixed with land-derived pebbles and plant debris (Hamada, 1964).

Chiton plates and scaphopods were etched from the sponge bioherms (USNM 703c, 728) and a few other localities.

Evidence of echinoderms is seen in all of the insoluble residues. Their fragments often constitute a sand or gravel in places such as in the China Tank Member of the Word Formation (USNM 706c), where botl crinoids and echinoids supply their parts to the debris. At this place echinoids are conspicuous in the form of large, odd, clubshaped spines (Kier, 1958). Huge crinoid stems characterize parts of the Lenox Hills Formation 
and are especially characteristic of the Decie Ranch and Sullivan Peak Members. These huge stem segments, 2 inches in diameter, occur in profusion about the Scacchinella clusters, forming essentially a crinoid stem conglomerate. Small crinoids ranging from the size of a pea to that of a pin head are common in some localities (USNM 702c and 706c), but generally large crinoid heads are rare. Crinoid debris is also abundant in the interbiohermal areas of the lower Skinner Ranch Member (USNM 720e). A few ophiuroids have been etched from two localities (USNM 703c and 75li). The specimens and isolated plates show the presence of these fossils so difficult to preserve. Huge crinoid stems are diagnostic of Wolfcampian rocks.

Arthropods are among the rarest of the fossils to appear in the insoluble residues. Trilobites occur in all of the strata, but they are most numerous in the Road Canyon Formation and the Willis Ranch Member of the Word Formation. In the former, several complete specimens of enrolled Anisopyge have been taken. Barnacle plates (Turrilepas) are fairly common at USNM 702c but were not seen elsewhere. Ostracodes are rare and scattered, but USNM 703c yielded a fair number of specimens described by Sohn (1950, 1954).

Finally, it is necessary to mention the occurrence of an occasional fragment of fish, but these are rare. The fragments consist of isolated teeth and ornament spines. A specimen of Helicoprion was taken by one of the parties of the American Museum of Natural History.

Processing the Blocks.-The first step in the processing of the blocks is to paint with ambroid (cellulose acetate) or some other acid-resistant material the side on which the block will rest in the tub. This, of course, is to prevent action of the acid on the base of the block, which, if not done, might cause the block to dissolve unevenly and to topple over or to etch from the bottom in such a way that the specimens on the lower side would be progressively crushed. It is important to study the block before it is placed in the acid to locate any large siliceous masses such as chert, large massive bryozoans, big corals, or other unusually large specimens. The block should be oriented in the acid in such a way that these possibly destructive masses be as low as possible, in order that, on being freed by the acid, they do not plummet down onto a pile of delicate shells already released. In some cases it is advantageous to place the block in the acid with the bedding planes parallel to the sides of the tub. This upright position, in the case of some productids, helps to yield more spiny specimens in nearly perfect condition. At any rate, all sides of each block should be studied to determine the position most advantageous for maximum production. It is, of course, not possible to see all buried lumps that may cause breakage with their release.

Blocks of a hundred pounds or less can be placed more readily by hand into the tubs by two men. Heavier blocks are more difficult to handle in this manner, and a tub can be destroyed if a large block is dropped into it. For the heaviest blocks a light hoist designed to lift about a ton is employed. Operated by a series of pulleys, the hoist makes the placement of a heavy block in the tub safe and easy (Plate 1: figure 2).

The Tubs.-After experimentation with soapstone and fired clay tubs, both of which proved unsatisfactory, vats of Haveg ${ }^{1}$ material were installed in the acid laboratory. These tubs measure 4.5 feet by 2.5 feet in length and width and have a depth of 18, 20, or 24 inches. The Haveg material has a thickness of 0.5 inch and will support blocks up to 400 pounds in weight when the tub base is supported along its entire bottom. The drain is located in one corner of the tub to facilitate emptying the contents. All corners on the base and sides of the tub are rounded to render impossible sticking of small specimens and to make it easier to clean them. Specimens from different blocks, if caught in the tub, could lead to many inaccuracies in the work. The greatest of care is taken when cleaning the tubs to see that all vestiges of a decalcified block have been removed. We decided on the use of the larger tubs because several small blocks from one locality can be processed at a time if no large block is available. It is inefficient to process the large blocks in small tubs, a fact that was discovered when tubs having dimensions smaller than the ones mentioned above were used. Our present tubs will take the largest blocks that can be handled under the conditions of our operation (Plate 1: figure 2).

\footnotetext{
${ }^{1}$ Haveg Corporation, Newark, Delaware.
} 
The coated blocks are placed on a monel metal screen basket (about 20 mesh). This basket has low sides and the screen, which is fairly stiff, can hold considerable weight. We found that screens deteriorate with constant use and should not be employed for large blocks when the strands become too limber. The purpose of the screen is to catch the freed shells and to permit fine mud and sand to run through the meshes. Blocks with large quantities of shells usually trap a considerable amount of the fine insoluble debris. This creates problems in the recovery of delicate specimens, because the mud must be washed from the shells on the screens by a gentle jet of water.

The monel metal screen to hold the block is placed on a plastic plate on a soapstone slab, which in turn rests on two soapstone supports. The reason for this arrangement is to make it easier to get the plate off the bottom when the block is decalcified.

After a block is placed in the tub in the desired position, water is poured in until the block is well covered. The acid is then added by means of a rubber siphon. In starting the process, three to five gallons of commercial hydrochloric acid (16 percent) is used. This is continued each day until accumulated calcium chloride from the etching slows the process. This heavy brine, which sinks to the bottom and retards action, is removed by siphon, and fresh water is added.

Removal of the brine lowers the solution to the level of the stone plate, thus revealing the screen and any shells that have been freed. Unusual, delicate specimens, fine perfect specimens, or those that might be injured by remaining in the solution should be removed at this time, leaving the hardier ones. Also, any large lumps that promise trouble should be taken off the block if possible. The block again is immersed, and the process is continued as above until the block has been completely decalcified.

The insoluble residue in the screen on the plastic plate is removed from the tub to a drain, and a light jet of water is played over the screen to eliminate as much fine mud as possible. After this procedure, the screen on its plastic plate is removed from the stone plate. The screen is then placed in a large tank of running water and allowed to wash for several hours, usually overnight. It is very important to remove all of the calcium chloride because it will deliquesce on humid days and, keeping the specimens constantly wet, will spoil the trays and labels on which they lie.

It is also important to use acid as free of sulphuric acid as possible. When the brine reaches a high concentration, deposition of fine needles of gypsum may take place. These may festoon the specimens and make them worthless if not cleaned off. This is not serious, but it should be avoided if possible because it means an additional step in the handling of such delicate material and may result in the loss of excellent or rare specimens. If specimens do become coated with fine needles of gypsum, they can be cleaned by soaking them for several hours in fresh, strong hydrochloric acid.

After the screens and contents have washed for several hours, they are removed from the running water and placed on racks to drain. Once they have drained, they may be placed in a drying oven, over a heater, or in whatever drying device is most convenient. Following the drying procedure, the screens are ready for picking and sorting. Generally it is best to pick off the large specimens first and then to take small samples of the finer debris and sprinkle them into a large tray to search for small specimens. Great care must be taken at this point, because some of the Permian fossils are difficult to recognize as complete specimens. It takes considerable experience to identify the shapeless dorsal valve of the cranias or the oddly digitate brachial valves of Pseudoleptodus or other of the lyttoniids, especially the small ones. It also takes a sharp eye to locate useful juvenile specimens. In addition, it is important to save all half valves or pieces that might be fitted together when all the material of one kind is assembled. Some of the best specimens in the national collection were pieced together, one part having been taken from one screen and the remainder from another. The picking process requires vigilance and care-indeed the success of the entire etching process requires the greatest care and patience.

After the investigator has picked the best material, he may find it advantageous to screen or size the remainder and examine the various size grades for special small types. He may be rewarded in his precaution by the discovery of fine juvenile material of a variety of genera. 
After a block has been completely decalcified and the residue has been removed from the acid and placed in the wash, one further step is necessary: cleaning the tub to catch all fine debris that has gone through the screen or floated away from the block. If one watches the solution of a small block in a glass receptacle, he will notice constant movement of small specimens. These fill with gas and rise to the surface of the acid and float about until they discharge their gas. Then they plummet to the bottom only to appear again at the top almost instantly. This will keep up until the specimen is completely decalcified and completely filled with liquid or gas. During these ascents and descents, the specimen usually floats away from the screen and is often drawn to the sides of the tub. Floating specimens are skimmed off before the tank is emptied. The sludge on the bottom of the tank is thus composed of fine debris in which is mixed some of the choicest of the small specimens. The cleaning of the tub is, therefor, a procedure that must be given the greatest of care. The tub must be "sterile" before it receives another block, and all the fine debris must have been carefully removed. This fine material is caught in a receptacle and then screened under water to catch the good small specimens with a minimum of breakage. Some of the best of the juveniles are obtained from the bottom sludge, and occasionally a wandering large specimen of excellent quality is found on the bottom.

It may be desirable to take an unusual specimen from a block before the entire mass is dissolved. This can be accomplished by the use of a separatory funnel mounted over the specimen, which permits the acid to drip on or near the specimen at some desired rate until it is freed.

Occasionally a specimen of unusual delicacy appears on a surface while a block is etching. It may be lost with ordinary methods, i.e., letting it take its chance with other shells on the screen. In such a case, the liquid can be drained off part of the block and the specimen covered by, or filled with, paraffin, which hardens quickly and clings to the damp specimen. This wax protects the specimen during the remainder of the solution process. The paraffin also may buoy the specimen sufficiently to float it, thus making an easy method of recovery of a rare individual. The paraffin may be removed easily by xylol or hot water. It may be desirable to free a specimen but not to allow the acid to enter its interior. The foramen and commissure are plugged with paraffin or ambroid, and any holes that develop during solution are also plugged in the same way.

Some specimens must be oriented in order to reveal delicate internal structures. This is especially true of loop-bearing or spire-bearing brachiopods. If these are allowed to etch without control, the acid works more rapidly on the inside surfaces of the shell and soon leaves the loop or spire enclosed in a lump of lime. This usually breaks off if the specimen is not vertical, i.e., with the beak down. Consequently, terebratulids and spiriferids should be treated separately by orienting them with the beak down and the foramen plugged. Solution can then be allowed through the anterior gape, or a hole can be made at some strategic point. This is slow, but good specimens may result. Spiriferids with well-preserved spires are among the great rarities in this collection.

Preservation of Specimens.-The specimens freed from limestone by the acid are often very fragile; in some examples they are very brittle and tend to fall to pieces along cracks, in others they are spongy and tend to crush readily. Both of these types can be preserved by soaking them in a hardening agent. We have used alvar dissolved in acetone, which has proved very satisfactory because of the deep, penetrating quality of the acetone: it enters the cracks of fragile forms and also tends to fill the interstices of the spongy shells. A thick solution should be avoided, because this will produce a high gloss on the specimens and make photographing them difficult. In addition, the specimens should not be soaked and dried in a very humid atmosphere as the alvar will turn opaque white.

Some specimens such as Enteletes and Parenteletes, which are thin-shelled, may be recovered with the interior details poorly preserved but with the exterior in good condition. These specimens are valuable for their outer details, but they cannot be preserved unless they are filled with a hardening agent. We fill such specimens with plaster of Paris by squirting it into the interior with a medicine dropper. This same treatment is given shells that consist of two silicious films. By this treatment, 
we have saved many specimens that otherwise would have been impossible to keep.

Transporting Specimens.-Because of their fragility, transporting silicified fossils creates a problem. In moving collections from the American Museum of Natural History in New York City and from the University of Kansas at Lawrence, we embedded specimens in paraffin. For one trip, the specimens were placed in trays, and paraffin was poured over the trays and specimens, cementing both to the container bottom. When the paraffin hardened, the specimens were immovable and safe from being jarred. For another shipment, specimens were placed in receptacles en masse. and wax was then poured over them to form a large block. In both methods blocks were transported without loss. To remove them, the wax is placed in hot water. The melted wax floats to the top of the water and hardens. It can be picked off as a lump and the specimens can be removed uninjured from the water.

Another method for the transportation of small silicified specimens is to place them in glycerine. The syrupy liquid permits no sudden shocks, and quick movement within it is impossible.

Storage of Specimens.-The delicacy of many of the siliceous specimens and the long, fragile spines of the productids make storage of them a difficult problem. Many of the productid brachial valves and the nonspiny brachiopods are arranged for protection in covered boxes between layers of cotton. This type of preservation appears to be completely adequate for most of the specimens. Generally it is necessary to cover the top of the specimens with a sheet of fine tissue to prevent the upper layer of cotton from picking up individuals when that layer is lifted: the specimens commonly have small projections that may catch in the fibers of the cotton. Unless the precaution of using the tissue is taken, the specimens may drop off and be broken when the cotton is lifted. With fairly stout shells, the bed of cotton can be deep and the inside of the box cover may be used to hold them in place, making an upper layer of cotton unnecessary.

For very unusual specimens, "riker mounts," i.e., glass-topped boxes, have been employed. These can be used with a bed of cotton, the inner glass surface holding the specimens on the cotton, or, in more unusual cases, the specimens may be cemented into

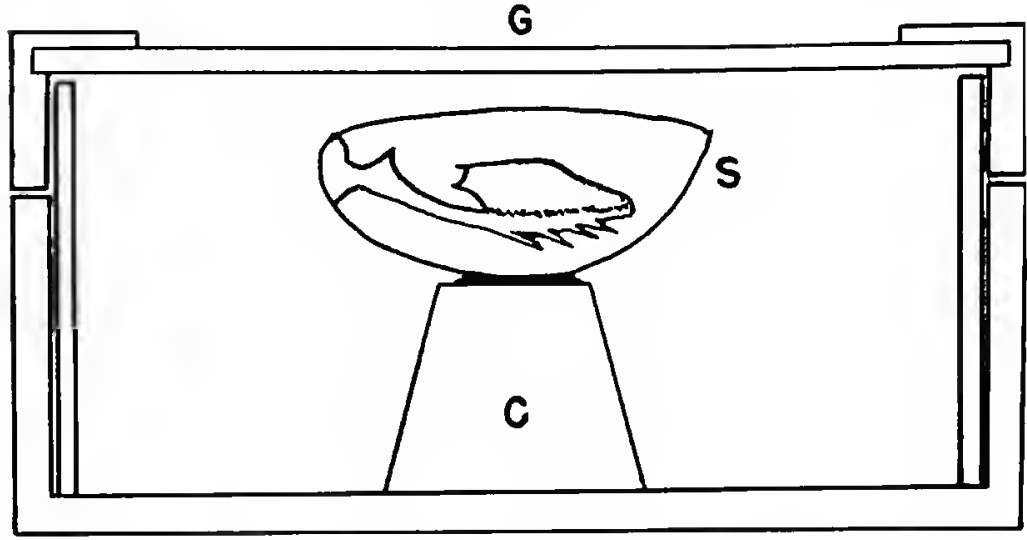

FIgURE 2.-Riker mount (glass-covered box) for delicate specimens; most terebratulids with loops in the national collection are so mounted ( $\mathrm{G}=$ glass, $\mathrm{S}=$ specimen, $\mathrm{C}=$ cork).

the riker. Our favorite method of mounting for interiors that show loops or spires is to cement a small cork to the bottom of the riker and then to cement a black card of appropriate size to the surface of the cork. The choice specimen is then cemented to the black card, giving protection and easy visibility. The specimen also can be photographed without being removed from the riker. Such a method is ideal for small terebratulids with delicate loops. We have not used plastic as a mounting medium because of the difficulty in photographing specimens so mounted, although this method would give the greatest protection. The plastic blocks also create difficulties in the close study of specimens.

Collections Supplementing the Glass MounTAINS SPECIMENs.-It became apparent early that specimens would be urgently needed to supplement those from the Glass Mountains. This necessity grew from our desire to know other described species and to compare them with specimens from the Glass Mountains. It was also necessary to have specimens from other facies to understand assemblages in types of sediments not found or rarely seen in the Glass Mountains.

The greatest need for supplementary collections arose in connection with species described by G. H. Girty (1909) and Robert E. King (1931) from the Sierra Diablo and Guadalupe Mountains. Girty established many species, nearly all of which were taken from the "white limestone" (=Capitan Limestone) or some of its clark limestone equivalents. Many of Girty's species are based on poor, or often incomplete, specimens that actually do not show any generic characters by modern standards. 
Girty's species and, before him, Shumard's from the same area were the first and, in some cases, the only described Permian fossils. Consequently, they have been widely and uncritically identified. Robert E. King identified many of the Girty species in the Glass Mountains, all at levels far below the Capitan, which, in the Glass Mountains, generally has failed to yield any good faunas. Capitan species thus seem unlikely to be found in the Glass Mountains at levels below the Capitan. Specimens of Girty's species also were needed to learn interior details to establish their generic identities. Many of his species from the Capitan Limestone are difficult to prepare or the interior details have been lost in fossilization.

A similar argument holds for some of $R$. E. King's and Girty's species collected in the Sierra Diablo. The generic identity of some of them is uncertain from the specimens in their collections. This is especially true of the productid species in which interior details are required for correct generic assignment.

Stehli's (1954) work also inspired a need to have specimens from the Sierra Diablo. The reason, however, was far different from that in the above cases. Stehli's species are defined adequately so far as interior details are concerned, but it proved to be necessary to obtain additional material, especially of the large productids, in order to try to obtain growth series of such genera as Nudauris, Spinifrons, and Antiquatonia.

Collections also were made in north-central Texas from the silty-shale beds of the Finis and Jacksboro Members of the Graham Formation through the Wichita Group. This collecting produced interesting and important productids and indicated unsuspected Permian affinities of some of the brachiopods of the Cisco Group. Waagenoconcha was discovered in the Jacksboro Shale, and the same formation produced a specimen of Martinia. Collections also were made in the Permian beds (mostly Wolfcampian) of Oklahoma, Kansas, and Nebraska. The variety of genera and species is not as great in these shaly areas as in the limestones of the Glass Mountains, the Guadalupe Mountains, and the Sierra Diablo, but important comparative material was found that was useful in defining genera and understanding ecological conditions.
In addition to the material outlined above, collections were obtained from other parts of the country, all of them proving helpful in one way or another. Dr. Kenneth Ciriacks presented the National Museum of Natural History with 13 blocks of limestone from the Phosphoria Formation (Franson Member), which yielded excellent comparative material of Bathymyonia, Derbyia, Ctenalosia, and others that help to show this fauna is connected only remotely with that of the Glass Mountains.

Problems in the Study of Silicified Fossils.It is generally believed that silicified fossils are so well preserved that they solve all problems. Unfortunately, silicification may cause serious difficulties in the study of fossils. While gross characters of the interior and exterior are usually apparent, fine details of the ornament and of the interior frequently cannot be obtained, or they are completely and irretrievably destroyed. One of the drawbacks to the use of silicified specimens in the study of brachiopods is the general impossibility of obtaining details of the shell structure. These are not always vitally needed but when they are, resort must be had to unsilicified material if it can be obtained.

In the Glass Mountains, specimens of every quality of silicification can be obtained, some that show fine details in exquisite perfection and others with the interior details in greater fidelity than hitherto known. Specimens from USNM 702c, $706 \mathrm{e}$, and several other places generally have the silica deposited on them as a thin film. In these specimens, detail of the interior is usually good, but some thickening of the exterior characters can be detected, which indicates that minor features of the ornament have been changed, as in Acosarina mesoplatys, for example. These small changes could result in the creation of species not needed, but it is better to duplicate than to be mistaken.

Many specimens, especially some from Split Tank and many from King's fossil bed (=Taylor Ranch Member) in the upper part of the Hess Formation, are composed of solid silica or are mottled by beekite rings. These are the least satisfactory for study because the silicification is so gross that fine details are completely lost. In spite of this, the specimens are useful-one must work with all of the material that can be had. 
Specimens newly taken from the residues appear to be clean, but few of the silicified specimens really are ready for study until they have been cleaned under a microscope. This is frequently an arduous, time-consuming, and unrewarding task. But it must be done if the specimens are to be photographed, measured, or used in comparative work. Most of the limestones are dirty or sandy, and mud or sand grains cling to the inside of specimens or festoon the loops, spires, or other delicate structures. They cannot be cleaned away from some specimens, but in others it is necessary to do so in order to reveal the various structures in all of their detail. It is important to wash specimens thoroughly of all accumulated mud immediately after the residues have been removed from the acid; the mud is soft and can be eliminated with a gentle stream of water from a hose or chemical washbottle. Sand grains generally cannot be eliminated so easily. Many of the specimens from USNM $706 \mathrm{e}$, which appear so beautiful, often take hours to clean because the sand grains are cemented to the interior or exterior surfaces. These must be scraped away with a flattened needle. Delicate interiors can be filled with paraffin and scraped clean with a sharp needle without injuring the fragile structures. It has been necessary in many specimens to leave them dirty, because the foreign matter is so strongly adherent that any attempt at removal would jeopardize the safety of the speci- men. Obtaining a perfect specimen depends on many factors. Foremost is the kind and quality of the silicification. A well-silicified specimen, if it is not too large, will survive the treatment necessary in its recovery. The larger a specimen, the more difficult it is to extract from the matrix.

One of the most important factors in the recovery of perfect specimens is their position in the rock in relation to the orientation of the block in the acid bath. A specimen that is so positioned by accident or intent, that it is well supported throughout the dissolving process is more likely to survive in perfect form than a neighboring specimen, which will be freed in such a way that it is suspended by a delicate appendage or narrow edge.

This point may be illustrated by reference to three hypothetical productids in a hypothetical block. Two are located on the side and one in the middle of a small block. Those on the side begin to appear soon after dissolution is started and their spines are first revealed. Then appears the body of the shell and finally the spines on the opposite side. At some point during this process the weight of the shell will cause the main part to break away from these delicate spines. Thus, the two lateral specimens will be imperfect because the spines on some part of the shell were not strong enough to support the entire specimen until it could be freed. The fortunate specimen near the center of the block, on the other hand, will be well supported

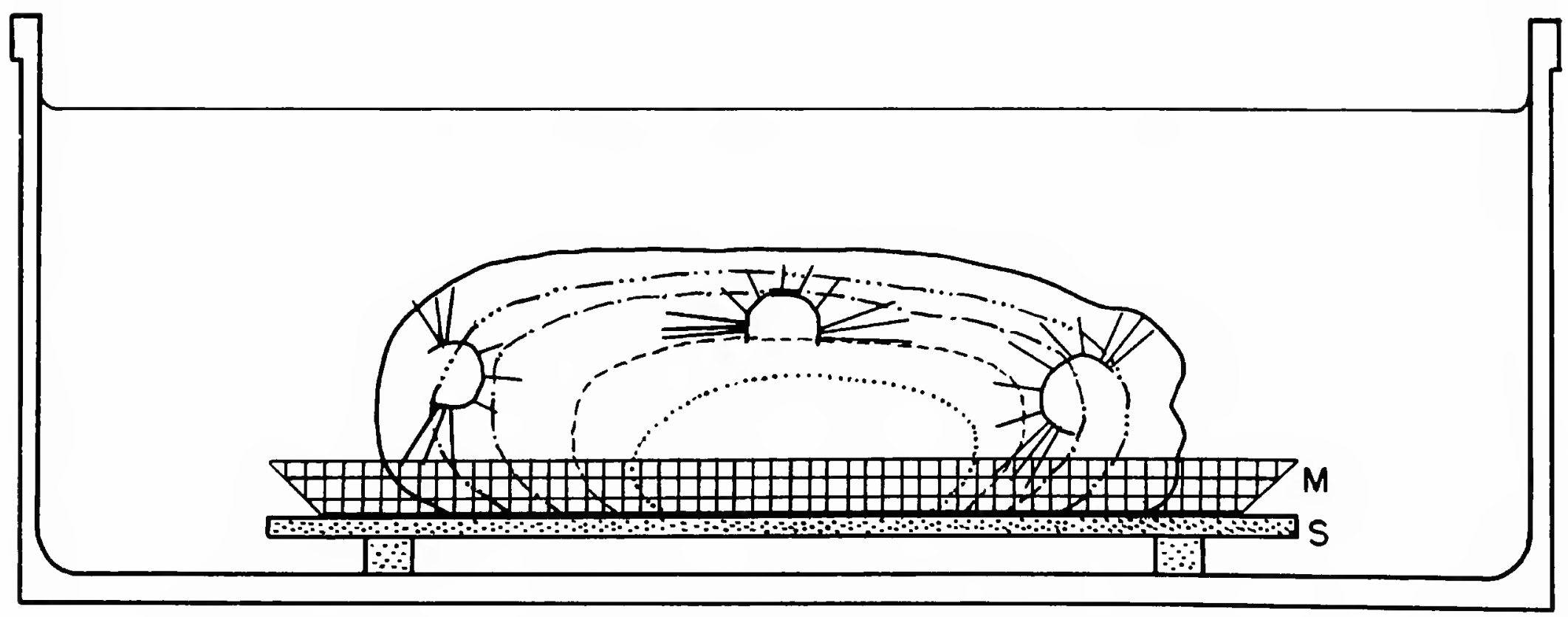

FIGURE 3.-Diagram showing the method of etching large blocks and the effect that position in the block has in determining the completeness and quality of a freed specimen ( $M=$ monel metal screen basket; $S=$ soapstone slab). 
during the entire dissolution process, and the result will be a "perfect" specimen when ultimately freed (Figure 3).

A block should be studied with care before it is placed in the acid to determine how the majority of the specimens lie and what will be the most advantageous position in which to carry out the process. In some blocks the specimens lie along a bedding plane and are best dissolved with the bedding planes perpendicular to the tub floor.

The revelation of a perfect loop or spire is another happy accident of position in the rock. In the terebratulids, the acid enters the interior through the foramen and the commissures, if these are not tightly welded. The acid thus acts fastest along the contact of the matrix and the inside of the shell. The result is soon the isolation of a rounded or oval lump of matrix around the loop. If the specimen is lying in a disadvantageous position, this lump will be too heavy for the loop and will break it off. If however the specimen is in an upright position, the loop may be able to support the lump of matrix until it is finally dissolved. The same process acts for spires, but these are more complex and more delicate than loops and seldom survive the solution process. The best way to obtain a loop or spire is to prepare it specially on specimens already taken out of the matrix, carrying out the solution under controlled conditions and, in some shells, leaving the delicate structures supported underneath by matrix.

Photographing Silicified Specimens.-Mounting a spiny productid for photographing creates a difficult problem. Because of the spines, the ordinary cementing media cannot be used. We have found that lead shot (dust grade) is ideal for this purpose. The specimen can be posed at any angle in the shot without hurting or affecting the spines. Another means of photographing small and delicate silicified specimens is to cement them with ambroid or other cement on the head of an insect pin. The pin can be stuck in a cork or plasticine ball at any angle desired. After the picture is made, the specimen can be dismounted by immersion in a solvent.

Color of the specimens is a big factor in their photography. The gray, yellowish, or dark specimens make no serious problems when they are coated with ammonium chloride dust. When the specimens are dead or lustrous white, as many are, then problems in lighting and definition arise. The white specimens tend to produce pictures of low contrast and lifeless appearance even when the lighting is correct. To obviate this unfortunate condition, many of the specimens are painted gray or black. India ink is perfectly satisfactory for the spongy specimens but cannot be removed, except with extreme danger to the specimens. We use an "Opaque" 2, which is removable in many cases, difficultly so in others. In some instances, the ink is diluted to produce a gray rather than black color. When coated with ammonium chloride dust, these blackened or gray specimens give superb pictures. It is no tragedy to leave the specimens colored black, because their study quality is actually enhanced rather than injured. Since india ink has a tendency to peel when thoroughly dry, it should not be used for glossy or smooth specimens.

\section{Stratigraphy of the Glass Mountains}

Collecting Program.-In the Glass Mountains this was confined to three major groups of rocks: those of the Wolfcamp Series, the Leonard Series, and the Word Formation of the Guadalupe Series. Because most of the sequence above the Fourth Limestone of the Word Formation (=Appel Ranch Member) is composed of dolomite, that part of the section was not studied. Fossils appear chiefly as cavities or impressions in the dolomite, and no silicified fossils, or any others besides fusulinids, have been found in this part of the sequence except for a fault block northwest of Dugout Mountain (USNM 732q), that contains undolomitized fossils with Hegler affinities. The following discussion, therefore, includes only the parts of the section from which silicified specimens have been taken. It also includes a discussion of the upper part of the Gaptank Formation of present usage, because it contains, in its upper part, essentially the same brachiopod fauna as that of the lower part of the Wolfcamp Series (Neal Ranch Formation). New or important species from the Gaptank Formation are included in the systematic part of this monograph because of their bearing on the fauna of the Wolfcamp.

\footnotetext{
${ }^{2}$ John T. Barlow Opaque, Phillips and Jacobs, Inc., Philadelphia, Penn.
} 
Previous Work.-No serious or extensive geological work was done in the Glass Mountains prior to 1916. R. T. Hill (1901) described the geography of the mountains and made collections of fossils in Comanche Canyon (possibly the canyon leading to the Appel Ranch) that later were described by G. H. Girty (1909). In a brief "Review of the Geology of Texas," J. A. Udden, C. L. Baker, and E. Böse (1916) named five of the familiar Glass Mountains formations. Udden named the Gaptank Formation in this publication (page 47), while he and the others (pages 51,52) named the Leonard, Word, Vidrio, and Gilliam Formations. The next year Udden $(1917: 41,43)$, in a more extended discussion, published detailed sections in the Glass Mountains and added two more formations: the Wolfcamp and Hess. Thus, the basic pattern of the Glass Mountains stratigraphy was blocked out by these Texas geologists.

Interest in the Permian of the Glass Mountains increased with the beginning of exploration for oil in West Texas. P. B. King (1926) discussed the geology and structure of part of the Glass Mountains. From then until the present, he has been the leader of work in the Glass Mountains and has contributed more to their understanding than has any other geologist. The next year I. A. Keyte, W. Blanchard, Jr., and H. L. Baldwin (1927) discussed the Gaptank-Wolfcamp sequence in the eastern part of the mountains. In the same year P. B. King (1927) described the Bisset Formation in the Glass Mountains, and Schuchert (1927) discussed the Pennsylvanian and Permian Systems of West Texas.

P. B. King and R. E. King (1929) described the Dugout Creek overthrust, and the same year these two wrote a description of the stratigraphy of the Pennsylvanian and Permian strata of Trans-Pecos, Texas. P. B. King's (1931) important monograph on the geology and structure of the Glass Mountains included a good geological map of the region. In that year R. E. King's (1931) monograph on the brachiopods of the Glass Mountains was published. These two studies, embodying all of the important ideas on the Glass Mountains to appear up to the present time, are the standard relerences. In the next few years P. B. King (1932, 1934) published several other papers on the Glass Mountains, culminating in his Geology of the Marathon
Region (1938), which summarized and brought up to date his own work and that of others.

An important step in the understanding of the Permian of Texas was made by John Emery Adams and collaborators (1939), who revised the nomenclature of the Permian in North America and elevated the Wolfcamp and Leonard Formations to the rank of series. Further views on the Glass Mountains were published by P. B. King (1942) in an extensive discussion of the Permian of West Texas. The beginning of dissatisfaction with the scheme of stratigraphy in the Glass Mountains was voiced by Daniel Jarvis (1957), who stated the need for revision of the Wolfcamp Series. Charles A. Ross (1959) proposed revision of the Wolfcamp Series and created two new formations where hitherto there had been but one. Ross (1960, 1962a, 1962b, $1963 \mathrm{a}, 1963 \mathrm{~b})$ described the stratigraphy of the Wolfcamp and Leonard Series and the Word Formation, essentially the same units as those discussed below. Carl O. Dunbar and his committee published a chart depicting the correlation of the Permian Formations of North America (Dunbar and others, 1960). The Glass Mountains section is shown with the revisions by Ross in the Wolfcamp Series but without other changes. Garner Wilde (1962) joined the ranks of the skeptics and pointed to needed revisions of parts of the Glass Mountains sequence. Cooper and Grant (1964) proposed new formation and member names to facilitate their descriptive work on the brachiopods; the Skinner Ranch and Cathedral Mountains Formations were established. The former formation was divided into three members in the western part of the mountains: Decie Ranch, Poplar Tank, and Sullivan Peak. At this time also the First Limestone Member of the Word Formation of $\mathrm{P}, \mathrm{B}$. King was named the Road Canyon Member, but later it was elevated to formation rank and transferred to the Leonardian (Cooper and Grant, 1966).

\section{Revision of Part of the Glass Mountains Sequence}

The stratigraphic pattern set out by Udden, Baker, and Böse (1916) has been changed little since it was proposed. P. B. King (1931) and R. E. King (1931) modified the supposed relation of the Hess and Leonard Formations as set out by Udden, but 
they did not change the general scheme. The revision of Wolfcamp rocks by Ross (1959) and the new names proposed by Cooper and Grant (1964, 1966) are the most important changes up to the present time. A minor revision of the lower part of the Leonard Series of P. B. and R. E. King was suggested by Cooper and Grant (1964:1586; 1966: E6), and they recommended that the Road Canyon Formation be placed at the top of the Leonard Series. Revision of the mapping in the Sierra del Norte is needed. Correlation of the various parts of the section are another matter, and these are discussed in detail in a later part of this section, where major changes in the understanding of the Glass Mountains sequence are proposed.

Pre-Permian Sequence - Gaptank Formation.The Permian rocks of the Glass Mountains rest unconformably on parts of the underlying Pennsylvanian formations, most notably and extensively on the Gaptank Formation. The original definition of the Gaptank Formation included the Wolfcamp Formation. The two were separated by Udden (1917:38), but the exact boundary between them has not yet been clearly settled to the satisfaction of all workers in the Glass Mountains. The type section of the formation is located south of the tank, called Gap Tank, in Stockton Gap on the Fort Stockton-Marathon Highway (U. S. Highway 385) about 25 miles northeast of Marathon. The formation extends westward from the type section at the base of the mountains to Dugout Mountain, a distance of nearly 30 miles. A significant gap appears in its distribution in the five miles between Iron Mountain and the east end of the Lenox Hills. At the type section about one mile south of Stockton Gap, P. B. King (1931:44) recognized 21 units that aggregate in thickness about 1,800 feet in a broad east-west anticline. The lower thousand feet is siliceous and has little limestone, but the upper 800 feet contains considerable limestone. These two members, according to P. B. King (1931:44), correspond respectively to part of the Strawn, Canyon, and Cisco Series of the Pennsylvanian. The lower part of the sequence (beds 1-12) consists mostly of shale and sandstone in which occur five layers of conglomerate. In the upper part (beds 13-21), five beds of limestone form conspicuous members. A few of the layers are fossiliferous and have faunas that permit recognition of the parts of the Pennsyl- vanian mentioned above. Bed 10, a thick layer of shale and sandstone just under the fifth conglomerate (=bed 11) is richly fossiliferous. It includes some Permian brachiopods such as Parenteletes and Diplanus. According to Moore (1944: chart 6, column 39), the fifth conglomerate bed occurs at the base of the Cisco (Virgilian) Series. In the type section the beds above this conglomerate (beds 12-21) are poorly fossiliferous but contain thick limestones. The uppermost (or fifth) limestone crops out along the mountain front for a considerable distance west of Stockton Gap. The uppermost part of the Gaptank, the well-known $U d$ denites-bearing Shale Member, is not present in the type section, but it is well displayed in the Wolf Camp Hills. Inasmuch as the brachiopod fauna of this member in the Wolf Camp Hills is so similar to that of the overlying Wolfcamp rocks, our discussion of the Gaptank will be confined largely to this portion except for a few paleontologically interesting parts of the large outcrop area of Gaptank Formation in the Marathon Basin west of Marathon. These have a bearing on discussions of correlation.

Application of the name "Uddenites zone" or the more cumbersome "Uddenites-bearing Shale Member" to the hundred feet or more of the upper Gaptank is inaccurate. The ammonite Uddenites is confined only to a small part of this sequence, and it is found also at another level in the Gaptank (Miller, A. K., 1930:400, pl. 39: figs. 17-19). Nevertheless, we recognize the Uddenites-bearing Shale Member and the strata above it to the base of the Wolfcampian as an important stratigraphic unit despite the cumbersome and inaccurate designation.

Uddenites-BEARING Shale Member.-This member is best exposed in the Wolf Camp Hills. Faunally and lithically it is strongly related to both the underlying Gaptank and the overlying Neal Ranch Formations. In the Wolf Camp Hills it is sandwiched beween two thick layers of biohermal limestone. The Gaptank under the Uddenites-bearing Shale Member is heavy-bedded, massive, dark gray, and contains scattered fossils, including the fusulinid Triticites cullomensis Dunbar and Skinner and T. comptus Ross. Some of the brachiopods from this limestone occur also in the overlying Uddenites-bearing Shale Member. This thick limestone can be traced across the front of the Wolf 
Camp Hills, and, thus, it forms a convenient base.

The member is terminated above by the Gray Limestone of P. B. King (1931:55) in the Wolf Camp Hills. This is a thick, massive, easily recognized limestone, but its age and faunal relationships now are not clearly understood. The Uddenites-bearing Shale Member is definitely delimited in the Wolf Camp Hills, but the same limits do not define the member farther east (Plate 12: figure 3).

The limestone of the upper Gaptank beneath the Uddenites-bearing Shale Member is located on both sides of the mouth of Geologists Canyon. To the east it rises up the hill in an elongated recum. bent $S$, and then it levels off to cross the front of hill 5060, the highest point in the Wolf Camp Hills. From there it descends somewhat to underlie the saddle on the east side of hill 5060. From this saddle it slopes and thickens gradually to the east side of the Wolf Camp Hills, where it plunges below the surface of the plain at the base of the east end of the hills. In places the sinuosity of this layer affects the thickness of the overlying $U d$ denites-bearing Shale Member (Plate 4: figures $1,2)$.

On the west side of Geologists Canyon a prominent knob is underlain by this limestone, which is overlain by the Uddenites-bearing Shale Member, here mostly shale. This is the westernmost occurrence of the thick Gaptank limestone.

The Uddenites-bearing Shale Member is extremely variable in lithology and thickness across the front of the Wolf Camp Hills. At the knob on the west side of Geologists Canyon, it is fairly thick, 113 feet according to P. B. King (1931:55, section 24, bed 1). It is best exposed in the saddle on the north side of the knob, which is on the west side of the canyon near its mouth. Here the north slope of the knob exposes the upper, thin limestones of the member and the underlying soft, gray shale. The shale is best exposed in the saddlehere called the "goniatite" or "Uddenites saddle" -which is floored by naked shale (Plate 4: figure 1). The recent years of drought have altered this place considerably and have revealed a better section of the shale than hitherto known. The goniatites for which this location is famous weather from the upper part of the shale and are scattered on the north, west, and east slopes of the knob, but they have long since been removed nearly completely from the saddle by collectors. The upper limestones are brown to orange yellow and are exposed on the north side of the saddle just under the overlying Gray Limestone. These limestones of the Uddenites-bearing Shale Member are thick bedded, and large blocks have slipped down to strew the slope on the east side of the saddle. They afford good fossils, including rare unlimonitized ammonites. Little shale is exposed on the west side of the saddle because most of it has been eroded away to create the valley between the Gaptank hard limestone and the Gray Limestone of the Wolfcamp.

The Uddenites-bearing Shale Member is well exposed in a few places on the east side of Geologists Canyon. A remnant appears in a swale in the Gaptank Limestone just east of the canyon mouth. Here a specimen of Omphalotrochus was taken from the shale (Yochelson, 1954). Where the limestone of the Gaptank thickens and is elevated, the Uddenites-bearing Shale Member thins. These complementary thickenings and thinnings are very noticeable on the west side of hill 5060. At one point, between the "o" and the "l" in "Wolf" on the Hess Canyon Quadrangle in the Wolf Camp Hills, the Gray Limestone of the Wolfcamp rests directly on the Gaptank Limestone, and thus it pinches out the shale completely. East of this point and near the west end of hill 5060, the member thickens again, and here a section was measured in it. The thickness of the Uddenites-bearing Shale Member thus coincides with this sag in the Gaptank Limestone (Plate 12: figure 3). The measured section is as follows:

Neal Ranch Formation (Gray Limestone Member feet of P. B. King)

Uddenites-bearing Shale Member

G. Slope containing gray shale that yields brown chips of ferruginous material and occasional goniatites ............................................... 15

F. Calcareous coarse sandstone ....................... 10

E. Granular limestone with Parenteletes ............... 5

D. Cobbly limestone and shale with Rhynchopora and Eridmatus

C. Mostly covered, probably shale with an occasional limonitic ammonite ............................... 10

B. Granular, yellow-brown limestone ................. 1.5

A. Slope covered with shale chips ................... 15

Heavy bedded Gaptank limestone 
The Uddenites-bearing Shale Member can be traced across the front of hill 5060 between the contour intervals of 4800 and 4900 feet, and this is one of the best places to collect its fossils. Care must be taken, however, in the collecting because the slope is thickly covered with rubble and slide material from the various layers of the member. A section was not measured on this part of the hill, but the thickness is approximately 80 feet.

On the east side of hill 5060 and the low hill next to the northeast is a broad flat underlain by the upper Gaptank limestone, which is just below the edge of the saddle. The broad flat contains bioherms, some of them algal, belonging to the lower part of the Uddenites-bearing Shale Member and about the same as those in the lowest limestone in the hill to the northeast of the saddle (here called hill 4950 because its top is marked by a closed contour at this level). The saddle is R. E. King's locality 199, which produced a number of interesting Permian brachiopods, including Parenteletes and Scacchinella.

The section on hill 4950 lying on the east side of the large saddle and between hills 5060 and 4952 is unlike that to the west. On the west face of this hill just above the massive Gaptank Limestone a bioherm yielded the brachiopod Scacchinella. The measured section in hill 4950 is as follows:
Neal Ranch Formation (Gray Limestone Member

feet of P. B. King)

Uddenites-bearing Shale Member

D. Shale occupying a flat at the top of the hill..... I5

C. Massive limestone with fusulinids forming a ledge on the edge of the hill ..................... 16

B. Cobble-covered shale slope............................ 20

A. Cobbly limestone at base with biohermal brown, algal limestone weathering yellow and with large Syringopora heads.

Massive Gaptank Limestone

Traced eastward, the section alters somewhat, is well exposed under the saddle on the west side of hill 4952, and has essentially the same thickness as the preceding section. On the west side of this easternmost hill of the Wolf Camp Hills, the massive Gaptank is followed by 16 feet of cobbly beds, which are overlain by the lower brown layer with Syringopora 32 feet thick. This is succeeded by a shaly-cobbly slope representing an interval of 26 feet. The capping limestone of the Uddenites-bearing Shale Member is 15 feet thick, but the overlying shale has disappeared. Scacchinella appears in the cobbly beds and in the upper thick limestone (15 feet) overlying them.

The upper (15-foot) limestone forms the floor of this easternmost saddle and of the dip slope to the north on the west side of hill 4952, and it

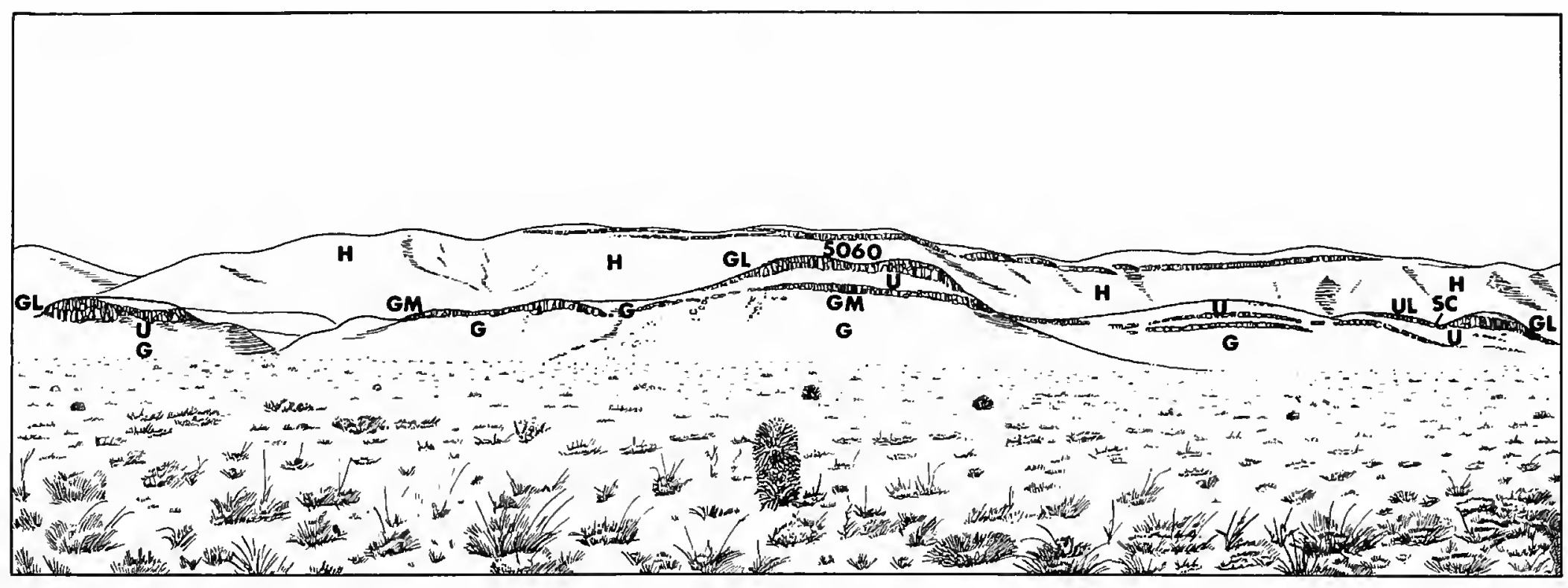

FIgURE 4.-South front of the Wolf Camp Hills showing the position of members and formations ( $G=$ Gaptank Formation, GL=Gray Limestone Member of P. B. King, GM=upper massive bed of Gaptank Formation, $\mathbf{H}=$ Hess Formation, $\mathrm{SC}=$ Scacchinella, $\mathbf{U}=U$ ddenites-bearing Shale Member of Gaptank Formation, UL=upper limestone bed of Uddenites-bearing Shale Member that contains Scacchinella; see Plate 2: figure 2). 
directly underlies the 135 feet thick knob that caps the hill. This knob is the Gray Limestone of P. B. King, here completely altered to dolomite. On the slope forming the front of these two hills, 4950 and 4952, the upper Gaptank ledge undulates at different levels, causing the Uddenites-bearing Shale Member to change in thickness.

The northeast slope of hill 4952 also exhibits Uddenites-bearing Shale Member, but it is impossible to make a section on this slope because of the debris and float blocks covering the surface. The upper limestone (bed $\mathrm{C}$ ) of the section in hill 4950 appears to thicken. The brown bed in bed A also appears to thicken and blocks of it are abundant on the slope.

Uddenites-bearing Shale Member Northeast of Wolf CAmp Hills.-The upper Gaptank is variable along the front slope of the foothills extending northeast from the Wolf Camp Hills to the Fort Stockton-Marathon road (U. S. Highway 385). A small irregularly conical hill with about 4,850 feet elevation (top contour) lies 1.5 miles northeast of the eastern end of the Wolf Camp Hills. Here a section of about 450 feet is exposed, but the few fossils collected do not warrant its correlation with the Uddenites-bearing Shale Member. The base of the section is dark biohermal limestone crumbling to cobbles. It contains algae, the brachiopods Teguliferina and Hystriculina, and may be the same limestone as that underlying the Uddenitesbearing Shale Member in the Wolf Camp Hills. Above it comes a sequence of 155 feet of shale with thin layers of brown limestone containing eugonophylloid algae. The shale is capped by 38 feet of sandstone and limy sandstone, followed by a partly covered sequence with shale and limestone in the float for 45 feet. The section is capped by 95 feet of massive and granular limestone forming a high bluff. P. B. King (1931:145, section 26) places this limestone at the base of the overlying Hess, but it contains Gaptank fusulinids and may represent a thickened extension of the upper limestone of the Uddenites-bearing Shale Member of the east end of the Wolf Camp Hills. The Hess conglomerate is not exposed on this hill, and the thick upper Gaptank limestone is succeeded by red shale of the Hess Formation (=Lenox Hills equivalent of Ross).
Goniatites of the Uddenites-bearing Shale Member were found in the slopes of a chain of foothills beginning two miles northeast of the east end of the Wolf Camp Hills. Three numbered crests identify these foothills from southwest to northeast: 4815,4752 , and 4762 . The sections measured under these hills are dissimilar, but all contain a lower shale, usually a thick sandstone, and a thick, capping, bluff-making limestone that is overlain by the basal conglomerate of the Hess Formation (=Lenox Hills of Ross) (Plate 19: figure 3).

A small knob at the base of hill 4815 is capped by a thick biohermal ledge of Gaptank limestone that holds up the crest of the knob. On top of this lies shale with large tetracorals near the base. This is followed by shale with thin layers of brown limestone and sandstone that are succeeded by a thick sandstone capped by the limestone forming the prominent cliff at the top of the hill. This limestone can be traced for some distance along the mountain front. It is not the Gray Limestone of P. B. King (as King originally supposed), but probably it is the upper limestone capping the $U d$ denites-bearing Shale Member just below the Gray limestone at the east end of the Wolf Camp Hills. This correlation is based on the fact that it contains Triticites primarius Merchant and Keroher, which also is found beneath the Gray Limestone in the Wolf Camp Hills. King (P. B., 1942:649) also came to this conclusion when he stated: "Thus the gray limestones mapped as Wolfcamp immediately west of Gap Tank now appear to belong to the Gaptank formation. . .."

At the hill capped by summit 4752 , the section is thicker and the massive beds of sandstone are missing. These thick sandstones are evidently lenticular, because they appear at different levels and cannot be traced for long distances. At hill 4752 a thick bed of shale at the base of the section contains two beds of brown limestone 60 feet apart that yield goniatites including Uddenites. The upper bed is USNM 701r (= bed 13 of P. B. King, 1942: 55 , section 27) and the lower one is reported by P. B. King (1931:55, bed 9, section 27). The top of the hill is capped by a thick layer of limestone, a thickened extension of that appearing in the hill 4815 to the west. The capping limestone is over- 
lain by conglomerate and red shale of the overlying Hess Formation (= Lenox Hills of Ross).

In the easternmost hill (4762) a somewhat shorter section is revealed. Here the lower slopes are covered, but, where the hill steepens, shale containing thin beds of brown limestone and sandstone measure 105 feet. This is followed by 45 feet of sandstone, and this in turn by more than 100 feet of gray and white limestone, the upper, harder white part standing out as a prominent bluff. This is undoubtedly the same limestone that forms the capping ledge of the foothills to the west and probably to the east, except in the Wolf Camp Hills, where the Gray Limestone is the capping ledge. The Hess conglomerate appears on the northside of a small ravine that divides this hill from the main mountain front. The Uddenites fauna was not identified with certainty to the east, and fossils are so few and difficult to find in the vicinity of Stockton Gap that the Uddenites-bearing Shale Member was not identified at this place.

Other Gaptank Localities.-The large area of Gaptank west of Marathon was not studied extensively, but two localities south of the Arnold Ranch are of interest. An important place for brachiopods is exactly 1.25 miles due south of the Arnold Ranch. This place was discovered by accident in our effort to find the ammonite bed from which Prouddenites and Uddenites were taken. On the P. B. King map (1938: pl. 16), the ammonite bed is located 1.25 miles south of the Arnold Ranch. It actually occurs 1.95 miles south of the Arnold Ranch (= King locality $\mathrm{C}$, not $\mathrm{B}=$ USNM $700 \mathrm{~g}$ of Cooper) and is located incorrectly on the Geological Survey map. The ammonite locality appears correctly on the map by $\mathbf{P}$. B. and R. E. King accompanying the Geology of the Glass Mountains (P. B. King, 1931).

The locality 1.25 miles south of the Arnold Ranch (= locality B of P. B. King, 1938: pl. 16) like the ammonite locality farther south, contains a large, solid biohermal mass of limestone. This appears in a shale enclosing cobbly limestone beds. That the mass is a bioherm is evident because it is not bedded, contains much finely laminated limestone, suggesting algae, thin-cupped colonial corals (Amplexocarinia) in abundance, and scattered brachiopods. The mass is about 20 feet long and 3 to 4 feet high. The rock is massive and extremely hard as it has not been appreciably weathered. This locality is noteworthy because it is a Pennsylvanian bioherm comparable to many of those in the Uddenites-bearing Shale Member. It is also noteworthy because of the prenuncial Permian types of brachiopods it contains. These are Limbella and Scacchinella, the latter a primitive form with little or no vesicular tissue in the apex. The one specimen of fusulinid taken after very diligent search is a Triticites dated as Virgilian by Mr. Garner Wilde, Humble Oil and Refining Company (letter to Cooper, 20 March 1962) (Plate 16: figure 1).

\section{Wolfcamp Series}

The rocks overlying the Gaptank Formation in the Glass Mountains were named the Wolfcamp Formation by Udden (1917:41). Since the formation was named, it has suffered from disagreement among workers as to its age and its boundaries. Wolfcampian rocks have been called the Wolfcamp Series, and they have been placed as the earliest major division of the Permian System in the United States. Rocks deposited in Wolfcampian time, thus, have a great interest, and the Wolf Camp Hills are the most significant reference section for these rocks and their contained fossils (Plate 1: figure 3; Plate 2: figure 2).

The Wolf Camp Hills were not a happy choice from which to select a name with such wide ramifications. The Wolf Camp Hills contain only a small part of the rocks laid down in the complete series called Wolfcampian, and the faunas of the type Wolfcampian rocks hitherto have been poorly known. The present work is the first extensive paleontological study of the type Wolfcampian fauna.

In the Glass Mountains, Wolfcampian rocks occur across the entire mountain front, usually in low foothills except for an interval between the east end of the Wolf Camp Hills and the Fort Stockton-Marathon road (U. S. Highway 385). The sequence in the Wolf Camp Hills now has become famous in spite of our ignorance of details of its faunal succession.

Udden used the name "Wolfcamp Formation" for the generally shaly sequence exposed in the western part of the Wolf Camp Hills. Udden (1917: 
29) applied the name to his beds 10-26 of section 7 and gave the thickness as 448 feet. The section rested on his bed 7 ( $=$ bed 2 or the Gray Limestone of P. B. King) and was capped by a thick bed of conglomerate ( $=$ Hess conglomerate $=$ Lenox Hills conglomerate of Ross). The Uddenitesbearing shale and the Gray Limestone of King were part of the Gaptank Formation. Böse (1917: 17 and Tables 1 and 2) placed the Uddenites-bearing shale in the Permian, thus including the Gray Limestone with it. King (P. B., 1931:54) recognized Udden's and Böse's interpretation of the formation, but in the western part of the Glass Mountains he assigned to it rocks of different character, mostly conglomerates. King also discovered a conglomeratic sequence in the Hess Ranch Horst that he correlated with the Wolfcamp Formation. Later the Uddenites-bearing shale was excluded from the formation by P. B. King (1938:79) when Plummer and Scott (in P. B. King, 1938:79) demonstrated that its ammonites are exactly like those of the Cisco Series in north-central Texas.

The first revision of the Wolfcamp Formation was made when John E. Adams and collaborators (1939) raised the formation name to that of a series. Jarvis (1957:4) studied the Wolfcamp Formation along the Glass Mountains front and recognized that the Wolfcamp Formation of the type region was unlike that in the western part of the mountains. He likened the latter western part to the Hess Formation of Udden. Ross (1959) restudied the Wolfcamp Formation as defined by P. B. King and made a drastic revision of it. The sequence in the Wolf Camp Hills, the type Wolfcamp Formation, was renamed by Ross the "Nealranch Formation" 3 with boundaries from the top of the Gray Limestone of P. B. King (= bed 2 of King's section, 1931) to the Hess conglomerate. Rejection of the Gray Limestone (= bed 2 of P. B. King) from the Wolfcamp Formation was based on work of Sellards (1932:148) and evidence resulting from his own work on fusulinids. The conglomeratic sequences in the western part of the Glass Mountains, in accordance with Jarvis' views, were discovered to be faunally, as well as lithically, distinct from the Neal Ranch Formation. Accord-

\footnotetext{
"Originally written in this form by Ross but later revised by him (Ross, 1960) to "Neal Ranch."
}

ingly, these conglomeratic beds were named the "Lenoxhills Formation" 4 and were stated to overlie the Neal Ranch Formation.

Overlying the Lenox Hills Formation, rocks hitherto regarded as early Leonardian in age are grouped into a formation now placed in the Wolfcamp Series. This formation, the Skinner Ranch (Cooper and Grant, 1964), contains many fossils related to the Wolfcamp below and some that link it to the upper part of the Pennsylvanian Gaptank Formation as well.

\section{Neal Ranch Formation}

The Neal Ranch Formation has its type section on the Bill Neal Ranch, at the Wolf Camp Hills 13 to 14 miles northeast of Marathon. Ross's type section was made not far east of King's section, near that of Udden, but he does not include the Gray Limestone as King (1938) did in his later definition of the formation. We do not agree with this action of Ross and hereby restore the Gray Limestone (bed 2 of P. B. King) to its position at the base of the Neal Ranch Formation. Our reasons for restoration of this member to its old position are explained below in a discussion of the Wolfcampian faunas.

Considerable difficulty is experienced, in the Wolf Camp Hills, in making a continuous section of the Neal Ranch Formation that conforms to prior published sections. King's (P. B., 1931:54) section made in the western part of the hills does not conform with those prepared by Jarvis, Cooper, or Ross. The place selected by King for his section does not give as complete a sequence as can be obtained along the south-flowing branch of Geologists Canyon, where Ross (1963a:21) measured his section. None of the geologists subsequent to King has been able to confirm his system of numbers. Although we measured sections in the same places as King, Jarvis, and Ross, our sequence is not precisely like theirs. Localities cited by Batten, Finks, and Yochelson in their works on the gastropods and sponges frequently refer to bed 9 or beds 9-12 of Cooper. These are not the same as the numbers in King's section; bed 9 of Cooper is bed 12 of King.

\footnotetext{
"As with the lower formation, Ross originally combined the two elements of the name.
} 


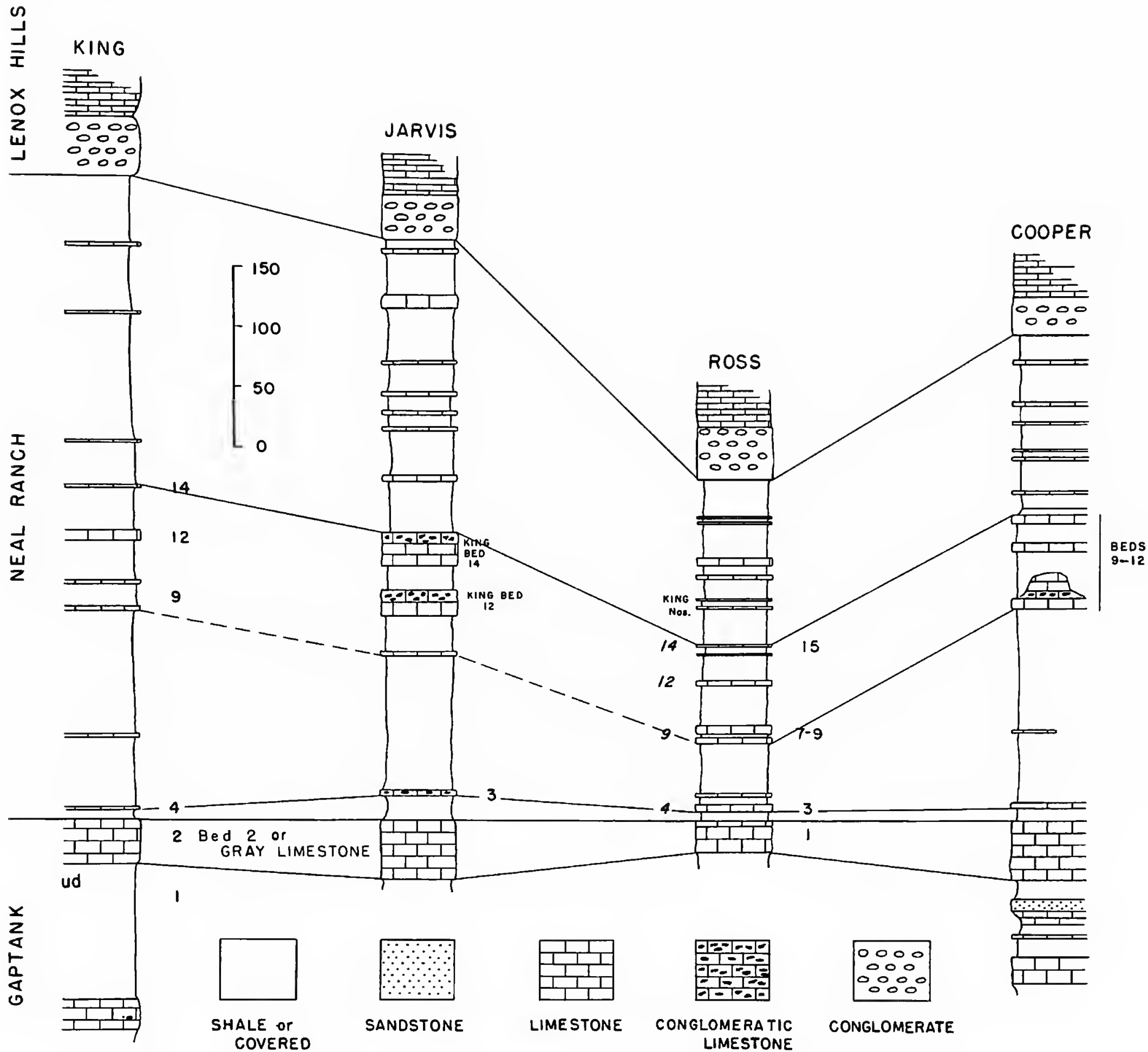

FIGURE 5.-Diagram comparing the section of the Neal Ranch Formation prepared by P. B. King with those prepared by Jarvis, Ross, and Cooper ( $\mathrm{ud}=U$ Uddenites zone; scale in feet).

Another difficulty arises from the fact that the Neal Ranch Formation thins eastward. Consequently, the excellent section given by Jarvis (1957: 5) differs in thickness and sequence from that of Ross (1963a:21), which was measured east of Jarvis's locality, where the strata are thinner. We offer our own section and a diagram comparing it with those of Jarvis, Ross, and King in an effort to make them all conform. It is important that the level of all Neal Ranch fossils be located as accurately as possible.

The Neal Ranch Formation consists of 412-547 feet (composite section) of dark gray shale alternating with thin or massive beds of limestone, some of them swelling to interesting and important bioherms with unsuspectedly rich and varied faunas. A revised section of the Neal Ranch Formation is given below, and the important beds 
are discussed in detail. The section is composite, because the sequence is not the same across the hills and a continuously exposed section of the beds cannot be found. The thickness of the basal limestone or Gray Limestone Member of P. B. King diminishes to the west of its thickest point, and the shale beds also thicken and thin. The sudden appearance of bioherms in the section also makes measurement difficult and uncertain. The section between beds 2 and 12 of P. B. King was measured in the west end of the hills, up Geologists Canyon, and then at its first elbow, up the hill to the north, ending with King's bed 12 (=bed 9 of Cooper). The remainder of the section, which has no counterpart in King's measured section, was taken from bed 12 of King on the west side of the north branch of Geologists Canyon, from the second elbow to the base of the conglomerate on the hill slope 0.7 mile $\mathrm{N} 76^{\circ} \mathrm{W}$ of hill 5060 .

The composite section of the Neal Ranch Formation is as follows:

\section{Hess Conglomerate \\ D. Predominantly shalc with thin and thick layers of limestone ranging from a few inches to 6 feet (details given under the units) \\ C. Biohermal limestone, shale, and cobbly lime- stone conglomerate \\ $40-75$ \\ B. Dark shale with occasional thin, scattered limestone layers \\ A. Gray Limestone Member

Gaptank Formation (Uddenites-bearing Shale Member)

Gray Limestone Member of P. B. King.-P. B. King (1931:55) first used the name "Gray Limestone Member" for three beds that overlie the Uddenites-bearing Shale, his beds 2 to 4 . In 1931 he regarded the Uddenites-bearing shale as the lowest part of the Wolfcamp Formation (=his bed 1). In his section, bed 2 consists of 37 feet of gray limestone, which forms cliffs and is a conspicuous physiographic feature in the Wolf Camp Hills, especially hill 5060, where it forms a high bluff that was thought by King to be limestone (but not exposed where the section was measured). Bed 4 also was assigned to the Gray Limestone, but this bed contains a distinctive fauna of marked Per- mian affinities. ${ }^{5}$ Furthermore, on the north slope of hill 5060 a considerable thickness of shale intervenes between beds 2 and 4 . Beds 3 and 4 are hereby removed from the Gray Limestone Member because of the distinctive character of the fauna of bed 4. Hereafter, in this discussion, only bed 2 of King will be called the Gray Limestone Member (Plate 12: figure 3).

Philip B. and R. E. King (in P. B. King, 1931) mapped the Gray Limestone across the Wolf Camp Hills and eastward to the Fort Stockton Road (U. S. Highway 385). Later, P. B. King (1942:648) recognized that the Gray Limestone did not have this great lateral extent. Further studies of the fusulinids and detailed sections in the foothills northeast of the Wolf Camp Hills make it clear that the thick gray limestones so like the Gray Limestone Member at the base of the Neal Ranch Formation are really layers in the Gaptank Formation. The Gray Limestone is thus confined to the Wolf Camp Hills.

Three separate areas in the Wolf Camp Hills exhibit the Gray Limestone Member, the westernmost area being the locality at which P. B. King measured his section and named the member. In the western end of the Wolf Camp Hills several good exposures of this limestone occur. In the central part of the hills the limestone forms a prominent cliff capping hill 5060. A small butte in the extreme eastern end of the hills is capped by a thick mass of dolomite identified by us as the Gray Limestone Member.

Westernmost Area: In the western part of the Wolf Camp Hills the Gray Limestone is exposed in Geologists Canyon, on an isolated butte on the west side of the canyon mouth, and in the hill slope west of the butte. The limestone can be followed up the canyon for 0.4 mile to the first tributary that comes into the main stream from the north (about where the 4650-foot contour crosses the canyon). The top of the Gray Limestone appears in the canyon bed at this junction (USNM 701). The Gray Limestone, however, can be traced in the next gully from the south (the first indentation of the 4700 -foot contour upstream from the

\footnotetext{
"King (1942:647) states that "The overlying gray limestone bed at the base of The Wolfcamp formation (beds 2 and 3) contains a few specimens of Schwagerina."
} 
4650 -foot contour) and can be proved to join the main ledge that forms the crest of hill 5060 .

The Gray Limestone forms the crest of the butte on the south side of the saddle exposing the $U d$ denites-bearing Shale Member. It also forms the north side of the saddle, but it is thinner and can be walked westward as it descends the face of the hill west of the saddle and finally passes under the alluvium at the southwest nose of the hill. The Gray Limestone thins from 40 to 10 feet in this direction as it descends to the basin floor. The Gray Limestone in this part of the Wolf Camp Hills is massive, thick-bedded calcarenite with fossils difficult to extract. At the extreme west end of the Wolf Camp Hills, near the point where it passes under the alluvium, the Gray Limestone is only a few feet thick. Fusulinids occur at two levels in the Gray Limestone near the top of the small butte at the canyon mouth (USNM 706p and 706q) (Plate 4: figure 1).

Central Area: The Gray Limestone caps hill 5060 and forms the highest part of the Wolf Camp Hills near their center. Here the limestone is 75 to 100 feet thick and in places is conglomeratic, suggesting that the mass is reefy and that it was eroded and broken in places. Here also the rock is a calcarenite, but in places it is dense, reef-type rock with flanking limestone conglomerates. Fossils are not easy to obtain from this part of the member. The Gray Limestone forms a long dip slope on hill 5060 and forms the south wall of Geologists Canyon before it plunges beneath the surface 0.56 mile due west of hill 5060 (Plate 2: figure 2; Plate 12: figure 3).

The bed of a gully just east of the junction of the tributary from the north reveals the Gray Limestone. The margin of the east bank of this gully is shale (bed 3), capped by the limestone band that forms bed 4 of P. B. King. The shale thins to the south and east, and bed 4 probably overlaps the shale to lie on the Gray Limestone. This cannot be seen because the tributary stream has cut along the edge of the probable overlap and removed the shale and overlying limestone down the dip of the beds for a short distance.

The south wall of the gully is formed by the steep face of the Gray Limestone as it plunges abruptly beneath the surface. This appears to be not a dip slope of the Gray limestone but probably an eroded surface. West of the gully the surface of the Gray Limestone is irregular, and its surface is strewn with fossiliferous limestone pieces of uncertain derivation. Near the junction of the gully and Geologists Canyon (USNM 722x) is a small bioherm mostly of algae enclosing specimens of Eolyttonia phialiforma, new species. We believe that this bioherm belongs to the Gray Limestone. Possibly it grew on the limestone and belongs rather to the shaly bed 3 .

Eastern Area: The Gray Limestone on hill 5060 is interrupted on the east by a broad saddle ( $R$. E. King 199) that reveals some beds and bioherms of the Uddenites-bearing Shale Member. On the north slope of the hill to the east, which has a crest of 4952 feet, limestone lithically like the Gray Limestone overlies the upper limestone and shale of the Uddenites-bearing Shale Member, but it does not form a bluff and it appears north of the edge of the hill except for knob 4952. The hill between 5060 and 4952 reveals the Gray Limestone on its north side, making the long dip slope. At hill 4952 the Uddenites-bearing Shale Member is capped by 135 feet of massive carbonate, mostly dolomite. Fossils were not found in the dolomite mass at this place, and all we can say regarding the dolomite is that it occupies the position of the Gray Limestone and probably represents another local, probably reefy, thickening of the member (Plate 3: figure 4).

No evidence of the Gray Limestone was seen northeast of the Wolf Camp Hills. P. B. King (1942:648) recognized beds formerly called Gray Limestone in this direction as members of the Gaptank Formation. This is also the decision of Ross (1963a:12, 13). All of the thick limestones capping the foothills to the northeast of the Wolf Camp Hills clearly belong to the Gaptank Formation. West of the Wolf Camp Hills no trace of the Gray Limestone was found or has been reported. Relationship to the Uddenites-bearing Shale Member: The Wolf Camp Hills is the only part of the Glass Mountains where the contact of the Gray Limestone and the Uddenites-bearing Shale Member can be studied. P. B. King (1942:647) states: "Here the Wolfcamp lies on the Gaptank Formation without angular discordance and with no clear sign of erosion, although some miles south the Gaptank and older beds are steeply folded." The Uddenites-bearing Shale Member is variable 
in thickness under the Gray Limestone, and in places it is absent. Furthermore, the limestones of the Uddenites-bearing Shale Member in places are biohermal with the result that the Gray Limestone rested on an uneven surface. No faunal break between the two members seems evident, but the contact certainly is disconformable. The uneven surface on which the Gray Limestone was laid was owing to irregularities of deposition and to the formation of bioherms. The relationship is complicated further by the fact that the Gray Limestone itself is evidently lenticular or reefy, swelling and thinning along its outcrop. The overlap of bed 4 onto the Gray Limestone is further illustration of the irregularity of thickness of the Gray Limestone.

Dark Shale with Scattered Limestone LayERs.-This interval is variable in thickness; none of the published measurements are in agreement, and the numbering of the beds in the interval is not uniform. The shale was laid down on an irregular surface as explained above, the top of the Gray Limestone being very irregular. Inasmuch as P. B. King's section has been consulted and referred to so often, we use his numbers with the suggestion that the comparative diagram (Figure 4) be consulted for equivalency between sections.

Beds 3-4 of P. B. King: Bed 3 consists of dark gray shale of variable thickness, being about $10 \mathrm{feet}$ thick where it is well displayed in the gully that drains into Geologists Canyon from the south, opposite the point where bed 4 passes below the canyon floor. No fossils were taken from this bed. The interval between bed 2-the Gray Limestone Member-and bed 4 is greater than 10 feet on the west side of the Uddenites saddle. Here the slope distance is about 50 feet vertically, denoting a thickness of about 70 feet for bed 3 , but no shale is exposed on the steep slope.

Bed 4 consists of yellow-brown calcarenite of variable thickness, usually 3 to 4 feet, but becoming thicker where it is biohermal. In places at its base it is composed of cobbly limestone with fair-sized rounded limestone pebbles and cobbles that pass upward to more solid calcarenite. There they terminate in a layer of detrital calcarenite and shell breccia with a flat upper surface. This bed can be traced eastward from the first elbow above the mouth of Geologists Canyon, along the base of the north wall just above the stream bed. It passes beneath the canyon floor about 50 yards upstream from the small gully on the east side of the Gray Limestone at USNM 701.

Bed 4 can be traced southward along the east side of the small gully and then eastward along the north bank of the gully at its right-angled elbow. There it forms the brink of the gully and holds up the small hill. The gully is formed by migration of the stream along the soft shale of bed 3 between the Gray Limestone and bed 4 . This gully is thus migrating down the dip of bed 3 . The north side of the gully is the last outcrop of bed 4; it is overlain by higher members of the Neal Ranch Formation to the east.

Bed 4 in places contains many fossils, but they are difficult to extract unless silicified. Only a few satisfactory places where this type of preservation occurred were found in this bed. The edge of the gully described above in the north slope of hill 5060 is such a place (USNM 727d). Here silicified brachiopods are common, among them Geyerella, Parenteletes, and Tropidelasma. Fusulinids (Dunbar and Skinner, 1937:585, 670) of the genera Triticites and Paraschwagerina have been taken from this bed.

Bed 4 is well exposed on the west side of the Uddenites saddle as it rises from the canyon to loop over the hill on the north side of the $U d$ denites saddle. The bed then desqends the south face of the hill to the plain at the west end of the Wolf Camp Hills. Two localities (USNM 701-1 and $727 \mathrm{e}$ ) on this slope yielded silicified fossils from bed 4 (Plate 5: figure 2).

Beds 5-8 of $P$ B. King: Nowhere in the Wolf Camp Hills are these beds exposed well enough to obtain from them good faunas or a clear idea of the beds' nature. This sequence comprises mostly dark gray shale, about 163 feet thick, on the west side of the first tributary gully on the north, extending into Geologists Canyon to a point opposite USNM 701, where the Gray Limestone passes under the stream bed. At this place the shale is well, but not completely, exposed and is blue black and crumbly. The interval represented by it appears along the north side of the canyon to the east and west and forms the slope facing the Uddenites saddle. Fossils have been taken from this interval, but it is impossible to be sure that 
they were derived from the shale, because the slopes are covered liberally with float material from higher in the section. An occasional large Reticulatia appears to have been derived from this interval. The limestone layers, beds 6 and 8 of P. B. King, were not identified. Probably these are lenticular and may not have much lateral extent, or they may have become covered since King measured his section.

Biohermal Limestone, Shale, and Cobbly ConGLOMERATE.-Because of their unusual development into bioherms, this group of limestones and shale contains the most important and prolific faunas in the Wolf Camp Hills. They are located where it was possible to take large blocks from them. Unfortunately, the exact equivalency of the beds described herein with beds 9-14 of P. B. King is not entirely clear, because bed 9 as recorded by King (1931:55) was not defined lithically (it was an interval in which certain fossils were collected and was not a bed). Our identification of it is based largely on the fossil list derived from loose blocks in the 19-foot interval measured by $P$. B. King (1931:55; 1938:96). Bed 12 is more readily identified, and more than likely it furnished the blocks identified as bed 9 , because the faunas are the same and the bed is clearly mapped (P. B. King, 1931:54, fig. 19). King's 12 forms a conspicuous capping ledge of the hill north of the Uddenites saddle and on the north side of the east-west part of Geologists Canyon. Bed 14 is definitely R. E. King's locality 92 . We have, therefore, identified all of the limestones between the dark shales of the previous interval (beds 5 to 8 ) and the capping ledge as beds 9 to 14. This is in accordance with the faunas listed by R. E. King and the geographic location of beds 12 and 14 . In the western and central parts of the Wolf Camp Hills, these beds form a natural unit composed mostly of limestone and aggregating in a thickness of about 75 feet. The interval is variable in thickness and lithology, and intercalation of additional layers takes place eastward. Consequently, exact numbering is diffcult. Cooper's estimate (Figure 4) indicates that his bed 9 is probably part of King's bed 12 (Plate 4: figure 4).

It seems best to discuss this sequence of beds geographically, mentioning first those that occur from the north tributary of Geologists Canyon near
USNM 701 to the west end of the hills, where the layers are thickest and best developed, and then the extension of the beds east of USNM 701 to their disappearance near the north elbow of Geologists Canyon. A third area occurs about a mile west of the Wolf Camp Hills, but, because of the uncertainty of correlation of beds 9-14 in it, we discuss this area in the discussion that deals with the upper part of the Neal Ranch Formation.

The best section, and the one that yielded most of the silicified fossils, is in the westernmost hill (capped by two closed contours at 4900 feet) above and on the north side of the Uddenites saddle and west of the gully from the north. This hill is characterized by two small knobs, each containing an interesting biocherm (USNM 70lc, 70lh). (Plate 16: Figure 2).

Area West of North Tributary: Overlying about 163 feet of dark shale (beds 5-8), on the west side of the small tributary from the north, are two distinct beds of limestone with some interbedded shale that are taken to represent beds 9 to 12 of P. B. King (= Cooper's bed 9; Figure 4). The lower bed consists of 20 feet of brownish calcarenite with a flat ledge of shell breccia on the top. The ledge can be walked to the west side of the hill, where it underlies another bioherm. This bed of calcarenite and shell breccia is overlain by another interval of about 20 feet, beginning with cobbly, conglomeratic limestone about 3 feet thick. The latter is followed by a thick biohermal mass, part of bed 12 of P. B. King, which abounds in unusual reef-type brachiopods (USNM 701c). The slope to the northwest also contains bioherms of this stratigraphic level dotting the surface. Kings bed 14 (= Cooper's bed 12) is exposed at the head of the small tributary from the north, where it is cobbly at the base and has a great abundance of fusulinids and an occasional goniatite, Properrinites. Bed 14 can be traced along the north side of the gully between the small knob capped by the 4750 -foot contour and the hill to the south. The interval between the top of the dark shale (bed 8) and the top of bed 14 has been variously determined as being from 40 to 75 feet thick.

Beds in the knob on the western side of the hill are similar to those of the eastern one, but they are not as thick. The lower limestone (bed 9 of Cooper) forms the edge of the hill above the $U d$ - 
denites saddle, is 16 feet thick, and overlies a thick shale, here not exposed on the debris-covered slope. The 16-foot limestone is capped by a flat calcarenite bed a foot or more thick. The lower part of the 16-foot bed starts with limestone cobbles that grade into more solid conglomeratic limestone, then into calcarenite, and finally into the flat calcarenite and breccia bed.

Lying on the upper flat bed just mentioned and helping to form the small knob is another bioherm about 5 feet thick, composed of algae, sponges, and a variety of brachiopods. This bed (11 and 12 of P. B. King?) is overlain by another flat calcarenite and a breccia about a foot thick, with shale between. On the north side of the bioherm, the breccia bed is irregular, laps onto the side of the bioherm, and is broken into quadrangular blocks to form a mosaic surface. In places the mosaic is domed where it has been compressed onto the top of a bioherm. (Plate 4: figure 3). The large 5-foot bioherm (USNM 701h) contains an abundance of small Geyerella and enormous Parenteletes. These two limestone beds can be followed on the west slope of the hill a short distance to the north, where they plunge under the surface of the plain. USNM $701 \mathrm{k}$ represents the same layer (bed 12 of King) before it plunges under ground (Plate 4: figure 3).

The lower part of this interval (beds 9 to 12 of Cooper $=12$ to 14 of P. B. King) can be examined on the east side of the north-flowing tributary. The lower limestone caps the small hill represented by the 4750-foot contour on the north side of Geologists Canyon; bed 14 or the top of the sequence appears on the north side of the gully dividing this hill and the spur of the main mountain front to the north. On the east side of the hill, capped by contour 4750, Geologists Canyon makes its second elbow-here to the north-and isolates this small hill. On the west bank of the north branch of Geologists Canyon, a fine and almost complete sequence of the upper Neal Ranch Formation can be studied. The ledge capping the hill with contour 4750 passes under the floor of Geologists Canyon exactly at the second elbow, where the canyon turns to the north and the upper ledge of bed 14 appears on the west bank of the now south-flowing stream about 250 feet north of the elbow. The slope facing south below bed 14 (= bed 13 of P. B. King) abounds in large fusulinids and goniatites. This is the only locality in the Neal Ranch Formation (= type Wolfcamp Formation) known to us that has produced many goniatites (USNM $706 \mathrm{x}=715 \mathrm{e}$ ). This bed thins conspicuously to the west. The interval between the beds identified as "Bed 9" and that called "Bed 14" is 75 feet thick. It consists of 5 feet of limestone (= bed 9), 42 feet of shale, 5 feet of limestone, 17 feet of shale with goniatites, capped by 2 to 6 feet of hard limestone (= bed 14). The beds just below the uppermost limestone are cobbly conglomerate and contain fossils in the cobbles and loose fossils in the shale between them (Plate 4: figure 4).

The slope on the south side of Geologists Canyon, just east of the hill capped by the 4750 -foot contour and forming the west side of a northflowing tributary to Geologists Canyon, is held up by the lower part of bed 9 (of Cooper). It ascends the slope to the south and laps onto the Gray Limestone Member (if projected). This slope contains many bioherms and is a prolific source of our silicified fossils (USNM 701a and 70la ${ }^{3}$ ).

Shale and Thin Limestone Sequence (Section ABove BED 14 OF P. B. KING).-This sequence is well exposed in two places in the Wolf Camp Hills: one in the center of the hills and the other at the extreme west end beyond the main chain. The Neal Ranch Formation above bed 14 in the section parallel to the north branch of Geologists Canyon is 144 feet thick. It consists of a shale sequence with 9 bands of limestone ranging from 6 inches to 6 feet in thickness. In general, the limestones are brown in color when weathered and are hard calcarenite. A prominent band about 57 feet below the base of the Hess conglomerate is biohermal and variable in thickness. The intervals between the limestones are variable as can be determined by following them along the outcrop. The shale between the uppermost limestone and the Hess conglomerate is also variable, but in places it is about 50 feet thick. The sequence of the Neal Ranch Formation in this central part of the Wolf Camp Hills appears to be thinner than the section measured in the western part of the hills.

We found no silicified beds in these limestones above bed 14, and fossils proved difficult to find. Fusulinids are fairly common in some of the layers, but other taxa are not well represented. 
The best section of the upper Neal Ranch Formation appears in a low hill 0.8 'mile westnorthwest of the outlier on the south side of the Uddenites saddle. This hill is slightly more than 100 feet high. The steep south face displays biostromes and bioherms abounding in silicified fossils. A section measured up the face of the hill and down the back slope to the north reveals at least 500 feet of shale and limestone like those in the section along the north branch of Geologists Canyon. P. B. King (1931:142, section 23) and Ross (1963a:65, section 19) measured, respectively, 527 and 532 feet in this hill. The section begins about 50 yards south of the south slope of the hill, where ledges of limestone first appear. From here to the conglomerate contact, 23 limestone beds were recorded, ranging in thickness from 6 inches to 8 feet. Shale intervals varied from a few feet to 60 feet. Blocks taken from this hill for dissolution came from the lower 30 to 50 feet of the slope (USNM 701d, 72lg), where the bioherms are best developed. Silicification was not noted in the higher beds.

P. B. King (1931:143) recognized "Bed 12" in this hill as bed 6 of his section 23. We were not able to corroborate this identification because the faunas taken from our USNM 701d are not entirely like those from his bed 12 (USNM 70lc, 70lh, $701 \mathrm{k}$ ). Our specimens date this level as bed 4 . This correction brings to accordance the thickness of the two sections.

Outside the Wolf Camp Hills.-West and east of the Wolf Camp Hills the Neal Ranch Formation has been eroded away. The largest area for the formation east of the Wolf Camp Hills is in Stockton Gap on both sides of the Marathon-Fort Stockton road (U. S. Highway 385). In foothills along the base of the Glass Mountains no Neal Ranch Formation has been found except near the Fort Stockton road. About a half mile west of this road, a wedge of Neal Ranch thickens to the east, the thick end of the wedge extending about 0.4 mile east of the road. Ross (1963a:81) reports 95 feet of Neal Ranch at this place, the section consisting of shale with thin bands of yellow limestone. Fusulinids are abundant, but other fossils are difficult to find. Gastropods, sponges, and a few brachiopods weather from the shale, but no silicified fossils were found.
In the Lenox Hills at the opposite end of the Glass Mountains Ross (1963a:59, section C) reports 44 feet of Neal Ranch in small exposures 1.5 miles west of Sullivan (Yates) Ranch road at the east base of hill 5300. Here the formation consists of clark brown limestone and yellow siltstone with small chert pebbles in the limestone.

Another area is located at the southwest end of the Lenox Hills (Ross 1963a:58, section 7) 1.25 miles northeast of Lenox, where 45 feet of gray biohermal limestone occur with numerous fusulinids, some ammonites, and brachiopods. The fossils are similar to those from beds 9-14 in the Wolf Camp Hills (USNM 715b). Some of the Neal Ranch at this place is biohermal, which may account for the odd dips at the base of the Lenox Hills conglomerate, but the conglomerates of the Lenox Hills appear to interfinger into these limestones. It seems likely that this so-called Neal Ranch Formation is in reality part of the Lenox Hills Formation. The ammonites at the base of the Lenox Hills at USNM $707 \mathrm{j}$ appear to be the same as those taken from bed 13 of P. B. King (USNM 715e) of the Neal Ranch Formation. There is thus possible an overlap of the Lower Lenox Hills with upper Neal Ranch.

A third important locality for the Neal Ranch Formation is at the base of the Hess Ranch Horst, in the arroyos at the base of hill 5816. In the arroyo leading up to the hill topped by the 5700 -foot contour on the west side of hill 5816, an interval of 280 feet from the igneous intrusion to the lowest conglomerate includes dark indurated shale with a limestone band containing fusulinids near the top (Wilde, 1962:71). The shales have been baked and hardened by contact with a large intrusion on the south side of the horst. Fossils are not common in the shale, but a few brachiopods, snails, and sponges were taken (USNM 704v = 702-1).

Another locality for this shale occurs in the notch 0.7 mile due east of hill 5816, where the Wolfcampian rocks are faulted against the Skinner Ranch Formation. Here about 100 feet of shale is exposed, again with a baked and altered base against the igneous intrusion. Few recognizable fossils were taken from the Neal Ranch shale at this place.

Myers (in Adams and Frenzel, 1952) and Bostwick (1962) described a section in a synclinal hill 
four miles west of Marathon on U. S. Highway 90 in which early Wolfcampian fusulinids occur. These may be older than Neal Ranch.

\section{Lenox Hills formation}

The Lenox Hills Formation overlies the Neal Ranch Formation unconformably and extends across the mountain front from Dugout Mountain to the east side of the Fort Stockton road (U. S. Highway 385). The formation is variable and exhibits several facies. The type section given by Ross (1960:120) a year after the formation was first published, is in "the Lenox Hills, one-quarter of one mile north of the Slick-Urschell no. I Mary Decie well site 7 miles, north 70 degrees west, of Marathon, Texas." This locality is at the base of hill 5300, the highest peak in the Lenox Hills. Here it overlies a supposed remnant of the Neal Ranch Formation. In a later publication, Ross (1963a:58, section 8) revised the locality to "the southeastern face of the Lenox Hills $21 / 2$ miles $N$. $10^{\circ} \mathrm{W}$. of the Decie ranch house; this is about $1 / 3$ mile N.-NE. of the Slick-Urschell no. 1 Mary Decie well site."

Like the Neal Ranch Formation below, the Lenox Hills Formation has different characteristics in different parts of the mountains. Consequently, the formation will be discussed on a geographic basis beginning with the type area in the Lenox Hills. Next, the sequence west of the type section in Dugout Mountain will be discussed, after which the development of the formation east of Lenox Hills will be considered. The discussion will end with an account of the succession in the Hess Ranch Horst, which is, perhaps, the best and longest section but contains many unusual features.

IN THE LENOX HILls.-The type section of the Lenox Hills Formation consists of two parts: a lower conglomerate and an upper shale. The conglomerate is extensive, and generally it can be seen in all parts of the mountain front and foothills. It is best displayed in the western part of the Lenox Hills, where it is well exposed above the Devonian cherts on the west side of the Slick-Urschell well site. The conglomerate also is exhibited in its entirety at the type section, where it has a thickness of 310 feet on the west side of hill 5300 (south of knob 5250). The thickness of the conglomerate varies in the Lenox Hills, from 200 to 400 feet in the western part, but it thins to the east. It is composed of a mixture of well-rounded limestone cobbles and chert pebbles, the latter often angular and ragged. In the section above the Devonian chert, where the conglomerate is well spread out, and at the type section, it is mainly small angular chert pebbles of various shades of green and red. The lower 50 feet of the Lenox Hills Formation on the west side of the Slick-Urschell well site contains 15 feet at the base with large pebbles of limestone and chert together. This is followed by 25 feet of thinner bedded conglomerate with small pebbles and this by 10 feet of biohermal limestone with flat algae. The following 300 or more feet (P. B. King, 1931:134, section 10, gives 420 feet for the conglomerate) are conglomerates of large and small pebbles closely packed together. About 25 feet above the base in this section, a 1-foot bed of dark limestone with small angular pebbles abounds in goniatites, including Artinskia and Properrinites (USNM 707j), an association suggestive of bed 13 of P. B. King in the Wolf Camp Hills. In addition to the ammonites, this conglomerate contains a few brachiopods, fragments of wood, and scattered seeds. Near the type section the lower beds that are biohermal also have yielded a few goniatites and other fossils (Plate 5: figure 4).

According to P. B. King (1931:135) and Ross (1963a:28), the formation thins to the east along the base of the Lenox Hills. Its thickest development is in the southwest end of the Lenox Hills. At the east end of the hills, according to Ross, it is 30 feet thick. It is also thinner than the maximum in Dugout Mountain.

At the type section of the Lenox Hills Formation, the conglomerate is succeeded by 158 feet (Ross, 1963a:59, section 8) of shale interbedded with sandstone and thin layers of limestone, both with lenses of conglomerate. The shale in places is capped by a thin layer of conglomerate, but in other localities the overlying Decie Ranch Member of the Skinner Ranch Formation rests directly on the shale. About a half mile west of the type section, the conglomerate is 310 feet thick and is followed by 172 feet of shale with interbedded thin sandstone and limestone conglomerate bands with small pebbles. Two limestone beds containing goniatites were found in the lower part of the shale, the lower 
(USNM $707 \mathrm{~m}$ ) is 20 feet stratigraphically above the conglomerate and the upper (USNM 707n) is 40 feet above the base of the shale. The upper part of the sequence is bluish shale with scattered thin limestone and sandstone beds (Plate 5: figure 4).

Another excellent section of the shale 140 feet thick overlies the conglomerate in the elongate, northeast-southwest trending hill a half mile south of hill 4902. Here the shale is capped by the Decie Ranch Member, which forms a small butte. The shale rests on the thickest part of the Lenox Hills conglomerate (P. B. King, 1931:134, section 10), and in this butte it contains about 25 feet of soft conglomeratic shale at the base followed by $67 \mathrm{feet}$ with scattered limestone and thin conglomeratic bands. The upper 48 feet is mostly bluish shale. The middle beds produced some goniatites and unusually well-preserved gastropods (USNM 707c) (Plate 5: figure 4).

The shale can be traced along the base of the Lenox Hills from the type section of the Lenox Hills Formation to the fault that sets off the spur at the east end of the Lenox Hills. Except for the localities mentioned, we were unable to find any prolific collecting places in the shale. This is unfortunate, because the megafauna of the Lenox Hills Formation is still very poorly known.

In Dugout Mountain.-The two-fold character of the Lenox Hills Formation seen in the Lenox Hills is displayed also in Dugout Mountain southwest of Lenox. In the eastern part of the mountain, the shale has been eroded off the conglomerate, and the overlying Decie Ranch Member rests directly on the Lenox Hills conglomerate (P. B. King, 1931:56, fig. 21 on p. 59). The thickness of the conglomerate is recorded by P. B. King (1931: 133) as 330 feet in the slopes under hill 5195. At this place the shale measures 60 to 100 feet and contains a 2- to 3-foot band of conglomerate near its middle, which has yielded fossil wood and seeds as well as goniatites and brachiopods (USNM 715). The assemblage is like that in the thin limestones in the lower 40 feet of shale in hill 5300 in the Lenox Hills (USNM 707m, 707n). Ross (1963a:28) states that the Lenox Hills Formation in Dugout Mountain is reduced to a few feet in thickness on the west side of the mountain. He also indicates intertonguing of conglomerate and shale and change of facies from conglomerates to thin-bedded limestone and shale. Except for the goniatite bed under the main summit, the Lenox Hills Formation in Dugout Mountain has yielded few fossils (Plate 13: figure 4).

East of Lenox Hills to Iron Mountain.-As already explained, conglomerate and shale of the Lenox Hills Formation can be traced readily along the base of the Lenox Hills to the fault at the spur just west of the Sullivan (Yates) Ranch road. From this place to Leonard Mountain, considerable confusion exists concerning the Lenox Hills Formation. Unfortunately, we are unable completely to resolve these difficulties.

King and King (in P. B. King, 1931: map) mapped a patch of Wolfcamp shale and conglomerate on the south side of hill 5021, measuring 63 feet but not a complete section. Another patch of conglomerate and shale 83 feet thick was mapped on the east side of the same hill. We examined both of these sequences. On the south side of hill 5021, under the Skinner Ranch Formation, at the westernmost saddle of the hill there are 50 feet of sandstone and conglomerates; the lower part is mostly sandy, but it becomes densely conglomeratic toward the top. Somewhat lower down on the slope, a concentration of loose blocks, yelloworange in color and abounding in Wolfcampian fusulinids, was seen. The position of these is about 25 feet below the lowest exposed section beneath the saddle. This indicates at least 25 feet more of Lenox Hills at this place. On the east side of hill 5021 a continuous section of Wolfcampian rocks cannot be obtained, but a 118-foot section of yellow sandy conglomerate and shale was measured.

Just east of hill 5021 there is a small knob containing beds of the Lenox Hills Formation with numerous fusulinids. Since these could not be resolved into a reasonable section, it is thought that the knob represents a detached block from higher in the section, which embraces part of the Lenox Hills and Skinner Ranch Formations.

In the hill (5280) just west of Iron Mountain, a band of Wolfcamp is mapped near the east base of the hill, from the southern end to the northern tip, and a measurement of 166 feet is given for it (P. B. King, 1931:138, section 15). It consists mostly of shale and sandstone with a 5-foot conglomerate at the base. Ross (1963a:60, section 10) measured a section at the south end of this hill and 
recorded 140 feet, which consisted chiefly of sandstone and siltstone with Wolfcampian fossils. Neither Ross nor we were able to identify the formation along the base of the hill to the north. Thus, a gap appears in the Lenox Hills outcrop belt from the south end of this hill to Leonard Mountain on the east side of Iron Mountain. Fossils are difficult to obtain in the exposures between Lenox Hills and Iron Mountain.

In Leonard Mountain.-The Lenox Hills Formation in Leonard Mountain is thick and important because it helps to clarify the sequences on the Hess Ranch Horst and those north of the Hess Ranch house. The formation is sandy and shaly on the west side of Leonard Mountain, but it consists largely of limestone on the east side (Plate 6: figure 3).

According to Ross (1963a:61, section 11), the Lenox Hills Formation on the northwest side of Leonard Mountain measures 255 feet thick and consists chiefly of siltstone and shale with some thick beds of calcarenite. Farther southeast along the base of the mountain at the southwest corner, Ross's (1963a:61, section 12) measurements indicate a great thickening of the formation. Here 661 feet of Lenox Hills Formation is recorded, the lower half consisting of calcirudite with some chert pebbles. The upper half consists of limestone and dolomite, the latter 120 feet thick. The section on the southeast nose of Leonard Mountain is thinner than the preceding section, but it is very important, because this is the site of King's main section of the Leonard formation, and the south face of Leonard Mountain is the type area designated by Udden for the Leonard Formation.

In P. B. King's (1931:140) interpretation of the southeast nose of Leonard Mountain, the conglomerate overlying the folded and steeply dipping Tesnus Formation was regarded as Wolfcampian, and the shale that comprises the lower slopes of the mountain was thought to be the Uddenites-bearing Shale Member of the Wolfcamp Formation. Limestone succeeding the shale was identified also as Wolfcamp, but above this limestone the section beginning with a thick conglomerate was identified as the Hess Formation. In King's section 17, bed 5 of the Wolfcamp, 250 feet thick, was suspected of being a detached block from higher on the mountain. This suspicion has proved true, and the other identifications have been subjected to revision by Wilde, Ross, and ourselves.

Investigations by these workers have led to a completely different interpretation of the sequence in this part of Leonard Mountain. The conglomerate and overlying shales resting on the Tesnus Formation are not the Uddenites-bearing Shale, but they are lower in the Gaptank Formation. The calcarenite overlying the shale contains Gaptank fusulinids and now is identified with that formation. The conglomerate overlying the Gaptank limestone now is recognized as the lower part of the Lenox Hills Formation, 179 feet thick on this part of the mountain. The conglomerate is overlain by 190 feet of light, gray calcarenite containing abundant Lenox Hills fusulinids. In addition to these, the calcarenite has at its base bioherms abounding in Scacchinella and Tropidelasma. In the past these were identified as belonging to the Hess Formation, having been mistaken for a similar zone higher in the sequence. However, these familiar "Leonard" types occur with characteristic Wolfcampian fusulinids on this southeast nose of the mountain and elsewhere in Wolfcampian rocks. Besides the fossils mentioned at this biohermal level, large specimens of Parenteletes, a good Wolfcampian indicator, were collected (Plate 20: figure 2).

The fossiliferous zone just above the conglomerate and its fusulinids are well developed on the northeast slope of the mountain, in the saddle just south of the two knobs at about the 5100-foot contour. According to Ross (1959:299), this calcarenite intertongues with shale on the west side of the mountain. It is interesting to note that, at the northeast base of Leonard Mountain, the Scacchinella beds of the basal Skinner Ranch Formation are well developed and that Schwagerina crassitectoria is present. The latter occurs on the west slope of the high knob northeast of the summit of the mountain (bench mark 5860), at about 5725 feet elevation. This indicates the general position of the underlying Lenox Hills Formation in the steep southeast cliff face of the mountain. This point corresponds to about the highest point (5816 feet) on the Hess Ranch Horst. The same facies shift from Scacchinella patch reefs, or bioherms, to finegrained detritals occurs in Leonard Mountain, the 
Hess Ranch Horst, and in the hill north of the Hess Ranch house.

The upper part of the section on the southeast nose of Leonard Mountain includes 200 to $250 \mathrm{feet}$ of dolomite, which forms the prominent cliff so conspicuous on the southeast side of the mountain. As will be explained under discussion of the Skinner Ranch Formation, the lower part of the dolomite belongs to the Lenox Hills Formation, but the greater part of it on this side of the mountain belongs to the Skinner Ranch.

Attention must be called to the detached blocks that are prominent on the southeast side of the Mountain. One of these has a vertical height of 150 feet; many fine specimens of Lenox Hills fossils were taken from it (USNM 705s). Ross (1963a: 16) presents a map showing the distribution of these detached blocks at the base of the southeast side of the mountain. Similar toreva blocks, containing some beds of the Lenox Hills conglomerate, also occur on the south base of hill 5021 on the east side of the Sullivan (Yates) Ranch road and at the southwest end of the Lenox Hills (Plate 8: figure 2).

The conglomerate of the Lenox Hills Formation on the southeast side of Leonard Mountain is coarse, with pebbles up to several inches in diameter cemented in limestone. Many of the pebbles are limestone, but some are siliceous. The conglomerate can be traced readily along the east side of the mountain to the northeast corner, where it forms the floor of the valley under the elliptical knob formed by the 5000 -foot contour. Above the conglomerate, the east slope of the knob is formed by 138 feet of gray limestone, weathering to brown and containing numerous Wolfcampian fossils. No Hess-type limestone or dolomite tongues were identified in the upper Lenox Hills Formation at this place (Plate 3: figure 3).

In Hess RANch HoRst.-The Hess Ranch Horst forms a wedge-shaped chain of hills on the south side of Hess Canyon and on the north side of the canyon leading up to the Old Word Ranch. Two summits are prominent and important in the chain: the lowest on the west side of the horst hill is 5305; the highest is 5816 on the east side of the horst, which sends out a long spur to the northeast, ending in a knob identified by the closed 5650 -foot contour. The section in hill 5305 seems to be the thinner of the two, but the entire section cannot be seen. The most complete section occurs on the slopes leading up to the summit at hill 5816 (Plate 3: figures 1,2 ).

Just west of the summit at hill 5816 and at the base of the hill, a ravine has exposed a section of the Neal Ranch Formation. Another but shorter sequence of this shale occurs in the ravine leading up to the summit at hill 5816. At the east end of the horst, Ross (1963a:65, section 18) records 104 feet of this shale. In the two ravines mentioned above, shale occupies the lower 50 feet of slope, but the first conglomerate was seen above a covered interval 120 feet vertical. This suggests a shale interval of nearly 300 feet (Wilde, 1962:71). This shale is overlain by the Lenox Hills Formation, which exhibits two facies in the horst?

The Lenox Hills Formation is estimated to be 600 to 700 feet thick in the middle hill of the horst. It consists of 350 feet of limestone conglomerate, sandstone, and shale, which is overlain by 260 feet

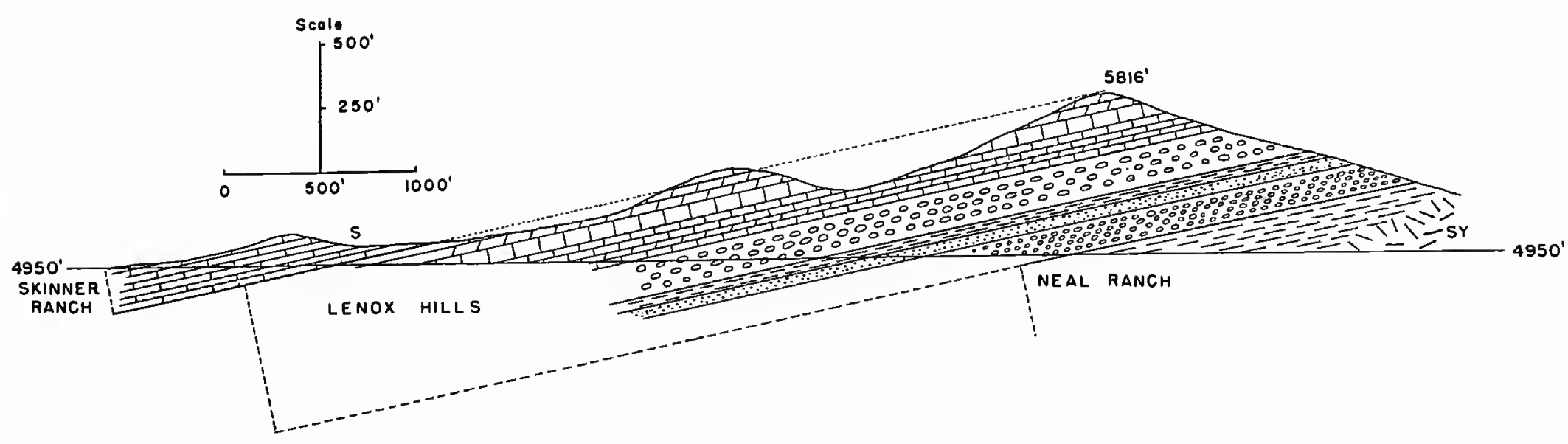

Figure 6.-Section through the Hess Ranch Horst showing the relation of the Skinner Ranch Formation to the main body of the Horst ( $S=$ Scacchinella, $S Y=$ Syenite intrusive). 
of calcarenite and thin-bedded dolomite. The lower part of this sequence was regarded by P. B. King (1931:56, 14l) as mostly Wolfcamp Formation (310 feet), and the uppermost conglomerate was assigned along with the calcarenite and dolomite to the Hess Formation. The presence of Wolfcampian fusulinids throughout the section, to within 27 feet of the summit at hill 5816, indicates that the entire section on the south front of the horst, except the very summit, belongs to the Wolfcamp Series, in spite of the fact that the upper part of the sequence has the facies of the Hess Formation.

The lower coarse clastics consist of a thick conglomerate approximating 135 feet, followed by thinner beds of brown sandstone and shale 115 feet thick, terminating in another conglomerate about 100 feet thick. The two conglomerate bands usually produce ledges or bluffs on the hillside. The intermediate layers are mostly sandstone, but one 4-foot bed of white-weathering dolomite was detected, the first appearance prophetic of the "east Hess facies." The sequence above the upper coarse conglomerate consists mainly of sandy limestone, light-colored, thin conglomerate beds containing small pebbles, and thin layers of dolomite-in all about 260 feet thick. The top of the hill is capped by 27 feet of dark dolomite. The whitish limestones and dolomites suggest relationship to the Hess Formation, but the entire sequence to the 27 feet of dark dolomite contains Wolfcampian fusulinids. Actually, this part of the section and the conglomerates can be related directly to the lower several hundred feet of the Hess Formation, as explained below.

From the summit of hill 5816 northwestward to the west base of the Hess Ranch Horst, the beds overlying the Wolfcamp appear to be the Skinner Ranch Formation. These contain Scacchinella and other fossils, which identify them with the basal Skinner Ranch (= Decie Ranch Member). The Scacchinella beds cannot be traced to the summit of the horst at hill 5816 , because a facies change takes place up the dip, the Scacchinella beds passing into Hess lithology with Schwagerina crassitectoria. This facies change is discussed more fully under the Skinner Ranch Formation. Although the Decie Ranch Member of the Skinner Ranch Formation changes facies up the dip to the summit of hill 5816 this is not true at the next hill to the west, hill 5305 in the horst.

In hill 5305 the conglomerate is thick. About 480 feet of it is exposed, but the sequence above the conglomerate measures only 200 feet and consists of mealy and cobbly limestone with brachiopods that include Parenteletes. These beds are overlain by thick-bedded dolomite containing patches of limestone. Biohermal structures can be detected in this part of the section, which forms the top of hill 5305. Scacchinella was found 25 feet vertically below the crest of the hill, indicating the presence of the Skinner Ranch Formation. It is to be emphasized that the Skinner Ranch Formation on the crest of this hill has the biohermal facies, but at the top of hill 5816 this facies has been displaced by a Hess facies with Schwagerina crassitectoria. The long dip slope from the crest of hill 5305 is all in the basal Skinner Ranch Formation. Several places on this slope are excellent localities for collecting the Scacchinella titan fauna.

The crest of the summit at hill 5816 is mostly dark dolomite. Northeast along the summit of this narrow hill is another knob, formed by the 5800 foot contour, with essentially the same elevation as the main summit. Here in the dark dolomite a huge Omphalotrochus was seen. These gastropods are abundant in the lower Skinner Ranch associated with Scacchinella. The narrow spur continues still farther to the northeast, but the elevation becomes lower, terminating in a knob capped by the 5700-foot contour. At this place a layer of dark limestone yielded an abundance of the fusulinid Schwagerina crassitectoria. The level of this species appears to be slightly higher in the section than at

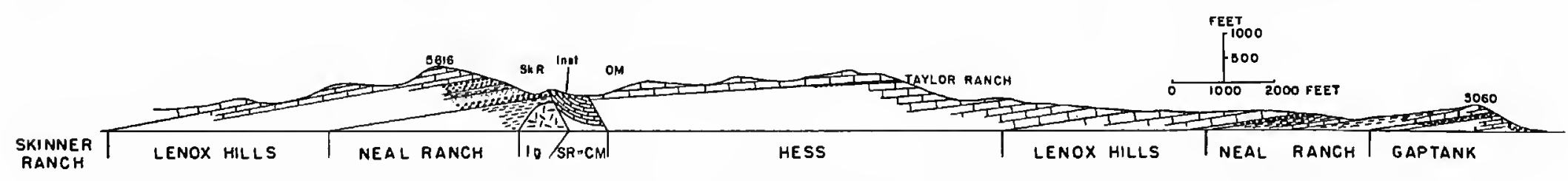

Figure 7.-Section through the Wolf Camp Hills and the Hess Ranch Horst showing igneous intrusion and fault (SkR=Skinner Ranch, Inst.=Institella, $\mathrm{CM}=$ Cathedral Mountain, Ig=igneous body, SR-CM=fault slice of Skinner Ranch and Cathedral Mountain). 
hill 5816, but the discrepancy is not great. All summits along the crest of the Hess Ranch Horst are in the basal Skinner Ranch Formation or its equivalent in the Hess, the $S$. crassitectoria zone. The top of hill 5305 is in the biohermal facies, but the summit of hill 5816 and the long spur to the northeast is in the Hess (S. crassitectoria zone) facies.

ImMediately North of Hess Ranch House.Although the region is small in area, it is extremely important for an understanding of the relationship between the Lenox Hills and Skinner Ranch Formations. The Hess Ranch area repeats the relationships seen on the northeast end of Leonard Mountain and on the northwest slope of hill 5305 of the Hess Ranch Horst. The stratigraphy of this small area north of the Hess house is complicated by dolomitization of several of the beds, which in places can be walked from limestone into dolomite.

The base of the hill is composed of 180 feet of limestone conglomerate with rounded limestone boulders. The conglomerate is overlain by massive biohermal limestone and calcarenite with fossils. Since the fossils are not silicified, they must be broken from their matrix. Of significance are large specimens of Parenteletes from just above the conglomerate, which resemble those from bed 12 (of P. B. King) of the Neal Ranch Formation. Fusulinids are abundant in the limestone that lies between the conglomerate and the dolomite that forms the top of the hill defined by the 5050-foot contour. This dolomite is the approximate boundary between the Lenox Hills Formation and the Skinner Ranch Formation. Characteristic fossils of the latter formation were taken from undolomitized patches within the dolomite on the top of the hill (USNM 711d). Fusulinids are characteristic of the upper Lenox Hills, with Monodiexodina linearis the most abundant species. This is abundant on the slopes west of the knob, and can be collected up to the contact with the Skinner Ranch Formation. The contact here is like that on Leonard Mountain, where the Scacchinella beds of the Skinner Ranch directly overlie the Lenox Hills limestone.

North of the Hess Ranch house, Scacchinella representing the level of the Decie Ranch Member is abundant in biohermal masses and occurs as scattered valves in the debris between the bioherms. This is one of the best places in the Glass Mountains to examine characteristic occurrences of this unusual brachiopod (King 208, USNM 705a). The Scacchinella beds can be traced up the north slope of the knob, but the tracing is complicated by patchy dolomitization of the beds.

Traced eastward along the Glass Mountain front from the Hess Ranch, the Lenox Hills Formation displays a much different facies. Not far east of the ranch house, Hess lithology wedges into the calcarenites of the Lenox Hills and Skinner Ranch Formations, and the entire sequence changes to thin-bedded calcarenite and dolomite. The basal conglomerate of well-rounded cobbles has been traced eastward from the Hess house to the Wolfcamp Hills, where it overlies the Neal Ranch Formation and where it is the Hess conglomerate of Udden and P. B. King. The upper boundary of the Lenox Hills equivalent, there displaying the lithology of the Hess Formation, is limited upward by the occurrence of Schwagerina crassitectoria and S. guembeli, which also mark the position of the

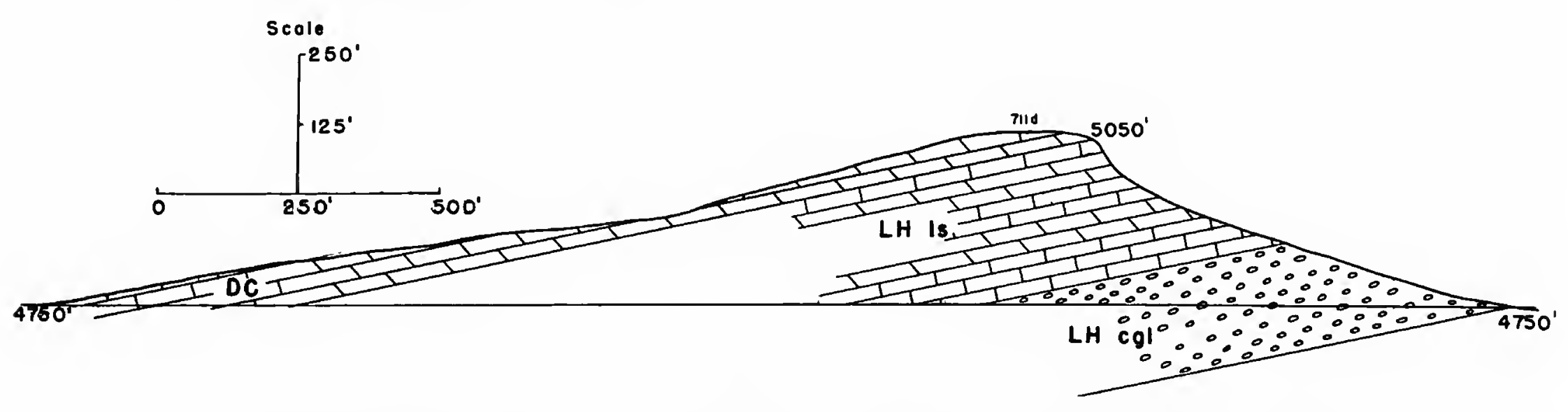

FigURE 8.-Section 0.5 mile north of the Hess Ranch house showing dolomitized Lenox Hills and Skinner Ranch limestones ( $\mathrm{LH} \mathrm{cgl}=$ Lenox Hills conglomerate, LH ls=Lenox Hills limestone, $\mathrm{DC}=$ Skinner Ranch Formation [Decie Ranch Member equivalent]). 
lower Scacchinella beds of the Skinner Ranch Formation. Scacchinella has not yet been found in the rocks immediately overlying Hess lithology that contains Wolfcampian fusulinids.

The same relationship can be traced across the mountain front east of the Hess Ranch house. The limestone cobble conglomerate thickens, thins, and disappears in places at the base of the sequence, but the remainder of this part of the Hess Formation thickens by the introduction of red shale and sandstone near the base. The upper part is composed of thin-bedded limestone and dolomite. The sequence is capped by the zone of Schwagerina crassitectoria, about 200 feet thick. No fossils important to the present study were collected from the Hess facies of Lenox Hills age. Indeed, few fossils other than fusulinids were seen in these beds.

\section{SKINNER RANCH FORMATION}

Overlying the Lenox Hills Formation is a complicated mass of conglomerates, shales, and limestones containing distinctive faunas. The type section of the formation is the northwest end of Leonard Mountain, in the hill terminated by the 5250-foot contour. Here it is composed mostly of calcarenite with some bioherms at the base. Interesting facies developments take place east and west of the type section. To the east, the formation interfingers with the Hess Formation, but to the west, in hill 5021, a wedge of shale cleaves it into two limestone members. The shale wedge continues to thicken farther to the west. Understanding of the formation is best achieved, in our view, by studying it from west to east, from its thickest part to the place where it becomes a single entity. In the western part of the mountains, from Dugout Mountain through the Lenox Hills to hill 5021, three members are clearly defined from the bottom: Decie Ranch, Poplar Tank, and Sullivan Peak Members. A fourth member, the Dugout Mountain Member, is recognized in Dugout Mountain. The following discussion will consider the members geographically and will then describe the formation in its type region and eastward.

Decie Ranch Member.-The type section of the Decie Ranch Member is 1.25 miles southwest of hill 5300 in the Lenox Hills, where it forms the first prominent massive ledge lying on upper shale of the Lenox Hills Formation. It is the western facies of the Hess Formation of P. B. King (1931: 62), and it represents westward wedging of King's Hess Formation on eroded Wolfcamp rocks. At its type section in the Lenox Hills the member is 98 feet thick, but usually it varies from 40 to 70 feet (Plate 9: Figure 3).

In Dugout Mountain: The Decie Ranch Member is well exposed in Dugout Mountain, and it is somewhat thicker there than the average is in the Lenox Hills. It is well displayed over the Lenox Hills shale just under the high point (5195 feet) of the mountain, where it is about 95 feet thick. It maintains a thickness of about 80 to 95 feet along the mountain. The member is extremely variable; no two sections show the same sequence. Generally, however, the lower part contains coarse boulder conglomerates, some of the boulders attaining a long dimension of four feet. Most of them, however, are coarse, well-rounded cobbles. Much of the rock is coarse calcarenite or calcirudite, made up of broken shells, foraminifera large and small, and other organic debris mixed with scattered small pebbles and sand. Some sandstone beds also are present. Interspersed among the conglomerates are interesting bioherms composed largely of the cementing brachiopods Scacchinella, Geyerella, and Derbyia. All of these are of gigantic size, and an occasional enormous bellerophontid snail is present. Because of its massive nature the member forms bluffs and a bench on the mountain (Plate 10: figure 4).

In the Lenox Hills: At the south end of the Lenox Hills, the Decie Ranch Member attains a thickness of nearly 100 feet, overlying the Lenox Hills shale at the type section in the hill 1.25 miles southwest of hill 5300 . At this place the basal bed is massive limestone conglomerate 32 feet thick without visible bedding, containing rounded cobbles and boulders up to 1 foot in diameter. This is followed by a well-differentiated section of sandstone, limestone, pebble conglomerate, and some yellow, silty shale beds, aggregating 44 feet in thickness. The section is capped by 22 feet of coarse calcarenite. Bioherms occur scattered in the lower and upper massive beds. Eastward the Decie Ranch Member has been traced along the base of the Lenox Hills as a prominent band that thickens and thins. It is thinner east of the section men- 


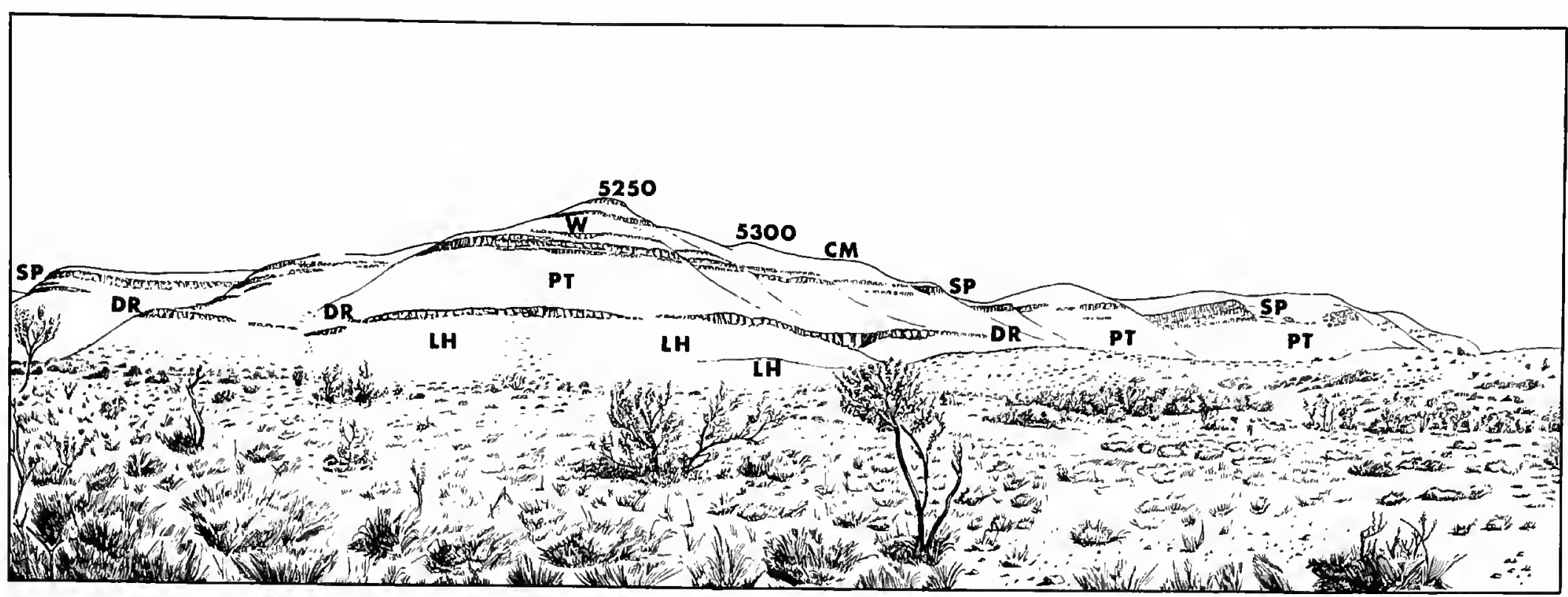

FIGURE 9.-South front of the Lenox Hills on Decie Ranch showing the formations and members $(\mathrm{CM}=$ Cathedral Mountain Formation with Third Limestone Member of Leonard Formation of P. B. King above W, DR=Decie Ranch Member of Skinner Ranch Formation, LH=Lenox Hills Formation consisting of conglomerate below and shale above, lying under Decie Ranch Member ledge, PT = Poplar Tank Member of Skinner Ranch Formation, SP = Sullivan Peak Member of Skinner Ranch Formation, W=Wedin Member of Cathedral Mountain Formation with abundant Institella; see Plate 7: figure 3).

tioned above, and it measures only 40 to 70 feet in places. Nevertheless, it maintains its conglomeratic characteristic throughout its extent in the Lenox Hills (Plate 5: figure 4; Plate 7: figure 3; Plate 12: figure 2).

The Decie Ranch Member abounds in fossils. Several localities yielded extensive collections (USNM 707a, 714t). Large sessile types of brachiopods are the commonest fossils: Scacchinella, Derbyia, Geyerella, and Streptorhynchus. Fusulinids are abundant in places: Monodiexodina linearis, Schwagerina hessensis, and S. hawkinsi.

Small faults have displaced the Decie Ranch member at both ends of the Lenox Hills. At the southwest end the member is thrown down to the base of the hill along the base of the escarpment facing U.S. Highway 90 . Here the waterworn surface of the member displays many Scacchinella in cross-section (USNM 729g). At the northeast end of the Lenox Hills, on the west side of the Sullivan (Yates) Ranch road, a small fault has thrown the Decie Ranch member down to the base of the hill. It was here mistaken for the Wolfcamp (Lenox Hills) because of misidentification of the beds above it (P. B. King, 1931: map) (Plate 2: figure 3).

In Hill 5021: Because of structural complications in this hill, the member is exposed along the base of the hill where it occurs as large float blocks. It also occurs in normal sequence above the sandstone and conglomerate of the Lenox Hills Formation. At the west end of the hill, the Decie Ranch Member is about 60 feet thick and forms the saddle between the two westernmost knobs. Here Scacchinella is abundant in several small bioherms. This is the easternmost locality at which the Decie Ranch is overlain by shale of the Poplar Tank Member (Plate 10: figures 1-3).

Several large float blocks of considerable thickness occur along the base of hill 5021. One, at least 98 feet high, lies on the west side of the hill just north of the windmill, and another lies just south of the knob at hill 5021. Good collections of Scacchinella and other fossils of this member were taken from these blocks. The western block (USNM $707 \mathrm{w}$ ) yielded the best silicified Scacchinella in the Glass Mountains (Figure 11; Plate 10: figure 2).

East of hill 5021, the Decie Ranch Member cannot be readily distinguished; however, Scacchinella bioherms are common in the base of the Skinner Ranch Formation and for some distance above the base. These undoubtedly are at the level of the Decie Ranch Member even though some faunal differences can be detected. 


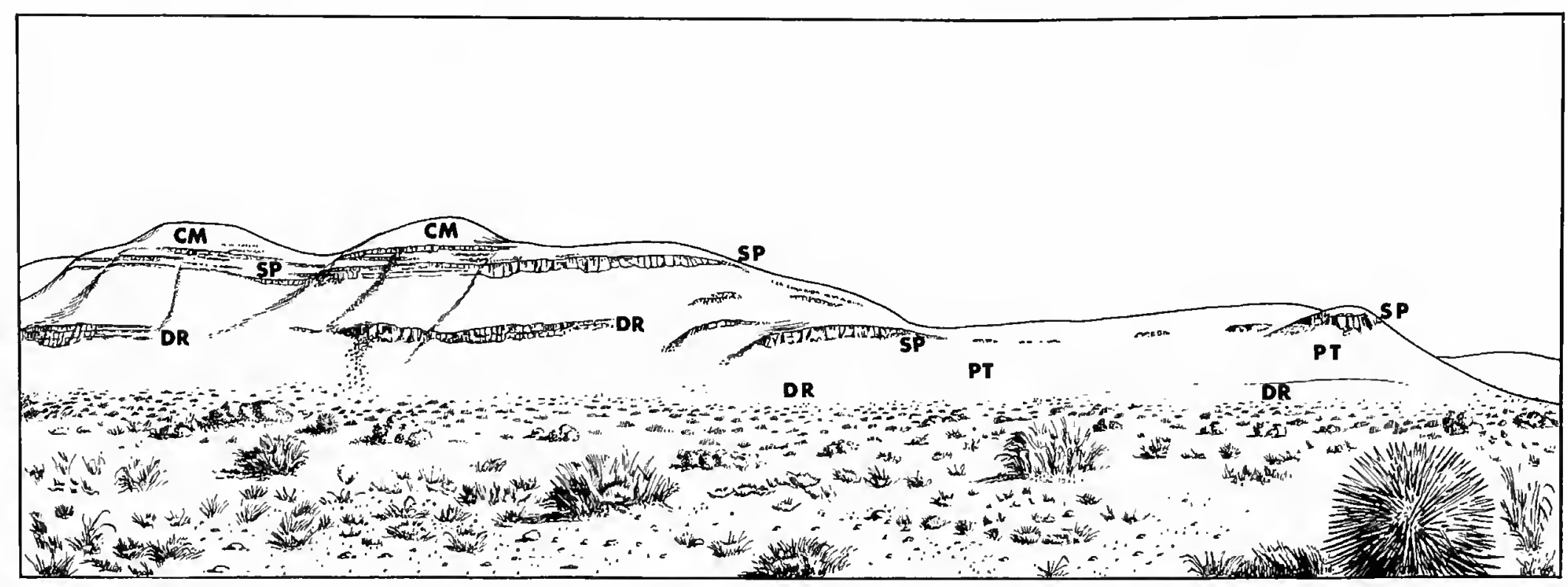

Figure 10.-Spur at east end of Lenox Hills on the west side of the Sullivan (Yates) Ranch road; the Sullivan Peak Member of the Skinner Ranch Formation in the spur has been dropped into apparent continuity with the Decie Ranch Member of the Skinner Ranch Formation in the main body of the hill $(\mathrm{CM}=$ Cathedral Mountain Formation [orange-yellow] shale, DR = Decie Ranch Member, PT = Poplar Tank Member of Skinner Ranch Formation, SP= Sullivan Peak Member; see Plate 2: figure 3).

Poplar Tank Member.-This formation takes its name from Poplar Tank located on the map by P. B. and R. E. King (in P. B. King, 1931) not far west of the Sullivan Ranch (now Yates Ranch) road about 1.5 miles south of the east end of the Lenox Hills. The type section is in hill 5300, where a nearly complete section is exposed. This member is predominantly shale, siltstone, or sandstone, but it is extremely variable with no two sections alike. At the type section, about 250 feet consists of thick beds of shale containing thin beds of conglomeratic limestone, pebble bands, and shell breccias. In the calcarenitic limestones there are 1- to 2-foot-thick layers of pinkish brown chert. Many beds in the upper part of the section contain thin skins of silica one or two inches thick, the surface of which is often covered with peculiar productoid brachiopods, especially the genus Spyridiophora. Occasional conglomerate bands contain cobbles of large size. The shale contrasts strongly with that of the Cathedral Mountain shale, which is usually platy.

The Poplar Tank Member forms most of the lower slopes of the Lenox Hills between the two thick, bounding limestones, the Decie Ranch Member below and the Sullivan Peak Member above. An excellent locality, apparently produced in large part by the recent years of drought, appears on the south slope of hill 4801 at the south end of the Lenox Hills. This section, which measures 315 feet, has a thick shale forming the uppermost part, whereas at the type section the top is limestone (Plate 9: figure 2).

The Poplar Tank Member is well exposed and 180 feet thick in Dugout Mountain. It is well displayed under the main high knob of the mountain, and also it is well established in the deep ravines on the north side of the crest.

East of the type section the Poplar Tank member becomes thinner. In the fault block at the east end of the Lenox Hills on the west side of the Sullivan (Yates) Ranch road, the member is thinner than it is to the west. On the opposite side of the road, about a mile to the northeast in hill 5021, it is still thinner, measuring only 40-50 feet. Farther east in this hill, it wedges out and the Decie Ranch and Sullivan Peak Members come together (Plate 10: figures 1, 2).

Sullivan Peak Member.-The uppermost member of the Skinner Ranch Formation is the Sullivan Peak Member, the "First Limestone Member of the Leonard Formation" of P. B. King (1931:64, $66)$. It is well developed in Dugout Mountain, the Lenox Hills, and in hill 5021. The type section of the member is above that of the Poplar Tank Member in hill 5300 of the Lenox Hills. Here, about 
120 feet thick, it consists of detrital limestone, limestone conglomerate, limestone with scattered small pebbles, and ferruginous sandstone. The member is variable, and no two sections have much similarity (Plate 7: figure 3).

In Dugout Mountain P. B. King's (1931:133) section 7 gives its thickness as 153 feet, somewhat thicker than it is at the south end of the Lenox Hills. It forms the prominent mass at the top of the mountain and forms bluffs and cliffs in several places. Strongly conglomeratic in the lower part, it is coarse calcarenite or calcirudite in the upper portion (Plate 13: figure 4).

The Sullivan Peak Member has its best development in the Lenox Hills, where it varies from about 65 feet at the southwest end to 200 feet at the northeast end. The variation is due to intertonguing of beds and the appearance of bioherms in the section. This member contains the best bioherms to be seen in the Glass Mountains; the bioherms are discussed under a separate heading (Plate 18: figure 1).

In the Lenox Hills the lower conglomeratic part of the member is conspicuous at the south end, where boulders up to five feet long have been seen. Furthermore, several bioherms here are surrounded by the coarse conglomerate. At the east end of the Lenox Hills, on the steep hill facing the Sullivan (Yates) Ranch road, the upper part of the member contains numerous bioherms. They are present also at the westernmost knob of hill 5021, where the easternmost exposure of the member is located. East of this point the member merges with the Decie Ranch Member by the wedging out of the Poplar Tank Member.
Fossils of the Sullivan Peak Member are like those of the Decie Ranch Member with a liberal inheritance from the Poplar Tank. The bioherms contain Scacchinella, Coscinophora, Tropidelasma, Spyridiophora and Geyerella. Scacchinella becomes rare east of hill 5021.

Dugout Mountain Member.-This name was proposed for a sequence of limestones and intervening shales between the top of the Sullivan Peak Member of the Skinner Ranch Formation and the base of the Cathedral Mountain Formation. (Cooper and Grant, 1966). The sequence includes the Second, Third, and Fourth Limestone Members of the Leonard Formation on Dugout Mountain as described by P. B. King (1931:133, section 7). The Sullivan Peak Member represents the First Limestone of -the Leonard on Dugout Mountain, and this can be identified also on the south slopes of the Lenox Hills to the east, as explained above. In contrast, however, the Second, Third, and Fourth Limestones of the Leonard on Dugout Mountain are different lithologically and faunally from limestones similarly numbered by P. B. King in the Lenox Hills. These differences are indicated by the faunas of the Dugout Mountain limestones, which have fossils like those of the Sullivan Peak Member. King's Fifth Limestone of the Leonard Formation on Dugout Mountain has a fauna different from those below, but identical to that of the Second Limestone of the Leonard Formation in the Lenox Hills (see "Leonard Limestones" under "Cathedral Mountain Formation"). Leonard limestones 2-4 on Dugout Mountain stratigraphically underlie the Second Limestone of the Leonard of the Lenox Hills.

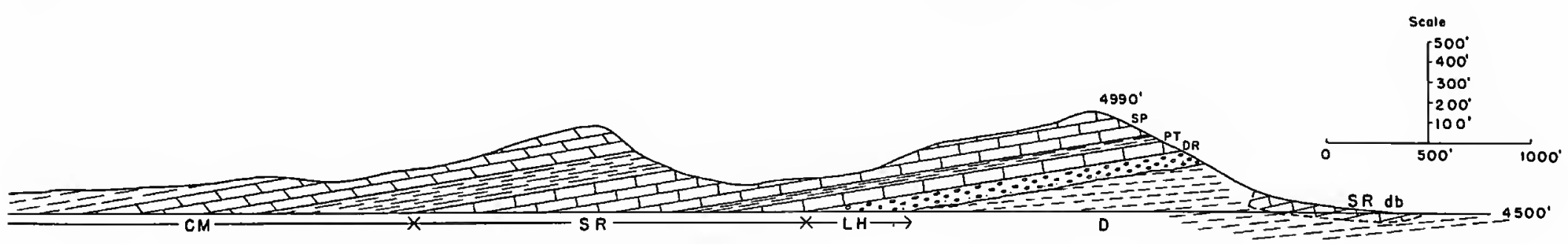

Flgure 11.-Section through the west knob of hill 5021 (Decie Brothers Hill) showing thinned Poplar Tank Member, which is pinched out on the east side of hill 5021 by the Decie Ranch and Sullivan Peak Members of the Skinner Ranch Formation; note also detached block of Decie Ranch Member (CM=Cathedral Mountain Formation [shale and part of Third and Fourth Limestones of Leonard Formation of P. B. King here as one unit], D=Dimple Formation of Pennsylvanian System, $\mathrm{LH}=$ Lenox Hills Formation much thinned, DR=Decie Ranch Member of Skinner Ranch Formation, PT =Poplar Tank Member of Skinner Ranch Formation, SP= Sullivan Peak Member of Skinnex Ranch Formation, SR=Skinner Ranch Formation, $S R \mathrm{db}=$ detached block of Decie Ranch Member; sce Plate 10: figures 1 and 3). 


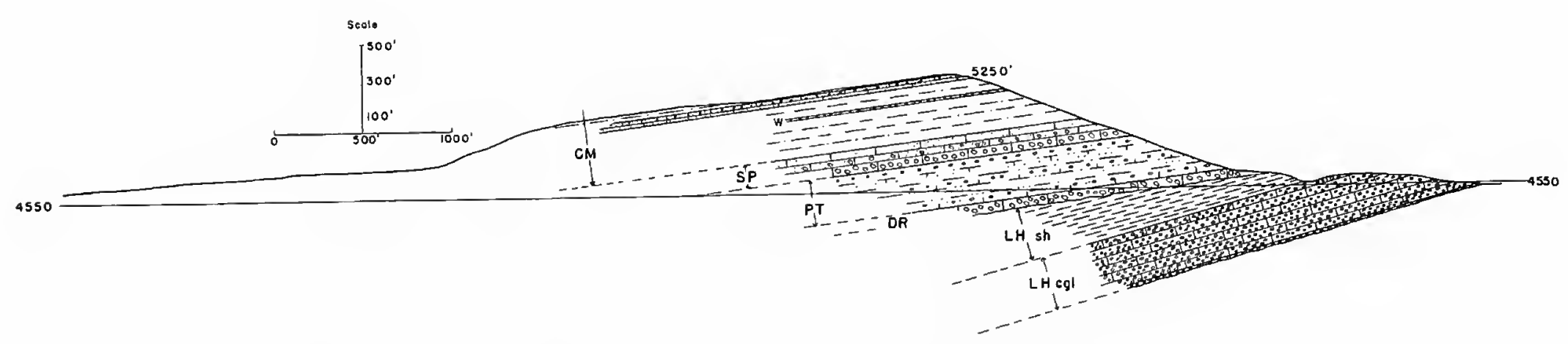

Figure 12.-Section in the central part of the Lenox Hills through the hill capped by the closed 5250-foot contour, one-fourth mile west of hill 5300 ( $\mathrm{CM}=$ Cathedral Mountain Formation with upper sandy and conglomerate limestone beds probably of Third Limestone of Leonard of P. B. King, DR = Decie Ranch Member of Skinner Ranch Formation, LH cgl=conglomerate of Lenox Hills Formation, LH sh=shale of Lenox Hills Formation, PT $=$ Poplar Tank Member of Skinner Ranch Formation, SP =Sullivan Peak Member of Skinner Ranch Formation; see Plate 7: figure 3).

The Dugout Mountain Member of the Skinner Ranch Formation has its type section in Dugout Mountain, on the north slope of the mountain, along the line of King's section 7 cited above. The sequence that is mostly yellow shale aggregates 514 feet in thickness. The intercalated limestones are mostly cherty calcarenite, dark brown in color, and commonly with siliceous coatings on the bedding surfaces. Fossils are distributed uniformly, but some small bioherms appear with their characteristic brachiopods and other fossils. The brown and somewhat bituminous limestone contains numerous ammonites, including small Perrinites, Propinacoceras, and others. Since some of the beds on the mountain have suffered from dolomitization, the fossils are not well preserved. The ammonites are exceptionally good, however, and these limestones are a prolific source of them. Two conspicuous knobs on the north slope of Dugout Mountain are excellent places to study these upper Skinner Ranch Beds (USNM 700r, 700s).

Hill 4811 is an excellent place to study the Second and Third Limestones of P. B. King. The Sullivan Peak Member of the Skinner Ranch Formation occurs near the base of the hill. It is succeeded by 47 feet of chert, sandstone, and shale, on which rests 27 feet of the Second Limestone of P. B. King (USNM 700t). This is followed by 20 feet of yellow shale and chert, and the hill is capped by 15 feet of limestone, which is the Third Limestone of P. B. King (USNM 700s). Spyridiophora appears in the limestone and indicates rela- tionship to the Skinner Ranch Formation. The total thickness of Dugout Mountain Member on hill 4811 is 109 feet (Plate 6: figure 2).

The small knob capped by the 5000-foot contour just 0.5 mile northwest of the summit of Dugout Mountain is also capped by the Third Limestone Member of King. This contains about 30 feet of biohermal limestone, some of it dolomitized and considerably altered, but nevertheless containing many fossils, some of them recoverable (USNM 700r) (Plate 10: figure 3).

The Fourth Limestone of King proved to be poor in fossils, but we found Spyridiophora in it. The fact that it underlies the Fifth Limestone of P. B. King, which contains the basal fauna of the Cathedral Mountain Formation, and the presence of Spyridiophora lead us to place this limestone with the two below-in the Skinner Ranch Formation. At any rate, there is a considerable faunal change with the appearance of the Institella fauna in the Fifth Limestone (=Wedin Member), and it is here that we draw the boundary between the Skinner Ranch and Cathedral Mountain Formations in Dugout Mountain and the Lenox Hills.

Between Dugout Mountain and the Lenox Hills is a 2-3 mile gap in the mountains, making it impossible to trace any beds from one mountain to the other. It is our belief that the thin limestones of the Dugout Mountain Member either pinch out east of Dugout Mountain or unite with the Skinner Ranch Formation in the same manner that the Decie Ranch and Sullivan Peak Members 


\section{LENOX HILLS}

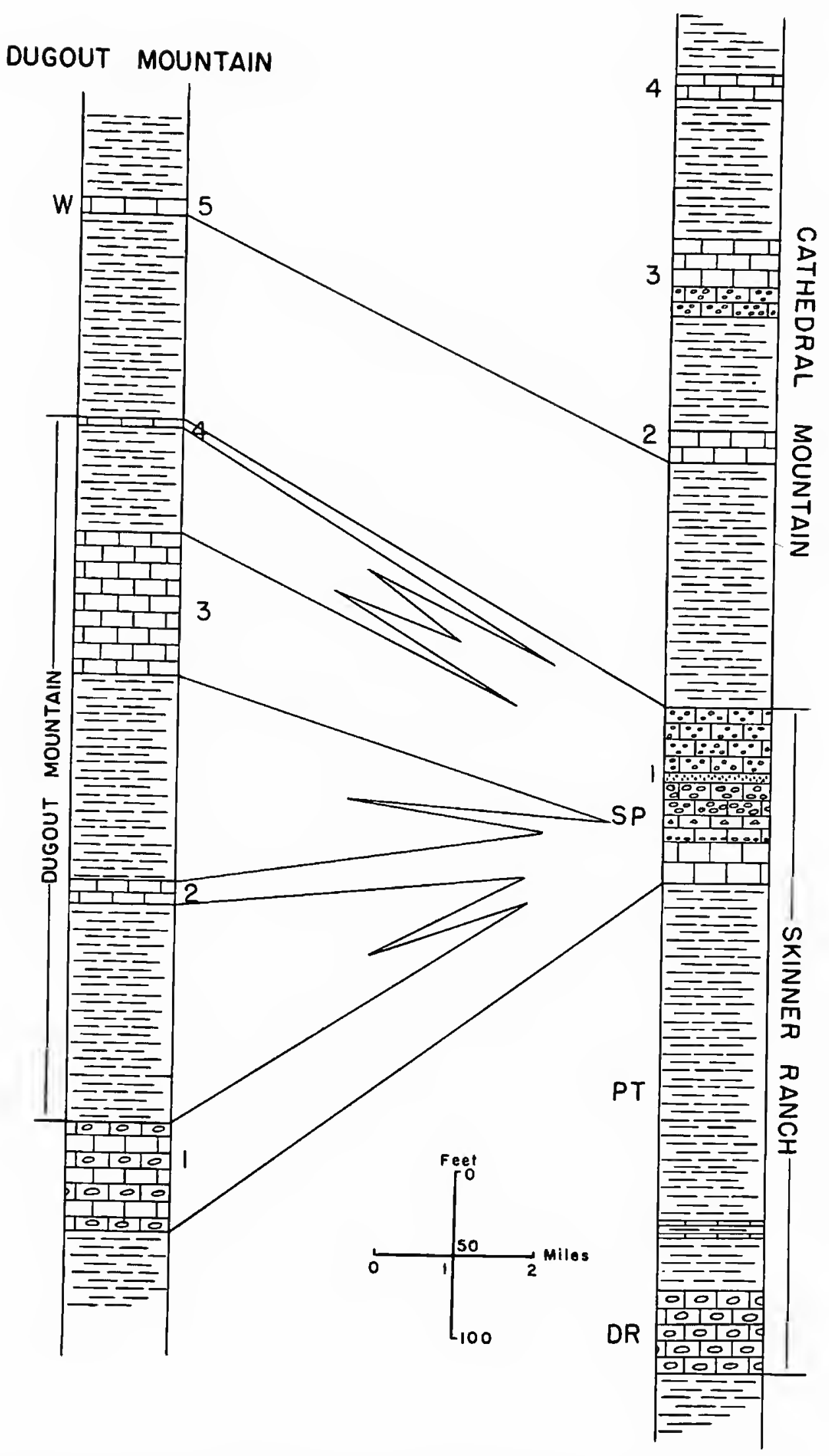

Figure 13.-Diagram shows probable correlation of Dugout Mountain Member of Skinner Ranch Formation within the Skinner Ranch (numbers 1-5=P. B. King's Leonard Limestones in both sections, DR = Decie Ranch Member of Skinner Ranch Formation, PT=Poplar Tank Member of Skinner Ranch Formation, SP =Sullivan Peak Member of Skinner Ranch Formation [formerly First Limestone Member of Leonard of P. B. King], W=Wedin Member of Cathedral Mountain Formation [Fifth Limestone Member of Leonard of P. B. King on north side of Dugout Mountain, but Second Limestone Member of Leonard of P. B. King in southwest end of Lenox Hills]; measurements and thicknesses of Dugout Mountain section are mainly from King's [1931:132] section 6 on west side of Dugout Mountain). 
merge to the east. It is suggested that the shales intervening between the limestone beds become thin and are overlapped eastward. The possibility that the Dugout Mountain Member is eroded from the top of the Skinner Ranch Formation cannot be overlooked, but we have no evidence that this is the case. We do, however, have evidence from the sections to the east, that overlap of intervening shales and coalescence of beds does take place. This is true in the cited instance of the Skinner Ranch Formation, and it is known to take place in the Cathedral Mountain numbered limestones and the Word numbered limestones, the latter coalescing east of the Word Ranch near Split Tank.

Another alternative is suggested by an occurrence of ammonites at the south end of the Lenox Hills (USNM 730k, 736d) identical to those in the Dugout Mountain Member. This ammonite bed is part of the Sullivan Peak Member just below the Cathedral Mountain Formation. The rock containing the ammonites is lithically like that of the limestone of the Dugout Member. Possibly this ammonite bed represents P. B. King's Fourth Limestone, or it may represent the united limestones 2 to 4 or either the Second or Third Limestones, with the others missing. At any rate it is a remnant of the Dugout Mountain Member.

SkinNer Ranch Formation Undivided.-The type section of the Skinner Ranch Formation in the northwest knob of Leonard Mountain is 509 feet thick and consists mostly of calcarenite with very little shale but some fairly thick, pinkishbrown chert bands. The lower part of the Skinner Ranch Formation in Leonard Mountain has numerous bioherms containing Scacchinella just east of the type section. These can be followed along the dip up the mountain to the east for a considerable distance and furnish good specimens. Higher in the section, the Skinner Ranch Formation contains few bioherms, but it is mostly calcarenite in thin or thick beds, some of those near the top having a thin skin, an inch or two in thickness, of dark brown siliceous material usually with abundant fossils, especially Spyridiophora and Glyptosteges. These peculiar and readily recognized productoids are characteristic of the Skinner Ranch Formation. Another fossil of importance is Torynechus (formerly Uncinuloides of R. E. King), the stenoscismatid with costellate exterior and flatly truncated anterior. This genus occurs in some abundance at the top of Leonard Mountain in the saddle just east of the top of the northwest knob. The crest of the knob in the type section is composed of 41 feet of extremely massive and coarse calcarenite with occasional small pebbles. This massive unit was not recognized on the southeast side of the mountain. It contains Institella and is now placed in the overlying Cathedral Mountain Formation (Plate 2: figure 1; Plate 6: figure 1).

West of Leonard Mountain the undivided Skinner Ranch appears as bluffs and cliffs along the east face of hill 5280. The lower part of the sec-

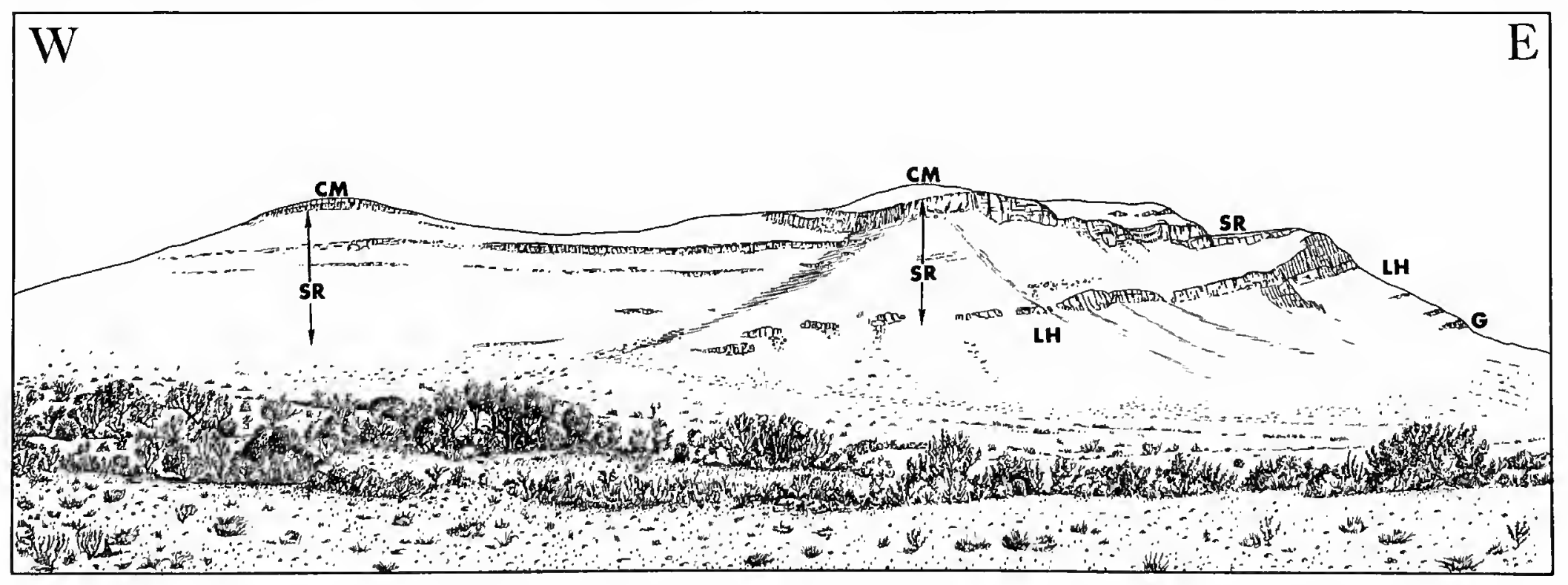

FIGURE 14.-South side of Leonard Mountain showing formations (G=Gaptank Formation, $\mathrm{CM}=$ Cathedral Mountain Formation, $\mathbf{L H}=$ Lenox Hills Formation [mostly shale], SR= Skinner Ranch Formation; see Plate 2: figure 1). 


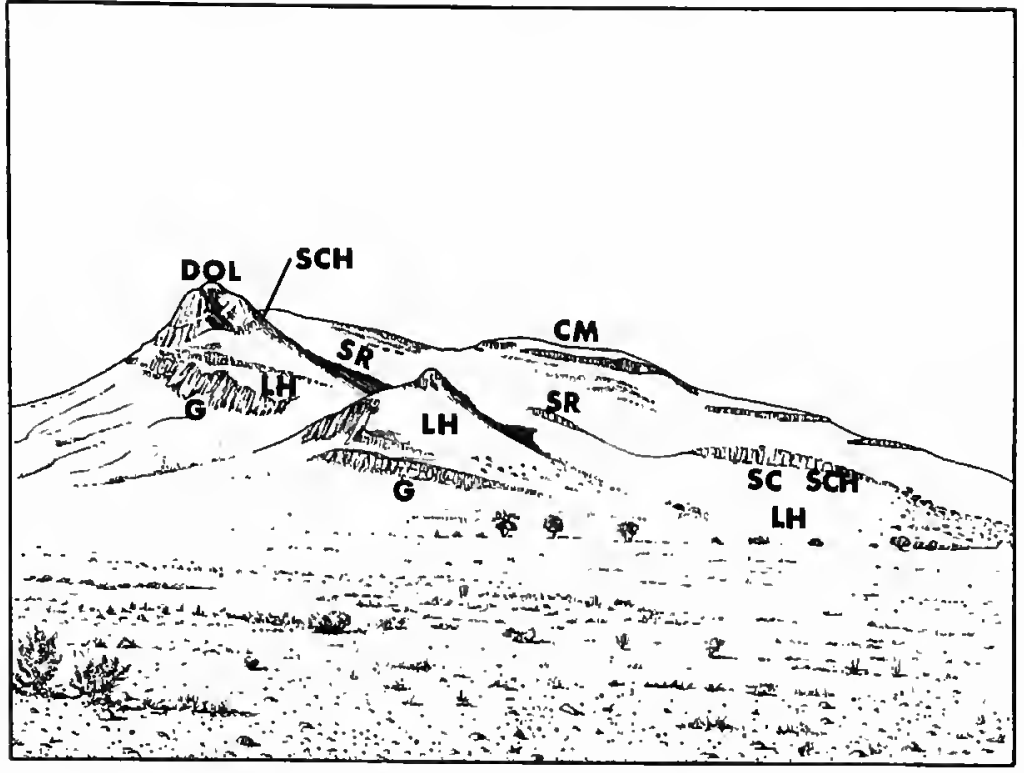

Figure 15.-East side of Leonard Mountain showing deep amphitheater and formations and distribution of two important fossils $(\mathrm{CM}=$ Cathedral Mountain Formation, a thin skin of shale and limestone on top of mountain, DOL = large dolomite mass composed of Lenox Hills and Skinner Ranch equivalents, $G=$ Gaptank Formation [limestone and shale], LH=Lenox Hills Formation consisting of lower conglomerate and upper limestone on this side of mountain, $\mathrm{SC}=$ Scacchinella beds of Skinner Ranch Formation that can be traced into dolomite, $\mathrm{SCH}=$ Schwagerina crassitectoria Dunbar and Skinner, SR=Skinner Ranch Formation; see Platc 6: figure 3).

tion is strongly conglomeratic, but the upper part is calcarenite. Scacchinella is rare in this hill, but it was found at the bottom and near the middle of the section. At the north end of this hill, most of the Skinner Ranch Formation has been dolomitized, and fossils or other details are difficult to see. At the top of the hill (USNM 723h) Spyridophora, Glyptosteges, and Torynechus occur in the uppermost layers as in the type section.

The Skinner Ranch Formation is undivided at the east end of hill 5021. Good exposures of the formation also occur in the low hills between hill 5021 and hill 5280. At the west end of the former hill, the Skinner Ranch is differentiated into its three members, but the shale of the Poplar Tank Member wedges out in the middle part of the hill. At the top of the Skinner Ranch Formation in hill 5021, Spyridiophora and Torynechus were found in the upper beds as in Leonard Mountain and hill 5280. These fossils are therefore good guides to the upper part of the Skinner Ranch Formation (Plate 10: figure 1).
The easternmost full section of the Skinner Ranch Formation is on the east side of Leonard Mountain, where a section of about 410 feet may be pieced together. Understanding of this section is marred by dolomitization of parts of the section. For example, the Scacchinella beds of the lower Skinner Ranch are well exposed in and on the side of the ravine that forms a broad amphitheater on the northeast side of the mountain. Here one can walk on the Scacchinella bed almost continuously until it merges with the lower part of the thick dolomite that forms the most conspicuous cliff on the southeast side of the mountain. On the southeast nose of Leonard Mountain, much of the dolomite belongs to the Skinner Ranch Formation. It is interesting to note discovery of the large gastropod Omphalotrochus in the lower part of the dolomite, a fossil abundant in the Scacchinella beds on the northeast side of the mountain and elsewhere to the east and north, especially in the Hess Ranch Horst. Part of the sequence that P. B. King (1931:62) described as Hess on this side of Leonard Mountain belongs to the Skinner Ranch Formation (beds 6 and 7, in section 17). This includes most of the thick dolomite and the overlying limestones exposed for about 0.25 mile from the edge of the mountain to the lowest of the shale of the Cathedral Mountain Formation, which in turn is exposed on the knob west of bench mark 5860 .

The Skinner Ranch Formation forms much of the steep bluff on the south side of Leonard Mountain, and the upper beds are well displayed below the knob just west of the bench mark on which the base of the Cathedral Mountain Formation is exposed. Skinner Ranch beds are also exposed on the north side of the mountain in the upper slopes. An isolated knob circumscribed by the 4750 -foot contour 0.85 mile northwest of the Hess Ranch house is composed of biohermal beds and calcarenites with goniatites. Spyridiophora and Glyptosteges are present, indicating the upper part of the Skinner Ranch Formation.

Three other exposures of the upper part of the Skinner Ranch appear in small fault blocks northeast of the Hess Ranch. The first of these is 1.55 miles northeast of the Hess house on the west spur of hill 5726. Here a small block of Skinner Ranch with Spyridiophora is overlain by Cathedral Moun- 
tain Formation with Institella. A second, smiliar block is located 2.6 miles northeast of the Hess house. The third occurrence is in the elliptical hill on the east flank of the Hess Ranch Horst, exactly 3 miles northeast of the Hess house. This hill is composed of Skinner Ranch limestone, lying against the Lenox Hills Formation of the horst, and the igneous instrusive. Here, too, the Skinner Ranch is overlain by Cathedral Mountain limestone with Institella, which forms the east slope of the hill near the base. The lower part of the Skinner Ranch is well displayed just north of the Hess house and at the north base of hill 5816, and it forms the long north slope of hill 5305.

In the exposure north of the Hess Ranch house, the section is greatly complicated by dolomitization and faulting. Overlying the Lenox Hills Formation is a veneer of the Skinner Ranch Formation perhaps 50-60 feet thick at the north end near the Hess pasture gate. Here the Skinner Ranch contains many bioherms abounding in Scacchinella, inter-biohermal detritals containing Omphalotrochus, and, in the higher part, the fusulinid Schwagerina crassitectorin. Dolomitization of the section has destroyed some of the fossil evidence. Fortunately, however, the dolomitization is not complete and patches of limestone within the dolomites contain good fossils of the lower Skinner Ranch. An undolomitized patch occurs at the very highest part of the hill (knob capped by the 5050foot contour (= USNM 711d). The dolomite with occasional limy patches occurs on the north side of the hill for about 0.75 mile, and all can be assigned to the lower Skinner Ranch Formation.

An almost exact duplicate of the hill north of the Hess house occurs in hill 5305, the westernmost hill of the Hess Ranch Horst. Dolomitization is only a minor complication in this hill, which is an excellent place to collect the fossils of the lower part of the Skinner Ranch Formation. The south slopes of hill 5305 reveal the conglomerate and overlying limestone of the Lenox Hills Formation. Near the top of the hill appears an interval of dolomite with patches of limestone. This layer consists of dolomitized bioherms and undolomitized patches, which yield fossils of the lower part of the Skinner Ranch Formation. The north slope of the hill is completely made up of this formation; about 200 feet is exposed from the top of the hill to the base. Besides the characteristic Scacchinella, the lower and middle parts of the slope contain abundant Omphalotrochus and Schwagerina crassitectoria. This lower part of the Skinner Ranch Formation can be traced to the north base of hill 5816, highest and largest hill of the horst chain. Here the biohermal beds are not complicated by dolomitization and Scacchinella, and other bioherms are exhibited to perfection. About the same thickness appears here as on hill 5305. Unlike hill 5305, however, the Scacchinella beds cannot be traced to the south, up the long north slope of hill 5816, because they either pass into the facies of the Hess Formation or they are eroded off the lower and middle slopes of hill 5816. The Hesstype rocks at the top of the hill and knobs to the east are clearly Skinner Ranch equivalent because they contain Schwagerina crassitectoria. This relationship is discussed below.

\section{Hess Formation}

The Hess Formation is a great body of rock in the eastern part of the Glass Mountains, best exposed from the Hess Ranch house and eastward. It consists of a variety of lithic types that are mostly unfossiliferous and contain few fossils except fusilinicls. The Hess Formation generally has been classified with the Leonard Series, but lately it has been discovered that it is wholly, or at least in part, pre-Leonardian, depending on one's point of view.

Udden (1917:43) named the Hess Formation for exposures on the Hess Ranch, where it is well exposed. Udden explained that this formation overlies the Wolfcamp Formation unconformably and that it is separated from the underlying beds by a cobble conglomerate. He also believed that the formation was overlain unconformably by the Leonard Formation. Udden was uncertain as to the westward extent of the Hess Formation, and he suggested that it might be present in Leonard Mountain and perhaps in the ridge west of Iron Mountain. If present, Udden suggested that the formation would be considerably thinned in that direction. In spite of these cloubts, the Hess Formation was indicated on his map across the entire mountain front. 
P. B. King and R. E. King (1929:126) pronounced the lower half of the beds on Leonard Mountain (referred to as the Leonard Formation by Udden) to be in reality Hess, and stated the Hess Formation was represented in the hills to the west of Leonard Mountain. They also recognized two facies of the Hess Formation: (1) the East Facies, constituting the fine-grained limestones and dolomites from Hess Ranch eastward, and (2) the West Facies, massive, usually non-dolomitic gray granular limestone. The two facies merged about 2 miles northeast of the Hess Ranch house. Much of the upper part of the section in the Hess Ranch Horst was also considered by P. B. King $(1931: 56,141)$ to be Hess, and he described a mingling of the two facies on the horst. In 1932 P. B. King (page 347) indicated that the Leonard shale in the west end of Leonard Mountain passed into limestones of the Hess Formation (West Facies) and the latter into the East Facies in the vicinity of Hess Ranch (Plate 8: figure 1). P. B. King (1934: 730) next proposed that the Hess Formation be restricted to beds in the eastern part of the mountains, and relegated them to the rank of a member. In 1938 P. B. King (page 98) repeated his findings that the Leonard shale is separated from the Hess thin-bedded limestone by "limestone reefs" and that the Hess is best regarded as a member of the Leonard Formation.

Jarvis (1957:6), as a result of studies of the Wolfcamp and Hess Formations, concluded that the conglomerates in the western part of the mountains, which were referred by P. B. King to the Wolfcamp, were, in fact, more like Hess conglomerates and should be referred to that formation. He also recommended that the Hess be returned to its original status as a formation. Ross (1959:299) redefined the Wolfcamp, establishing the Neal Ranch Formation for the shaly lower part and the Lenox Hills Formation for the upper conglomerate. The Lenox Hills conglomerates were traced by him eastward across the mountain front and were found to lie above the Neal Ranch Formation and to include the Hess conglomerate of the type Hess Formation. Later Ross (1960) described the fusulinids of the Hess Formation, but he continued to call it the Hess Member of the Leonard Formation. Cooper and Grant (1964) recommended that the Hess be regarded as a separate formation, and they indicated its lateral relationship to the Skinner Ranch Formation.

The foregoing remarks on the history of this formation show that it originally was regarded as lying between the Wolfcamp and Leonard Formations, but later it was thought to be the equivalent of the Leonard shale but separated from it by limestone reefs. These views more recently have been shown to be erroneous; the Hess conglomerate is actually Wolfcampian, a part of the Wolfcamp Series. Ross, by his work on the fusulinids, indicated that the Hess for about 400 feet above the conglomerate actually contains fossils of the Wolfcamp Series. Our findings, detailed below, corroborate these views, which are further strengthened by extensive faunal evidence. In view of these discoveries, our discussion of the Hess will be in two parts: (1) Hess Formation (Lenox Hills equivalent), and (2) Hess Formation (Skinner Ranch equivalent).

Lenox Hills Equivalent.-On the basis of the history just reviewed and by way of orienting the reader, it is necessary to offer some preliminary remarks before examining details of the Hess Formation. It is important to note that much of Udden and Böse's Hess in the western part of the mountains is actually the Lenox Hills Formation of Ross and is the Hess alluded to by Jarvis (1957:6). The band of Hess (western facies) appearing on P. B. and R. E. King's map (in P. B. King, 1931) along the base of the Lenox Hills overlies the Hess of Böse and Udden and is the Decie Ranch Member of the Skinner Ranch Formation. The Hess conglomerate on Leonard Mountain is part of the Lenox Hills Formation of Ross and is the equivalent of the Hess conglomerate of the type region. Therefore, most of the Leonard Mountain sequence is not Leonard, although it was part of the Leonard type section. This complication is explained under the discussion of the Leonard Formation.

In discussing the part of the Hess Formation that is equivalent to the Lenox Hills Formation, it is best to describe the rocks in the type section. The interval in the western part of the mountains lies between the Gaptank Formation below and the Decie Ranch Member of the Skinner Ranch Formation above (the latter containing abundant Scacchinella or its cohort Schwagerina crassitectoria). In the type section of the Hess, therefore, 
WOLF CAMP

HILLS

HESS RANCH HORST
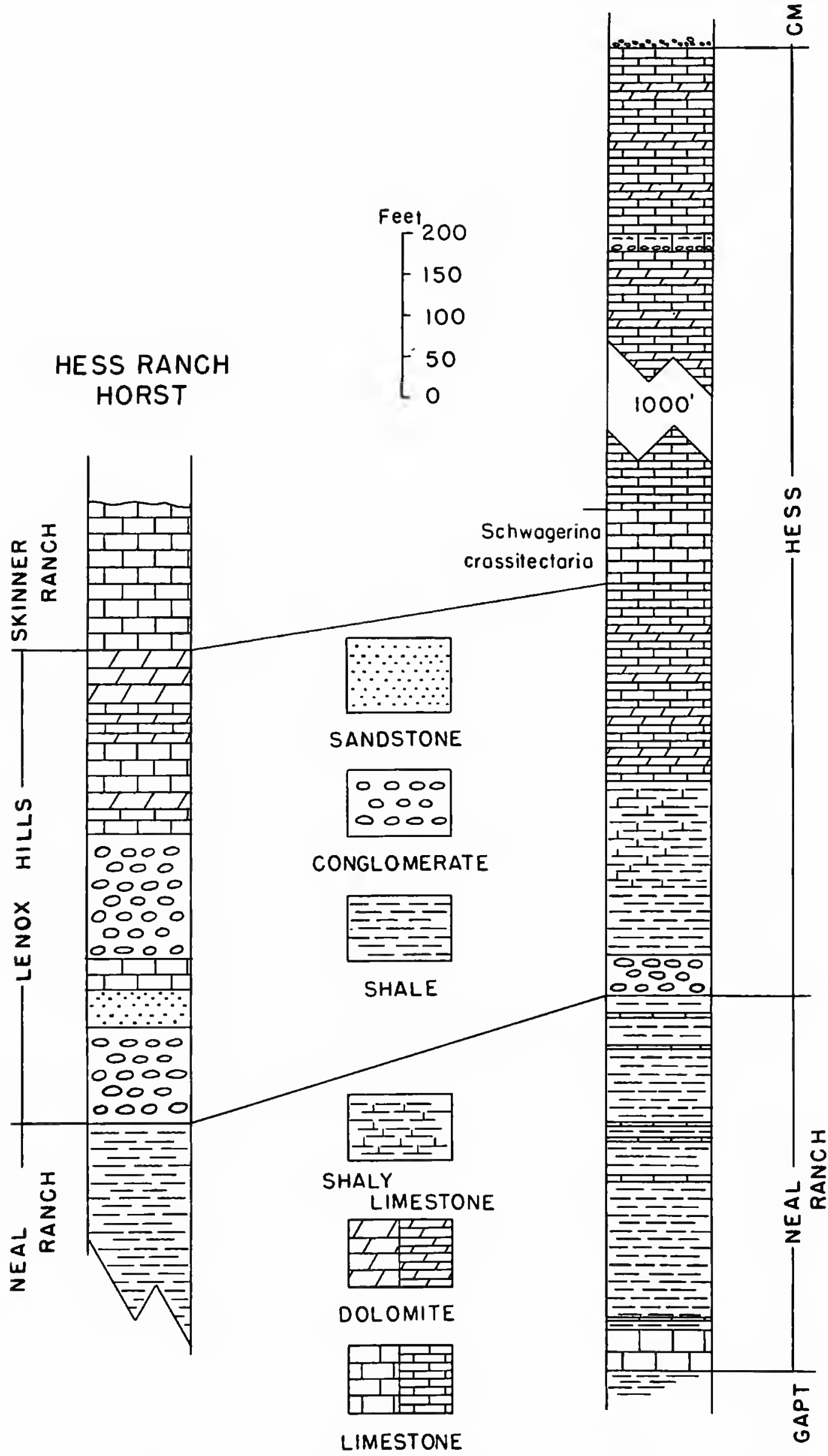

Figure 16.-Correlation of the Lenox Hills Formation in the Hess Ranch Horst with that in the Wolf Camp Hills area (Gapt=Gaptank lormation, $\mathrm{CM}=$ Cathedral Mountain Formation). 
the Lenox Hills Formation equivalent will be defined by the beds between the unconformity on the Gaptank Formation or the Neal Ranch Formation and the base of the Schwagerina crassitectoria zone.

The conglomerate at the base of the Hess Formation can be traced east and west from the Wolf Camp Hills. West of these hills it can be found almost continuously at the base of the mountain front to the Hess Ranch, where the outcrops end. Just north of the Hess Ranch house it is well exposed at the base of the hill, where it consists of 187 feet of limestone cobble conglomerate. In Leonard Mountain, the next outcrop area to the west, this conglomerate appears above Gaptank limestone. It is the Hess conglomerate of King, identified by Ross as the Lenox Hills conglomerate.

East of the Wolf Camp Hills the Hess conglomerate is traceable to the east side of the road ( $U$. S. Highway 385) at Stockton Gap. It is not continuous to the east, and it thickens and thins, attaining a thickness of 200 feet in places in the eastern part of the belt. It is missing from the section in the somewhat conical foothill 1.5 miles northeast of hill 4852 at the east end of the Wolf Camp Hills. In this eastern range the conglomerate is composed of rounded limestone cobbles.

Overlying the conglomerate is a varying sequence of red and green shale, thin limestone, and sandstone, with very few fossils. West of the Wolf Camp Hills the section contains progressively less shale, but east of the hills shale beds become thick and important. Shales and thin beds of dolomite attain a thickness of 300 feet east of the Wolf Camp Hills. The Lenox Hills equivalent part of the Hess Formation is limited at the top by thin-bedded limestone abounding in the fusulinids Schwagerina crassitectoria Dunbar and Skinner and $S$. guembeli Dunbar and Skinner, which characterize the base of the Skinner Ranch Formation on the Hess Ranch Horst and Leonard Mountain.

The Lenox Hills equivalent of the Hess Formation thus proves to consist of variable conglomerates at the base followed by red and green shales, some thick sandstone, and all with thin limestone and dolomite beds intercalated. This part of the section ranges from 300 feet to about 460 feet thick. The boundary between Hess-Lenox Hills equivalent and Hess-Skinner Ranch equivalent is a paleontologic one, not a lithic break.

Skinner Ranch Equivalent.-The Hess Formation above the Lenox Hills equivalent is a great mass of thin-bedded limestone and dolomite with some heavy, massive bands and occasional layers of conglomerate, shale, and sandstone. The limestone is described by Ross $(1960: 120)$ as silty biomicrosparite in the lower 200 feet and biosparite in the next $600 \mathrm{feet}$, while the uppermost 400 feet are mostly "limestone which is recrystallized biosparite or biomicrosparite." Tongues of shale, siltstone, and silty limestone appear in the eastern part of the mountains. Two important traceable beds are the "double ledge" and the "fossil bed" of P. B. King (1931:60). The formation is thickest in the eastern part of the hills, where it attains 1600 feet. The section thins to the west and is about 1290 feet thick about 2 miles east of the Hess Ranch house. Only two parts of this great mass of limestone concern this monograph. One is the lower fusulinid zone, and the other is the "fossil bed" of P. B. King (Plate 8: figure 1).

Schwagerina crassitectoria Zone: This zone is generally about 200 feet thick and contains the two fusulinids Schwagerina crassitectoria Dunbar and Skinner and $S$. guembeli Dunbar and Skinner. Ross (1960:121) noted that, in the lower part of their range, the two species are morphologically similar and occur together. Higher in their range they become distinct, $S$. guembeli increasing in size and rotundity and $S$. crassitectoria becoming more elongated and having less complicated axial deposits. Generally, at these levels, they are no longer associated in the same beds. Ross states that, in the upper part of its range, $S$. guembeli is commonest in biosparite and biomicrosparite whereas $S$. crassitectoria in the upper part of its range occurs in biomicrosparite. This suggests to Ross that the two gradually became adjusted to different environments. In the eastern Glass Mountains $S$. guembeli ranges a few feet into the succeeding zone of Parafusulina allisonensis Ross.

The significance of this thick zone of $S$. crassitectoria and $S$. guembeli is the establishment in the Hess Formation of the level of the Scacchinella beds, approximately the level of the Decie Ranch Member of the western part of the Skinner Ranch Formation. As shown above, S. crassitectoria occurs 
with Scacchinella on the northeast side of Leonard Mountain, on the north slope of the Hess Ranch Horst, and north of the Hess Ranch. The transition of biohermal basal Skinner Ranch into Hess facies occurs on the long north slope of the horst and on the east side of Leonard Mountain.

Fossil Bed of P. B. King (= Taylor Ranch Member): This is an extremely important stratigraphic unit because of its abundance and variety of fossils and because of the clue the fossils give to the correlation and relationships of the Hess Formation. It can be traced from east of the Hess Ranch to the eastern part of the mountains. It is one of the key beds used by Ross $(1960: 120)$ in describing the stratigraphy of the Hess. In order better to understand this datum and to provide ease of designation, we have introduced the name "Taylor Ranch Member" of the Hess Formation (Cooper and Grant, 1966) and designated the type section on the Bill Neal Ranch on the southwest slope of the hill, capped by the 5750 -foot contour, which is located between hills 5767 and 5821 (USNM 716o) (Plate 9: figure 1). Here, the following section was measured:

Hess Formation, Taylor Ranch Member

feet

Fossiliferous light brown limestone with orangebrown chert

Cobbly limestone with some shale and abundance of fossils

Yellowish conglomerate with smooth matrix and pebbles of limestone up to 3 inches.

Hess Limestone and Dolomite

This member is not developed uniformly in all parts of the hill, because the thick fossil bed loses its abundance of fossils to the east, but the conglomerate is persistent and some fossils usually can be found by diligent search (Plate 9: figure 1).

West of the type-locality, just under the nose of hill 5725, there occur thick sponge bioherms that mostly are composed of large Heliospongia and bead-like Girtycoelia. The sponges are accompanied by a variety of brachiopods, gastropods, and pelecypods to constitute one of the most prolific collecting places in the mountains (USNM 702d). Some important species for correlation occur in the sponge bioherms. Spyridiophora, which is rare but in excellent condition, constitutes one of the paleontological links of the Taylor Ranch Member to the upper part of the Skinner Ranch Formation (Plate 19: figure 2).

The westernmost occurrence of the member is USNM 702e about 0.5 mile north of hill 5751 . There the member contains a fairly prominent but thin shale bed and an abundance of Rhipidomella hessensis $\mathrm{R}$. E. King that is not equalled elsewhere. This locality contains several important species. A cast of Scacchinella found in the vicinity of the sponge bioherms and a brachial valve found northwest of the Conoly Brooks Ranch are very important discoveries.

P. B. King (1931:60), besides calling this the "fossil bed," also proposed the term "Perrinites compressus horizon" after the ammonite described by Böse (1917:166). The name is not apt, because the ammonite is excessively rare. Böse had only two specimens, and we have taken only two in all the collecting done in the mountains. Moreover, the species $P$. compressus Böse is now regarded as a synonym of $P$. hilli (Smith), the more widely distributed species of the genus.

Above the Taylor Ranch Member.-A considerable thickness of limestone and dolomite intervenes between the Taylor Ranch Member and the base of the Cathedral Mountain Formation, which is a conglomerate composed of small pebbles, many of them white quartz. P. B. King (1931) and Ross (1960) describe this interval, but they record considerable variation in the thickness. Both authors agree that the section thins to the west. The maximum thickness reported by P. B. King (1931: 145, section 27) is 410 feet, but Ross (1960:119, section 2) records over 700 feet in essentially the same section at the Conoly Brooks Ranch. Regardless of thickness, the interval lies between the Taylor Ranch Member and the base of the Cathedral Mountain, which is essentially the base of the Institella beds of the Cathedral Mountain Formation. These upper beds of the Hess are, like those below, thin limestone, dolomite, or massive dolomite with many unidentifiable fusulinids. In some places the fusulinids are coated by algal material. Ross (1960:119) records three species of fusulinids from this part of the section: Parafusulina spissisepta Ross, $P$. brooksensis Ross, and $P$. vidriensis Ross. As explained in our chapter on correlation, these post-Taylor Ranch Member beds are included as a unit with the Hess Formation, as partial equiv. 
alents of the Skinner Ranch Formation. They are overlain by Institella throughout their extent, from near the Hess Ranch to a mile east of Split Tank, and therefore are regarded by $u$ s as belonging to the Hess Formation. Moreover, they are lithically like the Hess, and the few fossils found in them are Hess types (USNM 726n).

In Leonard Mountain: King (P. B., 1931:62, 140, section 17) identified 746 feet (erroneously recorded as 646 feet) of Hess limestone in Leonard Mountain in 7 beds. This sequence now proves to be referable to the Gaptank, Lenox Hills, and Skinner Ranch Formations. Beds $3-5$ in P. B. King's section (1931:62) belong to the Lenox Hills Formation of Ross, bed 3 being the Hess conglomerate ( $=$ Lenox Hills Formation) traceable in the hills east of the Hess Ranch, and the limestone forming bed 5 contains characteristic Wolfcamp Series fossils (= part of Lenox Hills Formation). Beds 6 and 7 of this section belong to the Skinner Ranch Formation, better exposed and more characteristic on the southwest side of the mountain. In King's section 17, bed 6 is composed largely of dolomite and is the great "reefy" mass so conspicuous on the southeast nose of the mountain. As explained elsewhere in more detail, dolomitization on Leonard Mountain has caused confusion, leading King to identify it as "east facies of Hess," when it is actually dolomitized west facies of Hess, which, in turn, is really partly Lenox Hills Formation and partly Skinner Ranch Formation. King's Hess section on 'Leonard Mountain is Hess equivalent, but it does not represent all of the section. A similar situation exists on the Hess Ranch Horst, but there only the lower part of the Hess is involved.

In the Hess Ranch Horst: The great mass of the Hess Ranch Horst in hill 5816 rests on the Neal
Ranch Formation (all shale at this place) and is capped by beds with Schwagerina crassitectoria. The rocks are thus blocked in by the same boundaries that define the Lenox Hills Formation. P. B. King (1931:56, 141, section 20) recognized 305 feet of Wolfcamp limestone and shale above the " $U d$ denites shale" (= Neal Ranch Formation of present usage) and recognized 429 feet of Hess Formation composed of 7 units that included some conglomerate (bed 1), 214 feet of limestone said to be eastern Hess facies (beds 5 and 6), the latter topped by 116 feet of light gray limestone in massive beds (bed 7) resembling "the cliffs on Leonard Mountain, made up of the western facies of the Hess." All of these beds now are known to contain Wolfcampian fusulinids and to belong to the Lenox Hills Formation. The horst sequence, assigned to the Wolfcamp and Hess by King, is thus proved to belong to that part of the Hess (of its type section), which includes the interval from the basal conglomerate to the Schwagerina crassitectoria Zone, the part that in the eastern Glass Mountains is mainly red and green shale and sandstone. The passage of these facies of western and eastern expression is difficult to demonstrate lithologically because of unfortunate gaps in continuity, but it can be demonstrated amply and adequately by paleontology.

Facies Relationships.-The facies relationships of the Hess Formation as outlined by King and others are considered almost classic examples in the geological and stratigraphical literature, but they are only partly true. The relationships depicted for Leonard Mountain and the western part of the Hess Ranch area-in which it is indicated that shaly Leonard on the northwestern side of Leonard Mountain passes into reefs on the southeastern side and then into the Hess thin-bedded

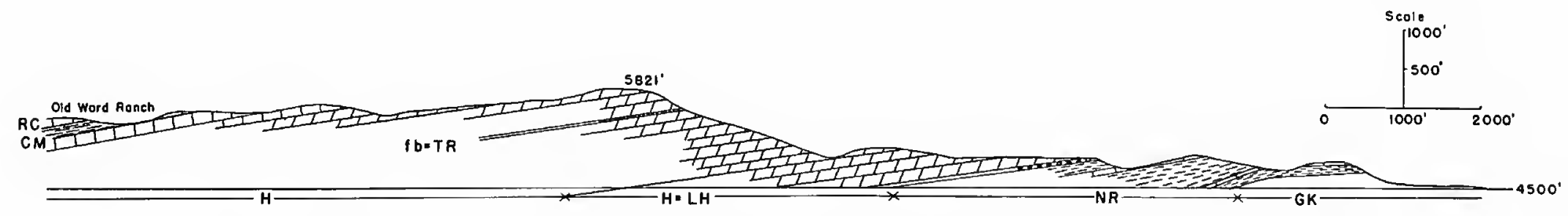

Figure 17.-Section through the Wolf Camp Hills to Old Word Ranch showing great development of the Hess Formation (GK=Gaptank Formation, NR=Neal Ranch Formation, $H=$ $\mathbf{L H}=$ lower part of Hess equals Lenox Hills Formation of Ross, $H=$ Hess Formation, $\mathrm{fb}=$ TR $=$ fossil bed of P.B. King equals Taylor Ranch Member, CM=Cathedral Mountain Formation, RC=Road Canyon Formation). 


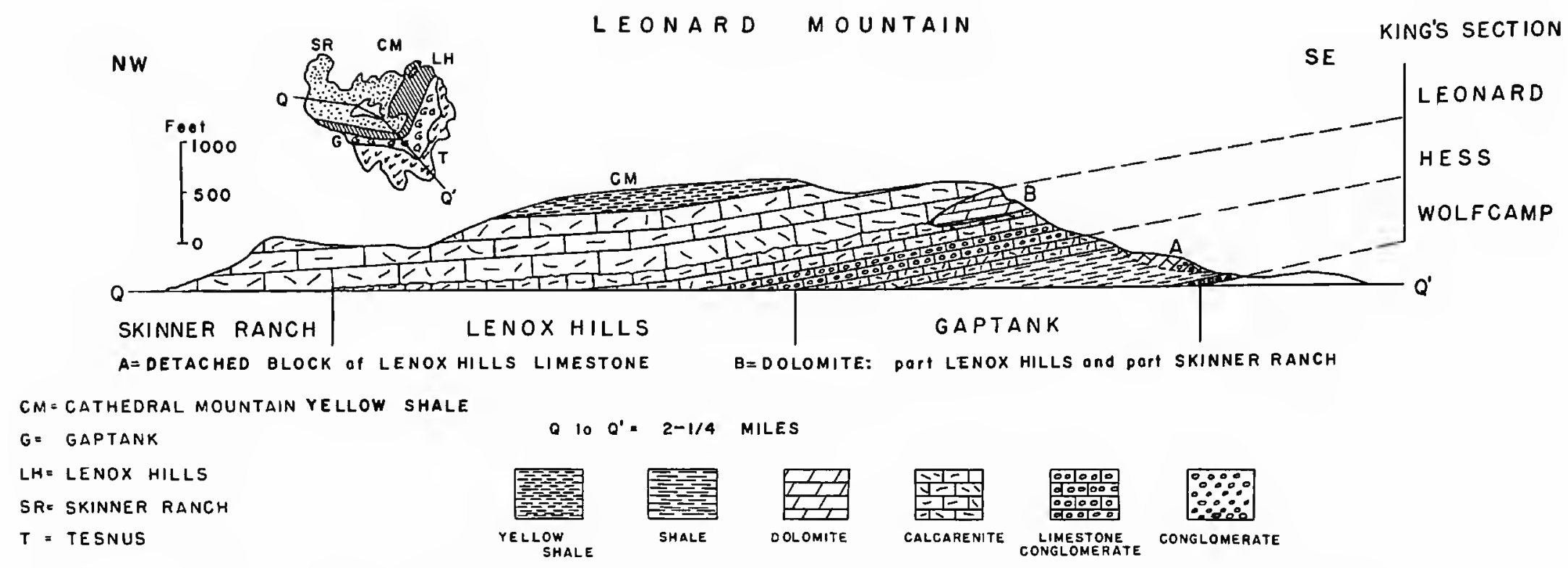

FIgURE 18.-Section through Leonard Mountain showing dolomite block (B) and detached block of Lenox Hills Formation (A) (see Plate 6: figure 3; Plate 8: figure 2)

limestone-is in part true, but the picture must be carried farther west than Leonard Mountain to get the full perspective. We have shown that the Poplar Tank shaly member is pinched out rather than interfingered into the Skinner Ranch Formation, but, although a few yellow shale beds can be seen in the Skinner Ranch Formation, we found no such relationship as indicated for Leonard Mountain (P. B. King, 1932:347). The Skinner Ranch Formation underlies the main mass of the "Leonard shales" (= Cathedral Mountain Formation) on Leonard Mountain and to the west. The Skinner Ranch Formation constitutes a great mass of calcarenite, and it is the massive formation of Leonard Mountain that can be demonstrated by paleontological correlation to be the lateral equivalent of the main part of the Hess thin-bedded limestone.

The relations of the Lenox Hills Formation to the lower part of the Hess Formation are shown on Leonard Mountain, on the mountain mass east of Hess Ranch, and in the Hess Ranch Horst. The lower 300-500 feet of the Hess east of Hess Ranch and all but the main knobs of the Hess Ranch Horst are equivalent to the Lenox Hills Formation. Demonstrating the equivalency of the Skinner Ranch with the bulk of the Hess Formation is more difficult because a great gap exists between Leonard Mountain and the hills east of Hess Ranch and the north slope of the Hess Ranch Horst. In spite of this gap, concrete evidence of the presence of beds equivalent to those higher in the Skinner
Ranch Formation than are found on the horst appears in the small hill 0.85 mile northwest of the Hess house (USNM 709a, 727f, 727m, 727n). There, numerous fossils of the upper part of the Skinner Ranch were taken, including not only brachiopods of significance, but also ammonites.

The 100 or 200 feet of lower Skinner Ranch Formation on the north slope of the west end of the Hess Ranch Horst (hill 5305) contains abundant Schwagerina crassitectoria, and the same fusulinid occurs on the summit of the horst (USNM 714h) but in characteristic Hess thinbedded lithology. It is evident that a lithological change takes place up the long north slope of the horst, but also that the mingled lithologies largely have been eroded away (see Figure 26).

\section{Leonard Series}

Like the Wolfcamp Series below it, the Leonard was elevated in rank from the status of a formation to that of a series (Adams et al., 1939). Furthermore, the content of the series has suffered some change from its original definition to its recent reconstitution.

\section{Type Section of the Leonard Formation}

Udden, Baker, and Böse (1916:51) only indirectly designated the type section of the Leonard, stating that the "section characterised here has been meas- 
ured in Leonard Mountain and north of it." They did not state what parts of Leonard Mountain were measured nor how far north they carried the measurements.

Udden (1917:46) was more specific in stating that the "formation which makes the greater part of the south face of Leonard Mountain has been given the name of this prominent feature in the landscape north of Marathon." Udden's section started at the west end of the mountain and extended northward, parallel to Gilliland Caynon (Plate 8: figure 2).

In 1929 P. B. and R. E. King (page 131) pointed out that the lower half of Udden's type section was Hess and part Gaptank (= Lenox Hills and Skinner Ranch Formations of this report). P. B. King (1931:63) reiterated this view and commented upon "the massive limestones which outcrop on the south face of Leonard Mountain, and which have been shown by the writer to correspond to the upper part of the Hess at its type locality." King, therefore, placed the contact of the two formations (Hess and Leonard) at the natural line of subdivision between the shales above and the massive limestones below. So defined, the only Leonard Formation on Leonard Mountain is that forming the knob 0.25 mile northwest of bench mark 5860 and that appearing on the northwest slope of the mountain. The Leonard thus occupies the north slope of the mountain and the valley and lower slopes of the hills on the north side of the valley. In 1932 P. B. King suggested that the Leonard Formation consisted of three interlocking facies: a shaly sequence in the west, a thin-bedded limestone in the east, and the two separated by reef limestone. King (1934:730) proposed the Hess Formation as a member of the Leonard Formation, a nomenclature that existed until Jarvis (1957) recommended restoration of the Hess as an independent formation (see Figure 18).

Ross (1960) did not follow Jarvis' suggestion to reinstate the Hess as a formation, but he continued to regard it as a member of the Leonard. In 1962, however, Ross (1962b) recommended splitting the Leonard Formation into three members, which he designated in ascending order $\mathrm{A}, \mathrm{B}$, and $\mathrm{C}$. Member A includes the basal conglomerate limestone (Decie Ranch Member of the Skinner Ranch Formation) and the succeeding shale (Poplar Tank
Member) to the base of the first Leonard limestone. Member B includes all of the numbered limestones from the first to the fifth. Member $\mathrm{C}$ extends from the base of an extensive sandstone to the base of the Word Formation (Road Canyon Formation) and includes the great mass of Leonard soft shale in the western part of the mountains.

\section{Cathedral Mountain Formation}

Cooper and Grant (1964) revised the Leonard Formation, recommended that the name be restricted to the series designation, and proposed Cathedral Mountain for the siliceous sequence from the top of the Skinner Ranch Formation (= Mcmloc $A$ of Ross plus the first Leonard limestone of P. B. King) to the base of the Road Canyon Formation ( $=$ First Limestone of the Word Formation). The Cathedral Mountain Formation thus includes Ross Member $\mathrm{B}$ (minus the first limestone) and all of Member C. The Ross members do not form natural bio- or lithostratigraphic units in our opinion; therefore, we have not adopted them. Furthermore, in our treatment of the Leonard Series, we expand it to include the Road Canyon Member of the Word Formation, which now has become the Road Canyon Formation of the Leonard Series. As explained in the chapter "Faunas and Correlations of Glass Mountains Formations," this assignment has a paleontological as well as stratigraphical basis. We also individualize the Fifth Limestone of the Leonard on Dugout Mountain and the Second Limestone of the Leonard in the Lenox Hills as the Wedin Member of the Cathedral Mountain Formation.

In The TyPe AREs.-The type section of the Cathedral Mountain Formation is on the line of P. B. King's (1931:66) section 12 and includes his beds 19-38, aggregating 1245 feet in thickness. Beds $1-18$ of this section belong to the Poplar Tank and Sullivan Peak Members of the Skinner Ranch Formation. The type section, predominantly shale, chert, and sandstone, contains some conspicuous beds of sandstone and limestone. The shale of the Cathedral Mountain, especially the yellow, platy kind is well indurated, silty, or often sandy, cherty, and blocky, very hard and usually a beautiful orange and red, the staining of ten paralleling the blocky joints and creating interest- 


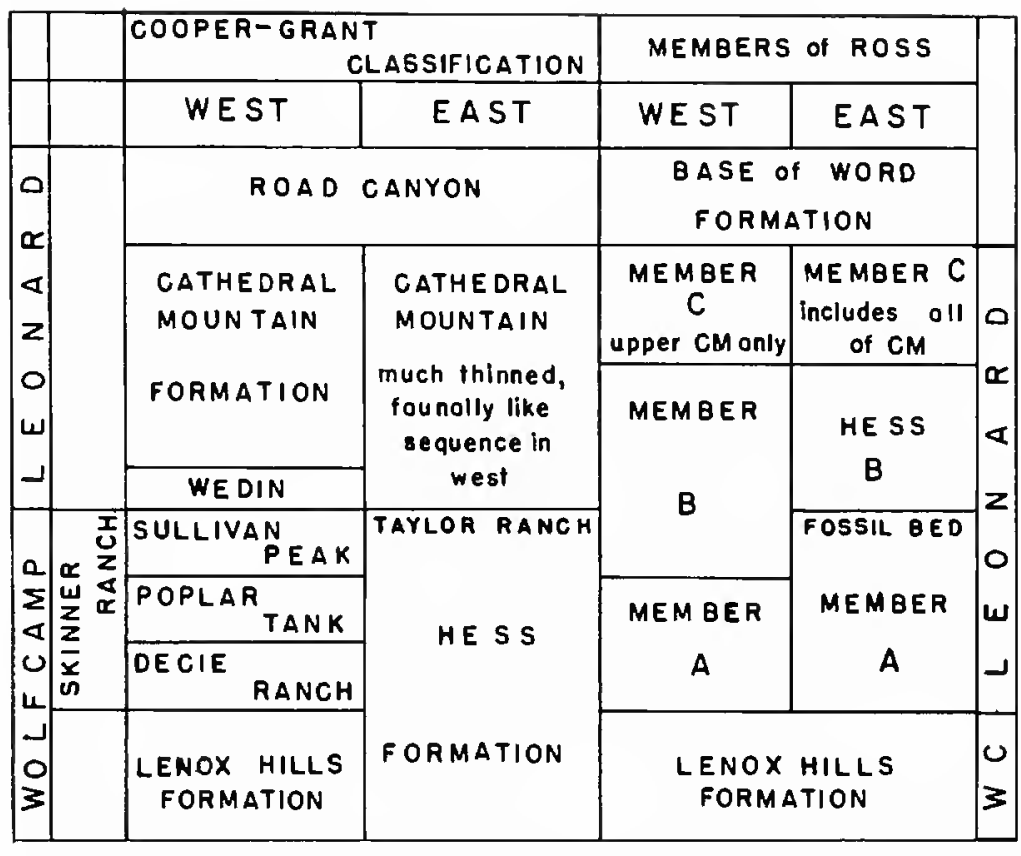

FIGURE 19.-Comparison of members of the Leonard "Formation" of Ross with the Skinner Ranch and Cathedral Mountain Formations.

ing patterns. The limestones are commonly conglomeratic, the pebbles usually small and composed of quartz or chert, occasionally red or white. In the conglomeratic, calcarenitic limestones, the ammonite Perrinites commonly occurs. The lower orange and pink, hard, indurated, silty shales and cherts form the knobs on the north slopes of the Lenox Hills, and the upper part of the formation lies on the lower slopes of Cathedral Mountain beneath the Road Canyon and Word Formations, which form most of the upper part of the mountain. The valley between the Lenox Hills and Gathedral Mountain is underlain by the Cathedral Mountain Formation. Good exposures appear in low hills and knobs in the valley. One hill composed mostly of sandstone occurs 1.35 miles south of Sullivan Peak. It is unusual because the nearly solid mass of sandstone surrounds a characteristic smooth-limestone bioherm that contains the brachiopod Institella, among other fossils. This is a possible erratic block of the Wedin Member.

The contact with the Sullivan Peak Member of the Skinner Ranch Formation is sharp and clear because it consists of yellow Cathedral Mountain shale and chert on light-gray Sullivan Peak limestone in most places in the Lenox Hills. It also occurs in the valley on the south side of hill 4920 . The upper contact is more difficult to find because it is covered by slide from the Word Formation.
On the south side of Cathedral Mountain, where rock is exposed, the shale of the Cathedral Mountain Formation is in contact with bioherms of the lower Road Canyon Formation.

East of the type section at the Clay Slide an excellent exposure of the upper shale can be studied (Plate 7: figure 2). In this vicinity the base of Cathedral Mountain is in contact with the Sullivan Peak Member of the Skinner Ranch Formation at the constriction of the 4750 -foot contour on hill 5021. Here the yellow siliceous shale lies on the Skinner Ranch Formation, which forms the saddle. The limestone or dolomite above the Skinner Ranch in the lower Cathedral Mountain King (P. B., 1931: map) has mapped as the First Leonard Limestone. This is actually not the First Limestone, but it is the same as the one marked "Limestone 3-4," which makes hill 4920. The "First Limestone of the Leonard" forms the top of hill 5021 and is the upper part of our Skinner Ranch Formation. The other limestone is a dolomite rather than a limestone and contains abundant Perrinites.

The valley between hill 5021 and the Clay Slide is underlain by the Cathedral Mountain Formation. The low hill about 0.35 mile east of Clay Slicle, containing interesting exposures of limestone and sandstone, is a good place to collect the fauna of the Cathedral Mountain Formation. Perrinites is common and Institella is present but difficult to find. Fossils also are abundant in a ravine just east of Clay Slide (USNM 707q). The upper beds of the Cathedral Mountain Formation appear in several ravines entering Gilliland Canyon, such as the one just southeast of elevation 4869 on the Gilliland Canyon Road.

Leonard Limestones of P. B. King in the Lenox Hills.-P. B. King's (1931) sections 10-12 in the Lenox Hills all indicate the presence of limestone beds in the Leonard shale, which he designated by numbers 1-4. The First Limestone was separated by Cooper and Grant (1964) as the Sullivan Peak Member of the Skinner Ranch Formation. Inasmuch as this First Limestone is correlatable across the Lenox Hills to the west onto Dugout Mountain, it has been inferred hitherto that the other numbered limestones of the two hill masses are the same. Certainly the consecutive numbering in both places encouraged such a view. 


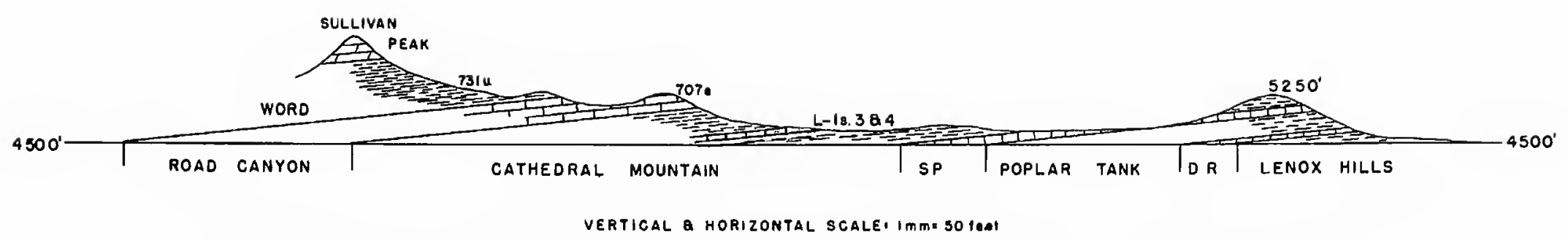

Figure 20.-Section through the hill capped by the closed 5250 -foot contour, just west of hill 5300 , to Sullivan Peak in Cathedral Mountain (DR=Decie Ranch, SP =Sullivan Peak, both members of the Skinner Ranch Formation, L-ls. $3 \& 4=$ Leonard limestones 3 and 4 of P.B. King).

Identification of the fauna of King's Second Limestone in the Lenox Hills with the Fifth Limestone of Dugout Mountain dispels this idea.

Although we have assigned King's First Limestone Member to the Skinner Ranch Formation, the other limestones remain in the Cathedral Mountain Formation. For the sake of discussion, we do not alter the numbering of King. In the Lenox Hills the Second Limestone is well exposed at several places (USNM 714w, 727p), and it can be followed to hill 5300 where it pinches out. Its thickness is variable and amounts to 20 feet just below the west knob of hill 5300. This limestone, the Wedin Member of the Cathedral Mountain Formation, contains an unusual fauna and is therefore singled out for further discussion.

Separated from the Second Limestone by about 80-90 feet of yellow siliceous shale is King's Third Limestone in hill 5300, consisting of 15 feet of small pebble conglomerate and 32 feet of gray limestone that contains numerous specimens of Perrinites. On the north dip slope of the west knob of hill 5300, the limestones contain numerous specimens of Institella in biohermal beds. The conglomerate is variable and thins to the east (Plate 7: figure 3).

The Fourth Limestone Member (P. B. King, 1931:135, section 11) is recorded as 12 feet thick in section 11, but on the east side of the Lenox Hills it merges with the Third Limestone to form a combination of sandy limestones that become conglomeratic near the top. This combined limestone is characterized by abundant Perrinites and extends onto the north slope of hill 5021 .

P. B. King and R. E. King (in P. B. King, 1931) mapped the First Limestone of the Leonard Formation on the northwest slope of hill 5021 and on the next hill to the northeast. It forms a broad belt in the first hill but only a narrow band in the second one. Actually these bands belong to the combined Third and Fourth Limestones of the Leonard rather than to the First Limestone. Partly dolomitized, they abound in large ammonites of the genus Perrinites, a feature quite unlike that of the First Limestone (= Sullivan Peak Member of the Skinner Ranch Formation). It is now known that the First Limestone unites with the Decie Ranch Member of the Skinner Ranch Formation. This combination appears in the Kings' map as the "Hess Limestone." The Leonard Limestone appearing in the hill between hills 5021 and 5280 is the last appearance of any of the limestones of the Cathedral Mountain.

Summarizing the above, we see that the four limestones King individualized by number pinch out to the east by union with lower beds. The First Limestone is the Sullivan Peak Member of Cooper and Grant; the Second Limestone, the Wedin Member, pinches out in hill 5300 near the middle of the Lenox Hills; the Third Limestone unites with the Fourth at the east end of the Lenox Hills and pinches out east of hill 5021. This was misidentified as the First Limestone on the east side of the Sullivan (Yates) Ranch Road.

WEDIN MEMBER.-The Second Limestone Member of the Leonard of P. B. King noted above is an important datum for the base of the Cathedral Mountain Formation. It was individualized, therefore, by Cooper and Grant (1966) as the "Wedin Member"-named after the Ava Scribner Wedin No. 1 Well on the Decie Ranch about 2.25 miles southeast of the type section. Since the Decie Ranch was at one time owned by the Wedin family, the name is doubly appropriate. The type section of the member is under the west knob of hill 5300 , which is defined by the closed 5250 -foot contour. 
Here the member is 20 feet of biohermal limestone abounding in Institella and Agelesia. The member pinches out about a mile to the east, but to the west it forms conspicuous ledges on the north slope of the west end of the Lenox Hills. It is also well exposed but somewhat thinner on the northwest side of Dugout Mountain, where it forms a belt almost a mile long. It is the highest rock mapped by P. B. King and R. E. King (in P. B. King, 1931) in the Dugout Mountain sequence, where it was called the Fifth Limestone Member of the Leonard. The member thus extends from the center of the Lenox Hills westward to the northwest side of Dugout Mountain, a distance of 6 miles. The Wedin Member contains the first appearance of the Institella and Agelesia assemblage, the first of the Cathedral Mountain faunas traceable across the entire mountain front except for the gap between hill 5300 and Leonard Mountain (Plate 7: figure 1).

In Leonard Mountain.-The bulk of Leonard Mountain is composed of the Skinner Ranch Formation. This is overlain by yellow shaly beds of the Cathedral Mountain Formation, which appear on the mountain in the knob 0.25 mile northwest of bench mark 5860. Most of the north slope from this point is composed of the upper beds of the Skinner Ranch Formation, the type section of that formation appearing at the west end of the mountain, where it forms a conspicuous knob and extends into the valley floor. The Cathedral Mountain Formation is exposed at places in the valley, especially where small bioherms are resistant enough to stand above the floor. The upper part of the Cathedral Mountain Formation is exposed in the lower slopes of the hill north of Leonard Mountain, where they are overlain by the Road Canyon Formation. Excellent exposures with abundant fossils appear in the saddle between Leonard Mountain and the hill to the north. The ravines near the base of the mountain to the north (5674) contain good exposures of the yellow shale, and the thin limestones and bioherms contain numerous fossils. Good specimens of large Perrinites are fairly common. Perhaps the best collecting place is R. E. King's locality 123 (=USNM $71 \mathrm{lq}$ ). This and the few exposures of the upper Cathedral Mountain Formation that appear in the ravines at the base of the slopes of hill 5801 and to the mouth of Road Canyon are the last exposures of the typical Cathedral Mountain Formation. The Cathedral Mountain has been cut out by the Hess Ranch Horst, but the interval appears again several miles to the east in a different facies.

Institella is perhaps the most significant brachiopod of the Cathedral Mountain and seems to be confined to it. It occurs at several levels in the formation, but on Leonard Mountain it is at the very base. On top of Leonard Mountain the knob 0.25 mile northwest of bench mark 5860 is composed of about 80 feet of yellow, silty shale, followed by 5.5 feet of thick-bedded calcarenite containing Institella and other fossils. This is followed by $1-2$ feet of chert with the same fossils, which in turn is succeeded by thin-bedded limestone that forms the top of the knob. The thin plates of limestone at the top are composed almost completely of Institella, with many of the valves crushed together and in great profusion.

The calcarenite capping the west knob of Leonard Mountain contains Institella and is assigned to the Cathedral Mountain. This same bed appears midway between Leonard Mountain and the hill to the north (USNM 709), but it does not extend to the highest part of the mountain to the south and east.

In Dugout Mountain Region.-The Cathedral Mountain Formation has a considerable development in the Dugout Mountain region, but much of it, which is soft shale, is buried under the plain on the north side of the mountain. In our discussion of the Skinner Ranch Formation, we showed that the lower part of the Leonard of P. B. King contained several limestones, numbered 2-4 by him, separated by beds of yellow, silty shale and chert. These limestones and shales, although lithically like the Cathedral Mountain Formation, contain fossils like those of the Skinner Ranch below. We, therefore, have named this sequence the "Dugout Mountain Member of the Skinner Ranch Formation" (Cooper and Grant, 1966). The Cathedral Mountain Formation thus begins with P. B. King's Fifth Limestone Member at its base. This limestone is here called the "Wedin Member of the Cathedral Mountain Formation" and introduces the Institella fauna (see above).

The Wedin Member at the base of the section forms a narrow northeast trending belt at the 


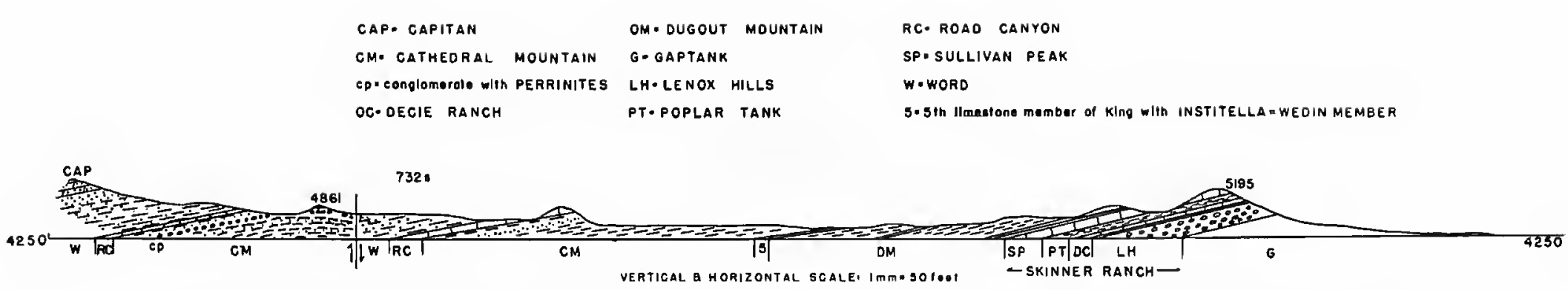

Figure 21.-Section through Dugout Mountain, past the site of Old Payne Ranch, through hill 4861, to hill capped by the 5600-foot closed contour in the northwest corner of the Monument Spring quadrangle.

northwest base of the mountain. Here the member is only 12 feet thick (P. B. King, 1931:133), but it has numerous bioherms that contain abundant Institella and Agelesia exactly like those on the north slope of the Lenox Hills and near the old Word Ranch. On Dugout Mountain the silicification of fossils proved disappointing, but numerous specimens were obtained in the Wedin Member by conventional mcans.

Above the Wedin Member the section is covered, concealing more than 500 feet of section (P.B. King, 1931:133). Above this are nearly 300 feet of shale and sandstone, the latter forming conspicuous brown masses in the valley. Perrinites is reported (P. B. King, 1931:133) in the upper beds, which are like those at the Clay Slide and Cathedral Mountain. The thick sandstone also resembles that occurring south of Sullivan Peak. P. B. King's (1931:133) section aggregates 987 feet from the top of the Dugout Mountain Member of the Skinner Ranch Formation to the base of the Road Canyon Member.

The upper few hundred feet of the Cathedral Mountain Formation near the Old Payne Ranch site occur in situations suggestive of the Clay Slide. Indeed the conspicuous conical hill 0.25 mile northwest of the Old Payne Ranch site contains a long gash in the shales under the massive limestone of the Road Canyon Formation strongly reminiscent of the Clay Slide. Here fossils are fairly common and Perrinites occurs in a thin band of orangebrown limestone. Exactly the same sequence, but in a slightly different setting, can be seen in hill 4861 and in the one immediately to the northwest, which includes the 4750-foot contour. In hill 4861 a conspicuous round-pebble conglomerate occurs about one-third the height from the base. This conglomerate abounds in well preserved Perrinites and other Leonardian cephalopods. The hill and the other immediately to the northwest are capped by the Road Canyon Formation (Plate 13: figures $1,2)$.

The presence of the Road Canyon Formation at several localities in the Sierra del Norte from a point about 2 miles west-northwest of the Old Payne Ranch site indicates that the lower slopes of this range west of Dugout Mountain belong to the Cathedral Mountain Formation. Due west of the new house along the road (USNM 737s) there occur dolomitic beds with large pebbles and an abundance of Perrinites. Farther south on the mountain front at USNM $741 \mathrm{~s}$, thin detrital beds contained Institella and Agelesia, indicating $\mathrm{Ca}$ thedral Mountain, but we were unable to identify Road Canyon in this section.

In Old Word Ranch (= Split Tank Area).-Cathedral Mountain Formation rocks are exposed in the canyon (Comanche Canyon? =east branch of Hess Canyon of some inhabitants) from the igneous body on the east side of the Hess Ranch Horst, past Old Word Ranch, the Appel Ranch, Split Tank, and beyond. It is rather thin in this region, 301 feet thick near Split Tank and 237 feet thick in P. B. King's (1931:145) section 27. The base of the sequence is conglomerate with numerous small quartz pebbles (Plate 12: figure 4), followed by Hess-type limestones, then bioherms overlain by yellow siliceous shale. Above the shale there is a thick sequence of biohermal limestone, which is succeeded finally by a considerable thickness of yellow shale with abundant Rugatia and Peniculawiis mckeei (see Figure 22 for details). Institella is common to rare in parts of the lower half, but it was not found in the upper shaly part.

The Split Tank section has furnished many of the finest silicified fossils from these mountains, 


\section{SPLIT TANK}

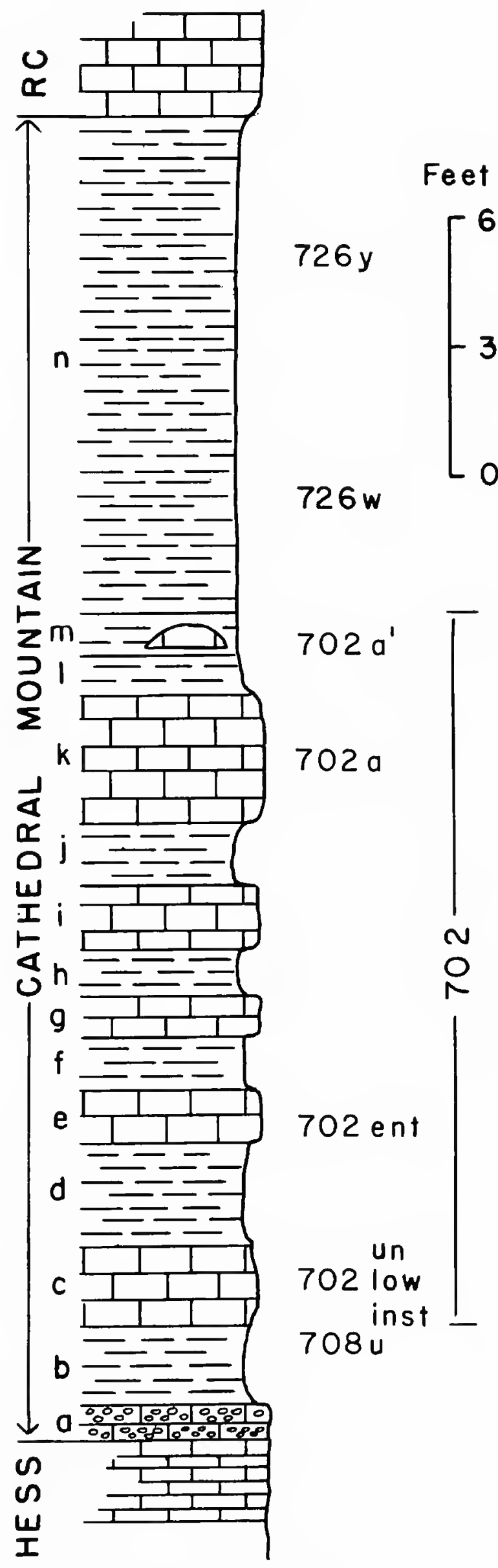

Figure 22.-Columnar section of the Cathedral Mountain Formation 0.5 mile east of Split Tank showing stratigraphic level of locality numbers ( $\mathrm{RC}=$ Road Canyon Formation). and the supply has not been depleted. The section is noteworthy for its bioherms, some of which are characterized by an abundance of particular brachiopods. Institella and Torynechus (formerly Uncinuloides) bioherms occur in the lower part of the section. Above them are bioherms replete with Enteletes and Hercosia. In the upper part, just below the thick shales, there occur remarkable bioherms composed almost entirely of Collemataria.

Southwest of the old Word Ranch site the Cathedral Mountain Formation is not well preserved; just east of the Hess Ranch Horst it is greatly dolomitized, and many of the fossils have been destroyed. The map by P. B. and R. E. King (in P. B. King, 1931) indicates a belt of Wolfcamp limestone on the south side of the igneous body at the base of the Hess Ranch Horst. These limestones are indicated by Ross (1963a: map [Plate 1]) as of Leonard age. We corroborated their postWolfcamp age by collecting Institella from their upper part at several places, thus clearly establishing their position at the base of the Cathedral Mountain Formation. The beds with Institella overlie heavy bedded limestone of the upper Skinner Ranch Limestone Formation. The Skinner Ranch part of this limestone lies against the igneous body at a high angle. The basal conglomerate of the Cathedral Mountain Formation occurs at the base of these Institella limestones and can be traced northeastward up the canyon for several miles. It is especially well developed near the Old Word Ranch on the steep dip slope forming the south side of the canyon.

\section{Road Canyon Formation}

This formation forms the top of the Leonard Series throughout the mountains from the Split Tank area to Dugout Mountain. It is an excellent datum in the stratigraphy of the Glass Mountains. Its name originally was proposed by Cooper and Grant (1964) as a member of the Word Formation. Previously it had been designated as the First Limestone Member of the Word Formation by P. B. King (1931:71) but, because of the predominantly Leonardian character (Miller, 1945a) of the launa, we have transferred it to the Leonard Series. The changeable character of the formation from place to place makes its discussion on a geo- 
graphic basis necessary. Five areas are considered: (1) the triangular hill north of Leonard Mountain, which contains the type section, (2) the Old Word Ranch area, (3) the Sullivan Peak region, (4) Gilliland Canyon, and (5) the area northwest of Old Payne Ranch, northwest of Dugout Mountain.

In Hills North of Leonard Mountain.-North of Leonard Mountain lies a triangular group of hills, which are bounded on the north by the eastwest Road Canyon and on the west and east, respectively, by the convergent canyons Gilliland and Hess. The type section of the formation is located at the south angle of the triangle, approximately on the $103^{\prime} 15^{\prime \prime}$ parallel. The formation crops out on the south side of the mouth of Road Canyon and forms a conspicuous ledge on the hillsides facing Hess and Gilliland Canyons, but it passes under the Gilliland Canyon floor about 1.25 miles south of the western mouth of Road Canyon. The formation in these hills displays a great variety of lithologies; in fact, all types occur in the formation except the thin-bedded black shales, which appear to the east and west of the type area (Plate 16: figure 4; Plate 14: figure 2).

At the type section, the formation is 228 feet thick and consists of bioherms with Coscinophora at the base, followed by bioherms abounding in Hercosestria, more limestone with Coscinophora, and then a series of varied thin beds followed by a thick biohermal mass. No two sections of the formation in these hills are alike, a fact that is to be expected when dealing with bioherms. Coscinophora bioherms of considerable size can be seen on both sides of the triangular block of hills. Other fossils also are abundant; the area is one of the best in the mountains for collecting silicified fossils. The variety of animals is great. Not only are brachiopods abundant, but also a variety of gastropods and pelecypods may be retrieved in nearly perfect preservation. Perrinites, found in this area south of the eastern mouth Road Canyon (USNM 726c), attests to the Leonardian age of the formation. It is difficult to cletermine a faunal sequence in the formation, but a crude succession of forms seems to be manifest.

The bioherms near the base on both sides of the hills are characterized by Hercosestria and a variety of other forms such as Edriosteges, Texarina, and Cyclacantharia, which also are seen to the east in the conical knob (USNM 702c) 1.25 miles southwest of Old Word Ranch.

One of the best of the bioherms (Plate 16: figure 4 ) occurs at the base of the type section on the east nose of hill 5779 about 2.5 miles due north of the Skinner Ranch house. Over 82 feet thick, it begins with a thick limestone conglomerate at the base, followed by fine-grained calcarenite, which is succeeded by the biohermal limestone. This large rounded mass, visible for a considerable distance, is one of the largest bioherms in the mountains. The beds above the bioherms contain one conspicuous bed of yellow shale 14 feet thick. The top boundary of the section is uncertain because of the appearance of yellow shale in the upper part of the section. The uppermost thick calcarenite and bioherms (bed 10) are followed by yellow shale with thin, inter-bedded limestone, but these contain fossils like those of the Road Canyon below. A similar situation exists at the top of the formation on both sides of the triangular hill.

Lenses and thin layers of limestone with Road Canyon fossils appear just above Road Canyon on the west side of Hess Canyon and on the east side of Gilliland Canyon. On the former, the lenses and layers are usually only a few feet above the main mass of the Road Canyon Formation, but on the east side of Gilliland Canyon, lenses occur 25 feet above the main body of the formation (USNM 720d). Nevertheless, the fossils in them are Road Canyon types with affinities with the Road Canyon below. We have, therefore, included these beds in the Road Canyon Formation.

In OLd Word Ranch AREA.-This area extends from the east end of the Hess Ranch Horst northeastward along the north side of the canyon that runs from the Hess gate past the Old Word Ranch to the Appel Ranch house. The vicinity of the Old Word Ranch is the type area for the Word Formation; the Road Canyon was originally the First Limestone of the Word of P. B. King. The best and most accessible sections are at the site of the Old Word Ranch, where P. B. King (1931:143, section 24) records 140 feet, including 60 feet of thin-bedded bituminous limestone weathering light gray and, above it, 80 feet of dark gray dolomite (Plate 13: figure 3). The section overlies siliceous shale of the Cathedral Mountain. P. B. King made no mention of the bed of bioherms at the base of 
the thinly laminated beds (USNM 703a). These have the same fossils as the bioherms at the base of the Road Canyon Formation just southwest of the mouth of Road Canyon (USNM 719x). At the Old Word Ranch site the thin-bedded dark limestones contain several lenses teeming with fossils (USNM 703, 703c, 703d). The first of these contains a remarkable fauna of ammonites including Perrinites (Miller, 1945a); the second yielded a remarkable sponge and molluscan fauna, and the third produced some unusual spirifers and other fossils. Northeast of the Old Word Ranch, the Road Canyon Formation becomes dolomitic and merges with the higher limestones of the Word Formation by pinching out of the shale between them (Plate 13: figure 3).

Southwest of the Old Word Ranch, the Road Canyon can be traced to the fault bounding the Hess Ranch Horst. Near the horst the rocks are greatly dolomitized and difficult to identify, but, near the crossing of the south branch of Hess Canyon with the road from the Old Word Ranch, two important localities have yielded fine collections. One of these, USNM 702c, forms the top of a small knob on the inside of a wide loop of the road 1.35 miles southwest of the Old Word Ranch. Here Hercosestria and many other species characteristic of the bioherms at the base of the Road Canyon Formation were taken.

In Sullivan Peak Area.-The thickest development of the Road Canyon appears in Cathedral Mountain and on the hills just east of it to Clay Slide. The best place to study the member is on the spur terminating slightly less than a mile south of Sullivan Peak (Plate 1: figure 5; Plate 5: figure $3)$. The section was measured to be 367 feet by P. B. King (1931:70, section 12, Word, beds 1-6) and is composed largely of thin- and thick-bedded bituminous limestone. The rocks are very fossiliferous, with characteristic bioherms at the base. The fauna from the dark limestone includes many species not seen elsewhere or extremely rare in other parts of the formation. Along with the rare specimens, characteristic Leonardian types have been collected, such as Perrinites, Peniculauris, and Rugatia. Clifton (1945:1770) records Wangenoceras dieneri Böse "from strata of the Word First Limestone Member (= Road Canyon Formation) in outcrops near Sullivan Peak." Clifton's Waage- noceras is now called Stacheoceras normani Miller and Furnish (1957).

On the east side of the Sullivan (Yates) Ranch road, two long hills extend to the east; the farthest one contains the Clay Slide. These two hills are capped by the Road Canyon Formation and are lithically like the section below Sullivan Peak. Perhaps the most interesting feature of these hills, especially the one nearest Sullivan Peak, is the occurrence in the bituminous limestones of large bioherms composed mostly of the peculiar lyttoniid Coscinophora. In places the rock is literally made up of the pedicle valves of this ostreiform brachiopod. Similar bioherms also were seen on the east side of Sullivan Peak toward the Yates place. Although Coscinophora occurs at other levels in the Skinner Ranch-Cathedral Mountain interval, it is most abundant in the Road Canyon Formation (Plate 17: figures 3 and 4).

Traced westward along the lower slopes of Cathedral Mountain, the Road Canyon Formation seems to be split by insertion of shaly wedges (P. B. King, 1931:135, section 11). King reports 127 feet of bituminous limestone at the base, followed by 50 feet of shale and another 50 feet of limestone. Above this there are two thinner limestone beds ( 15 and 16 feet thick) that may belong to the Road Canyon Formation, the Word beginning at the base of King's bed 8, which is composed of 235 feet of siliceous shale and sandstorle.

In Gilliland Canyon.-About 1.5 miles north of Clay Slide, King's map (in P. B. King, 1931) indicates an isolated mass of Road Canyon Formation faulted down and appearing inconspicuously in the plain, where it has been exposed by an intermittent stream (USNM 724b). The map also shows a band of the First Limestone of the Word extending along the west side of Gilliland Canyon and forming a conspicuous bench along the hillside. The limestone is mapped as overlying Leonardian rocks. We sampled this limestone in three places (USNM 723t, 723w, 731m) and found it to belong to the Third Limestone of the Word (= Willis Ranch Member) rather than to the First Limestone (= Road Canyon Formation). It contains a great abundance of Waagenoceras dicneri, Echinosteges tuberculatus (R. E. King), and other characteristic Word fossils (USNM 723t). Furthermore, the limestone generally is light gray, is very 
sandy, and also contains much interbedded sand in the form of brown layers and lenses. The lithic character of the rock is exactly like that seen in the Willis Ranch Member at the junction of Road and Gilliland Canyons, a well-known location for the Third Limestone of the Word and its fossils.

Examination of the map will thus indicate that the Third Limestone of the Word crosses the canyon near bench mark 4973 and rises along the west side of Gilliland Canyon. The Road Canyon Formation beneath it descends below the canyon floor 1.25 miles south of the mouth of Road Canyon, but it does not rise above the floor on the west side until the isolated mass northeast of Clay Slide is reached (USNM 724b).

Northwest of Dugout Mountain.-In the low hills west of the Old Payne Ranch (no longer in existence) on the northwest side of Dugout Mountain, the Road Canyon Formation is reduced to two layers of limestone separated by siliceous shale. The lower limestone is recorded by P. B. King (1931:131, section 5) as 40 feet thick and the upper one as 20 feet thick; the two are separated by 60 feet of shale. Our measurements show the thicknesses to be variable. We measured 70 feet of the lower limestone of the Road Canyon Formation in the conical hill 0.25 mile northwest of the Old Payne Ranch. The lower part of the hill is composed of yellow-orange siliceous shale of the Cathedral Mountain. The cap of the hill is composed of some biohermal limestone in the lower part, but mostly of dark bituminous limestone abounding in fusulinids.

In the low hills 0.75 mile southwest of the Old Payne Ranch, we found the lower limestone to be about 20 feet thick, but the upper limestone is only 8 feet thick and is underlain by 15 feet of sandstone. The upper limestone is crumbly and a veritable mass of fusulinids and other less abundant fossils. The brachiopods proved to be characteristic Road Canyon species. Above this thin limestone, there occurs a thick sequence of massive sandstone and siliceous shale of the Word Formation. The Road Canyon thus appears to thin significantly west of Sullivan Peak.

Other and hitherto unidentified exposures of the Road Canyon Formation occur 1.5 miles northwest of Old Payne Ranch. In hill 4861, which is conical and with a section like that 0.25 mile north- west of Old Payne Ranch, the Road Canyon forms the crest of the hill. It is biohermal and has much detrital material in the form of fusulinids between the bioherms. Coscinophora was found here and in the next hill to the northwest. This is a low, flat hill, the lower part of which is marked by the 4750-foot contour. Here the Road Canyon formation consists of two limestones with intervening shale that contains some thin beds of limestone. The lowest bed, 20-30 feet thick, is variable but with bioherms at the base. The hill is capped by a 5-foot bed in two tiers, mostly of fusulinid limestone. The Road Canyon in this hill overlies Leonardian beds with Perrinites and is like the section in hill 4861, with the cephalopod-bearing conglomerate of the Cathedral Mountain Formation appearing at the base of the hill. The Leonardian sediments are in fault relation with the Word limestone south of it.

After discovery of the Road Canyon Formation in the foothills of the Sierra del Norte, we were able to trace the formation southward for a few miles along the mountain front. Throughout the observed extent of the formation it is very variable, consisting mainly of thin limestones separated by yellowish shales. The tracing was facilitated greatly by the discovery of a cobbly, dark bluish limestone abounding in ammonites of the genera Paraceltites and Texoceras. This ammonite bed was found along the mountain front at USNM $737 \mathrm{c}, 737 \mathrm{~g}$, 737n, 737y, and 739d. Opposite the abandoned house (NW, NW 3; USNM 737g) the ammonite bed is well developed. The same bed was seen about 2 miles farther south, 3.5 miles due west of Dugout Mountain, where the following section was measured:

K. Yellow shale at top of section

$\mathrm{J}$. Fine-grained limestone with fusulinids and small Enteletes like those of USNM $732 \mathbf{j} \ldots \ldots \ldots \ldots \ldots \ldots, 7$

I. Bluish-black limestone with ammonites................ 2

H. Fine-grained limestone ............................ I

G. Blocky, bluish-black limestone breaking into lumps and with many ammonites (like bed at

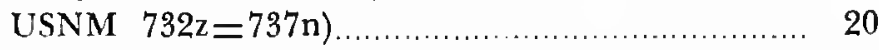

F. Granular limestone with fusulinids ................... 12

E. Siliceous, platy, buff-colored shale ..................... 20

D. Seven thick beds of dark limestone separated by yellow shale, fusulinids .............................. 75

C. Covered ........................................... 50

B. Sandstone of the Cathedral Mountain Formation... 20

A. Covered 
A mile still farther south, just southeast of the "s" in "mountains" (SE, NW 3: USNM 737y), another section of the Road Canyon is revealed as follows:

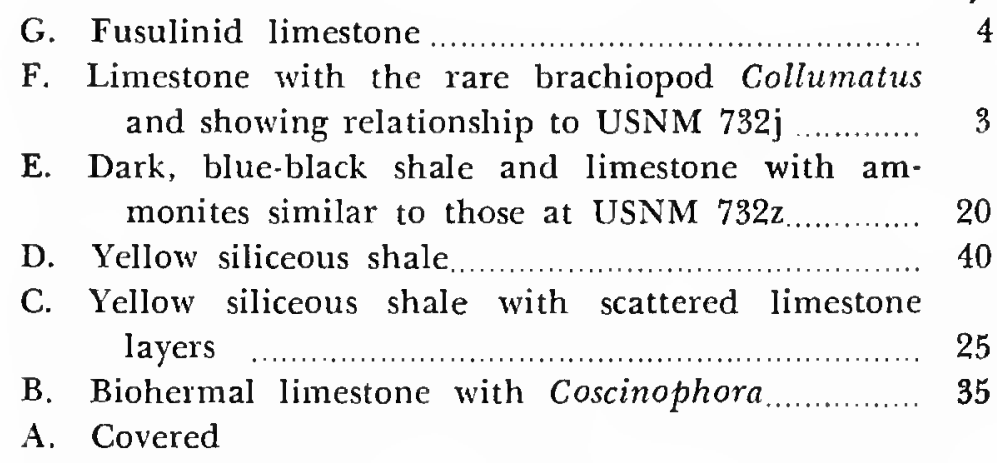

No two sections on the mountain front are alike, but the presence of the ammonite zone, though variable in thickness, and the presence of the upper fusulinid bed with Collumatus relates these Sierra del Norte localities to those in the foothills, such as USNM 732j, where the Collumatus and ammonite beds also can be seen. It is believed that west of Cathedral Mountain the Road Canyon thickens by introduction of shale and concentration of detrital material in lenticular beds that tend to fray the formation in a western direction. The Road Canyon was not successfully identified south of USNM 737y.

\section{Guadalupe Series}

In the Glass Mountains the Guadalupe Series consists of the Word and Capitan formations. Only the Word Formation will be discussed at length here because most of the Capitan Formation and its members, as well as some members of the Word Formation, are dolomitic or otherwise poorly fossiliferous and, therefore, not collected or studied in detail. So far as known, none of the dolomites yield silicified fossils; however, three limestone members of the Word Formation yield fine fossils in abundance.

\section{WORD FORMATION}

The Word Formation was named by Udden, Baker, and Böse (1916:52). Udden (1917) further enlarged on the formation, indicating its type section on the Word Ranch, where its massive facies is exhibited. P. B. King (1931) redescribed the formation, individualized its limestone members by numbers, and explained the two facies in the western part of the mountains and the carbonate facies in the eastern part.

The two facies begin in Gilliland Canyon north of Iron Mountain, approximately in the middle of the mountains. A western facies, predominantly of silty shale and sandstone, is recognized west of Gilliland Canyon, while the rocks to the east are characterized by carbonate (dolomite and limestone), which dominates the section in the area east of Split Tank. The western or shaly-sandy facies forms the thickest part of the formation, about 1470 feet, and thins to about 450 feet in the eastern part of the mountains.

East of Gilliland Canyon, and especially on the Hess Ranch in the intermediate zone of the facies P. B. King (1931:71) described four limestones, which were given consecutive numbers. The first or lowest limestone that is best exposed near Old Word Ranch is lithically and faunally unlike the others, but it can be traced across the mountains. This limestone not only is unique lithically, but also it contains an unusual and characteristic fauna, with strongest ties to the Leonardian rocks below. Cooper and Grant (1964:1586), therefore, recognized it as a member of the Word Formation (the Road Canyon Member). Later, they (1966) raised it to formation rank and placed it in the Leonard Series, as explained above. Separation of this First Limestone Member from the Word Formation does not affect the conception of the formation as outlined by King, because his overall view of the facies remains unchanged. The removal of this lowest limestone, however, does affect the numbering of the other Word limestones. Therefore, in order to make our discussion clearer and the location of the collections unambiguous, Cooper and Grant (1966) named the other limestones as members of the Word Formation.

The sections west of Gilliland Canyon above the Road Canyon Formation (=First Limestone of the Word) consist mainly of yellow platy shale, with some thin sandstone and thin limestone beds. Northwest of Dugout Mountain, thick sandstones appear in the sequence. Inasmuch as the shales are poorly fossiliferous and the thin limestones in this part of the area yield few good silicified fossils, little collecting was done in the Word west of Gilliland Canyon. 
The hills just north of Leonard Mountain are bounded on the west by Gilliland Canyon, on the north by Road Canyon, and on the east by Hess Canyon. The hilltops are capped by a thick limestone, but between the Road Canyon Formation and the hillcrest the section is mainly yellow siliceous shale, like that of the western facies. Shale and limestone in this area do not yield abundant good silicified material. The fossils are not so strongly concentrated as they are in sections farther to the east.

The area with the greatest abundance of fossils is on the east side of the Hess Ranch horst and in fault contact with it. Here four limestones of varying thickness are separated by siliceous shale of the western facies. These limestones, with the Road Canyon Formation, were designated by $\mathrm{P}$. B. King (1931:71) as First to Fourth Limestones. The Second, Third, and Fourth Limestones are hereby designated by names but retained as members of the Word: China Tank, Willis Ranch, and Appel Ranch Members.

China Tank Member (=Second Limestone MEMber of P. B. King).-This member consists of 113 feet (P. B. King, 1931:72) of siliceous brownish- to yellowish-gray limestone. The type section is the west side of hill 5611 not far east of the China Tank of the Hess Ranch (Cooper and Grant, 1966: 7). The tank is in Hess Canyon, 2.2 miles north, $75^{\circ}$ east, of the Old Willis Ranch on the P.B. and R. E. King map (1931). The tank takes its name from the luxuriant chinaberry trees that form a cattle shelter on its south side. The member at the type section is composed of highly fossiliferous limestone, nearly all of it containing silicified material (USNM 706c). It contains much echinoderm debris and some fine sand.

The China Tank Member is well displayed in the bluffs on the east side of Hess Canyon about 1.5 miles south of the head of its south branch, due west of Old Word Ranch. Here the member is massive and in large part dolomitized, but fusulinids are abundant in limy parts. Patches of silicified brachiopods and other fossils are rare and difficult to find. East of Old Word Ranch and in the vicinity of the Appel Ranch, the member loses its individuality and becomes mostly massive dolomite.
Willis Ranch Member (=Third Limestone Member of P. B. King).-The type section selected for this member by Cooper and Grant (1966:7) is near the eastern mouth of Road Canyon, 1 mile southwest of the Willis Ranch site (R. E. King $243=$ USNM 724u) (Plate 14: figure 1). Here P. B. King (1931:71) measured 308 feet of limestone, as follows:

Third Limestone Member

D. Oolitic gray limestone in thin ledges................. 69

C. Gray limestone, containing fossils, and several seams of small pebbles............................. 11

B. Brown calcareous sandstone ......................... 10

A. Light gray oolitic limestone, containing some chert masses and fossils including Waagenoceras, Cyclacantharia. 218

Good silicified fossils appear in the lower part of the member at the type section, but they are not as abundant as they are to the east. The Willis Ranch Member extends westward to the east side of Gilliland Canyon, where it is well exposed near the junction of this canyon with Road Canyon. This place is well known for its abundance of ammonites, especially Waagenoceras (Böse, 1917). It is also exposed in a broad patch opposite the mouth of Road Canyon on the west side of Gilliland Canyon, although it is mapped on the west side of this canyon as the Lower Member of the Word limestone, with Leonardian shale below it. From this place it can be seen as a conspicuous ledge on the western slope of Gilliland Canyon. It disappears underground 1.5 miles north of hill 4910 at the southwest end of Gilliland Canyon. It is not known west of here (Plate 14: figure 4).

Everywhere that it has been examined, the Willis Ranch Member is very sandy. When dissolved in acid, the limestone leaves a residue of sugary quartz sand. In Gilliland Canyon the formation is very sandy and contains lenses and layers of fine brown sand (Plate 14: figure 3). Fossils are not common in Gilliland Canyon, but one locality (USNM 723t) yielded an abundance of typical specimens. On the west side of Gilliland Canyon thin lenses of richly fossiliferous dark limestone occur just beneath the main mass of the member. These are unusually fossiliferous and contain a variety of species not seen at any other level (USNM 723w). The same types of fossils were found 30 feet below the mem. ber at its southernmost occurrence (USNM $731 \mathrm{~m}$ ) 
1.5 miles north of hill 4910. Similar fossils were also taken under Sullivan Peak (USNM 73lu; Plate 15: figure 4) and northwest of Old Payne Ranch (USNM 732s). These isolated localities are thought to mark the approximate position of the Willis Ranch Member, which disappeared at the southwest end of Gilliland Canyon.

The best place to collect the fossils of the Willis Ranch Member is on the east side of the Hess Ranch Horst, on the long slope marking the south side of Hess Canyon opposite the divide in the Canyon. There the member is 95 feet thick ( $\mathrm{P}$. B. King, 1931:72) and consists of yellowish-gray sandy limestone containing thick patches of fossils as death assemblages. The fossils are beautifully' silicified, and USNM 706 and 706e have yielded enormous quantities of specimens. Waagenoceras is especially abundant near the top of the section. USNM 706 is in the lower part of the member while USNM 706e is at the top. East of the Old Word Ranch, on the Appel Ranch, the Willis Ranch Member merges with the other massive members of the Word and becomes strongly dolomitic and difficult to separate from the others.

Appel Ranch Member (=Fourth Limestone Member of P. B. KING).-This member is characterized by the great amount of chert it contains. North of the Appel Ranch P. B. King (1931:143) recognized three beds as follows:

Fourth Limestone Member

C. Light gray crystalline limestone with abundant, small, brown chert nodules as well as an abundant fauna of brachiopods, fusulinids, and other fossils

B. Gray and brown limestone and dolomitic limestone, containing some chert nodules and many silicified fossils, interbedded with sandy brown limestone and some siliceous shale...... 255

A. Fossiliferous cherty dolomite, weathering to dirty gray, deeply pitted surfaces.

We designated the area north of the Appel Ranch as the type section for the member (Cooper and Grant, 1966:8). Here it is well clisplayed and nearly every layer exposed. The member is also well displayed on the north side of Hess Canyon near the point where the canyon bends to the north, and the member can be followed westward to the site of the Willis Ranch, where it frays out into the shale (Plate 15: figure 1).
On the east side of the bend in Hess Canyon, the Appel Ranch Member is exposed in a strongly dissected area that affords excellent collecting and opportunity to study the sequence. In places the rock is composed almost wholly of masses of large Parafusulina. In other places the brachiopods occur in death assemblages of shells matted together so closely that some of them are crushed and distorted. Nevertheless, the variety is great, and many species not seen in the lower members of the Word Formation appear in this member.

Before closing the discussion of the Word Formation, we must note a lens that lies not far above the Willis Ranch Member in the shale separating that member from the Appel Ranch Member. This is USNM 706b, which consists of about 2 feet of sandy limestone with abundant fossils thickly matted together. The fauna has some elements of the Willis Ranch Member and some of the overlying Appel Ranch Member, yet it is sufficiently distinctive to be recognized as a separate level. Our operations unfortunately have removed most of this thin local layer.

Northwest of Old Payne Ranch the section above the Road Canyon is poorly preserved, but occasional lenses and layers of limestone replete with fusulinids were seen. One of these (USNM 732s) contained Waagenoceras, Popanoceras, and brachiopods in addition to fusulinids. The faunal content suggested the fossiliferous zone just under the Willis Ranch Member on the west side of Gilliland Canyon (USNM 723w). Above this lens comes a conspicuous, thick sandstone. Above the sandstone there was found a fault block containing Cathedral Mountain Formation, with Perrinites in a thick conglomerate near the base exposed in a conical hill at an elevation of 4861 feet. This conglomerate contains rounded quartz pebbles ranging up to 3 inches in diameter. The hill is capped by Road Canyon Formation. The section also is well displayed in the next hills to the west and northwest. Above the Road Canyon in the section of the Word there are mainly sandy shale and sandstone with occasional thin limestone and blue shale. The section is similar to that seen under Sullivan Peak, but no characteristic Word fossils were found other than fusulinids (Plate 1: figure 4).

South of hill 4861 , about a mile, hill 4806 is a sandstone hogback (see Plate 15: figure 3) with 
Word fossils on the west slope. On the northwest side of this hill, Word ammonites (Waagenoceras) are common, but a low hill a little farther to the west is capped by Cretaceous limestone. It is the last limestone band on the King (1931) map due west of the road junction in NE, NW 3, Monument Spring quadrangle. This is the top of a downfaulted block (see Figure 21).

\section{Capitan Formation}

Although no detailed collecting was done in the Capitan Formation of the Glass Mountains, it is important to record one locality that was discovered by chance and that yielded some good brachiopods. This is a small downthrown block 1.1 miles north, $33^{\circ}$ west, of Old Payne Ranch site, Altuda quadrangle (USNM 732q). This is in cream-colored dolomitic limestone containing an abundance of the fusulinid Polydiexodina and of brachiopods, indicating the level of the Hegler Member of the Bell Canyon Formation in the Guadalupe Mountains. This place offers possibilities for further collecting. The Capitan should be searched for undolomitized patches as possibilities for collecting and dating.

\section{Faunal Zones in the Glass Mountains}

A zone fossil, to be useful, must be distinctive and easy to recognize, fairly abundant, and widespread. Few genera in the Glass Mountains answer to these requirements. The method of collecting also has so increased the ranges of some hitherto "good" guide fossils that their value as zone indicators has become limited. Ombonia, for example, was regarded as restricted to the Capitan Formation and the Lamar Member, but now it is known from the Road Canyon and Cherry Canyon Formations. The very rare Word precursors in the Road Canyon, such as Echinosteges and Yakovlevia, limit the value of these genera, which otherwise are identified most with the Word Formation. Only a few genera in the Glass Mountains have the qualifications of good zone fossils, and these with their present ranges are listed below.

Parenteletes: Although this is not so common as might be desired, it is identified readily by virtue of its strong plication and its sulcate anterior commissure. The genus has its roots in the Pennsyl- vanian, as it occurs in part of the Gaptank identified as of Canyon age. It extends into the Uddenites-bearing Shale and on through the Neal Ranch to the top of the Lenox Hills Formation and into the Poplar Tank Member. It is, thus, a guide in its Wolfcampian range to that part of the section that was described as the Wolfcamp Formation by P. B. King (1931) minus the Uddenites-bearing Shale Member.

Spyridiophora-Glyptosteges: These two highly sculptured aulostegids have nearly the same range, and one often occurs where the other is absent. Spyridiophora has the longer range, as it occurs first in the Neal Ranch Formation and extends through the Lenox Hills Formation into the top of the Skinner Ranch. It is also one of the fossils that correlates the Taylor Ranch to the top of the Skinner Ranch. Glyptosteges is a new genus to be described in a subsequent volume. It does not occur in the Neal Ranch or Lenox Hills, but it appears first in the Decie Ranch Member and becomes moderately common in the remainder of the Skinner Ranch Formation. It is the best fossil with which to identify the Dugout Mountain Member of the Skinner Ranch Formation. The two used together thus cover the entire Wolfcamp as defined in this monograph (excepting the Uddenites-bearing Shale Member). Both of these genera also occur in the Skinner Ranch equivalent of the Bone Spring Formation, but neither one has been seen in the Hueco Group.

Scacchinella: Some paleontologists object to the use of Scacchinella in stratigraphy because it is thought to be facies restricted. It is a facies fossil only in the sense that it really creates its own facies. As a cluster builder it helps to determine bioherms, but these may be in more than one type of environment. Furthermore, even facies fossils have value as horizon-markers in their own right. Scacchinella is such a fossil. Several of the levels in which this brachiopod appears are characterized by different species of the genus: $S$. primitiva, new species, occurs in the Pennsylvanian (Gisco); S. triangulata, new species, is found in the Uddenites-bearing Shale Member of the Gaptank Formation; S. exasperata, new species, appears in the Lenox Hills Formation; and $S$. titan, new species, characterizes the Skinner Ranch Formation. Each of these occurrences is in a biohermal environment, but in each 

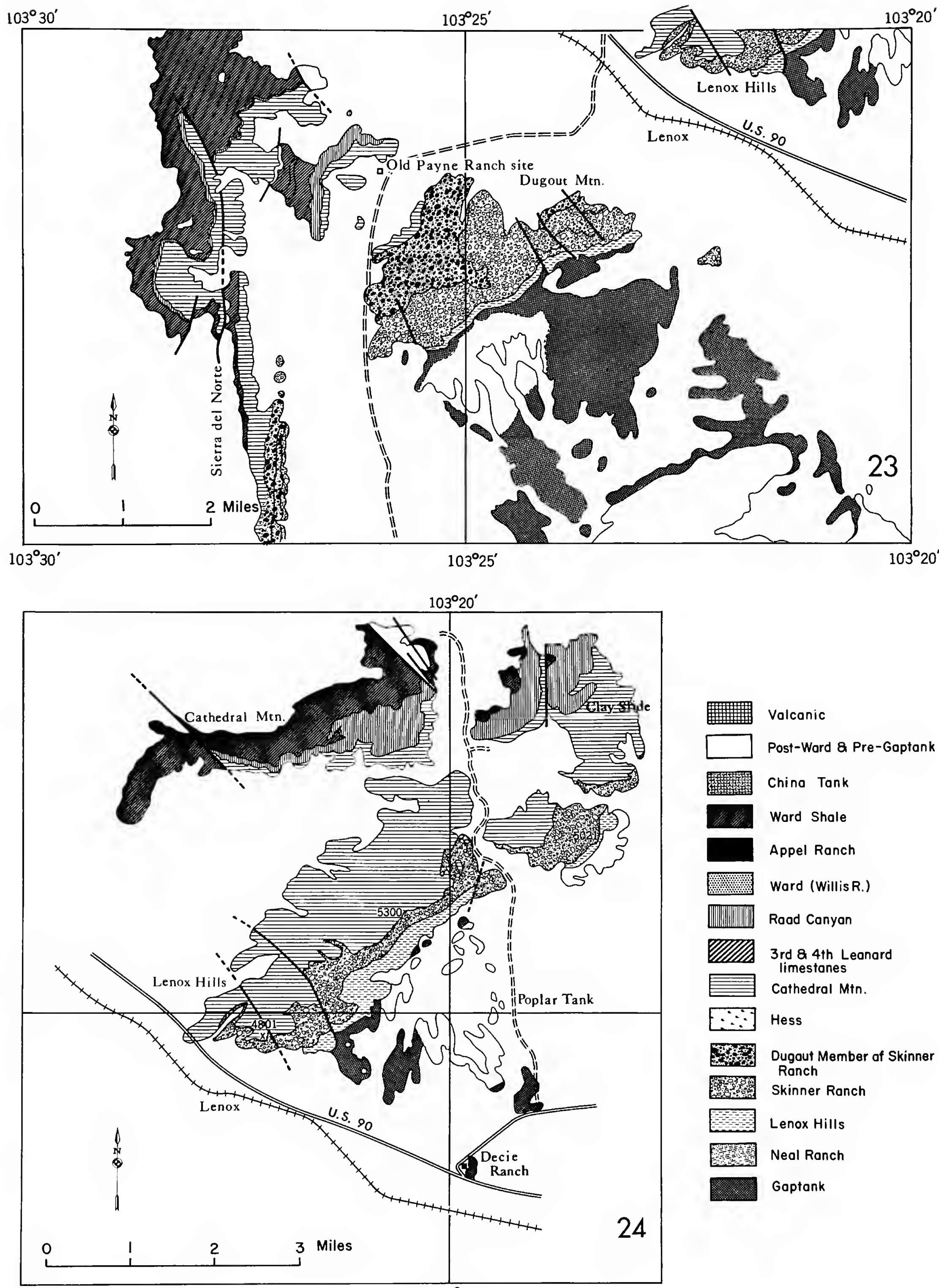

Volconic

$\square$ Post-Ward \& Pre-Gaptank

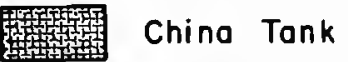

Zfere. Word Shale

Appel Ranch

Word (Willis R.)

Rood Conyon

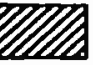

3rd 8 4th Leanord limestanes

Cathedral Mtn.

$\because \because$ Hess

Dugaut Member of Skinner

Ranch

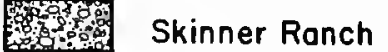

Lenox Hills

Weal Ranch

2.2. Gaptank 


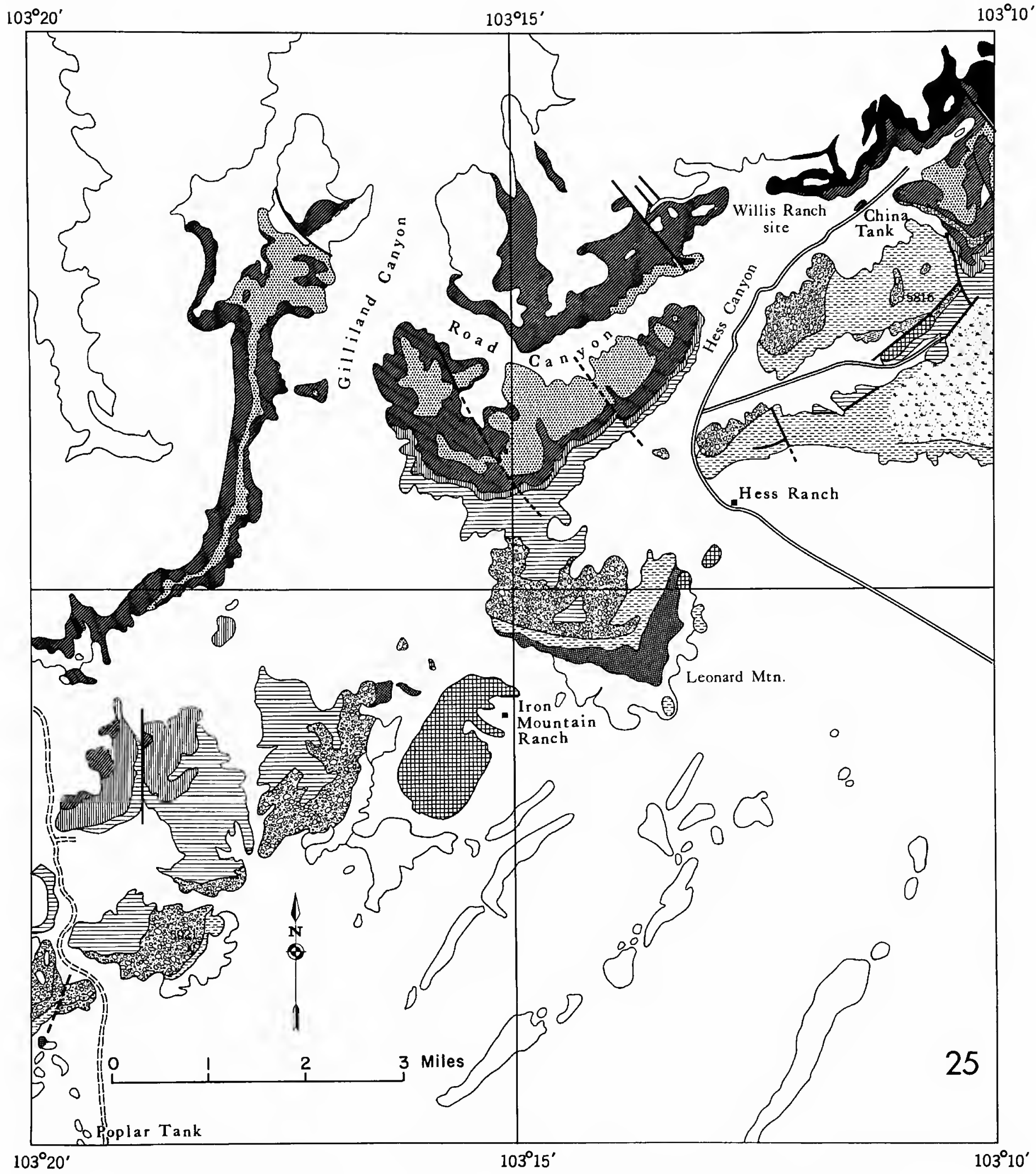

Figures 23-25.-Revised geological maps (after P.B. King): 23, Dugout Mountain area; 24, Lenox Hills; 25, Leonard Mountain. 
one of them Scacchinella is a conspicuous form, specifically diagnostic of that level. In the aggregate the genus thus becomes, in the Permian, an excellent guide to the Wolfcampian as defined in this monograph.

Orthotichia: This is not a conspicuous fossil, but it is easily recognized by its two finely costellate valves and uniplicate anterior commissure. Its range is that of the Wolfcamp, as defined herein, from the Uddenites-bearing Shale Member of the Gaptank Formation through the Skinner Ranch Formation.

Antronaria: A new genus to be described in a subsequent volume, these large rhynchonellids with their depressed costa or costae in the fold are recognized easily and are characteristic of the Skinner Ranch, beginning in the Decie Ranch Member and occurring through the Sullivan Peak Member and in the Taylor Ranch Member of the Hess Formation. A slight spillover into the Cathedral Mountain Formation occurs, but the genus is too rare there to lessen its value as a guide fossil to the Skinner Ranch Formation.

Teguliferina: Although this is a very distinctive fossil, it does not have a clean-cut range. It appears in the Pennsylvanian, but it flourished in the Wolfcamp and extended into the lower part (Decie Ranch equivalent) and Poplar Tank Member of the Skinner Ranch Formation. It is rare in the upper part of the Skinner Ranch Formation and the Taylor Ranch Member of the Hess Formation. The Wolfcampian is thus well provided with genera that are characteristic of all or parts of it.

Institella: This well-sculptured aulostegid, with its leptaenoid form, is one of the most easily recognized fossils in the Glass Mountains. It appears in abundance from the Dugout Mountain area to the Split Tank region. One interruption occurs in this wide lateral range in the vicinity of hill 5021 west to approximately hill 5300 in the Lenox Hills. It is the best indicator of the base of the Cathedral Mountain Formation, but these honors are shared almost equally by the little aulostegid Agelesia, whose size makes it a more difficult fossil to find.

Hercosia: This distinctive richthofeniid with its knife-blade median septum is recognized easily and is about the best guide fossil to the Cathedral Mountain, as it appears first in the Wedin Member in the western part of the mountains and in the base of the Cathedral Mountain Formation at the east end. Combined with Hercosestria, it becomes a guide to the Leonardian.

Hercosestria: This richthofeniid has the same interior as Hercosia, but the cone is covered by a network, the coscinidium. Hercosestria occurs in the lower part of the Cathedral Mountain Formation (USNM $721 \mathrm{u}$ ), but it is very rare there and elsewhere at this level. It is abundant in the Road Canyon Formation, where some bioherms are almost completely made up of the genus. Taken with Hercosia, which is common in the Cathedral Mountain Formation, the two genera combine to define the Leonardian.

Rugatia: This is a very easily identified productid of fairly large size, but it is restricted to the Cathedral Mountain and Road Canyon Formations. It is uncommon in the lower part of the Cathedral Mountain, is fairly frequent in the upper part, but rather rare in the Road Canyon. It is, nevertheless, a good guide to the Leonard rocks.

Peniculauris: The large size and general resemblance to Reticulatia or Dictyoclostus make Peniculauris an easy brachiopod to identify. It appears in the lower part of the Skinner Ranch (Decie Ranch Member), but it is rare throughout the Skinner Ranch. It is abundant in the Taylor Ranch Member and is rare to fairly common throughout the Cathedral Mountain. It is rare in the Road Canyon, where it reaches a very large size. The genus is thus a guide to the late Wolfcampian (as defined herein) and the Leonardian.

Liosotella-Paucispinifera: These two, which are similar internally but differ chiefly in degree of ornamentation, are highly characteristic of the Word Formation from the China Tank through the Appel Ranch Members. Their value is somewhat marred by the fact that both of them appear first in the Road Canyon Formation.

Yakovlevia: This genus has the same range as the previous two and is equally valuable. Its four major spines, two on the ears and two at the place of geniculation, are unmistakable.

Spiriferella: This easy-to-recognize spiriferid is common in the Willis Ranch Member of the Word Formation, less so in the China Tank and Appel Ranch Members. The genus is not an ideal guide fossil because it appears first in the top of the Road Canyon Formation. It is, however, extremely 
rare there and is not likely to be found except by intensive collecting.

\section{Facies in the Glass Mountains}

The Glass Mountains section of the Permian has long been a classic one in which to study facies. Although the types of rocks in the section are many, the column is predominantly one of coarse clastics with the fine-grained rocks generally in the minority. Facies may be indicators of environment, especially when the lithic characters and fossil contents are taken together. The oscillating environments indicate movements of land or sea, or changes in climate that affected the kind and amount of sediment delivered to the site of deposition. The Glass Mountains section may be generalized as a largely clastic sequence, with coarse sediments (Wolfcamp and Leonard) in the lower two-thirds and with the upper one-third consisting of finer grained sediments.

Limitations of THE Discussion.-This discussion of facies is not bolstered by detailed petrological analyses of the sediments, which are beyond the scope of this study and the capabilities of the writers. It is believed, however, that a general discussion of the facies, with an effort to record the fossil occurrences in relation to the sediments, will be of value to our consideration of the paleoecology of the region and will also be of value to sedimentationists who may try to read the story of the rocks without considering the fossils.

Conglomerates.-These are very conspicuous in the lower parts of the section, but they are rare or absent from the Word Formation. They are thick and common in the Wolfcampian but thinner in the Leonardian, although occurring in all parts of the section. The conglomerates may be divided crudely into those composed of transported material and those thought to be essentially residual.

The most conspicuous conglomerate made up of transported cobbles is that of the Lenox Hills Formation from Dugout Mountain eastward to hill 5280, where it thins to disappearance on the west flank of the Hovey anticline. The same type of conglomerate appears on the east side of this anticline, but it is never so thick as on the west and is discontinuous in its occurrence. It attains a thickness of 300-400 feet in its western range, where it forms most of the Lenox Hills Formation. At its base it interfingers with limestone and bioherms containing the fauna of beds 12-14 (of P. B. King) of the Neal Ranch Formation. It thus represents an uplift that started late in Neal Ranch time and continued nearly to the end of Lenox Hills time. The rock is composed mostly of rounded limestone cobbles up to several inches in long diameter and of some angular cherty fragments believed to have been derived from the Marathon Basin. Fossils are rare or absent in this conglomerate except in the bioherms and thin clastic aprons at the base.

A 40-foot thick conglomerate, without such large cobbles but with chert and quartz pebbles and some coarse sand, appears in the upper part of the Cathedral Mountain Formation. This occurs near the site of the Old Payne Ranch, where it appears at the base of the $\mathrm{C}$ Member of Ross. A thinner band of conglomerate, with cobbles up to 3 inches in long dimension, and considerable coarse sand appears near the top of the Cathedral Mountain Formation in hill 4861 on the Monument Spring quadrangle. It is especially mentioned for the occurrence in it of pockets made up almost wholly of large shells of the ammonite Perrinites. This conglomerate can be traced for several miles along the front of the Del Norte Mountains. It is noteworthy for the abundance of ammonites and other Leonardian fossils (Plate 13: figures 1, 2).

Another type of conglomerate probably should be called a limestone conglomerate or conglomeratic limestone. This has a fine-grained limestone matrix enclosing small pebbles, ragged chert debris, and a variety of small fossils ranging from small foram. inifers to sponges and ammonites. This type of conglomeratic limestone is often the most favorable lithology in which to find ammonites. Examples in the Wolfcampian may be seen at USNM $707 \mathrm{j}$ and 715, in the various limestones of the Dugout Mountain Member of the Skinner Ranch Formation, and in some limestones of the Third and Fourth Limestone Members of the former Leonard.

Many beds of conglomeratic limestone occur in the Poplar Tank Member of the Skinner Ranch Formation. In some places the beds are fairly thick. A thick conglomerate occurs at the base of the Third Limestone of the Leonard of P. B. King in knob 5250, just west of hill 5300. The conglom- 


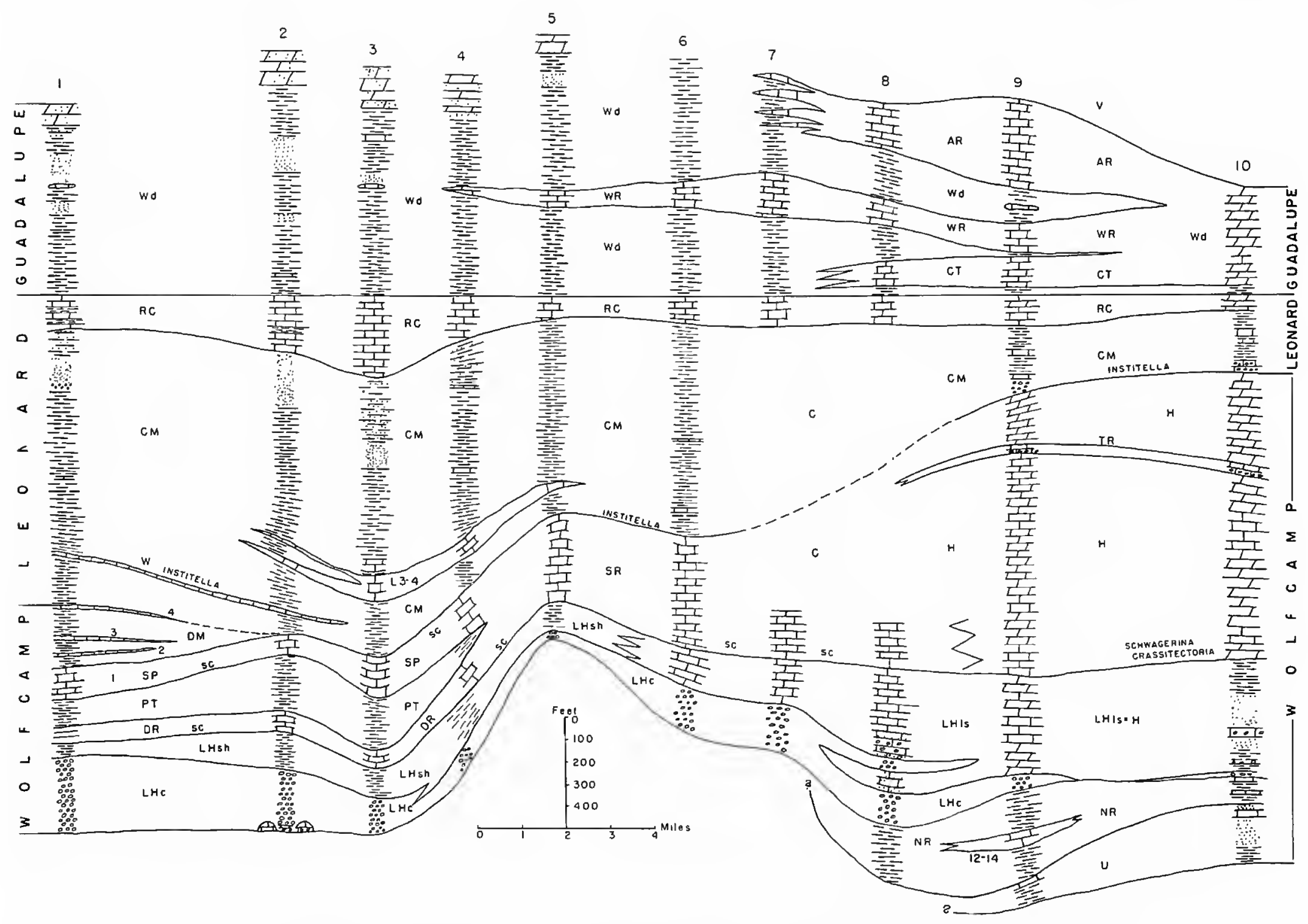

Figure 26.-Diagram for the Permian of the Glass Mountains, showing shift from predomi. nantly silicious facies in the west to carbonate facies in the east. Sections: (1) Dugout Mountain along the line of P. B. King's (1931:32, 132) section 7: (2) starting in the middle of the Lenox Hills and following the line of P. B. King's (1931:32, 135) section 11; (3) just west of Sullivan (Yates) Ranch road and essentially following P. B. King's (1931:32, 135, 136) section 12; (4) through hill 5021 (Decie Brothers Hill) on line of P. B. King's $(1931: 32,136)$ section 14; (5) through hill 5280 approximately along the line of P. B. King's $(1931: 32,137)$ section 15; (6) through Leonard Mountain and hills to the north along the line of P. B. King's (1931: 32, 139) section 17; (7) in vicinity of Hess Ranch house and hills to northwest; (8) through Hess Ranch Horst (Word Formation projected from east); (9) through the Wolf Camp Hills essentially along the line of P. B. King's (1931:32, 143) section 24; (10) on Conoly Brooks Ranch along the line of P. B. King's (1931:32, 145) section 27; thicknesses are approximate, some from King's sections, some original (AR = Appel Ranch Member of Word Formation, $\mathrm{C}=$ covered, $\mathrm{CM}=$ Cathedral Mountain Formation, $\mathrm{CT}=$ China Tank Member of Word Formation, DM=Dugout Mountain Member of Skinner Ranch Formation, DR=Decie Ranch Member of Skinner Ranch Formation, $\mathrm{H}=$ Hess Formation, L 3-4=Third and Fourth Limestone Members of the Leonard of P. B. King, LHc=conglomerate of Lenox Hills Formation, LHls=limestone of Lenox Hills Formation, LHls $=\mathrm{H}=$ Hess Formation equivalent of Lenox Hills Formation, LHsh=shale of Lenox Hills Formation, NR=Neal Ranch Formation, PT = Poplar Tank Member of Skinner Ranch Formation, RC=Road Canyon Formation, sc $=$ Scacchinella, SP $=$ Sullivan Peak Member of Skinner Ranch Formation, SR=Skinner Ranch Formation, $\mathrm{TR}=$ Taylor Ranch Member of Hess Formation, U=Uddenites-bearing Shale Member of Gaptank Formation, W=Wedin Member of Cathedral Mountain Formation, Wd $=$ Word Formation, WR $=$ Willis Ranch Member of Word Formation; in section 1 numbers $1-5=$ limestone members of Leonard Formation of P. B. King, in section 9 numbers 12-14=beds 12-14 of P. B. King in Neal Ranch Formation [=beds 9-12 of Cooper]; see text Figure 5). 
erate referred to above and most of those in the western part of the Glass Mountains often are composed of rounded limestone cobbles. An important conglomerate made up largely of small quartz pebbles, however, occurs at the base of the Cathedral Mountain Formation in the vicinity of Split Tank and extends as far west as the faulted blocks of the Skinner Ranch-Cathedral Mountain Formations on the south side of the Hess Ranch Horst.

The ammonite-bearing conglomerates and conglomeratic limestones often contain numerous other fossils, but they are generally in a poor state of preservation. Those in the Dugout Mountain Member are usually broken and fragmentary, making efforts to obtain a fauna either by breaking rock or by dissolving it rather a frustrating experience. Some fragments such as those of Torynechus can be recognized, but most of the debris is a loss.

In summary, it may be said that the fossils of the conglomerates are transported material, often fragmented, but, in the case of buoyant ammonites, frequently in very good preservation. All of the fossils probably represent transports from other environments except the examples that are found in bioherms in the conglomerates such as those at USNM 715b.

By residual conglomerates we mean the beds of boulders with little transported material that surround some of the bioherms, especially those at the west end of the Lenox Hills. The boulders around or between the bioherms in that location often attain a length in one dimension of 4 or 5 feet. The boulders are ragged, helter skelter, but appear to be derived from the bioherms. All of the fossils seen in the boulders at the west end of the Lenox Hills contained Permian fossils. We did not see any boulders in which we recognized exotic species. Indeed, one boulder only a short distance from the side of a bioherm (hill 4801) abounded in Scacchinella of the same type common in the Sullivan Peak Member (Plate II: figures 1, 4).

It has been suggested that this material and the large bioherms represent reef slide. A similar occurrence in the Chinati Mountains was so interpreted by Rigby (1958:308) (Plate 23: figure 3). We believe that this is not reef slide in the Glass Mountains or in the Chinatis because the large biohermal masses are conglomerate based, and, in one instance, part of the bioherm has grown over the conglomerate (see discussion under "Bioherms"; Plate 18: figure 3).

SANDSTONEs.-Lenses of quartz sand appear in places in the Skinner Ranch Formation. These form part of Member C of the Leonard of Ross. In the upper part of the Word Formation, below Sullivan Peak and near the site of the Old Payne Ranch house, thick layers of sandstone occur. These sands, like the conglomerates, represent near-shore conditions in shallow, probably strongly moving, waters. Fossils are almost unknown in these sandstones, although a few Word species were taken from the long dip slope of the sandstone hogback west of the old Payne Ranch site (hill 4806). As explained under the heading of "Bioherms," a single anomalous example was found in a sandstone mass south of Sullivan Peak (USNM 727x). Sole-marked sandstones occur in the Lower Cathedral Mountain Formation at USNM 723y. The sands are not an important factor in the preservation of fossils in the Glass Mountains.

Sands are commonest in the western part of the Glass Mountains and indicate an approach to the source of the sediments. In the limestone members of the Word Formation, sand forms an important part of the rock. This is exhibited especially by the Willis Ranch Member. This member contains an increasing amount of sand to the west, as shown in Gilliland Canyon, where the limestones contain stringers of sand (Plate 14: figure 3), and, with the increase in sand, there is a diminution of layers of fossils. Farther west of Gilliland Canyon, the sand becomes more and more abundant.

Although quartz sands are the most familiar type of sandstone, they are much less developed in the Glass Mountains, than are the lime sands, calcarenites, or calciruclites. The former range from finegrained to coarse-grained and are common in all parts of the section, but they are particularly conspicuous in the Skinner Ranch Formation, where they probably represent a former sand bar. As noted in the stratigraphic section, the Decie Ranch and Sullivan Peak Members pinch out the predominantly shaly Poplar Tank Member to form the Skinner Ranch Formation undivided. This consists largely of calcarenite that forms a barrier interfingering on the east with the fine calcarenites, oolites, and other lagoonal types of limestone of 
the Hess Formation but sending its Decie Ranch and Sullivan Peak tongues to the west.

The aprons of clastic material, mostly broken shells and crinoid debris surrounding the bioherms, are other examples of lime sand. These occur in the lower part of the Skinner Ranch Formation at USNM 705a and 720e. Coarse lime sands or calcirudites are common in the Road Canyon Formation but less so in the Word Formation.

A bioclastic sand facies of considerable interest is that of the fusulinid sands or fine gravels that are common in the Road Canyon in the Monument Spring quadrangle. Here, as at USNM $732 \mathrm{j}$ and $736 x$, beds of limestone $1-3$ feet thick are composed almost wholly of fusulinid shells. These represent lag deposits in which the finer material has been winnowed out and the heavier and coarser debris left behind. These beds are common in the Road Canyon Formation from Sullivan Peak westward, the part of the region where the Road Canyon begins to fray out in the thickening Leonard yellow shales. How many living brachiopods existed in these bioclastics is a question. Most of the specimens dissolved from them are worn, broken, or single valves. Good specimens are uncommon, but some of them survived the obviously rough conditions that existed at the time.

SHALE.-For convenience of discussion, the shales are divided into the blue to blue-black shales and the yellow shales, the latter characterizing parts of the Leonard and Word columns.

The Neal Ranch Formation and the upper part of the Lenox Hills Formation contain thick sequences of bluish shale. In the Neal Ranch Formation shale is predominant and separates thin layers of limestone and some limestones near the middle of the section that swell into bioherms. The lower shale of the Neal Ranch below bed 12 of King (= bed 9 of Cooper) is blue-black and contains few fossils; those that it does contain are predominantly Pennsylvanian types. The same may be said of the shale of the Uddenites-bearing Shale Member. It is the biohermal beds that contain the Permian types in both sequences. The upper shale of the Lenox Hills Formation in the Lenox Hills, which disappears eastward, is bluish-gray in color, and the megafossils it contains are generally Pennsylvanian types or like those of the $U$ ddenites-bearing Shale Member. The fusulinids, however, betray their Permian affinities. This shale also appears on Dugout Mountain.

Blue shale as exposed at Clay Slide forms a substantial part of the upper Cathedral Mountain Formation. The shale is rather sparsely fossiliferous, but fine specimens of Perrinites and Peniculauris are washed out of it (Plate 7: figure 2).

A shale unique in the area is that which comprises the bulk of the Poplar Tank Member of the Skinner Ranch Formation. It is dull brown, blocky, and breaks into angular pieces. It contains few fossils, but the thin conglomeratic limestones enclosed by it are usually fossiliferous, although the preservation is not good. The somewhat chocolate color of the Poplar Tank shale is in marked contrast to the yellow- to orange-weathering shale of the Cathedral Mountain Formation.

The Cathedral Mountain Formation is essentially a wedge of yellow shale interfingering to the east with carbonate biohermal tongues at the thinning end of the wedge in the eastern part of the mountains. The shale is largely siliceous (radiolarian and spicule-bearing), breaking into ragged plates, some of which may be discolored pink or red in rings, the weathering following the outline of the plate. Blocky chert that contains radiolaria and sponge spicules is often present. Higher in the section, above the Wedin Member, the shale is less strongly colored and is mainly dull yellowish. These shales thicken westward and also may be seen as tongues in the Road Canyon Formation and as separators of the bioclastic beds in the Del Norte Mountains. Similar shale also separates the limestone members of the Word Formation. We have not seen macrofossils in the Cathedral Mountain and Road Canyon shales but the Word yellow shales contain rare specimens of Crurithyris and Leiorhynchoidea. These shales probably indicate quieter water deposition away from the shore, in bays, or the result of moderate depression of the shelf.

Carbonate Facies.-The carbonates consist of dolomites and limestones, the former eractic in occurrence and of two kinds, the latter more concentrated and with a variety of types

Dolomite: The dolomites may be divided into two kinds: bedded dolomites and massive, unbedded dolomites. The former type appears in the Hess Formation, where thin layers are often bedded 
with thin layers of limestone. The Hess also contains thick layers of dolomite that often have a considerable lateral extent. Alteration of the original limestone in some of the beds has left a porous rock, the holes of which represent fusulinids that must have occurred in countless numbers.

The massive type of dolomite appears to have been formed subsequent to lithification and may have been induced by the intrusives that appear in places in the mountains. Leonard Mountain and the hill north of the Hess Ranch house are areas of considerable dolomitization, although the dolomite is patchy (Plate 8: figure 2). One can walk from dolomite into limestone, straddle the boundary, and see the alteration of the fossils from one lithology to the other. Perhaps the best example of this type of dolomite is the large mass on the southeast side of Leonard Mountain, where the thick dolomite has been mistaken for a reef. We have walked two levels, one high in the Lenox Hills, the other low in the Skinner Ranch, into this large mass. The presence in it of a large Omphalotrochus is evidence of Skinner Ranch affinities.

Most of the hill on the north side of the Hess Ranch house is composed of dolomite but upper Lenox Hills Formation and lower Skinner Ranch Formation can be identified in undolomitized patches. The incompleteness of the dolomitization makes possible identification of the various levels, because good fossils may be obtained in them. Fossils can often be seen in the dolomite but, as a rule, they are unidentifiable ghosts. Incomplete dolomitization can be encountered in parts of the Skinner Ranch Formation as on the knob 0.8 mile northwest of the Hess Ranch house. The limestone of the Dugout Mountain Member of the Skinner Ranch Formation is dolomitized incompletely on the prominent knob (USNM 700r) about a half mile northwest of Dugout Mountain.

Limestone: Perhaps the commonest type of limestone facies in the Glass Mountains was referred to under the heading of lime sands. These coarsely clastic limestones are most common in the lower two-thirds of the section, but two conspicuous areas of calcilutites occur in the Road Canyon Formation. These are the dark, nearly black, limestones that commonly are regarded as basinal in deposition and probably indicate fairly deep water. One area occurs on the north side of the Old Word Ranch site, and the other forms the long spur extending southward from Sullivan Peak.

The locality near the Old Word Ranch is about 60 leet of thin-bedded, platy, bituminous limestone, black when fractured, but weathering to light gray. Fossils are fairly common in patches and.in thin beds, but some of the layers are devoid of life remains. These thin beds rest on biohermal limestones at the base of the Road Canyon Formation.

The occurrence at Sullivan Peak (USNM 707e) rests on biohermal lower Road Canyon, and the bituminous platy limestone fills depressions in the biohermal beds. The black limestone is more than 300 feet thick. In parts of the section it is without fossils, but in the upper part fossils are very common and varied. The presence of abundant fossils suggests that this is not a deep water deposit, but probably it is a bay of quiet water on the old shelf.

The thin-bedded limestone of the Hess Formation, often interbedded with thin layers of dolomite, has been interpreted as a lagoonal facies. That it is unlike any other limestone in the Glass Mountains is clear. The rock is often a fine-grained calcarenite, oolite, or pellet limestone. It is light colored, and some layers, especially near the top, contain fusulinids coated with layered limestone, suggesting algal deposition.

Two other facies of the limestones need mention: the bioherms and the shell heaps. Both require more extended discussion than the preceding facies because a large share of the collections were taken from them.

\section{Organic Accumulations in the Glass Mountains}

\section{BIOHERMS}

Mound-shaped structures containing numerous fossils are abundant in many of the stratigraphic units in the Glass Mountains below the level of the Word Formation. They range in size from a few inches high and a foot or two across to more than 80 feet high and 100-200 feet across. Some of these in the small and middle size ranges are "currentdeposited" heaps of shells, which are characterized by stratification and well-packed shells and other organic debris that show some signs of abrasion. Others of all sizes have some parts bound together in interlocking frameworks of skeletal organisms 
that almost certainly were self-supporting during their lifetimes. We use the term "bioherm" for the mound-shaped structures with coherent organic framework, rather than employ the ambiguous and perhaps inappropriate term "reef." This distinction follows the recommendation of Cloud (1952) that the term "reef" be used for relatively large organic buildups that headed near the surf zone and were wave resistant and the term "bioherm" for "reef-like organic masses of uncertain, potential, or doubtfully wave-resistant nature."

Cumings (1932) proposed the term "biostrome" for bedded shell heaps, crinoid accumulations, or coral growths that did not produce mounds; this term is not properly applicable to certain bedded structures common in the Glass Mountains. These appear to be ordinary stratified beds, bounded top and bottom by bedding surfaces, but close inspection or leaching in acid shows them to be organically interlocking frameworks with interstitial micritic calcite, directly analogous to bioherms except that they failed to produce the mound shape. These are perhaps incipient bioherms that were inhibited by early burial or an unfavorable situation. They may coincide with the reefoid facies of Bain (1967), but, because they are prevalent in the Glass Mountains, we are using the name "zotikepium" from the Greek "zotikos" (= lively or vigorous) and "kepion" (= garden), in allusion to the lush garden-like nature of the bryozoan and sponge growths that form large parts of the structures. Both biohermal and zotikepial structures are common in the Glass Mountains in all of the formations and members, from the $U d$. denites-bearing Shale Member of the Gaptank Formation through the Road Canyon Formation. The Word Formation has none of these structures. This discussion does not take into account the Guadalupian formations above the Word, which are mostly dolomitized and not sufficiently studied to individualize important organic structures, except for the gross form of the Capitan "reef."

Difficulties in the Study.-The chief problem in the study of these complex but interesting structures is the fact that they are seldom seen completely or in three dimensions. Cross-sections are common; partly exhumed bioherms revealing their tops also occur frequently, but the bases seldom show. Many bioherms occur as bevelled mounds with some part cut away, either horizontally, vertically, or obliquely, to show the interior.

Fortunately, many of the bioherms of the Glass Mountains contain fine silicified fossils that reveal the framework of the structure in detail. Localities such as USNM 702un, 714w, 719x, 726o, and others yield large blocks, which, when decalcified, show their structure to be mainly a mass of bryozoans, sponges, or, more rarely, brachiopods.

Bioherms range in size from a few feet in height to about $80 \mathrm{feet}$, which is the thickest we have seen, with no obvious pattern. Generally, however, the largest ones are in the Sullivan Peak Member of the Skinner Ranch Formation and in the Road Canyon Formation.

Little has been published about the bioherms of the Glass Mountains. The King brothers did not discuss them, although P. B. King (1932) interpreted the dolomite mass on Leonard Mountain as a reef. The only serious studies, so far, of the bioherms are by Grant (1971), who analyzed their brachiopod faunas, and Bain (1967), who made a detailed investigation of the Cathedral Mountain bioherms in the vicinity of Split Tank (Hess Canyon quadrangle). Bain recognized a reef core with flanking beds of debris, the classic picture of the bioherm of the Paleozoic. He also recognized four other facies connected with the bioherm not hitherto described. In discussing bioherms here, we will consider them according to their stratigraphic sequence.

Pennsylvanian.-One area of bioherms appears in the Pennsylvanian of the Marathon Basin south of the Arnold Ranch. This bioherm is located just 1.25 miles south of the Arnold Ranch, Monument Spring quadrangle (Plate 16: figure 1). It is a low, rounded mass of hard, dark gray limestone about 15 feet long and 2-3 feet high, although its base is not exposed. The limestone contains an abundance of the fasciculate coral Amplexocarinia delicata Ross and Ross (1963b) and considerable laminated limestone of possible algal origin. The lreshness of the rock prevents collecting good fossils; nevertheless, among others, a primitive species of Scacchinella and a Limbella were obtained. The bioherm is lodged in Gaptank Shale, dated by P. B. King (1938) as equivalent to his bed 10 of the type Gaptank sequence. One fusulinid, found after 
exhaustive search in the bioherm, was declared by Garner Wilde (letter of 20 March 1962) to be Virgilian in age, which disagrees with King's assignment of bed 10 of the Gaptank to the Canyon in the Texan nomenclature (i.e., Upper Missourian).

This bioherm is anomalous because of the Permian-type fossils it contains. It occurs in a complexly folded and faulted orogenic belt and might be an exotic block. If so, its place of origin is unknown, because nowhere in the Gaptank Formation or the Lower Permian is a fauna like it known. In spite of these difficulties, it is composed of reef-core rock and has the characteristic form of a bioherm.

WolfCAmp SERIEs.-Bioherms are abundant in the lower Wolfcamp formations, but infrequent higher up. They are a problem in stratigraphy, because they abruptly swell the thin limestone beds and make measurements difficult on poorly exposed slopes or in ravines. One of the astonishing characteristics of these bioherms is their variety of faunal composition; no two have the same fauna ever though they may be in fairly close proximity. It is not possible to discuss all of the bioherms studied and collected in the Uddenites-bearing shale member and the Neal Ranch Formation; a few in different parts of the formation will serve as examples.

Neal Ranch Formation: This formation is about 500 feet thick and consists of a matrix of dark shale enclosing many lenses and layers of limestone. The thickest layer of limestone is bed 2 of P. B. King, otherwise known as the Gray Limestone, occurring at the base of the section. This is a great lenticular mass of calcarenite having a maximum thickness of nearly a hundred feet and a lateral extent of slightly more than a mile. It is thickest near its middle, capping the cuesta called hill 5060, and is the most prominent ledge of the Wolf Camp Hills. It tapers laterally to a few feet at the west end, but it is fairly thick (135 feet) where last seen on the east. This large lens might be interpreted as a bioherm or as a lime sand bank, but it has never been studied in detail; consequently, its composition is not known. Some brecciation occurs on the west side of the main mass. We found no silicification in the main mass of this lens, where it is thickest, but we found bio- herms in its north flank. Two bioherms of local importance occur on the long northward dipping slope, just before the lens plunges below the surface. The first is small (USNM 722x), only a few feet in lateral extent, and now mainly a remnant, weathered and rotted. It is composed mainly of a new species of Eolyttonia. Most of the brachiopods are surrounded by laminated limestone of undoubted algal origin, which welds the mass together. This bioherm certainly was larger originally. It is most important because it establishes the presence of Eolyttonia, a Permian genus, in the Gray Limestone of P. B. King, which Ross (1963a: 45) places in the Pennsylvanian (Virgilian).

The second bioherm in the Gray Limestone of P. B. King occurs in the bed of Geologists Canyon at its junction with a gully from the north, at approximately the point where the 4650 -foot contour (Hess Canyon quadrangle) crosses the main canyon floor (USNM 701). This structure can be seen only in plan, but it consists of a matted mass of bryozoans, sponges, and algal material containing an unusual assemblage of brachiopods (Hypopsia, Schuchertella, Eolyttonia, Tropidelasma). The brachiopods do not make up much of the mass of the bioherm, which is largely constructed of bryozoans.

Perhaps the most nearly ideal bioherm in the Neal Ranch Formation is that at USNM 701c (Plate 16: figure 3), which forms the top of the knob represented by the easternmost ring that is formed by the 4900 -foot contour in the hill just northwest of the "W" in "Wolf Camp Hills" (Hess Canyon quadrangle, edition of 1923, reprinted in 1946; prior editions of this quadrangle do not bear the name "Wolf Camp Hills"). This bioherm is a rounded mass about 20 feet thick which consists of amorphous unbedded micritic limestone strongly contrasting with the relatively thin-bedded calcarenites in which it is embedded. It rests on a 2-3 foot thick bed of limestone cobbles welded together by shale. The rock appears to be finegrained, but, when leached by acid, it shows a framework of sponges, bryozoans, and fine siliceous granular material and bioclastic debris. The remarkable feature of this bioherm is the amazing large specimens of Eolyttonia, nearly as large as a tea-cup saucer (Plate 157: figures 1, 2). Numerous other types of brachiopods are fairly common also. 
The fauna of this bioherm is in marked contrast to that forming the twin knob of this hill about 0.25 mile southwest of USNM 701c.

The bioherm on the second knob (USNM 70lh) is small and seen only in horizontal section. It was an irregular patch with height of two or three feet above the enclosing rock. Decalcified blocks of this limestone proved to be a welded mass of brachiopods, chiefly the genera Geyerella, Meekella, and Limbella, with abundant sponges and bryozoans. The rock appears to have no grain and, therefore, stands in strong contrast to the surrounding bioclastic calcarenite. In spite of the grainless appearance, it has fragments of echinoderms, small foraminifera, and some lumps of bedded limestone of possible algal origin. Decalcification revealed a variety of brachiopods other than the frame builders, especially a huge new species of Parenteletes with a full range of growth stages, from the earliest shell to large adults three inches in width. Although this bioherm is only 0.25 mile away from the one at USNM 701c, the two faunas are utterly unlike (Plate 11: figure 3).

At the same stratigraphic level, another bioherm about 0.25 mile to the northwest (USNM 70lk) produced an entirely different fauna in which Enteletes is abundant. This genus showed preference for bryozoan gardens. Some of the Wedin Member structures contained an abundance of this genus.

Although the thin limestones above bed 14 of P. B. King swell from biohermal development, we found none that contained silicified fossils. Bioherms are not common in the overlying Lenox Hills Formation, but a fair development was discovered at the west end of the Lenox Hills.

Lenox Hills Formation: No bioherms were seen in the Lenox Hills Formation between the Wolf Camp Hills and the Lenox Hills. These structures appear at the west end of the Lenox Hills westward from about hill 4902. At USNM 715b (Plate 12: figure 2) numerous bioherms occur at the base of the section, enclosed in coarse calcarenite and conglomerate. These are the beds that Ross (1963a: 24) identified as Neal Ranch Formation and claimed were in unconformable contact with the Lenox Hills conglomerate. The angularity is undoubtedly due to the irregular bedding usually associated with bioherms. But we found, near the base of the biohermal beds, interfingering layers of conglomerate that suggest the bioherms belong to the Lenox Hills Formation. At USNM 707j a few small bioherms occur 25 feet up in the conglomerate, and there is no question about their belonging to the Lenox Hills Formation. The fossils of the bioherms at USNM $707 \mathrm{j}$ and $715 \mathrm{~b}$ are clearly of Neal Ranch (beds 12-14) affinity, but the stratigraphic setting indicates that they were contemporary with the initial phases of Lenox Hills deposition. They have a rich brachiopod fauna with some Bivalvia and ammonites. No bioherms were seen in the Lenox Hills Formation of the Dugout Mountain area.

A unique bioherm in the Lenox Hills Formation is that on the southeastern nose of Leonard Mountain, just above the Lenox Hills conglomerate (USNM 705k; Plate 20: figure 2). This is a small mass, short in lateral extent but about 20 feet thick, containing Tropidelasma and a small Scacchinella as its most abundant constituents. Heliospongia and Parenteletes are also present. The rock is brownish gray with orange-brown, earthy patches. The bioherm is surrounded by fusulinid-bearing limestone conglomerate with shale matrix, the common base on which Wolfcampian bioherms rest.

Around the base of Leonard Mountain are large slipped (toreva) blocks of Lenox Hills limestone, often containing bioherms. One of these, USNM $705 \mathrm{~m}$, contains Scacchinella and Parenteletes. Although only one Scacchinella bioherm was seen in place, that in the detached block indicates that they were scattered about in the Lenox Hills limestone above the conglomerate in Leonard Mountain.

To summarize, two kinds of bioherms characterize the Wolfcampian: one is the classic, moundlike patch reef originating on a limestone gravel but building a solid mass of cementing organisms surrounded by debris from the bioherm; the second is rather formless, often in relatively thin beds representing patches or gardens of bryozoans, sponges, algae, and combinations that include accessory niche dwellers. The apparently amorphous, smooth-appearing limestone is fine calcareous debris that is sifted by precipitation in the quiet waters which occupy the spaces between the shells and the animal colonies that are formed by the life 
process of the animals. Lithically, this forms a micritic matrix for the numerous skeletons. These are the zotikepia defined earlier; USNM $721 \mathrm{~g}$ is an excellent example. These bioherms and zotikepia evidently existed in well-aeriated and agitated waters, but the bulk of the reefy bodies and the niches within them furnished quiet places where brachiopods could flourish.

Skinner Ranch Formation: Some of the largest and most interesting of the bioherms are those of the Skinner Ranch Formation. More of the classic, mound-like masses are present, but so is the horizontal type.

1. Decie Ranch Member. This member in its extent from hill 5021 to its last appearance on Dugout Mountain has no well-formed mound-like masses. The member is composed mainly of conglomerates, often with large boulders, but within these conglomerates are patches of Scacchinella with other rugged; cemented-reef types of brachiopods. Scacchinella clusters often occur with accumulations of huge crinoid stems, the latter often more than two inches in diameter, and so large and numerous that they make up local gravel patches. The Scacchinella community flourished on this gravel and developed into clusters or patch reefs. The rock in places is a mass of Scacchinella and, when rotted, is spongy and crumbly from the vesicular character of the large conical pedicle valves. Collecting from weathered masses seldom yields a good specimen, but, contrariwise, it is almost impossible to get good specimens from fresh rock. Scacchinella bioherms are difficult to locate, but the basal crinoid accumulations are often a clue to them. Because very little silicification has taken place in the Decie Ranch Member, the individual Scacchinella does not stand out conspicuously in these bioherms as it does in those of the basal Skinner Ranch Formation east of Leonard Mountain, north of the Hess Ranch, and on the north slope of the Hess Ranch Horst. The Decie Ranch Member occurrences suggest a rocky near-shore area, with communities of robust Scacchinella that are intimately grown with bryozoans (especially Meekoporella), which are scattered among boulders in shallow, perhaps turbulent water.

2. Poplar Tank Member. One bioherm that was studied and collected occurs in this member (USNM 708e; Plate 21: figure 2). This bioherm is
15-20 feet thick and about 60 feet laterally, underlain by and surrounded by limestone conglomerate. The rock is dark bluish gray, but it weathers to a light gray. Of fine-grained appearance, it contains considerable coarse debris. This bioherm is not silicified. It is characterized by abundant small productids (Oncosarina) and large Antronaria (new genus), along with rare Scacchinella. This seems to be more of an accumulation of biological debris in a conglomerate than a reefy mass. No reef core was seen, but it may not have been exposed (Plate 21: figure 2).

3. Sullivan Peak Member. Bioherms varying in size from small patches to large reef-like structures are fairly common in this member. These can be seen as light-colored, rounded masses weathered into relief on the hillsides. Several appear on the southeast slope of hill 5300 , but the best examples are located in hill 4801 facing U. S. Highway 90 at the very end of the Lenox Hills (Plate 18: figures 1-4). In lateral extent, one of these is among the largest bioherms in the mountains: 110 feet horizontally and 38 feet thick. The wellrounded top has a thin silicious skin. The base is conglomerate to a height of 5 feet, with boulders up to a foot in one dimension, and contains huge crinoid stems (Plate 18: figure 4). Above the crinoid stems the rock becomes fine grained, with numerous silicified bryozoans protruding from the surface. Scacchinella was not seen, but it probably existed in the mass, as it was seen in boulders flanking the bioherm. Another, smaller bioherm occurs west of the large one. The two are separated by a conglomerate 30 feet thick, composed of large boulders, occasional ones having a long diameter of 5 feet. This mass contains Geyerella, a common reef form. Several specimens are visible on the upper surface of this bioherm.

On the west side of the bioherm an extension of its fine-grained limestone overlies the conglomerate (Plate 18: figure 3). This lateral extension of the biohermal rock contains Acritosia and numerous sponges. Fossils contained in the boulders flanking or underlying the bioherm tongue proved to be types common in the bioherms. One block near the margin of the bioherm contains numerous Scacchinella. These fossiliferous pieces indicate that the boulders in the conglomerate were derived from bioherms. 
A short distance west of the large bioherms there occurs a small one, which is located on the bench around hill 4801 formed by the Sullivan Peak Member (Plate 16: figure 2). This small mound, 10 or 12 feet on one diameter and 2 or 3 feet high, protrudes from the conglomerate.

4. Skinner Ranch Formation Undivided. The Decie Ranch and Sullivan Peak Members pinch out the Poplar Tank Member and become a single unit in hill 5021, where the Skinner Ranch Formation becomes undivided. Nevertheless, the lower part of the formation retains many elements that identify it with the Decie Ranch Member. One of these is Scacchinella, which is very abundant and makes small reefs or bioherms almost completely composed of this genus. Three areas for the examination of these bioherms are: (1) the southwest side of Leonard Mountain about one mile north of the Iron Mountain (Skinner) Ranch; (2) one-half mile north of the Hess Ranch house; and (3) the base of the north slope of the Hess Ranch Horst.

(1) Southwest Side of Leonard Mountain. Scacchinella occurs in the lowest beds, where small clusters may be found. On the east side of the ravine near the center of the mountain (Plate 19: figure 1) four characteristic biohermal mounds may be seen. Originally they may have occupied the same level and then been offset by slumping (Plate 19: figure 1).

(2) North of Hess Ranch. Bioherms exposed here (USNM 705a) are all low, not more than two or three feet high. Scacchinella is very abundant, almost to the exclusion of all other fossils. These mounds are surrounded by layers of interbiohermal, bioclastic debris of worn and broken shells and crinoid stems. The Scacchinella are silica-filled, but, nevertheless, they cannot be freed from the limestone in good condition; usually they are recovered as inner fillings. Good free brachial valves are obtained from the interbiohermal beds, where they were washed after being freed from the pedicle valves that were anchored to the reefy mass. This locality is the site of numerous sponges, chiefly Defordia and Heliospongia, that grew about the bioherms. They are found usually in the interbiohermal beds along with a very large species of Omphalotrochus. At this locality the bioherms at the base of the hill are well preserved, but the limestone extending up the hill is usually dolomitized and the fossils destroyed. On the top of the hill overlooking the Hess Ranch house, limey patches in the dolomite contain good fossils and evidence of biohermal structures. The same types of bioherms with Scacchinella and Geyerella may be seen in the "amphitheater" in the north side of Leonard Mountain (Plate 11: figure 2).

(3) North Side of Hess Ranch Horst. This setting is exactly like that north of the Hess Ranch House, but the area of exposure is much larger and the beds are not dolomitized. Laterally the area of bioherms extends from the fault on the east side of the horst to the west end of hill 5305, a distance of about 2 miles and involving about 200 feet of strata. Bioherms occur at several levels and contain different faunas. Some are masses composed almost wholly of Scacchinella in the lower part of the section and may represent reef-cores USNM 720e; Plate 19: figure 4). The silicification like that north of the Hess Ranch is not good, but some silicafilled young individuals are excellent for studies of variation.

Above the Scacchinella bioherms there are others with the mound-like form. Although most are small and low, they have a rich fossil content. The compartmented bryozoan Meekoporella is common and offers niches wherein many of the smaller brachiopods dwelt. In these, Scacchinella is rare or lacking, but enormous specimens of Meekella and Derbyia are attached among the bryozoans; productids are uncommon. Many of these bioherms are surrounded by bioclastic debris of broken and disarticulated shells and layers of fusulinids (including Schwagerina crassitectoria Dunbar and Skinner).

The upper part of the Skinner Ranch Formation is exposed poorly from east of Leonard Mountain to the east sicle of the Hess Ranch Horst. Furthermore, east of Hess Ranch the formation changes facies into that of the Hess Formation.

Hess Formation (Taylor Ranch Member): One large bioherm occurs in the Taylor Ranch Member of the Hess Formation. At USNM 702d several masses of light, yellowish-gray limestone abound in the sponges Heliospongia and Girtyocoelia, together with a variety of other fossils, especially gastropods (Plate 19: figure 1). 
LeONARd SERIEs.-Although Bain (1967:212) reports that "Reef masses range from 20 feet to 125 feet long and up to 100 feet high," most of these structures are much smaller. Many of them do not have the characteristic mound-like form, but they are micritic masses in relatively thin-bedded strata, probably representing local concentrations of organisms, usually bryozoans, alive for a sufficient time to cement the whole with finely sifted calcium carbonate, but with little binding algae. Bioherms occur throughout the Leonardian. They are common, especially the reefoid type of Bain, in the Wedin Member on the north slope of Dugout Mountain and in the west end of the Lenox Hills. They are scattered between Leonard Mountain and hill 5674 to the north. They are also concentrated in the area east and west of Split Tank on the Appel Ranch. Here they have been minutely studied by Bain (1967).

Cathedral Mountain Formation (Wedin Member): These are of the reefoid type described by Bain and are usually composed of a framework of ribbon-like and fenestellid bryozoans. Every nook and cranny in these masses is occupied by cementing productids or other brachiopods: Hercosia, Chonosteges, Institella, and Agelesia. Plump Enteletes and an ocasional lyttoniid are present. Institella is uncommon in the bioherms at USNM $700 \mathrm{x}$ on the north side of Dugout Mountain, but it is abundant at USNM $714 \mathrm{w}$ at the west end of the Lenox Hills, where it and Agelesia make up a substantial amount of the organic mass. We look on these bioherms, which are not rounded mounds, as bryozoan patches resident for sufficient time to build matted masses of dead forms to which surviving generations attached. Finely precipitated calcite (forming micrite), formed by the life process of the animals from lime-saturated waters, sifted into the spaces between the bryozoans, dead and alive, cementing the whole into a solid mass unlike the surrounding sediments. These are the structures to which we apply the name "zotikepium."

Bain (1967) examined the bioherms from Split Tank for about 2000 feet to the east (USNM 702, 702a, 702ent, 702inst, and 702un). He identified six facies types associated with, or comprising, the bioherms. His map and text do not show any definite pattern to the facies. Reef cores usually are surrounded by the reefoid facies, but they may be surrounded by breccia, flank-bank facies (rare), or inter-reef facies. The latter facies is characterized mainly by normal deposition of biomicrite and micrite containing fossils wafted by currents from their moorings. The strata range from a few inches to slightly more than a foot thick. This facies is the widest spread of all.

The bioclastic facies comprises biomicrudite and biomicrite surrounding the bioherms. The map does not show clearly the extent of this facies. It contains many fragmentary fossils such as pieces of fenestellid bryozoans, crinoidal debris, echinoid spines and plates, as well as brachiopods and some molluscs. This facies was seen about the bioherms in the Skinner Ranch Formation north of the Hess Ranch and on the north side of the Hess Ranch Horst.

The molluscan facies is dark gray micrite occurring as lenses. It contains numerous gastropods, pelecypods, and cephalopods, representing a local, quiet water environment in which fine mud collected.

The flank-bank facies refers to concentrations of unbroken fossil material occurring on the margins of the reef cores or as isolated accumulations on bioclastic beds unrelated to reef growth. They may be zotikepia as described above. Concentrations adjacent to reefs are referred to by Bain as "flank deposits," and those unrelated to bioherms are termed "banks." These consist of dark brown to dark gray clastic limestone containing numerous brachiopods, bryozoans, corals, and echinoderms. The interstices between the fossils are filled with micrite. The banks are usually small, but the flank deposits may be large, up to 100 by 50 feet.

The reefoid facies refers to "massive accumulations of limestone which circumscribe reef cores" (Bain, 1967:224). It usually is limited in size, a few feet in diameter, and not well bound. The rock is gray biomicrite and biomicrudite, grading into the bioclastic facies. Skeletal material of brachiopods, bryozoans, sponges, and algae are cemented by fine micrite of physicochemical or biochemical origin, resulting in a fine-grained rock. According to Bain, Prorichthofenia (= Hercosia) is one of the major frame-builders of the reefoid structures and is common in the Split Tank area. He postulates a depth of water not exceeding 60 feet for this facies. 
The reef core facies is composed of light gray, dense, micritic masses ranging up to 125 feet long and 75 feet high. The framebuilding organisms are mainly fenestrate bryozoans and the bryozoanalgal consortium Acanthocladia. Of lesser importance are sponges and fistuliporoid bryozoans. Stromatolitic algae are the principal binding organisms and comprise the dominant portion of reef cores (Bain, 1967:226). Accessory organisms such as brachiopods, rugose corals, and gastropods often are found in the reef core.

We dissolved blocks from the east of Split Tank about 0.25 to 0.5 mile from the bioherms at USNM 702 un and 702inst. These suggest Bain's reefoid or flank-bank facies and are like those of the Wedin Member in their abundance of Institella. These are located between the fine pebble conglomerate and the first silicious shale stratum. They appear to be assigned to the Hess by Bain, but, occurring above the conglomerate and containing Institella, they clearly belong to the Cathedral Mountain, as defined by Cooper and Grant (1966), and above the Hess, by P. B. King's (1931) definition of the Leonard Formation. Probable reefoid facies with abundant Hercosia occurs above the shale at USNM 702ent and 702. Flank-bank or reefoid deposits abounding in the new lyttoniid genus Collemataria (USNM 702al) occur still higher in the section (Plate 20: figure 3). Above this level bioherms do not occur in the Cathedral Mountain Formation in the Split Tank area.

Bioherms are common in the Old Word Ranch area southwest of Appel Ranch house. One of these, close to the site of the Old Word Ranch (USNM 703bs), composed of light gray micrite, abounded in Agelesia, thus relating the lower Cathedral Mountain of this area to the Wedin Member of the extreme western end of the mountains (Plate 20: figure 4).

Still farther southwest, 1 mile below the Old Word Ranch site is USNM 726o (Plate 17: figure 1), one of the finest and most fossiliferous of the bioherms. It is a mass of an undescribed species of the brachiopod Hercosia, with abundant bryozoans, sponges, and some large pelecypods. The matrix is a smooth, medium gray micrite, undoubtedly of biochemical origin. The pelecypods are mostly Pectens, long scabbard-shaped Myalinas, and large spiny Pseudomonotis.
One of the most interesting of the Cathedral Mountain bioherms occurs in the isolated hill about 1.5 miles south of Sullivan Peak (USNM $727 \mathrm{x}$ ). This hill is slightly more than 100 feet high and is capped by 65 feet of fine-grained, brownish, sugary sandstone. In the midst of the sandstone there is a typical small bioherm of greenish- to bluish-gray limestone, about 15 feet wide and 6 feet high, containing Institella. Although we did not see evidence of displacement, this occurrence might be an exotic block, as it is surrounded by sandstone. Nevertheless, its internal structure is clearly that of a bioherm.

Road Canyon Formation: These bioherms mainly comprise two kinds: one type abounds in a variety of fossils but has a framework composed mostly of bryozoans and sponges; the other type contains great masses of the bizarre oldhaminid coscinophora. The first type generally is located at the base of the formation, while the Coscinophora patches are scattered at several levels.

The first type, with a variety of fossils, is widespread. The bioherms are variable in dimension, but they attain heights of 15-20 feet. They occur from the Old Word Ranch site to the Sullivan Peak area. Our USNM 703a, 702c, and $719 x$ are examples. Other bioherms can be studied on the east side of the low spur extending south of Sullivan Peak (Plate 17: figure 2), where they are overlain by the thin-bedded bituminous limestone of the main mass of the Road Canyon Formation. These, like most other bioherms, have the appearance of unbedded, smooth, sublithographic limestone (micrite) having a greenish- to bluish-gray color when fresh but weathering light gray and standing out in conspicuous contrast to the surrounding rocks. The upper surfaces, when exposed, are usually smooth and rounded. One of the commonest fossils in these bioherms is Hercosestria, a brachiopod that often nearly completely comprises small parts of the bioherm, but with Meekella and Derbyia attached within the mass. Edriosteges multispinosus Muir-Wood and Cooper is another common inhabitant of these bioherms. Most of the framework, however, is composed of bryozoans and sponges, which occur in countless numbers. At the Old Word Ranch site, we observed geopetal structures in a large Edriosteges (USNM 703a; Plate 21: figure 1), which were inclined parallel to 
the regional dip, suggesting the original horizontality and the normal growth position of the animal, good evidence that this bioherm is in place and undisturbed. At USNM 702c, in addition ta the usual reefy structures of Hercosia and Edriosteges, fine-grained limestone, abounding in brachiopods with both valves intact almost to the exclusion of other fossils, occurs associated with the bioherms. These seem to be accumulations of shells piled up against the bioherms in very fine micritic matrix (Plate 20: figure 1).

Another place where bioherms occur (Plate 14: figure 2; Plate 15: figure 2) in abundance is in the triangular hill north of Leonard Mountain. Bioherms can be found at the base of the Road Canyon Formation from the junction of Road and Hess Canyons, southward around the hill to Gilliland Canyon, and thence north to about bench mark 4869. An isolated area of bioherms occurs at the southwest end of Gilliland Canyon (USNM 724d). USNM 719x, 721x, and 72ly contain fine bioherms, yielding Hercosia, Edriosteges, and a variety of other brachiopods. In the Dugout Mountain area the Road Canyon is frayed out into the shaly facies, but small bioherms still can be found.

The largest of the Road Canyon bioherms is about 2 miles north of the Iron Mountain - Skinner Ranch house near the crest of the hill (USNM 724j; Plate 16: figure 4). It is about 80 feet thick, consisting of massive granular limestone of 44 feet, with a conglomeratic base, fine-grained calcarenite for 18 feet, and the upper 20 feet formed by massive, fine-grained limestone with bryozoans. It is overlain by yellow platy shale with thin-bedded limestone above that. The bioherm contains a great variety of fossils.

Coscinophora bioherms are scattered about in the Road Canyon Formation at almost any level above the basal bioherms. One of the finest of these is at USNM 721q (Plate 17: figures 2-4), with 35 feet of massive limestone rounded on top, forming a reefy mass. The lower 10 feet contains long slender corals and masses of Coscinophora. The middle 15 feet are mostly calcarenite, but the upper 10 feet again contain Coscinophora.

Similar masses packed with Coscinophora almost to the exclusion of all else occur in this hill on the east side of Gilliland Canyon and on the hill just east of Sullivan Peak (USNM 709c and 710u). A
Coscinophora bioherm was seen on the side of Sullivan Peak not far south of the Sullivan (Yates) Ranch. An occasional bioherm with Coscinophora occurs in the Del Norte Mountains, and loose specimens suggest the presence of others.

A bioherm unlike all others in the Road Canyon Formation was found at the Old Word Ranch site (USNM 703c). This was a small patch composed almost completely of various types of sponges. Since only the top of this bioherm could be sampled, its inner form is not known. The sponges occurred in untold numbers and in considerable variety; Finks (1960:33) records 18 genera of siliceous sponges. In addition to the sponges, many and various molluscs were taken; Batten (1958) and Yochelson (1956 and 1960) described 25 species of gastropods from this bioherm. A large number of undescribed bivalves also were obtained. The occurrence strongly suggests the Cherry Canyon (Getaway Member) sponge bioherm discovered by N. D. Newell and party in the Delaware Basin on the south slope of the Guadalupe Mountains (AMNH $512=$ USNM 728). A great variety of sponges occurs at this place, accompanied by a varied assemblage of gastropods and bivalves. We found no bioherms in the Word Formation of the Glass Mountains; most of the fossils occur in shell heaps or scattered in the sediment.

Summary.-We recognize two types of organic accumulations: (1) mounds or bioherms; and (2) the inconspicuous, unswollen beds of fossils that contain much material in positions of growth, termed here a "zotikepium" or lush garden.

The bioherms generally consist of a core of hard, dense, micritic limestone (reef-core), surrounded by bioclastic material that is derived from the bioherm (bioclastic facies). The bioherm generally is based on conglomerate (often composed of huge crinoid stems in the Wolfcampian) onto which cementing forms attached themselves to begin building the framework, which usually consists of bryozoans, sponges, and algae (Plate 12: figure 1). Continued growth occurred in the same place, one generation living on the shells and skeletons of the preceding one. Into the interstices between the living and dead skeletons, coarse and fine animal debris sifted, along with the fine precipitated calcium carbonate from biochemical reactions, pro- 
ducing the micritic matrix that binds the mass into a mound.

In the zotikepium on the other hand, a mound was not produced, although the same processes went on over a broad area to form a laterally extended accumulation. Growth, fairly uniform throughout, did not concentrate to produce a mound. This type is essentially a biostrome, but the definition of that term covers any bedded accumulation of biological origin, with or without a reefy frame.

\section{Shell Heaps}

Under this terminology are included masses of shells or other organic debris not bound by micritic matrix and not giving evidence of having been an adjusted biologic community. These heaps are very abundant throughout the section. Many are undoubtedly bottom sweepings of currents piled into quiet areas and shallow depressions or heaps resulting from storms. Many of the fossils in the heaps were dead shells before their burial, as they show signs of wear and some are riddled by borings. On many specimens, however, the epifauna are well preserved with both valves intact. These undoubtedly were living when buried. In most of the shell heaps the brachiopod valves are disassociated, especially the loosely hinged enteletaceans, productids, orthotetaceans, and related forms. Spiriferids usually have the valves separated, but many of the rhynchonellaceans and terebratulaceans, which are tightly articulated in life, occur with their valves in contact.

We found few conspicuous examples of this type of occurrence in the lower part of the Wolfcampian sequence. Here, fossiliferous beds are generally bioherms or zotikepia or debris derived from the bioherms (bioclastic facies).

Beds of transported and dead shells are especially common in the Dugout Mountain Member of the Skinner Ranch Formation. Thin beds made up of small pebbles and shell debris are common in this member, but the fossils dissolved from them are mostly worthless because they are so fragmentary and worn. Exceptions do occur, as at USNM 722-1, where sparse shell heaps yield abundant, fine fossils.

Dead shell assemblages (thanatocoenoses) appear higher in the Skinner Ranch Formation in the
Poplar Tank and Sullivan Peak Members. These shells may cover bedding surfaces or be abundant in the siliceous cherty skins that cover some of the limestone beds. Some of the thicker cherts also contain fossils on the surface.

Examples of shell heaps occur in the lower part of the Cathedral Mountain Formation at USNM $702 \mathrm{~b}$ and 72lu. Here, countless shells-mostly single valves of brachiopods, pelecypods, and gastropods, broken sponges, small cup corals, and battered bryozoans-are heaped together and cemented in a sandy lime matrix. Sponge spicules are abundant in the sediment, but fusulinids are rare. The faunas represent the Institella-Agelesia assemblage that characterizes most of the bioherms of the Wedin Member and the lower part of the Cathedral Mountain Formation. The shell heap at USNM $721 \mathrm{u}$ suggests current and storm sweepings from nearby or moderately distant bioherms, because "reef-dwelling" types appear in the debris.

Another shell heap occurrence entirely unlike that just mentioned occurs in the upper part of the Cathedral Mountain Formation in hill 4861 about 1 mile northwest of the Old Payne Ranch site (USNM 732u; Plate 13: figures 1 and 2). The rock is a coarse conglomerate with pebbles attaining a long diameter of 2-3 inches. In the conglomerate there are patches almost completely made up of shells of the large ammonite Perrinites. Scattered through the conglomerate, and with the ammonite masses, are typical Cathedral Mountain brachiopods such as Peniculauris and Rugatia. Besides Perrinites, large nautiloids, Medlicottia, and a few other ammonites have been found. We suggest that these banks of ammonite shells represent dead conchs floated onto shoals or beaches as described by Hamada (1964) for Nautilus pompilius in the Pacific today.

The Road Canyon Formation forming the spur on the south side of Sullivan Peak contains shell heaps and layers, mostly dead shells, in the thinbedded bituminous limestone making up most of the formation at this place. At the top of the Road Canyon south of Sullivan Peak there are thin beds that constitute a fusulinid sand or gravel. Similarly constituted beds attaining a thickness of 1-3 feet are common in the Road Canyon Formation in the Old Payne Ranch area and on the lower slopes of the Del Norte Mountains. A rich locality 
for brachiopods as well as fusulinids is at USNM $732 \mathrm{j}$, where Collumatus occurs. The topmost bed of the Road Canyon, it contains a variety of brachiopods and other fossils, mostly badly battered but containing sufficient good material to make profitable collecting.

The limestones of the Word Formation contain many layers that represent accumulations by currents. The China Tank Member has a number of levels containing such beds. The best and most typical locality is in the Willis Ranch Member at USNM 706e, where a foot-thick layer abounds in fossils. One block of 186 pounds (when decalcified) was estimated to have yielded more than ten thousand specimens. This clid not include fragments and bits of bryozoans. The dimensions of the block were approximately $16 \times 12 \times 12$ inches. The biological shell material constituted about 13 percent of the mass, and about 3 percent was sugary quartz sand. The variety of brachiopods in the layer totaled 84 species. Most of the specimens consisted of disarticulated valves, but only a small percentage, of complete shells. Abrasion had not affected most of them seriously. Most of the productids still retain all or part of their delicate spines, and some immature productids preserved the initial attachment rings and other early, very delicate spines. Although most of the larger specimens were dead when accumulated, many of the epifauna such as Heteralosia, immature Meekella, and Cooperina may have been living. Many of the concave and cavernous shells are occupied by spat or other small encrusting forms.

Deposits similar to the above occur in the Appel Ranch Member at USNM 715i and 719x. Great numbers of fossils are packed into an incredibly small volume of rock. This was probably accomplished by constant movement of the shells by currents until each had accommodated itself to the least space it could occupy.

Two other localities (USNM 706b and 737w) are lenses between the Willis Ranch and Appel Ranch Members, the former locality lying nearer the Willis Ranch and the latter, nearer the Appel Ranch Member. The lenses are about 1-1.5 feet thick and are closely packed with fossils. The rock also contains some sand and brownish silicious material. The faunas of these lenses are like that of USNM 706e.

\section{Organic Accumulations Outside the Glass Mountains}

Sierra Diablo.-Our studies in the Sierra Diablo were directed primarily to the collection of fossils for comparative purposes and did not include a study of the reef-like masses of the Victorio Peak Member of the Bone Spring Formation. The lower part of the Bone Spring, from which our collections are derived, are in part lag deposits, thanatocoenoses, and lime sand banks-all bioclastic. We did not recognize any bioherms in this part of the section. Stehli (1954) postulated a shallow water environment for his localities in the Sierra Diablo, with depths ranging from uncertain to 25 feet at one locality and to 100 feet at another. He comments on the enormous number of broken and separated brachiopod shells in proportion to other animal debris, which consists of broken coral clumps of Heritschia, worn fusulinids, occasional mollusc valves, and the usual abundance of crinoid debris. That the deposits are near-shore seems likely; if reef-marginal, as also suggested, the reef source is conjectural.

Delaware Basin.-Our collecting here was limited to a few localities of the Cherry Canyon and Bell Canyon Formations. The localities in the lowest part of the Getaway Member are in lenses of shell debris very much like those of the Word Formation in the Glass Mountains. These are clearly thanatocoenoses, in which most of the specimens consist of separated valves and the fauna is predominantly brachiopod.

The most interesting and best known of the Getaway fossil accumulations is that at AMNH 512 (=USNM 728). This is a sponge-mollusc community like that of USNM 703c in the Glass Mountains, but it is richer in brachiopods than the latter occurrence. This appears not to be a bioherm but a disrupted community, which suggests the zotikepia described above.

The Bell Canyon members collected in the Delaware Basin mostly contain brachiopod assemblages. Those of the Hegler Member contain numerous brachiopods, and in one locality (USNM 731), a variety of sponges. These localities contain numerous brachiopods that must have been living at, or near, where they were found. Many of the rhynchonellids, spiriferinids, and terebratulids have 
both valves joined and show no signs of wear. Some of the less tightly hinged brachiopods, such as $S p i$ riferella and the small productids Scapharina, Xenosteges, and Heteralosia, are disjointed.

The Lamar Member in the Basin contains one bed (USNM 728p) that is very rich in fossil material (Plate 22: figure 3). Most abundant are the genera Astegosia, Anomaloria, and Martinia, the valves of which commonly are disassociated and often broken. Since these brachiopods were articulated only loosely in life, they attest to some agitation of the water or to transport of the shells, but it would not have required great abuse to have created the condition in which they are found. They are in contrast to the same genera on the "reef" front, where the majority or a latge number of specimens have both valves joined. In the Lamar at USNM 728p, the terebratulids and rhynchonellids generally are conjunct, whereas the larger spiriferinids are more commonly disjoined. The evidence suggests moderately shallow water with some current or possibly wave action during storms. We can see no evidence that these shells were transported by gravity slides from the reef, because there is no lime sand or reef debris in the form of broken sponges or fragments of algae associated with them.

Guadalupe Mountains.-In this region as in the others of West Texas, our main objective was the collection of comparative material rather than studies in stratigraphy or ecology. Nevertheless, we did observe these conditions where we collected, and we have views based on the faunas derived from the acidizing program. We made no collections from the Bone Spring of the Guadalupe Mountains west front, but we have specimens from AMNH 658, which came from a "biohermal-like lens on the north wall" of the seventh canyon north of Indian Cave Canyon near Williams Ranch. This contained Institella, which usually preferred a "reefy" habitat.

Most of the Bell Canyon collections were taken from Rader Ridge (Plate 23: figure 4), where some effect of reef slide is evident, but specimens taken from the dark limestones generally can be described in the same terms as those farther out in the basin. The rhynchonellids in the Pinery Member, for example, are generally complete specimens, with only a few disassociated valves. This is true especially of Bryorhynchus, which is a very delicate, thin shell and might be broken easily. Some of these are distorted but not broken, probably the result of compaction of the sediments. Slide from the reef into the Rader dark sediments consisted of lime sand with typical Rader fossils, but these were not silicified and were recovered by breaking the rock. The silicified Rader fossils presented the same features as the other members of the Bell Canyon Formation. They all suggest specimens that lived in moderately quiet water and later were entombed where they lived or near their original habitats.

Nearly all of our fossils from the Capitan Formation were taken from the inclined beds along the mountain front. In these beds, brachiopods are concentrated in patches that may have been assemblages in situ or may have been transported a short distance. Many of the specimens have both valves intact, and this includes such loosely articulated forms as Martinia, Anomaloria, and Astegosia. Stenoscisma usually can be found with both valves together, as can many of the spirifers, spiriferinids such as Paraspiriferina, and the terebratulids. The small rhynchonellids such as Anteridocus swallovianus (Shumard) usually are complete. The large productid Thamnosia capitanensis (Girty) usually is complete and often retains its tubular anterior. Where slightly rotted, the Capitan calcarenite of this portion of the "reef" offers some of the best collecting in West Texas. The occurrences suggest specimens essentially in place or with only a slight amount of transportation (Plate 22: figure 1).

Chinati Mountains.-Important bioherms occur in the Chinati Mountains especially in the Breccia Zone of Udden's Cibolo Formation. Although these occurrences have been interpreted as reef slide by Rigby (1958), we believe these structures to be true bioherms. The biohermal beds abound in Scacchinella and prove to be an exact duplicate of the bioherms of the Decie Ranch and Sullivan Peak members in structure. Furthermore, the faunal content is so similar that correlation with the Skinner Ranch Formation is obvious (Plate 22: figure 4; Plate 23: figures 1, 2). 


\section{Fossils in the Various Facies}

It is generally believed that some fossils are closely restricted to certain types of sediment. This is partly true, but most fossils are distributed widely and usually occur in several kinds of sediment, e.g., Leiorhynchoidea, which is commonest in black or dark muds. In spite of such common occurrence, we have species from calcarenites, shell breccias, and yellow shales. The fossils mentioned below as the common inhabitants of certain kinds of sediment may be characteristic of that time and place, but they are not always restricted to that type of rock elsewhere.

In the Conglomerates.-In the Glass Mountains there does not seem to be any clear evidence of residual faunas in the conglomerates that are formed by transported materials. In the first place, the environment is not good to preserve fragile specimens, and the ones that are found in the conglomerates show evidence of transport by their fragmentary condition. The only fossils that were probably resident in a gravelly or bouldery sediment are those that occupied bioherms, and these are considered under that facies.

The most significant transported fossils in the conglomerates are the ammonites. Mentioned previonsly, they are almost certainly specimens that floated onto sand and gravel banks. In addition to the ammonites and often associated with them, there are fragments of wood and fairly well preserved seeds. These are further testimony to the near-shore and shallow-water environment of the transported conglomerates (Plate 13: figure 2).

We have not seen any indisputable specimens in the matrix of the boulder beds that surround the bioherms of the Sullivan Peak Member at the southwest end of the Lenox Hills.

In The Quartz SANDs.-Quartz sands in the Glass Mountains are not an inviting source of fossils. Although all of the sands were examined for fossils, the search was not exhaustive and the few that were found undoubtedly were transports from other environments, e.g., the specimens seen on the upper surface of the thick sandstone that forms hill 4806.

Inasmuch as the calcarenites or lime sands are composed largely of bioclastic material that includes crinoid debris and broken shells, these do not contain resident fossils, except for the bioherms that they may surround. We know of no fossils that are restricted to such an environment. The faunas are usually like those in neighboring bioherms.

IN THE SHALEs.-The bluish shales contain brachiopod types that are common in similar sediments in other parts of the column. The Uddenites-bearing Shale Member contains genera that occur in many of the Pennsylvanian shales, especially the Gaptank shale underlying the Wolfcamp: Rhipidomella, Parenteletes, Isogramma, Neochonetes, Chonetinella, Hystriculina, Kozlowskia, Kutorginella, Linoproductus, Reticulatia, Rhynchopora, Crurithyris, and Neospirifer. All of these except Parenteletes are common in the Gaptank shale and in the shales of the Pennsylvanian in the Midcontinent region. None of these is restricted to shale as its habitat, but they are common shale dwellers. The bioherms of the $U d$ denites-bearing Shale Member contain a different assemblage, mostly of Permian types such as Limbella and Scacchinella.

We have seen very few megafossils in the radiolarian and spicule-bearing shales of the Cathedral Mountain and Word Formations. In the latter, Crurithyris and Leiorhynchoidea occur, as they do elsewhere, in comparable inhospitable environments.

Paranorella, which occurs in black limestone and shale in Coahuila and the Delaware Basin, was taken in the blocky shale of the Poplar Tank Member. The occurrence is rare, however, and is the only specimen of this genus found in shale in the Glass Mountains.

In THE Limestone.-The dark limestones are often replete with fossils, a fact that makes identification of them as basinal deposits impossible. As evidenced by the fauna from USNM 707e, 703c, $703 \mathrm{~d}$, a great variety of types occurs in the dark limestone. These faunas include a few of the characteristic forms usually associated with bioherms. They do not include the common black limestone types such as Bryorhynchus, Leiorhynchoidea, and Paranorella, although one species of Glossothyropsis is present but very rare. Perhaps Liosotella costata, new species, is the most characteristic species in the dark limestones at USNM 707e. Other forms are the very wide-hinged Reticulariina subu- 
lata, new species, and an abundance of various chonetids. A similar association appears in the thin-bedded limestones of the upper part of the Cibolo Formation (thin-bedded zone of Udden), in which Liosotella costata, wide-hinged Reticulariina bufala, new species, and wide chonetids occur. This portion of the Cibolo Formation has been likened to the Bone Spring, but it should rather be compared to the Road Canyon Formation, of which it is probably an extension. The variety and abundance of fossils in these limestones is unlike the general sparsity of fossils characteristic of genuine basin deposits. We regard these as shelf deposits in shallow water, near a low, possibly swampy, land. The water was not necessarily quiet, because there is some heaping of shells and disjoining of the valves.

As noted previously, the lagoonal limestones of the Hess Formation contain few fossils other than fusulinids. We found a few macrofossils, however: a large colony of Waagenophyllum, an occasional ammonite, an occasional large Omphalotrochus. A piece of float that could have been derived only from the Hess Formation contained a few brachiopod species, including a new Martinia. It was found loose, just under the Hess Conglomerate (= Lenox Hills Formation of Ross), and could not have been derived from the Neal Ranch Formation. We are not able to say whether it came from the Wolfcampian portion of the Hess (= Lenox Hills Formation of Ross) or from the Skinner Ranch part. The assemblage is more suggestive of the Skinner Ranch than of the Lenox Hills.

IN THE BIoHerms.-Most of the bioherms are a framework of bryozoans and bryozoan fragments, among which the brachiopods found asylum. Many of the Permian brachiopods are cementing forms that flourished naturally only where a firm bottom for attachment was available. They, like the brachiopods today, favor a fairly quiet water situation. The abundance of niches provides living for a variety of brachiopods and accounts for the great diversity in faunas of bioherms. The bryozoan bioherm, therefore, offers the utmost for their requirements.

Only in a few examples and only with a few genera do the brachiopods contribute notably to the formation of a bioherm. In the Silurian and Devonian, brachiopods often make mounds of their own (Pentamerus and Stringocephalus), but they are not bioherms in the sense of being consolidated masses. They make mounds simply because they lived clustered together, the living shells attaching to the dead, until shifting seas obliterated them.

A few brachiopod genera, often called reef types, are identified with bioherms, but it is an interesting fact that the greatest, supposedly Permian reef, the Capitan "reef," has very few of these reef-type brachiopods. The following genera may contribute notably to the formation of bioherms or may produce clusters of their own that possess biohermal significance: Scacchinella, Hercosia, Hercosestria, Teguliferina, Derbyia, and Coscinophora. To a lesser extent, the following are moderately important contributors to bioherms or zotikepia: Edriosteges, Geyerella, Tropidelasma, Institella, Collemataria, and Agelesia.

Scacchinella: This and the next genus are the nearest to reef-type brachiopods in the Permian, as they are large and sturdy; because of these qualities, they probably were current resistant. They offered also a haven for other, smaller brachiopods. Scacchinella is found usually in biohermal assemblages, and it often makes up a large percentage of the bioherm. In spite of this, it may be found in small clusters away from the main biohermal masses. Although Scacchinella properly may be dubbed a "facies fossil," it shows a significant evolution in the development of the amount of vesicular tissue in the pedicle valve, which possesses great value as a time indicator. As described below, several levels of Scacchinella species have been detected.

Hercosia: This genus consists of much smaller species, but one actual bioherm (USNM 726o) was found in which $H$. delicata, new species, makes up most of the framework of the bioherm. Hercosin uddeni at USNM 702 often makes small clusters, but generally the richthofeniids only are dwellers in the bioherms. Cyclacantharia and the other Glass Mountains richthofeniids are rarer in bioherms. The former appears in bioherms (USNM 702c, 703a) of the Road Canyon, but it is more commonly found in nonbiohermal assemblages in the Word Formation.

Hercosestria: This genus seldom makes bioherms in which it is dominant; rather it is a participant in the making of the bioherm. 
Teguliferina: This is an important contributor to Wolfcamp bioherms (USNM 701d).

Derbyia: Derbyia is usually a participant in the making of bioherms, but in some parts of the Neal Ranch Formation (USNM 70ld, 742c) it is a dominant element, at least in parts of the bioherm.

Coscinophora: This genus may be the dominant element in the formation of some bioherms. It is a more common biohermal form than Collemataria, which usually is only a contributor. The flattish surfaces of Coscinophora and the curved inner surfaces of the interior of dead shells are favorite sites for small cementing forms (see Plate 129 for a reefy cluster of Coscinophora).

\section{Bioherms at Different Levels}

In the Permian column of the Glass Mountains, bioherms are predominantly bryozoan, but each has brachiopod elements characteristic of its level. A brief discussion of the bioherms at different levels follows and includes some of the accessory genera commonly found in bioherms.

Uddenites-bearing Shale Member.-Inasmuch as these bioherms have not been found in silicified condition, we do not know a great deal about them. They contain Scacchinella as a constituent, but this genus is not abundant and it was nowhere found to dominate a bioherm at this level. An accessory element in these bioherms is Parenteletes cooperi R. E. King, which often is fairly common.

Neal Ranch Formation.-Three levels of bioherms have been seen in this formation. The first is in the upper part of the Gray Limestone of $P$. B. King (USNM 701). This biohermal or possibly zotikepial structure was characterized especially by orthotetaceans of rare and unusual character, in addition to the usual bryozoa. Another small bioherm at USNM $722 \mathrm{x}$ is characterized by common Eolyttonia cemented by laminar calcite, which suggests an algal origin. The relationships of this bioherm to its surroundings suggest that it was at one time a much larger structure.

Bed 4 of P. B. King produced bioherms and zotikepia that are interesting for the abundance of Derbyia in the bioherms and the presence of Striatifera in the zotikepia. USNM 70Id is characterized by great abundance of small derbyias cemented into clusters with masses of Teguliferina. These are the only bioherms seen in which Derbyia and Teguliferina formed a substantial part of the mass. Parenteletes formed a prominent accessory element reminiscent of the bioherms of the Uddenites-bearing Shale Member. The zotikepium at USNM $721 \mathrm{~g}$ is rich in several types of bryozoans; it has numerous Striatifera attached to the colonies and a species of Pseudoleptodus attached to the Striatifera.

A variety of bioherms was seen in beds 12-14 of P. B. King (= beds 9-12 of Cooper) all faunally different. The bioherm at USNM 701c contains, as important elements, Eolyttonia, Limbella, Teguliferina, but none seem dominant. So abundant is Geyerella, the bioherm at USNM 70lh may be characterized as of this genus, which occurs cemented together in clusters and makes up a large percentage of the mass. Other reefy elements are Tropidelasma, Meekella, and Limbella. Important accessories are Parenteletes, Composita, Diplanus, Spyridiophora, and a host of rarer forms. The bioherm at USNM 701k has the same elements as the preceding, but it is specially noteworthy for a flood of Enteletes as an accessory. This genus is a common accessory in most of the bioherms and zotikepia.

Lenox Hills Formation.-The most important and interesting bioherm in the Lenox Hills Formation is the one on Leonard Mountain just above the conglomerate (USNM 705k). Most of the frame of this bioherm is made of a small new species of Scacchinella. This is assisted in frame building by abundant specimens of Tropidelasma and the accessory element Parenteletes.

Several Lenox Hills bioherms occur at USNM $715 \mathrm{~b}$ in the southwest end of the Lenox Hills. These have no silicified material, and our collections are not extensive. No special element stands out to characterize them, but Spyridiophora usually can be obtained.

Decie Ranch Member.-The bioherms in the western and eastern parts of the mountains at this level are different in composition, but they are believed, nevertheless, to be contemporaneous. In the Lenox Hills the Decie Ranch bioherms are definitely Scacchinella bioherms, that genus being the dominant element in size and numbers. With it, and intimately attached, there are a huge species of Geyerella, a stout Tropidelasma, a huge Der- 
byia, and an enormous Eolyttonia. Accessories in this assemblage are Oncosarina, Limbella, Enteletes, Antronaria, and Stenoscisma.

The bioherms at the same level in the more eastern part of the Glass Mountains on Leonard Mountain and the north side of the Hess Ranch Horst are dominated by Scacchinella, but the individuals, although large, seldom reach the enormous size of those seen in the Lenox Hills. Geyerella is missing or rare, and its place is taken by Meekella, which attains its largest size here (USNM 720e). An elongate Cyclacantharia occurs along with a large conical Eolyttonia. Accessory genera are Enteletes, large Stenoscisma, and Antronaria. Bioherms in the Cibolo Formation (Breccia bed of Udden) are like those of the Decie Ranch Member.

Sullivan Peak Member.-Most of these bioherms are not, or only partially, silicified. Their composition is like that of the Decie Ranch Member bioherms, but Scacchinella is no longer the dominant element. The one whose fauna is best known, USNM 733j, is composed partly of Coscinophora (Plate 5: figure 1), with Scacchinella rare, but Limbella fairly common. Another "reef-type" is Tropidelasma, but it is not abundant. Spyridiophora is present. Scacchinella, although widespread in the Sullivan Peak Member, is never so abundant as in the Decie Ranch Member and in the lower part of the undivided Skinner Ranch Formation.

TaYlor Ranch Member.-Only one small patch of bioherms is known in this member, and it is conspicuous for its sponges, Girtyocoelia and $\mathrm{He}$ liospongia. Brachiopods constitute only a minor element in the assemblage. Common bioherm-loving forms are present: a new notothyridid called Chondronia, huge Enteletes, Spyridiophora, Antronaria (common), and large Stenoscisma (Plate 19: figure 2).

Cathedral Mountain Formation.-Bioherms and zotikepia, common in the Wedin Member of this formation, generally are dominated by Institella and Agelesia. These are the commonest brachiopods, but brachiopods are not important in making these bioherms and zotikepia. Here the honors fall to the bryozoans. Contributing brachiopods in the Wedin Member are: Hercosia, Chonosteges, Compressoproductus, and Enteletes, which is common. In the eastern part of the Glass
Mountains in the vicinity of Split Tank, bioherms similar to those of the Wedin Member contain Institella, although the associated forms are different from those of the Lenox Hills and Dugout Mountain areas. Agelesia is somewhat rarer, but one bioherm (USNM 703bs) is very rich in this genus. Hercosia is abundant and forms clusters and small bioherms containing the accessory Enteletes. Another accessory is Niviconia globosa (R. E. King). Rugatia is found suspended by long spines among the branching bryozoa. Other accessories are: Edriosteges, Chonosteges, and Collemataria. If any genus is dominant, it is usually Hercosia.

Bioherms are not common in the Upper Cathedral Mountain, and the best was mentioned under the note on Hercosia. The frame-builder of the bioherm at USNM 726o is Hercosia; Edriosteges, Chonosteges, and Echinauris are accessories. Common in this assemblage is the large bivalve Pseudomonotis, spiny and ostreiform. A unique bioherm largely composed of the lyttoniid Collemataria occurs at USNM 702al.

Road Canyon Formation.-Bioherms of the lower part of the Road Canyon usually have a different assemblage from those of the upper part of the formation. The lowest part of the Road Canyon forms a biohermal zone that can be followed from a point near the Old Word Ranch site over to Sullivan Peak. Localities of these bioherms are USNM 703a, 702c, 719x. Hercosestria, a common member of these bioherms, does not make up the main mass, but it usually is abundant. Another abundant element is Edriosteges. With these are large Meekella, Coscinophora, Thamnosia, large Cyclacantharia, large Stenoscisma, and large Dielasma.

The bioherms of the upper part of the Road Canyon Formation may be described as Coscino. phora bioherms; this abundant genus is usually the dominant element. An interesting accessory is the tiny notothyridid Chondronia, which has been found only in bioherms or in association with them.

In summarizing the fossils of the bioherms, it may be said that only a few types are mound builders, although many species occur as accessories. Some, such as Chondronia, appear always to be associated in or near bioherms. It is probably fair to say that most of the fossils in Wolfcampian and 
Leonardian rocks, except those of the shales, more than likely lived on or around bioherms. Some of these, such as the assemblage in USNM 72lu, probably were swept together from biohermal sites.

In the shell heaps and bottom sweepings of the Word Formation, richthofeniids and aulostegaceans, which normally occurred in bioherms in the earlier sediments, probably had somewhat different habitats. There more than likely were not big clusters, to initiate bioherms, and there were no bryozoan zotikepia from which bioherms could be developed. The absence of bioherms along with the presence of genera that normally inhabited bioherms suggests that the Guadalupian conditions were different from those preceding. It is possible that the water, although shallow, was deeper than that of the biohermal locations and that the animals lived farther from shore in a less oxygenated and nutritious environment. The above discussion also is valid for the Sierra Diablo region and the Delaware Basin. In each of these regions, biohermal and accessory forms dwelt, but they did not form bioherms.

Sierra Diablo and Guadalupe Mountains.Our collections from this region come only from the lower part of the Bone Spring Formation, which faunally is related to the Skinner Ranch Formation of the Glass Mountains, that part of the section containing most of the bioherms. Although bioherms have been illustrated and studied in the lower Bone Spring (Stehli, 1954), we did not find any silicified ones comparable to those of the Glass Mountains; rather, our collections and those of Stehli are from the sweepings from the bioherms and possible zotikepia. The Sierra Diablo are clearly "shell heap" occurrences or thanatocoenoses. The fauna includes Scacchinella, Limbella, Acritosia, Teguliferina (Planispina of Stehli), and Meekella, all genera that normally are generous contributors to bioherms. Scacchinella americana Stehli, however, is very rare and small, and the species is unlikely to have been an important contributor to bioherms. Teguliferina and Acritosia are abundant and may have been framebuilders of small bioherms. They are the only likely members of this fauna to have been colonial. Meekella is abundant and may have contributed to the Teguliferina clusters in much the same fashion as Geyerella did in the Neal Ranch bioherms.
Eolyttonia and Collemataria are too rare to have been important contributors. Enteletes is the commonest accessory genus, although Stenoscisma is present, but rare. Much of this fauna consists of chonetids, small and large productids, rhynchonellids and spiriferinids, all of them brachiopods that probably occupied niches either in bioherms or zotikepia or even in shell heaps. The evidence suggests to us that there may have been bioherms at this time but that they probably were small and easily broken up.

We have not studied the Victorio Peak Member, but what we know of its faunal content indicates that it contains bioherms that suggest those of the Cathedral Mountain Formation (Plate 8: figure 3).

The great "reef" surrounding the Delaware Basin has few of the "reefy" brachiopods. Cyclacantharia and Sestropoma are present, but they are extremely rare. As a matter of fact, the "reef" contains none of the possible frame-building brachiopods. All of these except Geyerella became extinct before Capitan time. Collemataria is also a very rare animal in the reef rock. That brachiopods grew on the reef, in its niches and on its slopes toward the basin, is shown by the patches in the steeply dipping beds on the front of the mass. The brachiopods consist partly of niche dwellers taking advantage of the crannies in sponge and algal beds. A large number of the Capitan brachiopods evidently formed their own patches in which dead members of the assemblage furnished the anchorage for the next generation. Many of the loosely hinged genera such as Astegosia, Anomaloria, Reticulariina, Arionthia, new genus, Martinia, and Composita are found commonly with both valves intact and only a small number of single valves. This indicates fairly quiet water conditions on the "reef" slope. One can only conclude that the brachiopods were an insignificant element in the formation of the Capitan "reef" but that they found its surface and niches a favorable dwelling place.

Bell Canyon sediments marginal to the "reef" mass contain large numbers of brachiopods that occupy patches representing small heaps. Most of the specimens are small, and productids are extremely rare. The most abundant species are those of the Spiriferinacea, small Strophalosiacea, cho- 
netids, small rhynchonellids, and small terebratulids. In addition, stout, sticklike bryozoans and cup corals are abundant. Many specimens are found with both valves intact. Breakage is minimal, and the assemblage gives the impression of having dwelt where it was found. Although some of the species also occur in the Capitan Formation, the sediment contains considerable quartz sand, but no debris demonstrably reef derived was seen. It seems that these deposits of the Hegler, Pinery, and Rader Members represent sediments in front of the reef with resident faunas. Demonstrable reef slide appears in the Rader, but this is calcarenitic rock containing unsilicified brachiopods like those of the dark Bell Canyon limestone (Newell et al., 1953; Rigby, 1958).

The story of the fauna of the Lamar Member of the Bell Canyon Formation is much the same. The fauna has an entirely different composition from that of the lower members of the Bell Canyon, but essentially it is the same as that of the faunas mentioned as occurring on the slope of the "reef," abounding in Composita, Anomaloria, Astegosia, and Martinia. Rather than being derived from the reef slope and being transported to the base of the reef, as commonly believed, the Lamar fauna, our studies lead us to believe, lived at the base of the reef, but current agitation caused considerable disassociation of the valves. In the Lamar, complete specimens of any of the genera mentioned above are very rare. This is not so of the rhynchonellids, terebratulids, and spiriferinids, which often are found with valves intact. The fauna is composed almost exclusively of brachiopods, corals, and bryozoa, but molluscs are extremely rare.

Grant (1971) traced the decline of reef-dwelling and reef-associated brachiopods through the West Texas Permian section, pointing out that the supposedly greatest of all Permian reefs, the Capitan, contains an overwhelming proportion of the kinds of brachiopods that lived attached by a pedicle. The spiny brachiopods that give Permian faunas their distinctive aspect are scarce in the Capitan Limestone and its equivalent members in the Bell Canyon Formation. The decline in spiny brachiopods and the proportionate increase in pediculate forms began as low as the Skinner Ranch Formation. By the time the Capitan was deposited, the fauna had what might be considered a "Mesozoic aspect," in the sense that most Mesozoic brachiopods are pediculate.

\section{Paleoecology}

To understand the conditions that existed in the Permian of the Glass Mountains, it is necessary to examine the paleogeographic setting of the area. In addition, the rocks that make up the Permian of the Glass Mountains have their own story to tell of the times. Added to these two versions is the story told by the fossils. Determination of past conditions deduced from rocks may lead to ideas contrary to those indicated by the fossils. Interpretation of lithic data will not coincide necessarily with that determined by fossils. Deductions as to depth of water may be at variance because of conflicting evidence from sediments and fossils.

Paleogeographic Setting.-Philip B. King (1942) brought together basic information on the paleogeographic setting of the Glass Mountains, the Sierra Diablo, and the Guadalupe Mountains. He depicts, in his now well-known and much-figured map (King, 1942: figure 18), a Marathon Folded Belt lying south of a Southern Shelf area on which the sediments of the Glass Mountains were laid. This shelf faces the Marfa Basin area to the southwest and west and the Delaware Basin to the north. The Delaware Basin is'bounded on the west by the Diablo Platform and on the east by the Central Basin Platform, essentially submerged peninsulas extending south from the Northwestern Shelf Area of southern New Mexico. The Central Basin Platform forms the western margin of the Midland Basin, which is bounded on the east by the Eastern Shelf Area. The Marfa Basin is connected to the Delaware Basin by the Hovey Channel and the latter basin connects with the Midland Basin by the Sheffield Channel. The Glass Mountains occupy a very small amount of this vast area, and its deposits mainly are shelf deposits, mostly clastic limestones, conglomerates, and sandstone, with some important layers of shale. The source of the sediments was partly from the Marathon Folded Belt and partly from the west, as most of the section thickens in that direction. It seems likely that the Southern Shelf extended farther southwest than indicated by King, because 


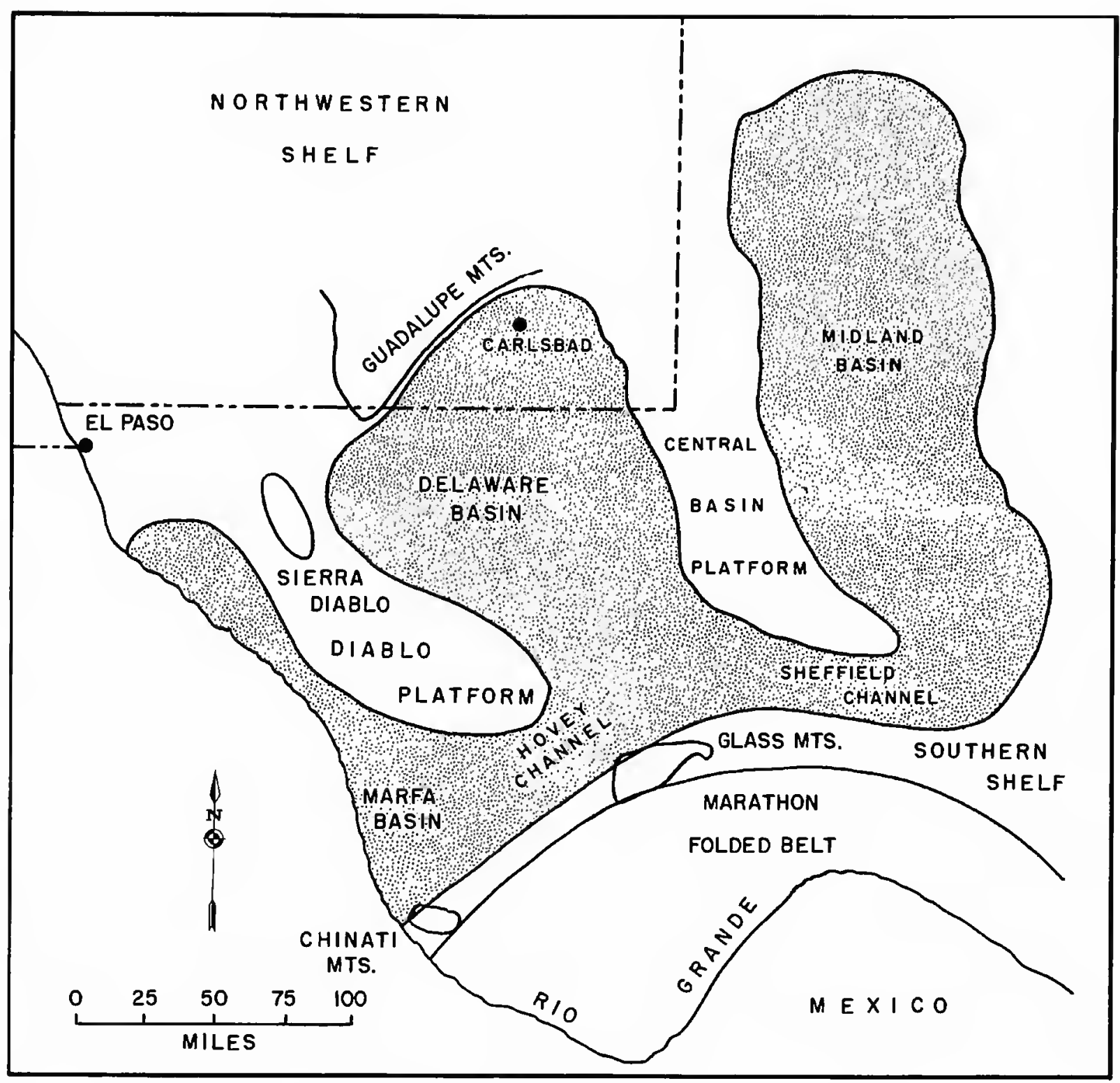

Figure 27.-Paleogeographic setting of the Permian of West Texas.

part, at least, of the Chinati Mountain (Cibolo Formation-Breccia beds of Udden) sequence are shelf deposits identical to parts of those of the contemporary Skinner Ranch Formation (Rigby, 1958: diagram, page 299).

Sediments of the Wolfcamp Series.-In the Wolfcampian we include the Uddenites-bearing Shale Member of the Gaptank Formation of P. B. King, which is identical to the Neal Ranch Formation in gross lithic aspect. We also include the Skinner Ranch Formation as explained elsewhere. Like the Neal Ranch, the Uddenites-bearing Shale Member contains bioherms based on limestone gravel and surrounded by detrital limestone that is enclosed in blackish to bluish shale containing scattered fossils. The bioherms of the Neal Ranch mainly are bryozoan-sponge assemblages, with algae suggesting existence in warm, sunlit, shallow water. Temporary submergence of the shelf, uplift of the Marathon Folded Belt, or a wet climatic cycle may account for the ultimate burial of the bioherms in the shale. Except for the local development of limestone cobbles associated with bioherms, conglomerates are rare in the Neal Ranch sedimentary suite. Quite the opposite is the condition in the Lenox Hills Formation.

Lenox Hills: In the western part of the Glass Mountains this formation contains a thick conglomerate that thins eastward to disappear on the flank of the Hovey anticline just west of Leonard Mountain. East of this fold, Lenox Hills conglomerate appears in Leonard Mountain and along the base of the mountains except for one place east of the Wolf Camp Hills. In the western part of the Glass Mountains, a shale separates the conglomerate from the overlying Skinner Ranch Forma- 
tion. In Leonard Mountain, bioherms appear in the limestone overlying the Lenox Hills conglomerate. Bioherms also occur above the conglomerate just north of the Hess Ranch. East of this point the conglomerate is overlain by a variety of rocks consisting of red beds and thin dolomitic limestone like that of the Hess Formation.

The Lenox Hills conglomerates point to an uplift of the Marathon Folded Belt that blotted out the early development of bioherms at its base. The shale succeeding the conglomerate in the Lenox Hills is a facies like that of the Neal Ranch, with a comparable fauna consisting of ammonites, gastropods, and pelecypods similar to those of the $U d$ denites-bearing Shale Member and the Neal Ranch Formation. The limestone above the conglomerate in Leonard Mountain is a coarse lime sand (calcarenite and calcirudite) fingering into the Hess calcarenite to the east. The red beds represent a local uplift that washed lateritic muds into the Southern Shelf Area.

It is interesting to note that thin beds of conglomerate in the Lenox Hills area contain numerous seeds and fragments of wood together with concentrations of ammonites. These two occurrences argue for shallow-water, near-shore deposition. The ammonites probably are dead shells that floated into shallow water and were deposited with piles of pebbles and fragments of waterlogged plant debris. On the southwest side of Leonard Mountain, a fairly large tree trunk was seen in the Lenox Hills shale.

Skinner Ranch: These sediments are very diverse, consisting of limestone conglomerate, calcirudite, calcarenite, and some fairly thick, but local, quartz sandstone beds. The conglomerates of the Decie Ranch and Sullivan Peak Members are notable for their coarseness. Ragged boulders up to five feet in one dimension occur and many over a foot long are present (Plate 11: figures 1, 4). In the Decie Ranch Member, the bioherms are not banks of reefy limestone, but rather they are tangled masses of bryozoans and large brachiopods, formed on a gravel bed or comprising an accumulation of large crinoid stems. This association suggests a near-shore environment, with high energy conditions. The uplifted Marathon Folded Belt supplied some of the conglomerate, but frag. mentation of the bioherms is also evident.
The Poplar Tank Member is of varied lithic character, which consists mainly of brown crumbly shale enclosing thin beds of limestone and conglomeratic limestone. In places, the calcareous layers contain a thin skin of pinkish chert containing numerous fossils and sponge debris. Sponges probably furnished much of the silica. The cherts contain members of the Spyridiophora fauna, demonstrably a shallow-water assemblage. The cherts here are not evidence of deep water, but rather of a concentration of spicular material.

Large moundlike bioherms occur in the Sullivan Peak Member. The most conspicuous example is in hill 4801 (Plate 18: figures 1, 3). The boulders occupying the space between the two adjacent bioherms are exceptionally large and almost entirely biohermal in their origin, as they contain the common Permian fossils of the bioherms. On the west side of the easternmost bioherm there is a boulder containing numerous specimens of Scacchinella. The setting is one of close shore, with violent water conditions that pounded the bioherms to fragment them and pile the debris at their bases.

The setting on hill 4801 of the Lenox Hills is like that of Udden's Breccia Bed in the lower part of the Cibolo Formation, on the northwest slope of the Sierra Alta Creek in the Chinati Mountains. For about 3 miles along the creek, large Scacchinella bioherms are based on gravels containing reworked Wolfcampian fusulinids. The bioherms are surrounded by coarse breccia, like that of the Glass Mountains. If these large masses were reef slide, as claimed by Rigby (1958), one would expect them to be at different levels in the conglomerate, helter skelter. Such is not the case; they occupy a general level and are not covered by the boulder conglomerate. We believe that these bioherms occupied an extension of the Southern Shelf Area in Skinner Ranch time and that conditions were like those postulated for the Sullivan Peak Member in the Glass Mountains, i.e., shallow water, near shore, with strongly agitated water.

The Skinner Ranch Formation east of Leonard Mountain is replete with small Scacchinella bioherms surrounded by bioclastic aprons, clearly a shallow-water environment.

On the east side of the Hess Ranch and on the north slope of the Hess Ranch Horst, the coarse calcarenites and calcirudites of the Skinner Ranch 
interfinger with the fine lime sands of the Hess Formation. The latter often abounds in lenses with fusulinids, the most abundant fossils. Occasional large fossils such as coral colonies, Omphalotrochus, and ammonites occur. Generally, however, the rocks are fine calcarenite, pellet limestone, and oolite. In places fusulinids are encased in laminated lime (algae). The ensemble suggests deposition in a quiet bay behind the great limesand bank or bar of the undivided Skinner Ranch Formation. This great limesand bank, 400 feet thick, formed a barrier between the western coarse clastics and the finer limesands of the Hess Formation.

The Taylor Ranch Member of the Hess Formation consists of a limestone conglomerate, followed by cobbly fossiliferous limestone that is capped by thick-bedded cherty limestone. Occasional bioherms have a high percentage of the sponges $\mathrm{He}$ liospongia and Girtyocoelia (USNM 702d; Plate 19; figure 2). Large productids (Peniculauris) are abundant as well as large snails (Omphalotrochus). Some crinoidal debris and numerous small brachiopods also are present. The member extends for a few miles near the top of the scarp, as far as the Conoly Brooks Ranch. The presence of the bioherm, the great abundance of rolled shells, and crinoid debris suggest a shallow-water accumulation. The Taylor Ranch essentially is a tongue of the Sullivan Peak Member extending beyond the main barrier of limesand.

Sediments of THE Leonard SERIEs. -The sedimentation in the Leonardian is different from that of the Skinner Ranch Formation. The Cathedral Mountain Formation is a great mass of shaly-silty rocks with interbedded limestone and occasional conglomerate. The mass thins eastward and interfingers with a thinned, predominately limestone sequence. The Cathedral Mountain is capped by the lithically complex Road Canyon Formation.

Cathedral Mountain: In the western part of the Glass Mountains the Cathedral Mountain Formation is divisible into two parts representing different conditions of sedimentation. The lower portion consists of a basal limestone member, the Wedin Member, largely biohermal and zotikepial (see below) in its makeup, overlapped by yellowweathering silicious shale, spiculite, and radiolarite. This material suggests more basinal deposition, as it has few macrofossils. These quieter water conditions are interrupted by deposition of clastic, conglomeratic limestone beds, the Third and Fourth Limestones of the Leonard of P. B. King, containing many ammonites (Perrinites) and many fragmentary and rolled fossils. These were deposited under shoal water conditions, and an occasional bioherm in them helps to bear this out. These conglomeratic limestones were followed by deposition of bluish shale and sandstone. The former contains large Peniculauris and large Perrinites in abundance. The sandstones extend from a point near Sullivan Peak westward to the foothills of the Del Norte Mountains, near the site of the Old Payne Ranch. Late in Cathedral Mountain time, local uplift shed conglomerates in the Del Norte Mountains (hill 4816), which suggest a shore zone with moderately coarse gravels that are composed of well-rounded pebbles, abundant transported ammonites, fragmentary brachiopods, and numerous plant stem fragments, producing the same type of environment as that in the Lenox Hills Formation.

These sands and conglomerates are the end of extensive conglomerate deposition in the Glass Mountains. The Road Canyon Formation has few conglomerates, and these generally are associated with bioherms. The overlying Word Formation, in our experience, has little or no conglomerate. Thus, in late Cathedral Mountain time the Marathon Folded Belt and other sediment sources were lowlying and furnished only fine grained material.

Cathedral Mountain in the Split Tank Area: One-half mile east of Split Tank the Cathedral Mountain Formation is only 300 feet thick, its base is a conglomerate of small quartz pebbles, and its lowest beds are of Hess-type lithology, with scattered bioherms. The lower third at Split Tank contains numerous bioherms surrounded by bioclastic debris. Bain (1967:233), as a result of his study of this area, maintains: "Water was probably no deeper than 55 to 60 feet over reef crests (the reefs 'rose fifteen feet above the sea floor'). Salinity was normal and turbulence moderate."

The higher Cathedral Mountain Formation in this area consists of thin limestone beds in irregularly bedded, limy, yellowish shale abounding in Peniculauris. The occurrence is reminiscent of the Taylor Ranch Member. 
Road Canyon: This formation presents considerable lateral variation in sediment type. From the site of the Old Word Ranch to Sullivan Peak, the lowest beds of the Road Canyon are composed of biohermal masses (Plate 17: figure 2) that have well-defined outlines, rounded tops, and a thickness of 20 feet in places. The bioherms chiefly are bryozoan-sponge assemblages, but with a great variety of brachiopods occupying niches in tangled masses. This is a shallow-water environment favorable to bioherm development. A depression of the shelf submerged these bioherms and brought a cover of black limy mud (Plate 13: figure 3) over them between Appel Ranch and Sullivan Peak, except for the hills just north of Leonard Mountain. The black muds are not true basinal deposits because they contain numerous fossils and are lacking in Leiorhynchoidea and ammonites, which are common basinal fossils (as in Bone Spring Formation and South Wells Member of the Cherry Canyon Formation).

In the hills north of Leonard Mountain, the Road Canyon Formation above the basal bioherms consists largely of bioclastic limestone with very little shale or black limestone. In the bioclastic beds, scattered bioherms of Coscinophora are present (Plate 17: figures 3, 4). Some of the bioclastic beds have high percentages of fossils. In the western area of Road Canyon, fusulinids may be present in such abundance as to constitute a sand or fine gravel. This area suggests a shoal on the shelf where agitated waters winnowed out fine debris to leave fossils of all sorts as a sand or gravel (USNM $732 \mathrm{j}$ ). Some of the fossils probably were washed into the shoal from black mud areas to the east and west, because many of the species are those common in the black muds.

West of Leonard Mountain on the spur south of Sullivan Peak, the Road Canyon Formation is exceptionally thick and is composed largely of dark to black limestone that, at several levels, is replete with fossils. The dark limestones fill cavities between the bioherms at the base (Plate 17: figure 2). At the top of the Road Canyon at this place, beds of fusulinids form a limesand. Similar beds can be seen in the Del Norte Mountains.

Beds of the Road Canyon Formation in the Del Norte Mountains are thinned greatly, compared to the section at Sullivan Peak, and they fray out into the yellow shale. The sediments are mainly bioclastic limestone abounding in fusulinids. The bioclastic beds are separated by thin layers of yellowish shale like that of the Cathedral Mountain Formation. Occasional bioherms occur in the area. USNM $700 \mathrm{v}$ and $732 \mathrm{j}$ represent the topmost bed of the Road Canyon. The bed is a foot or two thick and is composed largely of fusulinids, but it contains a variety of fossils, mostly brachiopods, showing evidence of transport. Chief among the fossils is Collumatus fixatus Cooper and Grant, a richthofeniid that lived tightly fixed to the substrate. All but two of the specimens of this genus obtained by us have been broken free of their moorings. Few of them retain the coscinidium or the brachial valve. Freeing such a tightly cemented form indicates an environment of turbulent water that removed the fine debris and left only the heavier fossils.

Just beneath this terminal layer, there is a bed of fine-grained calcareous shale abounding in ammonites. This is an excellent stratigraphic marker in the Del Norte Mountains. Ammonites are so abundant as to suggest that they are a concentration of dead shells in a local, quiet shoal area.

Sediments of the Guadalupe Series.-Sedimentation in the Guadalupian of the Glass Mountains is much less complicated than that of the preceding stages. In the Word Formation, that part of the Guadalupian that concerns us, there is a thick mass of sandstone and yellowish sandy shale in the western part of the Glass Mountains and the Del Norte Mountains. These contain tongues of limestone protruding into the mass from an eastern limestone unit. The limestone tongues, or members, are in ascending order: China Tank, Willis Ranch, and Appel Ranch Members. Small but important lenses appear between the last two members. The Willis Ranch Member is the most extensively developed unit and extends from the old Word Ranch site to the west side of Gilliland Canyon. West of Gilliland Canyon its level is represented by lenses. The Appel Ranch Member extends west to the Old Willis Ranch site, but the China Tank Member ends against the Hess Ranch Horst.

Each of these members is composed of calcarenite, containing sugary quartz sand and abundant fossils. These occur concentrated in layers in which incredible numbers of specimens are packed into a small space. The fossils are not graded in size, 
and many show evidence of transportation. The smaller, tightly articulated rhynchonellids and terebratulids usually retain both valves together, but the productids and other less strongly articulated forms occur as separated valves. Some genera are represented by several species in a single bed. The epifauna usually is well preserved, and some may have been living when buried. In a few places ammonites are common, although the Word sediments are devoid of conglomerates. The one band of conglomerate attributed to the Word on the flank of the Del Norte Mountains proved to contain abundant Perrinites and other fossils of the upper Cathedral Mountain Formation. Fusulinids of large size are common and frequently are current oriented. The Willis Ranch Member may be distinguished from the others by the large amount of sand contained in it. In Gilliland Canyon (Plate 14: figure 3), stringers and layers of quartz sand are common. This is near the place where the member loses its continuity. At USNM 706e, 4.1 miles northeast of the Hess Ranch, the limestone also is very sandy. A block weighing 186 pounds yielded 5 pounds of sugary sand. In places fusulinids are abundant enough to constitute a sand. This is especially true at the level of the Willis Ranch Member at USNM 732s, at the base of the Del Norte Mountains.

The depth of water and other conditions of these members are thought to be the same. After Road Canyon time, water over the shelf deepened and sandy limestone formed on a bottom abounding in shelled animals. Either the water depth was too great or the area was too far off shore to permit biohermal development. Agitation of the water by storms or currents was sufficient to pile the shells, living and dead, into heaps and lenses. Although reef types such as Collemataria and Cyclacantharia are present, these never formed bioherms but existed in small clusters easily knocked down, broken up, and transported by storm waves and currents.

Briefly, the story of conditions in the Glass Mountains may be depicted as follows: A narrow shelf existed along the margin of the Marathon folded belt, which produced in Wolfcamp through Leonard times an epineritic environment (Krumbein, et al., 1949:1869-1872). Bioherms and zotikepia of colonial forms developed in clear, sunlit water at a modest depth from tide zone to about 120 feet. Oscillations of water level, which altered the environment to infraneritic, 120-600 feet, resulted in burial of the bioherms in limy muds or shale (Wolfcampian and Leonardian) and black muds (Road Canyon). After deposition of the Road Canyon, conditions changed: no conglomerates formed and bioherms could not develop, although the bottom had a prolific fauna, often heaped into piles or rows by waves and currents.

\section{Epifauna}

Epifauna, as used here and by others, refers to the creatures that attach themselves to brachiopods and other shells. The Strophomenida of the Glass Mountains Permian are among the most numerous animals to attach themselves to the exoskeletons of living or dead contemporaries. The young of the Orthotetacea and Derbyiacea commonly attached themselves until they were big enough to break away, then lived loose on the sea bottom. The strophalosiids, by cementing the beak and strengthening their hold with struts in the form of spines, may occupy a host for a short time or throughout life. The Productacea may or may not cement the beak, but they commonly attached to crinoid stems or other cylindrical object by means of a spiny ring (Muir-Wood and Cooper, 1960; Grant, 1963, 1968). The oldhaminids also cemented to a host, dead or alive, and may have engulfed the host completely. The richthofeniids attached to any hard object and then, in reproducing, often showered themselves with their own larvae to the extent that the older and larger shells soon were engulfed.

The small aulostegacean Cooperina and the strophalosiaceans Heteralosia and Ctenalosia were attached throughout their lives. Some of these occupied living shells, but a favored location for Cooperina was inside the dead valves of Cyclacantharia and Echinosteges (Plates 210 and 212). Such locations assured quiet water and seclusion from larger enemies. Xenosteges, in the Cathedral Mountain Formation, also used the interior of the pedicle valve of Hercosia as a favorite dwelling spot. Small specimens of Chonosteges also occupied this niche, but often it did not have room to come to full adulthood.

The shape of the host shell often determined the ultimate form of the squatter. The pedicle valve of the lyttoniid Collemataria usually has a posteriorly 
directed callus or attachment, the "flap" of Williams (1965). But if the spat settled on the concave outer surface of a productid brachial valve, the flap would have been forced to grow anteriorly rather than posteriorly, with the result that the adult Collemataria would have the irregular conical form of Eolyttonia. Similar growth aberrations occur in Hercosestria. When the spat settles on a flat or concave shell without being confined, the individual will have a broadly conical form with a large apical angle.

Although brachiopods constitute a large amount of the epifauna that attached to brachiopod shells -and by weight or rapid growth may be lethal to a live host-other animals found the abundant brachiopod shells of the Permian to be convenient habitations. Foraminifera forming long slender tubes occur frequently, especially on Composita shells. Sponges are common epifauna, especially in their early stages. Living and dead shells of Coscinophora, in the Road Canyon Formation, and of Collemataria, in the lower Cathedral Mountain Formation, contain the small ball-like beginnings of Girtyocoelia and small colonies of Fissispongia. The spiral tubes of the worm Spirorbis occur through the sequence, but they are not common. Cup corals are common epifauna, especially in the Coscinophora bioherms, such as that in the Skinner Ranch Formation at USNM 733j and in the Road Canyon Formation at USNM 709c and 710u. Cup corals attached to Bryorhynchus (Plate 547: figures 38-40) occur frequently in the Bell Canyon Formation (Rader Member) at USNM 725f. The corals generally attached to the commissural edge of either valve on the side or front, suggesting that the brachiopod had an oblique living position. In one instance, the coral is more than twice the size of the brachiopod and engulfs part of the commissure, permanently sealing it.

A variety of bryozoans attach to brachiopod shells. These may be funnel-shaped fenestellids, branching forms, or more massive types. In a number of examples the bryozoans have grown over the margin in such a way as to seal it. These may have been dead shells to begin with, but it is also possible that the weight of the bryozoan colony may have suffocated the brachiopod or that an already attached bryozoan just continued to grow after the death of the brachiopod. In the Road Canyon Formation (USNM 702c) plates of a bar- nacle like Turrilepas are fairly common; this animal probably used some of the Brachiopoda as host.

\section{Accidents of Settling of Larvae}

Although it has been demonstrated that the larvae of some marine animals have the ability to select a settling spot favorable to them, evidence from the Glass Mountains suggests that some of the spots selected may have been lethal. The favored habitat of the brachiopod is in still water, in grottoes, or in niches that afford protection as well as quiet. In two examples cited below, the quest for a favorable spot led the brachiopod to its doom. Specimen 150820 (USNM) is a large lyttoniid, Collemataria, with the richthofeniid Cyclacantharia attached to its ventral surface. The Cyclacantharia is anchored by abundant rhizoid spines that make a veritable thicket around the cup. Nestled at the base of the cup and completely surrounded by spines on three sides, there is a small specimen of Meekella skenoides attached by its ventral surface (Plate 116: figure 8). The specimen grew large enough to butt against one of the lower spines. This and the proximity of the anterior margin of the dorsal valve to the base of the richthofeniid make it impossible for the brachial valve of the Meekella to have opened. Starvation or suffocation must have been the result.

The other specimen concerns a trapped Composita. A larva of Composita went through the mesh of the coscinidium of Hercosestria and attached to the brachial valve. Living was probably high for awhile, because the Composita had the advantage of the feeding streams of Hercosestria and must have grown fairly rapidly. But, alas, it became too big for its confined quarters and must have prevented both brachiopods from feeding normally. The death of the host as well as that of the intruder resulted. It is doubtful that the Composita could have attached itself or lived in the situation where it was found if Hercosestria had the valveflapping feeding labits postulated by Rudwick (1961) (see Plate 292: figures 1, 2; see also Plate 229: figure 34 for a trapped Derbyia).

\section{Color}

Color markings are regarded by Richter (1919) as evidence of shallow water. Several remarkable. 
specimens preserving their color patterns were taken from the Cathedral Mountain, Road Canyon, and Word formations. Color bands frequently have been seen on Dielasma or Beecheria in the Mississippian, but color-banded specimens have not been described from the Pennsylvanian. At USNM 702c and 707e in the Road Canyon Formation and at USNM 706e in the Word Formation, numerous specimens of Dielasma were found with outwardly curved radial bands of color. These originate near the beak and curve laterally to the margins. The bands are now dark brown, but probably they were red or crimson. The color pattern is reminiscent of that of modern Laqueus rubellus (Sowerby), which has curving red bands (see Plates 749, 750, 753).

In addition to the specimens of Dielasma, a brachial valve of Composita imbricata from USNM $721 \mathrm{u}$ in the Cathedral Mountain Formation has straight dark radii that extend from the beak to the anterior margin. They are very narrow at the beak, but they widen to the margin, where some have a width of about $2 \mathrm{~mm}$ (Plate 658: figure 31). Another genus not hitherto known to have color bands is Neophricadothyris (USNM spécimen 155121). These bands are like the preceding except that they are confined to the anterior half. They are direct, without any curvature (see Plate 636).

\section{Malformations}

Brachiopods are gregarious animals and frequently live clustered together. Some modern genera, such as Laqueus and Liothyrella, may suggest bunches of grapes when different generations festoon the adults of previous generations. Such gregariousness causes extreme crowding, and the crowding prevents many specimens from growing normally. Specimens malformed by crowding are common in our present seas. They were even more abundant in the Permian, when large numbers of the brachiopods cemented to the substrate or to their parents. Malformations especially are common in the bioherms formed by Hercosia, Hercosestria, and the clusters of Cyclacantharia. The apical angles of specimens of the same species of Hercosia often vary by as much as 70 degrees. Specimens that attempt to grow between robust adults commonly are elongated greatly and may be as narrow as a lead pencil.
Scacchinella, which is the foremost brachiopod bioherm builder, forms dense clusters in which many specimens are deformed. These commonly are small and narrow, but they may be twisted in any direction, and one cup (USNM specimen $15366 \mathrm{fg}$ ) is bent at an angle of 45 degrees. This may have resulted from part of the biohermal mass toppling over and the brachiopod being forced to grow in another direction. Another specimen from the same bioherm is twisted at a right angle. If the lower part of the pedicle valve of this specimen is held in a horizontal position, the upper half is at right angles to the lower half. Many other specimens from this bioherm (USNM 720e) are also distorted, but in less extreme ways (see Plate 278).

Impingement against an unyielding object, such as a branch of a bryozoan or a stout productid spine, can cause malformation. A specimen of Edriosteges multispinosus Muri-Wood and Cooper (USNM specimen 154183d) has a deep reentrant in the anterior margin that divides the anterior into two strong lobes. This may have resulted from impinging against a branch of a bryozoan colony (Plate 218: figures 12-20). The way such a deformation may be brought about is shown by a specimen of Rhamnaria tenuispinosa, new species (USNM specimen $154217 \mathrm{c}$ ), which is attached to a branching bryozoan in such a way that one branch has become embedded in the shell, producing a deep groove and anterior bilobation (Plate 261: figures 36,37 ).

Another source of such deformation is shown by a specimen of Rhamnaria kingorum Muir-Wood and Cooper, which found refuge on the concave surface of the brachial valve of Echinauris lateralis Muir-Wood and Cooper. The Rhamnaria spat has grown against one of the strong brachial spines that grow across the concave valve, presumably as defense against settling of larvae. The anterior margin of the Rhamnaria already has become anteriorly bilobate (see Plate 264: figure 22).

\section{Pathology}

Occasional specimens indicate possible pathological conditions. A specimen of Yakovlevia (USNM specimen 153979h; Plate 473: figure 17) shows a malformation of the muscle scar on the left (observer's) side. Not only is the left side affected, but also the right side is abnormal. The 
diductor scar on the right side occupies its normal position, but also it extends over the median ridge that normally is occupied by the adductor scars and usually separates the adductors. The adductor impressions lie in the left side of the median ridge, and much of the left diductor scar is aborted and misshapen. Similar deformities have been seen in the Devonian in specimens of Stropheodonta (USNM specimen 140852a), from the Romney Formation of West Virginia, and of Cariniferella tioga (Hall), from the Chemung Group of New York (Kaiser, 1964). As with Yakovlevia, the exterior of the pathological specimens is without injury; the deformation is concerned entirely with the interior.

Another pathological condition is illustrated by the cardinal process of a large Tropidelasma $\mathrm{cul}$ menatum Cooper and Grant, from the Neal Ranch Formation at USNM 70lh. The prong on the observer's right is aborted, and an excessive amount of calcareous tissue, in the form of a shallow cup, is laid around the anterior side of the prong. There is no sign of breakage of the prong, and the stub shows part of the characteristic slit that normally bears the diductor muscles (Plate 52: figure 28).

\section{Borings}

Shells with borings of one kind or another are fairly frequent in the Glass Mountains Permian. The rarest type is the perfectly round hole attributed to boring gastropods. A specimen of Torynechus caelatus Cooper and Grant from USNM 702 (USNM specimen 152595a) has both valves bored. The hole is slightly more than a millimeter in diameter and seems not to be bevelled. The boring on each valve is near the middle and consequently through the thinnest part of the shell.

Schlaudt and Young (1960) and Rodda and Fisher (1962) described and illustrated burrows from the Glass Mountains Permian that are attributed to acrothoracic barnacles. Schlaudt and Young stated that, if the burrows penetrated the shell, they were not produced by barnacles, but these authors speculated that the thin protective film of shell over the inside of the burrows was not preserved during silicification or that it was lost during the etching process. Numerous specimens from the Glass Mountains show a thin protective film, indicating that the brachiopod defended itself against the borer. Some valves are riddled almost completely by these borings, but the shells obviously were dead. Completely riddled shells are fairly common around bioherms such as that at USNM 733j in the Sullivan Peak Member (Plate 56: figure 21; see also Tomlinson, 1969).

A specimen of Derbyia texta, new species (USNM specimen 151176; Plate 87: figures 1, 2) and one of Meekella skenoides Girty (USNM specimen 153538) illustrate the reaction of the brachiopod animal to the boring barnacles. The larger borings in the Derbyia are about $0.75 \mathrm{~mm}$ wide and about $2.0 \mathrm{~mm}$ long, elliptical in outline. On the interior the brachiopod has formed a series of moundlike blisters to protect itself from the borers. None of the blisters is broken or open on the inside. Several of the blisters inside the Meekella are open, but the openings are irregular, and they suggest later breakage rather than openings produced by the boring organism.

Another type of boring is less prevalent than the preceding, and, in at least one instance, it produced a response from the host. These borings are minute, and they may be confused with the exopuncta of Rhipidomella, in the shells of which they occur. The borings are most prevalent near the margins of the valves, and they can be detected by their nearly vertical penetration, unlike that of the exopuncta, which conform with the radial ornament and which are strongly oblique and do not affect the inner layer. The borings may penetrate the inner layer and may even protrude into the shell as points where the animal has laid shell around them. Many of the borings are open on the inside of the shell, but the thin protective coverings were probably not preserved (Plate 666; figures 28,29 ).

A boring suggestive of the preceding occurs in Phrenophoria subcarinata Cooper and Grant (USNM specimen 148385g; Plate 553: figures 3539). This is a minute opening on the margin that leads into a slightly elevated blister and then a needlelike tube about $0.75 \mathrm{~mm}$ in length. The tube is not open at the end, but this may be due to silicification of the fine point. This kind suggests the endoparasitic phoronid described in Devonian brachiopods by Biernat (1961).

A tubular boring quite unlike those described above occurs in a specimen of Enteletes wordensis R. E. King. The boring is in the ventral valve of 
USNM specimen 153809r (Plate 686: figures 1113). The first hole appears on the right side of the shell on the margin, not quite halfway to the anterior. The hole on the exterior is $2.5 \mathrm{~mm}$ in diameter and produces a tube $7 \mathrm{~mm}$ long on the inside. This is jaggedly broken, but, when projected obliquely across the shell, it coincides perfectly with another tube bored on the costa that bounds the left side of the fold. The opening here is $2 \mathrm{~mm}$ wide, but the tube is only $4 \mathrm{~mm}$ long into the shell. This tube is open, but the edges are rounded and smoothed, suggesting that healing over the whole may have started. The borings are perfectly smooth inside.

\section{Faunas and Correlations of Glass Mountains Formations}

Faunal lists given in this section include some nomina nuda. This unfortunate circumstance comes about because of the economics of publishing such an extensive monograph. Originally it was intended that the entire work would appear at one time, but slender budgets for publication require the appearance of the monograph in several parts at varying intervals. To delete the nomina nuda would destroy or make ineffective some of our arguments on age, correlation, and faunal relationships. The nomina nuda will be validated in subsequent volumes.

\section{Gaptank Faunas}

Any discussion of the faunas of the Glass Mountains must begin with the Gaptank fauna from which the Permian species were descended. Some of the characteristic elements of the Permian fauna appear first in the Gaptank (exclusive of the $U d$ denites-bearing Shale Member). Of these, Parenteletes and Diplanus were taken from the Gaptank bed 10 of P. B. King, said to be Upper Canyon $=$ late Missourian, about 2 miles east of Gap Tank. Neither of these brachiopods is abundant, but the Parenteletes, usually crushed, is fairly common. Cryptacanthia, more typically Pennsylvanian but certainly the progenitor of Glossothyropsis, is fairly common at this place (USNM 700a; USGS 6705, 7085, 7088; P. B. King, 1937:77). Another common form in this bed is Teguliferina, which is an abundant Wolfcampian fossil. Other precursors of the Permian are huge Derbyia and Reticulatia. The associates of these Permian heralds are chat acteristic Pennsylvanian types.

In the western part of the Marathon Basin near the Arnold Ranch, other Permian types have been taken from a "block," possibly a displaced piece, but more probably a bioherm. This appears on P. B. King's map as "loc. b," but in reality it is locality C of his text (1938:81). The famous Prouddenites ledge on the map, mistakenly labelled "loc. C.," is 0.5 mile south of the brachiopod bioherm in question. The bioherm (USNM 700g) is about 1.25 miles due south of Arnold Ranch (Monument Spring quadrangle; Plate 16: figure 1). It consists of a large limestone block in Gaptank shale, composed of a mass of the coral Amplexicarinia delicata Ross and Ross and algae, with brachiopods scattered throughout. These include Scacchinella, Limbella, and a large Teguliferina, suggesting $T$. boesei (R. E. King). The Scacchinella is the most primitive species of that genus known, as it has no vesicular shell tissue in the apex of the pedicle valve. Its outer form is very similar to Derbyella Grabau. The Limbella species is small, but otherwise it is characteristic of the genus. The Teguliferina attains as large a size as any seen in definite Permian rocks.

The occurrence of these fossils is anomalous. The limestone block in which they occur is the only one of its kind in that part of the section. If it is an exotic block, its advanced fauna makes it difficult to postulate its place of origin or to explain its present location. The composition of the rock with its numerous corals and algae suggests a bioherm, rather than an exotic piece.

The block is similar to the one that produced the Prouddenites ammonite fauna, which lies 0.5 mile to the south and has been regarded as in place. Further evidence as to the age of the block containing Scacchinella is a single fusulinid specimen, which has been pronounced Virgilian in age by Garner Wilde (letter of 20 March 1962). P. B. King suggested that the fauna identified by Girty from the same locality as this block (locality $\mathrm{b}=\mathrm{C}$; King, 1938:81) is similar to that of bed 10 of the Gaptank type section. This bed at the east end of the mountains produced Parenteletes, not present south of the Arnold Ranch, but it is dated generally on its fusulinids and molluses as Missourian 


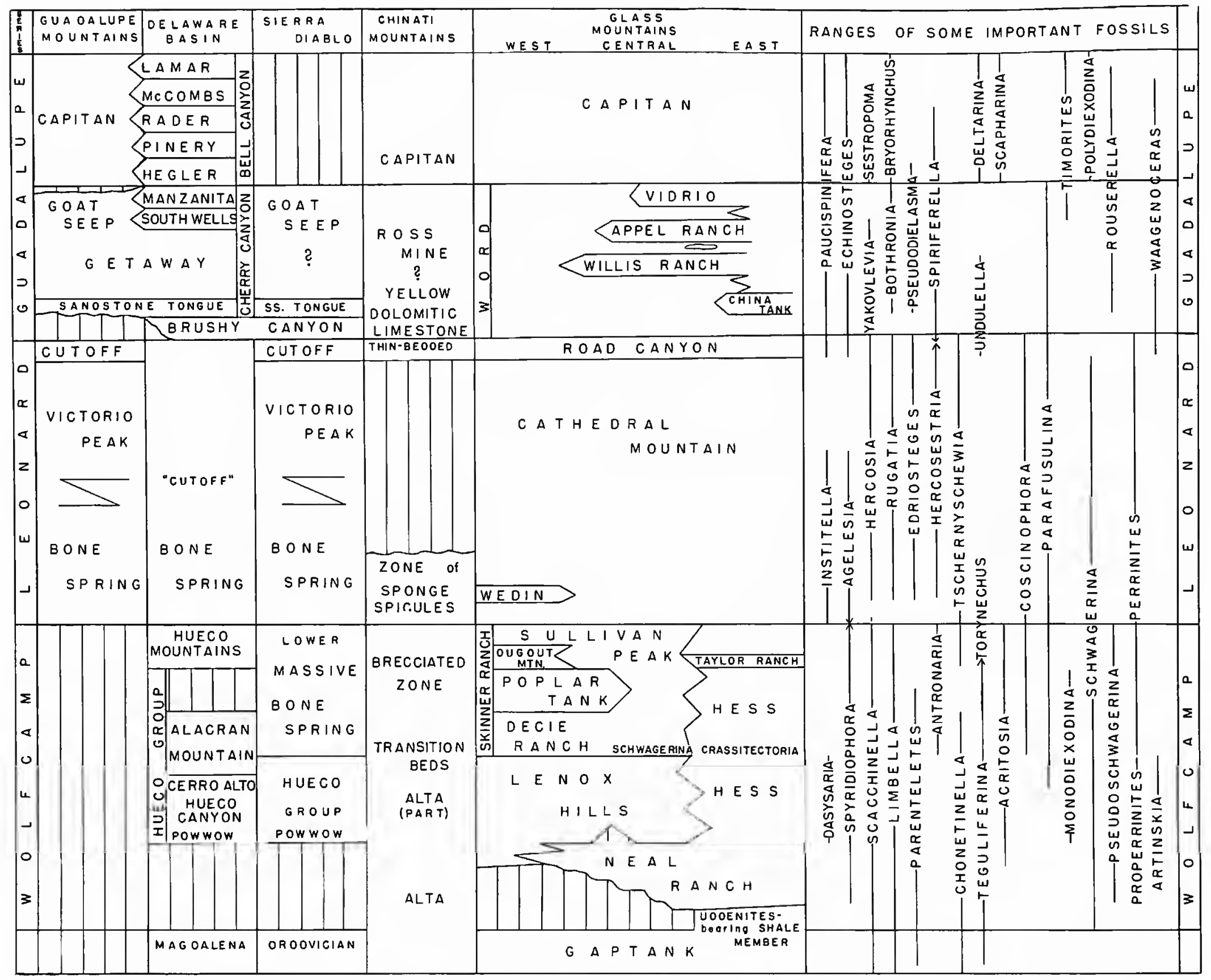

Figure 28.-Chart showing correlation of Permian formations in West Texas.

(Upper Canyon), a far older date than indicated by the Virgilian fusulinid in the Gaptank block or by its brachiopod fauna.

In the Pennsylvanian of north-central Texas, the early Cisco (Graham Formation) contains Permian elements such as Waagenoconcha and Martinia. Some workers may object to the latter genus being regarded as a Permian element, but, except for this occurrence, it is not known from American Pennsylvanian formations (although it is rather rare in the American Mississippian). Consequently, its appearance in the late Pennsylvanian heralds a Permian development. Poikilosakos from the Graham of north-central Texas also is a prophetic element foreshadowing the considerable development of
Pseudoleptodus in the Neal Ranch Formation and younger parts of the Permian. Gypospirifer, new genus, like Spirifer condor (d'Orbigny), of the Copacabana Formation in the Permian of Bolivia, occurs in the Cisco (Wayland Shale, USNM 728x).

A significant Permian element said to appear in the Gaptank Formation is Spyridiophora, reported as coming from bed 3 of the Gaptank (R. E. King, 1931:71), about 1 mile south of Gap Tank. The specimen was identified as Productus gratiosus occidentalis Schellwien by R. E. King and reported as occurring in a part of the section with Mesolobus of Missourian age. Inasmuch as Spyridiophora is not yet known anywhere else from the higher Pennsylvanian, it was suspected that the specimen 
might not have been taken at the place from which it was reported. The matrix of the specimen was searched for fusulinids, and those found were submitted to Mr. Garner Wilde, who reported them to be Wolfcampian species. This clearly indicates that the specimen is not from the Pennsylvanian and that Spyridiophora has its roots in the Permian.

Fifty-six genera pass from the Gaptank Formation into the overlying Permian. Some of these have not yet been found in the Uddenites-bearing Shale Member, but they do appear higher. In the list below, starred genera $\left({ }^{*}\right)$ are those passing from the Pennsylvanian to become the hard core of the Permian (Wolfcampian) fauna; genera marked with a degree sign $\left(^{\circ}\right)$ do not survive beyond the end of the Wolfcampian as defined herein; unmarked genera extend into, or terminate by, the end of the Leonardian. Meekella, for example, generally is not common in the Pennsylvanian, but it becomes one of the most frequent Permian forms in many environments. These Pennsylvanian elements of the Permian are: Antiquatonia ${ }^{\lrcorner}$, Beecheria $^{\circ}$, Calliprotonia ${ }^{\circ}$, Cancrinella*, Chonetinella, Cleiothyridina*, Composita*, Cooperina*, Crurithyris*, Cryptacanthia ${ }^{\circ}$ Derbyia*, Derbyoides $^{\circ}$, Dielasma* $^{*}$ Diplanus, Echinaria ${ }^{\circ}$, Echinauris*, Enteletes*, Eridmatus ${ }^{*}$, Fimbrinia ${ }^{*}$, Goniarina, Heteralosia*, Hustedia*, Hystriculina ${ }^{\circ}$, Isogramma, Juresania ${ }^{\circ}, K_{\text {Kolowskia }}{ }^{,}, K u$ torginella, Limbella ${ }^{\circ}$ Linoproductus*, Lissochonetes ${ }^{\circ}$, Martinia*, Neochonetes $^{\circ}$, Phricodothyris* [Con,drathyris?], Neospirifer*, Nudauris ${ }^{*}$, Orthotichia ${ }^{\circ}$, Parenteletes ${ }^{\circ}$ Petrocrania*, Poikilosakos ${ }^{\circ}$, Pontisia*, Psilocamara $^{\circ}, Q^{\text {Quadrochonetes }}{ }^{\circ}$, Reticulariina*, Reticulatia , Rhipidomella, Rhynchopora*, Roemerella, Scacchinella*, Schuchertella ${ }^{\circ}$, Gypospirifer ${ }^{\circ}$, Stenoscisma*, Streptorhynchus [correct genus uncertain], Sulcataria ${ }^{\circ}$, Teguliferina*, Waagenoconcha*, and Wellerella.

\section{WOLFCAMP FAunas}

Uddenites-bearing Shale Member.-The brachiopod fauna of the Uddenites-bearing Shale Member was listed by R. E. King (1931:147-150), who recognized the truly Permian elements in it as well as those with a Pennsylvanian aspect. Our collections from this zone unfortunately are not extensive, but we are able to offer some revision of this fauna and to emphasize its Permian flavor. Little attention has been paid to the typically Permian kinds of brachiopods (and some other phyla) in the Uddenites-bearing Shale Member in spite of the fact that R. E. King made an excellent discussion of them and that P. B. King later (1937:78) repeated his brother's analysis.

Innovations in the Uddenites-bearing Shale Member fauna are few. Orthotetella appears for the first time, as does Tropidelasma. Martinia is reported by $\mathbf{R}$. E. King, but we did not find it. Although Kochiproductus is reported in the Pennsylvanian of Peru (as Buxtonia) by Chronic (1953: $83,84)$, it appears so far as known, for the first time, in the Glass Mountains in the Uddenitesbearing Shale Member. King lists 36 species, and we record 45 species, from the Uddenites-bearing Shale Member. Combining the two lists, there are 54 species in all, many of which are strictly Permian types. For some of the forms assigned by $\mathrm{R}$. E. King to Pennsylvanian species, we have found it necessary to erect new names. The brachiopod fauna is distinctive, and we think its Permian affinities are sufficiently striking to use it as the base of the Wolfcampian in the Glass Mountains as did R. E. King (1931).

The 54 species in the combined list are distributed among 41 genera, of which 16 are definite Permian types, that is, they have their acme in the Permian: Parenteletes, Cenorhynchia, Diplanus, Tropidelasma, Orthotetella, Teguliferina, Pontisia, Scacchinella, Echinauris, Limbella, Kochiproductus, Kutorginella, Waagenoconcha, Gypospirifer, Martina, and huge forms of Meekella. In addition to these, three others may be considered as Permian forms: Fimbrinia, Nudauris (Productus semistriatus King, not Meek, whose type-species is a Pennsylvanian form), and Chonetinella. These last three and Kutorginella occur in the late Pennsylvanian. The first is rare in either period, the second is rare in the Pennsylvanian so far as known, the third becomes most abundant in the Early Permian, while the last is commonest in the Leonardian.

According to R. E. King, 31 of his 36 listed species pass into the overlying Neal Ranch Formation. Of the 33 listed by us, 14 also are identified in the Neal Ranch Formation: Chonetinella biplicata (R. E. King), C. spinolirata (R. E. King), Diplanus redactus, new species, Hystriculina ventroplana, new species, Echinauris subquadrata, new species, 
Kutorginella uddeni, new species, Limbella wolfcampensis (R. E. King), Gypospirifer anancites, new species, Meekella texana R. E. King, Pontisia kingi?, new species, Rhipidomella miscella, new species, Rhynchopora molina, new species, Teguliferina boesei (R. E. King), and Waagenoconcha prophetica, new species. There is no faunal break of any consequence. Innovations and expansions of stocks passing from the Uddenites-bearing Shale Member occur in the overlying Neal Ranch Formation.

Age: We take the presence in this shale member of Parenteletes, Limbella, Scacchinella, Waagenoconcha, Kochiproductus, and Gypospirifer as indicating a Permian age for these beds. The first three occur in the Trogkofel Limestone of the Carnic Alps; the last three occur in the Permian (Copacabana Formation) of Peru; outside the United States, Scacchinella is known only from lower Permian rocks. This is also true of Parenteletes, which occurs in Permian formations in Sicily, Japan, and China. An aulostegid strongly suggestive of Limbella occurs in the Trogkofel Limestone of the Carnic Alps (Productus cancriniformis of Schellwien, not Tschernyschew). Waagenoconcha is regarded widely as a Permian indicator in the United States (Knight, 1940:1129). Along with these brachiopods, two specimens of Omphalotrochus, also regarded as an important Permian guide, were taken from the Uddenites-bearing Shale Member (Yochelson, 1954).

Correlation: The correlation of this shale member has been confused for years because proponents using data from different phyla are in disagreement. The ammonites, fusulinids, and brachiopods indicate different ages to their practitioners, although the differences gradually are coming to be semantic rather than substantive. The ammonites at first were regarded as Permian by Böse (1917) and Smith (1929) but were transferred to Late Pennsylvanian by Plummer and Scott (1937:388) because of identity with species in the Cisco Group of north-central Texas. The fusulinids generally have been taken to indicate a late Pennsylvanian age, but Bostwick (1962), claiming to have discovered Schwagerina in the Uddenites-bearing Shale Member, advocates a Permian age for it.

Presence of Omphalotrochus in the member suggests a Permian age as argued by Knight (1940) and Yochelson (1954).
On the basis of brachiopods, R. E. King (1931:6) correlated the Uddenites-bearing Shale Member with parts of the Permian, citing the faunal similarity to the Copacabana beds of Bolivia and the Trogkofelschichten of Yugoslavia. Our findings indicate a closer similarity to the Permian of Bolivia than to that of Yugoslavia, which in our opinion correlates with Neal Ranch and Lenox Hills Formations rather than with the Copacabana.

Despite the absence of Scacchinella and other reefal types from the Copacabana of Bolivia, the correlation of the fauna of this formation with that of the Uddenites-bearing Shale Member is tenable. Actually, few typically Permian genera of brachiopods occur in the Copacabana fauna: Productus boliviensis, Kozlowskia capaci (d'Orbigny), Kochiproductus peruvianus (d'Orbigny), Waagenoconcha humboldti (d'Orbigny), and Gypospirifer condor (d'Orbigny). Forms similar to these occur in the Uddenites-bearing Shale Member. In addition, the following unusual Copacabana types also are found in the Uddenites-bearing Shale Member: Hystriculina, Reticulatia, Cancrinella, Fimbrinia, Echinauris boulei-type, Orthotichia, and Rhynchopora. Some of these also occur in the Cisco Group of the Upper Pennsylvanian. Some of the species of these genera are very similar in the two levels under consideration. The majority of common genera usually found in the upper Paleozoic are also specifically close in the formations being considered.

Neal Ranch Formation.-This formation brings more Permian elements into Texas to mingle with those inherited from the Uddenites-bearing Shale Member and with these persistent, transient forms extending from the Pennsylvanian. First appearances are: Altiplecus, Atelestegastus, Camarelasma, Hemileurus, Hypopsia, Lepidocrania, Nothopindax, Acosarina, Pseudoleptodus, Eolyttonia, Ctenalosia, Geyerella, Striatifera, Spyridiophora, and Spuriosa. The following genera, all of them rare, are confined to the Neal Ranch Formation according to our present knowledge: Atelestegastus, Camarelasma, Hemileurus, Hypopsia, and Nothopindax, The genus Spuriosa also occurs in the Hueco Canyon Formation. Its Neal Ranch occurrence probably is earlier. A few genera coming in from the underlying Uddenites-bearing Shale Member or the Pennsylvanian have their last appearance in the Neal Ranch Formation: Beecheria, Eridmatus, 
Juresania, Lissochonetes, Psilocamara, and Neochonetes. The remainder of the fauna is composed of a variety of orthotetids, derbyids, productids, lyttoniids, spiriferids, and athyridids. The orthotetids and derbyids are exceptionally well developed in the Neal Ranch. Some bioherms or small patch reefs almost completely comprise one or more of their genera. The bioherm at USNM $701 \mathrm{~h}$ contained great quantities of Geyerella, while those at USNM 701d were replete with Derbyia of several species. Great abundance of Meekella characterizes USNM 701g. Of the productids, special mention should be made of the abundance of Striatifera at USNM 721g, where specimens are scattered among bryozoan colonies that form a zotikepium.

Of particular interest and importance in the Neal Ranch Formation is the budding of the Oldhaminidina, which flower later in the Leonardian. Pseudoleptodus appears in fair abundance at USNM $721 \mathrm{~g}$ and $727 \mathrm{e}$, where it occurs attached to bryozoans and Striatifera. Eolyttonia usually is rare, but some local patches rich in this genus were discovered. The earliest oldhaminid patch occurs at USNM 722x either on, or in, the flank of King's bed 2 or Gray Limestone. Here, the specimens often are engulfed by concentrically banded limestone of probable algal origin. The large bioherm at USNM 701c has Eolyttonia of exceptionally large size.

Age: In correlating the Neal Ranch Formation is is necessary first to establish the age of the Gray Limestone Member, which P. B. King placed in the Wolfcamp Formation but which Ross (1963a: 13, 45) returned to the Gaptank. The Uddenitesbearing Shale Member immediately underlies the Gray Limestone Member, which forms a conspicuous lenticular mass in the center of the Wolf Camp Hills. Although this member traditionally was a part of the Wolfcamp Formation, Ross placed it at the top of the Gaptank Formation on the basis of certain fusulinids. We are unable to agree with this assignment because the brachiopods and ammonites we have collected from bed 2 indicate a Permian age. The collection from USNM 701, from the upper 15 feet of the member as exposed in Geologists Canyon opposite the first arroyo from the north in about the center of the hills, includes many Permian genera, such as: Diplanus, Geyerella, Hypopsia, Orthotetella, Eolyttonia, Cooperina, Limbella, Spyridiophora, Waagenoconcha, Paren- teletes, Altiplecus, and Camarelasma. In addition, species of Enteletes, Derbyia, Meekella, Cancrinella, Neochonetes, Crurithyris, Orthotichia, and Tropidelasma occur in the Gray Limestone and also extend into the overlying beds of the Neal Ranch Formation.

The brachiopods cited clearly indicate a Permian age, and the ammonites tell the same story. From the uppermost part of the member (USNM 701), Artinskia artiensis Grünewaldt was taken along with species of Eoasianites, Neopronorites, and Marathonites.

The fusulinid evidence for the age of this member is equivocal. P. B. King (1942:647) states, in referring to the Uddenites-bearing Shale Member, that the "overlying gray limestone bed at the base of the Wolfcamp formation (beds 2 and 3) contains a few specimens of Schwagerina." In footnote 182 on the page following the above reference, King states: "The occurrence of Schwagerina in the gray limestone has not been mentioned in any publication, and was reported to the writer by J. W. Skinner, September, 1938." The evidence of the brachiopods and ammonoids indicates a Permian age for this member. This evidence of the fusulinids needs further testing.

Most of the brachiopods from the Neal Ranch Formation come from the middle part, i.e., beds 12-14 of P. B. King (= beds 9-12 of Cooper). Most of the fossils from these beds are from bioherms and thus are restricted in distribution. Except for the lower part of the Cibolo Formation in the Chinati Mountains, we know of no Wolfcampian like the Neal Ranch. Some Neal Ranch elements such as Orthotetella, Acosarina, and Eolyttonia occur in the lower Bone Spring Formation, but they are regarded, on the basis of their associates, to be younger than the Neal Ranch.

The most significant genera of the Neal Ranch Formation for use in correlation are: Acritosia, Derbyoides, Diplanus, Eolyttonia, Geyerella, Limbella, Nudauris, Orthotichia, Parenteletes, Reticulatia, Spyridiophora, and Teguliferina. It will be noted that some of this list (numbers 3, 6, 8-11) already have been cited as leading members of the fauna of the Uddenites-bearing Shale Member. Most genera of the above list occur in the bioherms. Orthotichia, Nudauris, and Reticulatia also occur in the shales; the last genus mentioned seldom is seen in bioherms. Derbyoides and Reticulatia are 
more common in the midwest in the more shaly facies of the Early Permian.

Correlation: In the Permian correlation chart of the National Research Council (Dunbar, et al., 1960), the Neal Ranch Formation is correlated either by position, ammonites, or fusulinids, with formations elsewhere in the United States. The Neal Ranch brachiopods predominantly consist of forms confined to bioherms and a few others that occur in shale. No bioherms comparable to those of the Neal Ranch are known in Wolfcampian sediments in the Midcontinent or elsewhere. Consequently, correlation must be based on those forms of a facies comparable to that containing the genera that occur in the shales or nonbiohermal limestone.

Another difficulty in correlation between the Glass Mountains and other areas is the fact that the brachiopods of the Pennsylvanian and Permian are known so poorly. No recent monographic work has been done on the brachiopods of the Pennsylvanian and Permian of Oklahoma, Kansas, and Texas. The faunas of the Council Grove and Chase Groups scarcely are known and the same is true of those of the Pueblo, Moran, Putnam, and Admiral Formations of north-central Texas. A few species from the Permian of Nebraska are described by Dunbar and Condra (1932), but nothing comprehensive yet has been prepared.

The few species listed here as common to the Midcontinent region and the Glass Mountains do not help with definitive correlation. Although species of Hystriculina, Echinaria, Antiquatonia, Kozlowskia, Kutorginella, Neochonetes, Reticulatia, Neospirifer, and Juresania occur in the shales of the Neal Ranch Formation, all but two of the species are different from those of the Admire and Council Grove Groups in Kansas, Oklahoma, and Nebraska, or from those of the Permian formations of northcentral Texas. The brachiopods of the latter are more like those of the Midwest than they are like Neal Ranch brachiopods. On the basis of their fusulinids and ammonites, these Midcontinent formations are placed here in the Wolfcampian, but they are not correlated except in a general way.

Lenox Hills Formation.-This formation has not yet yielded a good supply of brachiopods or other fossils. Most of the formation is composed of conglomerate in the western part of the mountains and of dolomites, red shales, and conglomerate in the eastern part. In the Lenox Hills and Dugout
Mountain a conspicuous shale occurs high in the Lenox Hills Formation, but intensive search has yielded only a few ammonites, gastropods, brachiopods, and some fusulinids.

A problem exists as to whether or not the beds identified as Neal Ranch by Ross (1963a:24, pl. 1), which are rich in bioherms just east of hill 5300 , are in reality a part of the Lenox Hills Formation (our USNM 715b). As noted above, the conglomerate of the Lenox Hills interfingers with these supposed Neal Ranch limestones. The brachiopod fauna in them is that of the Neal Ranch Formation (beds $12-14$ of P. B. King $=$ beds $9-12$ of Cooper), but we believe that the field relations prove these limestones to be part of the Lenox Hills Formation. The Lenox Hills Formation in Leonard Mountain and some beds of the Hess Ranch Horst yielded a few specimens. Thin shales at the top of the Lenox Hills Formation just east of the Hess Ranch Horst (R. E. King $196=$ USNM 716r) yielded species not seen elsewhere. We did not find any silicified limestone in the Lenox Hills Formation.

The only innovation in the Lenox Hills Formation is the genus Dasysaria. In the Glass Mountains this genus is confined to that formation. It is very rare in the Glass Mountains, but it is abundant. in the Hueco Canyon Formation and in other parts of the Hueco Group in the Sierra Diablo, Hueco, and Franklin Mountains. It also is common in the Chase Group of Kansas and the Putnam and Admiral Formations of north-central Texas.

Two genera terminate in the Lenox Hills Formation: Sulcataria and Reticulatia. The first is a poorly known and rare chonetid, first seen in the lower Cisco and in the Neal Ranch Formation. The second is uncommon in the Glass Mountains, but it is frequent in the Midcontinent region and north-central Texas. Parenteletes, another diagnostic genus of the Lenox Hills, is not common in the Glass Mountains, but it attains a large size in the Neal Ranch Formation. It is very rare in the Lenox Hills Formation, but it was discovered in the base of the Poplar Tank Member of the Skinner Ranch Formation.

The large detached slide block of the Lenox Hills Formation, about one-third the height of Leonard Mountain on the southeast nose, is a source of Lenox Hills fossils (USNM 705m). These rocks are biohermal in part, but mainly a coarse calcarenite or rudite. From them, we have taken 
Geyerella equal in size to those of the Decie Ranch Member as well as large conical Eolyttonia. Other associated species are robust, and all strongly resemble those of the Decie Ranch Member of the Skinner Ranch Formation.

Of special interest in the Lenox Hills Formation on Leonard Mountain, just above the conglomerate, is the bioherm containing Scacchinella, Parenteletes, and Tropidelasma (USNM 705k). This is on the southeast nose of the mountain, and the horizon represented was mistaken early for the base of the Hess Formation. This is the only occurrence of abundant Scacchinella yet found in the Lenox Hills Formation. A few valves have been taken elsewhere, but the genus is rare in this formation.

Correlation of the Lenox Hills Formation with strata elsewhere in the United States is easier and more reliable than that of the Neal Ranch fauna. Fusulinids, ammonites, and brachiopods of the Lenox Hills seem to combine to tell essentially the same story. Dasysaria, restricted to the Lenox Hills in the Glass Mountains, is abundant in the Putnam and Admiral Formations, the Wichita Group, and the Hueco Canyon Formation. Reticulatia huecoensis (R. E. King) occurs in the uppermost Lenox Hills (King $196=$ USNM 716r). A Stenoscisma related to S. hueconianum (Girty) is present in the Glass Mountains and relates part of the Lenox Hills to the Alacran Mountain Formation of the upper part of the Hueco Group. Species of NeOspirifer, Echinauris, Nudauris, and Kutorginella are present in the Glass and Hueco Mountains. Kochiproductus is common in the Hueco Canyon Formation, but it has not yet been found in the Lenox Hills Formation, although it should be expected. Williams (1963:31), on the basis of fusulinids, correlates most of the Hueco Group with the Lenox Hills Formation, but he assigns the part of the Alacran Mountain Formation that contains Schwagerina crassitectoria Dunbar and Skinner to the Leonardian. The brachiopods of the Hueco Group are a fairly uniform lot, and probably they are correlated best with the entire Lenox Hills.

SKInNer RANCH Formation.-This formation in the western part of the Glass Mountains has three members, but it is undivided eastward from hill 5021. Each of the members has its own fauna and history. This is true of the undivided formation as well; the important events in each are mentioned below. In the Skinner Ranch Formation, certain persistent, transient elements from the Pennsylvanian finally are eliminated, but strong Wolfcampian flavor is maintained throughout the formation.

Decie Ranch Member: A few newcomers appear in this otherwise largely Wolfcampian assemblage: Acolosia, Chonosteges, Coscinophora, Cyclacantharia, Antronaria, Cartorhium, Oncosarina; Rhamnaria, Rugaria, Thamnosia. The remainder of the 29 genera of the Decie Ranch fauna were inherited from the Lenox Hills fauna.

A remarkable feature of this assemblage is the large size attained by many of its members. Scacchinella attains a length of 7 inches; Derbyia is 3-4 inches in width; Eolyttonia reaches the proportions of a teacup; Geyerella, Kochiproductus, Coscinophora, and Tropidelasma are all large forms. Perhaps the most striking feature of the assemblage is the presence of bioherms of Scacchinella. Intergrown with the Scacchinella are Geyerella, Tropidelasma, Eolyttonia, and Derbyia, which make a fairly strong mass. These bioherms commonly are based on a gravel of huge, crinoid-stem debris and are surrounded by coarse limestone pieces in the form of thick conglomerates. The whole member thus suggests a near-shore gravel bed in a zone of strongly moving waters. The patch reefs are strong, and they provided, in crannies and niches, abundant quiet shelter for the numerous small brachiopods that make up a large part of the Decie Ranch fauna.

Poplar Tank Member: The fauna of the Poplar Tank Member is not well known because much of the member is composed of brown, crumbly shale that yields few good fossils. The thin bands of limestone in the shale are conglomeratic, and their fossil content usually consists of fragmentary specimens often identifiable only to genus. The sandstones and conglomerates do not yield good fossils. An occasional bioherm, such as that at USNM $708 \mathrm{e}$, produces numerous fine but unsilicified fossils. Silicified material was not discovered in useful quantity. Many of the thin limestone beds are capped by an inch or two of brown chert, which usually is very fossiliferous, but the preservation is poor.

The Poplar Tank fauna contains most of the same species as that of the underlying Decie Ranch Member and the overlying Sullivan Peak Member. 
Large Scacchinella is present, and Spyridiophora is fairly common in contrast to its extreme rarity in the Decie Ranch Member. Parenteletes, at the bases of the member, is a Wolfcampian hangover like Spyridiophora. Nudauris, a Gaptank and Neal Ranch genus, was found in the Poplar Tank Member. The only novelty appearing in the Poplar Tank fauna is Paranorella, very rare and poorly preserved. This probably is predated by occurrence of the same genus in the lower Bone Spring Formation in the Sierra Diablo.

Dugout Mountain Member: The fauna of this member, which consists of the Second, Third, and Fourth Limestones of the Leonard of P. B. King (only in the vicinity of Dugout Mountain) and their intervening shales, is known very poorly. The limestones mainly are detrital, consisting of small pebbles, chert fragments, broken shells, and other debris. The result of collecting or dissolving blocks from these beds usually is a large quantity of fragmentary specimens difficult to identify. The known fauna is Wolfcampian in aspect, but new elements appear in it: Sceletonia, Torynechus, Glyptosteges, and Lepidospirifer. Another element of the Dugout Mountain fauna is that of the ammonites, which are abundant in the limestone beds. These include a new genus (formerly Propinacoceras) and small species of Perrinites. Other ammonites are: Eothinites hessensis Miller and Furnish, Metalegoceras, Peritrochia dunbari Miller and Furnish, and a species of Neocrimites.

The Dugout Mountain fauna is closest to that of the Sullivan Peak Member of the Skinner Ranch Formation. The two members share the rare genera Sceletonia, Torynechus, and Glyptosteges. We have not found Institella and its associates in this member. The fauna seems to have close ties below, and we have found its characteristic ammonites in the upper part of the Sullivan Peak Member at hill 4801 at the south end of the Lenox Hills.

Outside of the Glass Mountains, Sceletonia was found 130 feet above the base of the Bone Spring Formation at the north end of the Baylor Mountains (USNM 725c).

Sullivan Peak Member: This is the uppermost member of the Skinner Ranch Formation, and some major faunal changes take place in it. Most of the Wolfcampian elements and the last of the persistent holdovers from the Pennsylvanian disappear. Above the Skinner Ranch a number of new genera arrive to inaugurate the Leonardian: Genera appearing for the first time in the Sullivan Peak are Phrenophoria and Plectelasma. Genera seen for the last time in the Sullivan Peak are discussed under "Skinner Ranch Formation Undivided."

The most striking feature of the Sullivan Peak fauna is its similarity to the underlying Decie Ranch, Dugout Mountain, and Poplar Tank Members. Bioherms, often of large size, are fairly frequent in the Sullivan Peak Member, especially at the south end of the Lenox Hills in hill 4801. These contain large Scacchinella and Geyerella that almost attain the size of the large specimens from the Decie Ranch Member. Tropidelasma and other reef-dwelling types occur in the formation. Coscinophora of large size occurs in several bioherms, especially on the northeast side of Dugout Mountain (USNM 733j).

Perhaps the most characteristic elements of the fauna are Spyridiophora and Glyptosteges. The former is abundant in places, but the latter, although distinctive, is much less common. Torynechus also is a marker of the upper Sullivan Peak, but it is transient into the overlying Cathedral Mountain Formation. This is true also of Spyridiophora and Glyptosteges, but neither they nor Torynechus established themselves in the Cathedral Mountain fauna; they are extremely rare in the lower part of that formation.

Spyridiophora reticulata (R. E. King), the abundant species of the Sullivan Peak Member, occurs in the Sierra Diablo a short distance above the base of the Bone Spring Formation on the south side of the mouth of Victorio Canyon (AMNH $625=$ USNM 725e). It also occurs with Glyptosteges in Apache Canyon at the north end of the range. The rocks in Apache Canyon containing these species, although near the base of the formation, represent a higher horizon than that at Victorio Canyon.

Spyridiophora reticulata also helps to tie the Sullivan Peak fauna to that of the Taylor Ranch Member of the Hess Formation. Presence of Parafusulina spissiseptata Ross in both of these members is another help in establishing this link across the mountains between two very unlike facies (see "Taylor Ranch Member" under "Hess Formation"). 
Skinner Ranch Formation Undivided: From hill 5021 (west of Iron Mountain) eastward to its merger with the Hess Formation, the Skinner Ranch Formation cannot be separated satisfactorily into its component members. It is possible, however, to recognize faunas of the Sullivan Peak in the upper part and faunas of the Decie Ranch at the base. Some genera appear for the first time in the lower 200 feet of the Skinner Ranch Formation, which is the part believed to be correlative to the Decie Ranch Member. These newcomers are: Anomalesia, Crenispirifer, Elliottella, Metriolepis, Peniculauris, Spinifrons, and Tricoria. All of these except Peniculauris and Tricoria appear also in the lowest part of the Bone Spring Formation in the Sierra Diablo on the south side of Victorio Canyon (USNM 728e).

Several genera, mostly Pennsylvanian-Wolfcampian types, make their last appearance in the Skinner Ranch Formation: Anomalesia, Antiquatonia, Chonetinella, Elliottella, Fimbrinia, Glyptosteges, Hystriculina, Kozlowskia, Limbella, Oncosarina, Orthotichia, Parenteletes, Rugaria, Scacchinella*, Spyridiophora*, Teguliferina, and Tricoria. The disappearance of these genera, in our opinion, marks the end of the Wolfcamp Stage. Occasional specimens of the starred genera $\left({ }^{*}\right)$ have been found low in the Cathedral Mountain Formation. Exceedingly rare, they have never established themselves as members of the Cathedral Mountain fauna. A single fragment of Scacchinella probably is a reworked fragment.

Interesting developments involving the upper and lower parts of the Skinner Ranch fauna have been detected. It is our belief that the lower 100 to 200 feet of the Skinner Ranch near the Hess Ranch house and the Hess Ranch Horst represent the equivalent of the Decie Ranch Member. It is in this area that the Decie Ranch fauna is enriched by new elements. Variation in the Decie Ranch fauna may be detected along the Glass Mountains front from Dugout Mountain to the Hess Ranch and Hess Ranch Horst.

In the western part of the mountains, in the Lenox Hills, the Scacchinella and associated Derbyia, Geyerella, and Eolyttonia are exceptionally large. Eastward these appear to become smaller and more slender, while Geyerella and Tropidelasma nearly disappear from the numerous bioherms on the Hess Ranch Horst, although they are present just north of the Hess Ranch house. Beginning on the west side of Leonard Mountain, a number of small productids, such as Elliottella, Hystriculina, and Kozlowskia, reappear in the Decie Ranch Member. In the bioherms that dot the base of the north slope of the Hess Ranch Horst, Orthotichia is common and Cyclacantharia appears in some abundance. Although present, neither of these is conspicuous in the western part of the mountains. North of the Hess Ranch house, Tricoria is fairly common, but it is rare on the horst. Tropidelasma is rare or absent from Leonard Mountain, Hess Ranch, and Hess Ranch Horst exposures. Spyridiophora is rare in the western part of the mountains, but it was not seen in the equivalent of the Decie Ranch Member in the eastern part.

Another faunal aberration in the base of the Skinner Ranch Formation is the distribution of the fusulinid Schwagerina crassitectoria Dunbar and Skinner. This is common in the basal part of the Skinner Ranch Formation, referable to the Decie Ranch Member, but it has not been taken from the Decie Ranch Member proper in the Lenox Hills. It is reported by Ross (1962b:3, 9), however, at his locality $6 \mathrm{~A}$ in the center of the Lenox Hills, 245 feet above the base of the Leonard ( $=$ the base of the Decie Ranch Member). This level is near the top of the Poplar Tank Member of the present classification. It has not been seen by Ross or anyone else in the Decie Ranch Member. This species has a vertical range of more than 200 feet in the Hess Formation, and the occurrence recorded by Ross may indicate only the upper part of its range in the western part of the mountains.

The above data might be taken to indicate a difference in age of the Decie Ranch Member and the basal part of the Skinner Ranch Formation (undivided) between the western and eastern parts of the mountains. We have not been able to satisfy ourselves that this is the case. Too many other species and genera are common to the members in the two areas, and their Scacchinella bioherms always can be found just above the Lenox Hills Formation. It seems to be a fact, as abundantly seen in the Neal Ranch and higher in the Cathedral Mountain Formations, that the faunas of individual bioherms, even of ones in close proximity, may be startlingly different. The bioherm is an area of microenvironments that enhance the faunal diversity of any member or formation. 
Hess Formation.-This formation is notorious for the scarcity of megafossils and the poor preservation of those found in it. This is true of the whole formation except for two levels, one near the top and the other at the very top. The Hess Formation spans a considerable interval of the geological column in the Glass Mountains. The lower 400-500 feet of the formation contains fusulinids that date this part as Wolfcampian. Ross has applied the name "Lenox Hills Formation" to this part of the Hess section, in spite of the fact that the conglomerate at its base is thin or absent and the remainder of the formation consists of red shales, dolomites, and thin-bedded limestone totally unlike Lenox Hills lithology elsewhere. The Wolfcampian or "Lenox Hills" part of the Hess Formation continues up to the Schwagerina crassitectoria zone, which marks the level of the lower Skinner Ranch (Decie Ranch Member). This zone spans at least 200 feet of rock that we place in the Hess Formation above the Lenox Hills Formation (Cooper and Grant, 1966:3). The zone is the only marker for the lower part of the Skinner Ranch equivalent in the Hess Formation. The fauna of the Taylor Ranch Member marks the upper part of the Skinner Ranch level (Sullivan Peak Member) in the Hess Formation.

Taylor Ranch Member: The Taylor Ranch Member is a thin band of shaly limestone underlain by a limestone conglomerate (Cooper and Grant, 1966:3). The member can be traced near the crest of the mountains for several miles, from a mile or two east of the Hess Ranch nearly to the Conoly Brooks Ranch house. Although the member is barely 40 feet thick, its upper half is very fossiliferous and contains a variety of brachiopods. It also contains interesting bioherms (USNM 702e above the Bill Neal Ranch house), which contain large numbers of Heliospongia and Girtycoelia with Spyridiophora and other brachiopods. Although these sponges make up a large part of the main bioherm, brachiopods are abundant and some are known only from this reefy mass.

Two genera appear for the first time in the Taylor Ranch Member: Elassonia and Tschernyschewia. The former is a small rhynchonellid that appears in some abundance in higher formations. The latter is an exceptional brachiopod, and its discovery was completely unexpected because the genus is known elsewhere only in rocks that are dated as uppermost Permian. It is reported from the Dzhulfian of Armenia, from the Upper Productus Limestone of Pakistan, and from the Upper Permian of Yugloslavia. The genus first appears in the Taylor Ranch Member, but it also occurs in the Road Canyon Formation and in the lower Bone Spring Formation of the Sierra Diablo, each occurrence being in the Lower Permian as that period is now classified.

The Taylor Ranch Member contains (besides the newcomers mentioned above) Chonosteges, Diplanus, huge Enteletes, Thamnosia, Linoproductus, Oncosarina, abundant Peniculauris, Pontisia, abundant large Rhipidomella, Rugaria, Stenoscisma, and Spyridiophora. Elements of the Taylor Ranch fauna occur on Leonard Mountain in the notch near the top of the southeast nose, where large Rhipidomella hessensis and Spyridiophora were found.

Several specimens of Scacchinella were found loose on the slopes of the Taylor Ranch Member. These were traced by their lithology to a dolomite bed about 25 feet above the Taylor Ranch Member, but none was found in place.

The Taylor Ranch fauna is difficult to correlate in the Glass Mountains because of its isolation and because so many of its members are unknown elsewhere. The presence of Spyridiophora reticulata (R. E. King), Scacchinella, and Rhipidomella hessensis $\mathrm{R}$. E. King indicate relationship to the Sullivan Peak Member of the Skinner Ranch Formation. Other ties to the Sullivan Peak are Oncosarina, Peniculauris, and Meekella hessensis R. E. King. Antronaria speciosa, new species, strongly suggests A. mesicostalis (Girty) of the Bone Spring Formation, which correlates with the Skinner Ranch. A further tie to the Sullivan Peak is the presence of Parafusulina spissiseptata in the two members.

The uppermost fauna of the Hess Formation was found near Old Word Ranch (USNM 726n), where a few species occur in excellently silicified condition. This locality is noteworthy for Plectelasma kingi, new species, which also was found in the upper part of the Sullivan Peak Member in Dugout Mountain (USNM 727a).

In summarizing, we believe that the Taylor Ranch Member and upper Hess Formations are correlated most satisfactorily with the Sullivan Peak Member of the Skinner Ranch Formation. The Schwagerina crassitectoria zone establishes the 
position of the lower Skinner Ranch or Decie Ranch Member equivalent in the Hess Formation. Thus, the Hess above the Lenox Hills of Ross is the equivalent of the Skinner Ranch Formation.

\section{LEONARD FAUNAS}

As now conceived, the Leonard Series in the Glass Mountains consists of two formations: the Cathedral Mountain and the Road Canyon. The latter is the First Limestone Member of the Word Formation of P. B. King (1931), raised to formation rank by Cooper and Grant (1964) and placed in the Leonardian by them (1966). The Cathedral Mountain Formation, lower of the two, contains one member, the Wedin Member. The most diagnostic fossil to appear in the Cathedral Mountain Formation is Institella, which can be found at, or near, the base of the formation in all parts of the Glass Mountains except from the east end of Lenox Hills to hill 5021 (west of Iron Mountain).

There are 47 new genera that appear in the Leonardian and successfully blot out all of the Wolfcampian elements; 35 genera terminate during, or at the end of, the Leonardian (Road Canyon), to be replaced by the Word fauna.

Cathedral Mountain Formation.-This formation in the Lenox Hills and Dugout Mountain areas makes a striking color contrast to the underlying Skinner Ranch Formation. It usually begins with orange-colored, somewhat fissile, siliceous beds. The color contrast is striking, but in the eastern part of the mountains, from Hess Ranch east, the siliceous sediments are reduced to minor tongues and are no longer basal. The formation is introduced, however, at most places in the eastern part of the mountains by a small-pebble conglomerate. Where this is lacking, Institella usually can be found to establish the identity of the formation.

The Cathedral Mountain contains several limestone bands that originally were numbered from 1 to 5 (P. B. King, 1931). The First Limestone of the Leonard was separated by Cooper and Grant (1964) and made the Sullivan Peak Member of the Skinner Ranch Formation. The Second Limestone later was named "Wedin Member" by Cooper and Grant (1966), but the higher limestones were not named. These limestone beds contain few brachiopods, but, in places, they are fairly rich in ammonites, especially Perrinites. The Wedin
Member proved to be the key to the stratigraphy of the Cathedral Mountain Formation in the west end of the mountains. The Second Limestone of the Leonard Formation in the Lenox Hills proved to be faunally identical to the Fifth Limestone of the Dugout Mountain region. These two limestones are richly biohermal and contain Institella and other characteristic fossils in abundance.

Wedin Member: The correlation of this member is based on the tracing of a distinctive assemblage of fossils that occurs near the base of the Cathedral Mountain Formation in its western part but that occurs at the base in the eastern part. This fauna contains two brachipods in particular, Institella and Agelesia, that are most distinctive, but, along with these, there are many other genera that make up an easily recognized assemblage. The Institella beds contain numerous small bioherms, each of which usually has its own assemblage of the characteristic fossils.

The Wedin Member is known only on the north slope of Dugout Mountain and the west half of the Lenox Hills to about hill 5300. The same fauna, however, occurs from the top of Leonard Mountain to east of Split Tank. New genera that make their appearance in the Wedin Member and its correlate in the eastern part of the mountains are: Agelesia, Amphipella, Anemonaria, Chaeniorhynchus, Choanodus, Dyoros (Lissosia), Dyoros (Tetragonetes), Edriosteges, Grandaurispina, Echinauris, Hercosestria, Hercosia, Heteraria, Holotricharina, Institella, Loxophragmus, Nucleospira, Petasmaia, Ptygmactrum, Rallacosta, Rugatia, Scenesia, Siphonosia, Texarina, Thedusia, Trophisina, Xenosteges, and Xestosia. Some transient elements from the underlying Skinner Ranch Formation, such as Lepidospirifer, and Torynechus, appear in the lowest part of the Cathedral Mountain and Wedin Member. Spyridiophora, Glyptosteges, and Scacchinella have been found as great rarities in the lower Cathedral Mountain Formation (USNM 72lu), the latter possibly a pebble reworked from below. No trace of the former two was seen anywhere else in the Cathedral Mountain. Peniculauris is inherited from below, but it is not a conspicuous part of the lower Cathedral Mountain fauna in the western part of the mountains, although it is common in the eastern part. The Echinauris that appears in the Cathedral Mountain Formation differs from that in the Wolfcamp in 
having long halteroid spines on the lateral slopes over the ears.

Most of the Cathedral Mountain Formation consists of shale or fissile, siliceous rocks or cherts in the western part of the mountains, where it attains a thickness estimated at 1500 feet. In the eastern part of the mountains, this great thickness of shale is fingered into a section about 300 feet thick, mostly limestone. Naturally the fossils in the western part of the formation differ, by virtue of facies conditions, from those in the eastern part. Nevertheless, the generic assemblage is similar in the two regions. Peniculauris is common in the upper part of the Cathedral Mountain Formation all across the mountains. Rugatia also is frequent in the upper beds, but Institella is extremely rare, usually appearing only in occasional bioherms in the western part of the mountains.

The following genera are confined to the Cathedral Mountain Formation and therefore are diagnostic of it: Agelesia, Anemonia, Choanodus, Hercosia, Heteraria, Institella, Loxophragmus, Scenesia, Siphonosia, Trophisina, and Xestosia. Genera terminating in, 'or at the top of, the Cathedral Mountain are: Agelesia, Anemonaria, Choanodus, Glyptosteges, Hercosia, Heteraria, Institella, Lepidospirifer, Loxophragmus, Nucleospira, Nudauris, Rhipidomella, Scenesia, Siphonosia, Spyridiophora, Torynechus, Trophisina, and Xestosia.

Correlation: Outside of the Glass Mountains, the Bone Spring Formation in the Sierra Diabloexclusive of the thick beds equivalent to the Skinner Ranch Formation at the base but including the Victorio Peak Member at the top-can be correlated with the Cathedral Mountain Formation. Institella is present in collections from the Victorio Peak Member. Also included in this correlation is the Bone Spring along the west side of the Guadalupe Mountains, where Institella also occurs (USGS 7677, 7700, 7722).

The Kaibab fauna, as published by McKee (1938), correlates with the upper part of the Cathedral Mountain Formation. Abundant large Peniculauris, Rugatia paraindica, and $R$. occidentalis are important elements in indicating this correlation. Because of their poor preservation, we have been unable to identify other species illustrated by McKee. Some of these bear names of species that are more characteristic of the Capitan Formation and that need revision when better specimens are found.

Identification of Cathedral Mountain correlatives in the shaly formations east of the Glass Mountains in the midcontinent is fraught with the same difficulties as those connected with identification and correlation of Wolfcampian rocks. The Leonardian of the midcontinent and of north-central Texas is based on fusulinids or ammonites, but it contains numerous brachipods of a few kinds: dictyoclostids, linoproductids, chonetids, Derbyia, Meekella, Composita, and a few others, all of which have a Pennsylvanian rather than a Permian aspect.

Road Canyon Formation.-From northeast to southwest, parallel to the Glass Mountains front, this formation exhibits a variety of facies that indicate many special environments. The fauna is highly varied as a result of this great lithic variation. The brachiopod assemblage also is rich and varied, including many unusual species and occurrences of generic types quite unexpected at this level. The fauna is derived clearly from the Cathedral Mountain fauna, but it contains many innovations: Allorhynchus, Ametoria, Bothrostegium, Chonetinetes, Cactosteges, Collumatus, Costispinifera, Echinosteges, Horridonia, Liosotella, Mesolobus, Notothyris, Ombonia, Paucispinifera, Petasmatherus, Holosia, Rhytisia, Simplicarina, Spinarella, Spiriferinaella, Taphrosestria, Undulella, and Yakovlevia.

Genera confined to the Road Canyon Formation are: Ametoria, Bothrostegium, Collumatus, Horridonia, Mesolobus, Rhytisia, Simplicarina, Spinarella, and Taphrosestria.

Several of the newcomers in the fauna are transient into the overlying Word Formation, and they become important members of that fauna: Allorhynchus, Cactosteges, Costispinifera, Echinosteges, Leurosina, Liosotella, Notothyris, Ombonia, Paucispinifera, Spiriferinaella, Undulella, and Yakovlevia.

Genera terminating at the end of the Road Canyon Formation are: Acosarina, Ametoria, Amphipella, Anteridocus, Bothrostegium, Chaeniorhynchus, Chondronin, Chonosteges, Collumatus, Coscinophora, Edriosteges, Elassonia, Goniarina, Hercosestria, Kochiproductus, Kutorginella, Mesolobus, Peniculauris, Petasmaia, Rhytisia, Rugatia, Simplicarina, Spinarella, Taphrosestria, and Tschernyschewia. 
One of the astonishing appearances in the Road Canyon Formation is Mesolobus. The specimen has all the features of this unusual chonetid. It is likely, however, that the specimen represents a parallel chonetid stock rather than a stock in the same line as the well-known Pennsylvanian genus. Other unusual occurrences are Geyerella and Ombonia, which is remarkable because they were taken from the same piece of rock. These two genera are similar but not too difficult to separate, because their spondylia are different and their cardinalia quite unlike. The Ombonia is prophetic of the occurrence of this genus higher in the column. It is very rare in the Cherry Canyon Formation, but common in the Capitan and the higher Bell Canyon Formation (Lamar Member). Geyerella is a holdover from the Wolfcampian, but it also is known as a great rarity in the Capitan and Bell Canyon Formations (Lamar).

Although nine Word genera appear in the Road Canyon Formation, the fauna is predominantly Leonardian. This is seen not only in the large number of Leonardian species that it contains, but also in the lingering of Perrinites in the formation. Leonard elements of importance are: Peniculauris, Rugatia, Chonosteges, Acosarina, Hercosestria, and Goniarina. Another feature of considerable interest in the Road Canyon is the last appearance of the small bioherms or patch reefs, largely made up of bryozoans, sponges, and brachiopods. We have not found any bioherms in the Word succession. The Word fossil assemblages seem to be death assemblages, whereas, from the Uddenites-bearing Shale Member through the Road Canyon Formation, bioherms and conglomerates are common. The Word can be distinguished from the Leonard not only by widespread conglomerates in the latter, but also by their almost complete absence from the Word Formation.

Correlation: The intermediate character of the Road Canyon Formation makes it difficult to correlate. As mentioned above, it is predominantly a Leonard fauna and includes some of the best guides to the Leonard, such as Peniculauris and Rugatia, among the brachiopods, and Perrinites, the ammonite said to be most characteristic of the Leonard. All of the Word or Guadalupe elements in the Road Canyon are rare fossils, some having been found as single specimens after much collecting.
Strong elements of the Road Canyon fauna occur high in the Cibolo Formation in the Chinati Mountains in the thin-bedded zone of Udden. The coarse-ribbed Liosotella is very common in the two formations.

Wilde (1968), in his discussion of the Cutoff (Shale) Formation in the Apache Mountains and Guadalupe region, concludes that this formation is to be correlated with the Road Canyon Formation. The Cutoff in the Sierra Diablo has been difficult to place, but the occurrence of Perrinites in it has led to is placement in the Leonard Series (P. B. King, 1965:78). This has been contradicted by the presence of fusulinids usually assigned to the Guadalupe Series. The same situation also exists in the Glass Mountains region, in which the fusulinids of the Road Canyon usually are dated as early Word (Wilde, 1968:12).

Correlation of the Road Canyon Formation with the Cutoff indicates other correlations as outlined by Wilde (1968). The Cutoff has been correlated and traced by Boyd (1958) into the lower part of the San Andres Formation. The lower part of the San Andres was correlated by R. E. King (1931:26) with the Leonard because of the presence of "Productus ivesi" (= Peniculauris) and "Productus occidentalis" (= Rugatia). Both of these are common in the Cathedral Mountain and occur still higher, in the Road Canyon Formation. They are good indicators of the Leonard Series. So little is known about the faunas of the San Andres Formation, other than its fusulinids, that only the most tentative conclusions can be drawn.

Some elements of the Permian fauna of the Coyote Butte Formation in central Oregon suggest correlation with the Road Canyon Formation. In spite of the European and Asiatic types in the fauna, the small "Muirwoodia" (= Yakovlevia) are very similar to those of the Road Canyon. Antiquatonia, Kochiproductus, Martinia, small Waagenoconcha, small "Leptodus?," costellate chonetids, and small alate Stenoscisma all suggest the Leonard. Small Spiriferella is rather suggestive of later affinities, but it also occurs in the Road Canyon. Cooper (1957a:18) correlated the Oregon (Coyotte Butte) fauna with that of the lower Word of the Glass Mountains, now the Road Canyon; relationship to the Cache Creek fauna of British Columbia also was suggested by Cooper. 


\section{Guadalupe Faunas}

WORD Formation.-The Word Formation in the western part of the mountains consists of a thick silicious shale sequence with several limestone members. The shale contains some fossils, usually Leiorhynchoidea and Crurithyris, but they are infrequent. The bulk of the fauna is confined to the limestones. Cooper and Grant (1964) named the First Limestone of the Word of P. B. King the "Road Canyon Formation" and thereby upset the number system established by King. Later, Cooper and Grant (1966) substituted names for King's numbered limestones. The Second Limestone became the "China Tank Member," the Third Limestone became the "Willis Ranch Member" and the Fourth Limestone was named "Appel Ranch Member." In each of these members the fossils occur as death assemblages, heaps of shells, concentrated in small or large patches, but not in bioherms.

China Tank Member: This is the least extensive of the three members, but it is very rich in fossils that have fine preservation. Only two genera appear in this member for the first time: Ectoposia and Pseudodielasma. The member contains a total of 65 genera, most of which also occur in the higher Word members. No genera terminate in the member. Many species, as well as genera, are also transient into the higher Word. The fauna of the lowest part of the Getaway Member (AMNH 600, USNM 732) of the Cherry Canyon Formation strongly resembles it.

Willis Ranch Member: The Third Limestone Member of the Word Formation (P. B. King, 1931) has a much wider distribution than the preceding member. It can be traced from the Appel Ranch westward to the west side of Gilliland Canyon, where it disappears except for lenses that can be found high on the slope of Sullivan Peak and on the northeast side of Dugout Mountain. This formation, especially at USNM 706e, contains some of the finest fossils found in the Glass Mountains. Despite the great abundance of fossils, only three newcomers are recorded: Bothronia, Leiorhynchoidea, and Polymorpharia. The first two continue higher; the last occurs also in the Getaway Member of the Cherry Canyon Formation. Four genera terminate in the Willis Ranch Member: Acolosia, Cactosteges, Enteletes, and Undulella.
Outside the Glass Mountains the fauna most like that of the Willis Ranch appears in the lower part of the lower Getaway Member of the Cherry Canyon Formation (USNM 732, AMNH 600). Diagnostic genera are: Echinosteges, Liosotella, Grandaurispina, Cyclacantharia, Leurosina, Paucispinifera, Pseudodielasma, Rhamnaria, Undulella, and Xenosteges.

In regard to the termination of Enteletes in the Willis Ranch Member it should be emphasized that this concerns West Texas only. Enteletes has not been identified in the Capitan or its equivalents, but it is reported from highest Permian in Dzhulfa, Armenia, and in the Salt Range of Pakistan. This variation in range and that reported below for Tschernyschewia make intercontinental correlation difficult indeed.

Lenses Between Willis Ranch and Appel Ranch Members: USNM $706 \mathrm{~b}$ is a lens about $200 \mathrm{feet}$ above the Willis Ranch Member that produced an enormous supply of fine fossils of genera also occurring in those two members. The specific composition is quite different, however, and the fauna very distinctive. It is noteworthy for the last appearance, in the Glass Mountains of Cenorhynchia, Costispinifera, Paranorella, and Petasmatherus. Although the generic composition of this lens and the superjacent and subjacent members are almost identical, the abundance of the genera is very different. The fauna of the lens, for example, abounds in Stenoscisma, which is very rare in the members above and below. We do not know any fauna outside of the Glass Mountains like that of the lens.

Another lens or series of lenses (USNM $737 \mathrm{w}$, $742 \mathrm{~b}$ ) occur about 325 feet above the Willis Ranch Member. These contain species similar to those of the Willis Ranch and prophetic of some in the Appel Ranch Member, but notable for their robust character. The most noteworthy species is a large Pseudoleptodus.

Appel Ranch Member: This is the uppermost member of the Word Formation to produce good silicified fossils. Consequently, it is the place of disappearance of a number of genera, but with only two innovations, namely, Bryorhynchus and Divaricosta.

The following last appearances are recorded: Bothronia, Cancrinella, Cooperina, Cyclacantharia, Dyoros (Tetragonetes), Eolyttonia, Grandaurispina, 
Leurosina, Linoproductus, Neophricadothyris, Rhynchofora, Spiriferinaella, Texarina, Waagenoconcha, and Yakovlevia. It is possible that a species of Cyclacantharia occurs in the Carlsbad Formation in the Guadalupe Mountains and that the genus is not terminal in the Appel Ranch Member.

The fauna outside of the Glass Mountains most like that of the Appel Ranch Member is that of the upper part of the lower Getaway Member of the Cherry Canyon Formation. These two members share the following genera: Bothronia, Ctenalosia, Cooperina, Divaricosta, Dyoros (Tetragonetes), Grandaurispina, Leurosina, Reticulariina, Spiriferella, Spiriferinaella, Texarina, Xenosteges, and Yakovlevia.

Capitan Limestone Formation.-The beds above the Appel Ranch Member (the Vidrio Member and the Capitan Formation) generally are dolomitized and do not yield good fossils. Nevertheless, on the northwest side of Dugout Mountain a small fault block near the foot of the Sierra del Norte (USNM 732q) furnished good exposures of fossiliferous Capitan. The rock is not dolomitized at this place. The fossils are not well preserved, but the fusulinid Polydiexodina is fairly common, with a few brachiopods such as Stenoscisma, Pseudoleptodus, Liosotella, large Collemataria, Cartorhium, Elivina, and Echinauris. The assemblage suggests correlation with the Hegler Member of the Bell Canyon Formation.

Rocks lying above the Appel Ranch Member cover a great area in the northern part of the Glass Mountains. These have never been searched for fossils except for a locality northeast of Altuda (USNM 718a), where King reports some Capitan species. Search of this vast region for undolomitized parts of the sequence might yield interesting collections.

\section{Stratigraphy and Fossils of Other West Texas Areas}

In order to understand the correlation and fossils of the Glass Mountains with other areas in West Texas, a brief review of the stratigraphy of the Hueco Mountains, the Sierra Diablo, the Guadalupe Mountains, and the Chinati Mountains is given. We have made collections in all of these areas with the twofold purpose of understanding the Permian fossils described by G. H. Girty
(1909), R. E. King (1931), and others and of refining correlations among these mountain ranges.

\section{Hueco Mountains}

The Hueco Mountains, about 25 miles east of El Paso, are composed mostly of Pennsylvanian and Lower Permian rocks, respectively, the Magdalena Limestone and the Hueco Group (T. E. Williams, 1963). According to Williams (1963), the upper part of the Magdalena contains a Bursum fauna of very Early Permian age, but above it there are 200 feet of light gray limestone containing Pseudoschwagerina, an indisputably Permian fusulinid. The Hueco Group lies unconformably on the Magdalena. Williams raised the Hueco Formation to a group, which previously had been divided by $P$. B. King into three unnamed units. Following the lead of King, Williams proposed three formations in ascending order: Hueco Canyon, Cerro Alto, and Alacran Mountain Formations.

Hueco Canyon Formation.-The lowest unit of the Hueco Group consists of a conglomerate and calcareous mudrock called the Powwow Member. Above it are 470-600 feet of olive-gray, thick to moderately thickly bedded limestone. The Powwow rocks generally weather to a red color. The conglomeratic part consists of pebble and cobblesize elements. This part of the member is confined to Powwow Canyon on the west side of the Hueco Mountains. Fossils have not been taken from the Powwow Member, but they are abundant in the limestone immediately overlying it.

The base of the Hueco Canyon Formation contains the most varied of the Hueco brachiopod faunas, as exhibited by exposures in Powwow Canyon $(U S N M 499 b=725 z)$. About a mile northeast of Powwow Tank at the west end of Powwow Canyon, fossils are varied and abundant. The commonest species are: Kochiproductus peruviana (d'Orbigny) (= K. quadrata, new species), Dasysaria wolfcampensis (R. E. King), Echinauris cf. $E$. boulei (Kozlowski), Nudauris tribulosa, new species, Gypospirifer anancites, new species (usually misidentified as Spirifer condor d'Orbigny), and Kutorginella dartoni (R. E. King). Pontisia franklinensis, new species, is common and Composita is frequent. Important, rarer brachiopods are Enteletes, Reticulariina, and Waagenoconcha. A variety 
of fusulinids has been identified from this part of the section.

In the Glass Mountains the brachiopod fauna most like that of the basal Hueco Canyon Member is that of the Uddenites-bearing Shale Member, which contains large Kochiproductus and all of the other genera cited except Dasysaria, which is not known in that part of the section in the Glass Mountains. This Powwow fauna is also like that of the Copacabana Formation of Bolivia, described by Kozlowski (1914). The correlation is not in accordance with that indicated by the fusulinids, which suggested to $T$. E. Williams a correlation with the Lenox Hills Formation. The ammonite evidence also suggests a higher position. In spite of these contradictions, the resemblance of the three brachiopod faunas is striking.

Cerro Alto Formation.-This formation consists of 445-465 feet of "medium gray, mediumand thin-bedded limestone typically possessing undulatory bedding" (T. E. Williams, 1963:21). It contrasts in bedding and darker color to the Hueco Canyon Formation below. This middle formation is fairly rich in molluscs, but the brachiopods are poorly represented, usually by Composita, Derbyia, Meekella, and small rhynchonellids.

Alacran Mountain Formation.-This formation, similar lithically and faunally to the Hueco Canyon Formation, has a thickness of 622 feet. Within it there is a red interval about 120 feet thick called the "Deer Mountain Red Shale Member." Brachiopods are abundant in this formation, limestone surfaces often being covered with small Pontisia, Stenoscisma, and Composita. Although the number of specimens is legion, the generic representation is indeed meager. Perhaps the most conspicuous species is Stenoscisma hueconianum (Girty), but the most abundant species is Pontisia franklinensis, new species. A small Kozlowskia usually referred to $K$. capaci (d'Orbigny), and Composita mexicana (Hall) also are common.

Stenoscisma similar to $S$. hueconianum occurs in the upper part of the Lenox Hills Formation (USNM 716r), but that is the only similarity between this part of the two formations.

\section{Sierra Diablo}

WolfCamp Series.-This region exposes fine sections of Permian rocks from north of Van Horn,
Texas, to the south end of the Guadalupe Mountains, a distance of about 60 miles. The lowest formation is the Hueco Limestone, which is overlain by the Bone Spring Formation.

Hueco Formation: This limestone, described by P. B. King (1965), is of variable thickness and fossil content, ranging from less than 400 feet to 1100 feet in the Sierra Diablo and the adjacent Baylor Mountains just to the east. The formation is unconformable on several pre-Permian formations. Extensive exposures may be examined in the southern part of the area. These generally are very fossiliferous and have yielded good collections; some of the species are referred to in the present monograph.

In the southern part of the Sierra Diablo, a lower member, consisting of coarse clastics in the lower part but of thin-bedded limestone in the upper part (with numerous fossils), is called the Powwow Member, but it is not entirely conglomeratic, as it is in Powwow Canyon. The upper member of the Hueco Formation is thick-bedded limestone, becoming dolomitic in the north. This part has a restricted fauna. In the Baylor Mountains the Powwow Member is thin or missing. The main member of the Hueco in the Baylor Mountains is thin-bedded dolomitic limestone with scattered fossils.

The collections from the Hueco made in our study are mainly from the lower thin-bedded or shaly parts on Three Mile Mountain-just north of Van Horn (USNM 719), at the mouth of Victorio Canyon (USNM 728d) in the Sierra Diablo, and in Red Tank Canyon (USNM 725a, b) in the Baylor Mountains.

The brachiopod fauna consists of a small number of genera, but the abundance of specimens is remarkable. The most significant generic elements in the Hueco fauna of the Sierra Diablo is the abundance of Dasysaria, Linoproductus, Nudauris, and Kozlowskia, with occasional Reticulatia. Kochiproductus is rare in the Sierra Diablo. Composita usually is common, along with a small Hustedia. Enteletes and Wangenoconcha have been reported. This representation of the Hueco may be correlated with the Lenox Hills Formation because of the presence of Dasysaria.

That the Hueco Formation is known very poorly is shown by collections made in Red Tank Canyon by members of the American Museum of Nat- 
ural History and the National Museum of Natural History (AMNH 700, USNM 725a, b). Here, in about the middle of the section, patches of Acritosia yielded good silicified specimens. In addition, a few examples of Scacchinella were taken. With the Acritosia there occurred specimens of a huge Meekella, Composita mexicana (Hall), and Enteletes. Most of these elements appear again in the lower part of the Bone Spring Formation, some of them highly modified, but others essentially unchanged.

The Hueco Formation in the Sierra Diablo is succeeded by the Bone Spring Limestone (P. B. King, 1965:50-61). The lower part is occupied by massive limestones containing a fauna different from the dark, thin-bedded limestones that make up most of the formation. We place these massive beds of the Bone Spring in the Wolfcamp Series.

Lower Massive Bone Spring Formation: A feature of the Lower Bone Spring is the wedging in from the' south of clastics consisting of some conglomerate, but mostly of broken shells, fusulinids, broken and rolled corals, bryozoans, and other organic debris. Fossils are abundant and silicified. The beds constitute a marginal facies, which interfingers with the black limestone. The wedges thicken southward and often attain formidable thickness. Stehli (1954:278) interprets these gray limestone beds as a near-shore facies. Most of our collections from the Sierra Diablo are from these lower clastics and amplify Stehli's collections with a number of important additions.

The fauna of the lower clastic beds is very rich and contains many Wolfcampian elements (specimens marked with an asterisk appear in this part of the West Texas Permian for the first time; those with a degree sign are Wolfcampian-Pennsylvanian types): Acritosia, Altiplecus, Antiquatonia", Anomalesia*, Attenuatella*, Cancrinella, Chonetinella ${ }^{\circ}$, Composita, Crenispirifer*, Crurithyris “ Cryptacanthia ${ }^{\circ}$, Derbyia, Dielasma, Diplanus ${ }^{\circ}$, Dyoros (Dyoros)*, Elliottella*, Enallosia*, Enteletes, Eolyttonia, Fimbrinia ${ }^{\circ}$, Glossothyropsis*, Goniarina, Heterelasma*, Hustedia, Kozlowskia ${ }^{\circ}$, Limbella ${ }^{\circ}$, Linoproductus, Livellaria*, Meekella, Metriolepis*, Nudauris ${ }^{\circ}$, Orthotetella ${ }^{\circ}$, Pontisia ${ }^{\circ}$, Quadrochonetes $^{\circ}$, Ramavectus*, Rhamnaria*, Rhipidomel$l^{\circ}{ }^{\circ}$, Sarganostega*, Sceletonia*, Spinifrons*, Scacchinella $^{\circ}$, Stenoscisma, Teguliferina ${ }^{\circ}$, Undellaria*
The following genera terminate at this level: Cryptacanthia, Fimbrinia, Orthotichia, Orthotetella, and Teguliferina. This list of genera is almost identical to one that might be produced for the lower part of the Skinner Ranch Formation, especially as that part of the formation is developed at Hess Ranch and the north side of Hess Ranch Horst (USNM 705a, 720e).

The upper part of the lower, clastic beds of the Bone Spring Limestone contains the following additional genera (asterisk denotes first appearance in the Sierra Diablo): Chonosteges*, Glyptosteges* $^{*}$, Iotina*, Micraphelia*, Spyridiophora*, and Tschernyschewia*. All of these, except the third and fourth, are important genera in the upper part of the Skinner Ranch and Hess Formations. The correlation of the lower Bone Spring clastic beds with the Skinner Ranch Formation is very satisfactory and convincing. Most of the genera in the two formations are alike, and many of the species are identical, although more than 200 miles separate them. This fauna is now placed at the top of the Wolfcamp Series.

LEONARD SERIEs.-This region contains thinbedded Bone Spring Formation, Victorio Peak Limestone Formation, from which we made no collections, and, above it, Cutoff Shale Member.

Thin-bedded Bone Spring Formation: This formation consists mainly of thin-bedded black limestone in beds from less than an inch to a few inches in thickness. The formation is variable in thickness, depending on the irregular Hueco surface or passage of the upper beds into the Victorio Peak Limestone. At Apache Canyon it is 800 feet thick and thins to the southwest. In Victorio Peak and the region of the Victorio Flexure at its midpoint, the formation is 1050 feet thick. The Bone Spring black limestone is considered a basinal deposit, as it has few fossils and is strongly bituminous. The Bone Spring sea-bottom probably was not populated by many shelly organisms in the basin region (Plate 8: figure 3).

Victorio Peak Limestone Formation: We made no collections from the Victorio Peak Limestone, but we examined material collected by J. B. Knight that belongs to Princeton University and the United States Geological Survey. The following remarks are made for the sake of completeness in this study. 
The Victorio Peak Limestone is a great mass of calcirudite, possibly with some bioherms overlying the black limestone of the Bone Spring. It is best developed at the north end of the Sierra Diablo, where it is 975 feet thick. On the south slope of Victorio Peak, P. B. King (1965:73) gives its thickness as 1500 feet, but he states that the lower half intergrades with black limestone. King further reports interesting facies changes of the Victorio Peak Limestone west of the Sierra Diablo front to a dolomitic, thin-bedded, poorly fossiliferous limestone. "One facies gives place to the other in about a mile along a well-defined boundary that extends north-northwestward across the mountains from Victorio Canyon to a little east of Sierra Prieta" (King, 1965:73). This facies shift reminds King of the passage of the "Leonard" Hess (West Facies) in the Glass Mountains into the "East facies" of thin-bedded dolomites and limestones.

Because the Victorio Peak Limestone mainly caps the highest peaks of the northern end of the Sierra Diablo, the formation has a difficult access from the east. Its fauna therefore is poorly known. Available collections consist mostly of poor specimens, but enough important elements have been identified in them to get a fair idea of the correlation of this formation. The Princeton collections have abundant medium-sized Enteletes and large, strongly costate Stenoscisma. Of productids, perhaps the most prominent form is Peniculauris, but Xestosia also is common; Chonosteges and a small Liosotella are present. Neophricadothyris, Composita, and Hustedia are fairly common, along with a variety of small rhynchonellids.

Lepidospirifer and Institella clearly indicate a relationship to the Cathedral Mountain Formation of the Glass Mountains. R. E. King (1931:15) reports "Productus" ivesi and occidentalis and Kochiproductus [as Buxtonia] victorioensis. The latter is said by Cloud (in. P. B. King, 1965:76) to be common, but the species is confused with Peniculauris, which R. E. King identified as $P$. ivesi. Cloud is correct in stating that $P$. ivesi was incorrectly identified by King, but incorrect in assigning it to Kochiproductus. The Princeton collection from the Victorio Peak Limestone does not contain Kochiproductus, which usually is rare above the Hueco. It is quite evident from the small list presented by R. E. King and the equivocal one of Cloud-which contains Wolfcampian names unlikely in the fauna and not known in the Sierra Diablo-that much collecting and careful work needs to be done on the fauna of the Victorio Peak Limestone.

Cutoff Shale Member: Above the Victorio Peak Limestone a unit of 250-275 feet of dark limestone, shale, and sandstone has been identified. This bed at its type section contains very few fossils, and those found are equivocal. The fusulinids are said to indicate a Guadalupe age, but the presence of Perrinites suggests rather a Leonardian age (P. B. King, 1965:78). Brachiopods are said to be rare. We have not collected this formation and, therefore, have no opinion as to its age. Wilde (1968: 12) discusses it as being exposed in the Apache Mountains. Fusulinids from there indicate to him an early Guadalupian age and, more specifically, correlation with the Road Canyon Formation of the Glass Mountains. The Cutoff Shale in the Sierra Diablo and Apache Mountains occupies a position between Leonardian and Guadalupian formations. Its equivocal dating is in accordance with that of the Road Canyon Formation, which also contains guide elements of the Guadalupian and Leonardian. In the Delaware Basin the fossils of the Cutoff Shale suggest an earlier age (see "Guadalupe Mountains" below).

\section{Guadalupe Mountains and Delaware Basin}

This classical area for Permian studies in the United States was made known through the works of G. H. Girty (1909), P. B. King (1948), and N. D. Newell et al. (1953). For years, Girty's Guadalupian Fauna was the chief source of knowledge of American Permian fossils. Many species were established and their names were applied in Permian sections elsewhere in the United States throughout the entire span of the Permian. Our work in the Guadalupes and in the Delaware Basin consisted only in collecting from the Capitan Limestone, the Bell Canyon and Cherry Canyon formations, with the intention of obtaining calcareous and silicified material to help clarify the many equivocal Girty and Shumard species. We also have available the more extensive collections made by the American Museum of Natural History and those of the United States Geological Survey, both of which help to fill gaps where fossils are not silicified. 
WolfCAMP SERIES.-Rocks of Wolfcampian age are not exposed in the Guadalupe Mountains.

Leonard Series.-Rocks of the Bone Spring and Victorio Peak Limestones appear on the west slope of the Guadalupe Mountains, but the lower part of the Bone Spring is not exposed. As in the Sierra Diablo, the Bone Spring is a thick sequence of dark, often cherty limestone with thin, dark shale partings, beds of dark shaly limestone, and occasional lenticular granular masses. Two miles north of Bone Spring, 1700 feet of this limestone was recorded by P. B. King (1948:13). Fossils are rare in the black limestone. A bioherm-like lens 0.75 mile southwest of Williams Ranch, near the middle of the formation, (AMNH 658) yielded Institella.

The Victorio Peak Limestone is well developed in the Guadalupe Mountains. A lower member, 350 feet thick, of brownish-gray dolomitic and cherty limestone represents a phase intermediate lithically to the Bone Spring Limestone. The upper part of the Victorio Peak, 160 feet thick, is light gray and nondolomitic. It contains numerous fossils. North of Shirttail Canyon, a 100-foot middle division is inserted between the two members, which consists of light gray limestone with interbedded, fine-grained calcareous sandstone.

According to P. B. King, fossils are common in the Victorio Peak Limestone, but they are difficult to extract. Girty (in P. B. King, 1948:23) gives a list of species from the lower gray member, which includes Institella, Peniculauris, and Rugatia, all typical Cathedral Mountain species. The upper member also includes Peniculauris.

The Cutoff Shale overlies the Victorio Peak Limestone and has yielded fossils. Examination of the United States Geological Survey collection 7666 (blue) from the Cutoff Shale in the Delaware Basin, on the north side of Brushy Canyon, revealed a typical Cathedral Mountain assemblage: Rugatia, Niviconia globosa, Chonosteges, Hercosia, Xestosia, Megousia, Edriosteges, Institella, and Lepidospirifer. The fauna and age assignment at this place are not in accordance with the age assignment cited for the Cutoff Shale in the Apache Mountains or the Sierra Diablo. It is likely that two different units have received the same name.

Guadalupe Series.-The Guadalupe Series is more extensively developed in this region than in the Glass Mountains. The lowest formation, the
Brushy Canyon, consists of 1150 feet of massive and thin-bedded quartz sandstone, ranging from $\tan$ to black in color. It is thickest in the basin, extends northward along the west slope of the mountains, and wedges out on the Bone Spring flexure. The fauna is neither abundant nor well preserved. The collection, recorded by Girty (in P. B. King, 1948:30), contains Megousia, Echinosteges, and Dyoros, with a number of dubious productids. Newell et al. (1953:232) record the ammonite Waagenoceras. Paleontologically the formation seems to occupy the position of the Road Canyon Formation of the Glass Mountains, but the fauna is too little known for this to be a certainty.

The Cherry Canyon Formation, a much more varied sequence, overlies the Brushy Canyon Formation, and exhibits strong facies differences from northwest to southeast. In the northwestern part of the formation, a basal sandstone, the Cherry Canyon sandstone tongue 200-250 feet thick, is overlain by the reefy Goat Seep Limestone, attaining a maximum thickness of 1000 feet. Laterally to the southeast the Goat Seep interfingers with sandstones of the Cherry Canyon. In the sandstones there are three limestone members in ascending order: Getaway, South Wells, and Manzanita Limestones. All of the members are fossiliferous, some richly, but others with sparse faunas.

The Cherry Canyon Sandstone Tongue contains few fossils, but those present suggest the lower Word. A large Enteletes, suggesting $E$. wordensis $\mathrm{R}$. E. King, is present, as well as a few productids such as Paucispinifera, Liosotella, and Megousia. Spiriferella appears for the first time in the Guadalupe section in this formation. According to P. B. King, the Cherry Canyon Sandstone Tongue is the equivalent of limestone beds occurring below the Getway Member.

The Goat Seep fauna is very poorly known because poor preservation of the fossils by dolomitization of the limestone has destroyed many of their diagnostic features. The discussion of the fauna by Girty cites a number of obvious Word species, but he records others that are known elsewhere only in the Leonard Series (Cathedral Mountain) e.g., Niviconia globosa (R. E. King). The Enteletes cited is a Cathedral Mountain species; however, the occurrence of productids assignable to Paucispinifera, Grandaurispina, and Liosotella are much 
more indicative of the Word. It is evident from Girty's discussion and from his lists that much work needs to be done on the fauna of the Goat Seep. The faunas of the limestone members of the Cherry Canyon Formation in the Basin region are far more extensive, more easily collected, and much better known.

The Getaway fauna, as the result of collecting by parties from the American Museum of Natural History and from the National Museum of Natural History, is now one of the best known from the Guadalupe Mountains. King reports fossils in limy lenses occurring in the 100-200 feet of sandstone between the top of the Brushy Canyon and the base of the Getaway Limestone. Girty (in P. B. King, 1948:41) reports a rich fauna from these sub-Getaway limestones. Our USNM 732 (= AMNH 600) is in one of these thin limestones. Species characteristic of this lens are: Meekella skenoides Girty, Derbyia pannucia, new species, Echinosteges tuberculatus (R. E. King), Bothronia pulchra, new species, Paucispinifera tumida, new species, Grandaurispina undulata, new species, Undulella guadalupensis, new species, Crurithyris tholiaphor, new species, Reticulariina girtyi, new species, Rhamnaria sulcata, new species, Metriolepis exserta, new species, Cyclacantharia kingi Cooper and Grant, and many other less common species. This fauna has considerable similarity to that of the Willis Ranch Member in the Glass Mountains. Both Geyerella and Ombonia appear at this level as great rarities.

Girty (in P. B. King, 1948:42-44) gives a long discussion of the fauna of the upper part of the lower Getaway Member and records many species. He remarks on the absence of Enteletes, which last appeared in the Cherry Canyon Sandstone tongue. Many of the species listed above for the sub-Getaway lens appear in the Getaway Member, but, in addition, other important species are significant, such as Ctenalosia fixata, Cooper and Stehli, Polymorpharia polymorpha, new species, Liosotella wordensis (R. E. King), Grandaurispina rudis, new species, Dyoros (Tetragonetes) subquadratus, new species, Spiriferella gloverue, new species, and Yakovlevia costellata, new species. A few unusual species that are very rare appear at this level: Divaricosta squarrosa, Cooper and Grant, Strophalosia inexpectans, new species, and Rallacosta species. This fauna has some species in common with the Appel
Ranch Member of the Word Formation of the Glass Mountains, and the general aspect of the fauna is the same.

The South Wells Limestone Member, which lies above the Getaway, is not so richly fossiliferous. It is 200 or more feet thick and is composed of gray limestone, black limestone, and some sandstone beds. The black limestones often contain abundant Leiorhynchoidea, which is accompanied by Glossothyropsis and Paranorella. The two rhynchonellids are reminiscent of black limestones in the Las Delicias section in Coahuila, Mexico (Newell et al., 1953). Of productids, Girty (in P. B. King, 1948: 46) records the following common Word genera: Waagenoconcha, Cancrinella, Grandaurispina, and Liosotella.

The Manzanita Limestone Member consists of 75-100 feet of earthy, greenish limestone, weathering to a yellow. King and Fountain observed fossils in these limestones, but these fossils proved to be indifferently preserved and difficult to obtain.

The Bell Canyon Formation, 670-1038 feet thick, overlies the Cherry Canyon Formation. Like the latter, it is a mass of fine-grained sandstone containing limestone members. Five of these have been named (from the bottom up): Hegler, 30-40 feet (Plate 22: figure 2); Pinery, 25-100 feet; Rader, 15 feet; McCombs, 10 feet; and Lamar, 15-30 feetall dark limestones (Plate 22: figure 3). The faunas of the lower three are very similar, but that of the Lamar is quite distinct from the others. No extensive fauna is known for the McCombs. The Bell Canyon Formation interfingers toward the mountains (northwest from the Delaware Basin) into the Capitan Limestone, the great mass of reef rock and reef slide (Plate 22: figure 1). Completing the picture, the Carlsbad Formation, back reef facies, interfingers with the Capitan reef rock on the west. The Capitan and Carlsbad have distinctive faunas.

The faunas of the Hegler, Pinery, and Rader Members consist of numerous small brachiopods in which productids are rare, rhynchonellids common, and several genera of the Spiriferinidae abundant. Large productids are very scarce, but Thamnosia capitanensis (Girty) occurs usually as broken and worn specimens. Liosotella is present. Each of the members has first appearances of significance. First appearances in the Hegler Member are: Aphaurosia, Craspedona, Deltarina, Elivina, 
Fascicosta, Scapharina, Sestropoma, Timorina, and Xenosaria. The only newcomer recorded in the Pinery is Rigbyella. Terminal at the end of the Rader Member are: Glossothyropsis, Chonetinetes, Craspedona, Micraphelia, Rallacosta, and Xenosaria.

The Lamar fauna is characterized by a great flood of Martinia and by two genera that appear for the first time: Anomaloria and Astegosia. In addition to these, Aneuthelasma, Eliva, Lirellaria, and Strigirhynchus appear for the first time.

Missing from the Bell Canyon limestone members are some of the most abundant genera of the Permian, such as: Meekella, Enteletes, Rhynchopora, and Neospirifer. Meekella has not been found by us in any of the Bell Canyon limestones, but Geyerella appears as a very rare fossil in the Lamar. Enteletes in the Guadalupe Mountain and Delaware Basin region appears to have died out in the basal part of the Cherry Canyon Formation. No large spiriferids have been found by us in the Bell Canyon limestones.

Inasmuch as the Bell Canyon is the lateral equivalent of the Capitan Limestone, that formation contains many of the species of the Bell Canyon, and the various levels may be identified in the Capitan.

Our collecting in the Capitan Limestone mainly has been from the reef slide portion on the east and south fronts of the mountains. These areas have produced the Lamar fauna in abundance. The two facies complement each other nicely, that of the dark Bell Canyon limestone members yielding silicified interiors, but not furnishing much evidence as to the nature of the shell. The Capitan fossils are unsilicified and furnish information on the nature of the shell. The Capitan fauna thus is essentially the fauna of the Bell Canyon in unsilicified state.

Our collecting in the Capitan Limestone has made it clear that the fauna of this thick and extensive formation has been badly neglected. Collections of the American Museum of Natural History and the National Museum of Natural History combined indicate that many species still are to be found and that the total generic composition is not known. Large spiriferids that are undescribed have been found in places, but our specimens are insufficient for the task of description.
The fauna of the Carlsbad Limestone, back reef facies of the Capitan, also is very poorly known. The fauna is peculiar in lacking productids and rhynchonellids, but in containing numerous terebratulids. A Meekella is present, but spiriferids are lacking; Cyclacantharia is abundant.

\section{Chinati Mountains}

The reported occurrence (Stehli, 1954:334) of Scacchinella in the Permian of these mountains was the lure that attracted us to them. The exposures promised to help us in our understanding of the Scacchinella-bearing beds of the Glass Mountains. Several areas of Permian rocks occur in the Chinati Mountain region south of Marfa, Texas. All of them yield a different sequence, but our main quest was just east of the Cibolo Ranch House, near the junction of Sierra Alta and Cibolo Creeks, about 3 miles north of Shafter. Here, a section about a thousand feet thick faces west along Sierra Alta Creek. The outcrop area extends for about 3 miles in a northeasterly direction from the junction of the creeks almost to U.S. Highway 67. We also examined the area near Ojo Bonito, on the Love Ranch, about 10 miles northwest of the exposures on Sierra Alta Creek.

Not much has been written about the Chinati Mountains Permian, and the fossils are virtually unknown. The first to describe the area was J. A. Udden, who outlined the stratigraphy. In 1904 he named three formations: Cieneguita, Alta, and Cibolo, in ascending order. Since the first is dated as Pennsylvanian and the second has yielded no fossils as yet, these two have no concern here.

The Cibolo Formation.-This formation was suggested by Udden to be Permian and was divided into five rock units. Skinner (1940) made a study of this formation and determined, on the basis of fusulinids, that the entire sequence, except for the very topmost part, is Wolfcampian in age. R. E. King (1931) and A. K. Miller, who found the ammonoid Perrinites in the sequence, regarded much of the section as Leonard in age. Rix (1935a) prepared a doctoral dissertation on the Chinati Mountains and published information in a West Texas Geological Society Guide Book (1953b) to the area. He concludes that the age of the Cibolo Formation is Leonardian. 
All writers on the Cibolo Formation have recognized Udden's divisions of this formation, which are (from the bottom up): Transition Zone, Lower Brecciated Zone, Zone of Sponge Spicules, Thinbedded Zone, and Yellow Dolomitic Limestone.

Transition Zone: These beds are calcareous shale (Plate 23: figures 3,4) and sandstone, about 100 feet thick, containing many fossils, particularly fusulinids. In the upper part we collected the following brachiopods: Meekella magnifica, new species, Rhipidomella species, Orthotichia aff. $O$. kozlowskii R. E. King, Reticulatia robusta, new species, Eolyttonia gigantea, new species, Neospirifer infraplicata R. E. King, Scacchinella titan, new species, Stenoscisma multicostatum Stehli, and large Hustedia hessenis $\mathrm{R}$. E. King. This assemblage, as do the fusulinids, identifies the level as late Wolfcampian in age.

Lower Brecciated Zone: This zone consists of 130 feet of massive limestone blocks, with coarse, boulder-like rubble between them (Plate 23: figures 3, 4). The zone is interpreted by Rigby (1958: 308 ) as a reef talus mass, but $\operatorname{Rix}$ (1953a:45) regards the breccia as having been derived from massive limestone ledges in the breccia. Regardless of this difference of opinion, the block originated as reefy limestone, abounding in large Scacchinella (Plate 23: figure 2) and strongly resembling the Decie Ranch and Sullivan Peak Members of the Skinner Ranch Formation. We collected the following important species: Derbyia nasuta Girty, Geyerella cf. G. hessi, new species, Diplanus lamellatus (R. E. King), Acosarina dorsisulcata Cooper and Grant, Orthotichia newelli, new species, Enteletes species, Rhipidomella hessi R. E. King, Limbella species, Scacchinella titan, new species, Echinauris species, Antronaria mesicostalis (Girty), Stenoscisma problematicum, new species, Neospirifer infraplicata R. E. King, Eolyttonia magna, new species, Cleiothyridina rectimarginata, new species, and Crenispirifer angulatus ( $\mathrm{R}$. E. King).

This brachiopod assemblage at once suggests the Skinner Ranch Formation. Relationship to this formation in the Glass Mountains is shown by the Scacchinella, Geyerella, Rhipidomella, and Eolyttonia. Relationship to the lower Bone Spring, also of Skinner Ranch age, is shown in the presence of Pontisia mesicostalis and Orthotichia newelli.

Zone of Sponge Spicules: Overlying the Brecciated zone there occur 216 feet of thin-bedded limestone, chert, and sandstone containing many sponge spicules. Fossils are not common in this zone, but a few specimens of the ammonite Perrinites were found near the top and of Institella leonardensis (R. E. King) in the lower part. On the basis of Institella, we correlate it with the Cathedral Mountain Formation.

Thin-bedled Zone: Above the Zone of Sponge Spicules comes this zone of thin-bedded dark limestone. The individual beds swell and thin and between them is sandy shale. Fossils are fairly common in a few of the thin layers. Fusulinids in a few layers make up most of the rock. About 150 feet above the Spicule Zone occurs a thin bed with numerous silicified brachiopods. The bed yielded mucronate Reticulariina bufala, new species, Liosotella costata, new species, Megousia auriculata Muir-Wood and Cooper, Dyoros transversus, new species, Echinauris bella, new species, and Petasmatherus pumilus, new species. This list indicates correlation with the Road Canyon Formation in the Glass Mountains,

Yellow Dolomitic Limestone: This zone failed to yield us any brachiopods, but Rigby (in Rix, 1953a:51, 54) records numerous sponges that he regards as late Leonard or early Word in age.

Ojo Bonito AREA.-Here, dark shales are overlain by 120 feet of massive limestone containing numerous specimens of the ammonite Perrinites, probably Leonardian in age. Above this there is a thick sequence of shale and thin limestone containing a few fossils. The fusulinids and brachiopods indicate a Guadalupian (Word) age for these beds, which belong in the Ross Mine Formation of Rix (1953b).

\section{Register of Localities}

The localities herein include all of those represented in the collection of the National Museum of Natural History, Smithsonian Institution ( under the locality numbers of the United States National
Museum). Inasmuch as some of the material was derived from other museums and the United States Geological Survey, locality numbers of these organizations are also added, but the specimens be- 
long to the National Museum of Natural History. The locations generally are made as map measures from nearby bench marks, instrumentally determined elevations, hill tops, ranch houses, or other convenient reference points. These are often difficult to locate quickly by readers unfamiliar with the quadrangles covering the Glass Mountains. We have, therefore, listed alphabetically and numerically all of these important points to facilitate location of the collecting places.

The United States Geological Survey topographic maps are divided into nine rectangles by intersecting latitude and longitude lines. These are called subquads and are numbered in sequence, beginning in the upper right, in the manner of numbering used in the township-range system. Consequently, the subquad in the upper right corner is 1 , to the left are 2 and 3. Below 3, in order left to right, are 4 through 6; 7 lies in the lower right corner with 8 and 9 to the left.

Each subquad is further divided in to four equal rectangles: northeast, southeast, northwest, and southwest. Each of these rectangles is similarly subdivided. Location is made by reference to the quarter in which the site lies. Thus, a collecting spot may lie in the northwest quarter of the southwest quarter of subquad seven: NW, SW7.

Faunal lists for all localities will appear in the final volume of this study, rather than here, in order to avoid the introduction of a great number of undefined names and to make whatever changes become necessary in the meanwhile.

See "R. E. King Localities" (page 128) for the system of punctuation used throughout in the locality lists of this register.

\section{Altuda (15') Quadrangle}

\begin{tabular}{|c|c|}
\hline Bench mark 4627 . & NE, NE 7 \\
\hline Bench mark 4827. & $\ldots \mathrm{SW}, \mathrm{SE}, \mathrm{NE} 6$ \\
\hline Bench mark 4869 & SE, NE, SE 6 \\
\hline Bench mark 4973. & NW, SE 6 \\
\hline Bench mark $6125[=$ Sullivan Peak $]$ & SE, NE 8 \\
\hline Canyon, Gilliland & ..E1/2 6 \\
\hline Canyon, Road.. & NE, SE 6 \\
\hline Clay Slide.. & SE, NW 8 \\
\hline Hill 4902. & ..SW, SE 8 \\
\hline Hill 4910. & SE, NW 7 \\
\hline Hill 4920 . & NW, SW 7 \\
\hline Hill 5021 [=Decie Brothers Hill]. & NE, SW 7 \\
\hline Hill $5250 \ldots \ldots \ldots \ldots \ldots \ldots \ldots \ldots \ldots \ldots \ldots$ & center SE, SE 8 \\
\hline $\begin{array}{l}\text { Hill } 5280 \ldots \\
\text { Hill } 5300\end{array}$ & ...SW, NE 7 \\
\hline
\end{tabular}

Hill 5615

SE, SE, NE 6

Hill 5779 SE, SE 6

Hill 5874 SW, NE 6

Hill 5935

Hill 5939 SE, NW 8

Hill, "Windmill" SE, SW 6

Hills, Lenox N1/2, SW 7

Mountain, Cathedral.

SE 8 and SW 7

Mountain, Iron E center 8

Ranch, Iron Mountain [=Skinner] SE, NE 7

Ranch, Skinner E center, NE 7

Ranch, Sullivan [= Yates]

E center, NE 7

Sullivan Peak. NE, NE 8

Tank, Poplar. SE, NE 8 SW, SW 8

\section{Hess Canyon (15') Quadrangle}

Amphitheater in Wolf Camp Hills......................W center 5

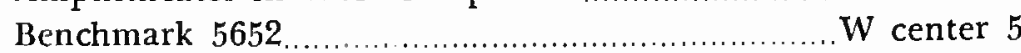
Benchmark $5860[=$ Leonard Mountain $] \ldots \ldots \ldots \ldots . . . \mathrm{N}_{1} / 2$, NW 9 Canyon, Comanche [= east branch Hess Canyon?] ... N1/2, SE 4 Canyon, Geologists. Canyon, Hess, SE, SW 5 . Canyon, Road .................................................. SW 4

Hill 4627 . SW, NE 1

Hill 4732 Hill 4752 . Hill 4762 SW, NE 1

Hill 4800 $\mathrm{S} 1 / 2$, NW 6 NE, NW 6

Hill 4815 SE, NW 1

Hill 4921

Hill 4952

Hill 5035

Hill 5060 .

Hill 5195 .

Hill 5157

Hill 5202

Hill 5233

Hill 5305.

Hill 5360

Hill 5453

Hill 5461

Hill 5490 .

Hill 5507 .

Hill 5543

Hill 5552

Hill 5575 .

Hill 5578 .

Hill 5611

Hill 5632

Hill 5674 SW, NW 6 NE, NW 6 NW, SE 5 SW, SW 1 center $S_{1 / 2} 5$ SE, SE 1 center $\mathrm{E}_{1} / 2, \mathrm{SE} 2$ NW, NE 6

W side SE, NW 1 NW, SE 4 SW, SE 2

Hill 5725

Hill 5726 .

Hill 5751

Hill 5767

Hill 5801

Hill 5803

Hill 5816

Hill 5821
N $1 / 2$, SW 4

NE, NW 5

.NE, NE 4

NW, NW 5 NE, NE 4 NW, NE 5

NW, NW 5 SW, NE 4 SE, NE 4

NW, SE, NE 5 SW, SW 4 NW, SW 5 NE, SE 4 SW, NW, SW 5 center $\mathrm{N}_{1} / 2$, SW 5 NW, SW 4 $S$ center $S 1 / 2$, NW 4 SW, SE, NE 4 NE, SW 5 
Hills, Wolf Camp

Horst, Hess Ranch

center $\mathrm{S} 1 / 25$

center E1/2, 4 $\mathrm{N} 1 / 2, \mathrm{NW} 9$

SE, NW 5

Ranch, Appel [= Old Word]

Ranch, Bill Neal [= Taylor]

Ranch, Brooks

NW, SW, SE 5

Ranch, Hess. NW, NE 6

Ranch, Old Word [=Appel]

Ranch, Taylor [= Bill Neal]....

Ranch, Willis

SE, SW 4

SE, NW 5

NW, SW, SE 5

SE, NW 4

Tank, Split

SE, NW 5

Tank, China

\section{Monument Spring (15') Quadrangle}

Bench mark 4190

NW, NE 2

Bench mark 5324 $\mathrm{N}$ center 4

Hill 4801

Hill 4806 NW, NE 2

Hill 4811

Hill 4861

Hill 5195 [=Dugout Mountain].

Hills, Lenox

Hills, Lenox

Mountain, Dugout

Point, Instrumental 4386

Point, Instrumental 4269

Ranch, Arnold.

NW, SW, NE 3

NE, NE, SW 3

SE, NW, NE 3

NW, SW 2

NW, NE 2

NE, NW, 2

W center 2

SW, NE, SE 3

SW, SE, SE 3

NE, SE 2

Ranch, Decie.

W center, NW 1

Ranch, Payne, Old

SE, NE 3

\section{Guadalupe Peak (15') Quadrangle}

Beacon, Airway.

$\mathrm{E}$ of center $\mathrm{N}$ line, $\mathrm{NW} 7$

Bench mark 4425

Bench mark 5315

Bench mark 5426 NW, NW, NE 8

SE, NW, SW 6

S $1 / 2, N W$, SW 6

Bench mark 5446

Camp, Nickel Creek

$\mathrm{E}$ of center $\mathrm{N}$ line, NW 7

Camp, Pine Spring.

W center, E1/2, NE 6

Canyon, Indian Cave

SW, NW 6

Canyon, Brushy

SW, SE 5

SW, SE 5

Canyon, McKittrick. NW 1

Canyon, Pine. NW, NW 6

Canyon, Shirttail NW 5

El Capitan

Frijole P. O. center $\mathrm{E}_{1 / 2} 5$ NE, NW 6

Hill 5130 .

SE, NW, NE 7

Hill 5206 .

SE, NW, NE 6

Hill 5406 center E1/2, SW, NE 7

Hill 5414

near center SE, SE 1 SW, SE, NE 7

Hill 6560

NW corner, NE 1

Hill Nipple

Mountain, Cutoff

Mountain, Pine Top

Pass, Guadalupe

Peak, Shumard.
Peak, Signal [=Guadalupe Peak]

$\mathrm{S} 1 / 2, \mathrm{NE} 5$

Point, Instrumental 5206

NE, SW, NE 6

Point, Instrumental 6910

NE, NE, NE 3

Pratt Lodge.....

NE, SE 1

Ranch, Hegler [=Ligon]

SE, SE 1

Ranch, Williams

Ridge, Rader.

SE, NW 5

Spring, Goat. SW, SE 1

Spring, Pine [=lower Pine Spring]

NE, NW 5

Spring, Pine, lower (see Pine Spring)

Spring, Pine, upper.

Tank, Pinyon.

SE, NW, NW 6

SE, NW, NE 7

\section{VAN HORN $\left(30^{\prime}\right)$ QUADRANGLE}

Bench mark 3625

Bench mark 3648

Bench mark 3806

Bench mark 4290

Bench mark 4970

Canyon, Apache

Canyon, Black John

Canyon, Red Tank

Canyon, Victorio

Gap, Seven Heart

Hazel Mine

Hill 4402

Hill 6073

Mountain, Three Mile

Mountains, Baylor

Peak, Apache,

Peak, Victorio

Ranch, Corn

Ranch, Figure Two

Ranch, Nutt

\section{LOCATION OF CANYONS \\ in Carlsbad Caverns West (15') Quadrangle}

Big.

SW, SW 9

Black center 9

Double

Nuevo.

Rattlesnake

Slaughter.

Walnut

Yucca

E $1 / 25, W_{1 / 2} 6$ center 6

NE, NE 6

$\mathrm{E}_{1 / 2} 5, \mathrm{~W}_{1 / 2} 6$

SE, SE 1

$S_{1 / 2} 5$

\section{R. E. King Localities}

Through the kindness of Dr. C. O. Dunbar, Yale University, the locality maps of R. E. King were lent for use in our studies. We have augmented this list of King's localities with additional map measures, which will help the reader to locate 
many of his collecting spots. Also, the stratigraphic assignments are those of King, but we have expanded them by giving the modern formation names in brackets. Finally, we have given the equivalent United States National Museum (USNM) numbers in brackets where they coincide with King's numbers. Special notes or comments, if needed, are in brackets at the end of the entry. This system of punctuation is used throughout all of the locality lists in this register.

1. Hess [=Skinner Ranch Formation]: Small hill 1 mile (0.9) $\mathrm{NW}\left(\mathrm{N} 33^{\circ} \mathrm{W}\right.$ ) of summit of Iron Mountain, 1.4 miles $\mathrm{N} 80^{\circ} \mathrm{W}$ of Skinner Ranch, Altuda quadrangle.

2. Wolfcamp (upper) [=Lenox Hills Formation]: Section 14, hill $\mathrm{W}$ of Iron Mountain, 2.28 miles $S 57^{\circ} \mathrm{W}$ of Skinner Ranch, Altuda quadrangle.

3. Leonard (about 50 feet above base) [= Skinner Ranch Formation]: 1 mile $(0.9) \mathrm{W}\left(\mathrm{N} 78^{\circ} \mathrm{W}\right)$ of summit of Iron Mountain, Altuda quadrangle [=USNM 723h].

4. Hess? [=Skinner Ranch Formation]: 0.6 mile $(0.58) \mathrm{N}$ $\left(\mathrm{N} 11^{\circ} \mathrm{E}\right)$ of hill 5021, second hill $\mathrm{W}$ of Iron Mountain, Altuda quadrangle. [=USNM 717f].

5. Leonard (below soft shale of the Clay Slide about 250 feet below top) [=Cathedral Mountain Formation]: Section 14, W of Iron Mountain, below soft shale of Clay Slide, 0.47 mile S $4^{\circ} \mathrm{W}$ of hill 4910, Altuda quadrangle [ $=$ R. E. King 301? =approximately USNM 717g].

6. Word [=lower Road Canyon Formation]: Section 14, near Clay slide, 0.4 mile S $15^{\circ} \mathrm{W}$ of hill 4910, Altuda quadrangle $[=\mathrm{R}$. E. King 301].

7. Leonard (bed 16) [= Cathedral Mountain Formation]: Section 14, W of Iron Mountain, Altuda quadrangle [number not on King's map].

8. Hess [= Skinner Ranch Formation]: Section 14 (contains some lower Leonard fossils [=Cathedral Mountain]), 1.3 miles $\mathrm{S} 22^{\circ} \mathrm{E}$ of hill $4910, \mathrm{~W}$ of Iron Mountain, Altuda quadrangle.

9. Leonard (below middle limestone layer of bed 9) [= Cathedral Mountain Formation]: 1.05 miles S $14^{\circ} \mathrm{E}$ of hill 4910, section 14, W of Iron Mountain, Altuda quadrangle.

10. Leonard (middle limestone layer of bed 9 and top of bed 12) [=Cathedral Mountain Formation]: Section 14, second hill W of Iron Mountain, same as above, Altuda quadrangle [number not on King's map].

11. Leonard (between middle limestone layer of bed 9 and top of bed 12) [=Cathedral Mountain Formation]: Section 14, same as above, second hill W of Iron Mountain, Altuda quadrangle [number not on King's map].

12. Leonard [= Cathedral Mountain Formation]: Section 14, top of bed 12, same as above, second hill $\mathrm{W}$ of Iron Mountain, Altuda quadrangle [number not on King's map].

13. Leonard (base of bed 14) [= Cathedral Mountain Formation]: Section 14, same as above, second hill $W$ of Iron Mountain, Altuda quadrangle [number not on King's map].
14. Leonard (lower part bed 15) [=Cathedral Mountain Formation]: Section 14, same as above, second hill $W$ of Iron Mountain, Altuda quadrangle [number not on King's map].

15. Leonard [ = Skinner Ranch and Cathedral Mountain Formation]: Scction 15, hill $5280 \mathrm{~W}$ of Iron Mountain, Altuda quadrangle.

16. Leonard [=Skinner Ranch Formation]: Section 15, slightly above or near the base, hill $5280 \mathrm{~W}$ of Iron Mountain, Altuda quadrangle.

17. Hess [=Sullivan Peak Member]: Projecting spur of range just $W$ of Marathon-Sullivan [Yates] Ranch road, 1.37 miles $\mathrm{N} 72^{\circ} \mathrm{E}$ of hill 5300, Altuda quadrangle [=USNM 707].

17a. Lower part projecting spur of range just $W$ of Sullivan Ranch road, Altuda quadrangle [=USNM 707].

1 th. Middle of spur of range just $W$ of Sullivan Ranch road, Altuda quadrangle.

17c. Top of projecting spur of range $W$ of Sullivan Ranch road, Altuda quadrangle.

18. Hess: Section 12.

19. Leonard (basal) [= Poplar Tank Member]: Section 12, bed I, $\mathrm{E}$ end of Lenox Hills, 0.8 mile $\mathrm{N} 82^{\circ} \mathrm{E}$ of hill 5300 , Altuda quadrangle.

20. Leonard (bed 1) [= Poplar Tank Member, by map location]: Section 12, 0.8 mile $N 73^{\circ} \mathrm{E}$ of hill $5300, \mathrm{E}$ end of Lenox Hills, Altuda quadrangle.

21. Leonard (near middle of bed 24) [ = Third and Fourth Limestone Members=Cathedral Mountain Formation]: Section 12, same as above, E end of Lenox Hills, Altuda quadrangle. [The locality descriptions and map locations of Iocalities 21-25 are not in complete accordance with P. B. King's (1931:66) section 21. All localities are given as bed 24 (= Third and Fourth Limestone Members). Localities 20-22 are on the edge of the hill 1 mile eastnortheast of hill 5300 at about an elevation of 5000 feet and are at the level of the Sullivan Peak Member. Localities 23-25 are in hill 4920, and 24 and 25 are certainly in the Third and Fourth Limestone Members. Locality 23, on the other hand, located at the base of the hill, may be in the top of the Skinner Ranch Formation (Sullivan Peak Member)].

22. Leonard (middle of bed 24) [= Cathedral Mountain Formation]: Section 12, same as above, $\mathrm{E}$ end of Lenox Hills, Altuda quadrangle [see, R. E. King 21].

23. Leonard (near middle of bed 24) [= Cathedral Mountain Formation?]: Section 12, below hill 4920 and $\mathrm{N}$ of locality 21, 0.18 mile $S$ of hill 4920, Lenox Hills, Altuda quadrangle [see, R. E. King 21].

24. Leonard (some distance above middle of bed 24 but below top of hill 4920) [=Skinner Ranch Formation?]: Section 12, 0.1 mile $S$ of top of hill 4920, Altuda quadrangle [see R. E. King 21; the list of fossils indicates Skinner Ranch, but the map location is in the Cathedral Mountain].

25. I.eonard (upper part bed 24, SW side of hill 4920) [=Cathedral Mountain Formation?]: Section 12, 0.25 mile $S 58^{\circ} \mathrm{W}$ of top of hill 4920 , Altuda quadrangle [=see R. E. King 21]. 
26. Leonard (bed 26) [= Cathedral Mountain Formation]: Section 12, SW side of hill 4929, 0.25 mile $S 85^{\circ} \mathrm{W}$ of top of hill 4920, Altuda quadrangle. [Localities 26-29 are marked on R. E. King's map on the north slope of hill 4920 near the top, but the various bed numbers in section 12 are not in accordance with the map location. See also R. E. King 21].

26s. Middle Leonard [=Cathedral Mountain Formation]: Same as above, $S$ of Sullivan Peak, Altuda quadrangle [C. Schuchert collector].

27. Leonard (beds 19-24) [= Cathedral Mountain Formation]: Section 12, same as locality $26, W$ side of hill 4920, Altuda quadrangle [see R. E. King 21].

28. Leonard (middle of bed 24) [=Cathedral Mountain Formation]: Same locality as 26, SW side of hill 4920 [see R. E. King 21].

29. Leonard [=Cathedral Mountain Formation]: Section 12, same locality as 26, Altuda quadrangle [see R. E. King 21].

30. Leonard (bed 28) [=Cathedral Mountain Formation]: Section 12, 1.4 miles $S 1^{\circ} \mathrm{W}$ of Sullivan Peak, Altuda quadrangle.

31. Leonard (bed 34) [=Cathedral Mountain Formation]: Section 12, same as above, Altuda quadrangle [=USNM $710 \mathrm{f}]$.

32. Word (lower) [=Road Canyon Formation]: S of Cathedral Mountain, 1.65 miles S $54^{\circ} \mathrm{W}$ of Sullivan Peak, Altuda quadrangle.

33. [Not described in R. E. King's locality list (1931:134) and not recorded on his map; several species recorded in text.]

34. Leonard: 0.5 mile $S$ of tank at locality 4555 [unidentifiable and not on King's map, but several species recorded in text].

35. Hess [= Decie Ranch Member]: 0.48 mile $S 8^{\circ} \mathrm{W}$ of hill 5300 at base of escarpment, $S$ edge of Altuda quadrangle [= part of USNM 707a].

36. Leonard: Section 11, bed 4, on hill 5300, Altuda quadrangle [no fossils recorded].

37. Leonard (bed 10) [= Cathedral Mountain Formation]: Section 15, tank $W$ of $\mathrm{N}$ end of Iron Mountain, 1.15 miles $\mathrm{N} 50^{\circ} \mathrm{E}$ of hill 4910, Altuda quadrangle.

38. Leonard (basal) [= Skinner Ranch with some Cathedral Mountain]: 0.25 mile $S 79^{\circ} \mathrm{E}$ of hill 5300 , center of Lenox Hills, Altuda quadrangle [=approximately USNM 708e; map location indicates Poplar Tank or Sullivan Peak Members, but list includes Cathedral Mountain Formation species].

39. Hess (top of bed 1) [= Decie Ranch Member]: Seclion 10, 1.2 miles $S 20^{\circ} \mathrm{W}$ of hill 5300 , Lenox Hills, Altuda quadrangle [=approximately USNM 727u].

40-43. All Altuda Member [no fossils recorded].

44. Word (lower limestone) [ = Road Canyon Formation]: Section 12, 0.70 mile $S 37^{\circ} \mathrm{E}$ of Sullivan Peak, Altuda quadrangle [=approximately USNM 731v].

45. Word (lower limestone) [=Road Canyon Formation]: Section 12, 0.40 mile SW of $44,0.95$ mile $S 13^{\circ} \mathrm{E}$ of Sullivan Peak, Altuda quadrangle.
46. Word (lower limestone) [= Road Canyon Formation]: Section 12, 0.25 mile $S$ of locality 44 and 0.2 mile $E$ of locality $45,0.92$ mile $S 26^{\circ} \mathrm{E}$ of Sullivan Peak, Altuda quadrangle [=USNM 707e].

47. Word (middle) [ $=$ Willis Ranch Member]: $W$ side of Gilliland Canyon below hill 4939, 2.15 miles $\mathrm{N} 5^{\circ} \mathrm{E}$ of hill 4910, NW of Iron Mountain, Altuda quadrangle.

48. Word (middle limestone) [ Willis Ranch Member]: 0.72 mile $S 29^{\circ} \mathrm{E}$ of bench mark 4973, NNW of Iron Mountain, Altuda quadrangle.

49, 50. Capitan [no fossils recorded in text].

51. Word (lower limestone) [= Road Canyon Formation]: NE of Clay Slide, 0.2 mile due $W$ of hill 4910, Altuda quadrangle [=near USNM 724a].

52. Leonard: Section 12, bed 37, lower part, calcareous sandstone, bearing ammonoids, 1.2 miles $S 84^{\circ} \mathrm{E}, \mathrm{S}$ of Sullivan Peak, Altuda quadrangle.

53. Word (lower, beds 1 and 2) [= Road Canyon Formation]: 1.7 miles $S 48^{\circ} \mathrm{W}$ of Sullivan Peak, Altuda quadrangle. [=USNM $710 \mathrm{~m}$ ].

54. Word (lower, bed 3) [= Road Canyon Formation]: Section 11, 1.65 miles S $50^{\circ} \mathrm{W}$ of Sullivan Peak, Altuda quadrangle.

55. Word (lower) [=Upper Word Formation?]: 1.1 miles SSW of hill 5935, 3.19 miles $S 62^{\circ} \mathrm{W}$ of Sullivan Peak, same horizon as R. E. King 54, Altuda quadrangle.

56. Capitan: 0.4 mile NNW of hill 5935, W end of Cathedral Mountain, Altuda quadrangle [ $=$ no fossils listed].

57. Capitan (Altuda Member): 1.5 miles NE of Altuda, Altuda quadrangle $[=$ USNM 718a].

58. Word (lower) [=Road Canyon Formation]: $S$ side of Cathedral Mountain, Altuda quadrangle [not recorded on map].

59-68. [No fossils recorded.]

69. Wolfcamp (lower shale): Just $\mathrm{N}$ of igneous plug, Hess Ranch horst [no fossils recorded].

70. Wolfcamp (middle-upper) [=Lenox Hills Formation]: Base of range about 1 mile $(0.75) \mathrm{S} 83^{\circ} \mathrm{E}$ of hill 5300 , W of Sullivan (Yates) Ranch Road, E end of Lenox Hills, Altuda quadrangle [=USNM 708n].

71. Wolfcamp [= Decie Ranch Member]: At base of escarpment between Sullivan (Yates) Ranch Road and a point 0.5 mile to $\mathrm{W}, 1.38$ miles $\mathrm{N} 70^{\circ} \mathrm{E}$ of hill 5300 , Altuda quadrangle [=USNM $707 \mathrm{~g}, 707 \mathrm{v}$.

72-74. Wolfcamp: [no fossils recorded].

75. Wolfcamp [= Gaptank Formation]: 0.85 mile $\mathrm{N} 38^{\circ} \mathrm{W}$ of summit of lron Mountain (Skinner) Ranch, Altuda quadrangle.

76. Wolfcamp (upper) [=Lenox Hills Formation]: Westcrmmost outcrop of Wolfcamp on Leonard Mountain, bed containing large Schwagerina, 1.65 miles $\mathrm{N} 33^{\circ} \mathrm{E}$ of top of Iron Mountain (Skinner) Ranch, Altuda quarrangle.

77. Wolfcamp (upper, lowest beds above basal conglomerate) [=Lenox Hills Formation]: 0.2 mile E of locality 76,1 mile $\mathrm{N} 84^{\circ} \mathrm{W}$ of bench mark 5860 on Leonard Mountain W edge of Hess Canyon quadrangle.

78-81. [No fossils recorded.] 
82. Wolfcamp (or Leonard): Float on middle of $\mathrm{S}$ side of Leonard Mountain, 0.32 mile $\mathrm{S} 70^{\circ} \mathrm{W}$ of bench mark 5860 on Leonard Mountain, Hess Canyon quadrangle.

83. Leonard [=Cathedral Mountain Formation]: Float at E base of Leonard Mountain, 0.85 mile $\mathrm{N} 75^{\circ} \mathrm{E}$ of bench mark 5860 on Leonard Mountain, Hess Canyon quadrangle.

84. Wolfcamp (Uddenites zone=Uddenites-bearing Shale Member): On NE side of Leonard Mountain, near small igneous intrusion [no fossils listed].

85. Wolfcamp [=Lenox Hills Formation]: $S$ middle part of Hess Ranch horst, W end; 2.4 miles $N 41^{\circ} \mathbf{E}$ of Hess Ranch, Hess Canyon quadrangle.

86. Wolfcamp [=Lenox Hills Formation]: S side of Hess Ranch horst, W end, Hess Canyon quadrangle [location not on map].

87. Wolfcamp (bed 12 and above) [=Neal Ranch Formation ]: Differentiated into 2 parts, low and high: High $=$ bed 12 and above; section 23, 1.48 miles $S 75^{\circ} \mathrm{W}$ of hill 5060, Wolf Camp Hills, Hess Canyon quadrangle. Low $=$ bed, 13, high=upper beds, Hess Canyon quadrangle. [=USNM 70Id (part I =bed 4)].

88. Wolfcamp (Uddenties Member, bed Ib) [=Gaptank Formation (Uddenites-bearing Shale Member)]: Section 24, at Wolf Camp, Hess Canyon quadrangle [not on map].

89. Wolfcamp (section 24, bed 4) [=Neal Ranch Formation]: Wolf Camp, Hess Canyon quadrangle.

90. Wolfcamp (bed 8) [=Neal Ranch Formation]: Section 24, 0.60 mile S $78^{\circ}$ E of hill 5060, Wolf Camp Hills, Hess Canyon quadrangle.

91. Wolfcamp (bed 12) [=Neal Ranch Formation]: Section 24, 0.65 mile $S 86^{\circ} \mathrm{W}$ of hill 5060, Wolf Camp Hills, Hess Canyon quadrangle.

9lx. Wolfcamp (Hess or Leonard) [ESkinner Ranch Formation?]: Loose pieces picked up on bed 12, section 24, the fossils, not recorded, of which indicate a Hess or Leonard age.

92. Wolfcamp (bed 14) [=Neal Ranch Formation]: Section 24, 0.73 mile $S 82^{\circ} \mathrm{W}$ of hill 5060, Wolf Camp Hills, Hess Canyon quadrangle [=USNM 701c].

92a. [No fossils recorded.]

93. Wolfcamp (bed 9) [=Neal Ranch Formation]: Section 24 , bed 9 , and float from next few higher beds on side of arroyo NE of Wolf Camp, 0.55 mile $\mathrm{N} 79^{\circ} \mathrm{W}$ of hill 5060, Wolf Camp Hills, Hess Canyon quadrangle.

93s. Wolfcamp (middle) [=Neal Ranch Formation]: Stream bank NE of Wolf Camp, Wolf Camp Hills, Hess Canyon quadrangle [collector, C. Schuchert].

94. Wolfcamp: Uddenites bed (Uddenites-bearing Shale Member), 0.5 mile $W$ of locality 95, 300 feet $S$ of hill 4815, and 3.5 miles NE of Wolf Camp.

95. Wolfcamp (bed 13, Uddenites-bearing Shale Member) [=Gaptank Formation]: Section 27, about 300 feet S $30^{\circ} \mathbf{E}$ of hill 4752 , Brooks Ranch, 4.4 miles NE of hill 5060, Hess Canyon quadrangle [=USNM 721-1].

96. Wolfcamp [= Neal Ranch Formation]: Lowest beds near Gap Tank 0.25 mile $\mathbf{E}$ of the $\mathbf{E}$ edge of Hess Canyon quadrangle in Stockton Gap.
97. Wolfcamp [=Neal Ranch Formation]: Basal beds, 0.25 mile SE of Gap Tank, Stockton Gap.

98. Hess (20 feet above Wolfcamp) [=Decie Ranch Member]: $W$ end of Glass Mountains, Monument Spring quadrangle [not on map].

99. Hess: E end of Dugout Mountain, along downfaulted spur [no fossils recorded].

100. Hess [= Decie Ranch Member]: $W$ end of Dugout Mountain, Monument Springs quadrangle.

101. [No fossils recorded.]

102. Hess (near top) [=Cathedral Mountain Formation]: Section $17,0.15$ mile $\mathrm{N} 50^{\circ} \mathrm{W}$ of bench mark 5860 on Leonard Mountain, Hess Canyon quadrangle.

103. Hess (or Leonard): Float on Wolfcamp at foot of escarpment about 1 mile $W$ of Marathon-Sullivan (Yates) Ranch road, 0.75 mile $\mathrm{N} 89^{\circ} \mathrm{E}$ of hill 5300, Lenox Hills, Altuda quadrangle.

104. Leonard [=Cathedral Mountain Formation]: 2.73 miles $\mathrm{N} 55^{\circ} \mathrm{E}$ of Hess ranch on $\mathrm{N}$ side of the escarpment, 1.22 miles $W$ of hill 5725, Hess Canyon quadrangle [=USNM $713 \mathrm{t}]$.

105. Hess [=Skinner Ranch Formation]: 0.65 mile $\mathrm{N} 21^{\circ} \mathrm{E}$ of hill 5305, 2.4 miles $\mathbf{N} 22^{\circ} \mathbf{E}$ of Hess Ranch, on $W$ end of Hess Ranch Horst, Hess Canyon quadrangle [=approximately USNM 716s].

106. Hess [=Skinner Ranch Formation]: On hill 5305, 1.7 miles N $25^{\circ}$ E of Hess Ranch, Hess Ranch Horst, Hess Canyon quadrangle [from beds below those at R. E. King 105].

107. Hess (upper) Perrinites compressus horizon [= Taylor Ranch Member]: Escarpment $W$ of Hess Canyon fault, from upper fossiliferous horizon, immediately below a conspicuous layer of massive limestone, 3.81 miles $\mathrm{N}$ $66.5^{\circ}$ E of Hess Ranch, just SE of hill 5725, Hess Canyon quadrangle [=USNM 702d].

108. Hess (upper) [= Taylor Ranch Member]: Between, and $S$ of, hills 5767 and $5821,4.75$ miles $\mathbf{N} 68^{\circ} \mathbf{E}$ of Hess Ranch, Hess Canyon quadrangle [=USNM 702m].

109-111. [No fossils recorded.]

112. Hess (upper): About 0.5 mile $S$ of forks of Hess Canyon, 1.35 miles $\mathrm{S} 52^{\circ} \mathrm{W}$ of Old Word Ranch, Hess Canyon quadrangle.

113. Hess (middle, bed 6) [=Lenox Hills Formation]: Section 27, near top of layer of nodular limestone on hill 4752,600 feet $\mathrm{N} 69^{\circ} \mathrm{W}$ of top, Conoly Brooks Ranch, Hess Canyon quadrangle.

114-116. [No fossils recorded.]

117. Hess (upper): Between hills 5233 and 5035 on $\mathbf{E}$ side of long valley, 1 mile $W$ of hill $5035,3.2$ miles $\mathrm{N} 25^{\circ} \mathrm{E}$ of hill 4752, Hess Canyon quadrangle.

118. [No fossils recorded.]

119. Leonard (upper) [=Cathedral Mountain Formation]: Below, and to the $\mathrm{W}$ of, Clay Slide, 0.6 mile $\mathrm{S} 10^{\circ} \mathrm{W}$ of hill 4910, Altuda quadrangle.

120. Leonard (middle-lower Perrinites horizon) [ $=$ Cathedral Mountain Formation]: 0.6 mile due $\mathrm{E}$ of hill 4910, NE of Clay Slide, Altuda quadrangle [=approximately USNM 72Iu]. [R. E. King gives this location in his text (1931:135) as 0.6 mile due east of hill 4910, but his map 
shows the location as 0.6 mile farther north. Our USNM locality $72 \mathrm{lu}$ is approximately 0.6 mile east of hill 4910 , and its fauna agrees with King's list. The map location is probably wrong; we could not find the fossils listed by King at his map point marked "120."]

121. Leonard (middle, bed 13 near top) [=Cathedral Mountain Formation]: Section 17, $\mathrm{N}$ of Leonard Mountain, 1.96 miles $\mathrm{N} 1^{\circ} \mathrm{E}$ of Iron Mountain (Skinner) Ranch, E edge of Altuda quadrangle.

122. Hess or Leonard (limestone below lower Leonard Shale) [=Skinner Ranch Formation]: On Leonard Mountain, 0.3 mile $\mathrm{N} 72^{\circ} \mathrm{W}$ of bench mark 5860 on Leonard Mountain, Hess Canyon quadrangle [ $=$ R. E. King 231].

123. Leonard (lower bed 14) [= Cathedral Mountain Formation]: Section 17, 1.2 miles NE of bench mark 4627 , 2.05 miles due $\mathrm{N}$ of Iron Mountain (Skinner) Ranch, $\mathrm{E}$ edge of Altuda quadrangle [=USNM 71lq].

124. Leonard (lower) [=Cathedral Mountain Formation]: Hill $S$ of forks of Hess Canyon, 1.25 miles $S 68^{\circ} \mathrm{W}$ of Old Word Ranch, Hess Canyon quadrangle.

125. Leonard (upper) [=Cathedral Mountain Formation]: 0.5 mile $S$ of hill $5611,2.24$ miles $S 73.5^{\circ} \mathrm{W}$ of Old Word Ranch, $\mathrm{S}$ of Hess Canyon, Hess Canyon quadrangle.

126. Leonard [=Cathedral Mountain Formation]: Above conglomerate bed near Old Word ranch house site, 450 feet $S 40^{\circ} \mathrm{W}$ of Old Word Ranch, Hess Canyon quadrangle.

127. Leonard [=Cathedral Mountain Formation]: Directly above conglomerate, 500 feet SW of Split Tank, 1.4 miles $\mathrm{N} 55^{\circ} \mathrm{E}$ of Old Word Ranch, Hess Canyon quadrangle.

128. Leonard [=Cathedral Mountain Formation]: $0.2-0.3$ mile $\mathrm{N} 50^{\circ} \mathrm{E}$ of Split Tank, 1.7 miles $\mathrm{N} 55^{\circ} \mathrm{E}$ of Old Word Ranch, Hess Canyon quadrangle [=USNM 702 (part); also from same horizon I mile ENE of Split Tank].

129. Leonard (upper) [= Cathedral Mountain Formation]: $\mathrm{N}$ of hill 4627 , NE corner of Hess Canyon quadrangle.

130, 131. [No fossils recorded.]

132. Word (First Limestone, bed 1) [=Road Canyon Formation]: Section 17, Leonard Mountain section, 2.23 miles $\mathrm{N} 3^{\circ} \mathrm{W}$ of Iron Mountain (Skinner) Ranch, Altuda quadrangle.

133, 134. [No fossils recorded.]

135. Word (Third limestone, bed 7c) [=Willis Ranch Member]: Section 17, SE end of hill 5779, mountain $\mathrm{N}$ of Leonard Mountain, $W$ edge, 2.60 miles $N 6^{\circ} \mathrm{W}$ of Iron Mountain (Skinner) Ranch, Altuda quadrangle.

136. Word (Third Limestone, bed 7f) [=Willis Ranch Member]: Section 17, same as above, mountain $\mathrm{N}$ of Leonard Mountain, Altuda quadrangle.

137. Word (Third Limestone) [ $=$ Willis Ranch Member]: Section 17, mountain $\mathrm{N}$ of Leonard Mountain, 2.5 miles $\mathrm{N} 4.5^{\circ} \mathrm{W}$ of Iron Mountain (Skinner) Ranch, E edge of Altuda quadrangle.

138. Word (Third Limestone) [=Willis Ranch Member]: Section 17, 0.53 mile due $\mathrm{E}$ of bench mark 4973, top of hill, $S$ of junction of Road and Gilliland canyons, Altuda quadrangle.
139. Word: Float at junction of Road and Gilliland canyons, Altuda quadrangle.

140. [No fossils recorded.]

141. Word (Lower Limestone) [= Road Canyon Formation]: Above Clay Slide, section 14 [=R. E. King 6].

142. Word (Fourth Limestone) [=Appel Ranch Member]: 0.6 mile $\mathbf{N} 47^{\circ} \mathbf{E}$ of Willis Ranch, Hess Canyon quadrangle.

143. Word (Fourth Limestone) [=Appel Ranch Member]: $\mathrm{E}$ and $\mathrm{W}$ of Hill 5578, 2 miles NE of Willis Ranch, Hess Canyon quadrangle.

144. Word (Second Limestone) [ $=$ Willis Ranch Member]: 0.5 mile $\mathrm{N} 42^{\circ} \mathrm{W}$ of hill $5611,4.03$ miles $\mathrm{N} 33^{\circ} \mathrm{E}$ of Hess Ranch, Hess Canyon, Hess Canyon quadrangle [=approximately USNM 706e]. [Identified as Second Limestone Member of Word Formation by R. E. King, but mapped as Third Limestone Member of the Word.]

145. Word (Second Limestone) [=China Tank Member]: 1.5 miles $\mathrm{N} 60^{\circ} \mathrm{W}$ of Old Word Ranch house, 0.33 mile WSW of hill 5507, Hess Canyon quadrangle.

146. Word (Third Limestone) [= Willis Ranch Member]: $S$ and $\mathrm{W}$ of $\mathrm{S}$ part of Comanche outlier, 0.75 mile $\mathrm{N} 64^{\circ}$ W of Old Word Ranch house, Hess Canyon quadrangle.

147. Word (First Limestone) [= Road Canyon Formation]: In channel of Hess Canyon near Leonard-Word contact [not shown on R. E. King's map].

148. Word (Fourth Limestone) [=Appel Ranch Member]: 1.08 miles $\mathrm{N} 5^{\circ} \mathrm{E}$ of Old Word Ranch house, Hess Canyon quadrangle.

150. Word (Fourth Limestone) [=Appel Ranch Member]: 0.5 mile SW of hill 5360, 2.2 miles N $24^{\circ} \mathrm{E}$ of old Word Ranch, Hess Canyon quadrangle.

151. Leonard [=Cathedral Mountain Formation]: 0.22 mile $\mathrm{NE}$ of Split Tank, 1.68 miles $\mathrm{N} 56^{\circ} \mathrm{E}$ of Old Word Ranch, Hess Canyon quadrangle.

152. Word (upper) [=Appel Ranch Member]: 3.08 miles N $36^{\circ} \mathrm{E}$ of Word Ranch house, Hess Canyon quadrangle.

153. Word (First Limestone) [= Road Canyon Formation]: $S$ side of hill 5611 , W side of Hess Canyon, 1.8 miles $S$ $72^{\circ} \mathrm{W}$ of Old Word Ranch, Hess Canyon quadrangle.

154. Word (upper): E from hill 5360 to big fault 5 miles NE of Old Word Ranch, 2.6 miles N $31^{\circ} \mathrm{E}$ of Old Word Ranch, Hess Canyon quadrangle.

155. Word (upper): $\mathrm{E}$ of big fault, 5.03 miles $\mathrm{N} 47^{\circ} \mathrm{E}$ of Old Word Ranch, as far as hill 4902, from $W$ side of latter hill, Hess Canyon quadrangle.

157. [No brachiopods recorded.]

159. Word (upper): Chert 0.65 mile S $84^{\circ} \mathbf{E}$ of hill 4800 , NE part of Hess Canyon quadrangle.

161. [No brachiopods recorded.]

162. Word (upper) [=Appel Ranch Mcmber]: Cherty limestone $\mathbf{E}$ of Comanchean outcrop $\mathbf{N}$ of Old Word Ranch, near King locality $150,1.9$ miles $\mathrm{N} 20^{\circ} \mathrm{E}$ of Old Word Ranch, Hess Canyon quadrangle.

163-167. [No fossils recorded.]

168. Wolfcamp [=Neal Ranch Formation]: Section 24, Gray Limestone Member [ = bed 2 at Wolf Camp], 0.25 mile $S 87^{\circ} \mathrm{W}$ of hill 5060 , Hess Canyon quadrangle. 
169a. Wolfcamp [=Neal Ranch Formation]: Just above Gray Limestone Member (bed 2), 0.75 miles $S 78^{\circ} \mathrm{W}$ of hill 5060, Wolf Camp, Hess Canyon quadrangle.

170. Word (upper): Thick prominent limestone 700 feet below top, $\mathrm{N}$ of Dugout Mountain, Monument Spring quadrangle.

171. Word (lower) [=Road Canyon Formation]: 0.4 mile $\mathrm{N} 78^{\circ} \mathrm{W}$ of Old Payne Ranch, NW of Dugout Mountain, Monument Spring quadrangle.

173. [No brachiopods recorded.]

174. Leonard [=Cathedral Mountain Formation]: Section 27, 0.5 mile $\mathbf{E}$ of hill $5157,4.58$ miles $\mathrm{N} 48^{\circ}$ of old Word Ranch, just $W$ of longitude $103^{\circ} 05^{\prime}$, Hess Canyon quadrangle.

175. Wolfcamp (below Gray Limestone Member) [= Gaptank Formation, Uddenites-bearing Shale Member]: About 0.25 mile $S 71^{\circ} \mathrm{W}$ of hill 5060, Wolf Camp Hills, Hess Canyon quadrangle.

175a. Wolfcamp (yellow-brown limestone in shale underlying Gray Limestone Member) [=Gaptank Formation, Uddenites-bearing Shale Member]: NE of locality 88, Wolfcamp Hills, Hess Canyon quadrangle.

176-191. [No fossils recorded.]

192. Word (Fourth Limestone) [=Appel Ranch Member?]: $\mathrm{N}$ of junction of Road and Gilliland Canyons, Altuda quadrangle. [number not on R. E. King's map; the Fourth Limestone Member is not mapped north of the junction of these two canyons, nor is it recorded in Section 17.]

193. Wolfcamp (upper) [=Lenox Hills Formation]: $S$ of high point on Dugout Mountain, 2.64 miles $S 40.5^{\circ} \mathrm{W}$ of Lenox, Monument Spring quadrangle [=USNM 715].

194. Wolfcamp (upper): Float on $S$ side of high point of Dugout Mountain (same as above), Monument Spring quadrangle.

195. Wolfcamp (lower shale) [=Neal Ranch Formation?]: 0.5 mile SW of hill 5816, Hess Ranch Horst, Hess Canyon quadrangle [number not shown on map].

196. Wolfcamp (upper) [=Lenox Hills Formation]: 0.5 mile $\mathrm{N} 43^{\circ} \mathrm{E}$ of hill $5305,2.23$ miles $\mathrm{N} 29^{\circ} \mathrm{E}$ of Hess Ranch, Hess Ranch Horst, Hess Canyon quadrangle [=USNM 716r].

197. Wolfcamp [=Lenox Hills Formation]: 0.25 mile $\mathrm{N}$ $33^{\circ} \mathrm{E}$ of hill $5305,2.03$ miles $\mathrm{N} 26.5^{\circ} \mathrm{E}$ of Hess Ranch, Hess Ranch Horst, Hess Canyon quadrangle [not listed by King, but present on his map].

198. Wolfcamp (upper) [=Lenox Hills Formation]: Graben near middle of Hess Ranch Horst, and same bed to $W$ of graben, 0.25 mile $S 62^{\circ} \mathrm{E}$ of hill $5816,2.85$ miles $\mathrm{N} 47^{\circ}$ $\mathrm{E}$ of Hess Ranch, Hess Canyon quadrangle.

199. Wolfcamp (Uddenites member, basal brown limestone about 15 feet above Gaptank limestone)[=Gaptank Formation, (Uddenites-bearing Shale Member)]: 0.3 mile $\mathrm{N}$ $23^{\circ}$ E of hill 5060 Wolf Camp Hills, Hess Canyon quadrangle [=USNM $701 \mathrm{f}$.

200. [No fossils recorded.]

201. Wolfcamp [=Gaptank Formation]: Brown limestone near base of hill, 0.38 mile $S 36^{\circ} \mathrm{W}$ of hill 4815 , about
4 miles NE of Wolf Camp, Hess Canyon quadrangle [=USNM 70lu].

202. Wolfcamp (directly below base of Hess) [=Uddenitesbearing Shale Member]: 0.8 mile $W$ of $\mathbf{E}$ end of quadrangle, 1.2 miles $\mathrm{N} 78^{\circ} \mathrm{E}$ of hill 5202, Hess Canyon quadrangle.

203. Wolfcamp (beds below Gray Limestone Member) [=Gaptank Formation]: On range of foothills at $\mathrm{E}$ edge of quadrangle, 1.97 miles $\mathrm{N} 81^{\circ} \mathrm{E}$ of hill 5202, Hess Canyon quadrangle.

204. Wolfcamp [= Neal Ranch Formation]: 0.5 mile $S$ of Allison and Gilbert Ranch [see geological map, King, 1931].

205. Hess [= Decie Ranch Member]: Foot of cliff of Dugout Mountain, 0.75 mile $S 49^{\circ} \mathrm{W}$ of summit, 3.25 miles $\mathrm{S}$ $44^{\circ} \mathrm{W}$ of Lenox, Monument Spring quadrangle.

206. Hess (uppermost) [= Decie Ranch Member]: 1 mile NE of Lenox, Monument Spring quadrangle.

207. Hess (upper) [=Skinner Ranch Formation]: W side of fault on spur $\mathrm{N}$ of high point, 0.28 mile $\mathrm{N} 9^{\circ} \mathrm{W}$ of bench mark 5860 on Leonard Mountain, Hess Canyon quadrangle [=approximately USNM 714a].

208. Hess [=Skinner Ranch Formation]: 0.6 mile $\mathrm{N} 17^{\circ} \mathrm{W}$ of Hess Ranch, Hess Canyon quadrangle [=USNM 705a].

209. Hess (150-200 feet below top) [=Skinner Ranch Formation]: 0.49 mile due $\mathrm{N}$ of bench mark 5860 on Leonard Mountain, directly below Leonard outlier on $\mathbf{E}$ side of fault, Hess Canyon quadrangle.

210. Hess [= base of Skinner Ranch Formation on top of Lenox Hills Formation]: White limestone at top of section on Hess Ranch horst, $\mathrm{N}$ of $\mathrm{NE}$ end of igneous intrusion, 0.22 mile $\mathrm{N} 54^{\circ} \mathrm{E}$ of hill 5816, Hess Canyon quadrangle.

211. Hess [=Skinner Ranch Formation]: 0.8 mile $\mathrm{N} 32^{\circ} \mathbf{E}$ of hill 5305, on Hess Ranch horst, 1.57 miles $\mathrm{N} 26^{\circ} \mathbf{E}$ of Hess Ranch, Hess Canyon quadrangle [=approximately USNM 720e].

212. Hess (upper fossiliferous horizon) [=Taylor Ranch Member]: 0.6 mile $S 62^{\circ} \mathrm{W}$ of hill $5725,3.28$ miles $\mathrm{N}$ $66^{\circ} \mathrm{E}$ of Hess Ranch, Hess Canyon quadrangle.

213-214. [No fossils recorded.]

215. Hess (upper fossiliferous horizon) [=Taylor Ranch Member]: Top of section, 0.6 mile $S 71^{\circ} \mathbf{E}$ of hill 5632, Hess Canyon quadrangle.

216-221. [No brachiopods recorded.]

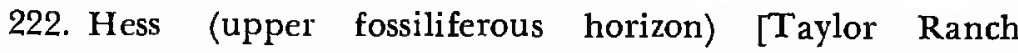
Member]: Scarp $E$ of head of $E$ fork of Hess Canyon about 0.17 mile $S 37.5^{\circ} \mathrm{W}$ of hill $5767,4.35$ miles $\mathrm{N}$ $67.5^{\circ} \mathrm{E}$ of Hess Ranch, $\mathrm{N}$ of Wolf Camp, Hess Canyon quadrangle [=USNM 716n].

223. Hess (uppermost): 1.0 mile $S 58^{\circ} \mathrm{W}$ of Old Word Ranch house, Hess Canyon quadrangle [=USNM 726n].

224. Leonard (First Limestone Member or slightly below) [=Sullivan Peak Member]: W end of Dugout Mountain, 0.75 mile $S 85^{\circ} \mathrm{W}$ of high point (hill 5195), 3.15 miles $S 50^{\circ} \mathrm{W}$ of Lenox, Monument Spring quadrangle. 
225. [No brachiopods recorded.]

226. Leonard (First Limestone Member) [=Sullivan Peak Member]: Central part of Dugout Mountain, 1.63 miles $\mathrm{S} 44^{\circ} \mathrm{W}$ of Lenox, Monument Spring quadrangle.

227. Leonard (Second Limestone Member) [=Dugout Mountain Member]: 0.5 mile $\mathrm{N} 69^{\circ} \mathrm{W}$ of high point, 2.8 miles $\mathrm{S} 51^{\circ} \mathrm{W}$ of Lenox, Dugout Mountain, Monument spring quadrangle.

228. Leonard (horizon of First Limestone) [=Sullivan Peak Member]: $\mathbf{E}$ of fault at $\mathbf{E}$ end of Dugout Mountain, 1.8 miles $S 41^{\circ} \mathrm{W}$ of Lenox, Monument Spring quadrangle.

229, 230. [No brachiopods recorded.]

231. Leonard (or uppermost Hess) [=Skinner Ranch Formation, probably mixed with Cathedral Mountain Formation]: Limestone containing chert pebbles directly below Leonard shale on $S$ face of mountain, 0.25 mile $\mathrm{N} 65^{\circ} \mathrm{W}$ of bench mark 5860 on Lconard Mountain, Hess Canyon quadrangle [ $=\mathrm{R}$. E. King 122].

232. Leonard (lower limestone on top of Leonard Mountain, above first bed of siliceous shale) [ = Skinner Ranch and Cathedral Mountain Formation]: Location same as above, Hess Canyon quadrangle [=USNM 709o].

233. Leonard (basal) [=Cathedral Mountain Formations]: On spur $\mathrm{N}$ of high point on $\mathrm{E}$ side of fault at $\mathrm{E}$ end of mountain, 0.45 mile $\mathrm{N} 8^{\circ} \mathrm{W}$ of bench mark on Leonard Mountain, Hess Canyon quadrangle.

234. Leonard [ = top of Skinner Ranch Formation or base of Cathedral Mountain Formation]: 0.65 mile $\mathrm{N} 68^{\circ} \mathrm{W}$ of hill 5726, S of Hess Ranch horst, 1.6 miles $N 50^{\circ} \mathrm{E}$ of Hess Ranch, Hess Canyon quadrangle $[=R$. E. King 245?].

235. Leonard (upper) [=Cathedral Mountain Formation?]: Section 24, 1 mile $W$ of Old Word Ranch house, Hess Canyon quadrangle.

236. Leonard (uppermost) [=Cathedral Mountain Formation]: 0.37 mile $\mathrm{S} 26^{\circ} \mathrm{E}$ of hill $5674, \mathrm{~N}$ of Leonard Mountain, 1.8 miles $\mathrm{N} 86.5^{\circ} \mathrm{W}$ of Hess Ranch, Hess Canyon quadrangle.

237. Word (lower limestone near latitude $30^{\circ} 10^{\prime}$ ) [ $=$ Cathedral Mountain Formation]: 0.43 mile N $55^{\circ} \mathrm{E}$ of bench mark 5324, 4.28 miles $\mathrm{N} 7^{\circ} \mathrm{E}$ of Black Peak, Del Norte Mountains, Monument Spring quadrangle.

238. Word (middle limestone) [= probably Cathedral Mountain Formation]: 2.4 miles $S 36^{\circ} \mathrm{W}$ of Old Payne Ranch, Del Norte Mountains, Monument Spring quadrangle.

239. Word (Third Limestone Member) [ =Willis Ranch Member]: Mountain $\mathrm{N}$ of Lconard Mountain, $\mathrm{S}$ side of Road Canyon, $W$ of divide separating drainage of Gilliland and Hess Canyons, 3.7 miles $\mathrm{N} 4.5^{\circ} \mathrm{W}$ of Skinner Ranch, W edge, Altuda quadrangle.

240. Word (Third Limestone Member) [=Willis Ranch Member]: Capping mountain $\mathrm{N}$ of Leonard Mountain, along line of section 18, NE side of hill 5801, 1.63 miles $\mathrm{N} 53^{\circ} \mathrm{W}$ of Hess Ranch, Hess Canyon quadrangle.

241. Word (First Limestone Member) [=Road Canyon Formation]: Mountain $\mathrm{N}$ of Leonard Mountain, $\mathrm{S}$ base of hill $5801,1.4$ miles $\mathrm{N} 60^{\circ} \mathrm{W}$ of Hess Ranch, Hess Canyon quadrangle.

242. Word (Third Limestone Member from bed below uppermost white limestone) [=Willis Ranch Member]: At $\mathbf{E}$ end of range $\mathbf{N}$ of Leonard Mountain, on $\mathbf{N}$ slope of hill 5453, 1.8 miles $\mathrm{N} 34^{\circ} \mathrm{W}$ of Hess Ranch, Hess Canyon quadrangle.

243. Word (Third Limestone Member) [ =Willis Ranch Member]: 0.48 mile $S 34^{\circ} \mathrm{E}$ of hill 5803, $\mathrm{N}$ side of Road Canyon, 1.03 miles $S 39^{\circ} \mathrm{W}$ of Willis Ranch, Hess Canyon quadrangle.

244. Word (Fourth Limestone Member) [=Appel Ranch Member]: 0.23 mile $N 5^{\circ} \mathrm{N}$ of Willis Ranch, Hess Canyon quadrangle.

245. Leonard (from bituminous limestone) [=top of Skinner Ranch or base of Cathedral Mountain Formation]: Downfaulted block $S$ of Hess Ranch horst, 0.65 mile $\mathrm{N}$ $68^{\circ} \mathrm{W}$ of hill $5726,1.6$ miles $\mathrm{N} 48^{\circ} \mathrm{E}$ of Hess Ranch, Hess Canyon quadrangle. [ $=$ R. E. King 234?].

246. Word (Fourth Limestone Member) [=Appel Ranch Member]: $\mathrm{E}$ of hill 5543 on $\mathrm{N}$ side of Hess Canyon, Hess Canyon quadrangle [=USNM 715i?].

247. Word (Fourth Limestone Member) [=Appel Ranch Member $:$ E side of Hess Canyon near its angle, 1.72 miles $\mathrm{N} 47^{\circ} \mathrm{W}$ of Old Word Ranch, Hess Canyon quadrangle.

248. Word (Fourth Limestone Member) [=Appel Ranch Member]: $\mathbf{E}$ side of Hess Canyon, near northernmost outcrop of formation, Hess Canyon quadrangle [number not on King's map].

249. Word (basal dolomite) [=Road Canyon Formation]: 1.03 miles $\mathrm{S} 76^{\circ} \mathrm{W}$ of Old Word Ranch, Hess Canyon quadrangle.

250. Word (Second Limestone Member) [=China Tank Membex]: Section 23, 1.68 miles $S 72^{\circ} \mathrm{W}$ of Old Word Ranch, NE of Hess Ranch Horst, Hess Canyon quadrangle [ $=$ R. E. King 264].

251. Word (First Limestone Member) [=Road Canyon Formation]: 0.75 mile S $69^{\circ} \mathrm{W}$ of Old Word Ranch on section 24, Hess Canyon quadrangle.

252. Word (Fourth Limestone Member) [=Appel Ranch Member]: On line of section 24, west of Comanche outlier N of Old Word Ranch, Hess Canyon quadrangle.

253. Word (Fourth Limestone Member) [=Appel Ranch Ranch Member]: 1.15 miles $\mathrm{N}$ of Old Word Ranch, $\mathrm{E}$ and $\mathrm{W}$ of Comanche outlier for a short distance, Hess Canyon quadrangle.

255. Word: [Not listed, number not on King's map; possibly Road Canyon Formation or a mixture].

256. Word (or Leonard): 0.58 mile $\mathrm{N} 65^{\circ} \mathrm{E}$ of hill 4627 , lower part of hill in a broad valley in NE corner of Hess Canyon quadrangle.

257. Word (middle and upper beds): 0.6 mile $\mathrm{N} 56^{\circ} \mathbf{E}$ of hill 4627, hill in middle of broad valley in NE corner of Hess Canyon quadrangle.

264. Word (Second Limestone Member) [= China Tank Member]: [Same as Locality 250.]

301. Leonard (midpart of Clay Slide): [=Cathedral Mountain Formation at R. E. King 60.] 


\section{Kansas University Localities (Moore)}

23. Upper Leonard (lower part) (=Cathedral Mountain Formation): About 0.5 mile $\mathbf{E}$ of Clay Slide and 0.5 mile SW of tank of West [=Iron Mountain] Ranch, about 50 feet above dense limestone containing abundant Perrinites, Altuda quadrangle [=USNM 720x].

30. Bell Canyon Formation (Pinery Member): Pine Spring, near El Capitan, Guadalupe Mountains, Guadalupe Peak quadrangle.

31. Cherry Canyon Formation (Getaway Member): $S$ of U. S. Highway 62-180 near El Capitan, Guadalupe Peak quadrangle.

9804. Putnam Formation (Lost Creek Member): 7.7 miles S of center of Coleman on $\mathrm{W}$ side of road, 0.6 mile $\mathbf{N}$ of road crossing of Home Creek (United States Geological Survey, Oil and Gas Investigation Preliminary Map 80, Sheet 1, Coleman County, Texas).

9818. Putnam Formation (Lost Creek Member): U. S. Highway 67-84-183 [=283], 5.5 miles SE of center of Coleman, at bend in road (United States Geological Survey Oil and Gas Investigation Preliminary Map 80, Sheet 1, Coleman County, Texas). [U. S. Highway 67 is no longer routed through Coleman.]

9880. Pubelo Formation (50 feet below top of Camp Creek Member): $\quad$ W side of Saddle Creek, 1.4 miles $\mathrm{S}$ and 0.6 miles $W$ of mouth, 0.7 mile $S$ of $E-W$ road crossing Saddle Creek, 10.25 miles nearly due $S$ of Gouldbusk in McCulloch County.

\section{United States Geological Survey Localities} (USGS)

664 (green). Kaibab Formation: Ochre Spring, Kaibab Plateau, Arizona.

2906 (green). Capitan Limestone Formation (lower): In foothill ridge about 3 miles SW of Guadalupe Peak, about 0.25 mile NW of locality 2924 and 150 feet higher up, Guadalupe Peak quadrangle (see Girty, map, 1909: pl. 1).

2919 (green). Brushy Canyon Formation (King 1948:30): Near locality 2920 and 300 feet above it, in notch in long ridge, about 250 feet above basal black limestone, in Delaware Mountain Sandstone, Guadalupe Peak quadrangle.

2920 (green). Bone Spring Formation (near top of basal black limestone): Small canyon among foothills about 2 miles $S$ of Guadalupe Peak, Guadalupe Peak quadrangle.

2926. Capitan Limestone Formation: Just below knob on crest of spur running $\mathrm{N}$ from El Capitan, about 1000 feet below summit of El Capitan and top of Capitan Limestone, part of material from horizon above or below, Guadalupe Peak quadrangle.

2930. Bell Canyon Formation (Pinery Member): Chiefly float, almost entirely from $\mathrm{N}$ side of Pine Spring Canyon, from 2 spurs embracing spring, supposed to be from "dark limestone" immediately above sandstones of Delaware Mountain Formation, some of it in place, Guadalupe Peak quadrangle.
2962. Delaware Mountain Formation: 2.5 miles $\mathrm{E}$ of tank in draw that cuts southern Delawares, Van Horn quadrangle.

2967 (green). Bone Spring Formation: Black Limestone below Delaware Mountain sandstone, low hills, about 2 miles $S$ of El Capitan, Guadalupe Peak quadrangle.

2969. Delaware Mountain Formation: About 30 miles NE of Van Horn, in Delaware Mountains, Van Horn quadrangle [=USGS 3500] (see Girty, map, 1909: pl. 1).

3763. Supposed to represent Delaware Mountain Formation [=Cathedral Mountain and Word Formations]: Comanche Canyon, Glass Mountains, 17 miles NE of Marathon, Big Bend, Texas [=USGS 3840?].

3840 (green). Delaware Mountain Formation: Mountains NW of Marathon, Texas, supposed to be same horizon as USGS 3763.

7404. Capitan Limestone Formation: 0.5 mile NNE of summit of El Capitan on NNE spur at elevation of $8100-8400$ feet, Guadalupe Peak quadrangle.

7416. Carlsbad Formation: 1.4 miles $\mathrm{S} 30^{\circ} \mathrm{E}$ of Grisham-

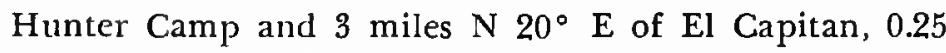
mile W of tank in "The Bowl," on S side of trail, Guadalupe Peak quadrangle.

7417 (blue). Capitan Limestone Formation: $\mathrm{N}$ and $\mathrm{S}$ sides of McKittrick Canyon, 0.5 mile below Grisham-Hunter Camp and 100 feet or less above level of canyon, Guadalupe Peak quadrangle.

7612. Capitan Limestone Formation (near base, Dog Canyon beds not far beneath): 1.75 miles $\mathrm{S} 80^{\circ} \mathrm{E}$ of Williams Lower Ranch, in NW part of Patterson Hills, Guadalupe Peak quadrangle.

7649. Cherry Canyon Formation (South Wells Member): 2 miles SE of D Ranch South Wells (map of southern Guadalupe Mountains, P. B. King, 1948: pl. 3).

7666. Bone Spring Formation (Cutoff Member): 0.25 mile $\mathrm{N}$ of Brushy Canyon, near its entrance, Guadalupe Peak quadrangle.

9999. Hueco Formation: 3.75 miles $S 1^{\circ} \mathrm{E}$ of Montoya, Canutillo quadrangle, Texas.

\section{American Museum of Natural History Localities (AMNH)}

L-2. [= AMNH 347.]

L-3. [ = AMNH 348.]

L-6. [=AMNH 351.]

21. Cherry Canyon Formation (Getaway Member): Vicinity of bench mark 5426, just $S$ of gully in road, Guadalupe Pass, Guadalupe Peak quadrangle.

25. Bell Canyon Formation (Lamar Member): 200 yards WSIV of bench mark 4425, 0.75 miles WSW of "NB Updike Williams \#l boring" and 2.5 miles SSW of El Capitan, Guadalupe Peak quadrangle.

28. Cherry Canyon Formation (Getaway Member): 300 yards due $S$ of Pine Spring Camp, Guadalupe Peak quadrangle.

39. Bell Canyon Formation (Pinery Member): Hill 5529, Rader Ridge 0.5 mile $W$ of Hegler (Ligon) Ranch, Guadalupe Peak quadrangle. 
37. Bell Canyon Formation (Lamar Member): Hill 5151, mouth of Mckittrick Canyon (geologic map of southern Guadalupe Mountains, P. B. King, 1948).

38. Bell Canyon Formation (Lamar Member): 0.5 mile NNW of Pratt Place, 1 mile SST of mouth of McKittrick Canyon (geologic map of southern Guadalupe Mountains, P. B. King, 1948).

39. Bell Canyon Formation (Lamar Member): $\mathrm{N}$ side of McKittrick Canyon (geologic map of southern Guadalupe Mountains, P. B. King, 1948).

40. Bell Canyon Formation (Lamar Member): $N$ side of Big Canyon, just below Watkins Ranch house, Carlsbad Caverns West (15') quadrangle.

46. Bone Spring Formation (lower): Fossiliferous dark gray limestone about 300 feet above base, 1 mile NW of mouth of Apache Canyon, Sierra Diablo, Van Horn quadrangle.

B188-6. San Andres Formation (transition facies between shelf and basin): $\mathrm{N}$ wall of Last Chance Canyon in SE $1 / 4$ section 32, T $23 \mathrm{~S}, \mathrm{R} 22 \mathrm{E}$, opposite mouth of White Oaks Canyon, Bandanna Point quadrangle.

B188-8. San Andres Formation (lower part $=$ transition facies): $\quad \mathrm{NW} 1 / 4 \mathrm{SW}_{1 / 4} \mathrm{SE} 1 / 4$ section 32, T $23 \mathrm{~S}, \mathrm{R} 22 \mathrm{E}$, Bandanna Point quadrangle, New Mexico.

347. Bell Canyon Formation (Lamar Member): $\mathrm{N}$ side of McKittrick Canyon Draw, N $80^{\circ} \mathrm{E}$ for 0.45 mile from Section Twelve Well near mouth, 1.7 miles $\mathrm{N}$ of McCombs Ranch house (geologic map of southern Guadalupe Mountains, P. B. King, 1948) [=AMNH L-2].

348. Bell Canyon Formation (Lamar Member): On E side of hill 0.2 mile $\mathrm{E}$ of elevation 4680 near junction of $\mathrm{D}$ Ranch road with U. S. Highway 62 (geologic map of southern Guadalupe Mountains of P. B. King, 1948) [=USNM 728p=AMNH L-3].

369. Bone Spring Formation: Top of Shirttail Canyon, above abandoned well, Humble E. P. Crowden A \#148, Pure Oil Co. Rig \#17, near Goat Spring, 0.4 mile S $48^{\circ}$ W of Shumard Peak, Guadalupe Peak quadrangle.

373. Bell Canyon Formation (Lamar Member): On spur S of tanks and pumping unit in small gulch of Bcar Canyon WV of Pratt's place (geologic map of southern Guadalupe Mountains, P. B. King, 1948).

375. Bell Canyon Formaion (Pincry Member-basin facies and overlying ref facies): $S$ slope of Pinnacle, Pinc Canyon, Guadalupe Peak quadrangle.

384. Bell Canyon Formation (Lamar Member): Bluff on the $\mathrm{N}$ side of Pratt's road approximately 0.75 mile from turnoff from highway, Guadalupe Peak quadrangle.

385. Bell Canyon Formation (McCombs Member): In flagstone quarrics on S side of road to McCombs Ranch and Pratt's Place, approximately 1.1 miles from turnoff from U.S. Highway 62 (geologic map of southern Guadalupe Mountains, P. B. King, 1948).

388. Bell Canyon Formation (Rader Member): Float, on $N$ spur of Rader Ridge near point where road bends to come up over Manzanita scarp due $W$ of Nickel Crcek Camp, Guadalupe Peak quadrangle.

389. Bell Canyon Formation (Rader Member, Lamar): In minor limestone quarries approximately 0.5 mile due $S$ of point where Bell Canyon crosses U. S. Highway 62, approximately 2 miles $\mathrm{NE}$ of Nickel Creek Camp, Guadalupe Mountains.

398. Bell Canyon Formation (Pinery Member): In head of small gully that meets Nickel Creek just below Hegler (Ligon) Ranch house, approximately 0.1 mile $S$ of ranch house, Guadalupe Peak quadrangle.

401. Bell Canyon Formation (probably Pinery Member): At head of Rader Ridge NE of Juniper Spring, Guadalupe Peak quadrangle.

403. Bell Canyon Formation (Rader Member): Crest of small hill immediately SE of Hegler (Ligon) Ranch, Guadalupe quadrangle.

404. Bell Canyon Formation (probably Rader Member): W of Hegler (Ligon) Ranch house approximately 1 mile up sniall canyon that runs past house near abrupt termination of massive Rader reef mass, Guadalupe Peak quadrangle.

410. Bell Canyon Formation (Rader Member): On small hill due $W$ of Hegler (Ligon) Ranch house and SW of Hegler Spring, Guadalupe Peak quadrangle [=USNM $725 \mathrm{~g}]$.

414. Cherry Canyon Formation (South Wells Member): Type-locality, hill NW of D Ranch South Wells (geologic map of southern Guadalupe Mountains, P. B. King, 1948).

417. Carlsbad Formation? (Unit 1): In fault block on $\mathbf{N}$ side of Devils Den Canyon, NE $1 / 4$ NW $1 / 4$ NE $1 / 4$ section 20, T 26 S. R 21 E, El Paso Gap quadrangle.

430. Bell Canyon Formation (Lamar Member): In Big Canyon on hill immediately $\mathrm{N}$ of Stanley Ranch house near crest of small ridge, in first fossiliferous limestones below bituminous limestones and above gray calcarenites, Carlsbad Caverns West (15') quadrangle.

435. Bcll Canyon Formation (probably Pinery Member): S slope of Nipple Hill, Guadalupe Peak quadrangle.

437. Bell Canyon Formation (Pinery Member): Near upper Pine Spring, Guadalupe Peak quadranglc.

475. Capitan Limestone (lower) and overlying Carlsbad Formation: N McKittrick Canyon, about 100 yards upstream from spur above scour pools, from stream bed to top of ridge, Guadalupe Mountains.

492. Bone Spring Formation (lower massive limestone beds, lenses of King, within 50 feet of base): About 2.5 miles above mouth of Apache Canyon on $\mathrm{N}$ side, Sierra $\mathrm{L}_{\mathbf{a}}$ lo V'an Horn quadrangle.

496. Cherry Canyon Formation (Getaway Member): Gully at intersection of airplane beacon road and U. S. Highway 62, near Guadalupe Pass, Guadalupe Peak quadrangle.

197. Bone Spring Formation (12 fect above base): 0.5 mile $S$ of hill $6073, N$ sicle of Apache Canyon, Sierra Diablo, Van Horn quadrangle.

500. Cathedral Mountain Formation (upper half): Just $\mathbf{E}$ of Split Tank, Hess Canyon quadrangle; blocks containing Instilella leonardensis are from base of Leonard Formation [=Cathedral Mountain]; others are from top of formation, which includes block numbers A-H, J-N, $\Omega$ and $\mathrm{X}$ [=USNM 702, 702a, 702ent, 702un]. 
501. Word limestone \#1 [= Road Canyon Formation]: 1 mile ( $=0.3$ mile) NW of Old Word Ranch house site, same as Cooper's 703 goniatite locality but from a different lens, Hess Canyon quadrangle [seems to be a mixed lot].

503. Word limestone \#1 [=Road Canyon Formation]: 1 mile (0.3 mile) NW of Old Word Ranch house site, Hess Canyon quadrangle [=USNM 703].

504. Uppermost Leonard [= Cathedral Mountain Formation]: At road level 1 mile SW of Old Word Ranch house site, Hess Canyon quadrangle.

505. Word Limestone \#3 [=Willis Ranch Member]: 2.3 miles ENE of Willis Ranch, Hess Canyon quadrangle [=USNM 706e].

506. Word Limestone, about middle lower part limestone \#3 [=Willis Ranch Member]: Approximately l mile $S$ of 505 [=USNM 706].

507. Upper Leonard [ = base of Road Canyon Formation]: Near top of conical hill, 1.5 miles SW of Old Word Ranch house, at $\mathrm{S}$ or inside loop of road, Hess Canyon quadrangle [=USNM 702c].

509. Word Limestone \#1 [=Road Canyon Formation]: About 1 mile SE of summit of Sullivan Peak, Altuda quadrangle [=USNM 707e).

512. Cherry Canyon Formation (upper part of the lower Getaway Member): Lens near break in slope on middle header on $W$ side of airway station road between $U$. S. Highway 62 and pipeline road, on crest of ridge, Guadalupe Peak quadrangle [=USNM 728].

519. Cherry Canyon Formation (lower Getaway Member): On slope of outlier due NE of bench mark 5315 in right angle bench in U. S. Highway 62 approximately 0.5 mile $\mathrm{E}$ of airway station takeoff, Guadalupe Peak quadrangle.

520. Leonard Formation [=Skinner Ranch Formation]: W fork of NE spur on Leonard Mountain, Glass Mountains, Hess Canyon quadrangle.

524. Bell Canyon Formation (probably Pinery Member): E slope of hill 0.375 mile $\mathrm{N}$ of elevation 4253 on hill 0.75 mile $\mathrm{E}$ of pump station, 0.75 mile $\mathrm{N}$ of pipeline road, Guadalupe Peak quadrangle.

528. Bell Canyon Formation (probably Pinery Member): East-west across hogbacks $\mathrm{N}$ of pipeline road across hills 2 miles due $\mathrm{N}$ of point 3940 near bend in highway approximately 2 miles $S W$ of Van Horn $Y$ [intersection] Guadalupe Peak quadrangle.

537. Bell Canyon Formation (Pinery Member): Up slope back of Lower Pine Spring, Guadalupe Peak quadranole.

547. Cherry Canyon Formation (Getaway Member): Inlier 1 mile due $W$ of Anderson Pritchard \#l border location. Guadalupe Mountains, Texas.

585. Cherry Canyon Formation (Getaway Member): Biohermal limestone from ledges on $S$ side of scarp, 0.75 mile due $S$ of Pine Spring Camp, Guadalupe Peak quadrangle.

591. Bone Spring Formation (lowest of reef lenses about 40 feet above base: Between $\mathrm{N}$ and middle branches of Black John Canyon, Sierra Diablo, Van Horn quadrangle.
592. Bone Spring Formation ("Molluscan ledge"): Between $\mathrm{N}$ and middle branches of Black John Canyon, Van Horn quadrangle.

600. Cherry Canyon Formation (Getaway Member $=$ subGetaway Zone): In small gully immediately $S$ of first cattle guard at junction of U. S. Highway 62 and road to airway beacon approximately 0.25 mile $\mathrm{E}$ of Guadalupe Pass, Guadalupe Peak quadrangle [=USNM 732] (see P. B. King, 1948:41).

624. Bone Spring Formation: Lower reef beds on $S$ side of Mine Canyon, 2 miles $S 60^{\circ} \mathrm{W}$ of Figure Two ranch, Van Horn quadrangle.

625. Bone Spring Formation (220 feet above top of "clastic" beds): $S$ side of mouth of Victorio Canyon, Sierra Diablo, Van Horn quadrangle [=USNM 728e, =USNM 741].

626. Hueco Formation: Marly beds at top of Hueco "clastic" beds, S side of Victorio Canyon, Van Horn quadrangle.

628. Bone Spring Formation: $S$ side of mouth of Victorio Canyon, Sierra Diablo.

629. Bone Spring Formation ( 30 feet above massive bed): 0.25 mile $S$ of mouth of Victorio Canyon, Sierra Diablo, Van Horn quadrangle [=USNM 728f].

631. Bone Spring Formation: Directly back (W) of Figure Two [Corn] Ranch house, Sierra Diablo, Van Horn quadrangle.

632. Bone Spring Formation (lower): On top of Sierra Diablo $S$ of Victorio Flexure, 1 mile $\mathrm{N}$ of southernmost outcrop of Bone Spring on top of scarp, Van Horn quadrangle.

634. Bone Spring Formation: Near middle of formation, 2 miles from mouth of Victorio Canyon, Van Horn quadrangle.

635. Bell Canyon Formation (Hegler Member, upper): Crest of hill 5406, approximately 1.25 miles due $S$ of Pinyon Tank, northern Pinyon Hills, Guadalupe Peak quadrangle.

636. Bell Canyon Formation (Pinery Member, lower): 0.25 mile $W$ of upper Pine Springs, Guadalupe Peak quadrangle.

652. Cherry Canyon Formation (Getaway Member) : Upper part of lower unit, 300 yards $S$ and $S W$ of Glover Ranch house, Guadalupe Peak quadrangle.

655. Bone Spring Formation ( 80 feet above base): W side of Texas Highway 54, northernmost of Baylor Hills, Van Horn quadrangle.

658. Bone Spring Formation: Biohermal-like lens on $\mathbf{N}$ wall of seventh canyon NW of Indian Cave Canyon and about 200 yards from mouth of canyon; 0.75 mile slightly $W$ of $S$ of Williams Ranch house, Guadalupe Peak quadrangle.

660. Bone Spring Formation: Bioherm on $S$ side of Bone Canyon very near entrance; about 100 feet below Brushy Canyon basal conglomerate; 0.1 mile $\mathbf{E}$ of Williams Ranch house, Guadalupe Peak quadrangle.

678. Bone Spring Formation (Cutoff Member): On slope 1 mile SW of point 6910 and 0.2 mile $W$ of fault in front of Cutoff Mountain, Guadalupe Peak quadrangle. 
696. Bone Spring Formation (100 feet above base): Northernmost Baylor Hills on $W$ side of Texas Highway 54, Baylor Hills, Van Horn quadrangle.

697. Bone Spring Formation: 208 feet above base on northernmost Baylor Hills on $\mathrm{W}$ side of Texas Highway 54, Van Horn quadrangle.

699. Bone Spring Formation (40 feet above base): Northernmost Baylor Hills on W side of Texas Highway 54, Baylor Hills, Van Horn quadrangle.

700. Hueco Limestone: Near top of hill on $\mathbf{E}$ side of last gully to drain $W$ at divide on Red Tank Road, Baylor Mountains, Van Horn quadrangle.

703. Cibolo Formation (Breccia Beds of Udden): Along Sierra Alta Creek, NE of Cibolo Ranch, Chinati Peak quadrangle [probable location supplied by Cooper and Grant].

725. Yates Formation (probably Capitan): ?Nuevo Canyon, reef marginal phase, section 8 (probably 18 ), T $25 \mathrm{~S}$, R $24 \mathrm{E}$, Carlsbad Caverns West quadrangle, Guadalupe Mountains, New Mexico [Nuevo Canyon is in section 18 , not 8 as listed].

774. Capitan Limestone Formation: McKittrick Canyon, on large spur halfway between mouth and Pratt Lodge, on crest of spur 150 feet above knob 6350, Guadalupe Mountains.

801. Capitan Limestone Formation: McKittrick Canyon, N side 300 feet $W$ of crest of ridge above Pratt Lodge at base of cliff in gully, $6350 \mathrm{feet}$, Guadalupe Mountains.

803. Capitan Limestone Formation: McKittrick Canyon, $\mathrm{N}$ side at crest of ridge above Pratt Lodge at base of cliff, 6300 feet, Guadalupe Mountains.

804. Capitan Limestone Formation: McKittrick Canyon, N side 300 feet $\mathrm{E}$ of crest of ridge above Pratt Lodge at base of cliff in gully, 6350 feet, Guadalupe Mountains.

806. Capitan Limestone Formation: Mckittrick Canyon, $\mathrm{N}$ side on flat above saddle on crest of ridge above Pratt Lodge, 6050 feet, Guadalupe Mountains.

813. Capitan Limestone Formation. N McKittrick Canyon, $S$ side on crest of spur, top of nose above locality 812 , 6150 feet, Guadalupe Mountains.

817. Capitan Limestone Formation: White City (Walnut Canyon), $S$ side 200 feet up canyon from locality 816 and 100 feet above valley floor, Guadalupe Mountains.

820. Capitan Limestone Formation: White City (Walnut Canyon), on crest of spur between Walnut and Bat Cave Canyon just above bench mark 3648, Guadalupe Mountains.

830. Capitan Limestone Formation: Rattlesnake Canyon, N side at mouth, 150 feet $W$ of locality 829 in draw, 4000 feet, Guadalupe Mountains.

837. Capitan Limestone Formation: Slaughter Canyon, NE side at base of last cliff (3 draws $\mathrm{N}$ of "836") N62W of bench mark 5524 .

840. Capitan Limestone Formation: Nuevo Canyon, spur of mouth $\mathrm{N}$ side first canyon $\mathrm{E}$ of Nuevo Canyon, second knob from top, 150 feet above locality 839, Guadalupe Mountains.
847. Capitan Limestone Formation: N side Slaughter Canyon, E side on trail, 100 feet above locality 846 , Guadalupe Mountains.

853. Capitan Limestone Formation: Double Canyon, $\mathrm{S}$ side, opposite Double Trail, 100 feet above locality 852 at base of cliff, Guadalupe Mountains.

1028. Guadalupian (Waagenoceras Zone): Bed 25, Arroyo La Difunta, Las Delicias, Coahuila, Mexico.

\section{United States National Museum Localities} (USNM)

\section{9b. [=USNM 725z.]}

USNM-Renfro locality 45. Graham Formation (Jacksboro Shale Member): 2 miles NE of Riley Ranch, on old Chico road, 3.5 miles $\mathrm{E}$ of Jacksboro, Jack County, Texas.

510. Graham Formation (Jacksboro Member): 1 to 1.5 miles NE of intersection of old Chico road with Wizard Wells road on Riley Ranch, 3.5 miles $\mathrm{E}$ of Jacksboro courthouse, Jack County, Texas.

510a. Pennsylvanian (Wayland Shale): E side of road in bluff 1.2 miles south of Gunsight, Stephens County, Texas.

5log. Graham Formation (Jacksboro Member): 3.5 miles NE of Jacksboro on old Jacksboro-Chico Road, 0.2 mile $\mathrm{N}$ of the Riley Ranch house, Jack County, Texas.

5llr. Graham Formation (Finis Member): Hills 0.5 to 1 mile $\mathrm{N}$ of a point 0.3 mile NE of intersection of old Chico road with Wizard Wells road, 3.2 miles E of Jacksboro, on Riley Ranch, Jack County, Texas.

512h. Graham Formation (Finis Member): $\mathbf{N}$ of Stradley school, on farm-market road (Texas Highway 206) to Graford, 2 miles S of Texas Highway 24, Jack County, Texas.

519. Shale below Cass Limestone: 200 yards $W$ of bridge on $\mathrm{N}$ line of section 12, T $10 \mathrm{~N}, \mathrm{R} 12 \mathrm{E}, 2$ miles $\mathrm{NW}$ of Nehawka, Cass County, Nebraska.

700. Gaptank Formation (middle of bed 10 of P. B. King): 2 miles $\mathrm{S} 17^{\circ} \mathrm{E}$ of Gap Tank, 1.25 miles $\mathrm{E}$ of point on Marathon-Fort Stockton road (U. S. Highway 385) 2 miles $S$ of Gaptank, about 23.5 miles NE of Marathon.

700a. Gaptank Formation (upper part of bed 10 of P. B. King): 0.25 mile $\mathrm{E}$ of locality 700 in small canyon.

700f. Gaptank Formation: At Milepost 580 on Southern Pacific Railroad, 3.85 miles $W$ of Marathon and 1.6 miles $S 58^{\circ} \mathrm{E}$ of Decie Ranch house, Monument Spring quadrangle.

700g. Gaptank Formation =Virgilian: 1.25 miles $S 1^{\circ} \mathrm{W}$ of Arnold Ranch house, 3.7 miles $S 52.5^{\circ} \mathrm{E}$ of hill 5195 (Dugout Mountain), Monument Spring quadrangle (Plate 16: figure 1).

$700-1$. Cathedral Mountain Formation (Wedin MemberFifth Leonard Limestone Member of P. B. King): 0.93 mile $S 1^{\circ} \mathrm{W}$ of Old Payne Ranch, 1.53 miles $\mathrm{N} 74^{\circ} \mathrm{W}$ of hill 5195, Dugout Mountain, Monument Spring quadrangle. 
$700 \mathrm{~m}$. Skinner Ranch Formation (Dugout Mountain Member, Lower part Third Limestone Member of P. B. King): 1.4 miles S $2^{\circ} \mathrm{W}$ of Old Payne Ranch, 1.5 miles S $89^{\circ} \mathrm{W}$ of hill 5195, Dugout Mountain, Monument Spring quadrangle.

700n. Skinner Ranch Formation (Dugout Mountain Member = Leonard Second Limestone Member of P. B. King): 1.55 miles $\mathrm{S} 5^{\circ} \mathrm{W}$ of Old Payne Ranch, 1.55 miles $\mathrm{S} 83^{\circ}$ W of hill 5195, Dugout Mountain, Monument Spring quadrangle.

700o. Skinner Ranch Formation (Dugout Mountain Member, Near middle of Second Leonard Limestone Member of P. B. King): 1.5 miles $S 7^{\circ} \mathrm{W}$ of Old Payne Ranch, 1.7 miles $S 85^{\circ} \mathrm{W}$ of hill 5195, Dugout Mountain, Monument Spring quadrangle.

700p. Skinner Ranch Formation (Dugout Mountain Member, upper Second Leonard Limestone Member of P. B. King): 1.45 miles $S 5^{\circ} \mathrm{W}$ of Old Payne Ranch, 1.65 miles S $87^{\circ} \mathrm{W}$ of hill 5195, Dugout Mountain, Monument Spring quadrangle. 700q. Road Canyon Formation: top of knob 0.25 mile $\mathrm{N}$ $30^{\circ} \mathrm{W}$ of Old Payne Ranch, Monument Spring quadrangle.

700r. Skinner Ranch Formation (Dugout Mountain, Third Leonard Limestone Member of P. B. King): Knob (5000 feet) 1.6 miles $S 37^{\circ} \mathrm{E}$ of Old Payne Ranch, 0.5 mile $\mathrm{N} 78^{\circ} \mathrm{W}$ of hill 5195, Dugout Mountain, Monument Spring quadrangle.

700s. Skinner Ranch Formation (Dugout Mountain Member, Third Leonard Limestone Member of P. B. King): Hill $4811,1.38$ miles $\mathrm{S} 25^{\circ} \mathrm{E}$ of Old Payne Ranch, 0.78 mile $\mathrm{N} 81^{\circ} \mathrm{W}$ of hill 5195, Dugout Mountain, Monument Spring quadrangle.

700t. Skinner Ranch Formation (Dugout Mountain Member $=$ Second Limestone Member of P. B. King): Hill 4811, 1.43 miles S $23^{\circ} \mathrm{E}$ of Old Payne Ranch, 0.9 mile $\mathrm{N} 87^{\circ}$ W of hill 5195, Dugout Mountain, Monument Spring quadrangle.

$700 \mathrm{v}$. Road Canyon Formation: 0.78 mile $\mathrm{S} 69^{\circ} \mathrm{W}$ of old Payne Ranch, 0.23 mile $\mathrm{N} 5^{\circ} \mathrm{E}$ of hill 4806, Monument Spring quadrangle [=USNM 736-1].

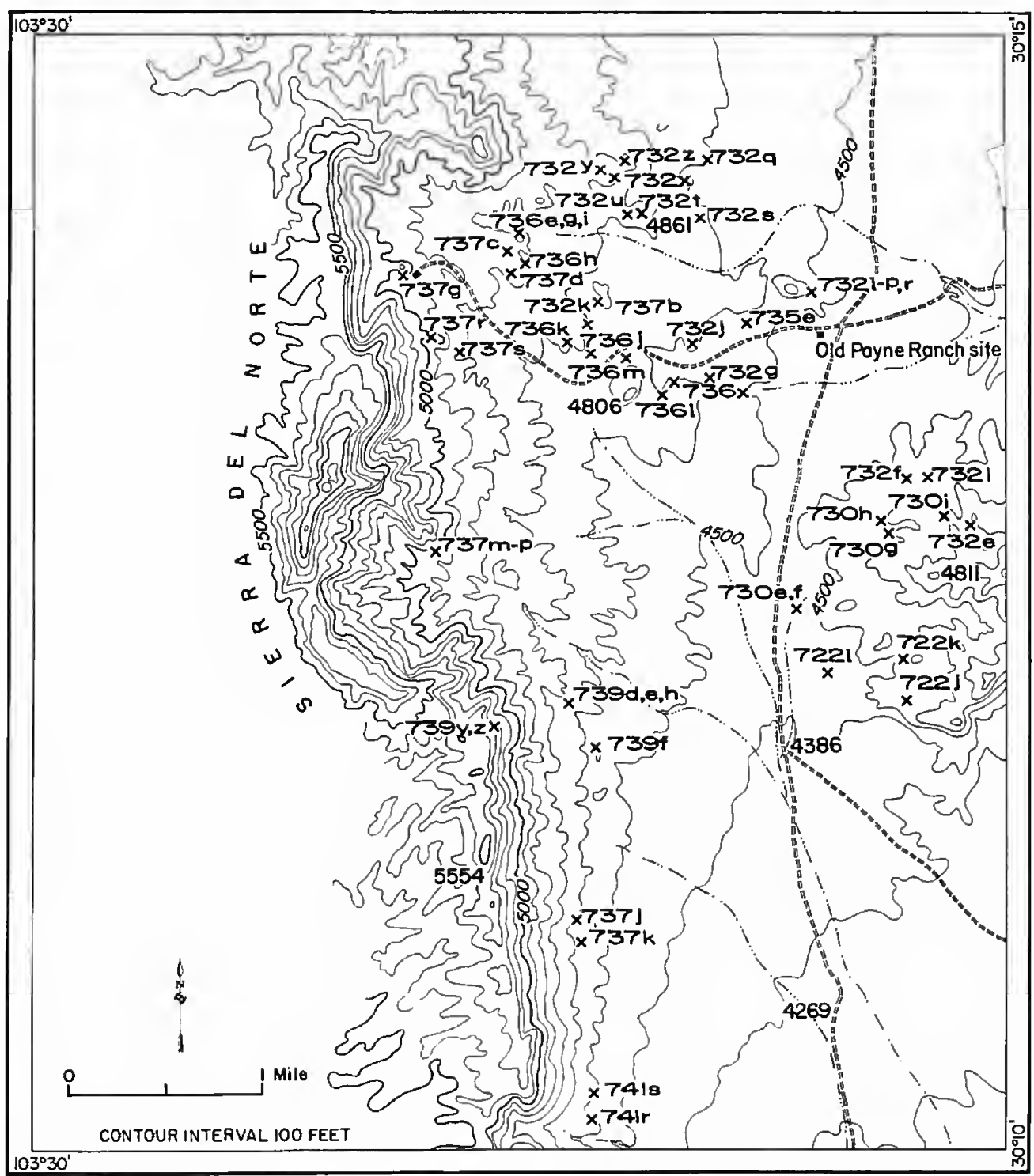

FIGURE 29.-Localities in the area northwest and west of Dugout Mountain including part of the Sierra del Norte. 
700w. Road Canyon Formation: 0.7 mile $S 69^{\circ}$ W of Old Payne Ranch, 0.3 mile N $5^{\circ} \mathrm{E}$ of hill 4806, Monument Spring quadrangle.

700x. Cathedral Mountain Formation (Wedin Member, Fifth Leonard Limestone Member of P. B. King): 0.66 mile S $36^{\circ} \mathrm{E}$ of Old Payne Ranch, 1.32 miles $\mathrm{N} 53^{\circ} \mathrm{W}$ of hill 5195, Dugout Mountain, Monument Spring quadrangle.

700y. Skinner Ranch Formation (Sullivan Peak Member, lower): 1.5 miles $\mathrm{S} 63^{\circ} \mathrm{E}$ of Old Payne Ranch, 0.7 mile $\mathrm{N} 8^{\circ} \mathrm{W}$ of hill 5195, Dugout Mountain, Monument Spring quadrangle.

700z. Skinner Ranch Formation (Poplar Tank Member, lower): 1.68 miles $S 50^{\circ} \mathrm{E}$ of Old Payne Ranch, 0.33 mile $\mathrm{N} 23^{\circ} \mathrm{W}$ of hill 5195, Dugout Mountain, Monument Spring quadrangle.

701. Neal Ranch Formation (upper 15 feet of bed 2, section 24, of P. B. King="Gray Limestone" Member): Bed of canyon, both banks and long dip slope to SE opposite small canyon from N, 0.4 mile up "Geologists Canyon" from its mouth, 0.6 mile $S 87.5^{\circ} \mathrm{W}$ of hill 5060, Wolf Camp Hills, Hess Canyon quadrangle.

70la. Neal Ranch Formation (bed 9, section 24, of P. B. King): NW facing slope on the $W$ side of a S-flowing arroyo, 0.4 to 0.5 mile $\mathrm{N} 87^{\circ} \mathrm{W}$ of hill 5060 , Wolf Camp Hills, Hess Canyon quadrangle.

$701 a^{1}$. Neal Ranch Formation (base of bed 9 of P. B. King): [=USNM 70la.]

$701 \mathrm{a}^{2}$. Neal Ranch Formation: Slopes between beds 2 and 9 of Cooper on $\mathbf{S}$ side of Geologists Canyon at forks, Wolf Camp Hills, Hess Canyon quadrangle.

$701 \mathrm{a}^{3}$. Neal Ranch Formation (bed 9, section 24, of P. B. King): From single block containing numerous sponges taken from biohermal mass on slope just $\mathbf{S}$ of canyon forks, 0.4-0.5 mile $\mathrm{N} 87^{\circ} \mathrm{W}$ of hill 5060, Hess Canyon quadrangle [=USNM 70la].

701b. Neál Ranch Formation [=USNM 701a.]

701c. Neal Ranch Formation (beds 9-12, section 24, of P. B. King): Bioherm on crest of hill facing and forming $N$ side of Geologists Canyon and $W$ side of small tributary canyon from N, 0.3 mile up Geologists Canyon from its mouth, 0.75 mile $S 84^{\circ}$ W of hill 5060, Wolf Camp Hills, Hess Canyon quadrangle $[=\mathrm{R}$. E. King 91] (Plate 16: figure 3).

701d. Neal Ranch Formation (approximately beds 12-14 of P. B. King) [ =USNM bed 4]: S face of low hill 1.47 miles $S 77^{\circ} \mathrm{W}$ of hill 5060, W end of Wolf Camp Hills, Hess Canyon quadrangle [see also USNM 721g].

70le. Gaptank Formation (Uddenites-bearing Shale Member): 300 feet $S$ of hill 5060, Wolf Camp Hills, Hess Canyon quadrangle (Plate 2: figure 2; Plate 12: figure 3).

70lf. Gaptank Formation (Uddenites-bearing Shale Member): Biohermal limestone with Parenteletes in saddle 0.33 mile $\mathrm{N} 21^{\circ}$ E of hill 5060, Wolf Camp Hills, Hess Canyon quadrangle $[=R$. E. King 199].

701g. Neal Ranch Formation (bed 9, section 24, of P. B. King): Patch of gray-brown limestone abounding in Orthotichia, in $\mathrm{S}$ branch of Geologists Canyon near its head, 0.35 mile $\mathrm{N} 84^{\circ} \mathrm{W}$ of hill 5060 , Wolf Camp Hills, Hess Canyon quadrangle. 701h. Neal Ranch Formation (bed 12, section 24, of P. B. King): Bioherm on $\mathrm{S}$ knob of hill 0.77 mile S $77^{\circ} \mathrm{W}$ of hill 5060, Wolf Camp Hills, Hess Canyon quadrangle (Plate 4: figure 3; Plate 11: figure 3).

701 k. Neal Ranch Formation (bed 12, section 24, of P. B. King): $W$ side of hill near base 0.97 mile $S 82^{\circ} \mathrm{W}$ of hill 5060, at 4750 feet elevation, W side of Wolf Camp Hills, Hess Canyon quadrangle.

701-1. Neal Ranch Formation (upper part, bed 4, section 24, of P. B. King): At 4625 elevation at $S$ base of hill 0.87 mile S $69^{\circ} \mathrm{W}$ of hill 5060, W side of Wolf Camp Hills, Hess Canyon quadrangle (Pate 5: figure 2).

$701 \mathrm{~m}$. Neal Ranch Formation (shale just above bed 14 of P. B. King): 0.7 mile $\mathrm{N} 84^{\circ} \mathrm{W}$ of hill 5060 , center of Wolf Camp Hills, Hess Canyon quadrangle.

701 . Gaptank Formation (Uddenites-bearing Shale Member): Specimens loose on sides of knob, and in saddle on $\mathrm{N}$ side of knob, the "Uddenites saddle," 0.75 mile $\mathrm{S}$ $66^{\circ} \mathrm{W}$ of hill 5060, Wolf Camp Hills, Hess Canyon quadrangle (Plate 4: figure 1).

701q. Gaptank Formation (upper Uddenites-bearing Shale Member): Limestone bed 25-30 feet below top of $U d$ denites shale on $\mathbf{E}$ side of saddle ("Uddenites saddle") just $\mathrm{N}$ of old Wolf Camp well site, 0.7 mile $\mathrm{S} 78^{\circ} \mathrm{W}$ of hill 5060, Wolf Camp Hills, Hess Canyon quadrangle.

701 r. Gaptank Formation (Uddenites-bearing Shale Member): Ammonite bed, in face of hill 4725, 300 feet SE of top of hill, at 4615 feet on Brooks Ranch, 5 miles NE of Wolfcamp. Hess Canyon quadrangle (Plate 19: figure 3).

701t. Gaptank Formation (Uddenites-bearing Shale Member): Lower part of Uddenites zone, brown beds and below (near middle), E side of saddle, 0.7 mile S $78^{\circ} \mathrm{W}$ of hill 5060, W end of Wolf Camp Hills, Hess Canyon quadrangle.

701 u. Gaptank Formation (Uddenites-bearing Shale Member): Base of hill 0.35 mile S $30^{\circ} \mathrm{W}$ of hill 4815 , Hess Canyon quadrangle $[=\mathrm{R}$. E. King 201] (Plate 4: figure 1).

70lv. Gaptank Formation (Uddenites-bearing Shale Member, beds $\mathrm{D}$ and $\mathrm{E}$ of Cooper's section): Trough on $\mathrm{W}$ side of hill 5060, 0.14 mile S $61^{\circ} \mathrm{W}$ of hill 5060, Wolf Camp Hills, Hess Canyon quadrangle.

701x. Gaptank Formation (Uddenites-bearing Shale Member): 25 feet of brown limestone at base of Uddenites zone, 0.1 mile S $46^{\circ} \mathrm{W}$ of hill 4952, Wolf Camp Hills, Hess Canyon quadrangle.

70ly. Gaptank Formation: Heavy ledge on E side of Geologists Canyon, 0.55 mile $S 68^{\circ} \mathrm{W}$ of hill $5060, \mathrm{~W}$ end of Wolf Camp Hills, Hess Canyon quadrangle.

7017. Neal Ranch Formation (beds 13 and 14, of section 24, of P. B. King): On $W$ side of $\mathrm{N}$ branch of Geologists Canyon above elbow, 0.48 mile $\mathrm{N} 66^{\circ} \mathrm{W}$ of hill 5060 , Wolf Camp Hills, Hess Canyon quadrangle [=USNM $706 \mathrm{x}]$.

702. Cathedral Mountain Formation (mostly Institella zone): Slopes on $\mathrm{S}$ side of road 0.4-0.5 mile NE of Split Tank, 1.9 miles $\mathrm{N} 56^{\circ} \mathrm{E}$ of Old Word Ranch house, Hess Canyon quaclrangle [=R. E. King 128, 151]. 
702a. Cathedral Mountain Formation (143-173 feet above base): 0.5 mile NE of Split Tank, 1.9 miles $\mathrm{N} 56^{\circ} \mathrm{E}$ of Old Word Ranch house, Hess Canyon quadrangle. [Consists of massive fine-grained greenish limestone abounding in small brachiopods together with some nautiloids.]

$702 \mathrm{a}^{1}$. Cathedral Mountain Formation: Massive lens 12 feet thick abounding in Collemataria 11 feet above thick limestones just below thick (116 feet) body of shale, 184 feet above base of Cathedral Mountain Formation, 0.5 mile NE of Split Tank, 1.9 miles N $56^{\circ}$ E of Old Word Ranch, Hess Canyon quadrangle (Plate 20: figure 3).

702b. Cathedral Mountain Formation (lower Institella zone): Lens about 0.5 mile SW of Split Tank, 0.95 mile $\mathrm{N} 51^{\circ}$ E of Old Word Ranch, Hess Canyon quadrangle.

702c. Road Canyon Formation: From conical knob on $S$ side of road at elbow just $W$ of $S$ branch of Hess Canyon, 4.5 miles by road $\mathrm{NE}$ of Hess gate, 1.35 miles $\mathrm{S}$ $66.5^{\circ} \mathrm{W}$ of Old Word Ranch and 4.03 miles $\mathrm{N} 50^{\circ} \mathrm{E}$ of Hess Ranch, Hess Canyon quadrangle [represents bioherms usually occurring at base of Road Canyon Formation] (Plate 20: figure 1).

702d. Hess Formation (Taylor Ranch Member): 130 feet below top of hill at about 5520 feet elevation, 3.2 miles $\mathrm{N} 67^{\circ} \mathrm{E}$ of Hess Ranch, 0.4 mile SW of head of $\mathrm{S}$ branch of Hess Canyon, 0.15 mile S $35^{\circ} \mathrm{E}$ of hill 5725, Hess Canyon quadrangle $[=R$. E. King 107; fossils occur in shaly limestone and sponge bioherms] (Plate 19: figure 2). 702e. Hess Formation (Taylor Ranch Member): Top of hill at 5700 feet elevation 0.15 mile $S 62^{\circ} \mathrm{W}$ of hill 5751 , 3.0 miles $\mathrm{N} 74^{\circ} \mathrm{E}$ of Hess Ranch house, 2.6 miles $\mathrm{N} 81^{\circ}$ W of hill 5060, Hess Canyon quadrangle.

702ent. Cathedral Mountain Formation (Institella zone): 69_ 81 feet above base, from smooth, greenish-gray, biohermal limestone with abundant Enteletes, 50 yards $\mathrm{W}$ of gully, 0.5 mile $\mathrm{E}$ of Split Tank, 1.98 miles $\mathrm{N} 58^{\circ} \mathrm{E}$ of Old Word Ranch house, Hess Canyon quadrangle.

702f. Hess Formation (Taylor Ranch Member): 500 feet $\mathrm{S}$ of hill $5767,0.45$ mile $S 62^{\circ} \mathrm{W}$ of hill $5821,4.8$ miles $68^{\circ} \mathrm{E}$ of Hess Ranch, Hess Canyon quadrangle.

702h. Neal Ranch Formation (shale above bed 12 of P. B. King): About 0.5 mile $\mathrm{N} 71^{\circ} \mathrm{W}$ of hill 5060 , center of Wolf Camp Hills, Hess Canyon quadrangle.

702inst. Cathedral Mountain Formation (base of Institella zone): In E-flowing arroyo just $\mathrm{W}$ of locality $702 \mathrm{un}, 0.55$ mile $\mathrm{N} \mathrm{72}{ }^{\circ} \mathrm{E}$ of Split Tank, 2.04 miles $\mathrm{N} 60^{\circ} \mathrm{E}$ of Old Word Ranch, Hess Canyon quadrangle [=USNM 702un, $26-45$ feet above base, on strike of 702 un and at essentially same level].

702j. Gaptank Formation (Uddenites-bearing Shale Member): Bed 9 of P. B. King in section 27, face of hill 4752, 500 feet $S$ of top, 5 miles NE of Wolf Camp, Hess Canyon quadrangle.

702k. Gaptank Formation (Uddenites-bearing Shale Member): 30 feet above Gaptank in cobbly bed on W slope of hill just E of hill 5060, Wolf Camp Hills, Hess Canyon quadrangle.

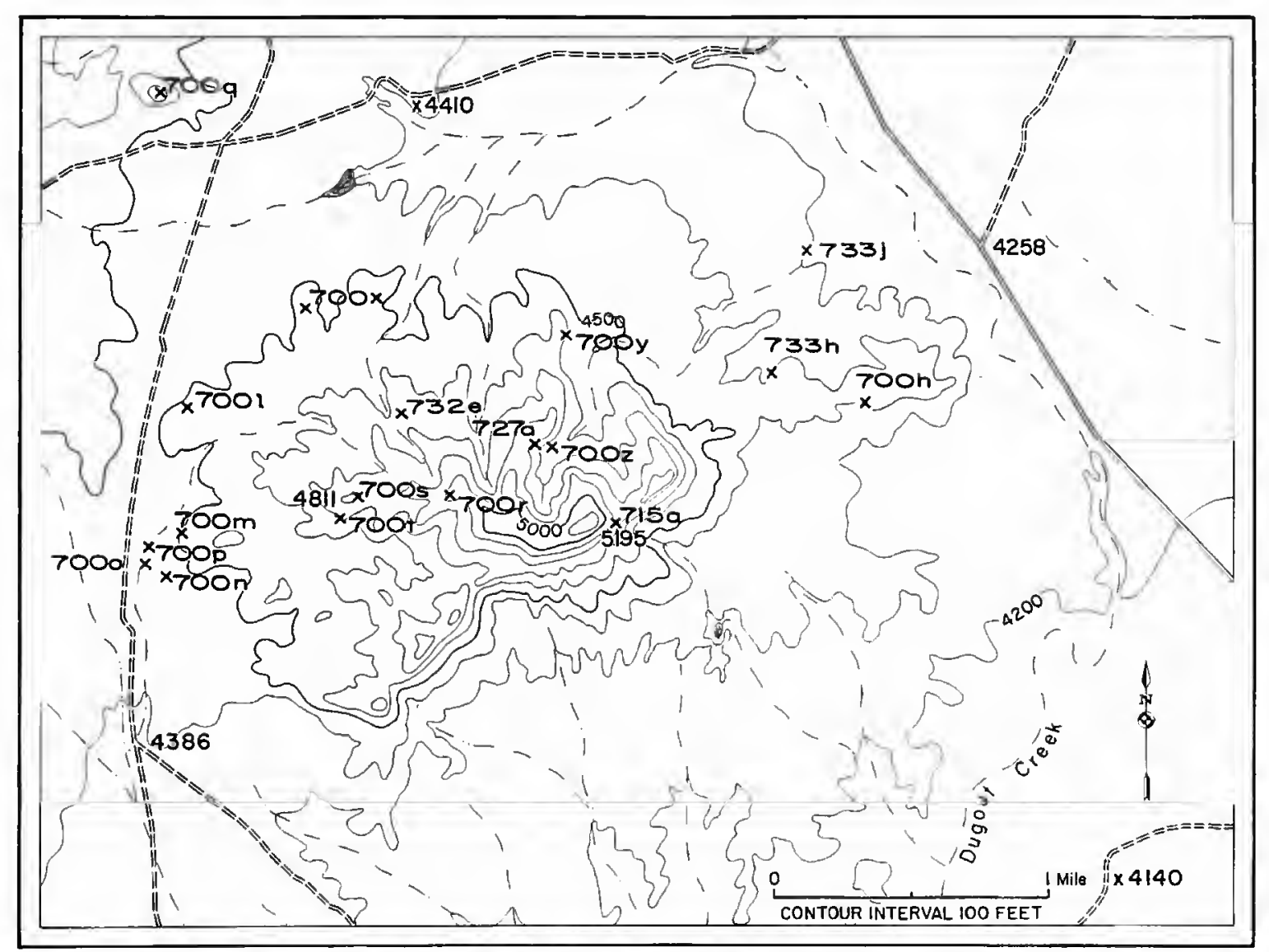

Figure 30.-Localities in Dugout Mountain. 
702-1. Neal Ranch Formation (bed B of Cooper, lower granular bed): At $S$ base of hill 5816 , at about 5100 feet elevation, in arroyo 0.5 mile $S 45^{\circ} \mathrm{W}$ of hill 5816, Hess Ranch horst, Hess Canyon quadrangle [=USNM 704v].

702-low. Cathedral Mountain Formation (Institella zone, lower): Part of locality $702,2.03$ miles $\mathrm{N} 59^{\circ} \mathrm{E}$ of Old Word Ranch, Hess Canyon quadrangle [includes section of Institella zone from basal conglomerate for 81 feet, and also includes parts of USNM 702un, 702inst, and $702 \mathrm{ent}$.

702m. Hess Formation (Taylor Ranch Member): Near top of hill about 5550 feet elevation, 0.18 mile $S 45^{\circ} \mathrm{W}$ of hill 5821, 4.75 miles $\mathrm{N} 69^{\circ} \mathrm{E}$ of Hess Ranch, Hess Canyon quadrangle $[=\mathbf{R}$. E. King 108].

702r. Gaptank Formation (Uddenites-bearing Shale Member): E slope of $W$ side of amphitheater, 0.8 mile $\mathrm{N} 40^{\circ} \mathrm{E}$ of hill 5060, Wolf Camp Hills, Hess Canyon quadrangle.

702o. Gaptank Formation (Uddenites-bearing Shale Member): Base of upper Uddenites zone hard band, slope $W$ of amphitheater, just $\mathrm{W}$ of hill 4952, 0.8 mile $\mathrm{N} 40^{\circ} \mathrm{E}$ of hill 5060, Wolf Camp Hills, Hess Canyon quadrangle.

$702 \mathrm{p}$. Gaptank Formation (Uddenites-bearing Shale Member): Algae beds, lower exposures at $\mathbf{E}$ end of Wolf Camp Hills, base of hill, 0.35 mile $N 39^{\circ} \mathrm{E}$ of hill 4952, Hess Canyon quadrangle.

702q. Gaptank Formation (Uddenites-bearing Shale Member, upper bed): 0.25 mile $S 50^{\circ} \mathrm{W}$ of hill 4952 , Wolf Camp Hills, Hess Canyon quadrangle.

702r. Gaptank Formation (Uddenites-bearing Shale Member): Above brown bed at base, about 500 feet $S$ of top of hill 4952, amphitheater, E side of Wolf Camp Hills, Hess Canyon quadrangle.

702s. Gaptank Formation (Uddenites-bearing Shale Member): Top of lowest bioherm, rim of canyon and gully, 700 feet $\mathrm{S} 53^{\circ} \mathrm{E}$ of hill 4815, 3 miles $\mathrm{W}$ of Montgomery (Conoly Brooks) Ranch, Hess Canyon quadrangle.

702t. Neal Ranch Formation: 200 yards S $45^{\circ}$ E of Gap Tank, E side of Stockton Gap, 16 miles NNE of Marathon.

702u. Gaptank Formation: Back slope of heavy ledge of "Basal Wolfcamp," about 0.5 mile W of Stockton Gap, 25 miles $\mathrm{N}$ of Marathon.

702un. Cathedral Mountain Formation (Institella zone, 26-45 feet above base in beds with Uncinuloides=Torynechus): Near junction of E-flowing lateral gully with main stream and along $\mathrm{S}$ side of E-flowing gully, 0.58 mile $\mathrm{N} 69^{\circ} \mathrm{E}$ of Split Tank and 2.08 miles $\mathrm{N} 58^{\circ} \mathrm{E}$ of Old Word Ranch house, Hess Canyon quadrangle [=USNM 702inst].

702v. Hess Formation: About 5000 feet elevation, 0.75 mile $\mathrm{N} 85^{\circ} \mathrm{W}$ of hill 4815, Montgomery (Conoly Brooks) Ranch, Hess Canyon quadrangle.

$702 w$. Hess Formation: At 4650 feet in hill 0.6 mile $S 84^{\circ}$ W of hill 4815, Montgomery (Conoly Brooks) Ranch, Hess Canyon quadrangle.

702x. Neal Ranch Formation: Small hill 150 yards $\mathrm{N} 50^{\circ}$ E of Gap Tank, W side of Stockton Gap, 26 miles $\mathbf{N}$ of Marathon.
7027. Gaptank Formation: 6 feet of dark gray limestone over sandstone on SE face of hill $4815,0.15$ mile $S 49^{\circ}$ E of top at 4620 feet, Montgomery (Conoly Brooks) Ranch, Hess Canyon quadrangle.

703. Road Canyon Formation (upper): Lens with goniatites near top of slope 0.35 mile $S 75^{\circ} \mathrm{W}$ of Old Word Ranch, 1.15 mile $S 37^{\circ} \mathrm{E}$ of hill 5507, and $0.65 \mathrm{mile} S W$ of road fork to Appel Ranch house, Hess Canyon quadrangle [=AMNH 503].

703a. Road Canyon Formation (bioherms at base): On NW side of road between fork to Appel Ranch house and sheep tank, 0.2 mile $\mathrm{N} 10^{\circ} \mathrm{E}$ of Old Word Ranch house, Hess Canyon quadrangle (Plate 21: figure 1).

$703 \mathrm{a}^{\mathbf{1}}$. Cathedral Mountain Formation (Collemataria beds): On $S$ side of road about 0.25 mile on road $S W$ of fork to Appel Ranch, about 0.1 mile along road SE of Old Word Ranch house, Hess Canyon quadrangle.

703b. Cathedral Mountain Formation (lower Institella zone): SE side of road between fork to Appel Ranch and sheep tank, 0.13 mile $\mathrm{N} 43^{\circ} \mathrm{E}$ of Old Word Ranch house, Hess Canyon quadrangle [same interval as USNM 702un and 702 inst].

703bs. Cathedral Mountain Formation (base of Institella zone): Light gray biohermal limestone containing Agelesia just above Hess, 0.17 mile $S 39^{\circ} \mathrm{W}$ of Old Word Ranch house, Hess Canyon quadrangle [Agelesia occurs in great abundance almost to the exclusion of other species ].

703c. Road Canyon Formation (lower): Detrital mass of sponges in basal part of dark platy limestone near edge of slope above 703a (basal bioherms), 0.2 mile on road SW of fork to Appel Ranch, 0.22 mile $\mathrm{N} 1^{\circ} \mathrm{E}$ of Old Word Rancl, Hess Canyon quadrangle [includes also thin platy spicule-bearing beds on each side of sponge mass].

703d. Road Canyon Formation (lower, just above basal bioherms in thin-bedded bituminous limestones, nearly at same level as USNM 703c): Lenticular mass in elbow of fork to Appel Ranch, at head of canyon 0.35 mile $\mathrm{N}$ $19^{\circ} \mathrm{E}$ of Old Word Ranch house, Hess Canyon quad. rangle.

703e. Word Formation (Second Limestone Member of P. B. King = China Tank Member): About 1.4 miles $S 68^{\circ}$ $W$ of Split Tank and 0.35 mile $\mathrm{N} 10^{\circ} \mathrm{W}$ of old Word Ranch, Hess Canyon quadrangle [=USNM 703z].

703f. Hess Formation: At 4955 feet elevation in hill 0.68 mile $\mathrm{N} 83^{\circ} \mathrm{W}$ of hill 4815, Montgomery (Conoly Brooks) Ranch, Hess Canyon quadrangle.

703g. Hess Formation: At 4980 fect 0.97 mile $\mathrm{N} 50^{\circ} \mathrm{W}$ of hill $5060 \mathrm{NW}$ of Wolf Camp Hills, Hess Canyon quadrangle.

703h. Hess Formation: At 4875 feet elevation in hill 0.68 mile $\mathrm{N} 83^{\circ} \mathrm{W}$ of hill 4815 , Montgomery (Conoly Brooks) Ranch, Hess Canyon quadrangle.

703i. Hess Formation: About 5000 feet elevation on $\mathrm{S}$ side of hill 1.45 miles $\mathrm{N} 87^{\circ} \mathrm{W}$ of hill 5060 , W of Wolf Camp Hills, Hess Canyon quadrangle. 


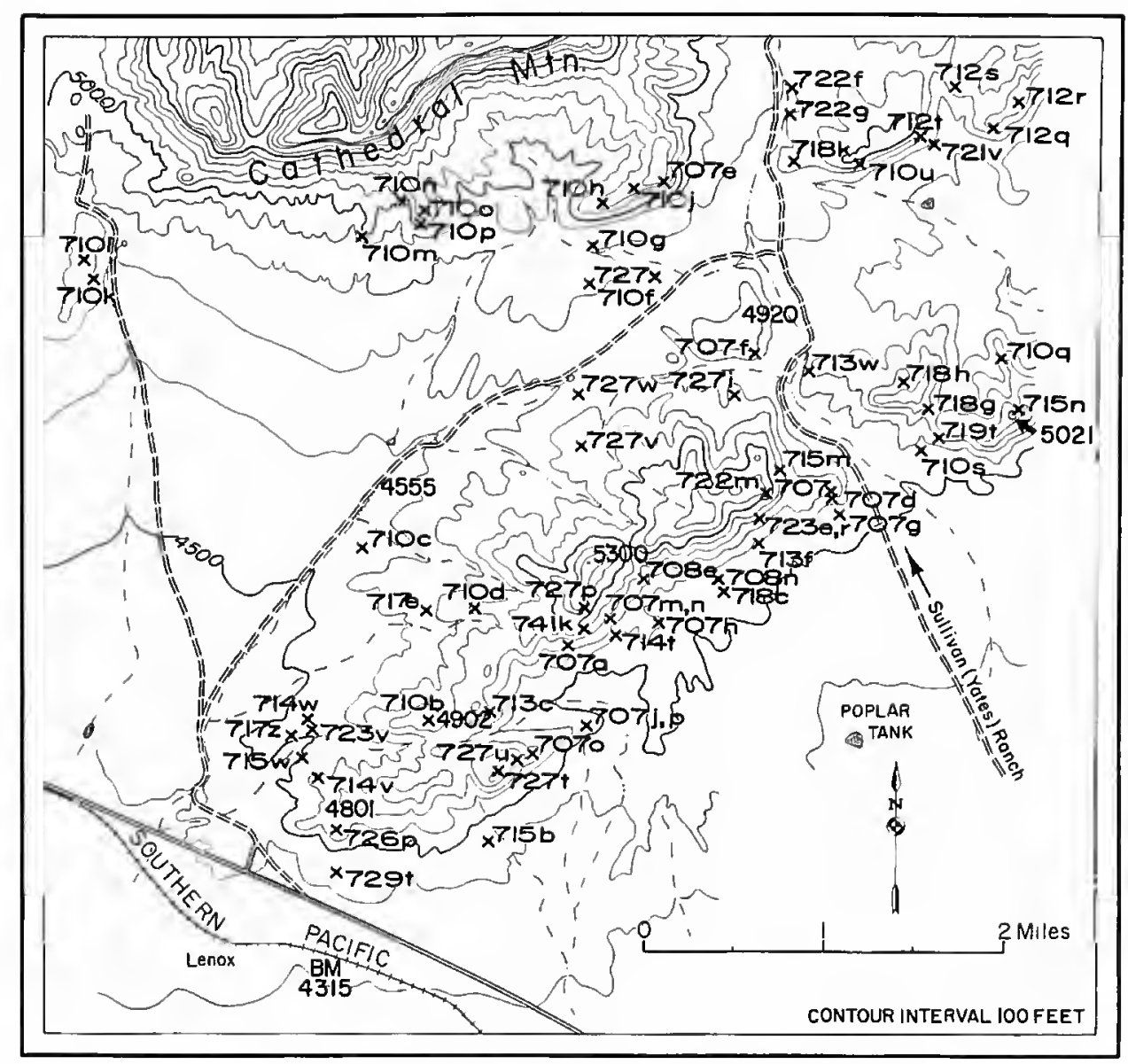

Figure 31.-Localities in the Lenox Hills.

703j. Hess Formation: Elevation 4950 feet, hill 0.68 mile $\mathrm{N}$ $85^{\circ}$ W of hill 4815, Montgomery (Conoly Brooks) Ranch, Hess Canyon quadrangle.

703k. Gaptank Formation: 32 feet below top of Gaptank Formation, 0.25 mile $\mathrm{E}$ of hill 4952. Wolf Camp Hills, Hess Canyon quadrangle.

703-1. Gaptank Formation (Uddenites-bearing Shale Member): 0.5 to 0.75 distance up slope under main ledgc, 350 feet $\mathrm{S} 34^{\circ} \mathrm{E}$ of top of hill 4752, 2.5 miles $\mathrm{NW}$ of Montgomery (Conoly Brooks) Ranch, Hess Canyon quadrangle.

$703 \mathrm{~m}$. Neal Ranch Formation: 25 feet below bed 12 of P. B. King, 0.5 mile $\mathrm{N} 70^{\circ} \mathrm{W}$ of hill 5060 , center of Wolf Camp Hills, Hess Canyon quadrangle.

703n. Neal Ranch Formation (24 feet above bed 14 of P. B. King): North of Geologists Canyon, 0.62 milc N 74 ${ }^{\circ} \mathrm{W}$ of hill 5060, Wolf Camp Hills, Hess Canyon quadranglc.

703o. Gaptank Formation (Uddenites-bearing Shale Member): Lower 5 feet of biohermal limestone on Gaptank, just under fence at $\mathbf{E}$ edgc of hill, W slope of hill NE of hill 5060, 0.5 mile $S 51^{\circ} \mathrm{W}$ of hill 4952, Wolf Camp Hills, Hess Canyon quadrangle.

703p. Gaptank Formation (Uddenites-bearing Shale Member): Between lower brown limestone and upper limestone ledge, $E$ slope of $W$ side of ampithcater, about 400 fect $S$ of hill 4952, E end of Wolf Camp Hills, Hess Canyon quadrangle.

703q. Hess Formation: 45 feet below top of hill, 1.48 miles $\mathrm{N} 86^{\circ} \mathrm{W}$ of hill $5060, \mathrm{~W}$ of Wolf Camp Hills, Hess Canyon quadrangle. 703r. Gaptank Formation: Base of cliff forming crest of hill at about 4760 feet, 0.25 mile $S 27^{\circ} \mathrm{W}$ of hill 4815 , Montgomery (Conoly Brooks) Ranch, Hess Canyon quadrangle.

703t. Neal Ranch Formation (fusulinid bed 2-3 feet below top of bed 14 of P. B. King): W side of small canyon from $\mathrm{N}, 0.68$ mile $\mathrm{N} 84^{\circ} \mathrm{W}$ of hill 5060, Wolf Camp Hills, Hess Canyon quadrangle.

703u. Neal Ranch Formation (35 feet above bed 14 of P. B. King): At head of S-flowing small tributary canyon, 0.65 milc $W$ of hill 5060, W side of Wolf Camp Hills, Hess Canyon quadrangle.

703v. Gaptank Formation (Uddenites-bearing Shale Membcr): Edgc of hill just $S E$ of knob at " $F$ " in Wolf, 0.35 milc $S 75^{\circ} \mathrm{W}$ of hill 5060, Wolf Camp Hills, Hess Canyon quadrangle.

703x. Gaptank Formation (Uddenites-bearing Shale Member): Just above lower brown ledge just $W$ of hill 4950 , Wolf Camp Hills, Hess Canyon quadrangle.

$703 y$. Skinner Ranch Formation (Poplar Tank Member): 20 fect above Decie Ranch Member, E slope of hill, 0.35 mile $S$ of hill 5300, Altuda quadrangle.

704. Word Formation (Fourth Limestone Member of P. B. King = Appel Ranch Member): 1.3 miles $\mathrm{N} 30^{\circ} \mathrm{W}$ of Old Word Ranch, at head of stream valley just $\mathrm{E}$ of Hess Canyon, Hess Canyon quadrangle [=USNM 710].

704a. Gaptank Formation (Uddenites-bearing Shale Member): 2 fect above P. B. King's bed 9 in section 27, 200 feet $S$ of top of hill 4752, Montgomcry (Conoly Brooks) Ranch, Hess Canyon quadrangle. 
704b. Lenox Hills Formation: 20 feet above Lenox Hills conglomerate, 0.36 mile $\mathrm{N} 16^{\circ} \mathrm{W}$ of Hess Ranch house, Hess Canyon quadrangle.

704c. Gaptank Formation (Uddenites-bearing Shale Member): 170 feet below top of hill $4762,0.2$ mile S $70^{\circ} \mathrm{E}$ of top of hill, 2.55 miles $\mathrm{N} 25^{\circ} \mathrm{W}$ of Montgomery (Conoly Brooks) Ranch, Hess Canyon quadrangle.

704d. Gaptank Formation: Coral bed at 4800 feet on S side of knob at NE end of hill $5280 \mathrm{~W}$ of Iron Mountain, 1.42 miles $\mathrm{N} 82^{\circ} \mathrm{W}$ of Skinner Ranch, Altuda quadrangle.

704e. Lenox Hills Formation: 5 feet above conglomerate, 0.36 mile $\mathrm{N} 16^{\circ} \mathrm{E}$ of Hess Ranch house, Hess Canyon quadrangle.

704f. Lenox Hills Formation: S side of knob at NE end of hill $5280,1.45$ miles $\mathrm{N} 82^{\circ} \mathrm{W}$ of Skinner Ranch, Altuda quadrangle [=USNM 705g].

704h. Gaptank Formation: 4606 feet elevation in saddle, W side of hill, 0.13 mile $S 86^{\circ} \mathrm{W}$ of hill 4752 , Mont gomery (Conoly Brooks) Ranch, Hess Canyon quadrangle.

704i. Lenox Hills Formation: 5705 feet elevation on $W$ face of hill 5816, in section along line $S 26^{\circ} \mathrm{E}$ of hill top, Hess Ranch Horst, Hess Canyon quadranglc.

704j. Lenox Hills Formation: At 5403 to 5435 feet elevation in section up hill along line $S 29^{\circ} \mathbf{E}$ of top of hill Hess Ranch Horst, Hess Canyon quadrangle. 704k. Lenox Hills Formation: Fusulinids in conglomerate at 5575 feet elevation above main ledge of conglomerate, in section up hill along line $S 29^{\circ} \mathrm{E}$ of top of hill 5816, Hess Ranch Horst, Hess Canyon quadrangle.

704-1. Lenox Hills Formation: At 5435 feet elevation in section up hill 5816 along line $S 29^{\circ} \mathrm{E}$ of hill top, Hess Ranch Horst, Hess Canyon quadrangle.

$704 \mathrm{~m}$. Lenox Hills Formation: At 5625 feet in same section as USNM 704-1.

704o. Lenox Hills Formation: Just above main ledge of conglomerate at 5540 feet, W face of hill 5816 at saddle, Hess Ranch Horst, Hess Canyon quadrangle.

704p. Lenox Hills Formation: At 5570 feet, 16 feet above conglomerate, 350 feet $S 5^{\circ} \mathrm{W}$ of hill 5816 , Hess Ranch Horst, Hess Canyon quadrangle.

704q. Lenox Hills Formation: At 5564 feet elevation (146 feet below top of hill), knob 0.3 mile $S 69^{\circ} \mathrm{W}$ of hill 5816, Hess Ranch Horst, Hess Canyon quadrangle.

704r. Lenox Hills Formation: 21 feet above conglomerate at elevation 5550 feet, 600 feet S $5^{\circ} \mathrm{W}$ of hill 5816 , Hess Ranch Horst, Hess Canyon quadrangle.

704t. Lenox Hills Formation: At 5550 feet elevation in S side of hill 0.35 mile $S 71^{\circ} \mathrm{W}$ of hill 5816 , Hess Ranch Horst, Hess Canyon quadrangle.

704u. Lenox Hills Formation: 114 feet below top of hill, section 0.35 mile $S 71^{\circ} \mathrm{W}$ of hill 5816, at 5586 feet elevation, Hess Ranch Horst, Hess Canyon quadrangle.

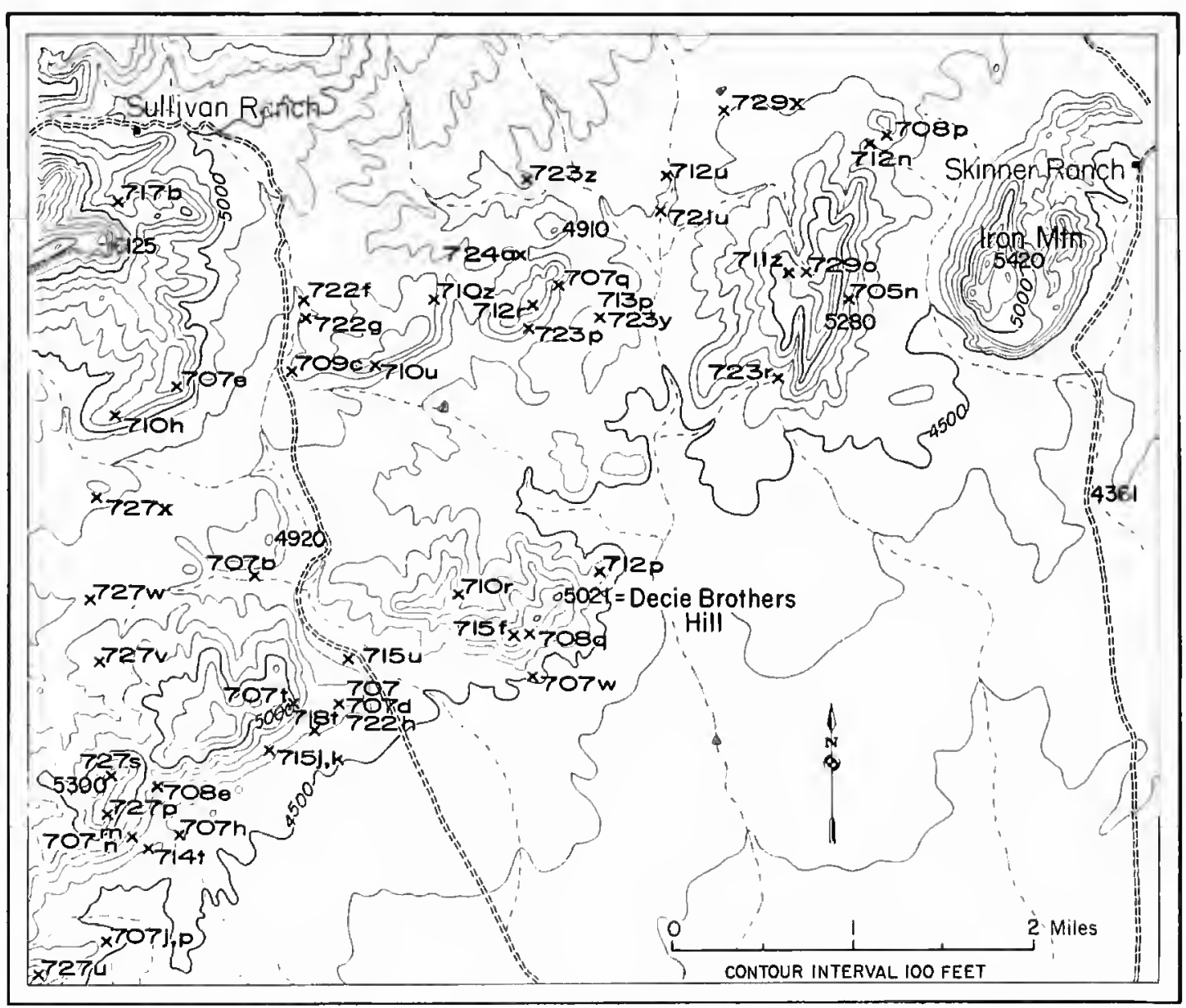

Figure 32.-Localities betwcen Sullivan (Yates) Ranch road and Iron Mountain. 
704v. Neal Ranch Formation: At 5060 to 5080 feet in arroyo at $S$ base of hill 5816, 0.48 mile $S 46^{\circ} \mathrm{W}$ of hill 5816, Hess Ranch Horst, Hess Canyon quadrangle.

704w. Gaptank Formation: 5000 feet elevation on NE slope of Lconard Mountain, 0.65 mile $\mathrm{N} 49^{\circ} \mathbf{E}$ of bench mark $5860,1.25$ miles $\mathrm{S} 31^{\circ} \mathrm{W}$ of Hess Ranch house, Hess Canyon quadrangle.

704y. Skinner Ranch Formation (Sullivan Peak Member): Loose on slope 0.3 mile $S$ of hill 5300, Altuda quadrangle.

705. Lenox Hills Formation: $W$ and $S$ slopes of hill 0.4 mile NNW of Hess Ranch, Hess Canyon quadrangle.

705a. Skinner Ranch Formation (base of Scacchinella beds and interbiohermal layers): 0.62 mile $\mathrm{N} 21^{\circ} \mathrm{W}$ of Hess Ranch, Hess Canyon quadrangle [ $=R$. E. King 208].

705b. Skinner Ranch Formation (base): 2.05 miles $\mathrm{N} \mathrm{21^{ \circ }}$ E of Hess Ranch, 1.18 miles $\mathrm{S} 78^{\circ} \mathrm{W}$ of hill $5816, \mathrm{~W}$ side Hess Ranch Horst, Hess Canyon quadrangle.

705ca. Gaptank Formation: Top of greenish shale near head of ravine on $\mathbf{E}$ side of SE nose of Leonard Mountain, $0.28 \mathrm{~S} 64^{\circ} \mathrm{E}$ of bench mark 5860, Hess Canyon quadrangle.

705d. Gaptank Formation: Same as 705c but from base of shale at 4850 feet.

705e. Gaptank Formation: Shale just above dike, NE side of Leonard Mountain, 1.1 miles N 29 $\mathrm{W}$ of Hess Ranch house, Hess Canyon quadrangle.

705f. Gaptank Formation: Shale below igneous dike, NE side of Leonard Mountain, 1.1 miles S $29^{\circ} \mathrm{W}$ of Hess Ranch house, Hess Canyon quadrangle.

705g. Lenox Hills Formation: Elevation of 4800-4850 feet on $\mathrm{S}$ slope of $\mathrm{N}$ end of hill $5280,1.45$ miles $\mathrm{N} 82^{\circ} \mathrm{W}$ of Skinner Ranch, Altuda quadrangle [=USNM 704f].

705h. Gaptank Formation (Uddenites-bearing Shale Member, lower): Elevation 4700 feet at base of hill at NE end of Wolfcamp Hills, 500 feet S $27^{\circ} \mathbf{E}$ of hill 4952, Hess Canyon quadrangle.

705j. Gaptank Formation: 5150 feet elevation on S slope of Leonard Mountain, 0.18 mile due $S$ of bench mark 5860, Hess Canyon quadrangle.

705k. Lenox Hills Formation (Scacchinella bioherm): At 5425 feet elevation on SE nose of Leonard Mountain, 0.2 mile $\mathrm{S} 80^{\circ} \mathrm{E}$ of bench mark 5860, Hess Canyon quad. rangle (Plate 20: figure 2).

705-1. Skinner Ranch Formation (base): Top of shale between Skinner Ranch and Lenox Hills Formations, bottom of section, 0.77 mile $\mathrm{N} 79^{\circ} \mathrm{W}$ of hill 5816 , Hess Ranch Horst, Hess Canyon quadrangle [=USNM 720e].

705m. Lenox Hills Formation (Scacchinella bioherm): Detached mass of Scacchinella bioherm on SE nose of Leonard Mountain, at 5050-5075 feet elevation 0.4 mile S $49^{\circ}$ $\mathbf{E}$ of bench mark 5860, Hess Canyon quadrangle. [This block is recorded by P. B. King (1931:140) as bed 5 of section 17, Leonard Mountain. He remarks in a note that this bed may be a "landslide of Hess limestone."]

705n. Skinner Ranch Formation: About 5150 foot contour, middle of $\mathbf{E}$ side of hill $5280,1.83$ miles $\mathrm{S} 70^{\circ} \mathrm{W}$ of Skinner Ranch, Altuda quadrangle.
7050. Skinner Ranch Formation: About 5150 foot contour, middle of $\mathbf{E}$ side of hill $W$ of Iron Mountain, hill 5280 , 1.83 miles $\mathrm{S} 70^{\circ} \mathrm{W}$ of Skinner Ranch, Altuda quadrangle.

705q. Gaptank Formation: About 4900 feet elevation on SE corner of Leonard Mountain, 0.48 mile S $45^{\circ} \mathrm{E}$ of bench mark 5860, Hess Canyon quadrangle.

705r. Skinner Ranch Formation (upper): Edge of Leonard Mountain at 5766 feet, about 400 feet $\mathrm{S} 62^{\circ} \mathrm{E}$ of bench mark 5860, Hess Canyon quadrangle.

705s. Lenox Hills Formation: Detached block at 4960-5100 feet elevation in small ravine on SE nose of Leonard Mountain 0.38 mile $\mathrm{S} 59^{\circ} \mathrm{E}$ of bench mark 5860, Hess Canyon quadrangle.

705t. Lenox Hills Formation: 10 feet above conglomerate, 0.35 mile $\mathrm{N} 20^{\circ} \mathrm{W}$ of Hess Ranch house, Hess Canyon quadrangle.

705u. Lenox Hills Formation: 20 feet above base, 0.25 mile $\mathrm{S} 75^{\circ} \mathrm{E}$ of bench mark 5860 , at 5430 feet elevation on SE nose of Leonard Mountain, Hess Canyon quadrangle.

$705 v$. Gaptank Formation: Uppermost shale at 5150 feet elevation on $S$ slope of Leonard Mountain, 0.18 mile due $\mathrm{S}$ of bench mark 5860, Hess Canyon quadrangle.

$705 x$. Gaptank Formation: 5190 feet elevation on SE nose of Leonard Mountain, 0.28 mile S $68^{\circ} \mathrm{E}$ of bench mark 5860 , Hess Canyon quadrangle.

70.5y. Gaptank Formation: 5245 feet elevation on SE nose of Leonard Mountain, 0.27 mile S $48^{\circ} \mathbf{E}$ of bench mark 5860, Hess Canyon quadrangle.

706. Word Formation (lower part of Third Limestone Member of P. B. King =Willis Ranch Member): $N$ slope of hill 5611 on $\mathrm{S}$ side of Hess Canyon near divide, 1.85 miles $S 82^{\circ} \mathrm{W}$ of Old Word Ranch, 3.78 miles $\mathrm{N} 40^{\circ}$ E of Hess Ranch, Hess Canyon quadrangle.

706a. Word Formation (China Tank Member): SW side of small ravine 3.9 miles $\mathrm{N} 37^{\circ} \mathrm{E}$ of Hess Ranch house, Hess Canyon quadrangle.

706b. Word Formation (thin lens between Willis Ranch and Appel Ranch Members): 0.2 mile SW of junction of Hess Canyon with its $\mathrm{S}$ branch, 1.9 miles $\mathrm{N} 65^{\circ} \mathrm{W}$ of Old Word Ranch site, and 4.78 miles $\mathrm{N} 34.5^{\circ} \mathrm{E}$ of Hess Ranch house, Hess Canyon quadrangle.

706c. Word Formation (near middle of Second Limestone Member of P. B. King = China Tank Member): SW slope and crest of spur of hill $5611,0.98$ mile $\mathrm{N} 21^{\circ} \mathbf{E}$ of hill 5816, 3.7 miles $\mathrm{N} 36^{\circ} \mathrm{E}$ of Hess Ranch and $\mathrm{SE}$ of "China" tank, Hess Canyon quadrangle.

706d. Word Formation (Fourth Limestone Member of P. B. King=Appel Ranch Member): Low hill in fault block, 0.1 mile NW of junction of Hess Canyon with its $S$ branch, 0.65 mile $\mathrm{N} 76^{\circ} \mathrm{E}$ of hill $5543,1.94$ miles $\mathrm{N}$ $60^{\circ} \mathrm{W}$ of Old Word Ranch, Hess Canyon quadrangle.

706e. Word Formation (top of Third Limestone Member of P. B. King $=$ Willis Ranch Member): $\mathbf{E}$ side of small arroyo 0.55 mile $\mathrm{N} 15^{\circ} \mathrm{W}$ of hill $5611,4.13$ miles $\mathrm{N} 34^{\circ}$ E of Hess Ranch, Hess Canyon quadrangle [=approximately R. E. King 144]. 
706f. Road Canyon Formation: Slope up hill 1.35 miles $\mathrm{N}$ $25^{\circ} \mathrm{W}$ of Hess Ranch, 0.9 mile $\mathrm{N} 71^{\circ} \mathrm{E}$ of hill 5801, Hess Canyon quadrangle.

706g. Lenox Hills Formation: 20 feet above conglomerate, 0.42 mile $\mathrm{N} 8^{\circ} \mathrm{W}$ of Hess Ranch house, Hess Canyon quadrangle.

706h. Lenox Hills Formation: At 4885 feet elevation [ $=$ USNM 706g].

706i. Lenox Hills Formation: At 4880 feet elevation [ $=$ USNM 706g].

706j. Lenox Hills Formation: 96 feet below top, in section on line $S 29^{\circ} \mathrm{E}$ of hill 5816, Hess Ranch Horst, Hess Canyon quadrangle.

706k. Lenox Hills Formation: 5550 feet in hill 5816 [= USNM 706j].

706-1. Hess Formation: 5005 feet elevation in section 0.73 mile $\mathrm{N} 83^{\circ} \mathrm{W}$ of hill 4815, Montgomery (Brooks) Ranch, Hess Canyon quadrangle.

706p. Neal Ranch Formation: Near top of bed 2 of P. B. King [= Gray Limestone], on knob just $S$ of Uddenites saddle, $W$ side of Wolf Camp Hills, 0.75 mile $S 60^{\circ} \mathrm{W}$ of hill 5060, Hess Canyon quadrangle. 706q. Neal Ranch Formation: Bed 15 feet above base of bed 2 of P. B. King [= Gray Limestone], knob on S side of Uddenites saddle, 0.73 mile $\mathrm{S} 64^{\circ} \mathrm{W}$ of hill 5060 , Wolf Camp Hills, Hess Canyon quadrangle.

706r. Road Canyon Formation: W slope of hill about 50 yards $\mathrm{E}$ of road, 1.25 miles $S 56^{\circ} \mathrm{E}$ of Sullivan Peak, Altuda quadrangle.

706s. Gaptank Formation (Uddenites-bearing Shale Member): Uppermost limestone, 0.25 mile $S 56^{\circ} \mathrm{W}$ of hill 4952 , center knob of Wolf Camp Hills, Hess Canyon quadrangle.

706t. Neal Ranch Formation (bed 4 of P. B. King): About 100 yards $W$ of Uddenites saddle, $W$ side of Wolf Cam $\Gamma$ Hills, 0.85 mile $S 66^{\circ} \mathrm{W}$ of hill 5060, Wolf Camp Hills, Hess Canyon quadrangle.

706u. Neal Ranch Formation: 40-50 feet below "Hess" con. glomerate [i.e. Lenox Hills], 0.65 mile $\mathrm{N} 76^{\circ} \mathrm{W}$ of hill 5060, Wolf Camp Hills, Hess Canyon quadrangle.

$706 \mathrm{v}$. Neal Ranch Formation: On E side of arroyo, 1.15 mile $\mathrm{N} 80^{\circ} \mathrm{E}$ of hill 5300 , Lenox Hills, Altuda quadrangle.

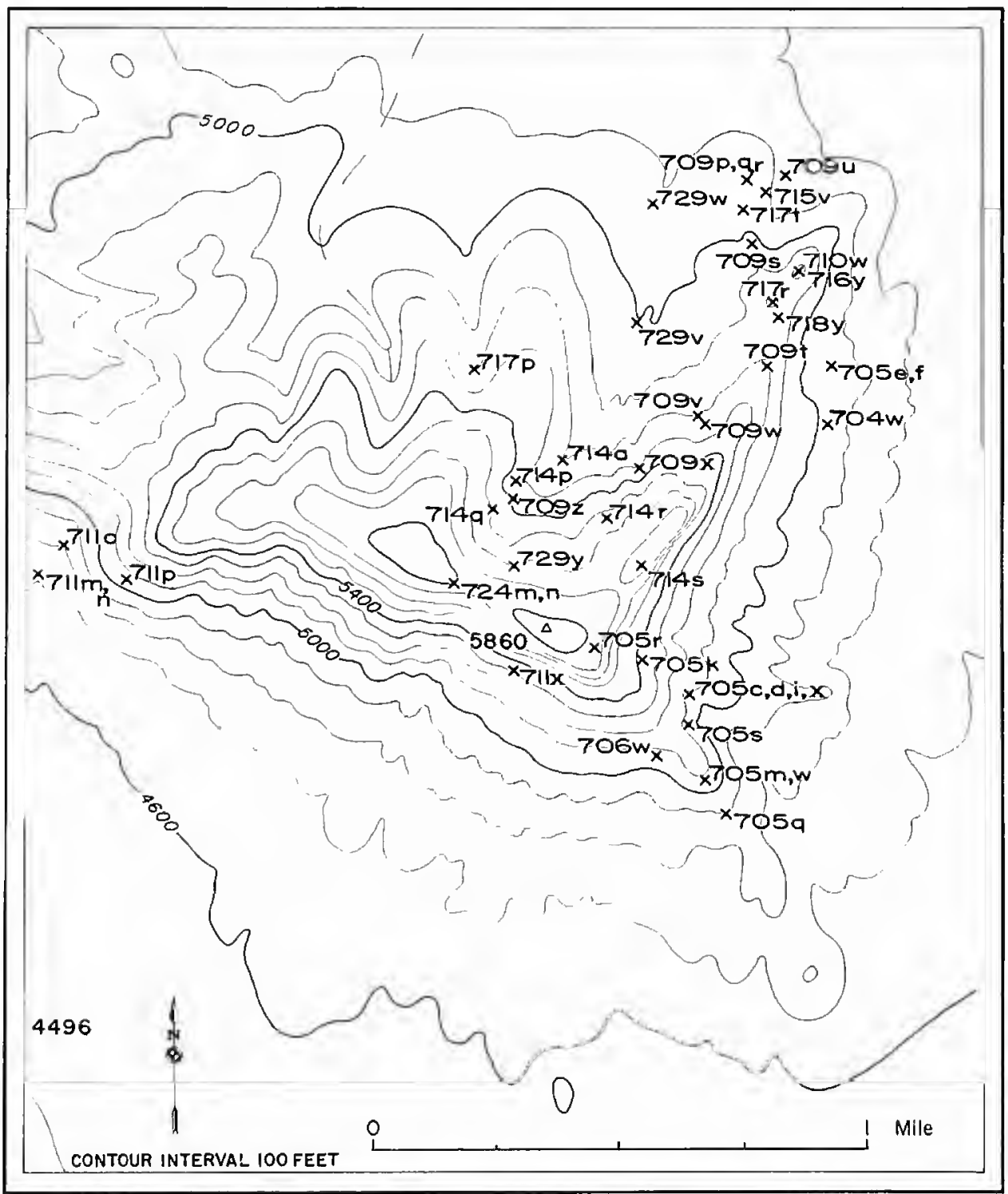

Figure 33.-Localities on Leonard Mountain. 
706w. Lenox Hills Formation: Detached block with Scacchinella on small flat on $W$ side of knob on SE nose of Leonard Mountain at approximately 5050 feet elevation, 0.34 mile $S 43^{\circ} \mathrm{E}$ of bench mark 5860, Hess Canyon quadrangle.

706x. Neal Ranch Formation (beds 12-14): Just $\mathrm{N}$ of elbow of Geologists Canyon 300 feet above (upstream) elbow, 0.47 mile $\mathrm{N} 68^{\circ} \mathrm{W}$ of hill 5060, Wolf Camp Hills, Hess Canyon quadrangle [=USNM 715e].

706y. Lenox Hills Formation: 20 feet above base of formation, 0.5 mile SE of hill 5300, $\mathrm{N}$ of Decie Ranch, Altuda quadrangle.

706z. Word Formation (China Tank Member): About 0.35 mile $\mathrm{N} 10^{\circ} \mathrm{W}$ of old Word Ranch, Hess Canyon quad. rangle [=USNM 703e].

707. Skinner Ranch Formation (Sullivan Peak Member): Nose of hill on $W$ side of Sullivan Ranch (Yates Ranch) road at canyon entrance, 1.0 mile $S 25^{\circ} \mathrm{E}$ of hill 4020 , 3.5 miles $\mathrm{N} 7^{\circ} \mathrm{E}$ of Decie Ranch, Altuda quadrangle [=R. E. King 17 (Plate 2: figure 3)].

707a. Skinner Ranch Formation (Decie Ranch Member): 0.45 mile $S 10^{\circ} \mathrm{W}$ of hill 5300 for 0.75 mile from this point along base of escarpment, 2.53 miles $\mathrm{N} 21^{\circ} \mathrm{W}$ of Decie Ranch, Lenox Hills, Altuda quadrangle (Plate 7: figure 3).

707b. Skinner Ranch Formation (Sullivan Peak Member, top): $\mathrm{N}$ side of arroyo 0.2 mile $S 20^{\circ} \mathrm{W}$ of hill $4920, \mathrm{l}$ mile NW of canyon entrance, 4.1 miles due $\mathrm{N}$ of Decie Ranch house, $\mathrm{E}$ side of Lenox Hills, Altuda quadrangle (Plate 12: figure 3).

707c. Skinner Ranch Formation (Sullivan Peak Member, top): Dip slope of hill, 0.32 mile $S 15^{\circ} \mathrm{W}$ of hill 4920 , 3.85 miles due $\mathrm{N}$ of Decie Ranch house, $\mathrm{E}$ side Lenox Hills, Altuda quadrangle.

707d. Skinner Ranch (Sullivan Peak Member): Knob of spur on $W$ side of entrance to canyon, $W$ side of road to Sullivan (Yates) Ranch, 1.38 miles $\mathrm{N} 73^{\circ} \mathrm{E}$ of hill $5300,3.5$ miles $\mathrm{N} 7^{\circ} \mathrm{E}$ of Decie Ranch, $\mathrm{E}$ end of Lenox Hills, Altuda quadrangle.

707e. Road Canyon Formation: On nose of foothill on SE side of Sullivan Peak, 0.9 mile S $25^{\circ} \mathrm{E}$ of Sullivan Peak, 5.3 miles $\mathrm{N} 5^{\circ} \mathrm{W}$ of Decie Ranch, Altuda quadrangle [=R. E. King 46] (Plate 5: figure 3; Plate 17; figure 2 ; text figure 20).

707g. Skinner Ranch (Decie Ranch Member): Base of spur on west side of road to Sullivan (Yates) Ranch at canyon entrance, 1.1 miles $S 26^{\circ} \mathrm{E}$ of hill $4920,3.5$ miles $\mathrm{N} 7^{\circ}$ $\mathrm{E}$ of Decie Ranch, E end of Lenox Hills, Altuda quadrangle $[=\mathrm{R}$. E. King $71=$ USNM 707-1].

707h. Skinner Ranch Formation: Probably detached biohermal blocks of Poplar Tank Member containing Coscinophora on small knob 0.51 mile $S 49^{\circ} \mathrm{E}$ of hill $5300,2.7$ miles $\mathrm{N} 12^{\circ} \mathrm{W}$ of Decie Ranch, near center Lenox Hills, Altuda quadrangle.

707ha. Skinner Ranch Formation (Poplar Tank Member): Loose blocks at USNM $707 \mathrm{~h}$.

707i. Skinner Ranch Formation (Poplar Tank Member): 0.5 mile NE of hill $4902,2.75$ miles $\mathrm{N} \mathrm{23^{ \circ }} \mathrm{W}$ of Decie Ranch house, Altuda quadrangle. 707j. Lenox Hills Formation (base): 25 feet above base of Lenox Hills Formation at 4560 feet elevation on nose of hill 0.85 mile $S 89^{\circ} \mathrm{E}$ of hill $4902,0.9$ mile S $2^{\circ} \mathrm{W}$ of hill 5300, W side of Lenox Hills, Altuda quadrangle [=USNM 707p; contains numerous goniatites in one thin layer].

707ja. Lenox Hills Formation: At very base of Wolfcamp just over Devonian on nose of hill 1 mile $\mathrm{E}$ of hill 4902 , NW of Decie Ranch, Altuda quadrangle.

$707 \mathrm{k}$. Lenox Hills Formation: 0.9 mile $\mathrm{S} 1.5^{\circ} \mathrm{W}$ of hill $5300,0.87$ mile due $\mathrm{E}$ of hill 4902, NW of Decie Ranch, Altuda quadrangle.

707-1. [=USNM 707g.]

$707 \mathrm{~m}$. Lenox Hills Formation: In shale member between conglomerate and overlying Skinner Ranch Formation (Decie Ranch Member), 10 feet above base at about 4580 feet elevation in ravine 0.37 mile $S 27^{\circ} \mathrm{E}$ of hill $5300,1.5$ miles $\mathrm{N} 63^{\circ} \mathrm{W}$ of Poplar Tank, 3 miles $\mathrm{N}$ of Decie Ranch, center of Lenox Hills, Altuda quadrangle.

$707 \mathrm{n}$. Lenox Hills Formation: 26 feet above Lenox Hills Conglomerate in goniatite bed, 0.37 mile $\mathrm{S} 27^{\circ} \mathrm{E}$ of hill 5300, Lenox Hills, Altuda quadrangle.

707o. Lenox Hills Formation: Lower 30 feet of shale below Decie Ranch Member, 0.6 mile $S 73^{\circ} \mathrm{E}$ of hill 4902, 1.1 miles $S 16^{\circ} \mathrm{W}$ of hill 5300, Altuda quadrangle.

707p. Lenox Hills Formation: 2.2 miles N of Decie Ranch at base of escarpment just above basal conglomerate, 0.85 mile $S 89^{\circ} \mathrm{E}$ of hill 4902,3 miles $\mathrm{E}$ of Lenox, Altuda quadrangle [=Plummer and Scott locality 22-t-128].

707 . Cathedral Mountain Formation (near base of thick shale unit): In ravine at base of hill just $E$ of Clay Slide, 0.3 mile $S 9^{\circ} \mathrm{E}$ of hill $4910,2.55$ miles $S 83.5^{\circ} \mathrm{E}$ of Sullivan Peak, Altuda quadrangle.

707r. Lenox Hills Formation: $W$ side of knob at $E$ end of Lenox Hills, on W side of Sullivan (Yates) Ranch road, 1.25 miles $\mathrm{N} 78^{\circ} \mathrm{E}$ of hill $5300,1.12$ miles $\mathrm{S} 16^{\circ} \mathrm{E}$ of hill 4920, Altuda quadrangle.

707s. Lenox Hills Formation: Center front of hills $\mathrm{N}$ of Decie Ranch, 0.5 mile $S 67^{\circ} \mathrm{E}$ of hill 5300 , Altuda quadrangle.

707t. Skinner Ranch Formation (Sullivan Peak Member): $\mathrm{E}$ side of hill facing spur at canyon mouth, $\mathrm{E}$ end of Lenox Hills, $\mathrm{N}$ of Decie Ranch, 1.62 miles $\mathrm{N} 68^{\circ} \mathrm{E}$ of hill 5300, Altuda quadrangle.

707u. Skinner Ranch Formation (base): Gully near base of hill 0.3 mile $S$ of hill 5021, Altuda quadrangle.

707v. Skinner Ranch Formation (Decie Ranch Member): Base of spur $W$ of road to Sullivan Ranch (Yates Ranch) at canyon entrance, 1.1 miles $S 25^{\circ} \mathrm{E}$ of hill 4920 and 1.4 miles $\mathrm{N} 78^{\circ} \mathrm{E}$ of hill $5300 \mathrm{E}$ side of Lenox Hills, Altuda quadrangle $[=\mathrm{R}$. E. King 71 (part) ].

707w. Skinner Ranch Formation (Decie Ranch Member equivalent): Detached block with Scacchinella at base of hill $\mathrm{E}$ of Sullivan Ranch (Yates Ranch) road, 0.47 mile $S 25^{\circ} \mathrm{W}$ of hill 5021, Altuda quadrangle (Plate 10: figure 3; text Figure 11). 


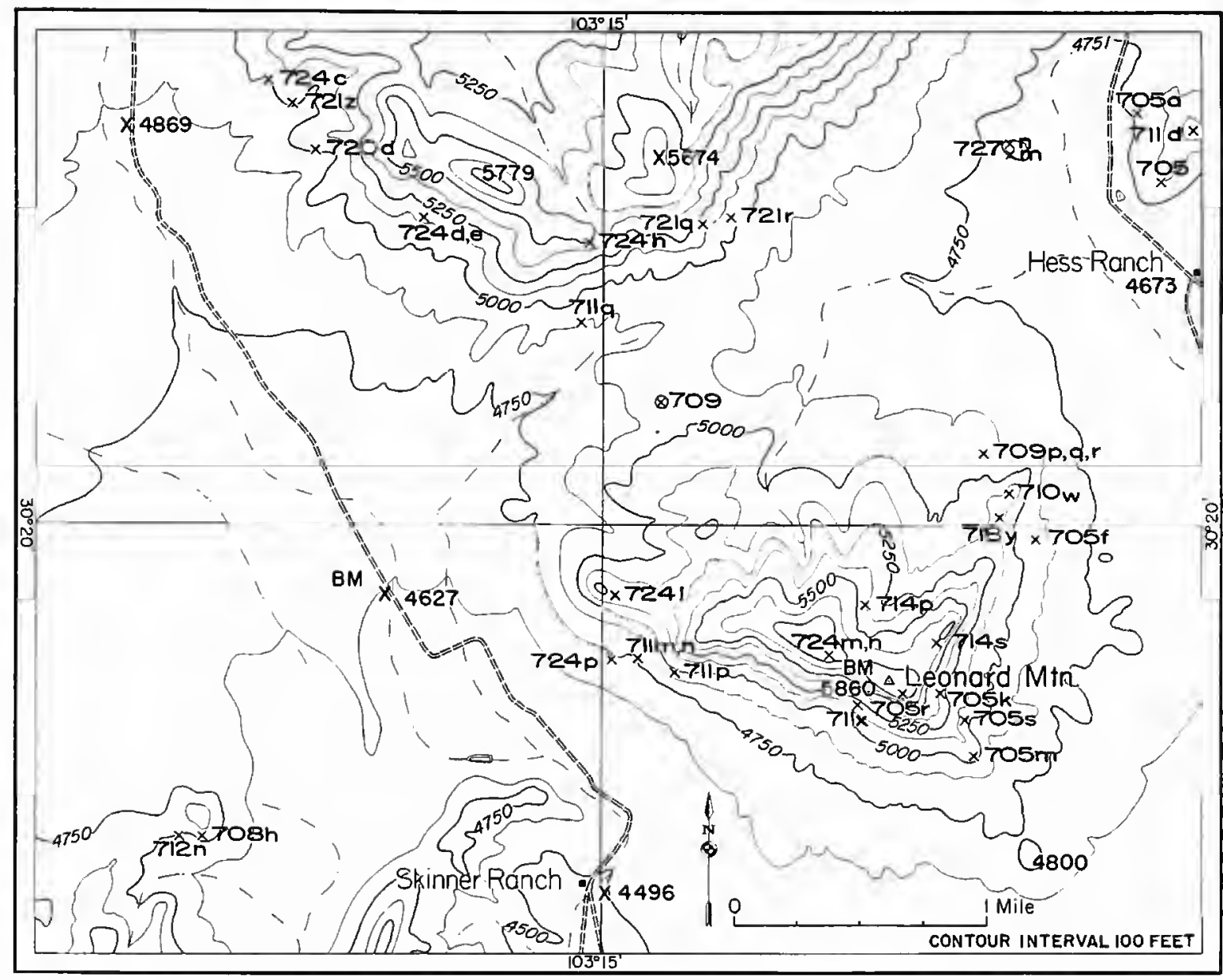

Figure 34.-Localities on Leonard Mountain and hills to the north.

707x. Skinner Ranch Formation (Decie Ranch member): Detached block with Scacchinella at 4730 feet elevation on nose of hill 0.4 mile $S 38^{\circ} \mathrm{W}$ of hill 5021, Altuda quadrangle.

$707 y$. Sec $708 \mathrm{q}$.

707z. Skinner Ranch Formation (base): 0.3 mile $S$ of hill 5021, E of Sullivan Ranch road, Altuda quadrangle.

708. Cathedral Mountain Formation (Institella zone): Fault block, 1.75 miles $\mathrm{N} 48^{\circ} \mathrm{E}$ of Hess Ranch and 0.62 mile $\mathrm{N} 68^{\circ} \mathrm{W}$ of hill 5726 , Hess Canyon quadrangle.

708a. Skinner Ranch Formation (Poplar Tank Member): Loose at fault on $W$ side of spur, $W$ side of Sullivan (Yates) Ranch road, at entrance to canyon, 2.8 miles $S$ $23^{\circ}$ E of Sullivan Peak, Altuda quadrangle.

708b. Wolfcampian (Neal Ranch Formation?): Roadcut on U. S. Highway 90, 4 miles $W$ of Marathon, Altuda quadrangle.

708c. Cathedral Mountain Formation: One-third way up hill just $W$ of divide, about 1.95 miles $S 65^{\circ} \mathrm{W}$ of Old Word Ranch site, Hess Canyon quadrangle.

708e. Skinner Ranch Formation (Poplar Tank Memberupper): Bioherm at 4815 feet elevation, 0.3 mile $S 75^{\circ}$ $\mathrm{E}$ of hill 5300, $\mathrm{N}$ of Decie Ranch, center of Lenox Hills, Altuda quadrangle [=approximately R. E. King 38] (Plate 21: figure 2).

708f. Skinner Ranch Formation: 30 feet above Decie Ranch Member in detached block, base of hill 5021, 0.45 mile $\mathrm{S} 30^{\circ} \mathrm{W}$ of hill 5021, Altuda quadrangle. 708g. Lenox Hills Formation: Base of hill $\mathbf{E}$ of Sullivan Ranch, Altuda quadrangle.

708h. Lenox Hills Formation: 4800 feet elevation on S side of knob at $\mathrm{NE}$ end of hill $5280,1.4$ miles $\mathrm{N} 83^{\circ} \mathrm{W}$ of Skinner Ranch (Iron Mountain) house, Altuda quad. rangle.

708i. Skinner Ranch Formation: 30 feet above base of limestone in detached block, 0.45 mile $S 28^{\circ} \mathrm{W}$ of hill 5021 , Altuda quadrangle.

708k. Lenox Hills Formation: At elevation 5700 feet in section up hill 5816,300 feet $S 63^{\circ} \mathrm{E}$ of hill 5816, Hess Ranch Horst, Hess Canyon quadrangle.

708 . Gaptank Formation: Knob 0.72 mile S $82^{\circ} \mathbf{E}$ of hill 5300, Lenox Hills, Altuda quadrangle.

708p. Gaptank Formation: Coral bed on $\mathrm{S}$ side of knob at $\mathrm{NE}$ end of mountain (5280) W of Iron Mountain, 1.46 miles $\mathrm{N} 81.5^{\circ} \mathrm{W}$ of Skinner Ranch, Altuda quadrangle.

708q. Skinner Ranch Formation (Decie Ranch member): SE face of hill $\mathrm{E}$ of road to Sullivan (Yates) Ranch, 20 feet below saddle between southern and middle knobs, 0.25 mile $S 40^{\circ} \mathrm{W}$ of hill $5021,3.15$ miles $S 46^{\circ} \mathrm{E}$ of Sullivan Pcak, E end of Lenox Hills, Altuda quadrangle (Plate 10: figure 2).

708u. Cathedral Mountain Formation (lower): Loose pieces on $S$ side of gully, under Institella zone and above basal quartz pebble conglomerate, 0.5 mile $\mathrm{N} 83^{\circ} \mathrm{E}$ of Split Tank, 1.95 miles $\mathrm{N} 62^{\circ} \mathrm{E}$ of Old Word Ranch, Hess Canyon quadrangle. [Although all of the pieces compris. 
ing this locality were loose, they were taken together and are regarded as in place; however, no other pieces like them have since been found.]

708w. Neal Ranch Formation (bed 4 of P. B. King): Loose on floor of canyon, 100 yards below confluence of Canyon branches, Wolfcamp Hills, Hess Canyon quadrangle.

708x. Cathedral Mountain Formation: W slope of amphitheater on Leonard Mountain, Hess Canyon quadrangle.

708y. Neal Ranch Formation (bed 8 of P. B. King): Hogback $\mathrm{N}$ of Geologists Canyon, Wolf Camp Hills, Hess Canyon quadrangle.

708z. Skinner Ranch Formation (Decie Ranch Member): 0.95 mile $\mathrm{N} 79^{\circ} \mathrm{E}$ of hill 5300, Lenox Hills, Altuda quadrangle.

709. Cathedral Mountain Formation (base): Small knob and saddle on $\mathrm{N}$ side of Leonard Mountain, 2.02 miles $\mathrm{S} 79^{\circ}$ $\mathrm{W}$ of Hess Ranch and 1.9 miles $\mathrm{N} 39^{\circ} \mathrm{W}$ of bench mark 5860 , Hess Canyon quadrangle.

709a. Skinner Ranch Formation: Small knob 0.77 mile $\mathrm{N}$ $3^{\circ} \mathrm{W}$ of Hess Ranch, 0.9 mile $\mathrm{S} 57^{\circ} \mathrm{E}$ of hill 5801 , Hess Canyon quadrangle. 709c. Road Canyon Formation (base): On W slope of hill just $\mathbf{E}$ of road to Sullivan (Yates) Ranch, 0.95 mile $\mathrm{N} 9^{\circ}$ E of hill $4920,1.25$ miles S $57^{\circ} \mathbf{E}$ of Sullivan Peak (bench mark 6125), Altuda quadrangle.

709d. Hess Formation: At 4961 feet in Section 1.4 miles $N$ $63^{\circ} \mathrm{E}$ of Hess Ranch house, Hess Canyon quadrangle.

709e. Hess Formation: At 5091 feet in section 1.4 miles $\mathrm{N}$ $63^{\circ} \mathrm{E}$ of Hess Ranch house, Hess Canyon quadrangle.

709f. Hess Formation: At 5147 feet in section 1.4 miles $N$ $63^{\circ} \mathrm{E}$ of Hess Ranch house, Hess Canyon quadrangle.

$709 \mathrm{~g}$. Hess Formation: At 5194 feet in section 1.4 miles $\mathrm{N}$ $63^{\circ} \mathrm{E}$ of Hess Ranch house, Hess Canyon quadrangle.

709h. Hess Formation: At 5200 feet in section 1.4 miles $\mathrm{N}$ $63^{\circ} \mathrm{E}$ of Hess Ranch house, Hess Canyon quadrangle.

709i. Hess Formation: At 5220 feet in section 1.4 miles $\mathrm{N}$ $63^{\circ} \mathrm{E}$ of Hess Ranch house, Hess Canyon quadrangle.

709j. Hess Formation: At 5250 feet in section 1.4 miles $\mathbf{N}$ $63^{\circ} \mathrm{E}$ of Hess Ranch house, Hess Canyon quadrangle.

709k. Hess Formation: At 5260 feet in section 1.4 miles $\mathrm{N}$ $63^{\circ} \mathrm{E}$ of Hess Ranch house, Hess Canyon quadrangle.

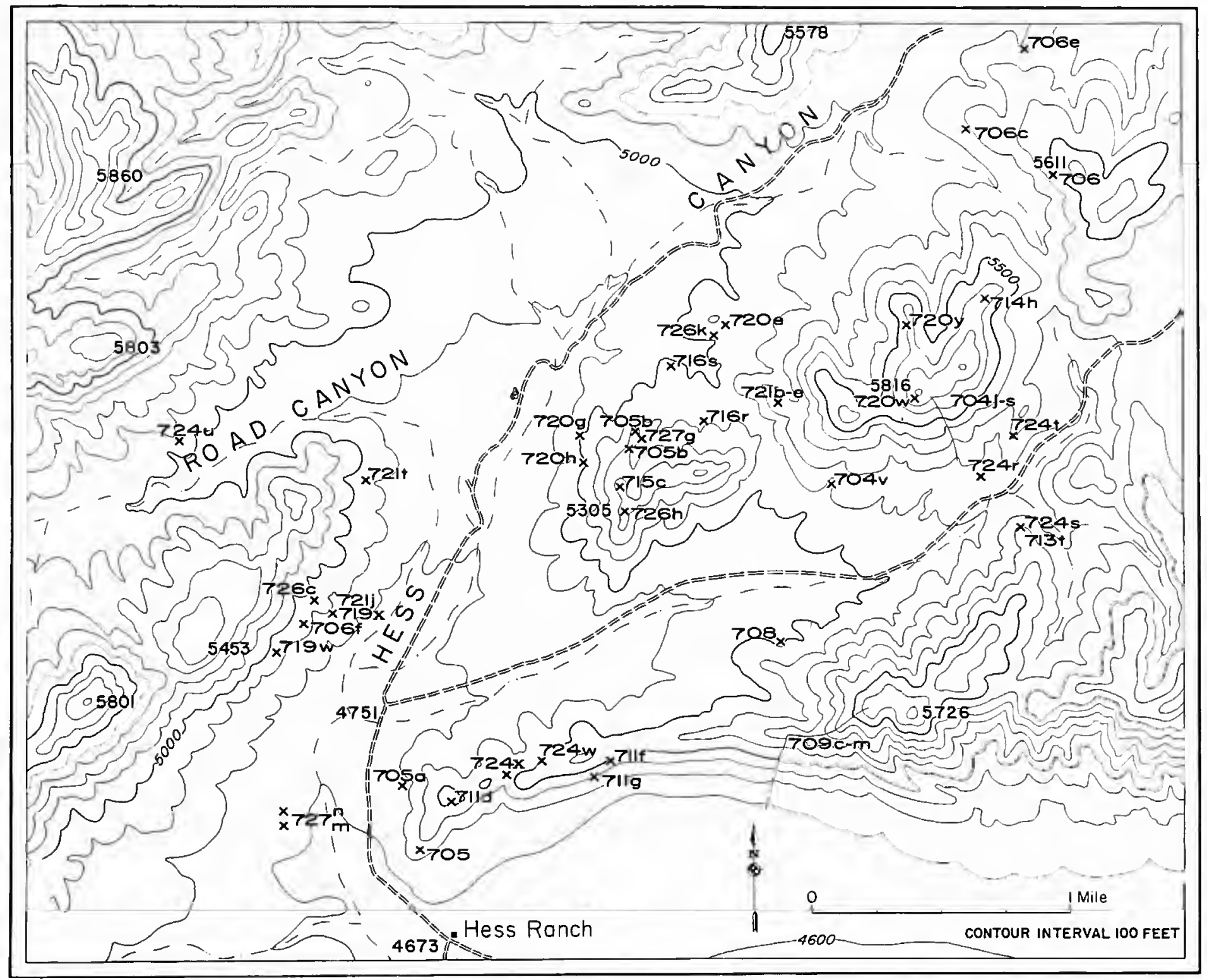

FIGURE 35.-Localities in the vicinity of the Hess Ranch house. 
709-1. Skinner Ranch Formation (Sullivan Peak Member): 0.63 miles $S 30^{\circ} \mathrm{W}$ of hill 5300 , Altuda quadrangle.

$709 \mathrm{~m}$. Hess Formation: At 5418 feet in section 1.4 miles $\mathrm{N}$ $63^{\circ} \mathrm{E}$ of Hess Ranch house, Hess Canyon quadrangle.

7090. Cathedral Mountain Formation (lower): Crest of knob 0.25 mile $\mathrm{N} 65^{\circ} \mathrm{W}$ of bench mark 5860 on Leonard Mountain, Hess Canyon quadrangle.

709 p. Skinner Ranch Formation (base): Base of massive ledge forming crest of knob, 1.05 miles $S 50^{\circ} \mathrm{W}$ of Hess Ranch house, NE end of Leonard Mountain, Hess Canyon quadrangle.

709q. Skinner Ranch Formation (base): 15 feet above base of massive ledge forming crest of knob, 1.05 miles $S 50^{\circ}$ $W$ of Hess Ranch house, NE end of Leonard Mountain, Hess Canyon quadrangle.

709r. Skinner Ranch Formation (lower): Top of massive ledge forming crest of knob, 1.05 miles $S 50^{\circ} \mathrm{W}$ of Hess Ranch house, NE end of Leonard Mountain, Hess Canyon quadrangle.

$709 \mathrm{~s}$. Lenox Hills Formation: 0.1 mile $S$ of knob at NE base of Leonard Mountain, 1.05 miles $S 45^{\circ} \mathrm{W}$ of Hess Ranch house, Hess Canyon quadrangle.

709t. Lenox Hills Formation: On the NE nose of hill 0.53 mile $\mathrm{N} 37^{\circ} \mathrm{E}$ of bench mark 5860 on Leonard Mountain, 1.25 miles $\mathrm{S} 37^{\circ} \mathrm{W}$ of Hess Ranch house, Hess Canyon quadrangle.

709u. Skinner Ranch Formation (base): On E slope of hill below knob, 1.05 miles $S 50^{\circ} \mathrm{W}$ of Hess Ranch house, Hess Canyon quadrangle.

$709 \mathrm{v}$. Skinner Ranch Formation: In sandy conglomerate at 5222 feet, 0.53 mile $\mathrm{N} 34^{\circ} \mathrm{E}$ of bench mark 5860 on Leonard Mountain, Hess Canyon quadrangle.

709w. Lenox Hills Formation: Under knob at 5280 feet elevation, $\mathrm{N}$ slope of Leonard Mountain, 0.48 mile $\mathrm{N}$ $37^{\circ} \mathrm{E}$ of bench mark 5860, Hess Canyon quadrangle.

$709 \mathrm{x}$. Lenox Hills Formation: $W$ side of first gully under knob (5750 contour), 0.375 mile $\mathrm{N} 24^{\circ} \mathrm{E}$ of bench mark 5860 on Leonard Mountain, Hess Canyon quadrangle.

709x. Skinner Ranch Formation: Detached block on slope 0.28 mile $\mathrm{N} 7^{\circ} \mathrm{W}$ of bench mark 5860 on Leonard Mountain, Hess Canyon quadrangle.

710b. Cathedral Mountain Formation: On top of hill 4902, 1.6 miles $\mathrm{N} 41^{\circ} \mathrm{E}$ of Lenox, Altuda quadrangle.

710d. Cathedral Mountain (Wedin Member): 2.25 miles $N$ $36^{\circ}$ E of Lenox, Altuda quadrangle.

$710 \mathrm{~g}$. Cathedral Mountain Formation: 1.18 miles due $S$ of Sullivan Peak, Altuda quadrangle.

710h. Road Canyon Formation (lower): 0.96 mile S $3^{\circ} \mathrm{E}$ of Sullivan Peak and for 600 feet NE around hilltop and on $\mathrm{E}$ sicle of knob, Altuda quadrangle.

710i. Road Canyon Formation: 0.87 mile S $21^{\circ} \mathrm{E}$ of Sullivan Peak, Altuda quadrangle.

710 j. Road Canyon Formation: 0.9 mile S $17^{\circ} \mathrm{E}$ of Sullivan Peak, Altuda quadrangle.

710 1. Road Canyon Formation: 3.1 miles $S 64.5^{\circ} \mathrm{W}$ of Sullivan Peak, 3.8 miles $\mathrm{N} 12^{\circ} \mathrm{W}$ of Lenox, Altuda quadrangle.

$710 \mathrm{~m}$. Road Canyon Formation: 1.7 miles $\mathrm{S} 48^{\circ} \mathrm{W}$ of Sullivan Peak, Altuda quadrangle $[=R$. E. King 53]. 710n. Road Canyon Formation: 1.45 miles $S 49^{\circ} \mathrm{W}$ of Sullivan Peak, Altuda quadrangle.

710o. Road Canyon Formation: 1.4 miles $S 43^{\circ} \mathrm{W}$ of Sullivan Peak, Altuda quadrangle.

710p. Road Canyon Formation: 1.52 miles $S 42^{\circ} \mathrm{W}$ of Sullivan Peak, Altuda quadrangle.

710r. Skinner Ranch Formation (Sullivan Peak Member, top): 0.55 mile $\mathrm{N} 85^{\circ} \mathrm{W}$ of hill $5021,2.75$ miles $S 45^{\circ}$ E of Sullivan Peak, Altuda quadrangle.

710 s. Skinner Ranch Formation (float): 0.53 mile $S 78^{\circ} \mathrm{W}$ of hill 5021, 2.87 miles S $40^{\circ} \mathrm{E}$ of Sullivan Peak, Altuda quadrangle.

710t. Road Canyon Formation: 0.33 mile N $40^{\circ} \mathrm{E}$ of Sullivan Peak, Altuda quadrangle.

710u. Road Canyon Formation: 1.65 miles S $63^{\circ} \mathrm{E}$ of Sullivan Peak, 1.25 miles $S 55^{\circ} \mathrm{W}$ of hill 4910 , Altuda quadrangle (Plate 3: figure 4).

710w. Lenox Hills Formation: Northernmost of two knobs on NE side of Leonard Mountain, 0.83 mile $\mathrm{N} 33^{\circ} \mathrm{E}$ of bench mark $5860,1.05$ miles $S 41^{\circ} \mathrm{W}$ of Hess Ranch house, Hess Canyon quadrangle.

710x. Skinner Ranch Formation (Poplar Tank Member): Section 0.35 mile $S 25^{\circ} \mathrm{E}$ of hill 5300, Altuda quadrangle.

710y. Skinner Ranch Formation (Sullivan Peak Member): Lowest conglomerate above thick shale, 108 feet above Decie Ranch Member, section 0.35 mile S $25^{\circ} \mathrm{E}$ of hill 5300, Altuda quadrangle.

710z. Road Canyon Formation: 0.75 mile $S 61^{\circ} \mathrm{W}$ of hill 4910,187 miles $S 79^{\circ}$ E of Sullivan Peak, Altuda quadrangle.

71lc. Lenox Hills Formation: 0.4 mile $\mathrm{N} 13^{\circ} \mathrm{W}$ of Hess Ranch house, Hess Canyon quadrangle.

71ld. Skinner Ranch Formation (base): 0.55 mile $\mathrm{N} 20^{\circ} \mathrm{W}$ of Hess Ranch house, Hess Canyon quadrangle (text Figure 8).

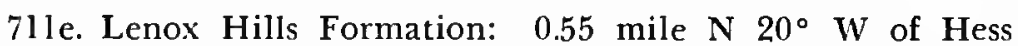
Ranch house, Hess Canyon quadrangle.

71lf. Hess Formation: 0.93 mile $\mathrm{N} 43^{\circ} \mathrm{E}$ of Hess Ranch house, Hess Canyon quadrangle.

$71 \mathrm{lg}$. Hess Formation: 0.83 mile $\mathrm{N} 42^{\circ} \mathrm{E}$ of Hess Ranch house, Hess Canyon quadrangle.

711h. Lenox Hills Formation: 0.67 mile N 21 $\mathrm{E}$ of Hess Ranch house, Hess Canyon quadrangle.

71li. Skinner Ranch Formation (base): 0.7 mile $\mathrm{N} 2^{\circ} \mathrm{W}$ of Hess Ranch house, Hess Canyon quadrangle.

71 k. Skinner Ranch Formation (base): 1.1 miles $\mathrm{N} 83^{\circ} \mathrm{W}$ of bench mark 5860 of Leonard Mountain, Hess Canyon quadrangle.

711-1. Skinner Ranch Formation: 60 feet above Scacchinella, 1.1 miles $\mathrm{N} 83^{\circ} \mathrm{W}$ of bench mark 5860 on top of Leonard Mountain, Hess Canyon quadrangle.

$71 \mathrm{~lm}$. Lenox Hills Formation: 0.92 mile $\mathrm{N} 85^{\circ} \mathrm{W}$ of bench mark 5860 on top of Leonard Mountain, Hess Canyon quadrangle.

71ln. Skinner Ranch Formation (base): 0.9 mile $\mathrm{N} 83^{\circ} \mathrm{W}$ of bench mark 5860 on top of Leonard Mountain, Hess Canyon quadrangle. 
71lo. Skinner Ranch Formation (lower): 0.9 mile $\mathrm{N} 84^{\circ} \mathrm{W}$ of bench mark 5860 on top of Leonard Mountain, Hess Canyon quadrangle.

71 p. Skinner Ranch Formation (lower): 0.75 mile $\mathrm{N} 87^{\circ}$ W of bench mark 5860 on top of Leonard Mountain, Hess Canyon quadrangle.

71lq. Cathedral Mountain Formation: 2.07 miles $\mathrm{N} 1^{\circ} \mathrm{E}$ of Skinner Ranch (Iron Mountain Ranch), 1.7 miles $\mathrm{N}$ $39^{\circ} \mathrm{W}$ of bench mark 5860, on Leonard Mountain, Altuda quadrangle [ $=$ R. E. King 123].

711r. Cathedral Mountain Formation (uppermost): 1.8 miles $S 26^{\circ} \mathrm{E}$ of bench mark $4973,0.45$ mile $\mathrm{S} 38^{\circ} \mathrm{W}$ of hill 5779, Gilliland Canyon, Altuda quadrangle.

71lu. Word Formation: 25 feet below Willis Ranch Member, 1.35 miles $S 40^{\circ} \mathrm{E}$ of bench mark 4973, Gilliland Canyon, Altuda quadrangle.

71lv. Road Canyon Formation: Top of 40-foot limestone in gulch 1.7 miles $\mathrm{S} 32^{\circ} \mathrm{E}$ of bench mark 4973, Gilliland Canyon, Altuda quadrangle.

711w. Cathedral Mountain Formation (top): 40 feet below Road Canyon Formation in gulch 1.7 miles $\mathrm{S} 32^{\circ} \mathrm{E}$ of bench mark 4973, Gilliland Canyon, Altuda quadrangle.

$711 x$. Neal Ranch Formation: 1.25 miles $N 59^{\circ}$ E of Skinner (Iron Mountain) Ranch house, 0.1 mile $\mathrm{S} 15^{\circ} \mathrm{W}$ of bench mark 5860 at about 5300 feet on $S$ slope of Leonard Mountain, Hess Canyon quadrangle.

711y. Skinner Ranch Formation: 1.83 miles $\mathrm{S} 67^{\circ} \mathrm{W}$ of Skinner (Iron Mountain) Ranch house, 4.05 miles S $84^{\circ}$ $\mathbf{E}$ of Sullivan Peak in hill 5280, Altuda quadrangle. 711z. Skinner Ranch Formation (upper): 0.35 mile $\mathrm{N} 34^{\circ}$ $W$ of hill $5280,3.75$ miles $S 87^{\circ}$ E of Sullivan Peak, $W$ of Iron Mountain, Altuda quadrangle.

712e. Hueco Formation: Basal upper Hueco 100 yards $W$ of bench mark 5318, 1.5 miles NNE of Hueco Inn, Hueco Mountains (15') quadrangle, Texas.

$712 \mathrm{~m}$. Hueco Formation: $S$ side of saddle of hill opposite bench mark 5318, 1.5 miles $\mathrm{N}$ of Hueco Inn, Hueco Mountains (15') quadrangle.

712n. Skinner Ranch Formation (base): 4.3 miles $\mathrm{N} 83.5^{\circ}$ $\mathrm{E}$ of Sullivan Peak, 1.48 miles $\mathrm{N} 84^{\circ} \mathrm{W}$ of Skinner (Iron Mountain) Ranch, $\mathrm{N}$ end of hill 5280, W of Iron Mountain, Altuda quadrangle.

712o. Cathedral Mountain Formation: 0.7 mile $\mathrm{N} 72^{\circ} \mathrm{E}$ of hill 4910, 1.3 miles $\mathrm{N} 39^{\circ} \mathrm{W}$ of hill 5280 , Altuda quadrangle.

712p. Skinner Ranch Formation (base): 3.28 miles $S 56^{\circ}$ E of Sullivan Peak, knob 0.28 mile $\mathrm{N} 58^{\circ} \mathrm{E}$ of hill 5021 , Altuda quadrangle.

712q. Road Canyon Formation: 2.3 miles $\mathrm{S} 78^{\circ} \mathrm{E}$ of Sullivan Peak, W side of Clay Slide, Altuda quadrangle.

712t. Road Canyon Formation: 1.87 miles S $87^{\circ} \mathrm{E}$ of Sullivan Pcak, Altucla quadrangle.

712u. Lenox Hills Formation: 0.23 mile $\mathrm{N} 64^{\circ} \mathrm{E}$ of hill 5021, 3.35 miles $S 55^{\circ} \mathrm{E}$ of Sullivan Peak, in saddle, Altuda quadrangle.

712v. Lcnox Hills Formation [=USNM 712u].

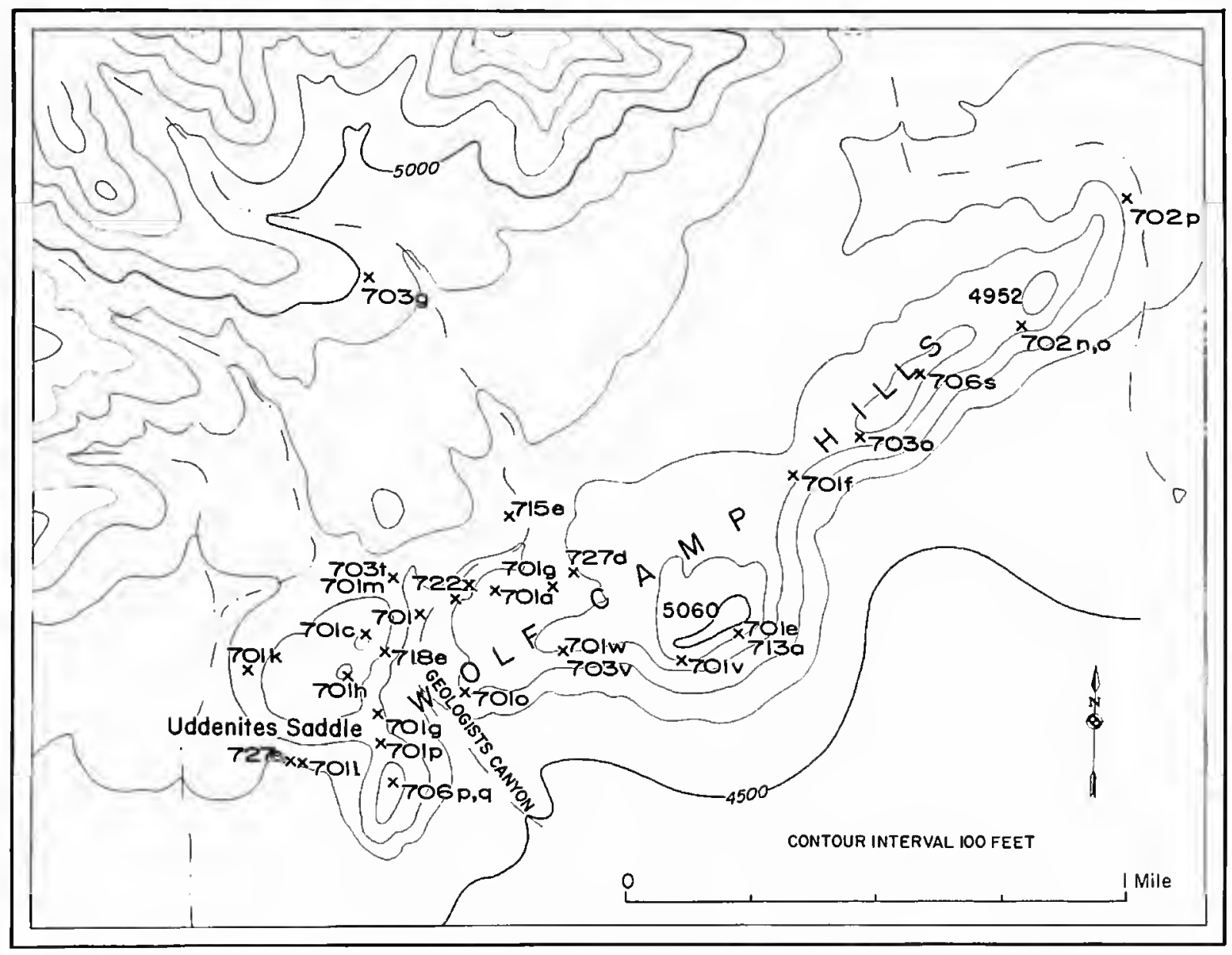

Figure 36.-Localities in the Wolf Camp Hills. 
712w. Neal Ranch Formation (Cooper bed 9) [=P. B. King bed 12]: 0.93 mile $S 75^{\circ} \mathrm{W}$ of hill 5060, Wolf Camp Hills, Hess Canyon quadrangle.

$712 x$. Neal Ranch Formation ( 85 feet above bed 12 of $\mathbf{P}$. B. King): Cooper bed $\mathrm{K}$, section of 23 May 1958, long section 0.53 mile $\mathrm{N} 71^{\circ} \mathrm{W}$ of hill 5060, Wolf Camp Hills, Hess Canyon quadrangle.

712y. Neal Ranch Formation (upper): Bed U of Cooper's 23 May 1958 section, 0.53 mile $\mathrm{N} 71^{\circ} \mathrm{W}$ of hill 5060 , Wolf Camp Hills, Hess Canyon quadrangle.

712z. Neal Ranch Formation (47 feet above bed 12 of P. B. King =Properrinites bed): Long section 0.53 mile $\mathrm{N}$ $71^{\circ} \mathrm{W}$ of hill 5060, Wolf Camp Hills, Hess Canyon quadrangle.

713. Word Formation (China Tank Member): Hillside 1.68 miles $\mathrm{N} 11^{\circ} \mathrm{W}$ of Hess Ranch house, Hess Canyon quadrangle.

713a. Gaptank Formation (Uddenites-bearing Shale Member): $S$ side of high cliff, 250 feet $S$ of hill 5060 , center Wolf Camp Hills, Hess Canyon quadrangle $[=$ USNM 701 e].

713b. Gaptank Formation (Uddenites-bearing Shale Member): $\mathrm{N}$ slope of upper limestone, 0.1 mile due $\mathrm{W}$ of hill 4952, Wolf Camp Hills, Hess Canyon quadrangle.

713c. Skinner Ranch Formation (Sullivan Peak Member): 0.33 mile $\mathrm{N} 78^{\circ} \mathrm{E}$ of hill $4902, \mathrm{~N}$ of Decie Ranch, Altuda quadrangle.

713d. Skinner Ranch Formation (Sullivan Peak Member): Top of Dugout Mountain (hill 5195), Monument Spring quadrangle.

713c. Gaptank Formation: Lower bioherm, SW side of the hill, 0.4 mile S $56^{\circ} \mathrm{W}$ of hill 4815 , Conoly Brooks Ranch, NE of Wolf Camp Hills, Hess Canyon quadrangle.

713g. Gaptank Formation (Uddenites-bearing Shale Member): Uppermost part of E end of Wolfcamp Hills, Hess Canyon quadrangle.

713i. Skinner Ranch Formation (Sullivan Peak Member): $85^{\prime}$ up in member or $25^{\prime}$ below brow of hill, E side of hill facing spur, $W$ side of Sullivan (Yates) Ranch road, E end of Lenox Hills, Altuda quadrangle.

$713 \mathrm{j}$. Lenox Hills Formation: Shale under conglomerate at 4575 feet, opposite ravine in main hill, 0.5 mile $W$ of Sullivan Ranch road, 1.2 miles due $S$ of hill 4920 , Altuda quadrangle.

713k. Neal Ranch Formation (lower bed 2 of P. B. King): Hill 5060, centcr of Wolf Camp Hills, Hess Canyon quadrangle.

713-1. Neal Ranch Formation (beds 4-8): W side of Wolfcamp Hills, just $\mathrm{N}$ of the Uddenites knob, Wolfcamp Hills, Hess Canyon quadranglc.

713m. Skinner Ranch Formation (Sullivan Peak Member): 70 feet up in member, hill 1 mile NE of hill 5300, Lenox Hills, Altuda quadrangle.

713n. Skinner Ranch Formation (top): Top of hill 5280, W of Iron Mountain, Altuda quadrangle [=USNM $705 \mathrm{n}]$.

71'30. Gaptank Formation (Uddenites-bearing Shale Member): 0.25 mile $\mathrm{S} 53^{\circ} \mathrm{W}$ of hill 4952 , Wolf Camp Hills, Hess Canyon quadrangle. 713p. Cathedral Mountain Formation: 0.4 mile $\mathrm{S} 47^{\circ} \mathrm{E}$ of hill 4910 , on knoll $S$ of road, $E$ of Clay Slide, Altuda quadrangle.

713q. Lenox Hills Formation: $E$ slope of hill, 0.5 mile WSW of hill 5816, Hess Ranch Horst, Hess Canyon quadrangle.

713r. Skinner Ranch Formation (Poplar Tank Member): Just on top of Decie Ranch Member, above shale under knob, 2 miles NE of Lenox, Altuda quadrangle.

713s. Skinner Ranch Formation (Decie Ranch Member): Ledge near top, under high knob (hill 5195) of Dugout Mountain, Monument Spring quadrangle.

713t. Cathedral Mountain Formation (lower): 2.73 miles N $55^{\circ} \mathrm{E}$ of Hess Ranch house, 1.22 miles $W$ of hill 5725 , Hess Canyon quadrangle $[=R, E$. King 104].

713u. Gaptank Formation (Uddenites-bearing Shale Member): Base of first thick ledge just $E$ of saddle, $E$ of hill 5060, Wolf Camp Hills, Hess Canyon quadrangle.

713w. Cathedral Mountain Formation: Spur on hill on $E$ side of arroyo, 0.75 mile $\mathrm{N}$ of entrance to canyon leading to Sullivan (Yates) Ranch, 0.42 mile $\mathrm{S} 47^{\circ} \mathrm{E}$ of hill 4920, Altuda quadrangle.

713x. [=USNM 716n.]

713y. Lenox Hills Formation: Loose fossils in shale just $\mathrm{N}$ of divide, 0.56 mile $S 89^{\circ} \mathrm{W}$ of hill 5816, Hess Ranch Horst, Hess Canyon quadrangle.

713z. Skinner Ranch Formation (Sullivan Peak member): Spyridiophora zone, section 0.35 mile $S 25^{\circ} \mathrm{E}$ of hill $5300,1.18$ miles $\mathrm{N} 60^{\circ} \mathrm{E}$ of hill 4902 , center of Lenox Hills, Altuda quadrangle.

714a. Lenox Hills Formation: At 5200 feet in deep gully 0.28 mile $\mathrm{N} 5^{\circ} \mathrm{E}$ of bench mark 5860 on north slope of Leonard Mountain, Hess Canyon quadrangle.

714b. Lenox Hills Formation: Detached block of massive granular limestone at 5248 to 5273 feet, 0.28 mile $\mathrm{N} 12^{\circ}$ W of bcnch mark 5860, on Leonard Mountain, Hess Canyon quadrangle.

714c. Lenox Hills Formation: 120 feet below top of knob 1.05 miles $S 50^{\circ} \mathrm{W}$ of Hess Ranch house, NE end of Leonard Mountain, Hess Canyon quadrangle.

714d. Skinner Ranch Formation (base): 1 foot above massive Wolfcamp (Lenox Hills) 1 mile $S 50^{\circ} \mathrm{W}$ of Hess Ranch housc, Hess Canyon quadrangle.

714e. Skinner Ranch Formation (Decie Ranch equivalent): Scacchinella zone, 0.28 mile $\mathrm{N} 5^{\circ} \mathrm{E}$ of bench mark 5860 , above deep gully on Leonard Mountain, Hess Canyon quadrangle [ $=$ R. E. King 207].

714f. Lenox Hills Formation: 10 to 15 feet below top of massive Lcnox Hills Formation on E slopc of knob, 1.05 miles $S 50^{\circ} \mathrm{W}$ of Hess Ranch house, Hess Canyon quadrangle.

714g. Lcnox Hills Formation: 5.5 feet below top of massive Lenox Hills on $\mathrm{E}$ slope of knob, 1.05 miles $\mathrm{S} 50^{\circ} \mathrm{W}$ of Hess Ranch housc, Hess Canyon quadrangle.

714h. Skinner Ranch Formation (base): Top of hill 3.75 miles $\mathrm{N} 41^{\circ} \mathrm{E}$ of Hess Ranch house, 0.72 mile $\mathrm{N} 50^{\circ} \mathrm{E}$ of hill 5816, Hess Canyon quadrangle. 
714i. Hess Formation: Nose of hill 0.68 mile $\mathrm{N} 64^{\circ} \mathrm{E}$ of hill 5821, N of Wolf Camp Hills, Hess Canyon quadrangle.

714j. Hess Formation: 1.5 miles $\mathrm{N} 58^{\circ} \mathrm{E}$ of hill $5821, \mathrm{~N}$ of Wolf Camp Hills, Hess Canyon quadrangle.

714k. Hess Formation: 1.53 miles $\mathrm{N} 66^{\circ} \mathrm{E}$ of hill $5821, \mathrm{~N}$ of Wolf Camp Hills, Hess Canyon quadrangle.

7140. Word Formation (Appel Ranch Member): 1.32 miles $\mathrm{N} 50^{\circ} \mathrm{W}$ of bench mark $5652,0.5$ mile $\mathrm{S} 60^{\circ} \mathrm{W}$ of hill 5575, NW of Old Word Ranch, Hess Canyon quadrangle.

714p. Skinner Ranch Formation (lower): 0.28 mile $N 11^{\circ}$ W of bench mark 5860 on Leonard Mountain, Hess Canyon quadrangle (Plate 11: figure 2). 714q. Skinner Ranch Formation: 0.25 mile $\mathrm{N} 22^{\circ} \mathrm{W}$ of bench mark 5860, Leonard Mountain, Hess Canyon quadrangle.

714s. Skinner Ranch Formation: 0.2 mile $\mathrm{N} 52^{\circ} \mathrm{E}$ of bench mark 5860, Leonard Mountain, Hess Canyon quadrangle.

714t. Skinner Ranch Formation (Decie Ranch Member): Detached block about 0.45 mile S $20^{\circ} \mathrm{E}$ of hill $5300, \mathrm{~N}$ of Decie Ranch, Altuda quadrangle.

714u. Skinner Ranch Formation (Sullivan Peak Member): 0.85 mile $\mathrm{N} 12^{\circ} \mathrm{E}$ of Lenox, 0.35 mile $\mathrm{N} 60^{\circ} \mathrm{E}$ of hill 4801, Monument Spring quadrangle.

714v. Cathedral Mountain Formation (Second Leonard Limestone Member of P. B. King $=$ Wedin Member): Small knob 0.25 mile $\mathrm{N} 21^{\circ} \mathrm{W}$ of hill 4801 , exactly 1 mile $\mathrm{N}$ $25^{\circ} \mathrm{E}$ of Lenox, Altuda quadrangle.

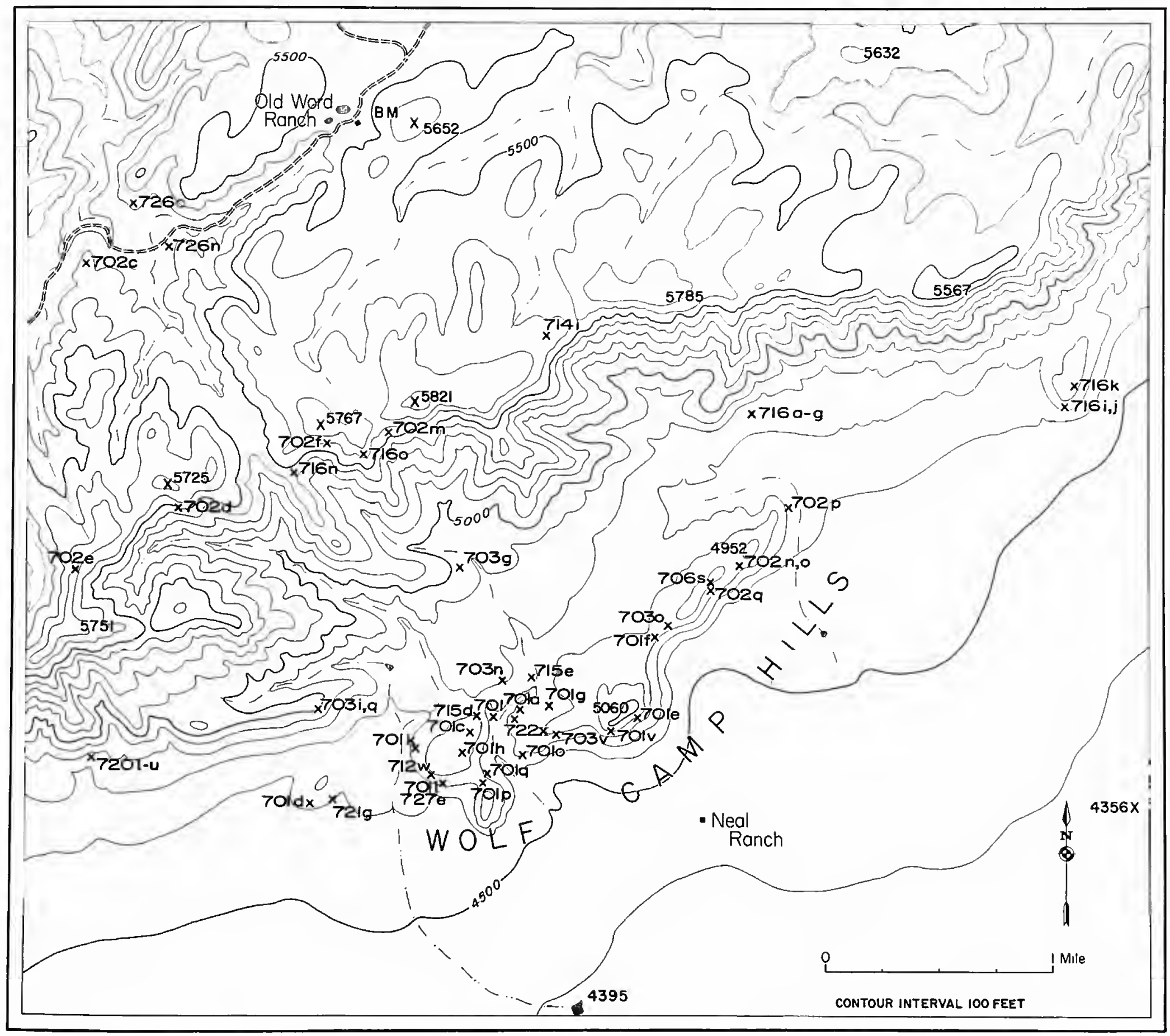

FIGURE 37.-Additional localities in the Wolf Camp Hills. 
714w. Cathedral Mountain Formation (Institella beds, Second Limestone Member of P. B. King =Wedin Member): Low hill 0.66 mile $\mathrm{N} 88^{\circ} \mathrm{W}$ of hill $4902,1.3$ miles $\mathrm{N}$ $18^{\circ} \mathrm{E}$ of Lenox, SW end of Lenox Hills, Altuda quadrangle.

714wa. Cathedral Mountain Formation (Second Leonard Limestone Member of P. B. King =Wedin Member): Blocks with Coscinophora [=USNM 714w].

714y. Skinner Ranch Formation (Sullivan Peak Member): 0.75 mile $\mathrm{N} 42^{\circ} \mathrm{E}$ of Lenox, Monument Spring quadrangle.

715. Lenox Hills Formation: Conglomeratic bed in shale, 30 feet below Skinner Ranch Formation (Decie Ranch Member), 0.1 mile E of hill 5195, Dugout Mountain, Monument Spring quadrangle (Plate 13: figure 4).

715a. Skinner Ranch Formation (Decie Ranch Member): Under high point of hill 5195, Dugout Mountain, Monument Spring quadrangle (Plate 10: figure 4).

715b. Lenox Hills Formation [= Neal Ranch of C. A. Ross]: Near base of hill under $W$ knob 1.6 miles $\mathrm{N} 68^{\circ} \mathrm{E}$ of Lenox at 4450-4490 feet elevation, 0.9 miles due $\mathbf{E}$ of hill 4801, Monument Spring quadrangle (Plate 12: figure 2). [The fact that these beds have Lenox Hills conglomerate beneath them and interfingering with them suggests that they belong to the Lenox Hills Formation.]

715c. Skinner Ranch Formation (Decie Ranch equivalent): 0.1 mile $\mathrm{N} 7^{\circ} \mathrm{W}$ of hill $5305,1.85$ mile $\mathrm{N} 21.5^{\circ} \mathrm{E}$ of Hess Ranch, on NW slope of westernmost hill of Hess Ranch Horst, Hess Canyon quadrangle.

715e. Neal Ranch Formation (beds $12-14$ of P. B. King): Just $\mathrm{N}$ of elbow of Gcologists Canyon to $\mathrm{N}, 300$ feet above (upstream) elbow, 0.47 mile $\mathrm{N} 68^{\circ} \mathrm{W}$ of hill 5060 , Wolf Camp Hills, Hess Canyon quadrangle [=USNM $706 \mathrm{x}]$.

715f. Skinner Ranch Formation (Sullivan Peak Member): 0.33 mile $S 46^{\circ} \mathrm{W}$ of hill 5021, $\mathrm{E}$ of Sullivan Ranch road, Altuda quadrangle.

715h. Skinner Ranch Formation (Sullivan Peak Member): 0.2 mile due $S$ of hill 4920, Altuda quadrangle.

715i. Word Formation (Appel Ranch Member): 0.45 mile $\mathrm{N} 84^{\circ} \mathrm{E}$ of hill $5543,4.68$ miles $\mathrm{N} 32^{\circ} \mathrm{E}$ of Hess Ranch, Hess Canyon quadrangle.

715j. Skinner Ranch Formation (Sullivan Peak Member): 25 -feet above Decie Ranch Member in section 0.95 mile $\mathrm{N} 79^{\circ} \mathrm{E}$ of hill 5300, Lenox Hills, Altuda quadrangle.

715k. Skinner Ranch Formation (Poplar Tank Member): 30 feet above Decie Ranch Member in section 0.95 mile $\mathrm{N}$ $79^{\circ}$ E of hill 5300, Lenox Hills, Altuda quadrangle.

$715 \mathrm{~m}$. Skinner Ranch Formation (Sullivan Peak Member): Side of hill 1.2 miles $\mathrm{N} 62^{\circ} \mathrm{E}$ of hill 5300, Lenox Hills, Altuda quadrangle.

715n. Skinner Ranch Formation: 0.15 mile $S 44^{\circ} \mathrm{W}$ of hill 5021 , E of Sullivan (Yates) Ranch Road, Altuda quadrangle.

715r. Skinner Ranch Formation (base): 42.4 feet above base of Grant's measured section, E slope of knob capped by 5000-foot contour, 1 mile S $50^{\circ} \mathrm{W}$ of Hess Ranch house, $\mathrm{NE}$ end of Leonard Mountain, Hess Canyon quadrangle [=USNM 709u]. 715t. Skinner Ranch Formation (Decie Ranch Member equivalent): 63 feet above base of Decie Ranch Member, E slope of knob, 1 mile $S 50^{\circ} \mathrm{W}$ of Hess Ranch house, NE end of Leonard Mountain, Hess Canyon quadrangle.

715v. Skinner Ranch Formation (Decie Ranch Member equivalent): 85 feet below top of knob near $S$ end, 1.0 mile $S 50^{\circ} \mathrm{W}$ of Hess Ranch, at NE end of Leonard Mountain, Hess Canyon quadrangle.

715z. Gaptank Formation: 75 feet below Skinner Ranch Formation on slope of hill 5280, just W of Iron Mountain, Altuda quadrangle.

716a. Hess Formation: At 4915 feet in long section 0.6 mile due $\mathrm{N}$ of hill 4952, Wolf Camp Hills, Hess Canyon quadrangle.

716d. Hess Formation: At 4987 feet in long section 0.6 mile due $\mathrm{N}$ of hill 4952 in mountain front $\mathrm{N}$ of Wolf Camp Hills, Hess Canyon quadrangle.

716f. Hess Formation: At 5111 feet in long section 0.6 mile due $\mathrm{N}$ of hill 4952, in mountain front $\mathrm{N}$ of Wolf Camp Hills, Hess Canyon quadrangle.

716h. Hess Formation: At 5400 feet in long section 0.6 mile due $\mathrm{N}$ of hill 4952, in mountain front $\mathrm{N}$ of Wolf Camp Hills, Hess Canyon quadrangle.

716i. Gaptank Formation: At 4753 feet in hill 1.6 miles N $66^{\circ} \mathrm{E}$ of hill 4952 , Hess Canyon quadrangle.

716k. Gaptank Formation: Loose piece on top of hill 1.6 miles $\mathrm{N} 66^{\circ} \mathrm{E}$ of hill 4952, Hess Canyon quadrangle.

$716 \mathrm{~m}$. Neal Ranch Formation: 206 feet above base of section, hill 1.4 miles $\mathrm{S} 81^{\circ} \mathrm{W}$ of hill 5060, Wolf Camp Hills, Hess Canyon quadrangle.

716n. Hess Formation (Taylor Ranch Member): 1.55 miles $S 14^{\circ} \mathrm{W}$ of Old Word Ranch, 0.2 mile $38^{\circ} \mathrm{W}$ of hill 5767, Hess Canyon quadrangle [ $=\mathrm{R}$. E. King 222].

7160. Hess Formation (Taylor Ranch Member): On front of mountain, 0.21 mile $S 52^{\circ} \mathrm{E}$ of hill 5767 , Hess Canyon quadrangle (Plate 9: figure 1).

716p. Skinner Ranch Formation (Decie Ranch Member equivalent): 1.52 miles $S 77^{\circ} \mathrm{E}$ of Willis Ranch, 0.87 mile $\mathrm{N} 69^{\circ} \mathrm{W}$ of hill 5816, Hess Ranch Horst, Hess Canyon quadrangle.

716q. Skinner Ranch Formation: 1.6 miles $\mathrm{S} 76^{\circ} \mathrm{E}$ of Willis Ranch, 0.80 mile $\mathrm{N} 70^{\circ} \mathrm{W}$ of hill 5816, Hess Ranch Horst, Hess Canyon quadrangle.

716r. Lenox Hills Formation (upper): 0.5 mile $\mathrm{N} 43^{\circ} \mathrm{E}$ of

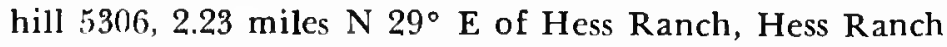
Horst, Hess Canyon quadrangle $[=R$. E. King 196].

716t. Skinner Ranch Formation (lower): 1.35 miles $S 59^{\circ}$ E of Willis Ranch, Hess Ranch Horst, Hess Canyon quadrangle.

716u. Lenox Hills Formation (topmost): 1.6 miles $S 66^{\circ} \mathrm{E}$ of Willis Ranch, 0.85 mile due $W$ of hill 5816 , Hess Ranch Horst, Hess Canyon quadrangle.

$716 \mathrm{v}$. Word Formation (Appel Ranch Member): 0.5 mile $\mathrm{N}$ $85^{\circ} \mathrm{W}$ of hill $5575,1.43$ miles $\mathrm{N} 35^{\circ} \mathrm{W}$ of Old Word Ranch, Hess Canyon quadrangle.

716w. Road Canyon Formation: 1.95 miles $\mathrm{N} 99^{\circ} \mathrm{W}$ of Hess Ranch house, Hess Canyon quadrangle. 
716x. Road Canyon Formation: 1.5 miles $\mathrm{N} \mathrm{20^{ \circ }} \mathrm{W}$ of Hess Ranch, 1.03 miles $\mathrm{N} 63^{\circ} \mathrm{E}$ of hill 5801, Hess Canyon quadrangle.

716xa. Road Canyon Formation: Yellowish sandy limestone [=USNM 716x].

$716 y$. Neal Ranch Formation: Very top of northeasternmost knob, 1.05 miles $S 41^{\circ} \mathrm{W}$ of Hess Ranch house, Hess Canyon quadrangle.

716z. [=USNM 709c.]

717a. Skinner Ranch Formation (Sullivan Peak Member): S end of Lenox Hills, E of hill 4801, Monument Spring quadrangle.

717b. Road Canyon Formation: Coscinophora bed, 0.33 mile S $17^{\circ} \mathrm{W}$ of Sullivan (Yates) Ranch house, Altuda quadrangle.

717c. Lenox Hills Formation: 0.48 mile $\mathrm{N} 18^{\circ} \mathrm{W}$ of Hess Ranch house, Hess Canyon quadrangle.

717e. Cathedral Mountain Formation (Wedin Member): 2.1 miles $\mathrm{N} 28^{\circ} \mathrm{E}$ of Lenox, 0.93 mile $\mathrm{S} 74^{\circ} \mathrm{W}$ of hill 5300 , Altuda quadrangle.

$717 \mathrm{~g}$. Cathedral Mountain Formation: Base of Clay Slide, 0.45 mile due $S$ of hill 4910 , Altuda quadrangle [=approximately R. E. King 5]

717i. Skinner Ranch Formation (Decie Ranch Member equivalent): 4750 feet elevation near base of $W$ end of Leonard Mountain, 0.85 mile N $4^{\circ} \mathrm{E}$ of Skinner Ranch, E edge of Altuda quadrangle.

717v. Skinner Ranch Formation: Saddle 0.6 mile S $79^{\circ} \mathrm{W}$ of hill 5021, Altuda quadrangle.

717q. [=USNM 710w.] 718d. Word Formation (Willis Ranch Member): $S$ side of Road Canyon, 1.5 miles $W$ of its $E$ entrance, Hess Canyon quadrangle.

718e. Neal Ranch Formation (beds 5-8 of P. B. King): Slope opposite canyon bed, 0.2 mile up from Geologists Canyon mouth, about 0.7 mile $\mathrm{S} 80^{\circ} \mathrm{W}$ of hill 5060, Wolf Camp Hills, Hess Canyon quadrangle.

718k. Road Canyon Formation: 1.32 miles $\mathrm{S} 55^{\circ} \mathrm{E}$ of Sullivan Peak, Altuda quadrangle.

718-1. Road Canyon Formation: 40 fect below top of plateau, 0.9 mile S $25^{\circ} \mathrm{E}$ of Sullivan Peak, Altuda quadrangle.

718n. Lenox Hills Formation: 1.28 miles $\mathrm{N} 77^{\circ} \mathrm{E}$ of hill $5300, \mathrm{~N}$ of Decie Ranch, Altuda quadrangle.

7180. Lenox Hills Formation: 1.15 miles $\mathrm{N} 75^{\circ} \mathbf{E}$ of hill $5300, N$ of Decie Ranch, Altuda quadrangle.

7I8p. Lenox Hills Formation: 1.66 miles $\mathrm{N} 57^{\circ} \mathrm{E}$ of Lenox, Monument Spring quadrangle.

718q. Neal Ranch Formation: 40-45 feet below "Hess" [=Lenox Hills] conglomerate on $W$ side of Geologists Canyon, 0.65 mile $\mathrm{N} 76^{\circ} \mathrm{W}$ of hill 5060, Wolf Camp Hills, Hess Canyon quadrangle.

718y. Lenox Hills Formation: Saddle just $S$ of 2 knobs about on 5150-foot contour, NE end of Leonard Mountain, 0.72 mile $\mathrm{N} 34^{\circ} \mathrm{E}$ of bench mark 5860, Hess Canyon quadrangle.

718z. Skinner Ranch Formation (Sullivan Peak Member): 1.1 miles $\mathrm{N} 20^{\circ} \mathrm{E}$ of Lenox, Altuda quadrangle.

719. Hueco Formation: Three Mile Mountain, 2.3 miles $\mathrm{N}$ $45^{\circ}$ W of Van Horn, Van Horn quadrangle.

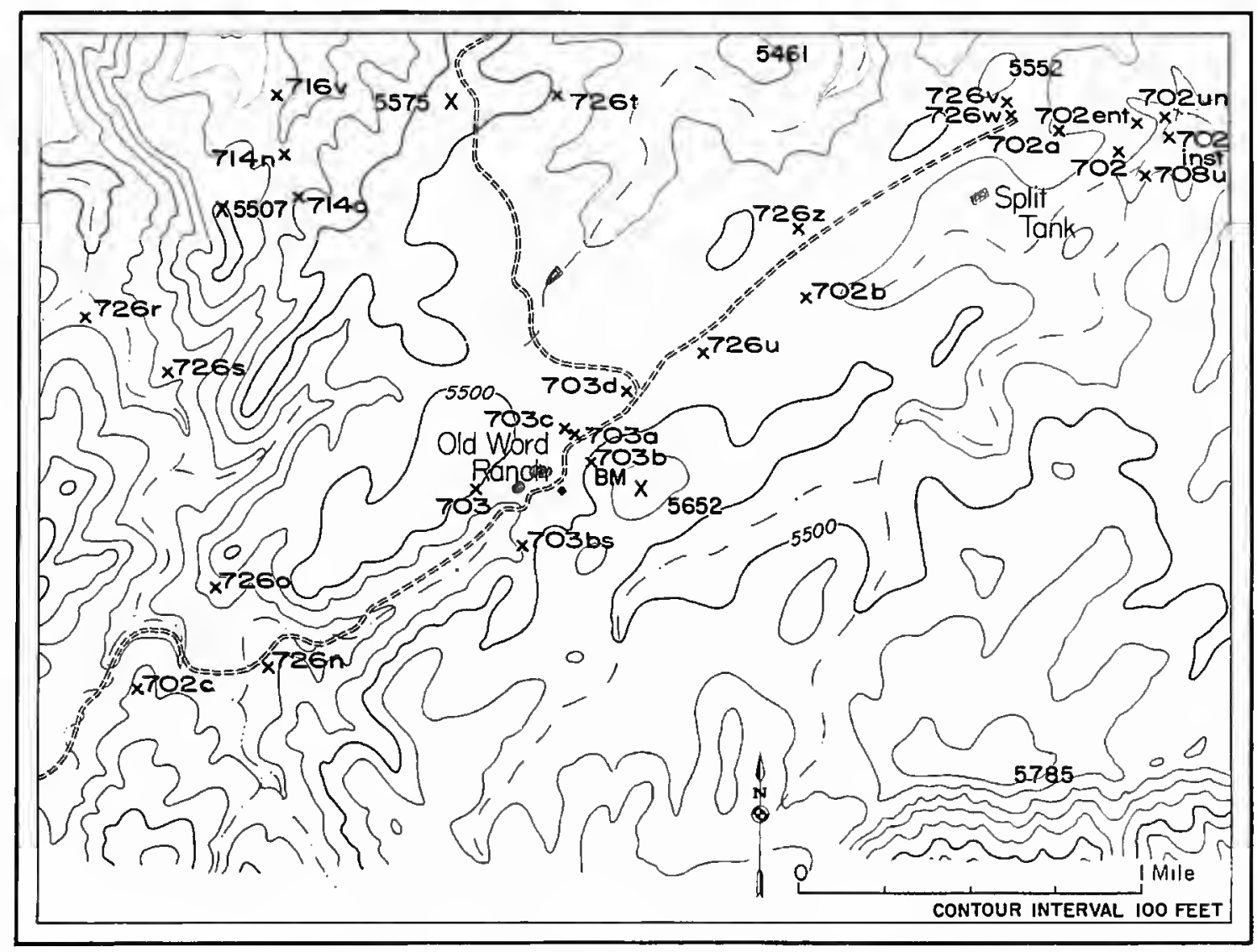

Figure 38.-Localities in the Old Word Ranch area. 
719a. Neal Ranch Formation: About 5150 to 5300 feet in gully at $S$ base of hill $5816,0.35$ mile $S 21^{\circ} \mathbf{E}$ of hill 5816, Hess Ranch Horst. Hess Canyon quadrangle.

$719 \mathrm{e}$. Word Formation (shale above Willis Ranch Member): Slope of hill near base, 4.12 miles $\mathrm{N} 32.5^{\circ} \mathrm{E}$ of Hess Ranch house, 2.17 miles $\mathrm{N} 80^{\circ} \mathrm{W}$ of Old Word Ranch, Hess Canyon quadrangle.

719q. Hess Formation (?): Float found on top of Neal Ranch Formation just below Hess [=Lenox Hills conglomerate] just west of the canyon about 0.2 mile NW of elbow, about 0.62 mile $\mathrm{N} 73^{\circ} \mathrm{W}$ of hill 5060 , Wolf Camp Hills, Hess Canyon quadrangle.

719r. Lenox Hills Formation: On E slope of hill below knob, 1.05 miles $S 50^{\circ} \mathrm{W}$ of Hess Ranch house, Hess Canyon quadrangle.

719s. Skinner Ranch Formation (Decie Ranch Member): 2-3 miles $S$ of Lenox, Monument Spring quadrangle.

719w. Road Canyon Formation (lower): 1.28 miles $\mathrm{N} 32^{\circ}$ W of Hess Ranch, 0.28 mile $S 83^{\circ} \mathrm{E}$ of hill 5453 , Hess Canyon quadrangle.

719x. Road Canyon Formation (lower): 1.42 miles $\mathrm{N} 19^{\circ}$ W of Hess Ranch house, 0.55 mile $\mathrm{N} 65^{\circ} \mathrm{E}$ of hill 5453 , Hess Canyon quadrangle.

719y. Skinner Ranch Formation (base): Ravine 2.2 miles

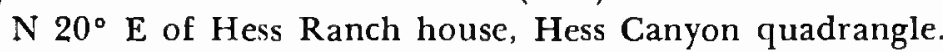

719z. Word Formation (Appel Ranch Member): 0.29 mile $\mathrm{S} 16^{\circ} \mathrm{W}$ of hill $5543,4.13$ miles $\mathrm{N} 28^{\circ} \mathrm{E}$ of Hess Ranch, Hess Canyon quadrangle.

720a. [ = USNM 719.]

720b. Hueco Formation: W base of Franklin Mountains, 5 miles E of White Spur, Canutillo (15') quadrangle.

720c. Hueco Formation (near base): $W$ base of Franklin Mountains, 5 miles E of White Spur, Canutillo (15') quadrangle.

720d. Road Canyon Formation (top): Lens 25 feet above top of Road Canyon limestone, 1.16 miles $\mathrm{S} 31^{\circ} \mathrm{E}$ of bench mark $4973,0.6$ mile $\mathrm{N} 82^{\circ} \mathrm{W}$ of hill 5779 , Altuda quadrangle.

720e. Skinner Ranch Formation (lower): Scacchinella zone, 0.83 mile $\mathrm{N} 67^{\circ} \mathrm{W}$ of hill $5816,1.57$ miles $\mathrm{S} 47^{\circ} \mathrm{E}$ of Willis Ranch, on NW side of Hess Ranch Horst, Hess Canyon quadrangle (Plate 19: figure 4).

720f. Skinner Ranch Formation (lower): 1.45 miles $\mathrm{S} 84^{\circ}$ W of hill 5816, W side of Hess Ranch Horst, Hess Canyon quadrangle.

720g. Skinner Ranch Formation (lower): At break in slope 1.35 miles $S 83^{\circ} \mathrm{W}$ of hill 5816, 0.34 mile $\mathrm{N} 30^{\circ} \mathrm{W}$ of hill 5305, N side of Hess Ranch Horst, Hess Canyon quadrangle.

720j. Skinner Ranch Formation: 0.65 mile $\mathrm{N}$ of Hess Ranch house, Hess Canyon quadrangle.

721 . Neal Ranch Formation (Upper): Base of small hill at $\mathrm{W}$ end of Wolf Camp Hills, 1.45 miles $S 77.5^{\circ} \mathrm{W}$ of hill 5060, 1.76 miles $S 14^{\circ} \mathrm{W}$ of hill 5821, Hess Canyon quadrangle fbiohermal beds containing abundance of striatifera].

721i. Gaptank Formation (Uddenites-bearing Shale Mcmber): 0.2 to 0.3 mile NE of hill 5060, NE end of Wolf Camp Hills, Hess Canyon quadrangle. 721j. Road Canyon Formation (about 25 feet below top): 1.45 miles $\mathrm{N} 19^{\circ} \mathrm{W}$ of Hess Ranch, 1.3 miles due $\mathrm{S}$ of Willis Ranch, Hess Canyon quadrangle.

721k. Neal Ranch Formation (base of bed $2=$ Gray limestone of P. B. King): West side Uddenites knob, W side of Wolf Camp Hills, 0.8 mile S $62^{\circ} \mathrm{W}$ of hill 5060, Hess Canyon quadrangle.

721-1. Gaptank Formation (Uddenites-bearing Shale Member): Kings section 27, bed 13, slope of hill 4732, 350 feet $\mathrm{S} 32^{\circ} \mathrm{E}$ of top, Montgomery (Conoly Brooks) Ranch, Hess Canyon quadrangle $[=$ R. E. King 95].

$721 \mathrm{~m}$. Gaptank Formation (Uddenites-bearing Shale Member): Loose on $W$ side of hill 5060, Wolf Camp Hills, Hess Canyon quadrangle.

7210. Road Canyon Formation (lower): 1.45 miles $N 19^{\circ}$ W of Hess Ranch house, 1.3 miles due $S$ of Willis Ranch, Hess Canyon quadrangle.

$721 \mathrm{p}$. Word Formation (China Tank Member): Main ridge extending into Hess Canyon, $\mathrm{N}$ from hill 5611 for 0.5 mile $\mathrm{W}$ of $103^{\circ} 10^{\prime}$ line on Hess Canyon quadrangle.

721 . Road Canyon Formation: At 5200 feet elevation, 1.83 miles $\mathrm{N} 83^{\circ} \mathrm{W}$ of Hess Ranch house, Hess Canyon quadrangle (Plate 17: figure 3).

721 r. Road Canyon Formation: 1.72 miles $\mathrm{N} 82^{\circ} \mathrm{W}$ of Hess Ranch house, 0.35 mile S $53^{\circ} \mathrm{E}$ of hill 5674, Hess Canyon quadrangle.

721s. Road Canyon Formation: 1.72 miles $\mathrm{N} 11.5^{\circ} \mathrm{W}$ of Hess Ranch house, 0.98 mile $\mathrm{S} 6^{\circ} \mathrm{E}$ of Willis Ranch, Hess Canyon quadrangle.

721 t. Road Canyon Formation: 1.8 miles $\mathrm{N} 10.5^{\circ} \mathrm{W}$ of Hess Ranch house, 0.93 mile $\mathrm{S} 7^{\circ} \mathrm{E}$ of Willis Ranch, Hess Canyon quadrangle.

721 u. Cathedral Mountain Formation (lower): 0.57 mile $\mathrm{N}$ $80^{\circ} \mathrm{E}$ of hill $4910,1.08$ miles $\mathrm{N} 55^{\circ} \mathrm{W}$ of hill 5280 , Altuda quadrangle.

721v. Cathedral Mountain Formation: 2 miles S $72^{\circ} \mathrm{E}$ of Sullivan Peak, Altuda quadrangle.

721 w. Road Canyon Formation: 1.33 miles $S 55^{\circ} \mathrm{E}$ of Sullivan Peak, Altuda quadrangle.

721x. Road Canyon Formation: 1.15 miles $S 26^{\circ} \mathrm{E}$ of bench mark 4973 in Gilliland Canyon, Altuda quadrangle.

721 y. Road Canyon Formation: 1.2 miles S $25^{\circ} \mathrm{E}$ of bench mark 4973, 0.65 mile due $W$ of hill 5779, Gilliland Canyon, Altuda quadrangle.

721z. Road Canyon Formation: 0.95 mile S $28^{\circ} \mathrm{E}$ of bench mark 4973, 0.78 mile $N 71^{\circ}$ W of hill 5779 , Gilliland Canyon, Altuda quadrangle.

722a. Phosphoria Formation: Muddy thin layer about 100 feet above road, in cherty limestone above road cut at upper end of Torrey Lake, Dubois, Wyoming.

722b. Phosphoria Formation: Cherty limestone above road cut at upper end of Torrey Lake, Dubois, Wyoming.

722c. [ = USNM 762.]

722d. Phosphoria Formation: E side of Long Valley, Nevada.

722c. Road Canyon Formation: 0.99 mile $S 26^{\circ} \mathrm{E}$ of bench mark 4973, 0.75 mile $\mathrm{N} 76^{\circ} \mathrm{W}$ of hill 5779 , Gilliland Canyon, Altuda quadrangle.

722f. Road Canyon Formation: 1.43 miles $\mathrm{S} 74^{\circ} \mathrm{W}$ of hill $4910,1.3$ miles $N 9^{\circ} \mathbf{E}$ of hill 4920, Altuda quadrangle. 


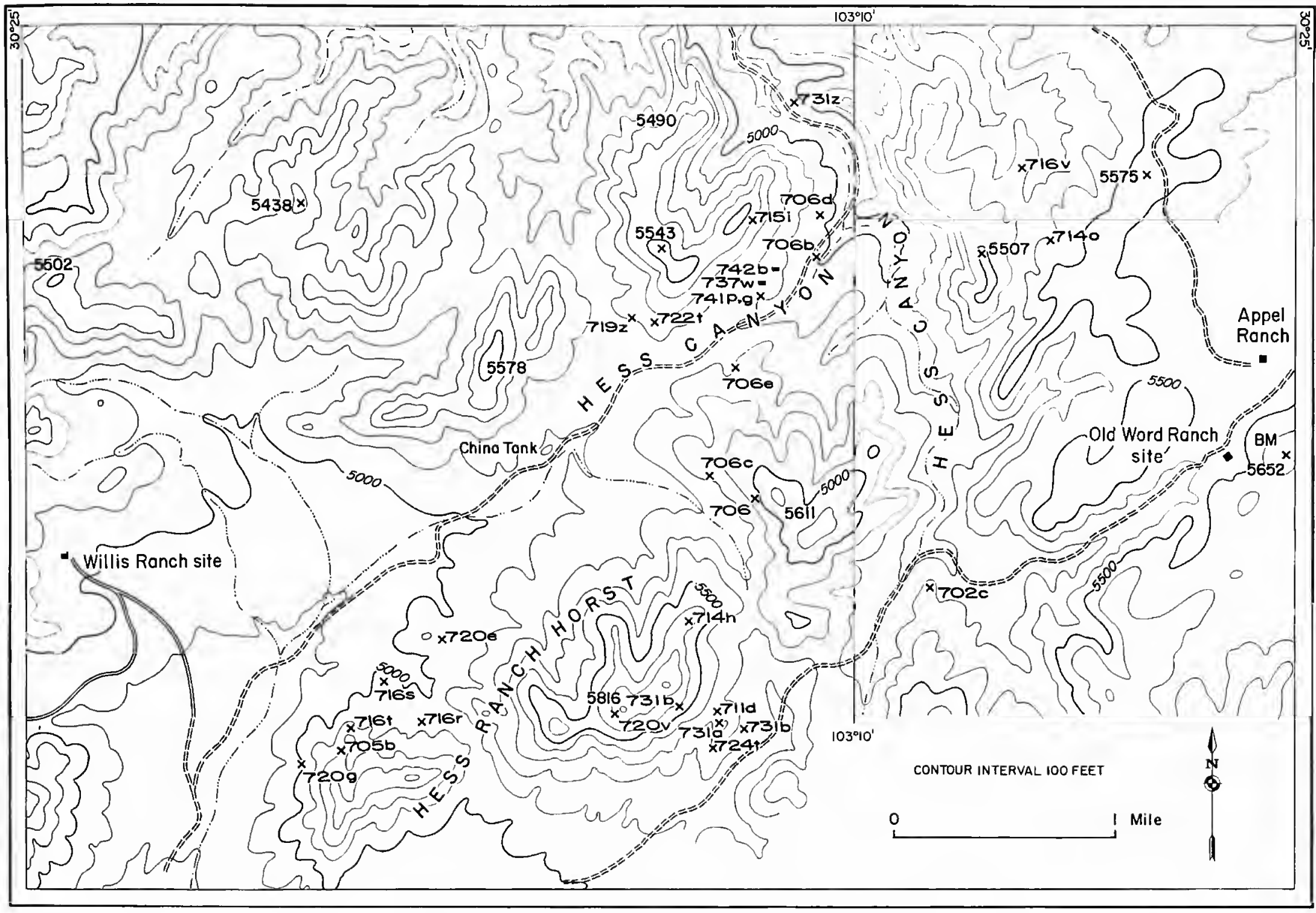

Figure 39.-Localities in Hess Ranch Horst area.

722g. Road Canyon Formation: 1.43 miles $S 74^{\circ} \mathrm{W}$ of hill $4910,1.3$ miles $\mathbf{N} 9^{\circ} \mathbf{E}$ of hill 4920 , Altuda quadrangle.

722h. Skinner Ranch Formation (Sullivan Peak Member): 1.05 miles $S 28^{\circ} \mathrm{E}$ of hill $4920,2.9$ miles $\mathrm{S} 28^{\circ} \mathrm{E}$ of Sullivan Peak, on $S$ side of knob of spur on $W$ side of road to Sullivan (Yates) Ranch, Altuda quadrangle.

722j. Skinner Ranch Formation (Sullivan Peak Member): 1.93 miles $\mathrm{S} 12^{\circ} \mathrm{E}$ of Old Payne Ranch, 1.2 miles $\mathrm{S} 62^{\circ}$ W of hill 5195, W side of Dugout Mountain, Monument Spring quadrangle.

722-1. Skinner Ranch Formation (Sullivan Peak Member): Beds with Spyridiophora 1.73 miles $S 1.5^{\circ} \mathrm{E}$ of Old Payne Ranch, 1.47 miles S $75^{\circ} \mathrm{W}$ of hill 5195 (Dugout Mountain) on W flank of Dugout Mountain, Monument Spring quadrangle (Plate 6: figure 2).

$722 \mathrm{~m}$. Skinner Ranch Formation (top): 0.88 mile S $4^{\circ} \mathbf{E}$ of hill $4920,1.6$ miles $S 71^{\circ} \mathrm{W}$ of hill 5021, Altuda quadrangle.

$722 \mathrm{n}$. Skinner Ranch Formation: 0.4 mile $\mathrm{S} 38^{\circ} \mathrm{W}$ of hill $5021,1.5$ miles S $64^{\circ} \mathrm{E}$ of hill 4920 , Altuda quadrangle.

722o. Skinner Ranch Formation (top): Southwestern knob of hill 5021, 0.33 mile $S 51^{\circ} \mathrm{W}$ of hill 5021, Altuda quadrangle.
$722 \mathrm{p}$. Hess Formation: 1.5 miles $\mathrm{S} 5^{\circ} \mathrm{W}$ of Old Word Ranch, 0.2 mile $S 39^{\circ} \mathrm{E}$ of hill 5767, Hess Canyon quadrangle [=approximately USNM 7160].

722t. Word Formation (Appel Ranch Member): 2.38 miles $\mathrm{N} 76^{\circ} \mathrm{W}$ of Old Word Ranch, 4.18 miles $\mathrm{N} 29^{\circ} \mathrm{E}$ of Hess Ranch, Hess Canyon quadrangle.

722v. Road Canyon Formation (Word lithology): Lens with Compressoproductus about 25 feet above limestone of Road Canyon, 1.15 miles $S 30^{\circ}$ E of bench mark 4973 , Gilliland Canyon, 0.6 mile $\mathrm{N} 82^{\circ} \mathrm{W}$ of hill 5779, Altuda quadrangle. [This is approximately the same level as USNM 720d.]

722w. Neal Ranch Formation (beds $9-12$ of Cooper): W side of Wolf Camp Hills, just $\mathbf{N}$ of the Uddenites saddle, 0.78 mile S $73^{\circ} \mathrm{W}$ of hill 5060 , Hess Canyon quadrangle.

722x. Neal Ranch Formation (top of bed 2 of P. B. King $=$ Gray Limestone Member): Small reefy patch of Eolyttonia encrusted by algae, on $\mathrm{W}$ side of small ravine on $\mathrm{S}$ side of Geologists Canyon, 0.4 mile above entrance and 0.53 mile due $W$ of hill 5060, Wolf Camp Hills, Hess Canyon quadrangle. [This patch lies on the flank of the Gray Limestone near the point where it plunges under the main canyon.] 
722z. Skinner Ranch Formation (Poplar Tank Member): 50 feet above top of Decie Ranch Member in same locality as USNM 7050.

723a. Road Canyon Formation: 1.48 miles $\mathrm{N} 19^{\circ} \mathrm{W}$ of Hess Ranch, 0.55 miles $\mathrm{N} 57^{\circ} \mathrm{E}$ of hill 5453, Hess Canyon quadrangle.

723d. Lenox Hills Formation: 60 feet above conglomerate, 5-7 feet above goniatite bed, 0.48 mile $\mathrm{S} 22^{\circ} \mathrm{E}$ of hill 5300 , about 4700 feet elevation, and 1.5 miles $\mathrm{N} 63^{\circ} \mathrm{W}$ of Poplar Tank, Altuda quadrangle.

723h. Skinner Ranch Formation (top): Top of hill 0.5 mile $\mathrm{N} 7^{\circ} \mathrm{E}$ of hill $5280,1.63$ miles due $\mathrm{E}$ of hill 4910 , on $\mathrm{W}$ brink of a ravine, first hill (5280) $W$ of Iron Mountain, Altuda quadrangle [ $=$ R. E. King 3].

723j. Skinner Ranch Formation: 0.2 mile $S 5^{\circ} \mathrm{E}$ of hill $4920,1.55$ miles $N 79^{\circ} \mathrm{W}$ of hill 5021, Altuda quad. rangle.

723k. Cathedral Mountain Formation (Base): 1.25 miles S $7^{\circ} \mathrm{W}$ of hill $4910,1.75$ miles $\mathrm{S} 66^{\circ} \mathrm{W}$ of hill 5280 , Altuda quadrangle.

723-1. Skinner Ranch Formation (top): 1.32 miles S $5^{\circ}$ W of hill $4910,1.8$ miles $S 61^{\circ} \mathrm{W}$ of hill 5280 , Altuda quadrangle.

723n. Cathedral Mountain Formation: 1.13 miles S $15^{\circ} \mathrm{E}$ of hill $4910,1.28$ miles $S 66^{\circ} \mathrm{W}$ of hill 5280, Altuda quadrangle.

723o. Skinner Ranch Formation: 1.12 miles $S 40^{\circ} \mathrm{E}$ of hill $4910,0.85$ mile $S 64^{\circ} \mathrm{W}$ of hill 5280 , Altuda quadrangle.

723 p. Cathedral Mountain Formation: 0.55 mile S $10^{\circ} \mathrm{W}$ of hill 4910, 1.55 miles $\mathrm{N} 88^{\circ} \mathrm{W}$ of hill 5280, Altuda quadrangle.

723q. Skinner Ranch Formation: 1 mile S 32 $\mathrm{E}$ of hill 4910,1 mile $S 71^{\circ} \mathrm{W}$ of hill 5280, Altuda quadrangle.

723r. Lenox Hills Formation: 1.45 miles $S 56^{\circ} \mathrm{E}$ of hill $4910,0.4$ mile $S 46^{\circ} \mathrm{W}$ of hill 5280 , Altuda quadrangle.

723s. Skinner Ranch Formation: 1.55 miles S $65^{\circ} \mathrm{E}$ of hill $4910,0.15$ mile $S 24^{\circ} \mathrm{W}$ of hill 5280 , Altuda quadrangle.

723t. Word Formation (Willis Ranch Member): 0.35 mile $\mathrm{S}$ $30^{\circ} \mathrm{E}$ of hill $5939,2.75$ miles $\mathrm{S} 70^{\circ} \mathrm{W}$ of hill 5779 , Gilliland Canyon, Altuda quadrangle.

723u. Cathedral Mountain Formation: 0.85 miles S $70^{\circ} \mathrm{E}$ of hill $5300,2.15$ miles $\mathrm{N} 31^{\circ} \mathrm{E}$ of Lenox, Altuda quadrangle.

723v. Cathedral Mountain (Wedin Member): 1.25 miles $\mathrm{N}$ $21^{\circ} \mathrm{E}$ of Lenox, 1.73 miles $\mathrm{S} 56^{\circ} \mathrm{W}$ of hill 5300 , Altuda quadrangle.

723w. Word Formation (Willis Ranch Member): 0.68 miles $\mathrm{N} 48^{\circ} \mathrm{W}$ of bench mark 4973, 1.86 miles $\mathrm{S} 77^{\circ} \mathrm{W}$ of hill 5615, Gilliland Canyon, Altuda quadrangle.

723x. Road Canyon Formation: 1.13 miles S $24^{\circ} \mathrm{E}$ of bench mark 4973, 0.77 mile $\mathrm{N} 87^{\circ} \mathrm{W}$ of hill 5779 , Gilliland Canyon, Altuda quadrangle.

$723 y$. Cathedral Mountain Formation: 0.5 mile $\mathrm{S} 30^{\circ} \mathrm{E}$ of hill $4910,1.2$ miles $\mathrm{N} 86^{\circ} \mathrm{W}$ of hill 5280 , Altuda quadrangle.

724a. Road Canyon Formation: 0.25 mile $\mathrm{N} 56^{\circ} \mathrm{W}$ of hill $4910,1.7$ miles $\mathrm{N} 77^{\circ} \mathrm{W}$ of hill 5280 , Altuda quadrangle.

724b. Road Canyon Formation: 1.13 miles $\mathrm{N} 11^{\circ} \mathrm{E}$ of hill $4910,2.2$ miles $\mathrm{N} 34^{\circ} \mathrm{W}$ of hill 5280 , Altuda quadrangle. 724c. Road Canyon Formation: 0.83 mile S $26^{\circ}$ E of bench mark 4973, 0.88 mile $\mathrm{N} 67^{\circ} \mathrm{W}$ of hill 5779, Gilliland Canyon, Altuda quadrangle.

724d. Road Canyon Formation (top): 1.55 miles $\mathrm{N} 38^{\circ} \mathrm{E}$ of bench mark $4973,0.25$ mile $S 62^{\circ} \mathrm{W}$ of hill 5779 , Gilliland Canyon, Altuda quadrangle.

724e. Road Canyon Formation: 1.55 miles S $38^{\circ} \mathrm{E}$ of bench mark 4973, 0.25 mile S $62^{\circ} \mathrm{W}$ of hill 5779, Gilliland Canyon, Altuda quadrangle.

721f. Word Formation (Willis Ranch Member): 1.95 miles S $40^{\circ} \mathrm{W}$ of bench mark $4973,2.45$ miles S $82^{\circ} \mathrm{W}$ of hill 5779, Gilliland Canyon, Altuda quadrangle.

724 g. Word Formation (Wills Ranch Member): Knob 0.55 mile $\mathrm{S} 51^{\circ} \mathrm{W}$ of bench mark $4973,1.73$ miles $\mathrm{N} 65^{\circ} \mathrm{W}$ of hill 5779, Gilliland Canyon, Altuda quadrangle.

724h. Road Canyon Formation: Bed $\mathrm{H}, 2.05$ miles $\mathrm{S} 50^{\circ}$ E of bench mark $4973,0.45$ mile $S 61^{\circ} \mathrm{E}$ of hill 5779 , Gilliland Canyon, Altuda quadrangle.

724i. Cathedral Mountain Formation. 2.1 miles S $37^{\circ} \mathrm{E}$ of bench mark $4973,0.58$ miles $\mathrm{S} 9^{\circ} \mathrm{E}$ of hill 5779 , Gilliland Canyon, Altuda quadrangle.

724j. Road Canyon Formation: Blocks from a loose piece from large, lower bioherm, 2.05 miles $\mathrm{S} 50^{\circ} \mathrm{E}$ of bench mark 4973, 0.45 mile $S 61^{\circ} \mathrm{E}$ of hill 5779, Gilliland Canyon, Altuda quadrangle (Plate 16: figure 4).

$724 \mathrm{k}$. Cathedral Mountain Formation: 1.23 miles $\mathrm{S} 33^{\circ} \mathrm{W}$ of hill 5801, 2.06 miles S $87^{\circ} \mathrm{W}$ of Hess Ranch, Hess Canyon quadrangle.

724-1. Skinner Ranch Formation: 1.02 miles $\mathrm{N} 71^{\circ} \mathrm{W}$ of bench mark 5860, 2.38 miles $\mathrm{S} 60^{\circ} \mathrm{W}$ of Hess Ranch, $\mathrm{S}$ side of Leonard Mountain, Hess Canyon quadrangle.

$724 \mathrm{~m}$. Cathedral Mountain Formation (base): Thin beds with Institella from $W$ knob on Leonard Mountain, 0.23 mile $\mathrm{N} 64^{\circ} \mathrm{W}$ of bench mark 5860, Leonard Mountain, Hess Canyon quadrangle (Plate 2: figure 1).

724n. Cathedral Mountain Formation (base): Thick bedded limestone above lowest shale, $W$ knob on Leonard Mountain, 0.23 mile $\mathrm{N} 64^{\circ} \mathrm{W}$ of bench mark 5860, Hess Canyon quadrangle.

7240. Lenox Hills Formation: 1 mile $\mathrm{N} 85^{\circ} \mathrm{W}$ of bench mark 5860, 2.53 miles $S 55^{\circ} \mathrm{W}$ of Hess Ranch house, Hess Canyon quadrangle.

724p. Skinner Ranch Formation: 1.0 mile $\mathrm{N} 85^{\circ} \mathrm{W}$ of bench mark $5860,2.55$ miles $\mathrm{S} 55^{\circ} \mathrm{W}$ of Hess Ranch, Hess Canyon quadrangle.

724q. Skinner Ranch Formation: 0.9 mile $\mathrm{N} 84^{\circ} \mathrm{W}$ of bench mark $5860,2.45$ miles $S 54^{\circ} \mathrm{W}$ of Hess Ranch, on Leonard Mountain, Hess Canyon quadrangle.

724r. Cathedral Mountain Formation: 0.42 mile S $32^{\circ} \mathrm{E}$ of hill 5816, 2.7 miles N $52^{\circ} \mathrm{E}$ of Hess Ranch, Hess Canyon quadrangle.

724s. Cathedral Mountain Formation (lower): 0.7 mile S $35^{\circ}$ E of hill 5816, 2.7 miles $\mathrm{N} 58^{\circ} \mathrm{E}$ of Hess Ranch, Hess Canyon quadrangle.

724t. Cathedral Mountain Formation (lower): SW end of narrow conical hill, 0.4 miles $S 67^{\circ} \mathrm{E}$ of hill 5816, 2.95 miles $\mathrm{N} 51^{\circ} \mathrm{E}$ of Hess Ranch, Hess Canyon quadrangle. 
724u. Word Formation (Willis Ranch Member):r In Road Canyon 0.95 mile $S 39^{\circ} \mathrm{W}$ of Willis Ranch, 0.46 mile $\mathrm{S}$ $37^{\circ} \mathrm{E}$ of hill 5803, Hess Canyon quadrangle (Plate 14: figure 1).

724v. Lenox Hills Formation: 0.65 mile $\mathrm{N} 19^{\circ} \mathrm{E}$ of Hess Ranch, 1.63 miles $\mathrm{S} 83^{\circ} \mathrm{W}$ of hill 5726, Hess Canyon quadrangle.

724w. Lenox Hills Formation: 0.7 mile $\mathrm{N} 36^{\circ} \mathrm{E}$ of Hess Ranch, 1.35 miles $\mathrm{S} 83^{\circ} \mathrm{W}$ of hill 5726, Hess Canyon quadrangle.

724x. Lenox Hills Formation: 0.75 mile $\mathrm{N} 28^{\circ} \mathrm{E}$ of Hess Ranch, 1.47 miles $\mathrm{S} 85^{\circ} \mathrm{W}$ of hill 5726 , Hess Canyon quadrangle.

724y. Word Formation: Top of knob, 1.7 miles S $11^{\circ} \mathrm{W}$ of Willis Ranch, 0.95 mile $\mathrm{N} 53^{\circ} \mathrm{E}$ of hill 5801, S of Road Canyon, Hess Canyon quadrangle.

724z. Word Formation: At 5200 feet elevation on knob 1.24 miles $\mathrm{S} 10^{\circ} \mathrm{W}$ of Willis Ranch, 0.95 mile $\mathrm{N} 56^{\circ} \mathrm{E}$ of hill 5801 , Hess Canyon quadrangle.

725a. Hueco Formation: W side of hill 4970, 0.25 mile $\mathrm{N}$ of divide in Red Tank Canyon, on Nutt Ranch, 2.1 miles $\mathrm{N} 85.5^{\circ} \mathrm{E}$ of bench mark 4290, Van Horn quadrangle.

725b. Hueco Formation: W side hill with bench mark 4970, 0.25 mile $\mathrm{N}$ of divide in Red Tank Canyon on Nutt Ranch, 2 miles $\mathrm{N} 79^{\circ} \mathrm{E}$ of bench mark 4920, Van Horn quadrangle.

725c. Bone Spring Formation: 130 feet above Hueco limestone on $\mathrm{E}$ side of hill 4402, $\mathrm{N}$ end of Baylor Mountains, $W$ side of Texas Highway 54, 0.6 mile $S 22^{\circ} \mathrm{W}$ of bench mark 3806, Van Horn quadrangle.

725e. Bell Canyon Formation (Lamar Member): 1.7 miles $\mathrm{N} 63^{\circ} \mathrm{E}$ of Hegler (Ligon) Ranch on $\mathrm{N}$ side of $\mathrm{U} . \mathrm{S}$. Highway 62-180, 0.25 mile $N$ of intersection with road to D-Ranch Headquarters (United States Geological Survey Professional Paper 215, plate 3, Culberson County).

725f. Bell Canyon Formation (Rader Member): 0.4 mile $\mathrm{S}$ $62^{\circ} \mathrm{W}$ of Hegler (Ligon) Ranch, on Rader Ridge, Guadalupe Peak quadrangle (Plate 23: figure 4).

725g. Bell Canyon Formation (Rader Member): 0.55 mile due $W$ of Hegler (Ligon) Ranch, Guadalupe Peak quadrangle.

725h. Bell Canyon Formation (Pinery Member): 0.452 miles $S 2^{\circ} \mathrm{W}$ of Hegler (Ligon) Ranch on Rader Ridge, Guadalupe Peak quadrangle.

725i. Lower Capitan Limestone Formation (=Upper Pinery): Smith Canyon, NE of Pine Spring Camp, Guadalupe Peak quadrangle.

725j. Capitan Limestone: Smith Canyon, Guadalupe Peak quadrangle.

725k. Capitan Limestone Formation: From 1 piece of limestone, 500 feet below head of ravine in Pine Top Mountain, 1.75 miles $\mathrm{N} 18.5^{\circ} \mathrm{W}$ of Pine Spring Camp, Guadalupe Peak quadrangle.

725-1. Capitan Limestone Formation: Same as USNM $725 \mathrm{k}$ but from several pieces of rock.

725m. Capitan Limestone Formation: 1.9 miles $\mathrm{N} 20.5^{\circ} \mathrm{W}$ of Pine Spring Camp, head of ravine leading from Upper Pine Spring to Pine Top Mountain, Guadalupe Peak quadrangle. 72.5n. Bell Canyon Formation (Pinery Member): 0.32 mile $\mathrm{N} 62^{\circ} \mathrm{W}$ of Hegler (Ligon) Ranch, on Rader Ridge, Guadalupe Peak quadrangle.

7250. Bell Canyon Formation (Rader Member): Hill 5414, 0.3 mile $\mathrm{N} 44^{\circ} \mathrm{W}$ of Hegler (Ligon) Ranch, Guadalupe Peak quadrangle.

725p. Capitan Limestone Formation: El Capitan Peak, Guadalupe Peak quadrangle.

72.5s. Bone Spring Formation: Loose on E slope of hill 4402, W side of Texas Highway 54, N end of Baylor Hills, Van Horn quadrangle.

725v. Cibolo Formation (Spicule Beds of Udden): 15 feet vertically above beds of Wolfcamp age, $W$ end of Permian plate, at narrows of Cibolo Creek, Shafter quadrangle, Texas.

725y. Bone Spring Formation: Lens of crystalline limestone 100 feet above base of Bone Spring Formation on second knob $\mathrm{N}$ of mouth of Apache Canyon, $\mathrm{N}$ portal of Apache Canyon, Sicrra Diablo, Van Horn quadrangle.

725z. Hueco Canyon Formation: Just above Powwow Conglomerate between, and around, 2 knobs at 5000 feet clevation, $W$ end of ridge $N$ of $U$. S. Highway 62-180, W entrance to Powwow Canyon, 0.3 mile due $\mathbf{E}$ of elevation 4940, 0.9 mile $\mathrm{N} 20^{\circ} \mathrm{E}$ of Powwow Tank, 0.7 mile S $60^{\circ} \mathrm{E}$ of Dugout Tank, Helms West Well (71/2) quadrangle [=USNM $499 \mathrm{~b}$ ].

726c. Road Canyon Formation (beds with Perrinites): At about 4900 feet elevation, 1.37 miles $\mathrm{S} 4^{\circ} \mathrm{W}$ of Willis Ranch site, 0.98 mile $\mathrm{N} 68^{\circ} \mathrm{E}$ of hill 5801, Hess Canyon quadrangle (Plate 15: figure 2).

726d. Road Canyon Formation: At 4947 feet elevation, 1.37 miles S $4^{\circ} \mathrm{W}$ of Willis Ranch, 0.98 mile $\mathrm{N} 68^{\circ} \mathrm{E}$ of hill 5801 , Hess Canyon quadrangle.

726e. Road Canyon Formation: 1.25 miles S $4^{\circ} \mathrm{W}$ of Willis Ranch, 1.03 miles $\mathrm{N} 63^{\circ} \mathrm{E}$ of hill 5801 , Hess Canyon quadrangle.

726f. Road Canyon Formation (lower): 1.38 miles $\mathrm{N} 19^{\circ}$ $\mathrm{W}$ of Hess Ranch, 1.0 mile $\mathrm{N} 60^{\circ} \mathrm{E}$ of hill 5801 , Hess Canyon quadrangle.

726g. Skinner Ranch Formation: 1.65 miles $\mathrm{N} 55^{\circ} \mathrm{E}$ of Hess Ranch house, 1.28 miles S. $26^{\circ} \mathrm{W}$ of hill 5816 , Hess Canyon quadrangle.

726h. Skinner Ranch Formation: Top of hill, 300 feet $\mathrm{N}$ of hill 5305, W side of Hess Ranch Horst, Hess Canyon quadrangle.

726i. Lenox Hills Formation: S slope of hill 5305, 600 feet S $9^{\circ} \mathrm{W}$ of hilltop at 5305 feet, Hess Ranch Horst, Hess Ranch quadrangle.

726j. Skinner Ranch Formation: 1.37 miles $\mathrm{S} 52^{\circ} \mathrm{E}$ of Willis Ranch, 1.23 miles $S 21^{\circ} \mathrm{W}$ of hill 5816, Hess Ranch Horst, Hess Canyon quadrangle.

726k. Skinner Ranch Formation (lower): N slope of Hess Ranch Horst 1.57 miles $S 75^{\circ}$ E of Willis Ranch, 0.67 miles $\mathrm{N} 73^{\circ} \mathrm{W}$ of hill 5816, Hess Canyon quadrangle.

726-l. Skinner Ranch Formation: Just above saddle 0.25 mile $S 46^{\circ} \mathrm{W}$ of hill 5021, Altuda quadrangle.

726n. Hess Formation (upper): 1.33 miles $\mathrm{S} 7^{\circ} \mathrm{E}$ of hill $5507,1.0$ mile S $60^{\circ} \mathrm{W}$ of Old Word Ranch, Hess Canyon quadrangle $[=\mathrm{R}$. E. King 223]. 
726o. Cathedral Mountain Formation (upper): 1.08 miles $S 2^{\circ} \mathrm{E}$ of hill $5507,1.03$ miles $S 76^{\circ} \mathrm{W}$ of Old Word Ranch, Hess Canyon quadrangle (Plate 17: figure 1).

726q. Word Formation (China Tank Member: 1.l mile N $77^{\circ} \mathrm{W}$ of Old Word Ranch, 0.58 mile $S 3^{\circ} \mathrm{W}$ of hill 5507, Hess Canyon quadrangle.

726r. Word Formation (China Tank Member): 1.43 miles $\mathrm{N} 70^{\circ} \mathrm{W}$ of Old Word Ranch, 0.45 mile $S 44^{\circ} \mathrm{W}$ of hill 5507, Hess Canyon quadrangle.

726s. Word Formation (China Tank Member): 1.22 mile $\mathrm{N} 73^{\circ} \mathrm{W}$ of Old Word Ranch, 0.5 mile $\mathrm{S} 17^{\circ} \mathrm{W}$ of hill 5507, Hess Canyon quadrangle.

726t. Word Formation (Appel Ranch Member): 1.12 miles due $\mathrm{N}$ of Old Word Ranch, 1.06 miles $\mathrm{N} 73^{\circ} \mathrm{E}$ of hill 5507, Hess Canyon quadrangle.

726u. Cathedral Mountain Formation (upper): 1.35 miles $S$ $63^{\circ} \mathrm{E}$ of hill $5507,0.27$ mile $\mathrm{N} 50^{\circ} \mathrm{E}$ of Old Word Ranch site, Hess Canyon quadrangle.

726v. Cathedral Mountain Formation (upper): 1.75 miles $\mathrm{N} 49^{\circ} \mathrm{E}$ of Old Word Ranch, 0.075 mile $\mathrm{S} 73^{\circ} \mathrm{E}$ of hill 5552, Hess Canyon quadrangle.

726w. Cathedral Mountain Formation: 1.74 miles N. $51.5^{\circ}$ $\mathrm{E}$ of Old Word Ranch, 0.15 mile $\mathrm{S} 68^{\circ} \mathrm{E}$ of hill 5552 , Hess Canyon quadrangle.

726x. Cathedral Mountain Formation: 1.8 miles $\mathrm{N} 56^{\circ} \mathrm{E}$ of Old Word Ranch, 0.27 mile $\mathrm{S} 47^{\circ} \mathrm{E}$ of hill 5552, Hess Canyon quadrangle.

726y. Cathedral Mountain Formation: 2 miles $\mathrm{N} 55^{\circ} \mathrm{E}$ of Old Word Ranch, 0.35 mile $S 80^{\circ} \mathrm{E}$ of hill 5552, Hess Canyon quadrangle.

726z. Road Canyon Formation (lower): Biohermal facies 1.03 miles $\mathrm{N} 43^{\circ} \mathrm{E}$ of Old Word Ranch, 0.53 mile $S 20^{\circ}$ E of hill 5461, Hess Canyon quadrangle.

726za. Road Canyon Formation (lower): Interbiohermal beds at same locality as USNM $726 z$.

727a. Skinner Ranch Formation: 1.63 miles $\mathrm{S} 50^{\circ} \mathrm{E}$ of Old Payne Ranch, 0.37 mile N $31^{\circ} \mathrm{W}$ of hill 5195, Dugout Mountain.

727b. Skinner Ranch Formation: 1.8 miles $S 58^{\circ} \mathrm{E}$ of old Payne Ranch, 0.4 mile $\mathrm{N} 4^{\circ} \mathrm{E}$ of hill 5195, Dugout Mountain, Monument Spring quadrangle.

727c. Neal Ranch Formation (bed 2): 0.42 mile N. $88^{\circ} \mathrm{W}$ of hill 5060, 1.43 miles S. $19^{\circ} \mathrm{E}$ of hill 5821, Wolf Camp Hills, Hess Canyon quadrangle.

727d. Neal Ranch Formation (bed 4 of P. B. King): 0.33 mile $\mathrm{N} 74^{\circ} \mathrm{W}$ of hill $5060,1.43$ miles $\mathrm{S} 24^{\circ} \mathrm{E}$ of hill 5821, Wolf Camp Hills, Hess Canyon quadrangle.

727e. Neal Ranch Formation (bed 4 of P. B. King): 0.92 mile $S 69^{\circ} \mathrm{W}$ of hill $5060,1.7$ miles $\mathrm{S} 2^{\circ} \mathrm{E}$ of hill 5821 , Wolf Camp Hills, Hess Canyon quadrangle (Plate 5: figure 2).

727f. Skinner Ranch Formation (upper): Small isolated knob 0.80 mile $\mathrm{N} 54^{\circ} \mathrm{W}$ of Hess Ranch house, 0.9 mile $\mathrm{S} 57^{\circ} \mathrm{E}$ of hill 5801 , Hess Canyon quadrangle.

727h. Skinner Ranch Formation: 1.18 miles $S 83^{\circ} \mathrm{W}$ of hill $5816,0.3$ mile $\mathrm{N}$ of hill 5305, Hess Ranch Horst, Hess Canyon quadrangle. 727i. Lenox Hills Formation: 0.95 mile $S 77^{\circ} \mathrm{W}$ of hill $5816,0.33$ mile $\mathrm{N} 45^{\circ} \mathrm{E}$ of hill 5305, Hess Ranch Horst, Hess Canyon quadrangle.

727j. Word Formation (Appel Ranch Member): 0.25 mile $\mathrm{S} 4^{\circ} \mathrm{E}$ of hill $5543,0.37$ mile $\mathrm{N} 75^{\circ} \mathrm{E}$ of hill 5578, at divide in Hess Canyon, Hess Canyon quadrangle.

727k. Skinner Ranch Formation: 0.60 mile $\mathrm{N} 10^{\circ} \mathrm{W}$ of Hess Ranch, 1.35 miles $S 75^{\circ} \mathrm{E}$ of hill 5801, Hess Canyon quadrangle.

727-l. Skinner Ranch Formation: 0.65 mile $\mathrm{N} 12^{\circ} \mathrm{W}$ of Hess Ranch, 1.3 miles $S 74^{\circ} \mathrm{E}$ of hill 5801, Hess Canyon quadrangle.

$727 \mathrm{~m}$. Skinner Ranch Formation: Small isolated knob 0.78 miles $\mathrm{N} 54^{\circ} \mathrm{W}$ of the Hess Ranch, 0.9 mile $\mathrm{S} 57^{\circ} \mathrm{E}$ of hill 5801, Hess Canyon quadrangle.

727n. Skinner Ranch Formation: Small isolated knob 0.83 mile $\mathrm{N} 53^{\circ} \mathrm{W}$ of Hess Ranch, 0.85 mile $\mathrm{S} 59^{\circ} \mathrm{E}$ of hill 5801, Hess Canyon quadrangle.

727o. Cathedral Mountain Formation: 0.12 mile $\mathrm{S} 5^{\circ} \mathrm{E}$ of hill 5300, Altuda quadrangle.

$727 \mathrm{p}$. Cathedral Mountain (Wedin Member): 0.22 mile $53^{\circ}$ W of hill 5300, Altuda quadrangle (Plate 7: figures 1, 3).

$727 \mathrm{q}$. Cathedral Mountain Formation: 0.23 miles $\mathrm{S} 20^{\circ} \mathrm{W}$ of hill 5300, on NW side of knob ending with 5250 -foot contour, Altuda quadrangle.

727s. Cathedral Mountain Formation (Fourth Leonard Limestone Member of P. B. King?): Top of hill 5300, 2.85 miles $\mathrm{N} 31^{\circ} \mathrm{E}$ of Lenox, Altuda quadrangle.

727 t. Skinner Ranch Formation (Decie Ranch Member): 0.48 mile $\mathrm{S} 54^{\circ} \mathrm{E}$ of hill $4902,1.7$ miles $\mathrm{N} 57^{\circ} \mathrm{E}$ of Lenox, Altuda quadrangle.

727u. Skinner Ranch Formation (Decie Ranch Member): 0.53 mile $\mathrm{S} 68^{\circ} \mathbf{E}$ of hill $4902,1.84$ miles $\mathrm{N} 56^{\circ} \mathbf{E}$ of Lenox, Lenox Hills, Altuda quadrangle.

$727 \mathrm{v}$. Cathedral Mountain Formation (Foutth Leonard Limestone Member of P. B. King): W side of knob 2.3 miles $\mathrm{S} 1^{\circ} \mathrm{W}$ of Sullivan Peak, (bench mark 6125), 0.65 mile $\mathrm{N}$ $4^{\circ} \mathrm{W}$ of hill 5300 , Altuda quadrangle.

$727 w$. Cathedral Mountain Formation (Fourth Leonard limestone Member of P. B. King): 1.95 miles $S 2^{\circ} \mathrm{W}$ of Sullivan Peak (bench mark 6125), 1.0 mile $\mathrm{N} 5^{\circ} \mathrm{W}$ of hill 5300, Altuda quadrangle.

727x. Cathedral Mountain Formation: Bioherm in sandstone, $S$ side of isolated hill 1.38 miles $S 1^{\circ} \mathrm{W}$ of Sullivan Peak (bench mark 6125), 1.55 miles $\mathrm{N} 2^{\circ} \mathrm{W}$ of hill 5300 , Altuda quadrangle.

$727 y$. Hess Formation: S slope of hill 0.35 mile $\mathrm{N} 73^{\circ} \mathrm{E}$ of hill 4821, 0.5 mile $S 73^{\circ} \mathrm{W}$ of hill 5202, Montgomery (Conoly Brooks) Ranch, Hess Canyon quadrangle [fusulinids at 4880 feet ].

727x. Hess Formation: Fusulinids at 4920 feet on rim of hill 0.35 mile $\mathrm{N} 73^{\circ} \mathrm{E}$ of hill $4921,0.5$ mile $\mathrm{S} 73^{\circ} \mathrm{W}$ of hill 5202, Montgomery (Conoly Brooks) Ranch, Hess Canyon quadrangle.

728. Cherry Canyon Formation (Getaway Member, upper part of lower Getaway): 0.45 mile $S 35^{\circ} \mathrm{E}$ of bench mark 5426 in Guadalupe Pass, 2.55 miles $S 5^{\circ} \mathrm{W}$ of Pine Spring Camp, Guadalupe Peak quadrangle [= AMNH 512]. 
728d. Hueco Formation: 0.25 mile up from mouth of Victorio Canyon, 3.15 miles $S 53.5^{\circ} \mathrm{W}$ of bench mark 3648 , on Corn Ranch, Van Horn quadrangle.

728e. Bone Spring Formation: 2-foot bed of limestone 220 feet above top of "clastic" Hueco, 2.15 miles $S 54^{\circ} \mathrm{W}$ of bench mark 3648, S side of Victorio Canyon, Van Horn quadrangle $[=A M N H$ 625=USNM 741] (Plate 8: figure 3).

728f. Bone Spring Formation: From 18-inch bed of silty limestone, 0.6 mile $S$ of Victorio Canyon, 2.75 miles $S$ $44^{\circ} \mathrm{W}$ of bench mark 3648, Van Horn quadrangle [=AMNH 629] (Plate 8: figure 3).

728g. Bone Spring Formation: W side of Apache Canyon, 4.5 miles $\mathrm{N} 55^{\circ} \mathrm{W}$ of Figure Two Ranch house, Van Horn quadrangle [ $=$ AMNH 492].

728h. Bone Spring Formation: 0.5 mile $S$ of mouth of Victorio Canyon, 2.75 miles $S 48^{\circ} \mathrm{W}$ of bench mark 3648 , Van Horn quadrangle.

728i. Bell Canyon Formation (Lamar Member): Beside road in mouth of Big Canyon, 0.25 mile SE of Gray Ranch, SW $1 / 4$ SW $1 / 4$ section 29, T 26 S, R 22 E, Carlsbad Caverns West quadrangle.

728j. Cibolo Formation (Breccia Zone of Udden): Upper bioherms under thin-bedded shaly layers, 1 mile $N 79^{\circ}$ $\mathrm{E}$ of Cibolo Ranch house, in bluff above Sierra Alta Creek, Chinati Peak quadrangle.

728k. Cibolo Formation (Breccia Zone of Udden): Lower bioherms with Scacchinella, 0.8 mile $\mathrm{N} 83^{\circ} \mathrm{E}$ of Cibolo Ranch house, in bluff above Sierra Alta Creek, Chinati Peak quadrangle.

728-1. Cibolo Formation (Breccia Zone of Udden): Bioherms low in bluff of Sierra Alta Creek, 0.8 mile $N 83^{\circ}$ $\mathbf{E}$ of Cibolo Ranch house, Chinati Peak quadrangle (Plate 22: figure 4).

$728 \mathrm{~m}$. Cibolo Formation (top of Breccia Zone of Udden): Fusulinids from bed from upper bioherm, 1 mile $\mathrm{N} 79^{\circ}$ $\mathbf{E}$ of Cibolo ranch house, bluff on S side of Sierra Alta Creek, Chinati Peak quadrangle.

728n. Cibolo Formation (Thin-bedded Zone; top): Fusulinids in top limestone beds just below chert, 1 mile $\mathrm{N}$ $79^{\circ} \mathrm{E}$ of Cibolo ranch house, in bluff on $\mathrm{S}$ side of Sierra Alta Creek, Chinati Peak quadrangle.

7280. Bone Spring Formation (top of massive beds): About 4525 feet on nose of $\mathrm{S}$ side of Victorio Canyon, 2.5 miles $\mathrm{N} 47^{\circ} \mathrm{W}$ of bench mark 3625 , and 2.5 miles $\mathrm{S} 53^{\circ} \mathrm{W}$ of bench mark 3648, Van Horn quadrangle.

728p. Bell Canyon Formation (Lamar Member): Lower massive beds in bluff on $\mathrm{E}$ side of ranch road, 0.4 mile $S 54^{\circ} \mathrm{E}$ of junction of road to D-Ranch headquarters and U. S. Highway 62-180, E of Hegler Ranch, Guadalupe Mountains (Plate 22: figure 3).

728q. Bell Canyon Formation (Lamar Member): Massive limestone on $S$ side of Seven-Heart Gap at entrance, Van Horn quadrangle.

728r. Bell Canyon Formation (Lamar Member): Upper bituminous limestone 0.4 mile $\mathrm{E}$ of mouth of Seven-Heart Gap, Van Horn quadrangle. 728s. Bell Canyon Formation (Lamar Member): Top of massive limestone 1.1 miles NW of mouth of Seven-Heart Gap, Van Horn quadrangle.

728t. Bone Spring Formation (lower): Victorio Peak, Van Horn quadrangle.

728v. Bone Spring Formation (upper, 35 feet below top): Last Chance Canyon, $N$ side, above lower ranch, NE $1 / 4$ section 33, T 23 S, R 22 E, Eddy County, New Mexico.

728w. Cherry Canyon Formation (Getaway Member): Airways Beacon, bench mark 5446, 5.5 miles SE of E1 Capitan Guadalupe Peak quadrangle.

729. [= AMNH 369.]

729a. Hess Formation: Edge of hill 0.35 mile $\mathrm{N} 65^{\circ} \mathrm{E}$ of hill 4921, 0.5 mile $\mathrm{S} 76^{\circ} \mathrm{W}$ of hill 5302, Montgomery (Conoly Brooks) Ranch, Hess Canyon quadrangle [fusulinids at 4950 feet].

729b. Hess Formation: 0.6 mile $\mathrm{N} 53^{\circ} \mathrm{E}$ of hill 4921, 1.5 mile $S 67^{\circ} \mathrm{W}$ of hill 5135, Montgomery (Conoly Brooks) Ranch, Hess Canyon quadrangle.

729e. Hess Formation (=Lenox Hills Formation): Slope of hill, 0.33 mile $\mathrm{N} 74^{\circ} \mathrm{E}$ of hill $4921,0.48$ mile $S 71^{\circ}$ W of hill 5202, Montgomery (Conoly Brooks) Ranch, Hess Canyon quadrangle.

729h. Skinner Ranch Formation (Sullivan Peak Member): E sicle of hill capped by 5250 contour, facing spur on $W$ side of Sullivan Ranch road, 0.9 mile $S 7^{\circ} \mathrm{E}$ of hill 4920 , 1.55 mile $S 70^{\circ} \mathrm{W}$ of hill 5020 , N of Decie Ranch, Altuda quadrangle.

729i. Skinner Ranch Formation (Decie Ranch Member): Under main crest of hill 5195, loose, Dugout Mountain just under bluff formed by Decie Ranch Member, Monument Spring quadrangle.

729j. Skinner Ranch Formation (base): Top of knob at base of Hess Ranch Horst, $\mathrm{N}$ side, on $\mathrm{N}$ side of USNM $720 \mathrm{e}, 0.8$ mile $\mathrm{N} 67^{\circ} \mathrm{W}$ of hill 5816, Hess Canyon quadrangle.

729-1. Skinner Ranch Formation (top): Crest of westernmost knob of hill 5021, E of Sullivan Ranch road, Altuda quadrangle.

729o. Skinner Ranch Formation (Sullivan Peak Member, upper): $\quad W$ end, type section of member, knob at $W$ end of Leonard Mountain, Altuda quadrangle.

729p. Skinner Ranch Formation (Sullivan Peak Member): 0.25 mile $\mathrm{N} 17^{\circ} \mathrm{W}$ of hill $5280,1.43$ miles $\mathrm{S} 80^{\circ} \mathrm{E}$ of hill 4910, at head of ravine, Altuda quadrangle.

729q. Skinner Ranch Formation (Poplar Tank Member): Slope on $S$ end of hill 480I, S end of Lenox Hills, below large bioherms, Monument Spring quadrangle.

729r. Cathedral Mountain (Upper): Just under biggest bioherm in Road Canyon at $724 \mathrm{j}, 0.4$ mile $\mathrm{S} 60^{\circ} \mathrm{E}$ of hill 5779, Altuda quadrangle.

730. Cherry Canyon Formation (Getaway Member=subGetaway Zone, P. B. King): Near bench mark 5426 in arroyo $\mathrm{S}$ of U. S. Highway $62,0.5$ mile $\mathrm{W}$ of road bend at bench mark 5315, 2.25 miles $S$ of Pine Spring Camp, Guadalupe Peak quadrangle $[=\mathrm{AMNH} 600]$ (see P. B. King, 1948:41). 
730k. Skinner Ranch Formation (Sullivan Peak Member): Hill 4801, S end of Lenox Hills, Monument Spring quadrangle.

730m. Gaptank Formation: SE nose of Leonard Mountain, Hess Canyon quadrangle.

730n. Gaptank Formation (Uddenites-bearing Shale Member): Head of canyon NE of Wolf Camp, Wolf Camp Hills, Hess Canyon quadrangle.

7300. Skinner Ranch Formation: Faulted block, 1.6 miles N $54^{\circ} \mathrm{E}$ of Hess Ranch, 0.52 mile N $75^{\circ} \mathrm{W}$ of hill 5726 , Hess Canyon quadrangle.

730q. Cathedral Mountain Formation (base): Fault block, 1.7 miles $\mathrm{N} 53^{\circ} \mathrm{E}$ of Hess Ranch, 0.5 miles $\mathrm{N} 64^{\circ} \mathrm{W}$ of hill 5726, Hess Canyon quadrangle.

730r. Skinner Ranch Formation (upper): Fault block 1.62 miles $\mathrm{N} 50^{\circ} \mathrm{E}$ of Hess Ranch house, 0.65 miles $\mathrm{N} 67^{\circ}$ W of hill 5726, Hess Canyon quadrangle.

730s. Skinner Ranch Formation: Fault block 1.6 mile $\mathrm{N}$ $52^{\circ} \mathrm{E}$ of Hess Ranch house, 0.55 mile $\mathrm{N} 71^{\circ} \mathrm{W}$ of hill 5726, Hess Canyon quadrangle.

730u. Cathedral Mountain Formation: 1.47 miles $\mathrm{N} 45^{\circ} \mathrm{E}$ of Hess Ranch, 0.65 mile $S 31^{\circ} \mathbf{E}$ of hill 5305, Hess Canyon quadrangle.

730v. Skinner Ranch Formation: Side of knob near USNM 730r.

731. Bell Canyon Formation (Hegler Member): Top of hill 5130, 0.3 mile $S 13^{\circ} \mathrm{W}$ of Pinyon Tank, 2.25 miles S $62^{\circ}$ $\mathrm{E}$ of Airway Beacon, Guadalupe Peak quadrangle (Platc 22: figure 2).

731b. Cathedral Mountain Formation (lower): Beds with Institella 80 feet above road, on $\mathbf{E}$ slope of elliptical hill 0.52 mile $\mathrm{N} 88^{\circ} \mathrm{E}$ of hill $5816,0.9$ mile $\mathrm{S} 9^{\circ} \mathrm{W}$ of hill 5611,3 miles NE of Hess Ranch, Hess Canyon quadrangle.

73le. Road Canyon Formation: Top of Clay slide, Altuda quadrangle.

731j. Capitan Limestone Formation: McKittrick Canyon, Guadalupe Peak quadrangle.

731k. Lenox Hills Formation: 0.5 mile NNE of Hess Ranch house, Hess Canyon quadrangle.

731-1. Neal Ranch Formation (bed 12 of P. B. King): Center Wolf Camp Hills, Hess Canyon quadrangle.

$731 \mathrm{~m}$. Word Formation: 1.53 miles $\mathrm{N} 15^{\circ} \mathrm{W}$ of hill 4910 , 0.95 mile S $28^{\circ} \mathrm{W}$ of hill 5939, Altuda quadrangle (Plate 14: figure 4).

731o. Skinner Ranch Formation: 1.05 mile $S 79^{\circ} \mathrm{E}$ of hill 4910, 2.08 miles $\mathrm{N} 30^{\circ} \mathrm{E}$ of hill 5021, SW end of Gilliland Canyon, Altuda quadrangle.

731p. Word Formation: 1.96 miles $\mathrm{N} 13^{\circ} \mathrm{W}$ of Hess Ranch house, 0.9 mile $\mathrm{N} 32^{\circ} \mathrm{E}$ of hill 5453 , Hess Canyon quadrangle.

731q. Cathedral Mountain Formation (base) : 0.75 miles $S$ $1^{\circ} \mathrm{E}$ of hill $4920,1.6$ miles S $74^{\circ} \mathrm{W}$ of hill 5021, Altuda quadrangle.

731t. Cathedral Mountain Formation: 0.7 mile $S 1^{\circ} \mathrm{E}$ of hill $4920,1.6$ miles $S 76^{\circ} \mathrm{W}$ of hill 5021, Altuda quadrangle. 781u. Word Formation: 0.22 mile S 23० E of Sullivan Peak (bench mark 6125), 0.7 miles $S 7^{\circ} \mathrm{W}$ of Sullivan (Yates) Ranch, Altuda quadrangle (Plate 15: figure 4; text Figure 20).

731z. Word Formation (Appel Ranch Member): In Hess Canyon 0.4 mile $\mathrm{N} 78^{\circ} \mathrm{E}$ of hill $5490,0.75$ mile $\mathrm{N} 40^{\circ} \mathrm{E}$ of hill 5543, Hess Canyon quadrangle (Plate 15: figure 1).

732. Cherry Canyon Formation (Getaway Member =subGetaway Zone): Just $S$ of U. S. Highway $62,0.25$ mile $S$ $76^{\circ} \mathrm{E}$ of bench mark 5426 in Guadalupe Pass, Guadalupe Peak quadrangle $[=$ AMNH 600 and USNM 730]. (See P. B. King, 1948:41).

732a. Bell Canyon Formation (Hegler Member): Hill 5406, 1.25 miles $S 7^{\circ} \mathrm{E}$ of Pinyon Tank, Guadalupe Peak quadrangle.

732b. Skinner Ranch Formation (Decie Ranch Member): Center of Lenox Hills, $N$ of Decie Ranch, Altuda quadrangle.

732c. Word Formation: Lens above USNM 706b but below Appel Ranch Member, 3.28 miles $\mathrm{N} 36^{\circ} \mathrm{E}$ of Hess Ranch, 0.35 miles $\mathrm{S} 48^{\circ} \mathrm{E}$ of hill 5543, Hess Canyon quadrangle.

732d. Skinner Ranch Formation (Dugout Mountain Member): Third Limestone of Leonard of P. B. King, 1.36 miles S $34^{\circ} \mathrm{E}$ of Old Payne Ranch, 0.7 mile N $72^{\circ} \mathrm{W}$ of Dugout Mountain (5195), Monument Spring quadrangle.

732e. Skinner Ranch Formation (Dugout Mountain Member): Second Limestone Member of Leonard Formation of P. B. King, 1.25 miles $S 39^{\circ} \mathbf{E}$ of Old Payne Ranch, 0.75 mile $\mathrm{N} 62^{\circ} \mathrm{W}$ of Dugout Mountain (5195), Monument Spring quadrangle.

732i. Road Canyon Formation: Fusulinid bed at top of section, 0.75 mile $S 70^{\circ} \mathrm{W}$ of Old Payne Ranch, 0.25 mile $\mathrm{N} 76^{\circ} \mathrm{E}$ of hill 4806, Monument Spring quadrangle.

732j. Road Canyon Formation (upper): 0.64 mile due W of Old Payne Ranch, 0.45 mile $\mathrm{N} 47^{\circ} \mathrm{E}$ of hill 4806, Monument Spring quadrangle.

$732 \mathrm{~m}$. Road Canyon Formation: Base of bioherms on conical hill 0.25 mile N $28^{\circ} \mathrm{W}$ of Old Payne Ranch, Monument Spring quadrangle.

732q. Capitan Limestone Formation (lower massive beds): Fault block, 1.11 miles $\mathrm{N} 33^{\circ} \mathrm{W}$ of Old Payne Ranch, 1.3 miles $\mathrm{N} 17^{\circ} \mathrm{E}$ of hill 4806, Monument Spring quadrangle $[=$ Hegler Member of Capitan Formation equivalent].

732s. Word Formation: 0.85 mile $\mathrm{N} 46^{\circ} \mathrm{W}$ of Old Payne Ranch, 0.95 mile $\mathrm{N} 21^{\circ} \mathrm{E}$ of hill 4806 , Monument Spring quadrangle.

732t. Road Canyon Formation: S side, top of hill 4861, 1.12

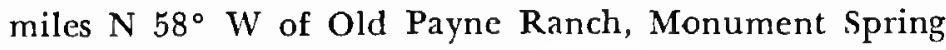
quadrangle.

732u. Cathedral Mountain Formation: Conglomerate on $W$ side of hill 4861, 1.15 miles $N 58^{\circ} \mathrm{W}$ of Old Payne Ranch, Monument Spring quadrangle (Plate 13: figures $1,2)$.

732w. Road Canyon Formation: Near top of hill 4861, 1.12 miles $\mathrm{N} 58^{\circ} \mathrm{W}$ of Old Payne Ranch, Monument Spring quadrangle. 
733. Bell Canyon Formation (Pinery Member): Hegler (Ligon) Ranch, 0.25 mile $S 55^{\circ} \mathrm{W}$ of ranch house and, up small canyon, Guadalupe Peak quadrangle.

733a. Road Canyon Formation: Low hill 1.27 miles $\mathrm{N} 49^{\circ} \mathrm{W}$ of Old Payne Ranch, 0.2 mile due $\mathrm{N}$ of hill 4861, Monu. ment Spring quadrangle.

733h. Skinner Ranch Formation (Decie Ranch Member): 0.9 mile $\mathrm{N} 49^{\circ} \mathrm{E}$ of Dugout Mountain (5195), 1.83 miles $\mathrm{N} 64^{\circ} \mathrm{W}$ of bench mark 4190 , Monument Spring quadrangle.

733j. Skinner Ranch Formation (Sullivan Peak Member, Coscinophora bioherm): 1.3 miles $\mathrm{N} 40^{\circ} \mathrm{E}$ of Dugout Mountain (hill 5191), 1.97 miles $\mathrm{N} 51^{\circ} \mathrm{W}$ of bench mark 4190, Monument Spring quadrangle (Plate 5: figure 1; Plate 129).

733-1. Skinner Ranch Formation (Dugout Mountain Member, Fourth Limestone of Leonard Formation of P. B. King): Limestone lens 1 mile $\mathrm{N} 33^{\circ} \mathrm{W}$ of Dugout Mountain (5195), 1.03 miles S $60^{\circ} \mathrm{E}$ of Old Payne Ranch, Monument Spring quadrangle.

$733 \mathrm{~m}$. Cathedral Mountain Formation: 0.55 mile $S 8^{\circ} \mathrm{E}$ of hill 5552, 0.7 mile $\mathrm{N} 63^{\circ} \mathrm{E}$ of Split Tank, Hess Canyon quadrangle.

733n. Road Canyon Formation: 0.72 mile S $69^{\circ} \mathrm{W}$ of Old Word Ranch, 1.12 miles S $27^{\circ} \mathrm{E}$ of hill 5507, Hess Canyon quadrangle.

733q. Word Formation (China Tank Member): 2.6 miles $\mathrm{N}$ $83^{\circ} \mathrm{E}$ of Willis Ranch, 0.35 mile $\mathrm{N} 77^{\circ} \mathrm{W}$ of hill 5611 , Hess Canyon quadrangle.

733r. Skinner Ranch Formation: 1.35 miles $S 49^{\circ} \mathrm{E}$ of Willis Ranch, 0.26 mile $\mathrm{N} 34^{\circ} \mathrm{W}$ of hill 5305, Hess Canyon quadrangle.

733z. Ross Mine Formation: 6-inch bed with fusulinids, 2 miles $\mathrm{N} 49^{\circ} \mathrm{W}$ of Ojo Bonito, Chinati Peak quadrangle.

735. Bell Canyon Formation (Rader Member): 0.25 mile $S$ $55^{\circ} \mathrm{W}$ of Hegler (Ligon) Ranch house, Guadalupe Peak quadrangle.

735b. Cathedral Mountain Formation (lower): Split Tank, Hess Canyon quadrangle.

735g. Cathedral Mountain Formation (upper): Near top of hill 4861, 1.12 miles N 58 $\mathrm{W}$ of Old Payne Ranch, Monument Spring quadrangle.

736. Bell Canyon Formation (Pinery Member): 1 mile $\mathrm{N}$ $20^{\circ} \mathrm{W}$ of Hegler (Ligon) Ranch house, Guadalupe Peak quadrangle.

736a. Bell Canyon Formation (Pinery Member): Pine Spring, Guadalupe Peak quadrangle.

736t. Cathedral Mountain Formation: Beds with Institella, 0.53 mile $\mathrm{S} 57^{\circ} \mathrm{E}$ of hill $5816,1.13$ miles $\mathrm{N} 78^{\circ} \mathrm{W}$ of hill 5725, Hess Canyon quadrangle.

736x. Road Canyon Formation (uppermost bed): 0.75 mile S $70^{\circ} \mathrm{W}$ of Old Payne Ranch, 0.25 mile N $5^{\circ} \mathrm{E}$ of hill 4806, Monument Spring quadrangle [=USNM $700 \mathrm{v}$, 732i].

737a. Capitan Limestone Formation: Spur on $\mathrm{N}$ side of Big Canyon, about 1000 feet above canyon floor, Guadalupe Mountains, El Paso Gap quadrangle. 737b. Word Formation: 1 mile $\mathrm{N} 82^{\circ} \mathrm{W}$ of Old Payne Ranch, 1.12 miles $S 4^{\circ} \mathrm{W}$ of hill 4861 , Monument Spring quadrangle.

737n. Road Canyon Formation (ammonite bed near top): 2.25 miles $\mathrm{S} 60^{\circ} \mathrm{W}$ of Old Payne Ranch, 2.1 miles $\mathrm{N} 59^{\circ}$ $W$ of point 4386 , Monument Spring quadrangle.

737u. Lenox Hills Formation (base $=$ Neal Ranch of Ross): 49 feet of biohermal beds at base of Lenox Hills Formation, 0.9 mile $\mathrm{N} 85^{\circ} \mathrm{E}$ of hill $4801,1.55$ miles $\mathrm{N} 62^{\circ}$ $\mathrm{E}$ of Lenox, Altuda quadrangle.

737v. Basal Cathedral Mountain Formation: Limestone of Hess lithology above basal conglomerate, 0.6 mile ${\mathrm{N} 61^{\circ}}^{\circ}$ $\mathrm{E}$ of Split rank, 0.45 mile $\mathrm{S} 83^{\circ} \mathrm{E}$ of hill 5552, Hess Canyon quadrangle.

737w. Word Formation: Lens between Willis Ranch and Appel Ranch Members, above lens at $706 \mathrm{~b}, 0.8$ mile $S$ $85^{\circ} \mathrm{W}$ of hill $5507,0.5$ mile $\mathrm{S} 77^{\circ} \mathrm{E}$ of hill 5543 , Hess Canyon quadrangle.

737y. Road Canyon Formation (top beds): 1.4 miles $\mathrm{N} 80^{\circ}$ $\mathrm{W}$ of point $4386,2.5$ miles $S 38^{\circ} \mathrm{W}$ of Old Payne Ranch site, Monument Spring quadrangle.

738. Bell Canyon Formation (Lamar Member): $\mathrm{N}$ side of McKittrick Canyon Draw, 0.3 mile N $70^{\circ} \mathrm{E}$ of Pratts scction 12 well, 1.7 miles $\mathrm{N} 48^{\circ} \mathrm{E}$ of Pratt Place, Guadalupe Mountains [=AMNH 347].

738a. Capitan Formation (Rader equivalent): $\mathrm{E}$ side of North McKittrick Canyon, 0.85 mile NE of Pratt Lodge, Guadalupe Peak quadrangle.

738b. Bell Canyon Formation (Lamar Member-middle): Slope of hill on $\mathrm{N}$ side of McKittrick Draw, about 0.7 mile $\mathrm{N} 25^{\circ} \mathrm{W}$ of Pratts Section Twelve Well, 1.7 miles $\mathrm{N} 22^{\circ} \mathrm{E}$ of Pratt Place, Guadalupe Mountains.

738c. Cibolo Formation (Breccia Zone of Udden): Loose blocks derived from the reefy beds on slope above USNM 728-1.

738d. Cibolo Formation (Transition Zone of Udden): From bed of Sierra Alta Creek just W of USNM 728-1, 0.75 mile $\mathrm{N} 83^{\circ} \mathrm{E}$ of Cibolo Ranch, Chinati Peak quadrangle.

738f. Cibolo Formation (Spicule Zone of Udden): Loose piece from ravine at $728-1,0.8$ mile $\mathrm{N} 83^{\circ} \mathrm{E}$ of Cibolo Ranch house, Chinati Peak quadrangle.

738g. Cibolo Formation (Thin-bedded Zone of Udden): 100 feet above spicule zone of Udden, 0.8 mile $\mathrm{N} 83^{\circ}$ E of Cibolo Ranch, Chinati Peak quadrangle.

738h. Cibolo Formation (Transition Zone of Udden): 1.3 miles $\mathrm{N} 75^{\circ} \mathrm{E}$ of Cibolo Ranch house, just under bioherm in shaly beds with loose fossils, Chinati Peak quadrangle.

738-1. Cibolo Formation (Thin-bedded Zone of Udden): 125 feet above base of Thin-bedded Zone, 1.3 miles $\mathrm{N}$ $75^{\circ}$ E of Cibolo Ranch, Chinati Peak quadrangle.

738n. Cibolo Formation (Transition Zone of Udden): 50 feet under Breccia Zone, under bioherms, just $E$ of largest bioherm and $W$ of volcanic plug, about 1.6 miles $\mathrm{N} 75^{\circ} \mathrm{E}$ of Cibolo Ranch house, Chinati Peak quadrangle. 
7380. Cibolo Formation (Spicule Zone of Udden): $W$ side largest bioherm, near gully, 1.3 miles $\mathrm{N} 75^{\circ} \mathrm{E}$ of $\mathrm{Ci}$ bolo Ranch house, Chinati Peak quadrangle.

738r. Cibolo Formation (Breccia Zone of Udden): Slope 0.5 mile $\mathrm{E}$ of igneous plug, 2.35 miles $\mathrm{N} 58^{\circ} \mathrm{E}$ of $\mathrm{Ci}$ bolo Ranch house, Chinati Peak quadrangle.

738s. Cibolo Formation (Breccia Zone of Udden): Near top of bioherm, 3.25 miles $\mathrm{N} 53^{\circ} \mathrm{E}$ of Cibolo Ranch house, Chinati Peak quadrangle.

738t. Cibolo Formation (Transition Zone of Udden): Float from Transition Zone, 0.5 mile $\mathrm{E}$ of volcanic plug, 2.35 miles $\mathrm{N} 58^{\circ} \mathrm{E}$ of Cibolo Ranch house, Chinati Peak quadrangle.

739. Capitan Limestone Formation: At level of Pass Summit at foot of Signal Peak [=Guadalupe Peak], Guadalupe Peak quadrangle.

739g. Skinner Ranch Formation (Sullivan Peak Member): 100 yards $W$ of bioherm at USNM $733 \mathrm{j}$.

$739 k$. Cibolo Formation (Spicule Zone of Udden, 20 feet above its base): Above highest bioherm, about 1 mile $\mathrm{N} 75^{\circ} \mathrm{E}$ of Cibolo Ranch, Chinati Peak quadrangle.

739-l. Skinner Ranch Formation (lower): 0.83 mile $\mathrm{N} 66^{\circ}$ $W$ of hill $5816,0.8$ mile $\mathrm{N} 28^{\circ} \mathrm{E}$ of hill 5305, 2.6 miles $\mathrm{N} 26^{\circ} \mathrm{E}$ of Hess Ranch, Hess Canyon quadrangle.

740. Capitan Limestone Formation: Just below knob on crest of spur running $\mathrm{N}$ from El Capitan, about 1000 feet below summit of El Capitan, Guadalupe Peak quadrangle [=USGS 2926 (green)].

740a. Bell Canyon Formation (Rader Member): Knob 0.5 mile S $45^{\circ} \mathrm{W}$ of Hegler (Ligon) Ranch (southern Guadalupe Mountains map of P. B. King, 1948: plate 3).

740c. Bell Canyon Formation (Hegler Member): W side of knob, 0.4 mile $\mathrm{S} 53^{\circ} \mathrm{E}$ of hill $5130,1.5$ miles $\mathrm{N} 15^{\circ}$ W of hill 5506, Guadalupe Peak quadrangle.

740d. Bell Canyon Formation (Hegler Member): 1 mile $S$ $39^{\circ} \mathrm{E}$ of hill $5130,0.92$ mile $\mathrm{N} 9^{\circ} \mathrm{E}$ of hill 5506 , Guadalupe Peak quadrangle.

740g. Bell Canyon Formation (Rader Member, reef slide): Rader Ridge, top of knob 1.2 miles $\mathrm{N} 88^{\circ} \mathrm{W}$ of $\mathrm{Heg}$ ler (Ligon) Ranch, 1.9 miles $\mathrm{N} 2^{\circ} \mathrm{W}$ of point 5206 on U. S. Highway 62-180, Guadalupe Peak quadrangle.

740h. Bell Canyon Formation (Rader Member, reef slide): Knob 1.55 miles due $W$ of Hegler Ranch, 2.0 miles $N$ $13^{\circ} \mathrm{W}$ of point 5206 on U. S. Highway $62-180$, Guadalupe Peak quadrangle.

740i. Bell Canyon Formation (Rader Member): 0.2 mile $\mathrm{N} 10^{\circ} \mathrm{W}$ of Hegler Ranch, 0.3 mile $\mathrm{N} 50^{\circ} \mathrm{W}$ of hill $5414,2.2$ miles $\mathrm{N} 55^{\circ} \mathrm{E}$ of Nipple Hill, Guadalupe Peak quadrangle.

740j. Bell Canyon Formation (Rader Member): 0.4 mile $S$ $25^{\circ} \mathrm{W}$ of Hegler (Ligon) Ranch, 1.65 miles $\mathrm{N} 65^{\circ} \mathrm{E}$ Nipple Hill, Guadalupe Peak quadrangle.

740k. Capitan Limestone Formation: About 7400 feet elevation, 0.8 mile $S 60^{\circ} \mathrm{E}$ of Guadalupe Pcak, 0.85 mile $\mathrm{N} 42^{\circ} \mathrm{E}$ of El Capitan, Guadalupe Peak quadrangle.

740-1. Bell Canyon Formation (Rader Member): 0.2 mile $\mathrm{N} 10^{\circ} \mathrm{W}$ of Hegler (Ligon) Ranch, 0.3 mile $\mathrm{N} 50^{\circ} \mathrm{W}$ of hill 5414, 2.2 miles $N 55^{\circ}$ E of Nipple Hill, Guadalupe Peak quadrangle.

740n. Capitan Limestone Formation: About 4950 feet elevation, NE side of Yucca Canyon, NE $1 / 4$ NW $1 / 4 \mathrm{SE}$ $1 / 4$, section $27, \mathrm{~T} 25 \mathrm{~S}, \mathrm{R} 23 \mathrm{E}, 2.7$ miles $\mathrm{N} 38^{\circ} \mathrm{W}$ of Colwell Ranch, Carlsbad Caverns West (15') quadrangle.

741. [=USNM 728e =AMNH 625.]

74la. Road Canyon Formation: Block from biohermal beds at base of Road Canyon, $W$ end of outcrop opposite Old Word Ranch, W end of USNM 703a.

74lk. Skinner Ranch Formation (Poplar Tank Member): Slope above USNM 707a, 0.65 mile NE of hill 4902 , Altuda quadrangle [unusual for having elements from low in Wolfcamp mixed with higher Skinner Ranch species].

741 p. Word (Upper lens): Uppermost of 2 lenses between Willis Ranch Member and Appel Ranch Member, 3.35 miles $S 63^{\circ} \mathrm{E}$ of hill 5543 and 1 mile $S 82^{\circ} \mathrm{W}$ of hill 5507, Hess Canyon, Hess Canyon quadrangle.

74lq. Lowermost of 2 lenses between Willis Ranch and Appel Ranch Member [at USNM 74lp].

74ls. Cathedral Mountain Formation (lower): 0.67 mile N $33^{\circ} \mathrm{E}$ of bench mark 5324, 0.3 mile $\mathrm{N}$ of $30^{\circ} 10^{\prime}$ parallel, Del Norte Mountains, Monument Spring quadrangle.

742. Bone Spring Formation: 18-inch bed of silty limestone with yellow clay pebbles, 30 feet above Hueco Forma. tion, 0.25 mile $\mathrm{S}$ of Victorio Canyon, Van Horn quad. rangle [=USNM 728f].

742b. Word Formation (lens below Appel Ranch Member): 0.45 mile $\mathrm{S} 12^{\circ} \mathrm{E}$ of hill 5543 and 2.03 miles $\mathrm{N} 66^{\circ} \mathrm{W}$ of Old Word Ranch, Hess Canyon quadrangle.

742c. Neal Ranch Formation (bed 4): Bioherm 50 yards west of USNM 727e.

743. [=USNM 728e.]

744. [= AMNH 631.]

745. Bone Spring Formation: 25-40 feet above Hueco limestone, hill 4402 at $\mathrm{N}$ end of Baylor Mountains on $\mathrm{W}$ side of Texas Highway 54, Van Horn quadrangle.

746. Bone Spring Formation: 50-100 feet above brecciated lens on $\mathrm{E}$ slope of Victorio Peak, Van Horn quadrangle.

747. Bone Spring Formation (Cutoff Shale Member): Slope 1 mile SW of point 6910 , and 0.2 mile $W$ of fault in front of Cutoff Mountain, Guadalupe Mountains, Texas [=AMNH 678].

748. Bell Canyon Formation (Pinery Member): Above Pine Spring, $\mathbf{N}$ of Pine Spring Camp, Guadalupe Peak quadrangle.

748a. Capitan Limestone Formation: First limestone ledge above Delaware sandstone, 1 mile NW of Frijole Post Office, Guadalupe Peak quadrangle.

750. Capitan Limestone Formation: About 4100 feet elevation, 0.5 mile $\mathrm{S} 12^{\circ} \mathrm{W}$ of Carlsbad Cave entrance, SW corner NE 1/4 SW 1/4, section 31, T 24 S, R 25 E, Carlsbad Caverns East (15') quadrangle, Eddy County, New Mexico. 
750a. Capitan Limestone Formation: Along road in Rattlesnake Canyon, NW corner SW 1/4 SE 1/4, section 4, T 25 S, R 24 E, Carlsbad Caverns West (15') quadrangle, New Mexico.

750b. Capitan Limestone Formation: E side of Slaughter Canyon about 0.2 mile up from mouth, SE $1 / 4 \mathrm{SE} 1 / 4$, section 23, T 25 S, R 23 E, Carlsbad Caverns (15') West quadrangle.

750e. Capitan Limestone Formation: Near contact between Capitan and Carlsbad Formations at elevation 4200 feet in SW $1 / 4$, section 31, T 24 S, R 25 E, Carlsbad Caverns East (15') quadrangle, Eddy County, New Mexico.

750f. Capitan Limestone Formation: Sandstone in big room of Carlsbad Caverns, Carlsbad Caverns National Park, New Mexico.

750g. Capitan Limestone Formation: NE side of McKittrick Canyon, Guadalupe Mountains.

753. Sosio Limestone Formation: Rocca de Salomone, 3 kilometers SW of Palazzo Adriano, 48 kilometers $S$ of Palermo, Province of Palermo, Sosio Valley, Sicily.

755. Sosio Limestone Formation: Rocca de San Benedetto, about 2 kilometers NNW of Rocca di Salomone, Palazzo Adriano, Palermo Province, Sicily.

760. Park City Formation (Franson Member, upper): From 10-foot interval of resistant limestone, on NW side of Washakic Reservoir, SW $1 / 4$ NE $1 / 4$, section 17, T 1 S, R $2 \mathrm{~W}$, Moccasin Lake quadrangle, Frement County, Wyoming.

761. Red Eagle Formation: Quarry in NW 1/4 SE 1/4, section 25, T $26 \mathrm{~N}, \mathrm{R} 5 \mathrm{E}, \mathrm{S}$ side of U. S. Highway 60 , 0.5 mile NE of Burbank, Oklahoma.

762. Park City Formation (Franson Member): $S$ fork of Little Wind River, Little Wind River Mountains, Wyoming.

763. Park City Formation (Franson Member): SW 1/4, section 26, T 13 S, R 10 W, Big Sheep Canyon, Beaverhead County, Montana.

766. Coleman Junction Formation: On U. S. Highway 67, 2.4 miles $\mathbf{E}$ of junction with $U$. S. Highway 283 in Santa Anna, Coleman County, Texas.

766b. Coleman Junction Formation: San Angelo Junction, 4 miles SE of Coleman, Texas.

767. Permian (Hughes Creek Formation): Center $\mathrm{N} y_{2}^{\prime}$, section 12, T $8 \mathrm{~N}, \mathrm{R} 8 \mathrm{E}, \mathrm{SE}$ of Bennett, Nebraska.

$806 d^{\prime}$. Monos Formation: Spiriferellina zone, knob with 217 meters elevation, just $S$ of $S$ face of hill (294 meters elevation), 1.2 kilometers $W$ of Alamo, Sonora, Mexico.

336l. Bursum Formation: 100 feet below level of Tularosa Clay pit fauna, shale and limestone in round hill above microgranite sill, NW $1 / 4$ NE $1 / 4$ NW 1/4, section $2, \mathrm{~T}$ $15 \mathrm{~S}, \mathrm{R} 10 \mathrm{E}$, Otero County, New Mexico.

\section{Glass Mountains Localities by Formation}

Appel Ranch Member (of Word Formation): USNM 704, $706 \mathrm{~d}, 714 \mathrm{o}, 715 \mathrm{i}, 716 \mathrm{v}, 719 \mathrm{z}, 722 \mathrm{t}, 726 \mathrm{t}, 727 \mathrm{j}, 731 \mathrm{z}, 742 \mathrm{~b}$.

Capitan Limestone Formation: USNM 732q.

Cathedral Mountain Formation: Moore 23; USGS 3763 (part), 3840; AMNH 500, 504; USNM 702, 702a, 702a ${ }^{1}$, 702b, 702ent, 702inst, 702 low, 702un, 703a, 703b, 703bs, $707 \mathrm{q}, 708,708 \mathrm{u}, 708 \mathrm{x}, 709,709 \mathrm{o}, 710 \mathrm{~b}, 710 \mathrm{~g}, 71 \mathrm{q}, 711 \mathrm{r}$, $711 \mathrm{w}, 712 \mathrm{o}, 713 \mathrm{p}, 713 \mathrm{t}, 713 \mathrm{w}, 717 \mathrm{~g}, 721 \mathrm{u}, 72 \mathrm{lv}, 723 \mathrm{k}$, $723 \mathrm{n}, 723 \mathrm{p}, 723 \mathrm{u}, 723 \mathrm{y}, 724 \mathrm{i} 724 \mathrm{k}, 724 \mathrm{~m}, 724 \mathrm{n}, 724 \mathrm{r}$, $724 \mathrm{~s}, 724 \mathrm{t}, 726 \mathrm{o}, 726 \mathrm{u}, 726 \mathrm{v}, 726 \mathrm{w}, 726 \mathrm{x}, 726 \mathrm{y}, 727 \mathrm{o}$, $727 \mathrm{q}, 727 \mathrm{~s}, 727 \mathrm{v}, 727 \mathrm{w}, 727 \mathrm{x}, 729 \mathrm{r}, 730 \mathrm{q}, 730 \mathrm{u}, 731 \mathrm{~b}$, $731 \mathrm{q}, 731 \mathrm{t}, 732 \mathrm{u}, 733 \mathrm{~m}, 735 \mathrm{~b}, 735 \mathrm{~g}, 737 \mathrm{v}, 741 \mathrm{~s}$ [for additional numbers see Wedin Member].

China Tank Member (of Word Formation): USNM 703e, 706a, 706c, 706z, 713, 721p, 726q, 726r, 726s, 733q.

Decie Ranch Member (of Skinner Ranch Formation): USNM 707a, 707g, 707v, 707w, 707x, 708q, 708z, 713s, $714 \mathrm{e}, 714 \mathrm{t}, 715 \mathrm{a}, 715 \mathrm{c}, 715 \mathrm{t}, 715 \mathrm{v}, 716 \mathrm{p}, 717 \mathrm{i}, 718 \mathrm{t}, 719 \mathrm{~s}$, $727 \mathrm{t}, 727 \mathrm{u}, 729 \mathrm{i}, 732 \mathrm{~b}, 733 \mathrm{~h}$.

Dugout Mountain Member (of Skinner Ranch Formation): USNM 700m, 700n, 700o, 700p, 700r, 700s, 700t, 730e, $730 \mathrm{f}, 730 \mathrm{~g}, 730 \mathrm{i}, 730 \mathrm{j}, 732 \mathrm{~d}, 732 \mathrm{e}, 732 \mathrm{f}, 733-1$.

Gaptank Formation: USNM 700, 700a, 700f, 700g, 701y, $702 \mathrm{u}, 702 \mathrm{z}, 703 \mathrm{k}, 703 \mathrm{r}, 704 \mathrm{~d}, 704 \mathrm{~h}, 704 \mathrm{w}, 705 \mathrm{ca}, 705 \mathrm{~d}$, $705 \mathrm{e}, 705 \mathrm{f}, 705 \mathrm{j}, 705 \mathrm{q}, 705 \mathrm{v}, 705 \mathrm{x}, 705 \mathrm{y}, 708 \mathrm{n}, 708 \mathrm{p}$, $713 \mathrm{e}, 713 \mathrm{~g}, 715 \mathrm{z}, 716 \mathrm{i}, 716 \mathrm{k}, 730 \mathrm{~m}$.

Hess Formation: USNM 702v, 702w, 703f, 703g, 703h, 703i, $703 \mathrm{j}, 703 \mathrm{q}, 706-1,709 \mathrm{~d}, 709 \mathrm{e}, 709 \mathrm{f}, 709 \mathrm{~g}, 709 \mathrm{~h}, 709 \mathrm{i}$, $709 \mathrm{j}, 709 \mathrm{k}, 709 \mathrm{~m}, 711 \mathrm{f}, 711 \mathrm{~g}, 713 \mathrm{v}, 714 \mathrm{i}, 714 \mathrm{j}, 714 \mathrm{k}$, $716 \mathrm{a}, 716 \mathrm{~b}, 716 \mathrm{c}, 716 \mathrm{~d}, 716 \mathrm{f}, 716 \mathrm{~h}, 718 \mathrm{u}, 719 \mathrm{q}, 722 \mathrm{p}$, $726 \mathrm{n}, 727 \mathrm{y}, 727 \mathrm{z}, 729 \mathrm{a}, 729 \mathrm{~b}, 729 \mathrm{e}, 729 \mathrm{u}, 730 \mathrm{x}, 730 \mathrm{y}$, $731 \mathrm{a}, 739 \mathrm{i}, 742 \mathrm{a}$.

Lenox Hills Formation: USNM 704b, 704e, 704f, 704i, 704k, $704-1,704 \mathrm{~m}, 704 \mathrm{o}, 704 \mathrm{p}, 704 \mathrm{q}, 704 \mathrm{r}, 704 \mathrm{t}, 704 \mathrm{u}, 705$, $705 \mathrm{~g}, 705 \mathrm{k}, 705 \mathrm{~m}, 705 \mathrm{~s}, 705 \mathrm{t}, 705 \mathrm{u}, 706 \mathrm{~g}, 706 \mathrm{~h}, 706 \mathrm{i}$, $706 \mathrm{j}, 706 \mathrm{k}, 706 \mathrm{w}, 706 \mathrm{x}, 706 \mathrm{y}, 707 \mathrm{j}, 707 \mathrm{ja}, 707 \mathrm{k}, 707 \mathrm{~m}$, $707 \mathrm{n}, 707 \mathrm{o}, 707 \mathrm{p}, 707 \mathrm{r}, 707 \mathrm{~s}, 708 \mathrm{~g}, 708 \mathrm{~h}, 708 \mathrm{k}, 709 \mathrm{~s}$, $709 \mathrm{t}, 709 \mathrm{w}, 709 \mathrm{x}, 710 \mathrm{w}, 711 \mathrm{c}, 711 \mathrm{e}, 711 \mathrm{~h}, 711 \mathrm{~m}, 712 \mathrm{u}$, $712 \mathrm{v}, 713 \mathrm{j}, 713 \mathrm{q}, 713 \mathrm{y}, 714 \mathrm{a}, 714 \mathrm{~b}, 714 \mathrm{c}, 714 \mathrm{f}, 714 \mathrm{~g}$, $715,715 \mathrm{~b}, 715 \mathrm{r}, 716 \mathrm{i}, 716 \mathrm{r}, 716 \mathrm{u}, 717 \mathrm{c}, 718 \mathrm{n}, 718 \mathrm{o}, 718 \mathrm{p}$, $718 \mathrm{y}, 719 \mathrm{r}, 723 \mathrm{~d}, 723 \mathrm{r}, 724 \mathrm{o}, 724 \mathrm{v}, 724 \mathrm{w}, 724 \mathrm{x}, 726 \mathrm{i}$, $727 \mathrm{i}, 731 \mathrm{k}, 737 \mathrm{u}$.

Lenses between Willis Ranch and Appel Ranch Members (of Word Formation): USNM 706b, 737w, 742b.

Neal Ranch Formation: USNM 701, 701a, 70la $\mathrm{a}^{1}, 70 \mathrm{la}^{2}$, $701 \mathrm{a}^{3}, 701 \mathrm{c}, 701 \mathrm{~d}, 701 \mathrm{~g}, 70 \mathrm{lh}, 701 \mathrm{k}, 701-1,701 \mathrm{~m}, 701 \mathrm{n}$, $701 \mathrm{z}, 702 \mathrm{~h}, 702-1,702 \mathrm{t}, 702 \mathrm{x}, 703 \mathrm{~m}, 703 \mathrm{n}, 703 \mathrm{t}, 703 \mathrm{u}$, $703 \mathrm{v}, 704 \mathrm{v}, 706 \mathrm{p}, 706 \mathrm{q}, 706 \mathrm{t}, 706 \mathrm{u}, 706 \mathrm{v}, 706 \mathrm{x}, 708 \mathrm{~b}$, $708 \mathrm{w}, 708 \mathrm{y}, 71 \mathrm{x}, 712 \mathrm{w}, 712 \mathrm{x}, 712 \mathrm{y}, 712 \mathrm{z}, 713 \mathrm{~h}, 713 \mathrm{k}$, $713-1,715 \mathrm{e}, 716 \mathrm{~m}, 716 \mathrm{y}, 718 \mathrm{e}, 718 \mathrm{q}, 718 \mathrm{r}, 719 \mathrm{a}, 721 \mathrm{~g}$, $721 \mathrm{k}, 721 \mathrm{n}, 722 \mathrm{w}, 722 \mathrm{x}, 727 \mathrm{c}, 727 \mathrm{~d}, 727 \mathrm{e}, 731-1,742 \mathrm{c}$.

Pcplar Tank Member (of Skinner Ranch Formation): USNM 700z, 703y, 707ha, 707i, 708a, 708e, 710x, 713r, $715 \mathrm{k}, 718 \mathrm{v}, 722 \mathrm{z}, 729 \mathrm{q}, 741 \mathrm{k}$.

Road Canyon Formation: AMNH 501, 503, 507, 509; USNM $700 \mathrm{q}, 700 \mathrm{v}, 700 \mathrm{w}, 702 \mathrm{c}, 703,703 \mathrm{a}, 703 \mathrm{c}, 703 \mathrm{~d}, 706 \mathrm{f}, 706 \mathrm{r}$, $707 \mathrm{e}, 709 \mathrm{c}, 710 \mathrm{~h}, 710 \mathrm{i}, 710 \mathrm{j}, 710 \mathrm{-1}, 710 \mathrm{~m}, 710 \mathrm{n}, 710 \mathrm{o}$, $710 \mathrm{p}, 710 \mathrm{t}, 710 \mathrm{u}, 710 \mathrm{z}, 711 \mathrm{v}, 712 \mathrm{q}, 712 \mathrm{t}, 716 \mathrm{w}, 716 \mathrm{x}$, $716 \mathrm{xa}, 717 \mathrm{~b}, 718 \mathrm{k}, 718-1,719 \mathrm{w}, 719 \mathrm{x}, 720 \mathrm{~d}, 721 \mathrm{j}, 721 \mathrm{o}$, $721 \mathrm{r}, 721 \mathrm{~s}, 721 \mathrm{t}, 721 \mathrm{w}, 721 \mathrm{x}, 721 \mathrm{y}, 721 \mathrm{z}, 722 \mathrm{e}, 722 \mathrm{f}$, $722 \mathrm{~g}, 722 \mathrm{v}, 723 \mathrm{a}, 723 \mathrm{x}, 724 \mathrm{a}, 724 \mathrm{~b}, 724 \mathrm{c}, 724 \mathrm{~d}, 724 \mathrm{e}$, $724 \mathrm{~h}, 724 \mathrm{j}, 726,726 \mathrm{~d}, 726 \mathrm{e}, 726 \mathrm{f}, 726 \mathrm{z}, 726 \mathrm{za}, 731 \mathrm{e}$, $732 \mathrm{i}, 732 \mathrm{j}, 732 \mathrm{~m}, 732 \mathrm{t}, 732 \mathrm{w}, 733 \mathrm{n}, 733 \mathrm{y}, 736 \mathrm{x}, 737 \mathrm{n}$, $737 \mathrm{y}$. 
Skinner Ranch Formation (undifferentiated): AMNH 520; USNM 705a, 705b, 705-1, 705n, 705o, 705r, 707h, 707u, $707 \mathrm{z}, 708 \mathrm{f}, 708 \mathrm{~g}, 708 \mathrm{i}, 708 \mathrm{k}, 709 \mathrm{a}, 709 \mathrm{p}, 709 \mathrm{q}, 709 \mathrm{r}$, $709 \mathrm{u}, 709 \mathrm{v}, 709 \mathrm{z}, 710 \mathrm{~s}, 711 \mathrm{~d}, 711 \mathrm{i}, 711 \mathrm{k}, 711-1,711 \mathrm{n}$, $711 \mathrm{o}, 711 \mathrm{p}, 711 \mathrm{y}, 711 \mathrm{z}, 712 \mathrm{n}, 712 \mathrm{p}, 713 \mathrm{n}, 713 \mathrm{x}, 714 \mathrm{~d}$ $714 \mathrm{~h}, 714 \mathrm{p}, 714 \mathrm{q}, 714 \mathrm{~s}, 715 \mathrm{n}, 715 \mathrm{t}, 716 \mathrm{q}, 716 \mathrm{t}, 717 \mathrm{v}$ $719 \mathrm{y}, 720 \mathrm{e}, 720 \mathrm{f}, 720 \mathrm{~g}, 720 \mathrm{j}, 722 \mathrm{~m}, 722 \mathrm{n}, 722 \mathrm{o}, 723 \mathrm{~h}$, $723 \mathrm{j}, 723-1,723 \mathrm{o}, 723 \mathrm{q}, 723 \mathrm{~s}, 724-1,724 \mathrm{p}, 724 \mathrm{q}, 726 \mathrm{~g}$, $726 \mathrm{~h}, 726 \mathrm{j}, 726 \mathrm{k}, 726-1,727 \mathrm{a}, 727 \mathrm{~b}, 727 \mathrm{f}, 727 \mathrm{~h}, 727 \mathrm{k}$, $727-1,727 \mathrm{~m}, 727 \mathrm{n}, 729 \mathrm{j}, 729-1,730 \mathrm{o}, 730 \mathrm{r}, 730 \mathrm{~s}, 730 \mathrm{v}$, $731 \mathrm{o}, 732 \mathrm{~b}, 733 \mathrm{r}, 739-1$.

Sullivan Peak Member (of Skinner Ranch Formation): USNM 700y, 704y, 707, 707b, 707c, 707d, 707t, 709-1, $710 \mathrm{~d}, 710 \mathrm{r}, 710 \mathrm{y}, 713 \mathrm{c}, 713 \mathrm{~d}, 713 \mathrm{i}, 713 \mathrm{~m}, 713 \mathrm{z}, 714 \mathrm{u}$, $714 \mathrm{y}, 715 \mathrm{f}, 715 \mathrm{~h}, 715 \mathrm{j}, 715 \mathrm{~m}, 717 \mathrm{a}, 718 \mathrm{z}, 722 \mathrm{~h}, 722 \mathrm{j}$, $722-1,729 \mathrm{~h}, 729 \mathrm{~m}, 729 \mathrm{o}, 729 \mathrm{p}, 729 \mathrm{~s}, 730 \mathrm{k}, 733 \mathrm{j}, 735 \mathrm{f}$ $736 \mathrm{~d}, 739 \mathrm{~g}$.

Taylor Ranch Member (of Hess Formation): USNM 702d, 702e, 702f, 702m, 716n, 716o, 722p, 729d.

Uddenites-bearing Shale Member (of Gaptank Formation): USNM 701e, 701f, 701p, 70lq, 701r, 701t, 701u, 701v, $701 \mathrm{x}, 702 \mathrm{j}, 702 \mathrm{k}, 702 \mathrm{n}, 702 \mathrm{o}, 702 \mathrm{p}, 702 \mathrm{q}, 702 \mathrm{r}, 702 \mathrm{~s}$, 703-1, 703o, 703p, 703v, 703x, 704a, 704c, 705h, 706s, 713a, 713b, 713o, 713u, 721i, 721-1, 721m, 72ln, 730n.

Wedin Member (of Cathedral Mountain Formation): USNM 700-1, 700x,710d, 714v, 714w, 714wa, 717e, 723v, $727 \mathrm{p}$.

Willis Ranch Member (of Word Formation): AMNH 505, 506; USNM 706, 706e, 718d, 723t, 723w, 724f, 724g, $724 \mathrm{u}, 731 \mathrm{~m}, 732 \mathrm{~s}, 735 \mathrm{c}, 736 \mathrm{w}$.

Word Formation: USGS 3763 (part); USNM 711u, 719e, $724 \mathrm{y}, 724 \mathrm{z}, 731 \mathrm{~m}, 731 \mathrm{p}, 731 \mathrm{u}, 732 \mathrm{c}, 732 \mathrm{~s}, 737 \mathrm{w}$.

\section{Guadalupe Mountains and Sierra Diablo LOCALities BY FORMATION}

Bone Spring Formation: AMNH 46, 369, 492, 497, 591, $592,624,625,628,629,631,632,634,655,658,660,696$, 699; USGS 2920, 2967; USNM 725c, 725s, 725y, 728e-h. $728 \mathrm{o}, 728 \mathrm{t}, 728 \mathrm{v}, 734 \mathrm{e}, 741,742,743,745,746$.

Brushy Canyon Formation: USGS 2919.
Capitan Limestone Formation: AMNH 475 (part), 774 $801,803,804,806,813,817,820,830,837,840,847,853$; USGS 2906, 2926, 7404, 7417, 7612; USNM 725j, 725k, $725-1,725 \mathrm{~m}, 725 \mathrm{p}, 731 \mathrm{j}, 737 \mathrm{a}, 738 \mathrm{a}, 739,740,740 \mathrm{k}, 740 \mathrm{~m}$, $740 \mathrm{n}, 740 \mathrm{o}, 748 \mathrm{a}, 750,750 \mathrm{a}, 750 \mathrm{~b}, 750 \mathrm{e}, 750 \mathrm{f}, 750 \mathrm{~g}$.

Carlsbad Formation: AMNH 417, 475 (part); USGS 7416.

Cutoff Shale Member (Bone Spring Formation): AMNH 678, 747; USGS 7666 (?).

Delaware Mountain Formation: USGS 2962, 2969.

Getaway Member (Cherry Canyon Formation): AMNH 21, $28,496,512,519,547,585,600,652$; USNM 728, 728w, 730, 732; Moore 31 .

Hegler Member (Bell Canyon Formation): AMNH 635; USNM 731, 732a, 740b, 740c, 740d, 740e.

Hueco Group: AMNH 626, 700; USGS 19999; USNM 712e, $712 \mathrm{~m}, 719,720 \mathrm{~b}, 720 \mathrm{c}, 725 \mathrm{a}, 725 \mathrm{~b}, 725 \mathrm{z}, 728 \mathrm{~d}, 741 \mathrm{a}-\mathrm{h}$.

Lamar Member (Bell Canyon Formation): AMNH 25, 37, $38,39,40,347,348,373,384,430$; USNM $725 \mathrm{e}, 725 \mathrm{j}$, 728i, 728p, 728q, 728r, 728s, 737, 738, 738b.

McCombs Member (Bell Canyon Formation): AMNH 385, 409.

Pinery Member (Bell Canyon Formation): AMNH 33, 375, 397 (?), 401 (?), 435 (?), 437, 524 (?); 537, 636; Moore 30; USGS 2930; USNM 725h, 725i, 725n, 733, 734, 736, 736a, 748.

Rader Member (Bell Canyon Formation): AMNH 388, $389,403,404(?), 410$; USNM 725f, 725g, 725o, 738a, 740a, 740g, 740h, 740i, 740j, 740-1.

South Wells Member (Cherry Canyon Formation): AMNH 417; USGS 7649; USNM 740f.

Yates Formation: AMNH 725

\section{Chinati Mountains Localities by Formation}

Cibolo Formation: (Transition zone) USNM 738d $738 \mathrm{~h}$, 738i, 738n, 738t. (Breccia Zone) USNM 728j, 728k, 728-1, $728 \mathrm{~m}, 738 \mathrm{c}, 738 \mathrm{e}, 738 \mathrm{j}, 738 \mathrm{r}, 738 \mathrm{~s}$; AMNH 703 (?). (Spicule Zone) USNM 738f, 738o, 738q, 738u, 738v, 738w, $739 \mathrm{j}$, 739k. (Thin-bedded Zone) USNM 728n, 738f, $738 \mathrm{~g}, 738-1,738 \mathrm{x}, 738 \mathrm{y}, 738 \mathrm{z}$.

Cibolo Formation (at Ojo Bonito): USNM 733w, 734a, 734b, 734c, 734d. (Ross Mine Formation) USNM 732z.

Cibolo Formation undivided: USNM $725 \mathrm{x}, 728 \mathrm{n}$.

\section{Literature Cited}

Adams, J. E., and H. N. Frenzel [leaders of field trip]

1952. West Texas Geological Sociely Guidebook: Spring Field Trip, Marathon Basin, Brewster and Pecos Counties, Trans-Pecos, Texas. Pages 26-28. [Figure 22 by Don Meyers.]

Adams, J. E., et al.

1939. Standard Permian Section of North America. American Association of Pelroleum Geologists Bul. letin, 23 (11):1673-1681.
Ager, D. V.

1965. Mcsozoic and Cenozoic Rhynchonellacea. In R. C. Moore, editor, Treatise on Invertebrate Paleontology, H:597-626, figures 478-510.

Aigner, G., and F. Heritsch

1931. Das Genus Isogramma im Carbon der Südalpen. Akademie der Wissenschaften zu Wien, Mathematische-Naturwissenschaftiche Klasse, Denkschriften, 102:303-316, 5 plates. 
Alekseeva, R. E.

1967. Brakhiopody i Stratigrafiia Nizhnego Devona Serero-Vostoka SSSR [Brachiopods and Stratigraphy of the Lower Devonian of Northeastern USSR]. Akad emiya Nauk SSSR Sibirskoe Otdelenie, Institut Geologii $i$ Geofiziki (Moscow), 144 pages, 16 plates.

Bain, R. J.

1967. Paleoecology of Some Leonardian Patch Reefs in the Glass Mountains, Texas. Brigham Young University Geology Studies, 14:195-236, 15 plates.

1971. An Overgrowth Relationship among Permian Fossils from Texas. Journal of Paleontology, 45 (1): 134-136.

Baker, C. L.

1929. Note on the Permian Chinati Series of West Texas. University of Texas Bulletin, 2901:73-84.

Bancroft, B. B.

1928. On the Notational Representation of the Rib-system in Orthacea. Manchester Literary and Philosophical Society Memoirs and Proceedings, $72(5)$ : $53-90,3$ plates.

Barrois, C.

1882. Recherches sur les Terrains Anciens des Asturies et de la Galice. Société Géologique du Nord Memoires, 2:630, 20 plates.

Batten, R. L.

1958. Permian Gastropoda of the Southwestern United States, 2: Pleurotomariacea: Portlockiellidae, Phymatopleuridae, and Eotomariidae. American $\mathrm{Mu}$ seum of Natural History Bulletin, $114(2): 157-246$, plates 32-42.

Bell, W. A.

1929. Horton-Windsor District, Nova Scotia. Canada Geological Survey, Department of Mines and Resources, Memoir, 155: 268 pages, 36 plates.

Biernat, Gertruda

1961. Diorygma atrypophila, n. gen., n. sp. A Parasitic Organism of Atrypa zonata Schnur. Acta Palaeontologica Polonica, 6:17-28.

Bittner, A.

1890. Brachiopoden der Alpinen Trias. Abhandlungen Kaiserlich-Königlichen Geologischen Reichsanstalt, 14: 325 pages, 41 plates.

1893. Neue Koninckiniden des Alpinen Lias. Kaiserlich-königlichen Reichsanstalt, Jahrbuch, 43 (1): 133-144, plate 4.

Boos, M. F.

1929. Stratigraphy and Fauna of the Luta Limestone (Permian) of Oklahoma and Kansas. Journal of Paleontology, 3 (3):241-253, I plate.

Böse, $\mathbf{E}$.

1916. Contributions to the Knowledge of Richthofenia in the Permian of West Texas. University of Texas Bulletin, 55: 50 pages, 3 plates.

1917. The Permo-Carboniferous Ammonoids of the Glass Mountains, West Texas, and Their Stratigraphical Significance. University of Texas Bulletin, 1762: 241 pages, 11 plates.
Bostwick, D. A.

1962. Fusulinid Stratigraphy of Beds near the GaptankWolfcamp Boundary, Glass Mountains, Texas. Journal of Paleontology, 36(6):1189-1200, plates $164-166$.

Bouchard-Chantereaux, N. R.

1849. Mémoire sur un nouveau genre de brachiopode formant le passage des formes articulées à celles qui ne sont pas. Annales des Sciences Naturelles, series 3, Zoologie, 12:84-93, I plate.

Boucot, A. J.

1959. A New Family and Genus of Silurian Orthotetacid Brachiopods. Journal of Paleontology, 33(1):2528 , plate 3 .

Boyd, D. W.

1958. Permian Sedimentary Facies, Central Guadalupe Mountains, New Mexico. State Bureau of Mines and Mineral Resources, New Mexico Institute of Mining and Technology, Bulletin, 49: vi +100 pages, 8 figures, 5 plates.

Branson, C. C.

1930. Paleontology and Stratigraphy of the Phosphoria Formation. University of Missouri Studies Quarterly, 5 (2): 99 pages, 16 plates.

1948. Bibliographic Index of Permian Invertebrates. Geological Society of America Memoir, 26: vii + 1049 pages.

1958. Review of Permian Invertebrate Faunas. Palaeontological Society of India Journals, Lucknow, Birbal Sahni Memorial, 3:103-113.

1966. New Genus of Spiriferoid Brachiopod from Oklahoma. Oklahoma Geological Survey Notes, 26 (3): 74-77, plate 1 .

Brill, K. G.

1940. Brachiopods of the Whitehorse Sandstone. In $\mathrm{N}$. D. Newell, The Invertebrate Fauna of the Late Permian Whitehorse Sandstone. Geological Society of America Bulletin, 51:316-319.

Broili, F.

1916. Die permischen Brachiopoden von Timor. In Ergebnisse der Expeditionen G.A.F. Molengraaff, J. Wanner und F. Weber, VII: 104 pages, 13 plates. Stuttgart.

Brown, Thomas

1849. Illustrations of the Fossil Conchology of Gt. Britain and Ireland. VII: 273 pages. London.

Browne, I. A.

1953. Martiniopsis Waagen from the Salt Range, India. New South Wales Journal, Proceedings, 36(4):100 107.

Brunton, $\mathbf{H}$.

1965. The Pedicle Sheath of Young Productacean Brachiopods. Palaeontology, 7 (4):703-704, plate 109.

Buch, L. von

1835. Ueber Terebrateln. Königliche Akademie der Wissenschaften, Berlin, aus 1833, pages 21-144, 3 plates. 
Campbell, K. S. W.

1953. Fauna of the Permo-Carboniferous Ingelara Beds of Queensland. University of Queensland, Department of Geology, Papers, 4(3):1-44, 4 figures, 7 plates.

1957. A Lower Carboniferous Brachiopod-Coral Fauna from New South Wales. Journal of Paleontology, 31 (1):34-98, 7 plates.

1959a. The Type Species of Three Upper Palacozoic Punctate Spiriferoids. Palaeontology, $1(4): 351-$ 363, plates 58-60.

1959b. The Martiniopsis-like Spiriferids of the Queensland Permian. Palaeontology, 1 (4):333-350, plates 50-57.

1961. New Species of the Permian Spiriferoids Ingelarella and Notospirifer from Queensland, and Their Stratigraphic Implications. Palaeontographica, 117 (A):159-192, 13 figures, plates 23-28, 1 table.

Caneva, G.

1906. Uber die Bellerophonkalkfauna: Zur frage der Perm-Triasgrenzen. Neues Jahrbuch für Mineralogie Abhandlungen (Stuttgart), 1:52-60.

1907. La fauna del calcare a Bellerophon: Contributo alla conoscenza die limiti Permo-Triassici. Societa Geologica Italiana Bolletini, 25 (3):427-452, plate 9.

Chao, Y. T.

1927. Productidae of China, part 1: Producti. Geological Survey of China, Palaeontologia Sinica, series B. 5 (2): 244 pages, 16 plates.

1928. Productidae of China, II: Chonetinae, Productinae and Richthofeniinae. Geological Survey of China, Palaeontologia Sinica, series B, 5(3): 103 pages, 6 plates.

Chronic, B. J.

1949. Brachiopoda. In N. D. Newell, B. J. Chronic, and T. G. Roberts, Upper Paleozoic of Peru, 46-114, plates 5-20. New York, N.Y.: Columbia University.

1953. In N. D. Newell, B. J. Chronic, and T. G. Roberts. Upper Palcozoic of Peru. Geological Society of America Memoir, 58: viii +276 pages, 44 plates.

Clifton, R. L.

1945. Permian Word Formation: Its Faunal and Stratigraphic Correlatives, Texas. American Association of Petroleum Geologists Bulletin, $29(12): 1766-1776$.

Cloud, P. E., Jr.

1942. Terebratuloid Brachiopoda of the Silurian and Devonian. Geological Society of America Special Papers, 38: xii +182 pages, 26 plates.

1944. In R. E. King, C. O. Dunbar, P. E. Cloud, Jr., and A. K Miller, Geology and Paleontology of the Permian Area Northwest of Las Delicias, Southwestern Coahuila, Mexico, Part 1II: Permian Brachiopods. Geological Society of America Special Papers, 52:49_ 69 , plates 17-19.

1952. Facies Relationships of Organic Reefs. American Association of Petroleum Geologists Bulletin, 36 (11):2125-2149.
Cohee, G. V.

1960. Series Subdivisions of Permian System. American Association of Petroleum Geologists Bulletin, 44 (9):1578, 1579.

Coleman, P. J.

1957. Permian Productacea of Western Australia. Department of National Development, Bureau of Mineral Resources, Geology and Geophysics, Bulletin, 40:188, 21 plates.

Conrad, T. A.

1839. Second Annual Report of the Palaeontological Department of the Survey, New York Assembly Document, 275:57-66,

Cooper, G. A.

1942. New Genera of North American Brachiopods. Washington Academy of Sciences Journal, $32(8)$ : 228-235.

1944. Phylum Brachiopoda. In H. W. Shimer, and R. R. Shrock, Index Fossils of North America, 277-365, plates 105-143. New York: John Wiley and Sons.

1952. Unusual Specimens of the Brachiopod Family Isogrammidae. Journal of Paleontology, 26(1):113119, plates 21-23.

1953. Permian Faunal Studies in the Glass Mountains, Texas. In Spring Field Trip to Chinati Mountains, Presidio County, Texas May 28-30, 1953. West Texas Geological Society [Guidebook], pages 70-76.

1956a. New Pennsylvanian Brachiopods. Journal of Paleontology, 30 (3):520-530, plate 61 .

1956b. Chazyan and Related Brachiopods. Smithsonian Miscellaneous Collections, 127: part I (text):xvi+ 1024 pages; part II (plates):1025-1245, 269 plates.

1957a. Permian Brachiopods from Central Oregon. Smithsonian Miscellaneous Collections, 134(12): 79 pages, 12 plates.

1957 b. Paleoecology of Middle Devonian of Eastern and Central United States: Treatise on Marine Ecology and Paleontology. Geological Society of America Menoir, 67 (2):249_278.

1957c. Study of the Wolfcamp and Related Faunas of the Glass Mountains, Texas. In Wolfcamp of the Glass Mountains and the Permian Basin, Permian Basin Section, Society of Economic Paleontologists and Mineralogists, Guidebook, pages 8-12.

1957d. Loop Development of the Pennsylvanian Terebratuloid Cryptacantlia. Smithsonian Miscellaneous Collections, 134 (3): 18 pages, 2 plates.

19:59. Genera of Tertiary and Recent Rhynchonelloid Brachiopods. Smitlisonian Miscellaneous Collections, $139(5)$ : iv +90 pages, 22 plates.

1970. Generic Characters of Brachiopods. In North Anerican Paleontological Convention 1969, Proceedings, Part C:194-263, 5 plates.

Cooper, G.A., C.O. Dunbar, Helen Duncan, A.K. Miller, and J. 13. Knight

1953. Permian Fauna of El Antimonio, Western Sonora, Mexico Smithsonian Miscellaneous Collections, 119 (2): 111 pages, 25 plates. 
Cooper, G. A., and R. E. Grant

1962. Torynechus: New Name for Permian Brachiopod Uncinuloides King. Journal of Paleontology, 36 (5): 1128-1129.

1964. New Permian Stratigraphic Units in Glass Mountains, West Texas. American Association of Petroleum Geologists Bulletin, 48(9):1581-1588, 2 figures.

1966. Permian Rock Units in Glass Mountains, West Texas. United States Geological Survey Bulletin, 1244-E; 9 pages, 2 plates.

1969. New Permian Brachiopods from West Texas. Smithsonian Contributions to Paleobiology, 1: 20 pages, 5 plates.

1970. New Name for Brachiopod Homonym and Citation of Types. Journal of Paleontology, 44 (3):579.

Cooper, G. A., and J. B. Knight

1946. Permian Studies at the Smithsonian Institution, Washington. Journal of Paleontology, $20(6): 625$ 626.

Cooper, G. A., and H. M. Muir-Wood

1951. Brachiopod Homonyms. Washington Academy of Sciences Journal, 41 (6):195-196.

1967. New Names for Brachiopod Homonyms. Journal of Paleontology, 41 (3):808.

Cooper, G. A., and F. G. Stehli

1955. New Genera of Permian Brachiopods from West Texas. Journal of Paleontology, $29(3): 469-474$, plates $52-54$.

Cox, E. T.

1857. A Description of Some of the Most Characteristic Shells of the Principal Coal-seams in the Western Basin of Kentucky. Geological Survey of Kentucky, Third Report, 566-576, 2 plates.

Crickmay, C. H.

1952. Nomenclature of Certain Devonian Brachiopods. 2 pages. Calgary, Canada: published by author.

Cumings, E. R.

1932. Reefs or Bioherms. Geological Society of America Bulletin, 43:331-352.

Cumings, E. R., and R. R. Shrock

1928. Niagaran Coral Reefs of Indiana and Adjacent States and Their Stratigraphic Relations. Geological Survey of America Bulletin, 39:579-620.

Dall, W. H.

1877. Index to the Names Which Have Been Applied to the Subdivisions of the Class Brachiopoda. United States National Museum Bulletin, 8: 88 pages.

Davidson, $T$.

1862. On Some Carboniferous Brachiopoda, Collected in India by A. Fleming, M. D., and W. Purdon, Esq., F.G.S. Geological Society of London, Quarterly Journal, 18:25-35, 2 plates.

1880. A Monograph of British Fossil Brachiopoda. Palaeontographical Society (London), supplement 4, number 3 (Supplement to the Permian and Carboniferous Species): 243-316, plates 30-37.
Dagys, A. S

1968. Yurskie i Rannemelovie brakhiopodi severa Sibiri [Jurassic and Early Cretaceous Brachiopods of Northern Siberia]. Akademiya Nauk SSSR, Trudy Instituta Geologii $i$ Geofiziki, 41: 167 pages, 26 plates.

Derby, O. A.

1874. On the Carboniferous Brachipoda of Itaitúba, Rio Tapajos, Prov, of Pará, Brazil. Cornell University, Science Bulletin, I (2): 63 pages, 9 plates.

Diener, C.

1897a. The Permocarboniferous Fauna of Chitichun Number 1. Geological Survey of Indin Memoirs, Palaeontologia Indica, series 15, 1 (3): 105 pages, 13 plates.

1897b. The Permian Fossils of the Productus Shales of Kumaon and Gurhwal. Geological Suriey of India Memoirs, Palaeontologia Indica, series 15, 1(4): 54 pages, 5 plates.

1899. Anthracolithic Fossils of Kashmir \& Spiti. Geological Survey of India Memoirs, Palaeontologia Indica, series $15,1(2): 95$ pages, 8 plates.

1903. Permian Fossils of the Central Himalayas. Geological Survey of India Memoirs, Palaeontologia Indica, series 15, 1 (5): 204 pages, 10 plates.

1911. Anthracolithic Fossils of the Shan States. Geological Survey of India Memoirs, Palaeontologia Indica, new series, $3(4)$ : 74 pages, 7 plates.

Dittmar, A. von

1872. Ueber ein neues Brachiopoden Geschlecht aus dem Bergkalk. Russische-Kaiserliche mineralogische Gesellschaft, Verhandlungen, St. Petersburg, series 2 , 7: 14 pages, 1 plate.

Douvillé, $\mathrm{H}$.

1909. Sur quelques brachiopodes a test perforé: Syringothyris, Spiriferella, Derbyia. Société Géologique de France, Bulletin, 4th series, 9:144-157, 1 figure, plates $4-5$.

Dresser, $\mathrm{H}$.

1954. Notes on Some Brachiopods from the Itaituba For mation (Pennsylvanian) of the Tapajos River, Brazil. Bulletins of American Paleontology, 35 (149): $15-84,8$ plates.

Dunbar, C. O

1940. The Type Permian: Its Classification and Correlation. American Association of Petroleum Geologists Bulletin, 24 (2):237-281

1941. Permian Faunas: A Study in Facies. Geological Society of America Bulletin, 52:313-332.

1955. Permian Brachiopod Faunas of Central East Green. land. Meddelelser om Grønland, 110 (3): 169 pages, 32 plates.

1958. A Zone of Pseudoschwagerina Low in the Leonard Series in the Sierra Diablo, Trans-Pecos, Texas. American Journal of Science, 251:798-813.

Dunbar, C. O., and G. E. Condra

1932. Brachiopoda of the Pennsylvanian System in $\mathrm{Ne}$ braska. Nebraska Geological Survey, Bulletin, second series, 5: 377 pages, 44 plates. 
Dunbar, C. O., and J. W. Skinner

1937. Permian Fusulinidae of Texas: The Geology of Texas. University of Texas Bulletin, 3701, $3(2)$ : 519-825, figures 89-97, plates, 42-81.

Dunbar, C. O., et al.

1960. Correlation of the Permian Formations of North America. Geological Society of America Bulletin, 71 (12):1763-1805, chart 7 .

Dutro, J. T., Jr.

1955. Occurrence of the Brachiopod Isogramma in the Baird Formation of California. Journal of Paleon. tology, $29(5)$ :920-922.

Dutro, J. T., Jr., and E. L. Yochelson

1961. New Occurrences of Leptodus (Brachiopoda) in the Permian of the Western United States. Journal of Paleontology, 35 (5):952-954, l plate.

Elias, M. K.

1937. Carboniferous and Permian of the Southern Urals. American Journal of Science, 33:279-295.

Elias, M. K., and G. E. Condra

1957. Fenestella from the Permian of West Texas. Geological Society of America Memoir, 70: $\mathrm{x}+158$ pages, 17 figures, 23 plates, 10 tables.

Emmrich, H.

1855. Notiz über den Alpenkalk der Lienzer Gegend. Geologische Bundesanstalt Wien, Jahrbuch, 6:444450 .

Finks, R. M.

1955. Conularia in a Sponge from the West Texas Permian. Journal of Paleontology, 29 (5):831-836, plate 82

1960. Late Paleozoic Sponge Faunas of the Texas Region. American Museum of Natural History Bulletin, 120 (1): 160 pages, 50 plates.

Fischer de Waldheim, G.

1825. Notice sur la Choristite: Programme d'invitation à la Société Impériale des Naturalistes de Moscou. 12 pages, I plate. Moscow.

1829. Quelques fossiles du gouvernement de Moscou. Société Impérial des Naturalistes de Moscou Bulletin, 1 (12):375-376.

1830 [1837]. Oryctographie du gouvernement de Moscou. lst edition, ix +26 pages, 60 plates; 2nd edition, 202 pages, 51 plates. Moscow: A. Semen.

Frebold, H.

1937. Das Festungsprofil auf Spitzbergen, IV: Die Brachiopoden und Lamellibranchiatenfauna und die Stratigraphie des Oberkarbons und Unterperms. In Norges Svalbard- og Ishavs-Unders $\emptyset$ kelser. Skrifter om Stalbard og Ishatet, 69: 94 pages, 11 plates. Oslo.

Frech, F.

1911. Die Dyas. In F, von Richthofen, China, volume 5: Abschliessende Bearbeitung der Sammlungen F. von Richthofens, pages 103-202, plates 19-28. Berlin: D. Reimen.
Fredericks, Georg

1916. Über einige oberpaläozoic Brachiopoden von Eurasien. Comité Géologique Memoires, .156: 87 pages, 5 plates.

1919. Note sur l'Origine de appareil septal Lyttoniinae. Vserossiiskoe Paleontologicheskoe Obshchstvo Ezhe. godnik [Societe Paleontologique de Russie, Annuaire ], 3:108-110.

1924a [1923]. Upper Paleozoic of the Ussuriland, I: Brachiopoda. Materialy po Geologii $i$ Poleznym Iskopaemym Dal'nego Vostoka [Records of the Geological Committee of the Russian Far East], 28: 52 pages.

1924b. O Verkhne-Kamennougol'nykh spiriferidakh Urala [On Upper Carboniferous Spiriferids from the Urals]. Geologicheskogo Komiteta Izvestiya (1919), $38(2): 295-324$.

1924c [1919]. Etudes paléontologiques, 2: Sur les Spiriferides du carbonifère supérieur de l'Oural. Bulle. tins du Comité Géologique (Petrograd), 38 (3):279 324.

1925a [1924]. Upper Paleozoicum of the Ussuriland, 2: Permian Brachiopoda of Cape Kalouzin. Materialy po Geologii $i$ Poleznym Iskopaemym Dal'nego Vostoka [Records of the Geological Committee of the Russian Far East], 40: 28 pages.

1925b. New Lyttoniinae from the Upper Paleozoic of the Oural. Uralskogo Obshchestra Liubitelei Estest. roispytatelei, Sverdlovsk, Zapiski [Société Ouralien des Amis de Science Naturelle, Bulletin], 40 (1): $59-65$.

1926a. Choristiti i Choristito-podobnic spiriferi izh Myatchkova [Choristites and Choristites-like Spirifers from Myatchkova]. Izvestiya Akademii Nauk SSSR [Bulletin of the Academy of Science, USSR] (Leningrad), $20(6): 253-276,2$ plates.

1926b. Tablitsa dlya opredeleniya semeistva Spiriferidae King [Synopsis of the Genera of the Family Spiriferidae King]. Izvestiya Akademii Nauk, SSSR [Bulletin of the Academy of Science, USSR], (Leningrad), 20 (6):393-422.

1927a. New Lyttoniinae from the Upper Carboniferous of Krasnoufimsk. Société Paléontologique de Rus. sie, Annuaire, 6:84-89.

1927b. Der Apikalapparat der Brachiopoda Testicardines (Morphologische Nomenclatur). Neues Jahrbuch für Mineralogie, Geologie und Paläontologie, LVII (B): 11 pages, plate 1.

1932a. Die Fauna des Obercarbons vom Flüsse Köschim. Törove im Petschoraland, Akademia Nauk SSSR, Paleontologicheskii Institut, Trudy, 2:135-185, 3 plates.

1932b. The Upper Paleozoic of the Western Slope of the Ural. Russia, I'sesoiuznoe Geologorazvedochnoe ob'edinenie, Trudy [All-union Geological and Prospecting Institute, Transactions], 106: 91 pages. 
1933. Palaeontological Notes, 4: On Some Upper Paleozoic Brachiopods of Eurasia. Tsentralii Nauchnoissledovatelskii Geologorazvedochnyi Institut SSSR Monografi [Central Geological and Prospecting Institute USSR Monograph], 2:24-33.

Gallitelli, E. M.

1954. Il Permiano del Sosio e i suoi Coralli. Palaeontographica Italica, 49 (new series, volume 19): 98 pages, 10 plates. [Complete list of brachiopods of Sosio Limestone.]

Gatinaud, G.

1948. Position generique de Spirifer canaliferus Lamarck (Brachiopode) et description d'une nouvelle variété. Bulletin du Muséum National d'Historie Naturelle (France), series 2, 20 (2) :201-206, 5 text-figures.

1949. Contributions à l'étude des brachiopodes Spiriferidae, 1: Exposé dune nouvelle méthode d'étude de la morphologie externe des Spiriferidae à sinus plissé. Bulletin du Museum, series 2, 21 (1-4):153159, 300-307, 408-413, 487-492.

Gauri, K. L., and Anton Ramovs

1964. Eolyttonia (Brach.) and Brachymetopus (Tril.) from the Upper Carboniferous (Orenburgian) of Karawanken, Yugoslavia. Neues Jahrbuch für Geologie und Paläontologie Abhandlungen (Stuttgart), $119(1)$ : 103-112.

Geinitz, H. B.

1884. Die Versteinerungen des deutschen Zechsteingebirges. 26 pages, 8 plates. Dresden and Leipzig: Arnoldische Buchhandlung.

Gemmellaro, G. G.

1892. Studi sopra due famiglie di Brachiopodi (Strophomenidae e Productidae) provenienti dei calcari con Fusulina della valle del fiume Sosio nella Provincia di Palermo. Societá di Scienze Naturali ed Economiche di Palermo Bolletini, 3:22-27.

1894. Sopra tre famiglie de Brachiopodi (Spiriferidae, Rhynchonellidae e Terebratulidae) provenienti dei calcari con Fusulina della valle del Fiume Sosio nella provincia di Palermo. Societá di Scienze Naturali ed Economiche di Palermo Bolletini, l: 6 pages.

1897. Sopra due nuovi generi di brachiopodi provenienti dei calcari con Fusulina della provincia di Palermo. Societá di Scienze Naturali ed Economiche di Palermo Giornale, 21:8-10. [Often cited as 1896.]

1899. La fauna dei calcari con Fusulina della Valle del Fiume Sosio nella provincia di Palermo. Societa di Scienze Naturali ed Economiche di Palermo Giornale, 22:95-214, 46 figures, plates 25-36.

Girty, G. H.

1903. The Carboniferous Formations and Faunas of Colorado. United States Geological Survey Professional Paper, 16: 546 pages, 10 plates.

1904. New Molluscan Genera from the Carboniferous. Proceedings of the United States National Museum, 27 (1372):721-736, plates 45-46.
1909 [1908]. The Guadalupian Fauna. United States Geological Survey Professional Paper, 58: 627 pages, 31 plates.

1910. The Fauna of the Phosphate Beds of the Park City Formation in Idaho, Wyoming and Utah. United States Geological Survey Bulletin, 436:3-82, 7 plates.

1920. Carboniferous and Triassic Fauna (of Utah). United States Geological Survey.Professional Paper, 111:641-648, 6 plates.

1927. Descriptions of Carboniferous and Triassic Fossils. In G. R. Mansfield, Geography, Geology and Mineral Resources of Part of Southeastern Idaho. United States Geological Survey Professional Paper, 152: 453 pages, 70 plates, 46 figures.

1929. New Carboniferous Invertebrates, II. Journal, Washington Academy of Sciences, 19(18):406-415, 1 plate.

1931. New Carboniferous Invertebrates, IV. Journal, Washington Academy of Sciences, 24(6):249-266, 1 plate.

Glaus, M.

1964. Trias and Oberperm in zentralen Elburs (Persien). Eclogae Geologicae Helvetiae, 57(1):497-508, 3 plates.

Glenister, B. F., and W. M. Furnish

1961. The Permian Ammonoids of Australia. Journal of Paleontology, 35 (4):673-736, plates 78-86.

Gobbett, D. J.

1963. Carboniferous and Permian Brachiopods of Svalbard. Norsk Polarinstitutt Skrifter, 127: 201 pages, 25 plates.

Gortani, M., and G. Merla

1934. Fossili del Paleozoico: Spedizioni Italiana de Filippi nell'Himalaia etc. (1913-1914). 323 pages, 27 plates. Bologna.

Grabau, A. W.

1931a. The Permian of Mongolia. In Natural History of Central Asia, 4: 665 pages, 72 figures, 53 plates. New York: American Museum of Natural History.

1931b. The Significance of the Sinal Formula in Devonlan and Post-Devonian Spirifers. Geological Survey of China Bulletin, $11(1): 93-96,2$ plates.

1931c. Studies for Students, series 1: Paleontology: The Brachiopoda. National University of Peking, Science Quarterly, 2:235-254, 397-422.

1932. Studies for Students, series 1: Paleontology: The Brachiopoda. National University of Peking, Science Quarterly, 3:75-112, 219-252.

1934. Early Permian Fossils of China, I: Early Permian Brachiopods, Pelecypods and Gastropods of Kueichow. Geological Survey of China, Palaeontologia Sinica, series B, 8 (3): 168 pages, 11 plates.

1936. Early Permian Fossils of China, II: Fauna of the Maping Limestone of Kwangsi and Kueichow. Geological Survey of China, Palaeontologia Sinica, $8(4)$ : 441 pages, 31 plates. 
Grabau, A. W., and Y. T. Chao

1927. Brachiopod Fauna of the Chihsia Limestone. Geological Survey of China Bulletin, 6:83-120.

Grabau, A. W., and H. W. Shimer

1907. North American Index Fossils. 1: 853 pages. New York: A. G. Seiler.

Grant, R. E.

1963. Unusual Attachment of a Permian Linoproduetid Brachiopod. Journal of Paleontology, 37(1):134140, plate 19.

1965a. The Brachiopod Superfamily Stenoscismatacea. Smithsonian Miscellaneous Collections, $148(2): \mathrm{vi}+$ 192 pages, 24 plates.

1965b. Supcrfamily Stenoscismatacea. In R. C. Moore, editor, Treatise on Invertebrate Paleontology, $\mathrm{H}$ : 625-632, figures 511-516.

1966a. A Permian Productoid Brachiopod: Life History. Science, 152 (3722):660-662, 2 figures.

1966b. Spine Arrangement and Life Habits of the Productoid Brachiopod Waagenoconcha. Joumal of $\mathrm{Pa}$ leontology, $40(5): 1063-1069,2$ figures, plates 131132.

1968. Struetural Adaptation in Two Permian Brachiopod Genera, Salt Range, West Pakistan. Joumal of Paleontology, 42 (1): 32 pages, 21 figures, 9 plates.

1970. Brachiopods fiom Pcrmian-Triassic Boundary Beds and Age of Chhidru Formation, West Pakistan. In Kummel, Bernhard, and Curt Teichert, Stratigraphic Boundary Problems: Permian and Triassic of West Pakistan. University of Kansas Special Publication, 4:117-151, 1 figure, 3 plates, 2 tables.

Stehli. l.. G., and R. E. Grant [Ed. note: listed out of order]

1970. Permian Brachiopods from Huehuetenango, Guatemala. Journal of Paleontology, 44(1):23-36, plates 8-13.

1971. Brachiopods in the Permian Reef Environment of West Texas. Proceedings of the North American Paleontological Convention, September, 1969, (J): 1444-1481, 22 figures.

Gray, G. E.

1840. Synopsis of the Contents of the British Museum. 42nd edition, 370 pages. London.

Greco, Benedetto

1938. Revisione degli Strofomenidi Permiani del Sosio conservati nel museo di geologia della $\mathrm{R}$. Universita di Palermo (parte prima). Giornale di Scienze Naturali ed Economiche di Palermo, 39(11): 46 pages, 2 plates.

1942. La fauna Permiana del Sosio, III: Brachiopoda, volume 1: Fam. Orthidae, Strophomenidae. $P a-$ laeontographica Italica, 40:115-159, plates 16-21.

Gregorio, A. de

1930. Sul Permiano di Sieilia (Fossili del ealcare con Fu. sulina di Palazzo Adriano non descritti del Prof. G. Gemmellaro conservati nel mio privato gabinetto). Annales de Geologie et de Palćontologie (Palermo), 52:18-32, plates 4-11.
Grubbs, D. M.

1939. Fauna of the Niagaran Nodules of the Chicago Area. Journal of Paleontology, $13(6): 543-560$, plates 61,62 .

Haack, Wilhelm

1914. Über eine marine Permfauna aus Nordmexiko nebst Bemerkungen über Devon daselbst. Zeitschrift der Deutschen Geologischen Gesellschaft (Berlin), 66 (4): 482-504.

Hall, James

1856. Descriptions and Notices of the Fossils Collected upon the Route. In Whipple's Reconnaisance near the 35th Parallel. United States Thirty-third Congress, Second Session, Senate Execulive Document 78 and House Executive Document 91, 4:99-105.

Hall, James, and J. M. Clarke

1890. Extract. In Palaeontology of New' York, VIII: 120 137, 160 [repaged as 2-20], plates 4E, 4F. Albany, New York.

1892-1895. An Introduction to the Study of the Genera of Palaeozoic Brachiopoda. New York Geological Survey, Palaeontology, 8(1): 367 pages, 20 plates (1892); (2): 317 pages (1893); pages 319-394, plates $21-84$ (1895).

Hall, W. E.

19:56. Marathon Folded Belt in Big Bend Area of Texas. American Association of Petroleum Geologists Bulletin, 40 (9):2247-2255.

Hamada, Tadashi

1964. Notes on the Drifted Nantilus in Thailand. XX1 in Contributions to the Geology and Palacontology of Southeast Asia. University of Tokyo, Scientific Papers of the College of General Education, 14(2): 255-278, 5 plates.

Hamlet, Beata

1928. Permische Brachiopoden, Lamellibranchiaten und Gastropoden von Timor. Jaarhoek ron het Mijmwezen (Dutch East Indies), 56(2): 115 pages, 12 plates.

Harker, Peter, and R. Thorsteinsson

1960. Permian Roeks and Faunas of Grinnell Peninsula. Aretic Archipelago. Geological Survey of Canada Memoir, 309: 89 pages, 25 plates.

Harliček, Vladimir

1956. The Brachioporls of the Branik and Hlubočepy Limestones in the Immediate Vicinity of Prague. Sbomik, Ustredmiho Ustaun Geologického, oddil Paleontologie, 22:653-659.

Hayasaka, Ichiro

1932. On Three Brachiopod Species of the Subfamily Orthotetinae in the Fusulina-limestone of Kinsyôzan, Alasaka-Mati, Prov. Mino, Japan. Tôhoku Imperial University, Faculty of Sciences and Agriculture, Memoir, 6(1), Gcological Series, 2: 7 pages, 2 plates. 
1933. On the Carboniferous Brachiopod Fauna from the Nabeyama Region, Totigi Prefecture, Japan. Tô. hoku Imperial University, Faculty of Sciences and Agriculture, Memoir, 6 (2), Geological Series, 3:9-44, plates 3-14.

1953. Hamletella, a New Permian Genus of Brachiopoda, and a New Species from the Kitakami Mountains, Japan. Paleontological Society of Japan, Transactions and Proceedings, new series, (12):89-95, plate 9.

Hayasaka, Ichiro, and S. Hayasaka

1953. Fossil Assemblages of Molluscs and Brachiopods of Unusually Large Size from the Permian of Japan. Paleontological Society of Japan, Transactions and Proceedings, (10):37-44, plate 5.

Hayes, P. T.

1964. Geology of the Guadalupe Mountains, New Mexico. United States Geological Survey Professional Paper, 446: iv +69 pages, 19 figures, 3 plates.

Heritsch, Franz

1927. Materialen zur Kenntnis des Karbons der Karnischen Alpen und der Karawanken Akademie der IVissenschaften in Wien, Mathematische-naturwissenschaftliche Klasse Situngsberichte, part I, 136(7): 295-332, 6 figures, 3 plates.

Herrmannsen, A. N.

1846. Indices generum Malacozoorum Primordia. 1: 637 pages. Kassel, Germany.

Hill, Dorothy

1950. The Productidae of the Artinskian Cracow Fauna of Queensland. University of Queensland Papers, 3 (2): 36 pages, 9 plates.

Hill, R. T.

1901. Physical Geography of the Texas Region. In United States Geological Survey, Topographic Atlas of the United States, folio 3: page 4.

Hoare, R. D.

1961. Desmoinesian Brachiopoda and Mollusca from Southwest Missouri. University of Missouri Studies, 36: $x$ iii +262 pages, 23 plates.

Huang, T. K.

1932. Late Permian Brachiopoda of Southwest China. Geological Survey of China, Palaeontologia Sinica, series $B, 9(1)$ : 138 pages, 9 plates.

1933. Late Permian Brachiopoda of Southewestern China, part II. Geological Survey of China, Palaeontologin Sinica, series B, $9(2)$ : 172 pages, 11 plates.

1936. On the Occurrence of Lyttonia in the Wolfcamp Series of the Glass Mountains of Texas with Notes on Lyttonids from South-west China. Geological Survey of China Bulletin, 14:489-496, 1 plate.

Hudson, R. G. S., and Sudbury, M.

1959. Permian Brachiopoda from Southeast Arabia. Notes et Mémoires sur le Moyen-Orient, VII:19-55, 6 plates.

Imbrie, John

1959. Brachiopods of the Traverse Group (Devonian) of Michigan, part 1: Dalmanellacea, Pentameracea, Strophomenacea, Orthotetacea, Chonetacea and
Productacea. American Museum of Natural History Bulletin (New York), $116(4): 345-409$, plates 38-67.

Ivanov, A. P.

1925. Sur la systématique et la biologie du genre Spirifer et de quelques brachiopodes de $\mathrm{C}_{11}$ et $\mathrm{C}_{111}$ du Gouvernement de Moscou. Moskovskoe Obshchestvo Ispytatelei Prirody, Otdel Geologicheskii [Société des Naturalistes de Moscou Bulletin], new series, 33:105-123.

1935. Brachiopods of the Middle and Upper Carboniferous of the Moscow Basin, part 1: Productidae Gray. Moskouskogo Geologicheskogo Tresta, Trudy, 8: 134 pages, 15 plates.

Ivanova, E. A.

1949. Usloviya sushchestvovaniya, obraz zhizni i istorya razvitiya nektorikh brakhiopod srednego i verkhnego Karbona Podmoskovnoi Kotlovini [Ecology, Life History and Development of Certain Brachiopoda of the Middle and Upper Carboniferous of the Moscow Basin]. Akademia Nauk SSSR, Trudy Paleontologicheskogo Instituta, 21: 144 pages, 20 plates.

1951. New Data on Productid Systematics (Genus Kutorginella). Akademia Nauk SSSR, Doklady, 77:329331.

Jarvis, Daniel

1957. Correlation of the Basal Permian Beds of the Western Glass Mountains. In Wolfcamp of the Glass Mountains and the Permian Basin, Permian Basin Section, Society of Economic Paleontologists and Mineralogists, Guidebook, 4-7.

Jux, Ulrich, and Friederich Strauch

1966. Die Mitteldevonische Brachiopodengattung Uncites DeFrance 1825. Palaeontographica, 125(A): 176-222, plates 21-25.

Kaiser, H. E.

1964. Pathological Conditions of the Soft Parts in a Devonian Brachiopod Species Stropheodonta. Neues Jahrbuch für Mineralogie, Geologie, und Paläontologie (Stuttgart), 4:196-198.

Keyser, E.

1883. Obercarbonische Fauna von Loping. In von Richthofen, China, 4:160-208, plate 21.

Keyserling, A. G.

1846. Geognostiche Beobachtungen. In A. G. Keyserling and $\mathbf{P}$. von Krusenstern, Wissenschaftliche Beobachtungen auf einer Reise in das Petschora-Land im Jahre 1843, pages 151-336, 22 plates. St. Petersburg: Carl Kray.

Keyte, I. A.

1929. Correlation of Pennsylvanian-Permian of Glass Mountains and Delaware Mountains. American Association of Petroleun Geologists Bulletin, $13(8)$ :903-906.

Keyte, I. A., W. G. Blanchard, Jr., and H. L. Baldwin, Jr. 1927. Gaptank-Wolfcamp Problem of the Glass Mountains. Journal of Paleontology, 1 (2):175-178, plate 81. 
Kier, P. M

1958. Permian Echinoids from West Texas. Journal of Paleontology, 32 (5):889-892, plate 114.

1965. Evolutionary Trends in Paleozoic Echinoids. Jouk nal of Paleontology, $39(3): 453-456$, plate 55.

King, P. B.

1926. The Geologic Structure of a Portion of the Glass Mountains of West Texas. American Association of Petroleum Geologists Bulletin, 10(9):877-884, map.

1927. The Bissett Formation, a New Stratigraphic Unit in the Permian of West Texas. American Journal of Science, 5th Series, 14:212-221, map.

1931[1930]. The Geology of the Glass Mountains, Texas, part 1: Descriptive Geology. University of Texas Bulletin, 3038: 167 pages, 15 plates, map.

1932. Limestone Reefs in the Leonard and Hess Formations of Trans-Pecos, Texas. American Journal of Science, 24 (143):337-354.

1934. Permian Stratigraphy of Trans-Pecos Texas. Geological Society of America Bulletin, 45:697-798, 13 figures, plates 103-107.

1935. Outline of Structural Development of Trans-Pecos, Texas. American Association of Petroleum Geologists Bulletin, $19(2): 221-261$.

1938[1937]. Geology of the Marathon region, Texas. United States Geological Survey Professional Paper, 187: ix +148 pages, 33 figures, 24 plates.

1942. Permian of West Texas and Southeastern New Mexico. American Association of Petroleum Geologists Bulletin, $26(4): 533-763,2$ plates.

1947. Permian Correlations. American Association of Petroleum Geologists Bulletin, $31(4): 776-777$.

1948. Geology of the Southern Guadalupe Mountains, Texas. United States Geological Survey Professional Paper, 215: 183 pages, maps.

1965. Geology of the Sierra Diablo Region. United States Geological Survey Professional Paper, 480: $\mathrm{vi}+185$ pages, maps.

King, P. B., and R. E. King

1929[1928]. The Pennsylvanian and Permian Stratigraphy of the Glass Mountains. University of Texas Bulletin, 2801:109-145, plate 1.

King, P. B., and N. D. Newell

1956. McCombs Limestone Member of Bell Canyon For. mation, Guadalupe Mountains, Texas. American Association of Petroleum Geologists Bulletin, 40 (2): 386-387.

King, R. E.

1931 [dated 1930]. The Geology of the Glass Mountains, part 2: Faunal Summary and Correlation of the Permian Formations with Description of Brachiopoda. University of Texas Bulletin, 3042: 245 pages, 5 figures, 44 plates.

1934. The Permian of Southwestern Coahuila, Mexico, American Journal of Science, 5th Series, $27(158)$ : 98-112.
King, R. H.

1938. New Chonetidae and Productidae from Pennsylvanian and Permian Strata of North-Central Texas. Journal of Paleontology, 12 (3):257-279, 4 plates.

King, Wiliiam

1844. On a New Genus of Palaeozoic Shells. Annals and Magazine of Natural History (London) 14(92): 312.

1850. A Monograph of the Permian Fossils of England. Palaeontographical Society Monograph, 3: xxxvii + 258 pages, 29 plates.

1856. Notes on Permian Fossils. Annals and Magazine of Natural History (London), 17 (21):258_269, 333341 , plate 12.

1859. On Gwynia, Dielasma and Macandrevia, Three New Genera, etc. Dublin Zoological and Botanical Association, Proceedings, 1 (3):256-262.

1865. Remarks on the Histology of Two Specimens of Rhynchopora geinitziana deVerneuil, from near the River Oukhla, Province of Archangel. Annals and Magazine of Natural History (London), series 3, $16: 124-128$.

Knight, J. B.

1940. Are the "Omphalotrochus Beds" of the U.S.S.R. Permian? American Association of Petroleum Geologists Bulletin, $24(6): 1128-1133$.

Konishi, Kenji, and J. L. Wray

1961. Eugonophyllum, a New Pennsylvanian and Permian Algal Genus. Journal of Paleontology, 35 (4): 659-666, plate 75 .

Kotlyar, G. V.

1961. The Genus Yakovlevia Fredericks. Doklady Akademia Nauk SSSR, 140(2):459-460, 3 figures.

Kozlowski, Roman

1914. Les Brachiopodes du Carbonifère Supérieur de Bolivie. Annales de Paléontologie (Paris), 9:3-97, 11 plates.

1929. Les Brachiopodes Gothlandien de la podolie Polonaise. Palaeontologia Polonica, 1: xiii +253 pages, 12 plates.

Krumbein, W. C., L. L. Sloss, and E. C. Dapples

1949. Sedimentary Tectonics and Sedimentary Environments. American Association of Petroleum Geologists Bulletin, 33 (11):1859-1891

Kühn, O.

1949. Lehrbuch der Paläozoologie. 326 pages, 224 figures. Stuttgart. [Brachiopods on pages 94-106.]

Kummel, Bernhard, and Curt Teichert

1966. Relations between the Permian and Triassic Formations in the Salt Range and Trans-Indus Ranges, West Pakistan. Neues Jahrbuch für Geologie und Paläontologie, 125 (Schindewolf Festschrift):297-333, 4 figures, plates 27, 28.

Kutorga, S. S.

1842. Beitrag zur Paläontologie Russlands. Verhandlungen der Russisch-Kaiserlichen Mineralogischen Gesellschaft zu St. Petersburg, 34 pages, 6 plates. 
1844. Zweiter Beitrag zur Paläontologie Russlands. Ver. handlungen der Russich-Kaiserlichen Mineralogischen Gesellschaft zu St. Petersburg, 4:62-104, 10 plates.

Lamont, A.

1935. The Drummock Group, Girvan: A Stratigraphical Revision, with Descriptions of New Fossils from the Lower Part of the Group. Geological Society of Glasgow, Transactions, 19 (2):288-334, plates 7-9.

Land, L. S., and Goreau, T. F.

1970. Submarine Lithification of Jamaican Reefs. Journal of Sedimentary Petrology, $40(1): 457-462$.

Lang, W. B.

1937. The Permian Formations of the Pecos Valley of New Mexico and Texas. American Association of Petroleum Geologists Bulletin, $21(7): 833-898$.

Licharew, B. K.

1913. Die Fauna der permischen Ablagerungen aus der Umgebung der Stadt Kirilov. Trudy Geologicheskago Komiteta, Russia, new series, 85: 99 pages, 5 plates.

1925. Zur frage über das alter der Perm-Kalksteine der Onega-Dwina Wasserscheide. Russisch-Kaiserlich Mineralogische gesellschaft, Leningrad Verhandlungen, series 2, 54(1):109-152, plates 1-2.

1928. Uber einige seltene und neue Brachiopoden aus dem Unterperm des nördlichen Kaukasus. Paläontologische Zeitschrift, 10:258-259, plate 5 .

1930. To the Classification of the Upper Paleozoic Representatives of the Subfamily Orthotetinae Waagen. Annuaire de la Societe Paléontologique de Russie 1928-29 [Russkogo Paleontologicheskogo Obshchestva, Ezhegodnik], 8:117-139, 2 figures.

1931. Uber eine problematische Brachiopode aus dem unterpermischen Ablagerungen des nördlichen Kaukasus. Société Paleontologique de Russie, Annuaire, 9:157-161.

1932. Fauna of the Permian Deposits of Northern Caucasus, I: Brachiopod Subfamily Orthotetinae (Waagen). Vsesoyuoznogo Geologo-Razvedochnogo Obedineniya SSSR, Trudy, 215: 54 pages.

1934a. On Some New Genera of Upper Paleozoic Brachiopods. Academie des Sciences URSS, Comptes Rendus, new series, $1(4): 210-213$.

1934b. Die fauna der Permischen Ablagerungen des Kolyma-gebietes [Fauna Permiskisch Kolymiskogo kraya]. Akademia Nauk SSSR, Trudy, Yakut, series $14(2)$ : 148 pages, 11 plates.

1935. Bemerkungen über einige oberpälaozoischer Brachiopoden. Zentralblatt für Mineralogie, Geologie und Pälaontologie, part B, 9:369-373.

1936. Some Uncommon Upper Paleozoic Brachiopods. Moskovskogo Obshchestio Ispytateley Prirody [Societe des Naturalistes de Mouscou] Bulletin, series geologique, $14(2): 133-158$, plates a-c.

1937. Permian Brachiopods of North Caucasus, Families: Chonetidae Hall and Clarke and Productidae Gray. Tsentralii Nauchno-issledovatelskii Geolo- gorazvedochnyi Institut SSSR [Central Geological and Prospecting Institute USSR Monograph], Monografi (Leningrad, Moscow), $39(1)$ : 151 pages, 13 plates.

1947. O novom podrode Muirwoodia roda Productus, Sow. s. 1. [On a New Subgenus Muirwoodia of the Genus Productus, Sow. s. 1.]. Akademyia Nauk SSSR, Doklady, 57 (2):187-190.

1964. Richthofenidae from the Permian of Southern Primor. Trudy Vsesoyuzhnogo Nauchno-Issledovatelskogo Geologicheskogo Institut [VSEGEI] (Leningrad), new series, 93:113-121, 2 plates.

1965. Neskolko zamechanii po pobody stati T. G. Sarychevoi "Oldhaminoidnic brakhiopodi iz Permi Zakavkazya" [Some Notes Apropos of T. G. Sarycheva's Article "Oldhaminoid Brachiopods from the Permian of Transcaucasia"]. Paleontologicheskii Zhurnal, 2:149-150.

Licharew, B. K., editor

1939. The Atlas of the Leading Forms of the Fossil Fauna of the USSR. Tsentralii Nauchno-issledovatekskii Geologorazvedochnyi Institut SSSR, (Leningrad), 6: 267 pages, 56 plates.

Licharew, B. K., and O. L. Einor

1939. Materiali k poznaniyo Verkhnepaleosoiskikh faun Novoi Zemli Brachiopoda [An Understanding of the Upper Paleozoic Faunas of Nova Zemlya, Brachiopoda]. Paleontologiya Sovietskoi Arktiki, r'ipusk t, Trudy Arklicheskogo Nauchno-Issledovatelskogo Instituta, 127: 245 pages, 28 plates.

Logan, Alan

1966. The Upper Paleozoic Productoid Brachiopod Horridonia timanica (Stuckenberg) and Its Close Relatives. Leeds Geological Association, Transactions, 8 (4):193-210, 1 figure.

Maillieux, Eugene

1939. La Faune des schistes de Barvaux-sur-Ourthe (Frasnien supéricur) de la Belgique. Musée Royal d'Histoire naturelle de Belgique, Bulletin, $15(53)$ : 8 pages.

Martin, William

1809. Petrifacta Derbyensia: Figures and Descriptions of Petrifactions Collected in Derbyshire. ix +28 pages, 52 plates. London: D. Lyon.

Marcou, Jules

1858. Geology of North America, with Two Reports on the Prairies of Arkansas and Texas, the Rocky Mountains of New Mexico, and the Sierra Nevada of California. 144 pages. Zurich.

McCunn, H. J., and R. D. Walker

1962. Geologic Relationships between Outcrops of the Diablo Plateau Region and the Subsurface of the Permian Basin of West Texas. In Society of Economic Paleontologists and Mineralogists, Permian Basin Section, Guidebook: Leonardian Facies of the Sierra Diablo Region, West Texas, 62-7:91103. 
McKee, E. D.

1936. In A. A. Stoyanow, Correlation of Arizona Paleozoic Formations. Geological Society of America Bulletin, 47 (4):459-540, 1 plate.

1938. The Environment and History of the Toroweap and Kaibab Formations of Northern Arizona and Southern Utah. Carnegie Institute of Washington Publication, 492: viii +268 pages, 51 plates.

Meek, F. B.

1860. Descriptions of New Fossil Remains Collected in Nebraska and Utah by the Exploring Expeditions under the Command of Capt. J. H. Simpson. Academy of Natural Sciences of Philadelphia, pages 308-315.

1864. Description of the Carboniferous Fossils. California Geological Survey, 1: 16 pages.

1871. Descriptions of New Species of Fossils from Ohio and Other Western States and Territories. Academy of Natural Sciences of Philadelphia, Proceedings, 23 (2):159-184.

1872[dated 1871]. Report on the Paleontology of Eastern Nebraska. In F. V. Hayden, United States Geological Survey of Nebraska, Final Report, United States, 42nd Congress, Ist Session, House Executive Document, 19:83-239, 10 plates.

1877. Paleontology. In Clarence King, United States Geological Exploration of the Fortieth Parallel, 4: 50 pages.

Meek, F. B., and A. H. Worthen

1870. Descriptions of New genera and Species of Fossils from the Paleozoic of the Western States. Academy of Natural Sciences of Philadelphia, Proceedings, 22-56.

Mendes, J. C.

1956. Orthotetacea e Dalmanellacea do Carbonifero superior do Rio Tapajós (Serié Itaitúba). Sociedade Brasileira de Geologia, Boletim, 5(1):11-38, 4 plates.

Menke, C. T.

1828. Synopsis methodica molluscorum generum omnium et specierum earum quae in Museo Menkeano adservantur. 91 pages. Pyrmonti.

Merla, Giovanni

1928. Contributo alla conoscenza della fauna dei caleari a Schwagerina della Valle del Sosio (Prov, di Palermo). Atti della Società Toscana di Scienza Naturali Mémoir (Pisa), 38:70-88, plate 2.

1930. La fauna del Calcare a Bellerophon della Regione Dolomitica. Instituto Geologico della Universita di Padova, Memoir, 9: 221 pages, 11 plates.

1934. Fossili anthracolitici del Caracorum. In spedizione italiana de Filippi nell'Himálaia Caracorum e Turchestan Cinese (1913-1914) (Bologna), series 2, 5:101-319, plates 20-27.

Miller, A. K.

1930. A New Ammonoid Fauna of Late Paleozoic Age from Western Texas. Journal of Paleontology', $4(4): 383-412,2$ plates.
1938. Age of the Permian Limestones of Sicily. American Journal of Science, 5th series, 26(154):409-427.

1938. Comparison of Permian Ammonoid Zones of Soviet Russia with Those of North America. American Association of Petroleum Geologists, Bulletin, $22(8): 1014-1019$.

1945a. Some Exceptional Permian Ammonoids from West Texas. Journal of Paleontology, 19(1):14-21, plates $7,8$.

1945b. Permian Nautiloids from the Glass Mountains and the Sierra Diablo of West Texas. Journal of Paleontology, 19 (3):282-294, plates 44, 45.

Miller, A. K., and W. M. Furnish

1940. Permian Ammonoids of the Guadalupe Mountain Region and Adjacent Areas. Geological Society of America Special Papers, 26:10+242, 59 figures, 44 plates, 6 tables.

1957. Ammonoids of the Basal Word Formation, Glass Mountains, West Texas. Journal of Paleontology, $31(6): 1052-1056$, plate 133.

Miller, A. K., and H. F. Garner

1953. Permian Ammonoid Zones of the West Texas Region. In Spring Field Trip to Chinati Mountains, Presidio County, Texas May 28-30, 1953. West Texas Geological Society [Guidebook], pages 6469.

Miller, A. K., and W. L. Youngquist

1947. Mollusca: Lower Permian Cephalopods from the Texas Colorado River Valley. University of Kansas Paleontological Contributions, 2(1): 15 pages, 3 plates.

1949. American Permian Nautiloids. Geological Society of America Memoir, 41: viii +218 pages, 39 figures, 59 plates.

Miloradovitch, B. V.

1935. Materials to the Study of the Upper Paleozoic Brachiopoda from the Northern Island of Novaya \%.cmlya. I'sesoiuzhyi Arkticheskii Instituta USSR (Leningrad), 19: 167 pages, 6 plates.

1936a. Lower Permian Fauna from the Island Mezhdusharsky [Southern Island of Novaya Zemlya]. Transactions of the Arctic Institute, Leningrad, USSR, 37:37-82, 4 plates.

1936b. Some Spiriferidae from the Middle and Upper Carboniferous of Timan. Transactions of the Arctic Institute, Leningrad, USSR, 30:4-65, 6 plates.

Moore, R. C.

1940. Carboniferous-Permian Boundary. American Association of Petroleum Geologists Bulletin, 24 (2): 282-336.

Moore, R. C., et al.

1944. Correlation of the Pennsylvanian Formations of North America. Geological Society of America Bulletin, 55:657-706, chart.

Muir-Wood, H. M.

1955. A History of the Classification of the Phylum Brachiopoda. viii +124 pages. London: British Museum (Natural History). 
1962. On the Morphology and Classification of the Brachiopod Suborder Chonetoidea. vii + 132 pages, 24 figures, 16 plates. London: British Museum (Natural History).

Muir-Wood, H. M., and G. A. Cooper

1960. Morphology, Classification and Life Habits of the Productoidea (Brachiopoda). Geological Society of America Memoir, 81: 447 pages, 135 plates.

1967. New Names for Brachiopod Homonyms. Journal of Paleontology, 41 (3):808.

Nelson, S. J., and C. E. Johnson

1968. Permo-Pennsylvanian Brachythyrid and Horridonid Brachiopods from the Yukon Territory, Canada. Journal of Paleontology, 42 (3):715-746, 13 figures, plates 90-96.

Netschajew, A. W.

1911. Die fauna der Perm-ablagerungen vom osten und vom aeussersten norden des Europaeischen Russ. lands, 1: Brachiopoda Russia. Memoires du Comité Géologique, St. Pétersbourg, new series, 61: 164 pages, 15 plates.

Newberry, J. S.

1861. Geological Report, Paleontology. In J. C. Ives, Report upon the Colorado River of the West. United States 36th Congress, Senate Executive Document and House Document 90, part 3:116-132, 2 plates.

Newell, N. D.

1934. Some Mid-Pennsylvanian Invertebrates from Kansas and Oklahoma: Fusulinidae, Brachiopoda. Journal of Paleontology, 8 (4):422-432, plates 52-55.

1940. Invertebrate Fauna of the Late Permian Whitehorse Sandstone. Geological Society of America Bulletin, 51:261-335.

1955. Depositional Fabric in Permian Reef Limestones. Journal of Geology, 63 (4):301-309.

1957. Paleoecology of the Permian Reefs in the Guada. lupe Mountains Area. Geological Society of America Memoir, 67:407-436.

Newell, N. D., and D. W. Boyd

1970. Oyster-like Permian Bivalvia. American Museum of Natural History Bulletin, 143 (4):217-282, 34 figures, 6 tables.

Newell, N. D., J. Chronic, and T. G. Roberts

1949. Upper Paleozoic of Peru. 241 pages. New York: Columbia University.

1953. Upper Paleozoic of Peru. Geological Society of America Memoir, 58:1-276, 44 plates.

Newell, N. D., J. K. Rigby, A. G. Fischer, A. J. Whitcman,

J. E. Hickox, and J. S. Bradley

1953. The Permian Reef Complex of the Cundalup' Mountains Region, Texas and New Mexico - A Study in Paleoecology. xix +236 pages. San Francisco, Calif.: W. H. Freeman and Co.

North, F. J.

1920. On Syringothyris Winchell and Certain Carboniferous Brachiopoda Referred to Spiriferina d'Orbigny. Geological Society of London, Quarterly' Journal, 76 (2):162-227, plates 11-13.
Norwood, J. G., and H. Pratten

1855. Notice of Fossils from the Carboniferous of the Western States, Belonging to the Genera Spirifer, Bellerophon, Pleurotomarin, Macrocheilus, Natica, and Loxonema, with Descriptions of Eight New Characteristic Species. Academy of Natural Sciences of Philadelphia, Journal, series 2, $3(8): 71-77$, plate 9 .

Oehlert, D. P.

1887. Brachiopodes. In P. Fischer, Manuel de Conchyliologie, 11:1190-1334, figures 892-1138.

1888. Descriptions de quelques espèces dévoniennes du le départment de le Mayenne. Societé études science d'Angers, 17:65-120 [Brachiopoda: pages 99-103].

1890. Notes sur différentes groupes établis dans le genre Orthis et en particulier sur Rhipidomella Oehlert (=Rhipidomys Oehlert, olim). Journal de Conchiliologie, series 3, 30:366-374.

Öpik, A. A.

1933. Über Plectamboniten. Tartu University (Dorpat), Acta et Commentationes, series A, $24(7): 79$ pages, 12 plates.

1934. Über Klitamboniten. Tartil University (Dorpat), Acta et Commentationes, series A, 26 (3): 239 pages, 48 plates.

d'Orbigny, Alcide

1842. Voyages dans l'Amérique méridionale. Paléontologie 3:50-56, plates 3-5. Paris: Pitois-Levrault et Cie.

Oriel, S. S., D. A. Myers, and E. J. Crosby

1969. In McKee, et al., Paleotectonic Investigation of the Permian System in the United States. United States Geological Survey Professional Paper, 515: xvi +271 pages [West Texas Permian Basin Region: 21-60], maps.

Ozaki, K.

1931. Upper Carboniferous Brachiopods of North China. Shanghai Science Institute Bulletin, I (6): 205 pages, 15 plates.

Ozawa, Y.

1927. Stratigraphical Studies of the Fusulina Limestone of Akasaka, Province of Mino. Faculty of Science, Imperial University of Tokyo, Journal, section II, 2 (3): 121-164, plates 34-46.

Paeckelmann, W.

1930. Die Brachiopoden des deutschen Unterkarbons, I. Preussischen Geologischen Landesanstalt, Abhandlungen, new series, 122: 326 pages, plates 9-24.

Pajaud, Daniel

1968. La néotenie chez Thécidées (Brachiopodes). Comptes Rendus l'Académie Science de Paris, series D, 267 (2):156-159.

Pittman, J. S., Jr.

1959. Silica in Edwards Limestone, Travis County, Texas. Silica in Sediments: Symposium. Society of Economic Paleontologists and Mineralogists, Special Publication, 7:121-134. 
Pitrat, C. W.

1965. Spiriferidina. In R. C. Moore, editor, Treatise on Invertebrate Paleontology, $\mathrm{H}: 667-728$, figures 543593.

Plummer, F. B., and Gayle Scott

1937. Upper Paleozoic Ammonites in Texas. In The Geology of Texas. University of Texas Bulletin, 3701, 3 (1): 516 pages, 41 plates.

Ramsbottom, W. H. C.

1952. The Fauna of the Cefn Coed Marine Band in the Coal Measures at Aberbaiden, near Tondu, Glamorgan. United Kingdom Geological Survey Bulletin (London), 4:8-32, plates 2, 3.

Raymond, P. E.

1911. The Brachiopoda and Ostracoda of the Chazy. Carnegie Museum, Annals, 7 (2):215-259.

Reed, F. R. C.

1944. Brachiopoda and Mollusca from the Productus Limestones of the Salt Range. Geological Survey of India Memoirs, Palaeontologia Indica (Calcutta), new series, XXIII (2): $x i v+678$ pages, 65 plates.

Reimann, I. G.

1945. Real and Simulated Color Patterns in Meristella Buffalo Society of Natural Science, Bulletin, 19 (2): 10-15, 1 plate.

Richter, Rudolf

1919. Zur Färbung fossiler Brachiopoden. Senckenbergiana, $1(3): 83-96$.

Rigby, J. K.

1958. Mass Movements in Permian Rocks of Trans-Pecos, Texas. Journal of Sedimentary Petrology, 28(3): 298-315, 14 figures.

Rix, C. C.

1953a. Geology of Chinati Peak Quadrangle, Presidio County, Trans-Pecos, Texas. University of Texas: Ph.D. dissertation.

1953b. Geology of the Chinati Mountain Quadrangle. In Spring Field Trip to Chinati Mountains, Presidio County, Texas May 28-30, 1953. West Texas Geological Society [Guidebook], pages 1-22, map.

Rodda, P. U., and W. L. Fisher

1962. Upper Palcozoic Acrothoracic Barnacles from Texas. Texas Journal of Science, 14(4):460_479.

Ross, C. A.

1959. The Wolfcamp Series (Permian) and New Species of Fusulinids, Glass Mountains, Texas. Journal of the Washington Academy of Sciences, $49(9): 299$ 316,4 plates.

1960. Fusulinids from the Hess Member of the Leonard Formation, Leonard Series (Permian), Glass Moun. tains, Texas. Contributions from the Cushman Foundation for Foraminiferal Research, 11 (4):117133, plates 17-21.

1962a. Permian Tectonic History in Glass Mountains, Texas. American Association of Petroleum Geologists, Bulletin, 46 (9):1728-1746.

1962b. Fusulinids from the Leonard Formation (Permian), Western Glass Mountains, Texas. Con- tributions from the Cushman Foundation for Fora. miniferal Research, 13(1): 21 pages, 6 plates.

1963a. Standard Wolfcampian Series (Permian), Glass Mountains, Texas. Geological Society of America Memoir, 88: vii +205 pages, 11 figures, 29 plates.

1963b. Fusulinids from the Word Formation (Permian), Glass Mountains, Texas. Contributions from the Cushman Foundation for Foraminiferal Research, $14(1)$ :17-31, plates 3-5.

1965. Late Pennsylvanian Fusulinidae from the Gaptank Formation, West Texas. Journal of Paleontology, 39 (6):1151-1176, plates 141-145.

1967. Stratigraphy and Depositional History of the Gaptank Formation (Pennsylvanian), West Texas. Geological Society of America Bulletin, 78:369-384, 4 plates.

Ross, C. A., and S. Oana

1961. Late Pennsylvanian and Early Permian Limestone Petrology and Carbon Isotope Distribution, Glass Mountains, Texas. Journal of Sedimentary Petrol ogy, 31 (2):231-244, 4 figures, 2 plates.

Ross, C. A., and J. P. Ross

1963a. Pennsylvanian, Permian Rugose Corals, Glass Mountains, Texas. Joumal of Paleontology, $36(6): 1163-1188$, plates $160-163$.

1963b. Late Paleozoic Rugose Corals, Glass Mountains, Texas. Journal of Paleontology, $37(2): 409-420$, plates $48-50$.

Rotai, A. P.

1951. Brachiopodi srednogo karbona Donetzkogo Basseina, Chast 1: Spiriferidae [Brachiopoda of the Middle Carboniferous of the Donetz Basin, part 1: Spiriferidae]. Trudly Vsesoyuzhnogo Nauchno-1ssledovatelskogo Geologicheskogo Institut [ISEGEI] (Moscow), 178 pages, 25 plates, 2 tables.

1952. Brachiopody srednego karbona Donetzkogo Basseina, chast 2: Marginifera [Brachiopods of the Middle Carboniferous of the Donetz Basin, part 2: Marginifera]. Trudy Vsesoyuzhnogo NauchnoIssledovatelskogo Geologicheskogo Institut [VSEGEI] (Moscow), 76 pages, 6 plates, 3 tables.

Rothpletz, August

1892. Die Perm-, Trias-, und Jura- Formation auf Timor und Rotti im indischen Archipel. Palacontographica, 39:57-106, plates 9-14.

Rudwick, M. J. S.

1961. The Feeding Mechanism of the Permian Brachiopod Prorichthofenia. Palaeontology, 3(4):450-471, plates $72-74$.

1964. The Function of Zigzag Deflections in the Commissures of Fossil Brachiopods. Palaeontology, 7 (1):135-171, plates 21-29.

1968. Some Analytic Methods in the Study of Ontogeny in Fossils with Accrctionary Skeletons. In Paleobiological Aspects of Growth and Development, a Symposium. Paleontological Society Memoir 2, Journal of Paleontology', 42 (Supplement to 5, part II of II):35-49, 17 figures. 
Rudwick, M. J. S., and R. Cowen

1968[dated 1967]. The Functional Morphology of Some Aberrant Strophomenide Brachiopods from the Permian of Sicily. Bolletino della Societa Palaeontologia Italiana, 6(2):113-176, 29 figures, plates 32-43.

Ruzhentsev, V. E.

1950. Upper Carboniferous Ammonites of the Urals. Akademyia Nauk SSSR, Trudy Paleontologiches. kogo Instituta, 29: 223, pages.

Ruzhentsev, V. E., and T. G. Sarycheva

1965. Razvitie i Smena Morskikh organizmov na Rubezhe Paleozoia I Mesozoia [Development and Alteration of Marine Organisms at the Paleozoic-Mesozoic Boundary]. Akademyia Nauk SSSR, Trudy $\mathrm{Pa}$. leontologicheskogo Instituta, volume 108, [Brachiopods: pages 198-253].

Rzhonsnitskaya, M. A.

1956a. Semeystvo Pentameridae i sem. Camarotoechiidae [Family Pentamerdae and Fam. Camarotoechiidae]. In V. K. Khalfina, Atlas Rukovodyashchikh Form iskopaemykh fauny i flory zapadnoy Sibirii [L. L. Khalfin, editor, Atlas of Leading Fossil Forms of Fauna and Flora of Western Siberia], 1: 502 pages, 85 plates; 2: 320 pages. Zapadno-Sibirskoe Geologicheskoe Upravlenie Tomskii Politekhnicheskii Institut.

1956b. Systematization of Rhynchonellida. In 20th Congreso Geologico Internacional Mexico, Resumenes de los Trabajos Presentados, pages 125-126 [abstract].

1958. K sistematike rinkhonellid [The Classification of the Rhynchonellids]. 20th Congreso Geologico Internacional, Mexico, section 7:107-121.

1959. K Sistematike Rinkhonellid [Systematics of the Rhynchonellids]. Paleontologicheskii Zhurnal, Akademiya Nauk SSSR, 1:25-35.

Sadlick, Walter

1963. Quadranetes, a New Carboniferous Chonetid. Journal of Paleontology, 37 (3):721-723.

1965. Anderidium, a New Term for Lateral Septa of Chonetids (Brachiopoda). Journal of Paleontology, 39 (1)157-159.

Sartenaer, Paul

1961a. Etude nouvelle en deux parties, du genre Camarotoechia Hall et Clark, 1893, first part: Atrypa congregata Conrad, Espèce-Type (1). Institut Royal des Sciences Naturelles de Belgique Bulletin, 37 (22): 11 pages, 2 plates.

1961b. Etude nouvelle en deux parties, du genre Camarotoechia Hall et Clark, 1893, 2nd part: Cupularostrum recticostatum, n. gen., n. sp. Institut Royal des Sciences Naturelles de Belgique Bulletin, 37 (25): 15 pages, 2 plates.

Sarycheva, T. G.

1949. Morphology, Ecology and Evolution of the Carboniferous Productids of the Moscow Basin (Genera Dictyoclostus, Pugilis and Antiquatonia). Aka. demyia Nauk SSSR, Trudy Paleontologicheskogo Instituta, 18: 304 pages, 36 plates.

1964. Oldgaminoidnye brakhiopody iz permi Zakavazya [Oldhaminoid Brachiopods from the Permian of Trans-Caucasia]. Palaeontologicheskii Zhurnal, (3): 58-72, plates 7-8.

Sarycheva, T. G., assistant editor

1960. Osnovi Paleontologii, spravochnik dlya paleontologov $i$ geologov SSR; Mshanki, Brakhiopody, 343 pages, 82 plates. Isdatelstvo Akademii Nauk.

Sarycheva, T. G., and B. K. Licharew

1960. Nadsemeistvo Productacea [Superfamily Productacea]. In T. G. Sarycheva, assistant editor, Osnovi Paleontologii, pages 223-238, figures 203-241.

Sarycheva, T. G., and A. N. Sokolskaja

1952. Opredelital Paleozoiskikh brakhiopod Podmoskovnoi Kotlovini [A Key to the Paleozoic Brachiopods of the Moscow Basin]. Akademyia Nauk SSSR, Trudy Paleontologicheskogo Instituta, 38: 307 pages, 71 plates.

schellwien, E.

1892. Die fauna des Karnischen Fusulinenkalks, part 1: Geologische Einleitung und Brachiopoda. $P a$ laeontographica, 39: 56 pages, 8 plates.

1900a. Beiträge zur Systematik der Strophomeniden des oberen Palaeozoicum. Jahrbuch für Mineralogie, Geologie und Paläontologie (Stuttgart), 1: 15 pages, 1 plate.

1900b. Die Fauna der Togkofelschichten. In den Karnischen Alpen und den Karawanken, I: Die Brachiopoden. Abhandlungen des Kaiserlich-königlichen Geologischen Reichsanstalt, Wien, $16(1)$ : 122 pages, 15 plates.

Schlaudt, C. M., and K. Young

1960. Acrothoracic Barnacles from the Texas Permian and Cretaceous. Journal of Paleontology, 34 (5):903-907, plates 119-120.

Schlotheim, E. F. von

1816. Beiträge zur Naturgeschichte der Versteinerungen. In geognostische Hinsicht. Akademie der Wissenschaften zu München, mathematische-physikalische Klasse, Denkschrift, 6:13-36.

Schmidt, Hermann

1931. Bau und Anheftungsweise des Brachiopoden Isogamma aus dem Oberkarbon Kärntens. Paläontologische Zeitschrift, Berlin, 13(4):278-283, plate 10.

Schmidt, Herta

1937. Zur Morphogenie der Rhynchonelliden. Senckenbergiana, $191(1 / 2): 22-69$.

Schuchert. Charles

1893. A Classification of the Brachiopoda. American $\mathrm{Ge}$ ologist, 11 (3):141-167.

1905. Catalogue of the Type Specimens of Fossil Invertebrates in the Department of Geology, United States National Museum. Section 1 in Merrill, Catalogue of Type Specimens of Fossils, Minerals, Rocks, and Ores, part 1: Fossil Invertebrates. United States National Museum Bulletin, 53 (1): 704 pages. 
1913. Brachiopoda. In K. A. von Zittel, (translated and edited by C. R. Eastman, Text-book of Paleontology, 1 (2nd edition): 355-420, figures 526-636. London: MacMillan and Co., Ltd.

1927. The Pennsylvanian-Permian Systems of Western Texas. American Journal of Science, 14(83):381401.

1935. Correlations of the More Important Marine Permian Sequences. Geological Society of America Bulletin, 46: 46 pages.

1939. Notes on the Brachiopod Genus Cardinocrania. American Journal of Science, 237:424-428, plate 1 .

Schuchert, C., and G. A. Cooper

1932. Brachiopod Genera of the Suborders Orthoidea and Pentameroidea. Peabody Museun of Natural His. tory Memoir, 4(1): 270 pages, plates A, 1-29.

Schuchert, C., and C. M. LeVene

1929. Fossilium Catalogus. 1: Animalia, part 42: Brachiopoda. 140 pages. Bertin: W. Junk.

Sellards, E. H.

1932. The Pre-Paleozoic and Paleozoic Systems in Texas. The University of Texas Bulletin, 3232:15-238, 6 plates.

Shaw, A. B.

1962. Rhynchonellid Brachiopods and a Torynifer from the Madison Group (Mississippian). Journal of Paleontology, 36(4):630-637, figure 1, plates 97-98.

Shumard, B. F.

1869 [1858]. Notice of New Fossils from the Permian Strata of New Mexico and Texas. Collected by Dr. George G. Shumard of the United States Government Expedition for Obtaining Water by Means of Artesian Wells along the 32d Parallel, under the Direction of Capt. John Pope, U.S. Corps Top. Eng. Academy of Science of St. Louis, Transactions, 1 (2): 108, 113, 290-297.

1860 [1859]. Notice of Fossils from the Permian Strata of Texas and New Mexico, Obtained by the U. S. Expedition under Capt. John Pope for Boring Artesian Wells along the 32d Paral., with Descriptions of New Species from These Strata and the Coal Measures of That Region. Academy of Science of St. Louis, Transactions, 1 (3):387-403, plate 11.

Simic. Vasilije

1933. Gornji Perm u zapadnoj Serbiji (Das Oberperm in Westserbien): Yugoslovia, Rasprave Geoloskog Instituta Kralj. Service géologique royaume de Yougoslavie, Memoirs, 1: 130 pages, 9 plates.

Skinner, J. W.

1940. Upper Paleozoic Section of Chinati Mountains, Presidio County, Texas. American Association of Petroleum Geologists Bulletin, 24(1):180-188.

1946. Correlation of the Permian of West Texas and Southwest New Mexico. American Association of Petroleum Geologists Bulletin, 30(11):1857-1874.

Smith, J. P.

1929. The Transitional Ammonoid Fauna of Texas. American Journal of Science, 5th series, 17:63-80, 3 plates.
Sohn, I. G.

1950. Growth Series of Ostracodes from the Permian of Texas. United States Geological Survey Professional Paper, 221C:33-39.

1954. Ostracoda from the Permian of the Glass Mountains, Texas. United States Geological Survey Professional Paper, 264A:1-24, 5 plates.

Sokolskaya, A. N.

1952. See Sarycheva, T. G., and A. N. Sokolskaja, 1952.

1954. Strofomenidy Russkoy Platformy [Strophomenids of the Russian Platform] Akademyia Nauk SSSR, Trudy Paleontologicheskogo Instituta, 15: 191 pages, 18 plates.

1960. Otryad Strophomenida i Nadsemeistvo Chonetacea [Order Strophomenida and Superfamily Chonetacea]. In T. G. Sarycheva, assistant editor, Osnovi Paleontologii, pages 206-223, figures 138-202.

1963. In T. G. Sarycheva, A. N. Sokolskaya, G. A. Beznossova, and S. V. Maksimova, Brachiopoda and Paleogeography of the Carboniferous of the Kuznetz Basin. Travaux Institute Paléontologie Academie Science URSS, 95: 547 pages, 64 plates.

Sowerby, James

1821 [1822]. Mineral Conchology. 4: 113 pages, plates 307-383.

Stainbrook, M. A., and R. F. Madera

1941. A Deep Subsurface Permian Fauna from Hockley County, Texas. Journal of Paleontology, 15(4): $376-383$, plate 55 .

Stehli, F. G.

1954. Lower Leonardian Brachiopoda of the Sierra Diablo. American Museum of Natural History Bulletin, $105(3): 263-358$, plates 18-27.

1955. Notes on Permian Rhynchonellids. Journal of the Washington Academy of Sciences, $45(3): 69-74,1$ plate.

1956a. Notes on Olhaminid Brachiopods. Journal of Paleontology, 35 (2):305-313, plates 41, 42.

1956b. Evolution of the Loop and Lophophore in Terebratuloid Brachiopoda. Evolution, 10:187-200.

1956c. A late Triassic Terebratellacean from Peru. Journal of the Washington Academy of Sciences, 46:101-103.

1957. Possible Permian Climatic Zonation and Its Implications. American Joumal of Science, 255:607-618.

1961a. New Genera of Upper Paleozoic Terebratuloids. Journal of Paleontology, 35(3):457-466, plate 62.

1961b. New Terebratuloid Genera from Australia. Journal of Paleontology, 35 (3):451-456, plate 61.

1965. Paleozoic Terebratulida. In R. C. Moore, editor, Treatise on Invertebrate Paleontology, H:730-762, figures 594-621.

Stepanov, D. L.

1936. Contribution to Knowledge of the Brachiopod Fauna of Spitzbergen. Leningrad State University A. S. Bubnof, Annals (Geology, Soil Science and Geography Series), 9 (2):114-128, 5 plates. 
1937. O Nekotorikh Verkhekamennougolnikh brakhiopodakh Urala [On Some Upper Carboniferous Brachiopods of the Ural]. Uchenie 7ath:sl:; I ...... gradskii Universitet, number 16 (Seria GeologoPochvenno-Geographicheskaya) issue 4, volume 3, 144-150.

Stoyanow, Alexander

1910. On a New Genus of Brachiopoda. Académie Impériale Science St. Pétersbourg Bulletin, series 6, 4 (Il):853-855.

1915. On Some Permian Brachiopoda of Armenia. Comité Géologique St. Pétersbourg Mémoir, new series, 111: 95 pages, 6 plates.

Strand, E.

1938. Miscellanea nomenclatorica zoologica et palacontologica, I-II. Archiv für Naturgeschichte, Berlin, 92 (A8):37-38.

Stubblefield, C. J.

1960. Sessile Marine Organisms and Their Significance in Pre-Mesozoic Strata. Geological Society of London, Quarterly Journal, 116:219-238.

Stuckenberg, A.

1898. Allgemeine geologische Karte von Russland, Blatt 127. Comité Géologique Mémoires 16(1): 362 pages.

Teichert, Curt

1966. Stratigraphic Nomenclature and Correlation of the Permian "Productus Limestone" of the Salt Range, West Pakistan. Geological Survey Pakistan Records, 15 (1): 20 pages, 6 figures.

Termier, H., and G. Termier

1957. Contribution à l'étude des brachiopodes permiens du Djebel Tebaga (extreme sud Tunisien). Société Gélogique de France, Bulletin, series 6, 7:197214, 8 plates.

1960 [1959]. Contribution à la classification des Brachiopodes: le Lophophore des Collolophides nov. ord. Appendice. Les Oldhamidés du Cambodge. Societe Géologique de France, Bulletin, series 7, 1 (3); 241-243.

Termier, Genevieve, Henri Termier, and Daniel Pajaud

1967. Découverte d'une Thécidée dans le Permien du Texas. Comptes Rendus des séances de l'Académie des Sciences (Paris), series D, 263:332-335.

Thomas, G. A.

1957. Olhaminid Brachiopods in the Permian of Northern Australia. Palaeontological Society of India, Journal, 2:174-182, plate 20.

1958. The Permian Orthotetacea of Western Australia. Australia Bureau of Mineral Resources, Geology and Geophysics, Bulletin, 39: 158 pages, 13 figures, 22 plates.

Thomas, H. D.

1935. The Brachiopod Punctospirifer pulchra (Meek). American Midland Naturalist, 16(2):203-207, 1 plate.

1937. Plicatoderbya, a New Permian Brachiopod Subgenus. Journat of Paleontology, 11(1):13-18, plate 3.
Thomas, Ivor

1910. British Carboniferous Orthotetinae. Great Britain Geological Survey Memoir, 1 (2):83-134, plate 13.

Thomson, J. A.

1926. A Revision of the Subfamilies of the Terebratulidae (Brachiopoda). Annals and Magazine of Natural History, series 9, 18:523-530.

1927. Brachiopod Morphology and Genera (Recent and Tertiary). New Zealand Board of Science and Art, Manual, 7: vi +338 pages, 2 plates.

Tomlinson, J. T.

1969. The Burrowing Barnacles (Cirripedia: Order Acrothoracica). United States National Museum Bul. letin, 296: $\mathrm{v}+162$ pages, 45 figures.

Trautschold, $\mathrm{H}$.

1876. Die Kalkbrueche von Mjatschkova, eine monographie des oberen Bergkalks. Société Impériale des Naturalistes de Moscou, Nouveaux Mémories, $13(5): 327-374$, plates 32-38.

Trenker, $\mathrm{W}$.

1867. Paläontologische Novitäten vom Nordwestlichen Harze, I: Ibergerkalk und Kohlengebirge von Grund. Abhandlungen der Naturforschenden Gesellschaft zu Halle, 10(1):3-60, 4 plates.

Tschernyschew, T. N.

1888 [1889]. Note sur une collection du carbonifere des environs de la ville de Vladivostok. Russia, Vsesouiznaia Geologorazvedochnoe Ob'edinenie, Izvestia [All-union Geological and Prospecting Institute, Bulletin ], 7 (22):353-359, 3 figures.

1889. Beschreibung des Central-Urals und des Westabhanges. In Allgemeine geologische Karte von Russland, Blatt 139. Comité Géologique Mémoires, 3 (4): 393 pages, 7 plates.

1902. Die obercarbonischen Brachiopoden des Ural und des Timan. Comité Géologique St. Pétersbourg, Mémoire, 16 (2): 749 pages, atlas, 63 plates.

1914. Die Fauna der oberpalaeozoischen Ablagerungen des Darvas. Comité Géologique St. Pétersbourg, Mémoire, new series, 104: 66 pages, 10 plates.

Tschernyschew, T. N., and P. Stepanow

1916. Obercarbonfauna von König Oscars und Heibergs Land. In Report of the Second Norwegian Arctic Expedition in the "Fram" 1898-1902. VidenskabsSelskabet $i$ Kristiania, 4 (34): 67 pages, 12 plates.

Tyrrell, W. W., Jr.

1969. Criteria Useful in Interpreting Environments of Unlike but Time-equivalent Carbonate Units (Tansill-Capitan-Lamar), Capiian Reef Complex, West Texas and New Mexico. Society of Economic Paleontologists and Mineralogists Special Publication (Tulsa), 14.

Udden, J. A.

1904. The Geology of the Shafter Silver Mine District, Presidio County, Texas. Texas University Mineral Survey Bulletin, 8: 60 pages, map.

1917. Notes on the Geology of the Glass Mountains University of Texas Bulletin, 1753:3-59. 
Udden, J. A., C. L. Baker, and E. Böse

1916. Review of the Geology of Texas. University of Texas Bulletin, 44: 164 pages, map.

Ulrich, E. O., and G. A. Cooper

1936. New Silurian Brachiopods of the Family Triplesiidae. Journal of Paleontology, $10(5): 331-347$, plates $48-50$.

Ustritsky, V. I.

1963. In V. I. Ustritsky and G. E. Cherniak, Biostratigrafiia i Brakhiopody Verkhnogo Paleoziia Taimyra [Biostratigraphy and Brachiopods of the Upper Paleozoic of Taimyr]. Nauchno-issledovatelskogo Institut geologii Arktiki, Trudy, 134: 139 pages.

Vanuxem, Lardner

1842. Geology of New York, part 3: Comprising the Survey of the Third Geological District. In Natural History of New York. 306 pages. Albany.

Verneuil, E. de

1845. Paléontologie, mollusques, brachiopodes. In R. I. Murchison, E. de Verneuil, and A. de Keyserling, Géologie de la Russie d'Europe et des Montagnes de l'Oural, 2 (3): 17-395, 43 plates. London: John Murray; Paris: Bertrand.

Waagen, W. H.

1882 [1885]. Salt Range Fossils, part 4: (2) Brachiopoda. Palaeontologia Indica, Memoir, series 13, 1:329 770 , plates 25-86 [ (1):329-390, plates 25-28, December 1882; (2):391-546, plates 29-49, August 1883; (3):547-610, plates 50-57, May 1884; (4):611728, plates 58-81, December 1884; (5):729-770, plates $82-86$, July 1885].

Walter, J. C., Jr.

1953. Paleontology of the Rustler Formation, Culberson County, Texas. Journal of Paleontology, 27(5):679_ 702, plates $70-73$.

Wang, $\mathrm{Y}$.

1955. New Genera of Brachiopods. Scientia Sinica, 4 (2): 327-357, 6 plates,

Wanner, Johannes, and Hertha Sieverts

1935. Zur kenntnis der permischen Brachiopoden von Timor, 1: Lyttoniidae und ihre biologische und stammes-geschichtliche Bedeutung. Jahrbuch für Mineralogie, Geologie und Paläontologie, BeilageBand, 74 (B):201-281, 4 plates.

Watson, D. M. S.

1917. Poikilosakos, a Remarkable New Genus of Brachiopods from the Upper Coal-measures of Texas. Geological Magazine, new series, 4:212-219, plate 14.

Waterhouse, J. B.

1964. Permian Brachiopods of New Zealand. New Zealand Geological Survey Palacontological Bulletin, 35: 288 pages, 81 figures, 37 plates.

1968. New Specics of Megousia Muir-Wood and Cooper and Allied Ncw Genus from the Pcrmian of Australia and North America. Journal of Paleontology, $42(5)$ :1171-1185, plates $154-156$.

Weller, J. M.

1944. Permian Trilobite Genera. Journal of Paleontology, $18(4): 320-327$.
Weller, Stuart

1910. Internal Characters of Some Mississippian Rhynchonelliform Shells. Geological Society of America Bulletin, 21:497-516, 18 figures.

1914. The Mississippian Brachiopoda of the Mississippi Valley Basin. Geological Survey of Illinois, Monograph, 1: 508 pages, 83 plates.

White, C. A., and O. St. John

1867. Descriptions of New Subcarboniferous Fossils, Collected upon the Geological Survey of Iowa; Together with a Notice of New Generic Characters Involved in Two Species of Brachiopoda. Chicago Academy of Science, Transactions, 1:115-127.

Whitfield, R. P.

1908. Notes and Observations on Carboniferous Fossils and Semifossil Shells, Brought Home by Members of the Peary Expedition of 1905-1906. American Museum of Natural History Bulletin, 24:51-58, 4 plates.

Wilde, G. L.

1962. Lower Permian Biostratigraphic Relationships and Sedimentation in Leonardian Facies of the Sierra Diablo Region, West Texas. Society of Economic Paleontologists and Mineralogists, Permian Basin Section, Guidebook, Publication, 62-7:68-77.

1968. In G. L. Wilde and R. G. Todd, Guadalupian Biostratigraphic Relationships and Sedimentation in the Apache Mountain Region, West Texas, part 1: Surface Correlations. Symposium and Guidebook, 1968 Field Trip, Permian Basin Section, Society of Economic Paleontologists and Mineralogists, Publication, 68-11:10-24.

Williams, Alwyn

1953a. The Classification of the Strophomenoid Brachiopods. Journal of the Waslington Academy of Sciences, $43(1)$ : 13 pages, 13 figures.

1953b. The Morphology and Classification of the Oldhaminid Brachiopods. Journal of the Washington Academy of Sciences, 43 (9):279-287, 3 plates.

1962. The Barr and Lower Ardmillan Series (Caradoc) of the Girvan District, South-west Ayrshire, with Descriptions of the Brachiopoda. Geological Society of London, Memoir, 3: 267 pages, 25 plates.

Williams, Alwyn, et al.

1965. Brachiopoda. Part $\mathbf{H}$ in R. C. Moore, editor, Treatise on Invertebrate Paleontology, 927 pages, 746 figures. Geological Society of America and University of Kansas Press.

Williams, J. S.

1938. Pre-Congress Permian Conference in the U.S.S.R. American Association of Petroleum Geologists Bulletin, $22(6): 771-776$

1939. Lower Permian of the Type Area, U.S.S.R. Journal of the W'ashington Academy of Sciences, 29(8):351353.

1943. Stratigraphy and Fauna of the Louisiana Limestone of Missouri. United States Geological Survey Professional Paper, 203: 133 pages, 9 plates. 
Williams, T. E.

1963. Fusulinidae of the Hueco Group (Lower Permian), Hueco Mountains, Texas. Peabody Museum of Natural History Bulletin, 18: viii + 122 pages, 10 figures, 25 plates.

Yanagida, Juichi

1964. Permian Brachiopods from Central Thailand. Kyushu University Faculty of Science Memoir, series D (Geology), 15 (1): 22 pages, 3 plates.

1967. Contributions to the Geology and Paleontology of Southeast Asia, xxxv: Permian Brachiopods from North-central Thailand. Geology and Palaeontology of Southeast Asia, 3:16-97, plates 11-23.

Yochelson, E. L.

1954. Some Problems Concerning the Distribution of the Late Paleozoic Gastropod Omphalotrochus. Science, $120(3110): 233-234$.
1956. Permian Gastropoda of the Southwestern United States, 1: Euomphalacea, Trochonematacea, Pseudophoracea, Anomphalacea, Craspedostomatacea, and Platyceratacea. American Museum of Natural History Bulletin, $110(3): 177-275$, plates 9-24.

1960. Permian Gastropoda of the Southwestern United States, 3: Bellerophontacea and Patellacea. American Museum of Natural History Bulletin, $119(4): 209$ 293, plates 46-47.

Young, Addison

1960. Paleozoic History of the Fort Stockton-Del Rio Region, West Texas. In Aspects of the Geology of Texas: A Symposium. University of Texas Publication, 6017:87-109.

Zugmayer, $\mathbf{H}$.

1880. Untersuchungen über rhätische Brachiopoden. Beiträge Paläontologie und Geologie ÖsterreichUngarns Orients, 1: 42 pages, 4 plates. 

PLATES 1-23 


\section{PLATE 1}

1. Acidizing laboratory of the National Museum of Natural History, showing tubs along the wall and carboys of acid on small tables beside them: Stainless steel tank in middle ground is for washing the decalcified residues.

2. Placing block in the acid tub by means of a hoist picturesquely called a "shoplifter."

3. Profile of the Wolf Camp Hills, showing dip of about $10^{\circ}$ to the northwest: Low knob on the right is composed of the Gray (bed 2) Limestone of P. B. King. The long slope in the background is composed of the same limestone. The valley in the middle ground represents the position of the Uddenites-bearing Shale Member and the long slope on the left is formed by Neal Ranch Formation (beds 12-14 of P. B. King = beds 9-12 of Cooper and Grant) : View is from southwest about 3 miles northeast of Hess Ranch house. (Hess Canyon quadrangle.)

4. Sierra del Norte about due west of the site of the Old Payne Ranch: Lower part of mountain comprises Cathedral Mountain Formation, but the greater part is the Word Formation, sandstone and limestone, overlain by the Cretaceous, which forms the crest of the mountain. (Monument Spring quadrangle.)

5. Sullivan Peak at the north end of Cathedral Mountain, composed of Capitan Formation (dolomite) underlain by sandstone and limestone of the Word Formation: The spur in front of the peak is formed by the Road Canyon Formation (USNM 707e) and the low hill in front of the spur is composed of the Cathedral Mountain Formation with topmost Skinner Ranch Formation at its base. (Altuda quadrangle.) 

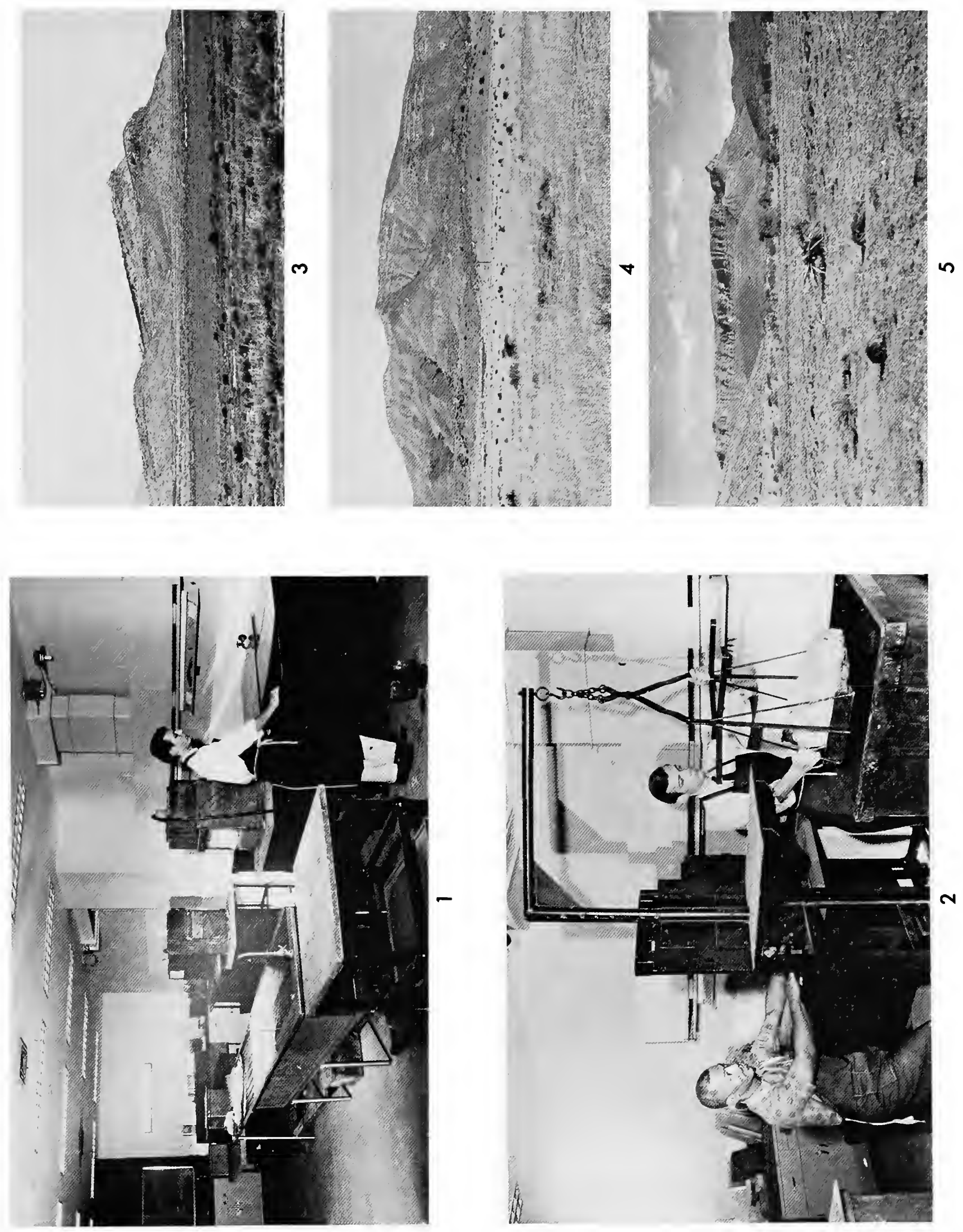


\section{PLATE 2}

1. West side of Leonard Mountain, showing the type section of the Skinner Ranch Formation at the north end, or left, of the picture: Seacchinella beds of the Skinner Ranch Formation appear at the base of the mountain on the left of the ravine. These beds can be traced southward up the mountain side for a considerable distance. Under them appears a slope formed by shaly beds of the Lenox Hills Formation. The highest point in the picture is formed of Cathedral Mountain Formation shaly beds with interbedded limestone containing Institella (USNM $724 \mathrm{~m}$ ). This is the only Leonardian shale on the mountain. The limestone capping the leftmost knob and containing Institella is assigned to the Cathedral Mountain Formation. Under this is the complete type section of the Skinner Ranch Formation. (Altuda quadrangle; see text Figure 14.)

2. South face of the Wolf Camp Hills: The high bluff in the center (hill 5060) is capped by the Gray Limestone or Bed 2 of P. B. King. Under it is the Uddenites-bearing Shale Member (USNM 70le), which rests on the uppermost limestone ledge of the Gaptank Formation. At the extreme left is a knob formed by the Gray Limestone, which marks the west side of the entrance to Geologists Canyon. The dark limestone bed between this knob and the center hill (5060) is the topmost, heavy, bedded layer of the Gaptank Formation. The hills forming a wall in the background are composed of the Hess Formation. (Center of Hess Canyon quadrangle; see text Figure 4.)

3. East end of the Lenox Hills on the west of the road to Sullivan (Yates) Ranch (view toward north): The spur or low hill on the right is composed of Poplar Tank Member of the Skinner Ranch Formation capped by the Sullivan Peak Member forming thick, solid ledges. The Decie Ranch Member is on the floor of the basin at the base of the hill. In the higher hills on the left the Decie Ranch Member, forming the lowest conspicuous ledge, is in seeming continuity with the Sullivan Peak Member forming the top of the spur. A fault near the break in slope between the two hills throws the spur downward to bring about this relationship. The second or highest conspicuous ledge is the Sullivan Peak Member. here very thick and containing bioherms with Scacchinella. The two highest knobs on the left and the highest parts of the hills are the lower beds of the Cathedral Mountain Formation, made up of orange-yellow, siliceous, shaly rock. (Altuda quadrangle; USNM 707, see text Figure 10.) 


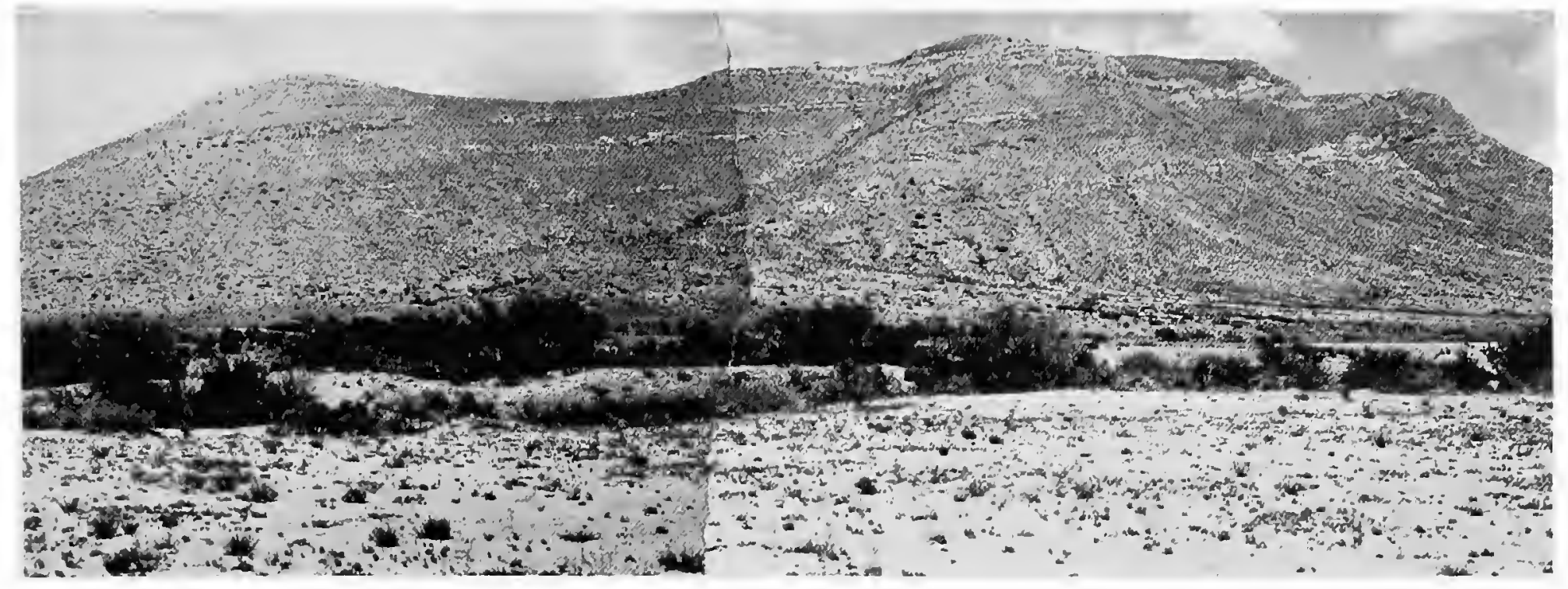

\section{1}
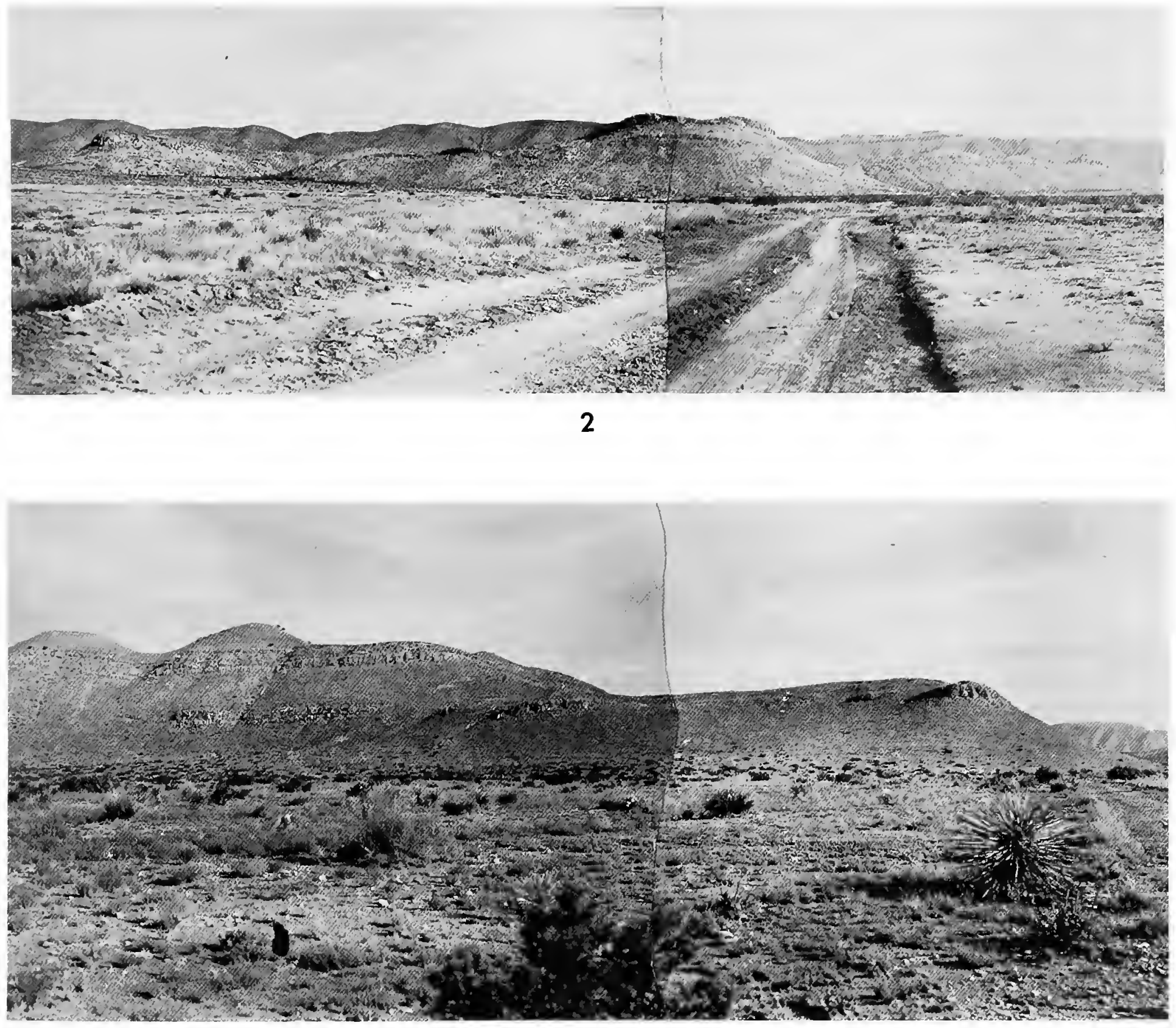


\section{PLATE 3}

1. Hess Ranch Horst viewed from the west, showing an unbroken section of the Lenox Hills Formation: The conspicuous ledges are formed of limestone conglomerate. (Hess Canyon quadrangle.)

2. West side of Hess Ranch Horst just west of hill 5816, showing the gigantic cross-bedding in the conglomerates of the Lenox Hills Formation. (Hess Canyon quadrangle.)

3. Lenox Hills limestone conglomerate at the northeast base of Leonard Mountain and about 1 mile northwest of Hess Ranch. (Hess Canyon quadrangle.)

4. Capping ledge of massive Road Canyon Formation (USNM 710u), overlying thick, upper Cathedral Mountain shale that contains Perrinites, about 2 miles southeast of Sullivan Peak. (Altuda quadrangle.) 

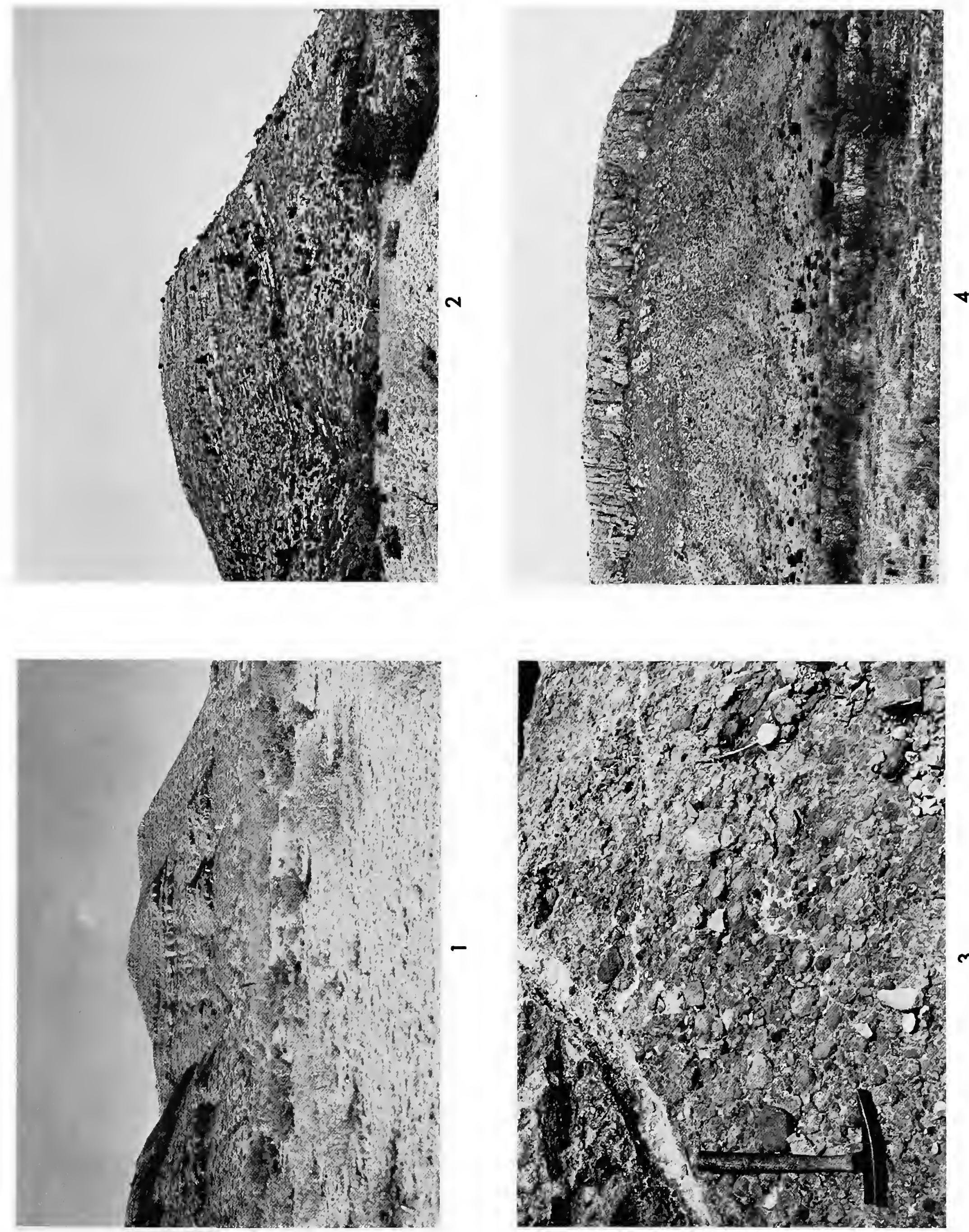


\section{PLATE 4}

1. The "Uddenites saddle," Uddenites-bearing Shale Member forming a saddle between two exposures of the Gray (bed 2) Limestonc of P. B. King, one forming the capping ledge of the knob on the left and the other dipping off to the north on the right. The sadrle between the limestone ledges is the famous locality for Uddenites and other ammonites (USNM 70lu), west end of the Wolf Camp Hills. (Hess Canyon quadrangle.)

2. Looking east from the saddle on the cast side of hill 5060, Wolf Camp Hills, showing the Uddenites-bearing Shale Member in profile: The back slope on the extreme left is the Gray Limestone of P. B. King, and the limestone at the very crest of the highest point is the uppermost limestone of the Uddeniles-bearing Shale Member. The lowest limestone ledge is the top of the Gaptank Formation. (Hess Canyon quadrangle.)

3. Mosaic in Neal Ranch Formation, formed by compaction of thin calcarenite over subjacent bioherms (USNM 70lh), west side of Wolf Camp Hills. (Hess Canyon quadrangle.)

4. Beds 12-14 of P. B. King (9-12 of Cooper and Grant) in the middle ground and the upper shale of the Neal Ranch Formation, forming the slope on the left and capped by the Lenox Hills Conglomerate, center Wolf Camp Hills. (Hess Canyon quadrangle.) 

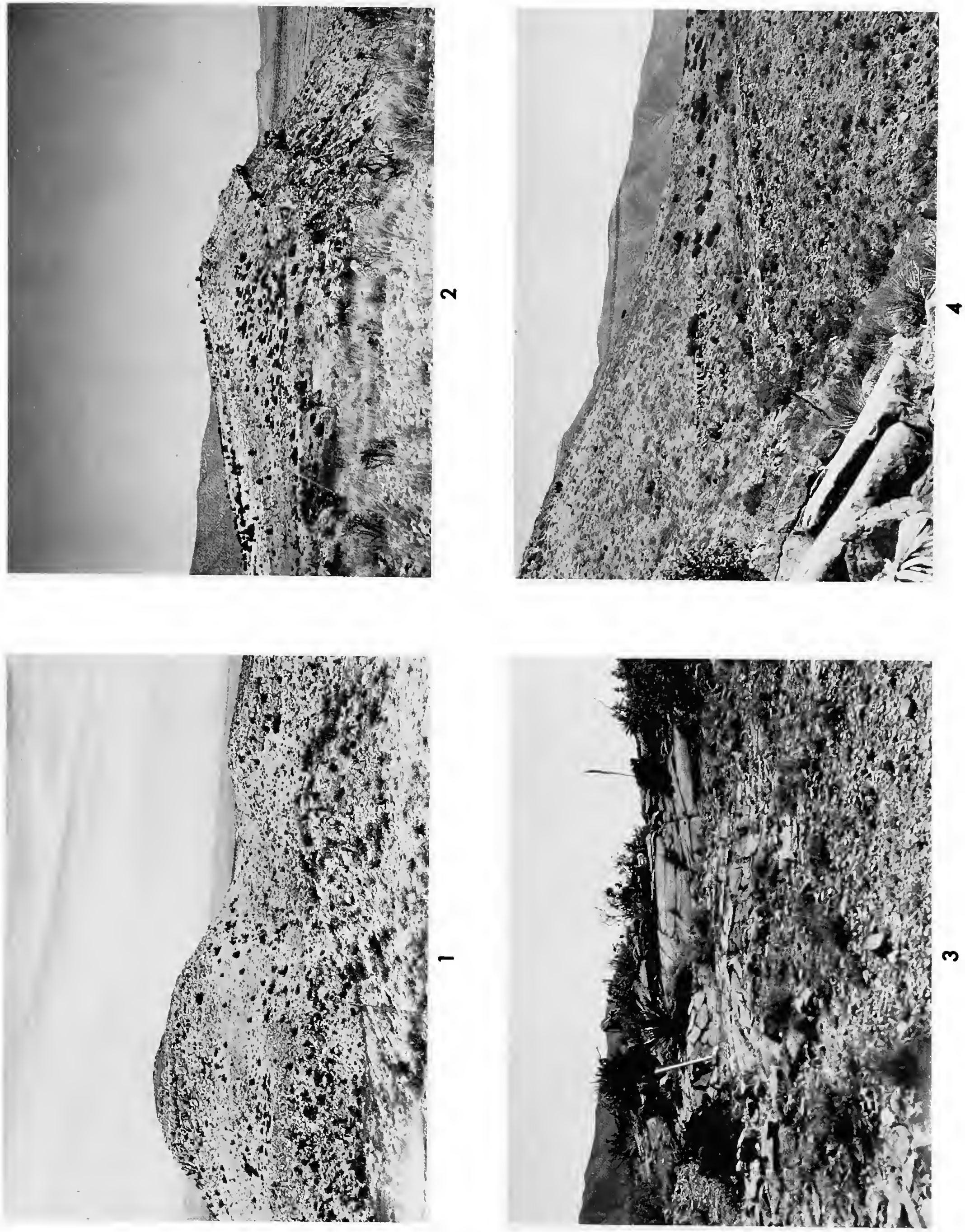


\section{PLATE 5}

1. Bioherm with Coscinophora in the Sullivan Peak Member of the Skinner Ranch Formation on the east side of Dugout Mountain (USNM 733j): The cold chisel points to specimens of Coscinophora; other specimens lie near the exlge of the block just under the chisel. This part of the bioherm was taken into the laboratory and decalcified. The result is shown on Plate 129 [volume II] (Monument Spring quadrangle.)

2. Bed 4 (of P. B. King) of the Neal Ranch Formation at the west end of the Wolf Camp Hills: View includes USNM 701-1 and 727e. (Hess Canyon quadrangle.)

3. View from the east, showing Sullivan Peak in the right middle ground: The long spur extending through the center to the left is underlain by the Road Canyon Formation (USNM 707e) and overlain by lower Word shale. (Altuda quadrangle.)

4. Small butte capped by the Decie Ranch Member of the Skinner Ranch Formation and immediately overlying shale of the Lenox Hills Formation: The shale is underlain by nearly 400 feet of Lenox Hills Conglomerate. View is about 0.25 mile south of hill 4902 at south end of the Lenox Hills. (Altuda quadrangle.) 

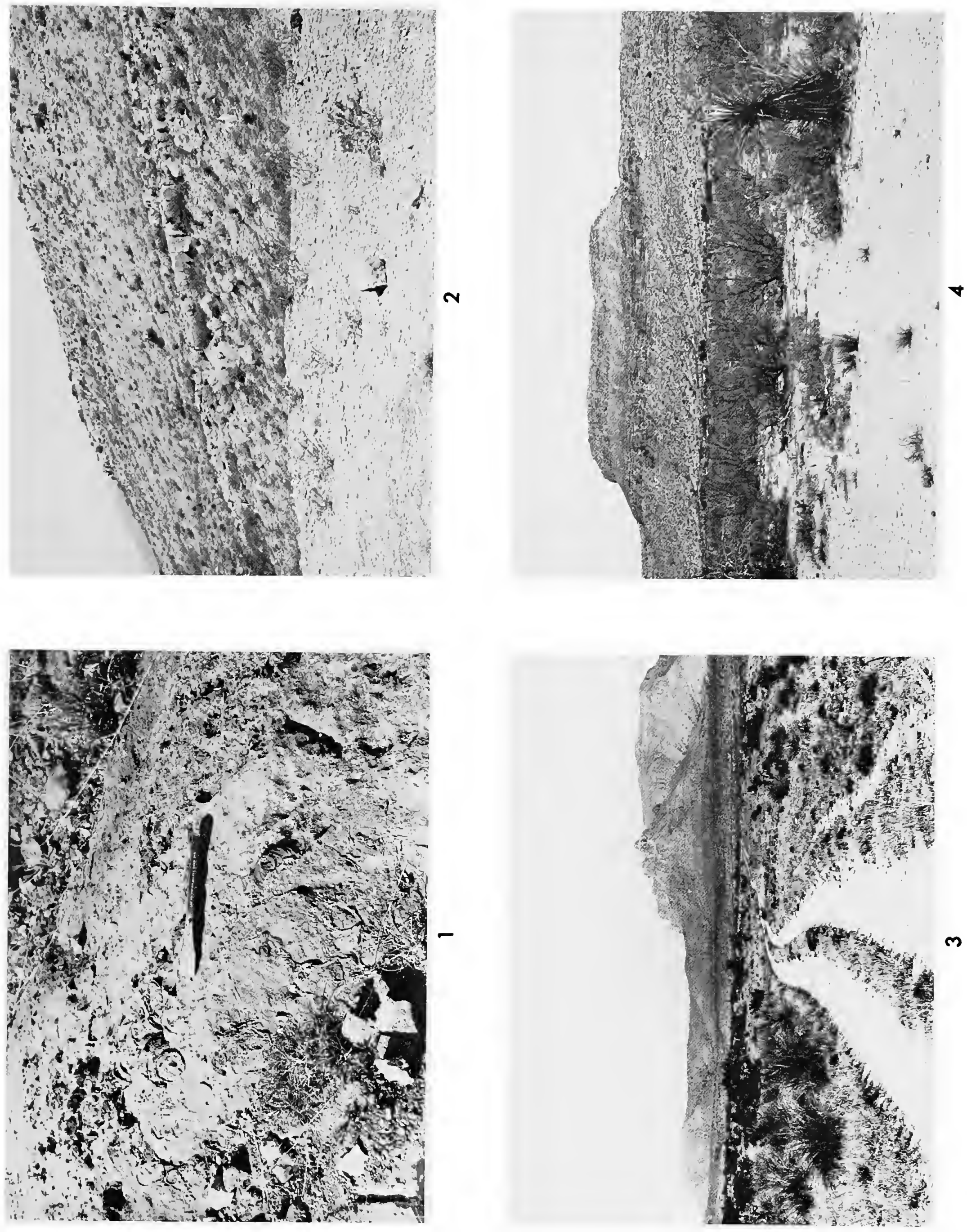


\section{PLATE 6}

1. Southwest face of Leonard Mountain, south end, showing thickening limestones and secondary dolomites: The farthest right ledges of inassive dolomite belong in the lower part of the Skinner Ranch Formation. (Hess Canyon quadrangle.)

2. Skinner Ranch Formation (Sullivan Peak Member) on the southwest side of Dugout Mountain (USNM 722-1), showing thick limestone beds. (Monument Peak quadrangle.)

3. East side of Leonard Mountain, seen from near Hess Ranch House: The soft lower slopes on the left are Gaptank shale and are overlain by massive limestone conglomerate of the Lenox Hills Formation. The two conical knobs on the left side of the mountain are composed of dolomite, and the saddle between them is Lenox Hills shale rich in fusulinids. The farthest right and stratigraphically highest dolomite knob is lower Skinner Ranch Formation, containing Schwagerina crassitectoria Dunbar and Skinner. The highest part of the mountain in the middle background is Skinner Ranch Formation capped by a thin layer of Cathedral Mountain shale with Instilella at the highest part of the mountain. (Hess Canyon quadrangle; sec text Figures $15,18$. ) 

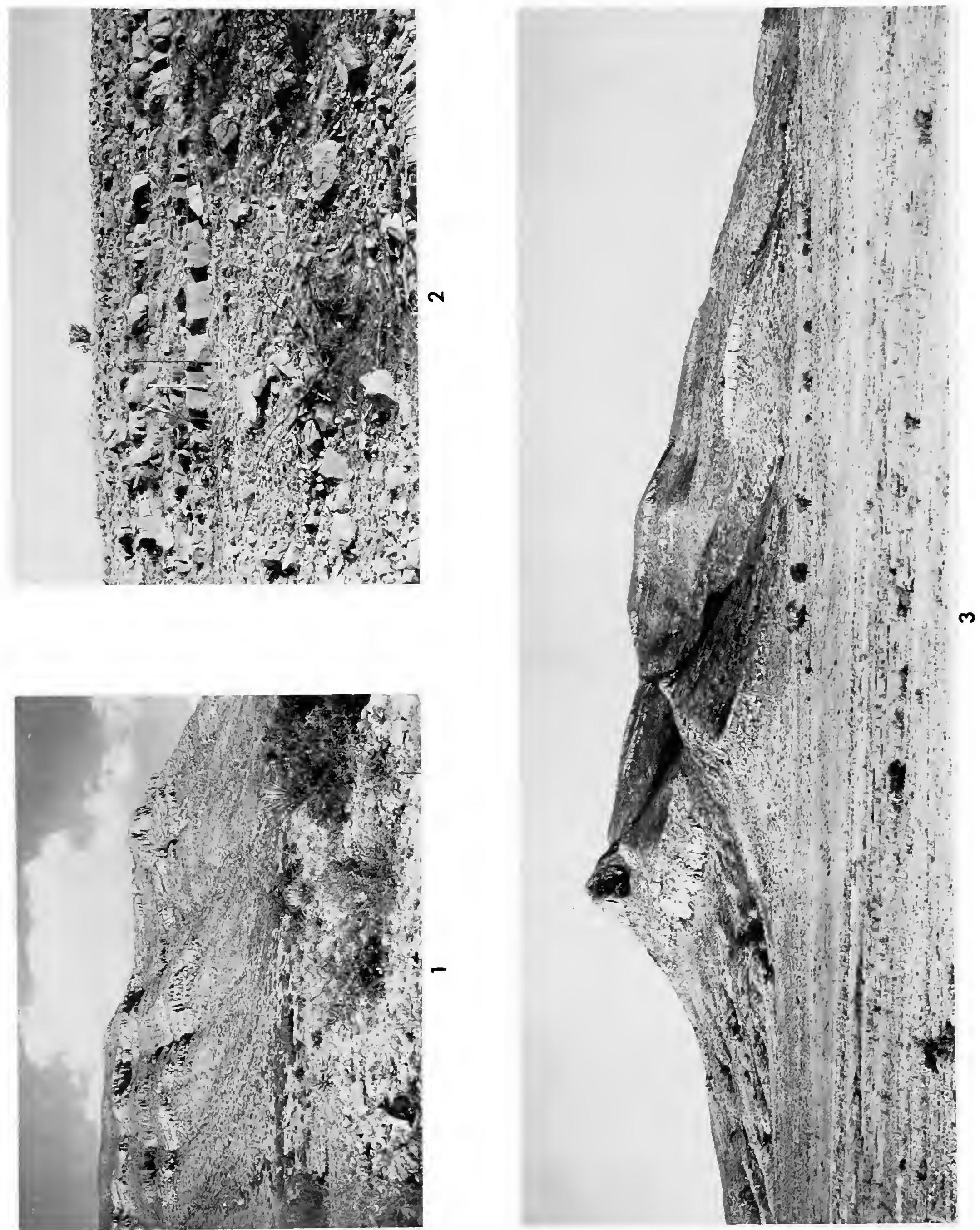


\section{PLATE 7}

1. Massive limestone of the Cathedral Mountain Formation, Wedin Member (just under the highest knob in the hill on the extreme left of figurc 3 below): This is USNM 727p, which produced Agelesia, Institella, and associated fossils of the Cathedral Mountain Formation. Hill capped by the 5250-foot closed contour about 0.25 mile south-southwest of hill 5300 . (Altuda quadrangle.)

2. Clay slide, a gash in the face of the hill just south of hill 4910 , showing the soft blue shale of the upper part of the Cathedral Mountain Formation: The limestone capping the hill is Road Canyon Formation. (Altuda quadrangle.)

3. Panorama of the Lenox Hills toward northeast, from hill capped by the closed 5250-foot (extreme left), 0.25 mile south-southwest of hill 5300. The lowest prominent ledge is the Decie Ranch Member (USNM 707a), and the next higher prominent ledge is the Sullivan Peak Member with the Poplar Tank Member between them, all constituting the Skinner Ranch Formation. Overlying the Sullivan Peak Member is the Cathedral Mountain Formation with the Wedin Member (USNM 727p) just below the prominent knob (hill 5250) on the left. The crest of the knob is formed by Third Limestone Member of the Leonarrl Formation of P. B. King. Along the base of the scarp, on the right and extending to the middle, are ledges of Lenox Hills conglomerate. The slope under the Decie Ranch Member is composed of Lenox Hills shale. (Altuda quadrangle; sce text Figures 9, 12.) 

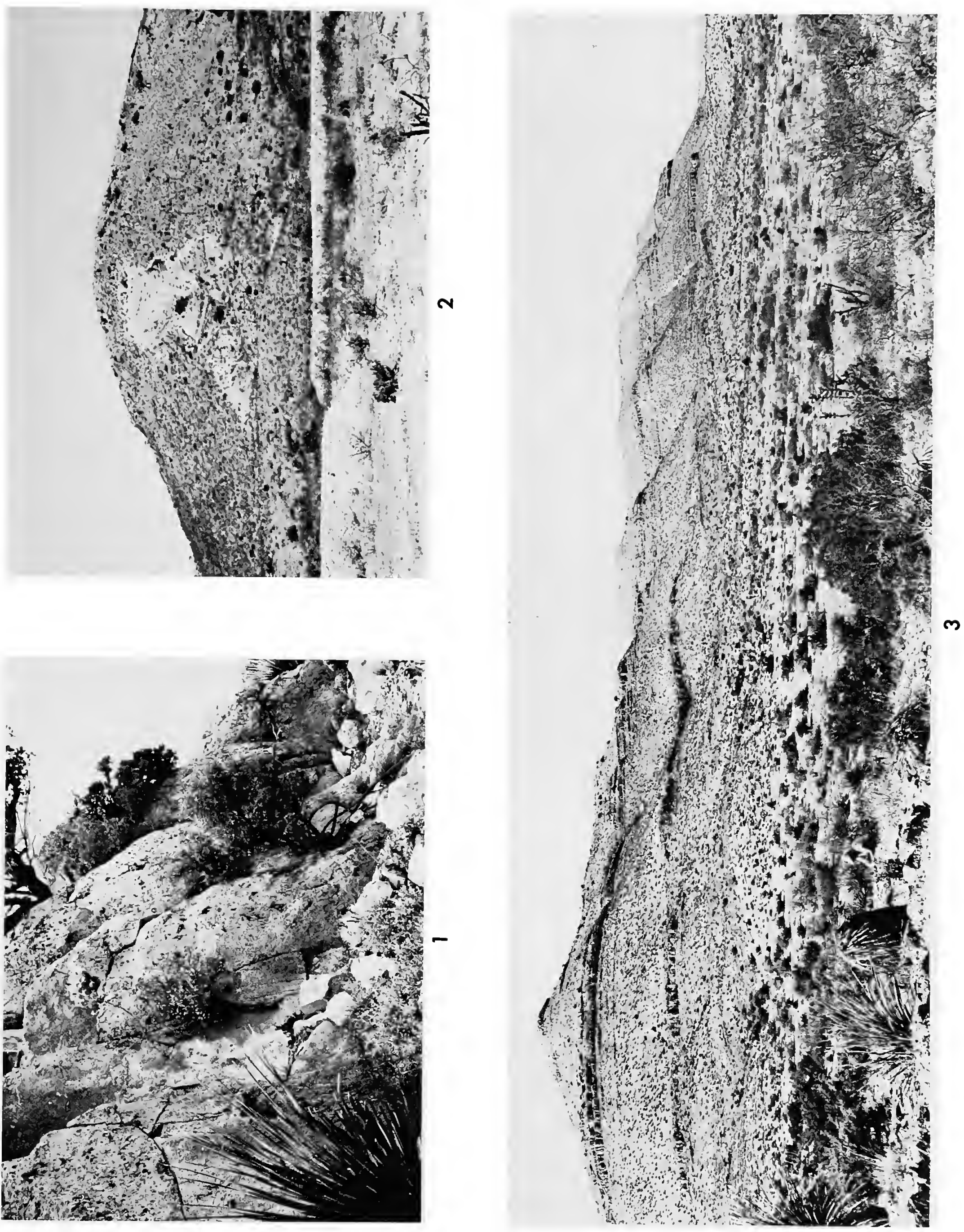


\section{PLATE 8}

1. Hill just east of the Hess Ranch house displaying nearly 1000 feet of the Hess Formation that overlies the Lenox Hills conglomerate at the base of the hills: Low foothills on the right are Wolf Camp Hills in profile (see text Figure 18; Plate 1: figure 3). Distance from left to right is about 3.5 miles. (Hess Canyon quadrangle.)

2. South face of Leonard Mountain: Low hills at base of mountain are toreva blocks of Lenox Hills Formation. The lowest limestone in place in the mountain belongs to the Gaptank Formation; medial massive beds are conglomerates and limestones of the Lenox Hills Formation; high cliffs are of Skinner Ranch Formation here massively dolomitized. No Leonardian beds (Cathedral Mountain) are visible on this side of the mountain. (Hess Canyon quadrangle; see text Figure 18.)

3. Panorama in the Sierra Diablo: Victorio Peak is the mountain mass on the left; Corn Ranch at left base of mountain (two white spots) and the cliffs on the right are along Victorio Canyon on the south of wall (USNM 728e). IISNM 728f is 0.5 mile south (left) of the canyon mouth. The lowest massive beds are the Skinner Ranch equivalents in the Bone Spring Formation. Below these is the Hueco Formation. Above them is the thinbedded basinal Bone Spring Formation. The massive heds capping the mountains on the left and right are dolomitic limestones of the Victorio Peak Formation. (Van Horn [30'] quadrangle.) 

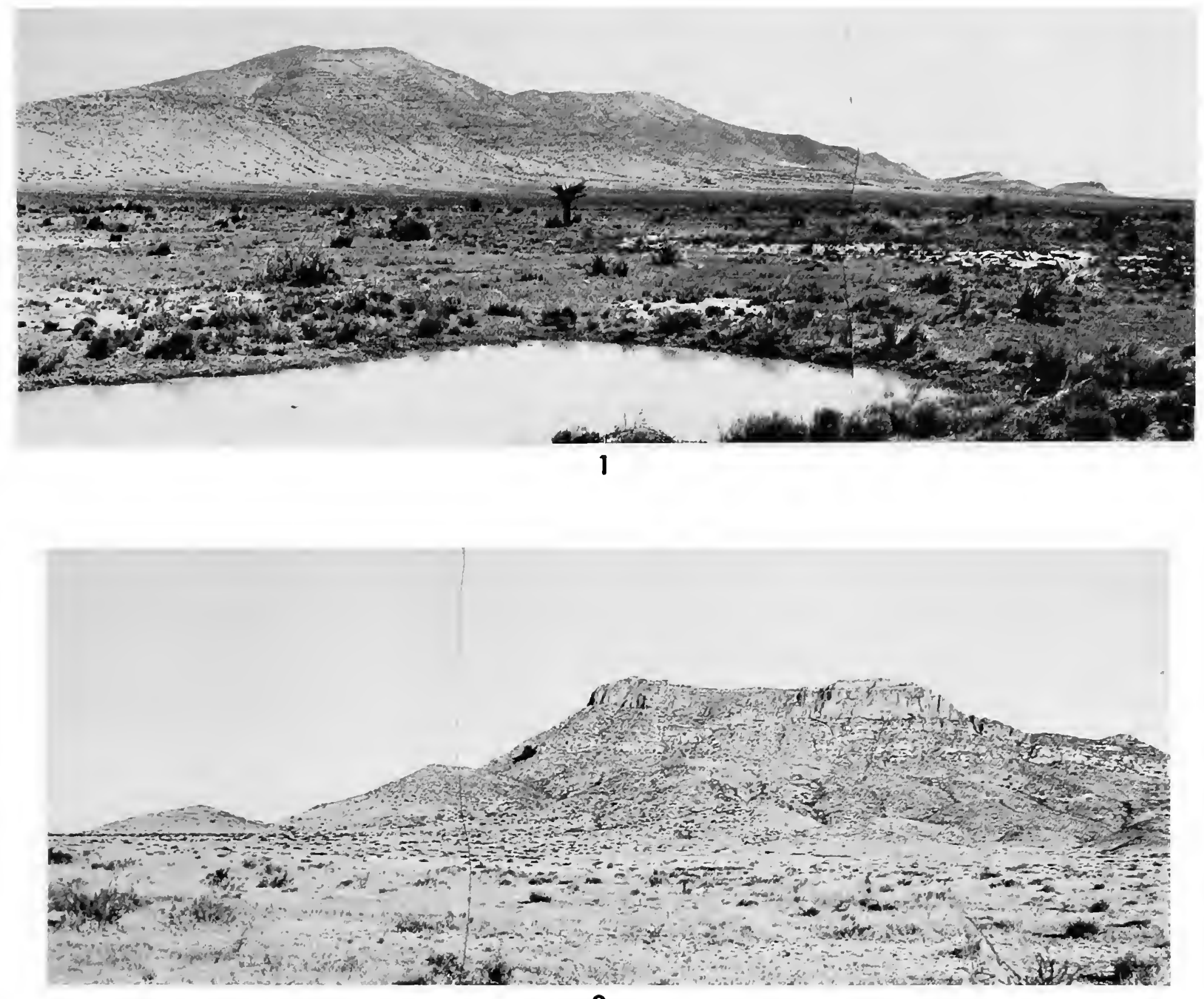

2

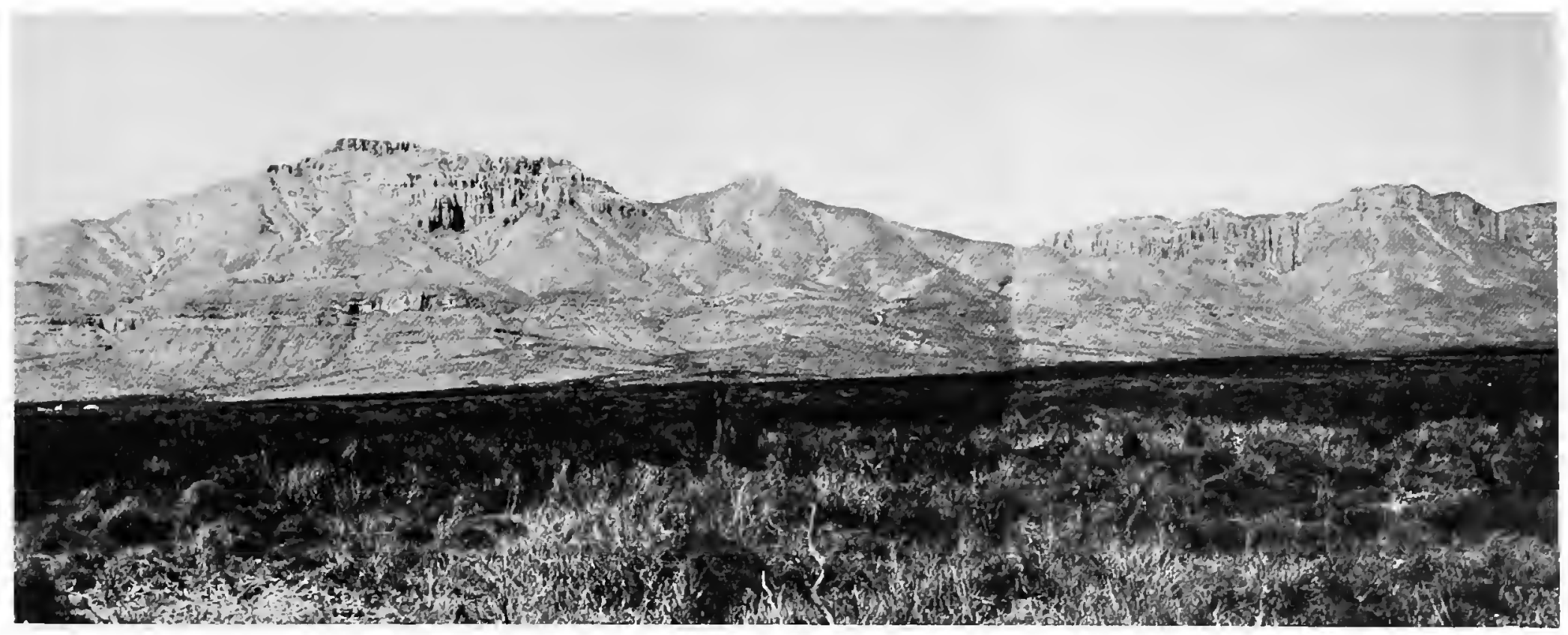




\section{PLATE 9}

1. Cherty limestone at the top of the Taylor Ranch Member of the Hess Formation (USNM 7160), 1.5 miles south of Old Word Ranch. (Hess Canyon quadrangle.)

2. Poplar Tank Member of the Skinner Ranch Formation, forming the south slope of hill 4801 beneath the Sullivan Peak Member of the Skinner Ranch Formation, south end of the Lenox Hills: The Poplar Tank Member is predominantly shaly, but it contains thin, blocky, sandy-to-conglomeratic limestone beds. (Monument Spring quadrangle.)

3. Profile view, showing the entire thickness of the Decie Ranch Member at its type section, overlying Lenox Hills shale, about 1 mile east-northeast of hill 4801, south end of the Lenox Hills. (Boundary between Altuda and Monument Springs quadrangles.)

4. Specimens wrapped in burlap and banded, ready for shipment: Banding with steel tape proved to be the most efficient and safest method of wrapping for shipment. (Marathon, Texas.) 

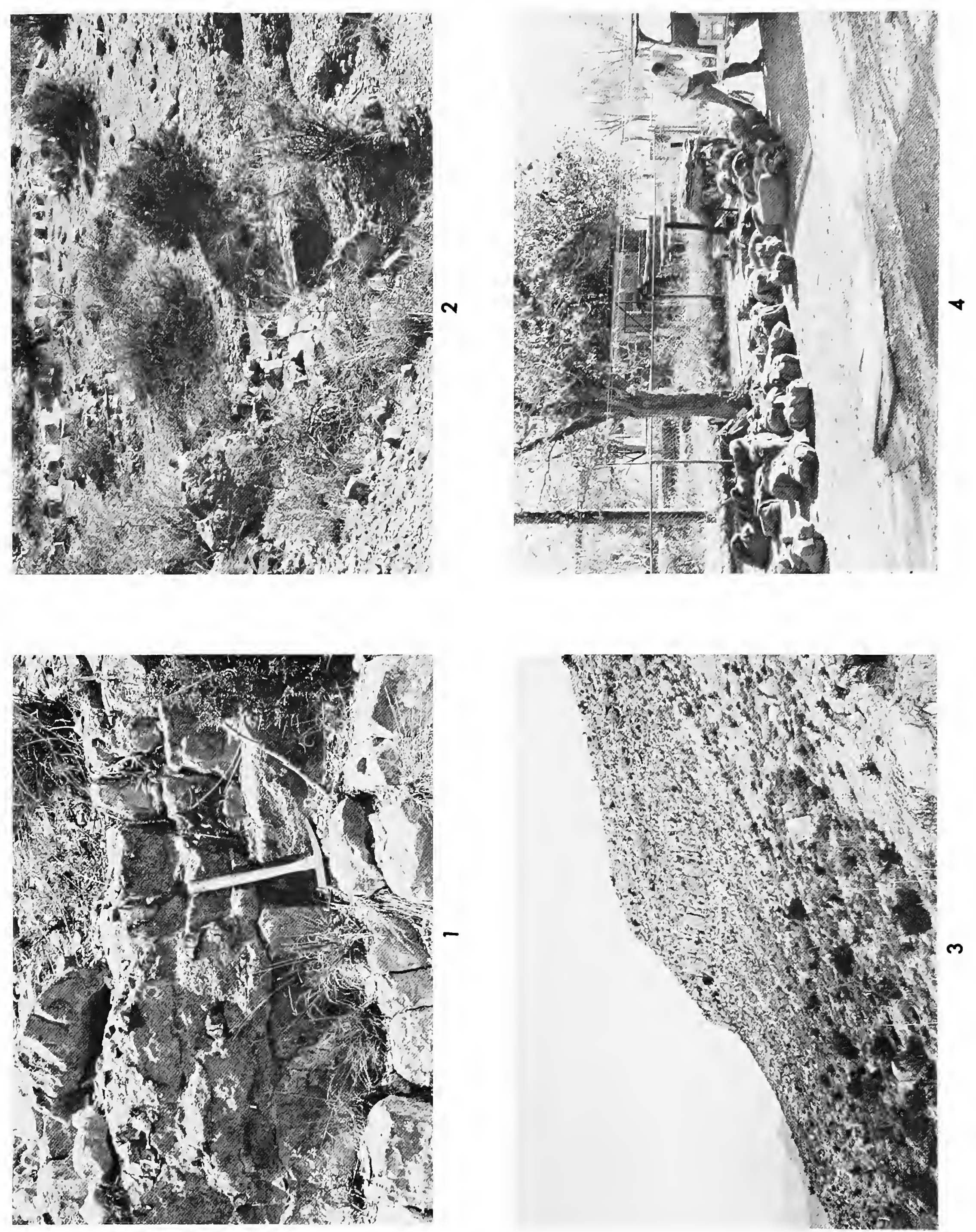


\section{PLATE 10}

1. Hill 5021 (center knob) of Decic Brothers Hill, one of the significant points in Glass Mountains stratigraphy: The extreme left hill contains Lenox Hills Formation in the lower part. The lowest ledge is the Decie Ranch Member, and the capping ledge is the Sullivan Peak Member. Between them is a considerably thinned Poplar Tank Member. To the right (east), the two limestone members converge and unite to form the undivided Skinner Ranch Formation. (Altuda quadrangle; see text ligure 11.)

2. View of hill 5021 from the south, with the peak 5021 on the right: The peak on the left corresponds to the extreme left knob in the previous picture. The saddle is formed of the Decie Ranch Member (USNM 708q), a prolific place to collect Scacchinella. The Decie Ranch and Sullivan Peak Members merge in the hill to the right (5021).

3. View from the south of the west or left knob of hill 5021 (Decie Brothers Hill): The white limestone at the base of the hill in the middle ground of the picture is a toreva block of the Decie Ranch Member of the Skinner Ranch Formation. This block produced the best of the silicified Scacchinella (USNM 707w). The slope above the light-colored bed consists of Pennsylvanian sandy shale, Lenox Hills Formation, Decie Ranch Member (first dark band), the Poplar Tank Member, and the capping ledge formed by the Sullivan Peak Member. (Altuda quadrangle; sce text Figure 1l.)

4. Full section of the Decie Ranch Member seen in profile (USNM 715a), Dugout Mountain. (Monument Spring quadrangle.) 

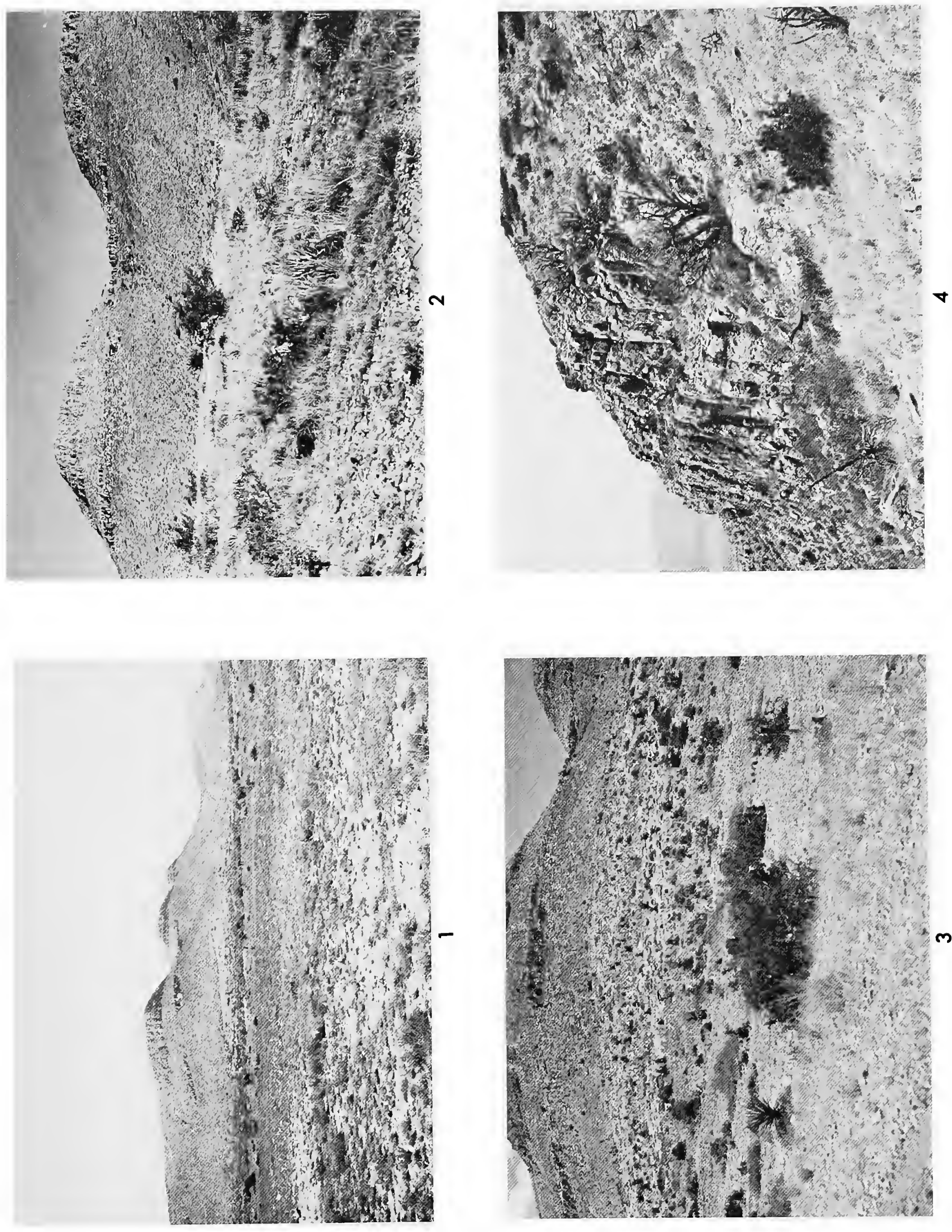


\section{PLATE 11}

1. Conglomerate lying on the west side of the large bioherm in hill 4801 at the south end of the Lenox Hills: In the upper right the massive rock of the bioherm may be seen (see Plate 18: figures 1-3). The boulders contain the same fossils as the bioherm (Scacchinella and Geyerella) and were undoubtedly derived from the bioherm or others like it.

2. Bioherm containing abundance of Scacclinella (USNM 714p); In the deep ravine on the northeast side of Lconard Mountain, 0.2 mile north-northeast of bench mark 5860 . (Hess Canyon quadrangle.)

3. Polished surface of biohermal limestone, Neal Ranch Formation, from USNM 70lh, showing cross-sections of sponges, detrital matter, and some laminated limestone, possibly algal, Wolf Camp Hills. (Hess Canyon quadrangle.)

4. View of the Sullivan Peak conglomerate at the south end of the Lenox Hills in hill 480I, showing an enormous boulder about 4 fect in long diameter. (Monument Spring quadrangle.) 


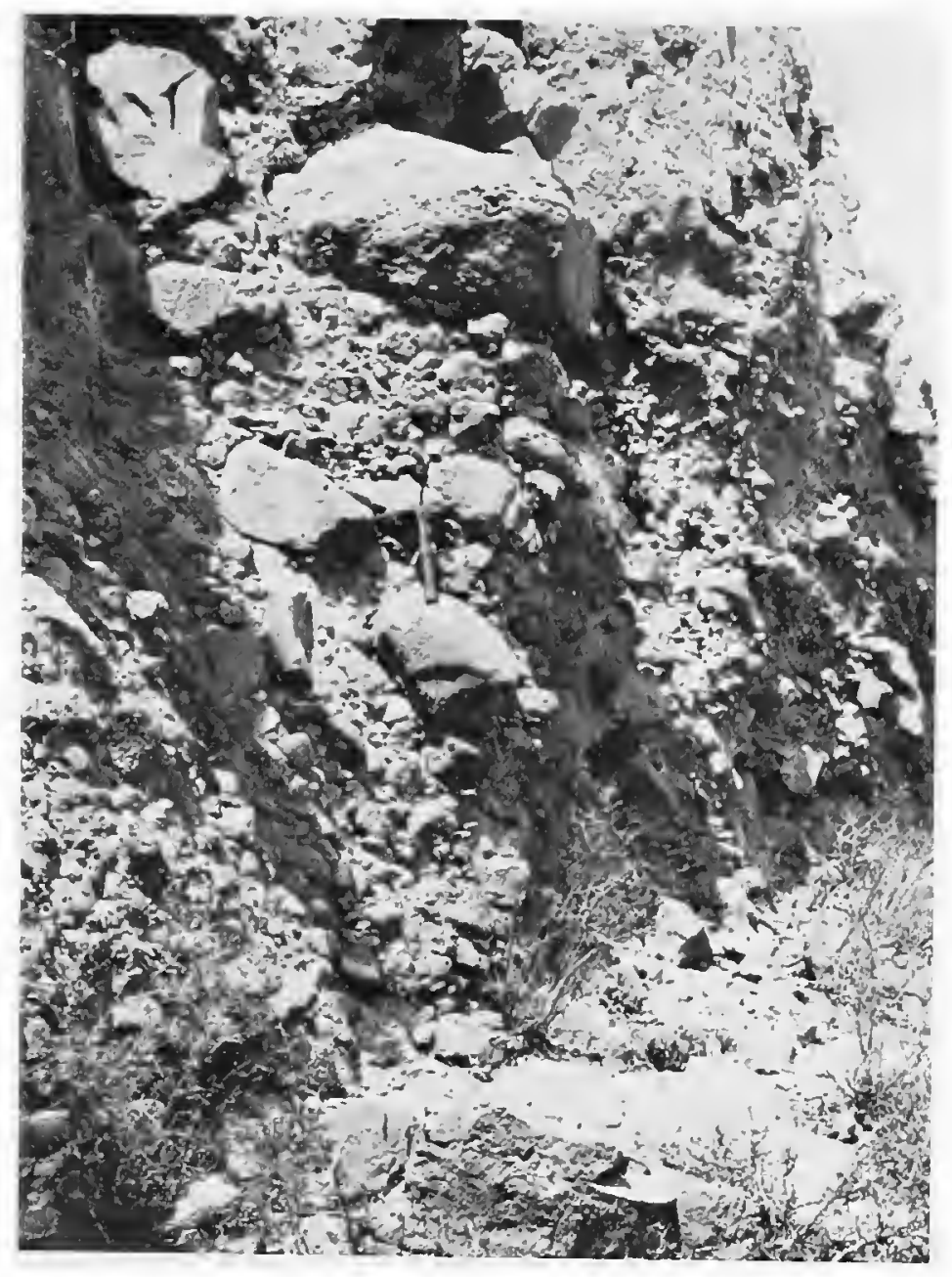

1

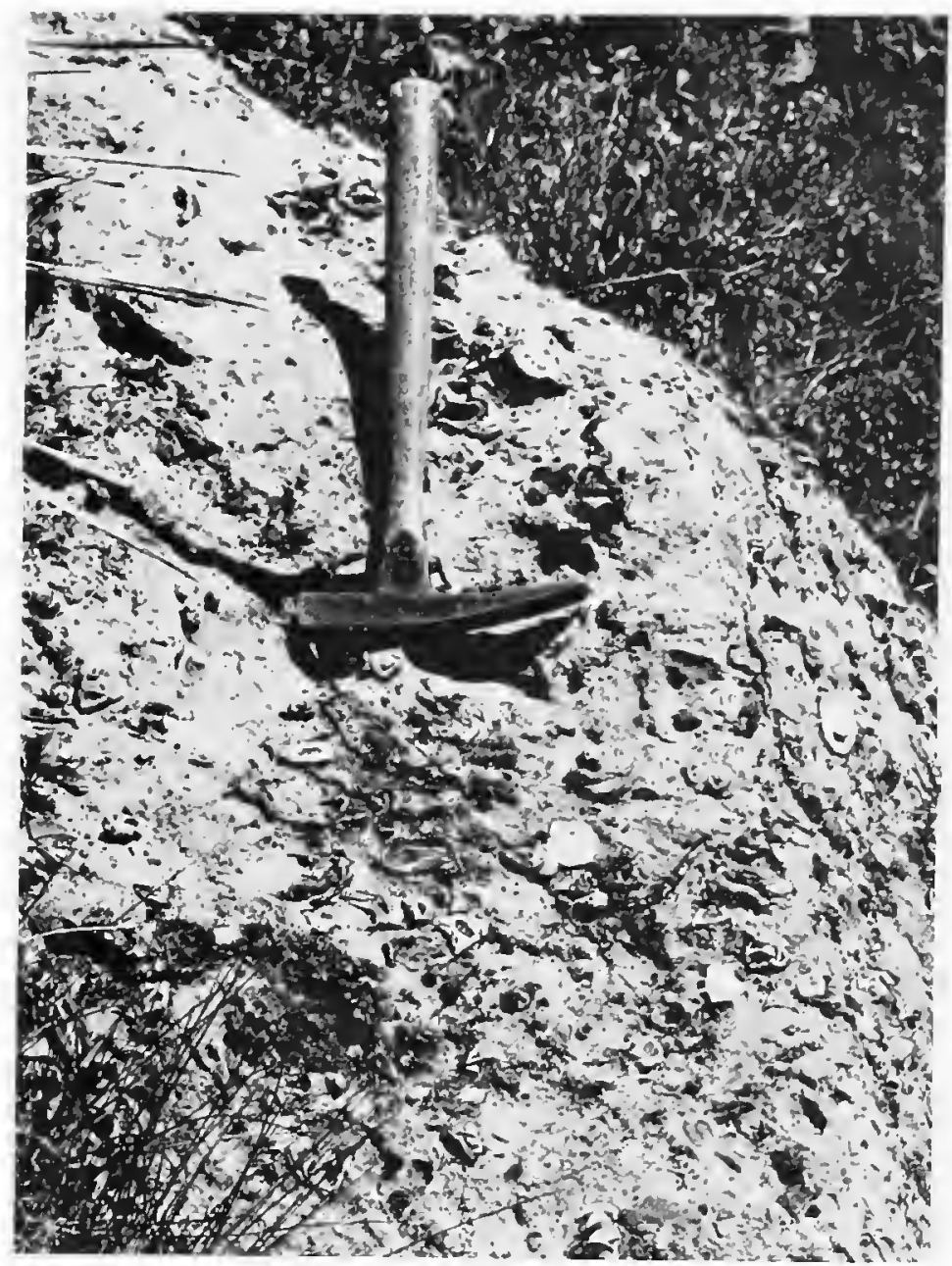

2

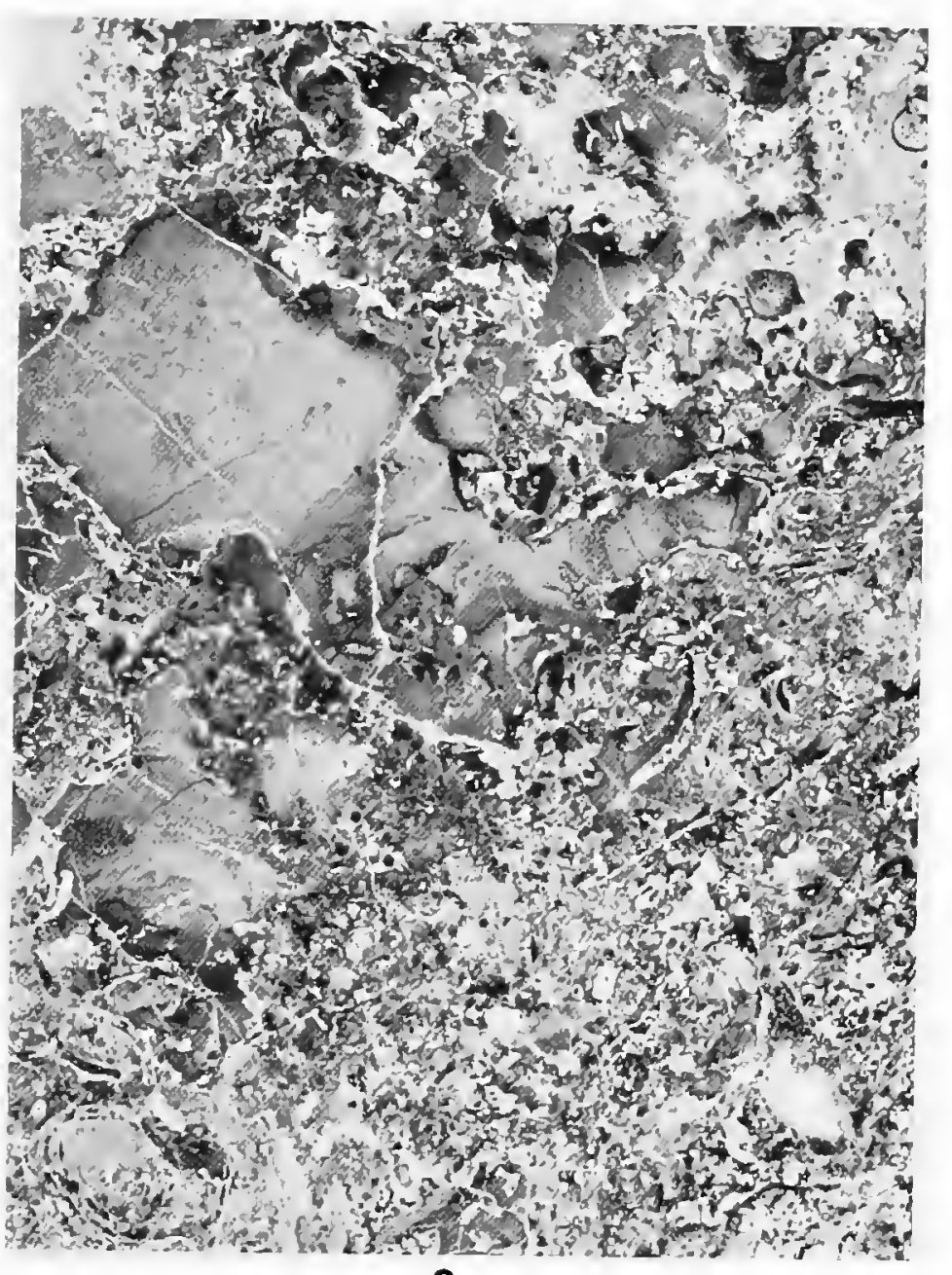

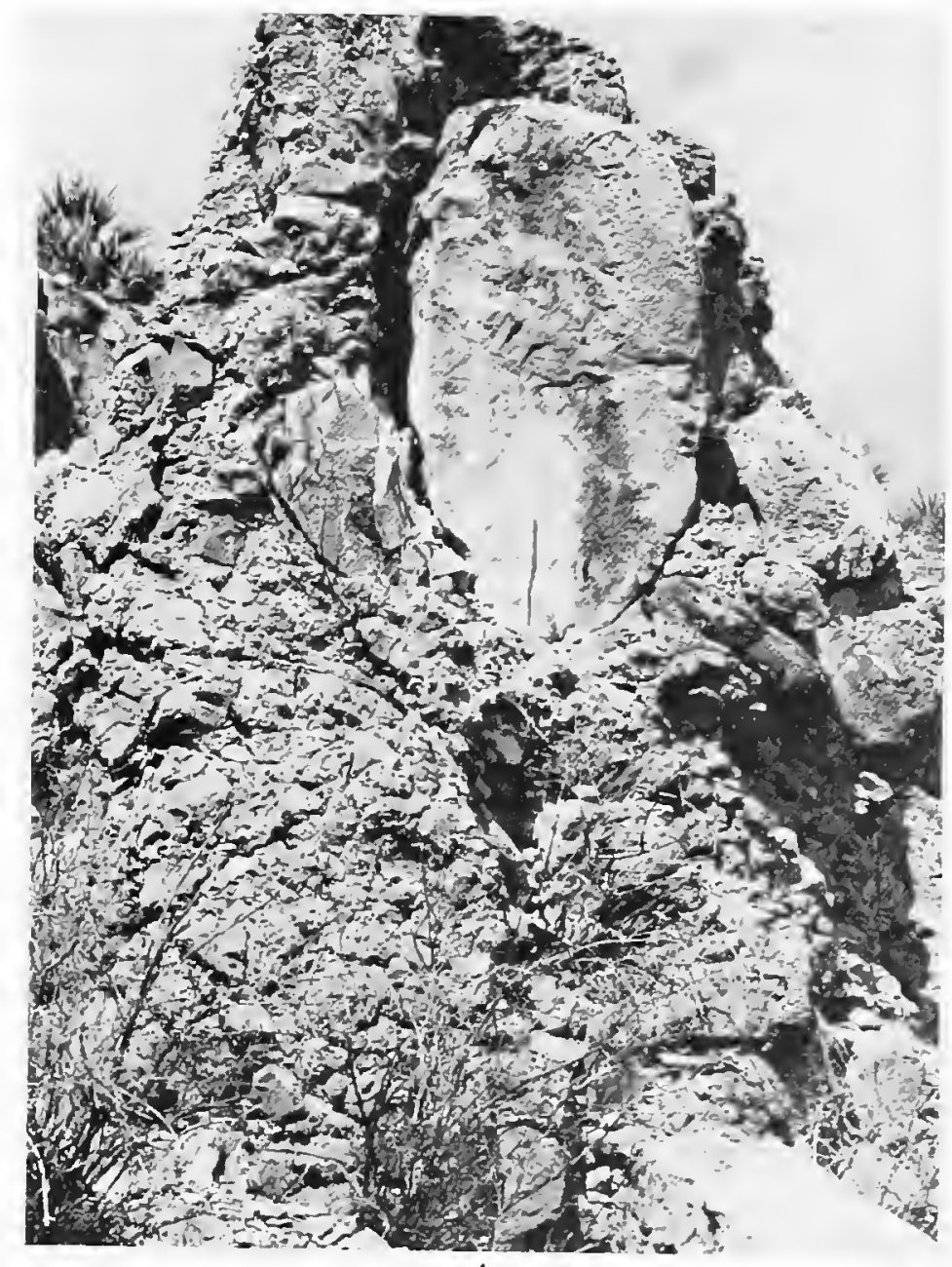


PLATE 12

1. Gigantic crinoid stems with a diameter of more than 2 inches $(60 \mathrm{~mm})$ in the Sullivan l'eak Member (USNM 707b), in the small canyon on the south side of hill 4920. (Altuda quadrangle.)

2. In the foreground, massive and biohermal beds of the basal Lenox Hills Formation [USNM 715b] (Neal Ranch of Ross (1963:23, 24); in the background, the lower dark ledge is Lenox Hills conglomerate and the capping leclge on the right is Decie Ranch Member of the Skinner Ranch Formation; Lenox Hills shale lies below the Decie Ranch Member. Beds of the Lenox Hills conglomerate finger into the limestones of the foreground. View is toward the south end of the Lenox Hills. (Altuda quadrangle.)

3. Largest hill (5060) of the Wolf Camp Hills, seen in profile: The slope just under the top ledge is the Uddenites-bearing Shale Member (USNM 70le). (Hess Canyon quacirangle.)

4. Small-pebble conglomerate at the base of the Cathedral Mountain Formation, about 0.5 mile south of Old Word Ranch site. (Hess Canyon quadrangle.) 

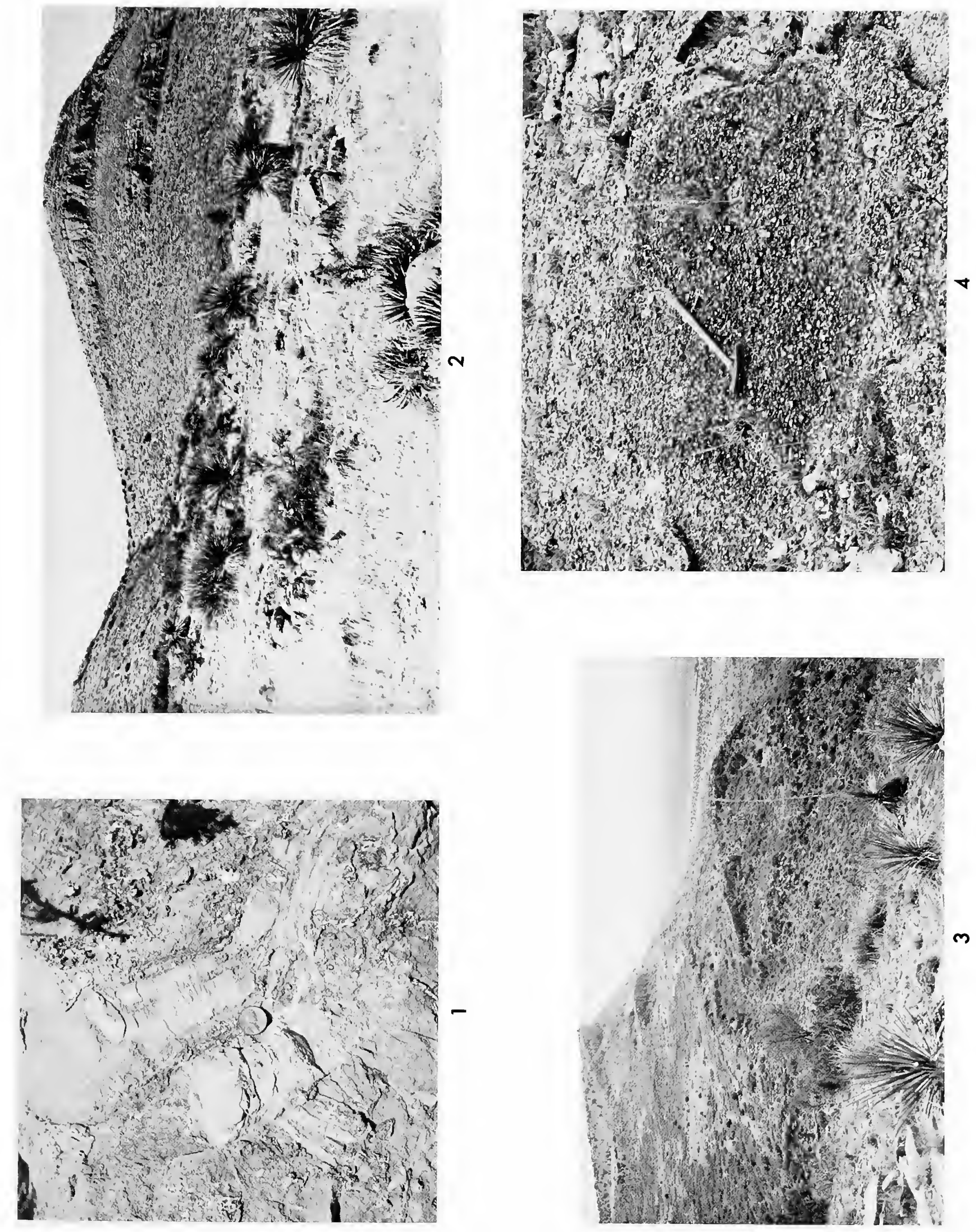


\section{PLATE 13}

1. Hill 4861, showing the nipple-like cap of Road Canyon Formation underlain by Cathedral Mountain shaly beds: The dark ledge forming an oblique line where the conical hill broadens is a conglomerate abounding in Perrinites (USNM 732u). (Monument Spring quadrangle: see Figure 2 below).

2. Close-up of the upper bed of the congloncrate in figure l above (hill 4861) with Perriniles (USNM 732u): Sce large pebble above hammer handle end. This conglomerate is thought to be a beach or shallow water deposit into which the large ammonites drifted after death. (Monument Spring quadrangle.)

3. Thin-bedded bituminous limestone in the lower part of the Road Canyon Formation, opposite (north of) the site of the Old Word Ranch house. (Hess Canyon quadrangle.)

4. East face of Dugout Mountain: Ledge at right is Lenox Hills conglomerate overlying the Gaptank Formation, which forms the lower slopes. The lowest leclge on the left is the Decic Ranch Member of the Skinner Ranch Formation overlying a 60 -foot bed of Lenox Hills shale that contains a limestone band abounding in ammonites (USNM 715). The highest part of the mountain on the left is capped by the Sullivan Peak Member of the Skinner Ranch Formation, overlying shaly beds of the Poplar Tank Member that rest on the Decie Ranch Member. 

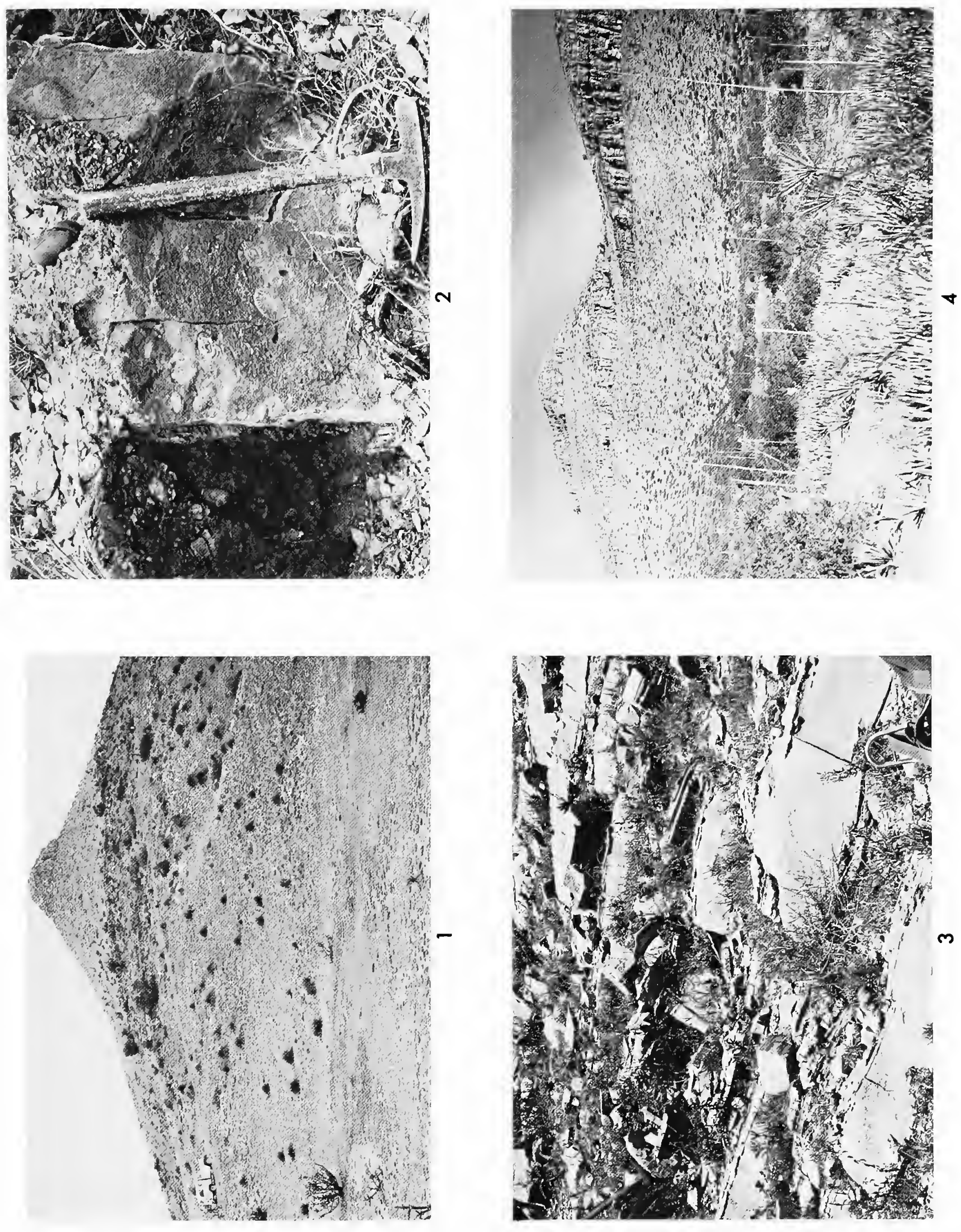


\section{PLATE 14}

1. Word Formation (Willis Ranch Member) at its type section in Road Canyon (USNM 724 u) about 1 mile up (west) the Canyon from its east mouth. (Hess Canyon quadrangle.)

2. Cherty, thick-bedded limestone of the Appel Ranch Member of the Word Formation, Appel Ranch. (Hess Canyon quadrangle.)

3. Sandstone stringers in Word Formation (Willis Ranch Member) in Gilliland Canyon, about 0.75 mile northwest of bench mark 4973. (Altuda quadrangle.)

4. West side of Gilliland Canyon at south end, showing lowest bench capped by the Willis Ranch Member of the Word Formation: At the extreme left this member (USNM $731 \mathrm{~m}$ ) extends as a continuous band, but to the west it is identified as discontinuous lenses. (Altuda quadrangle.) 


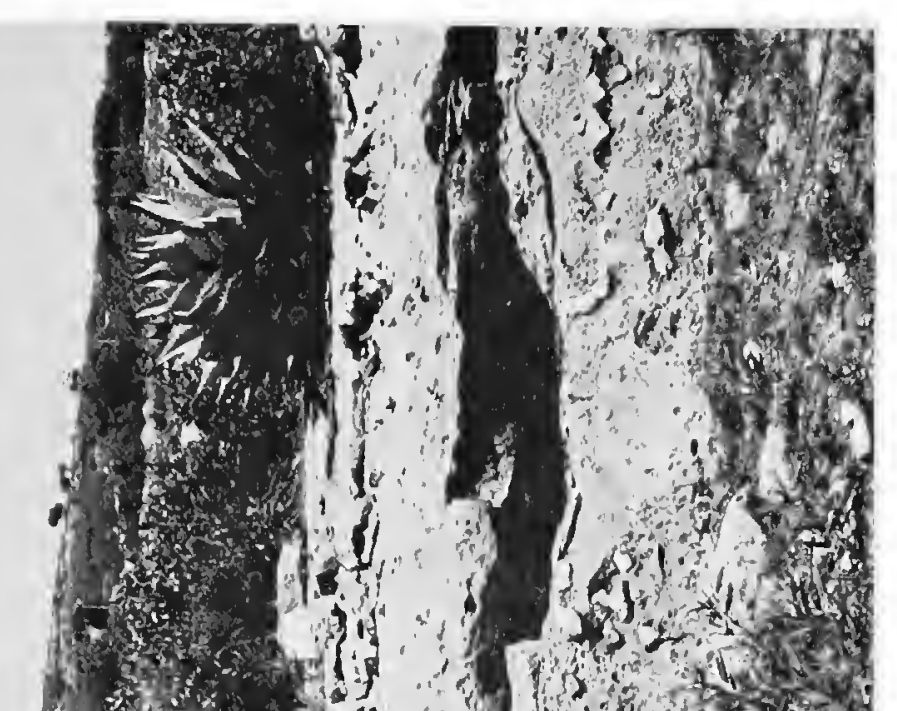

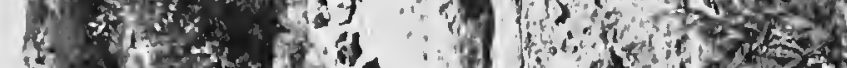

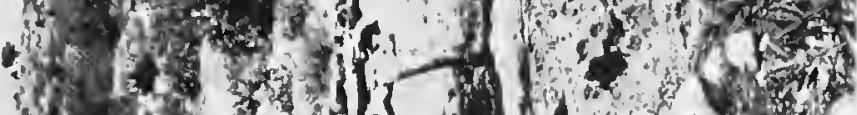

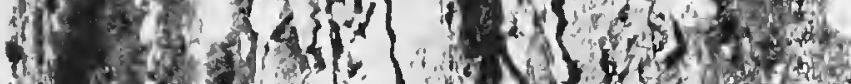

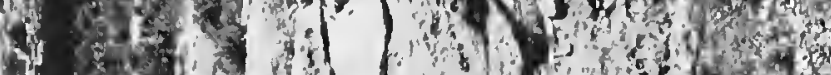

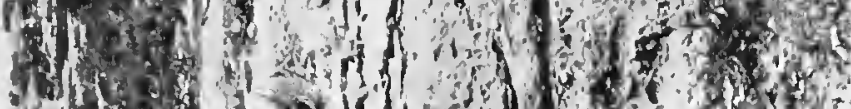

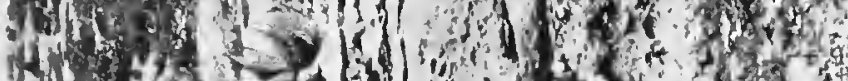

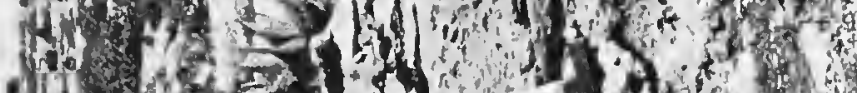

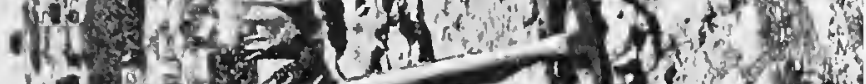
H.

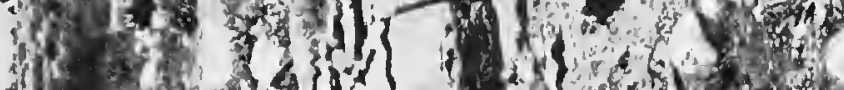

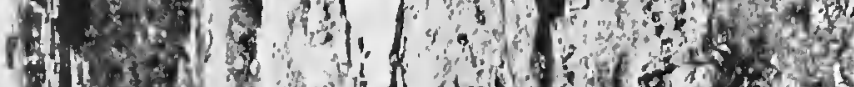

\section{r}

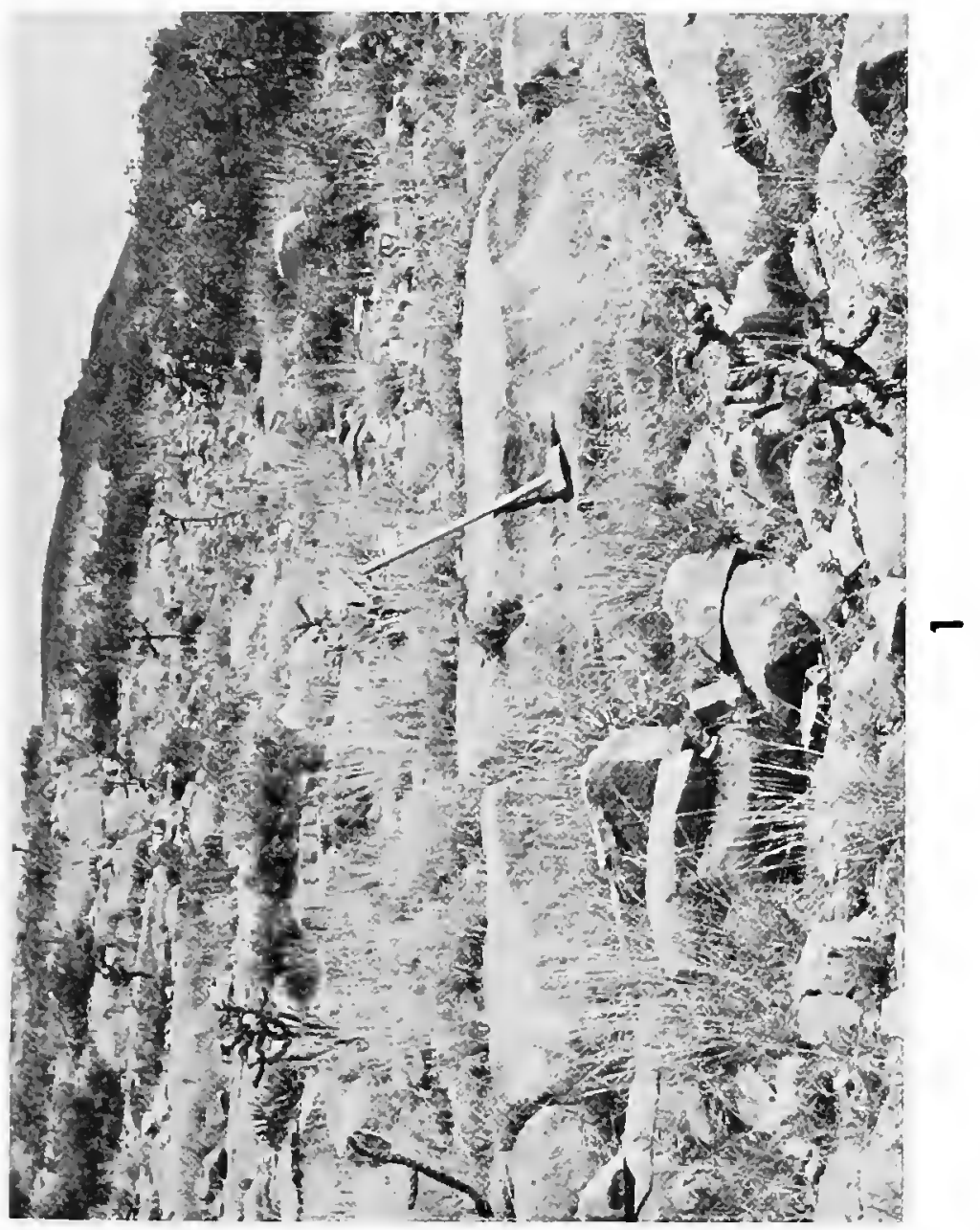

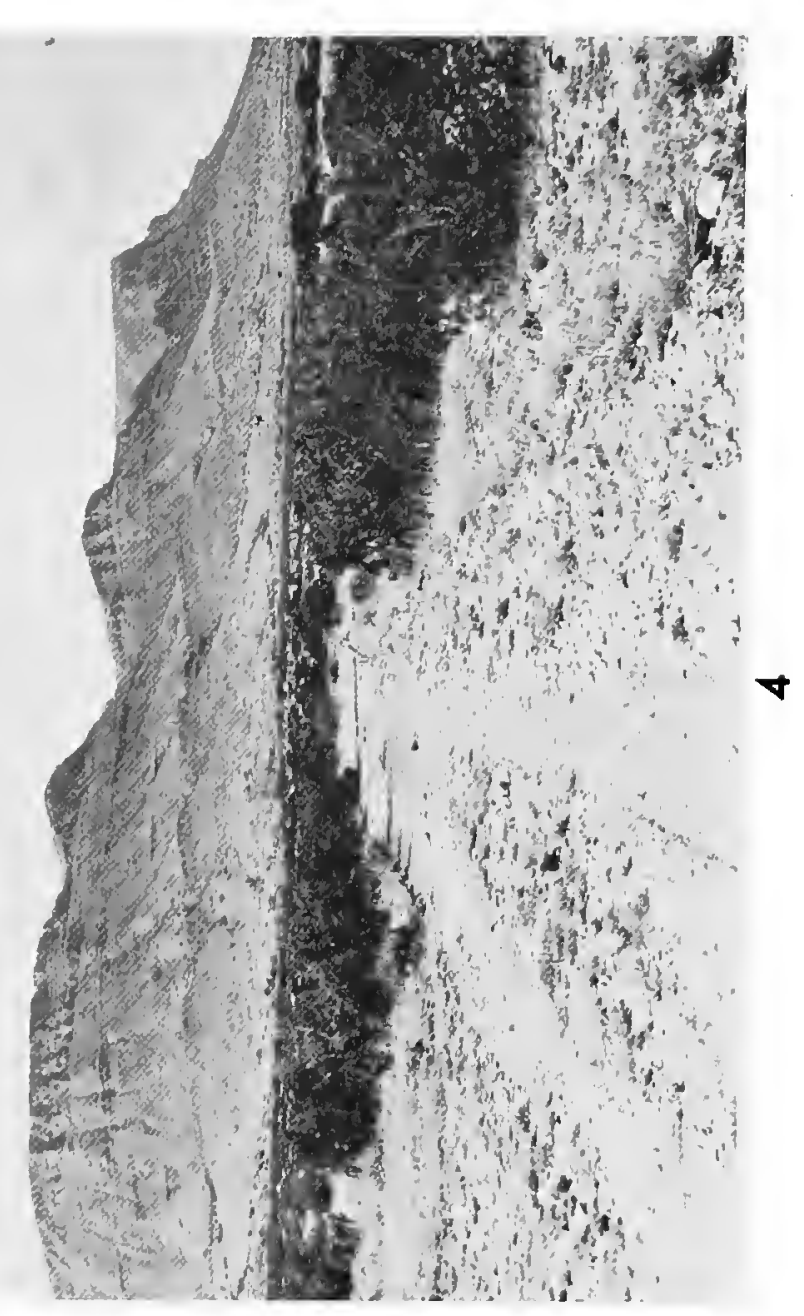

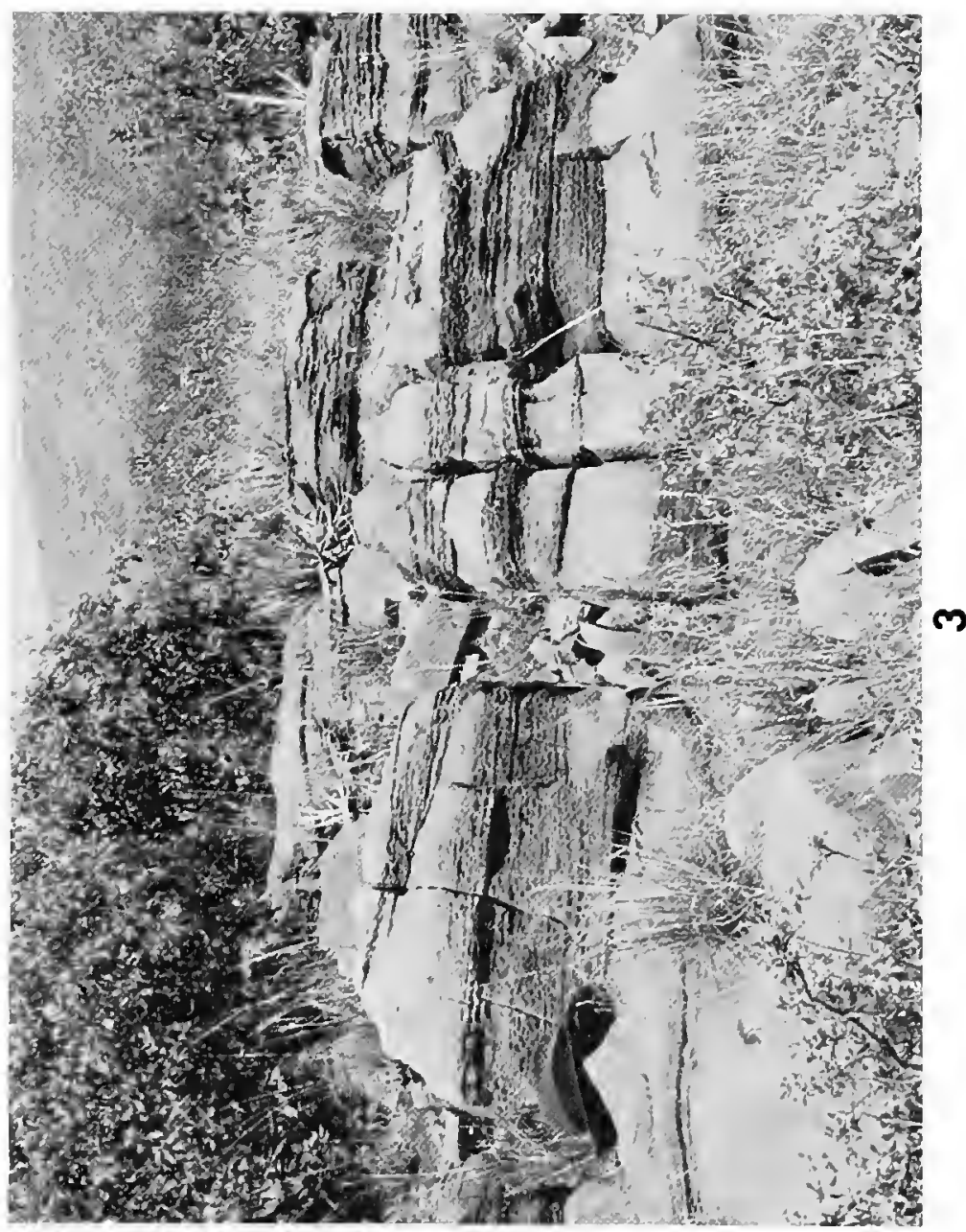




\section{PLATE 15}

1. Cherty limestone of the Appel Ranch Member of the Word Formation, in the north branch of Hess Canyon, about 2 miles northwest of Appel Ranch (USNM 731z). (Hess Canyon quadrangle.)

2. Road Canyon Formation in Hill 5453, 1.5 miles northwest of Hess Ranch, showing bioherms: The locality (USNM 726c) that produced large Perrinites is on the slope on the left sicle of the ravine. (Hess Ranch quadrangle.)

3. View looking northeast and taken about 2 miles west of the site of the Old Payne Ranch, showing low hills at the base of the Sierra del Norte in the background: The three hills on the right have different sections. The one nearest the edge of the picture is composed mainly of Cathedral Mountain Formation and is capped by Road Canyon Formation. The next low hill to the left is composed mostly of Road Canyon Formation, while the large hill with a long, flat dip slope is composed of Word Formation capped by a 40 -foot sandstone; it essentially marks the top of the Word at this place. The conical knob at the extreme left is hill 486I (USNM 732u), which is Cathedral Mountain for the most part but capped by biohermal Road Canyon Formation. This is the locality that produced many Perrinites from a conspicuous conglomerate in the Cathedral Mountain Formation.

4. Sullivan Peak in the background capped by Capitan dolomite and with a limestone lens of Willis Ranch Member of the Word Formation in the foreground (USNM 73lu): This is one of the discontinuous lenses mentioned in the legend to Plate 14: figure 4. (Altuda quadrangle.) 

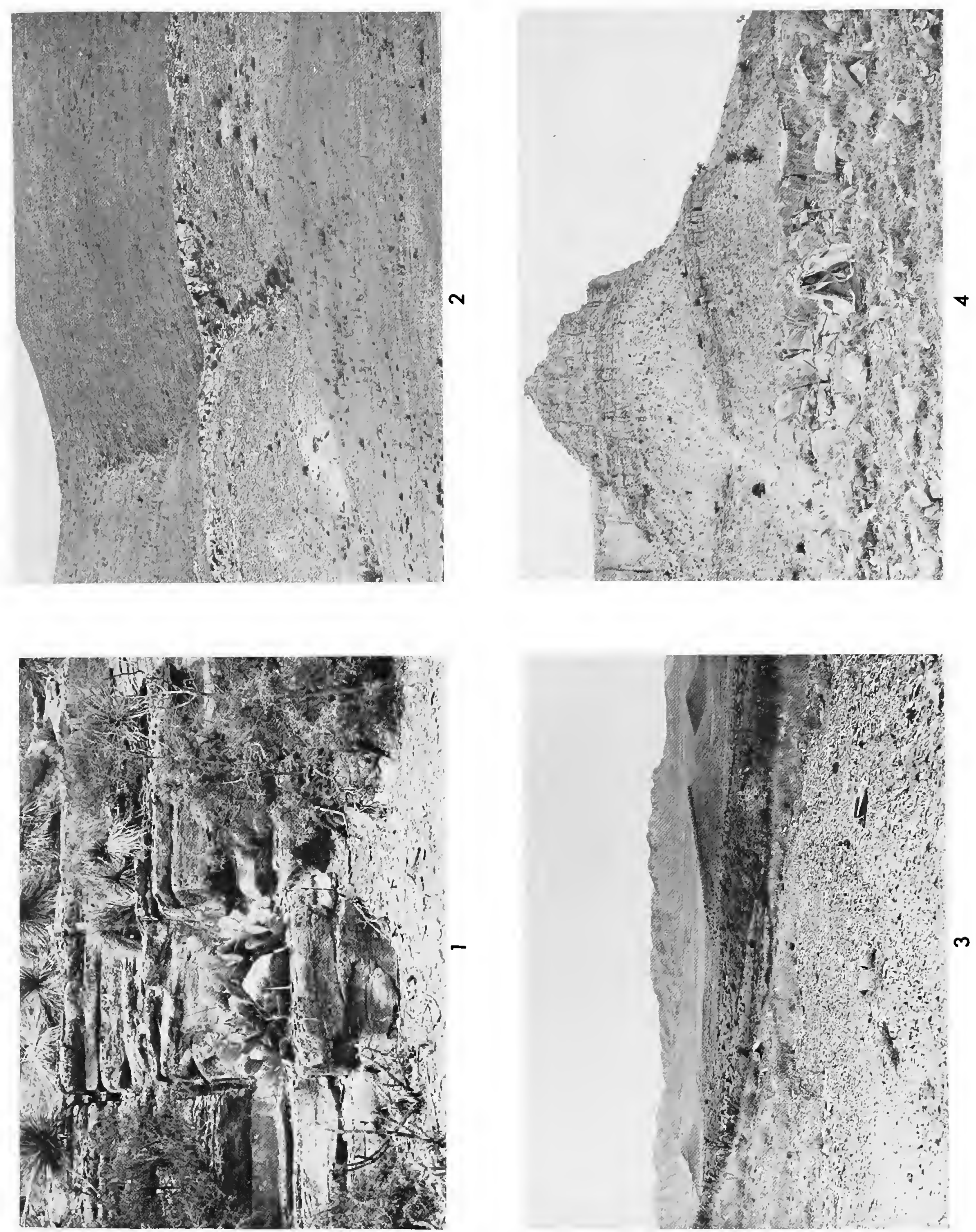


\section{PLATE 16}

1. Bioherm in the Gaptank Formation, 1.5 miles south of the Arnold Ranch (USNM 700g), containing the earliest species of Scacchinella and Limbella. (Monument Spring quadrangle.)

2. Small bioherm in the Sullivan Peak Member of the Skinner Ranch Formation in hill 4801 at the south end of the Lenox Hills. (Monument Spring quadrangle.)

3. Small bioherm in the Neal Ranch Formation in bed 12 of P. B. King, containing many Eolyttonia (USNM 70lc), Wolf Camp Hills. (Hess Canyon quadrangle.)

4. Large bioherm with a face of 80 feet vertical in the Road Canyon Formation on the nose of hill 5779, 2.4 miles north of Skimner (Iron Mountain) Ranch (USNM 724j). (East edge of Altuda quadrangle.) 

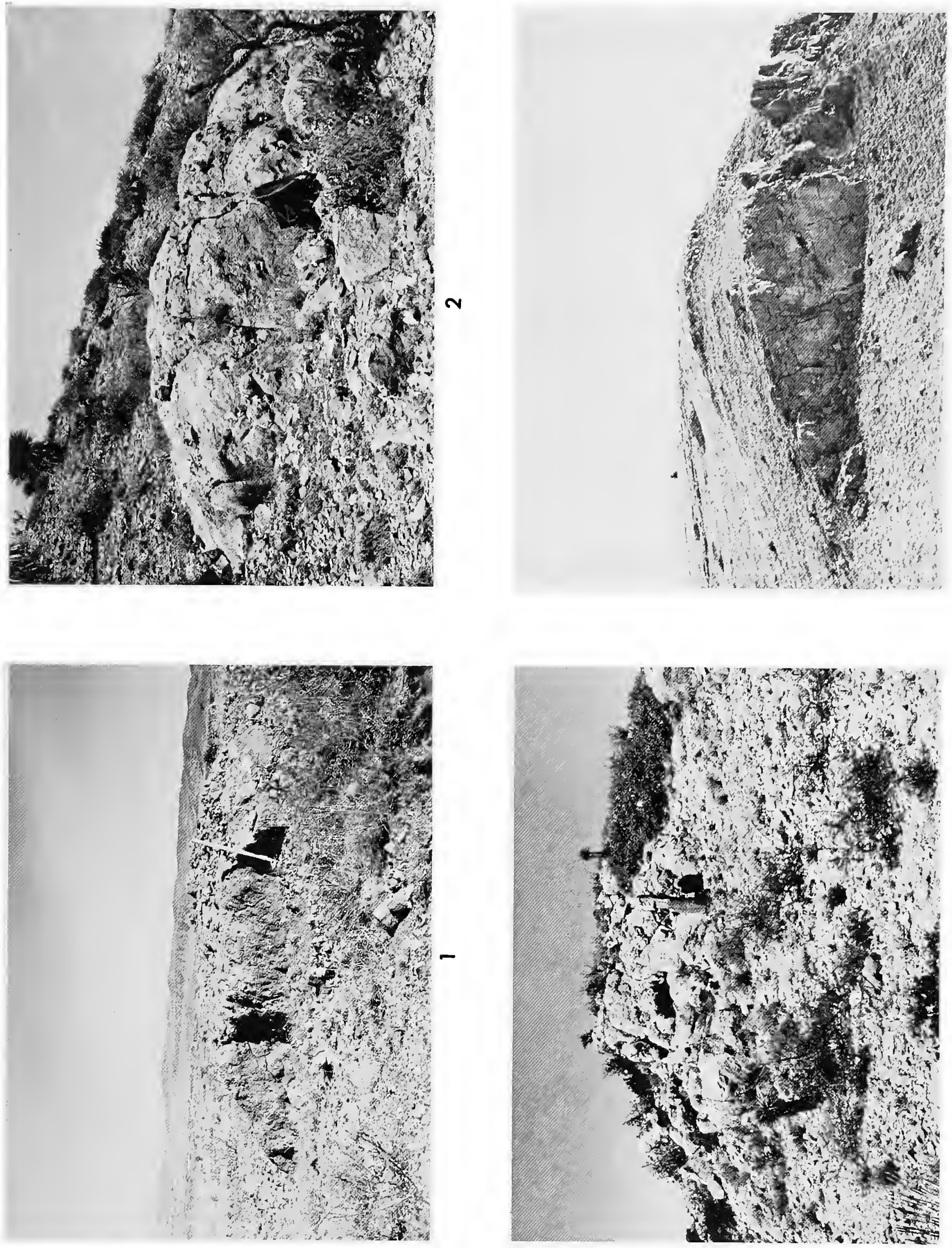


\section{PLATE 17}

1. Bioherm replete with Hercosia delicata, new species (USNM 7260), near top of Cathedral Mountain Formation, 1 mile southwest of the site of Old Word Ranch. (Hess Canyon quadrangle.)

2. Massive bioherms at the basc of the Road Canyon Formation in the east sicle of the spur extending south from Sullivan Peak (USNM 707e): Overlying the bioherms may be seen the thin-bedded limestone of the main mass of the Road Canyon Formation. (Altuda quadrangle.)

3. Large bioherm in the Road Canyon Formation with lower part on right crowded with the reef-forming oldhaminid genus Coscinophora (USNM 72lq), 1.8 miles west-northwest of the Hess Ranch house. (Hess Canyon quadrangle.)

4. Closeup view of the base of the preceding bioherm, showing abundant Coscinophora. 

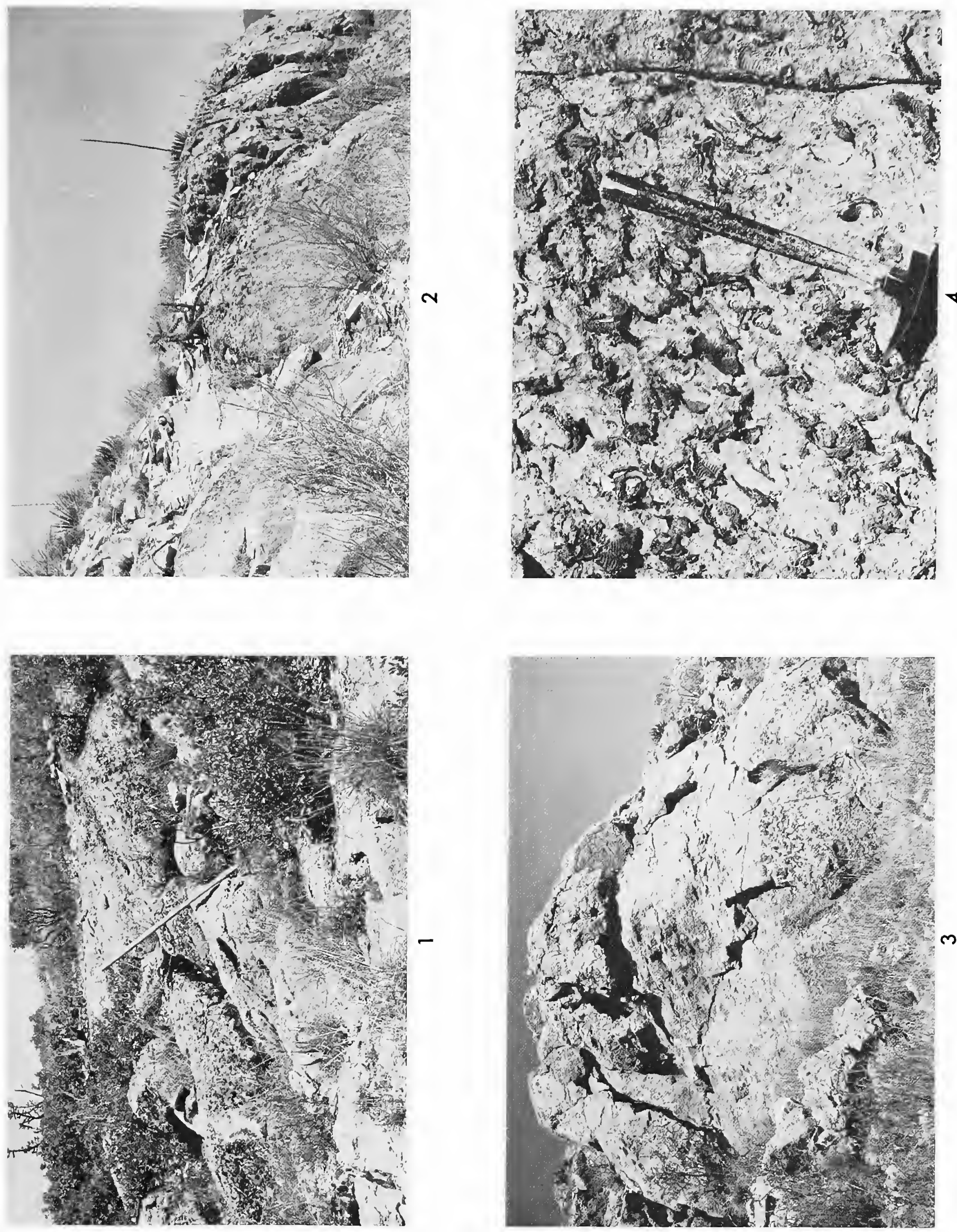


\section{PLATE 18}

1. Hill 4801 at the south end of the Lenox Hills, showing the prominent ledge formed by the Sullivan Peak Member, which contains large bioherms: The Cathedral Mountain Formation forms the conical mound. The Poplar Tank Member forms all the slope from the base of the hill to the Sullivan Peak Member. The Decie Ranch Member occurs near the base of the hill. Visible in the Sullivan Peak Member are two large bioherms separated by a boulder conglomerate. The Sullivan Peak Member to the left of the bioherm at the center is mostly boulder conglomerate. At the extreme right, the Sullivan Peak Member is displaced by a small fault. (Monument Spring quadrangle.)

2. Bryozoan masses in the lower middle part of the bioherm and above the crinoidal conglomerate at the base, hill 4801, Lenox Hills. (Monument Spring quadrangle.)

3. The larger bioherm of figure 1 in closer detail, showing its massive character and a portion overlying the conglomerate bed to its left.

4. Detail at the base of the same large bioherm, showing the conglomerate made up of gigantic crinoid stems in its lower part. These bioherms commonly start on a conglomeratic layer or mound before becoming bound by bryozoans, algae, and other reef organisms. 

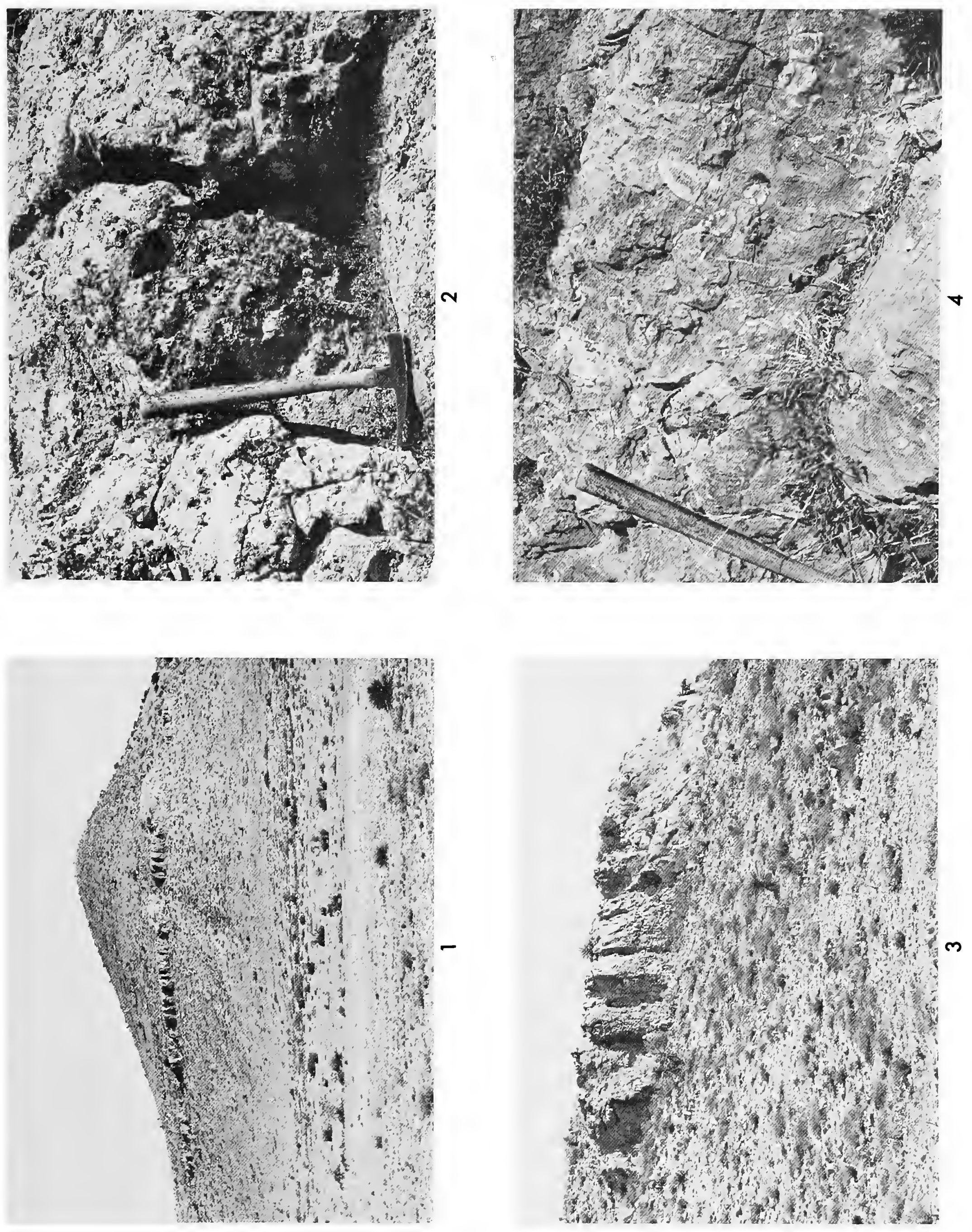


\section{PLATE 19}

1. Three bioherms, containing Scacchinella, in lower part of the Skinner Ranch Formation at its type section: West end of Leonard Mountain is about 1 mile north of Skinner (= Iron Mountain) Ranch. (East side of Altuda quadrangle.)

2. Bioherm, containing numerous individuals of the large cylindrical sponge Heliospongia (USNM 702d), Taylor Ranch Member of the Hess Formation, 3.8 miles northeast of Hess Ranch house. (Hess Canyon quadrangle; photo by W. T. Allen.)

3. Slope of hill 4752, containing ammonite beds (USNM 701r), capped by limestone correlated with upper part of Uddenites-bearing Shale Member, Montgomery (Conoly Brooks) Ranch. (Hess Canyon quadrangle.)

4. Closeup of a bioherm showing great abundance of Scacchinella, north base of Hess Ranch Horst (USNM 720e). (Hess Canyon quadrangle.) 

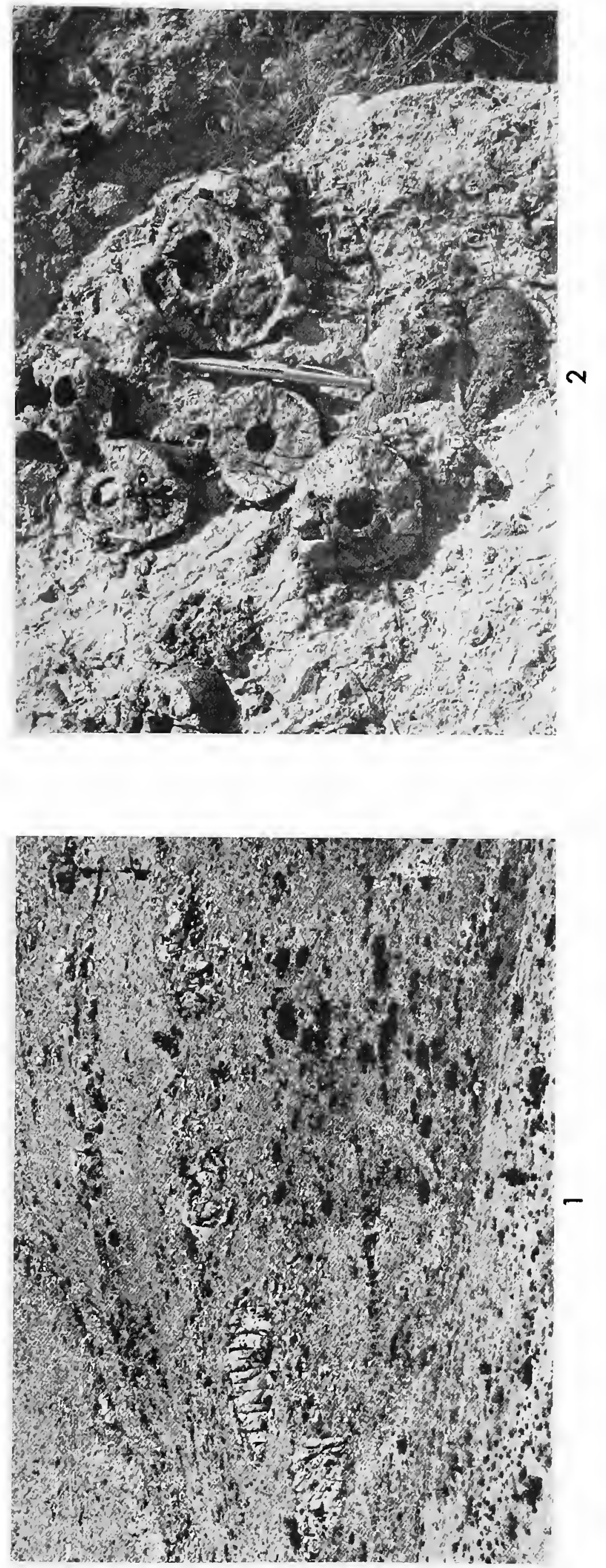

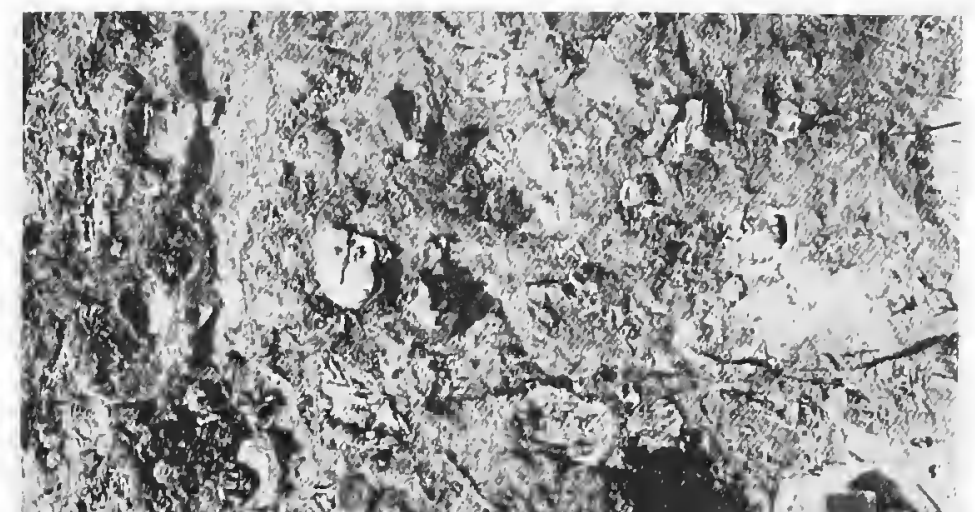

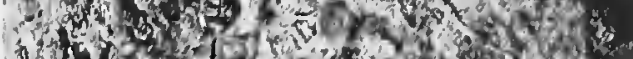

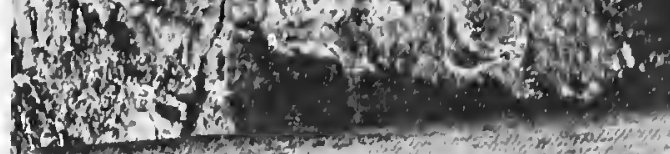

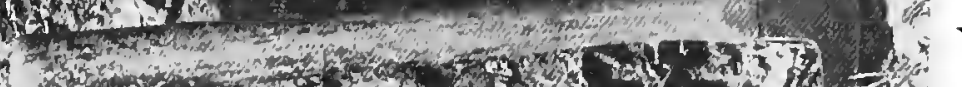

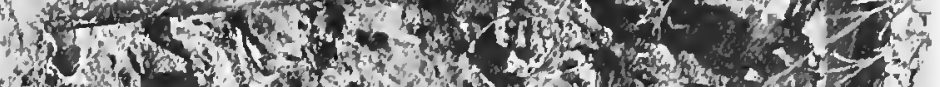
4.

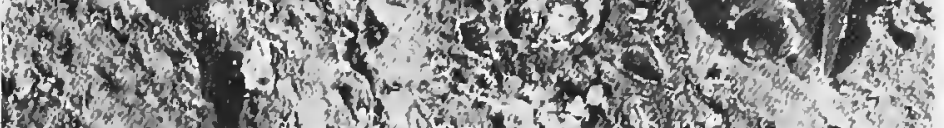

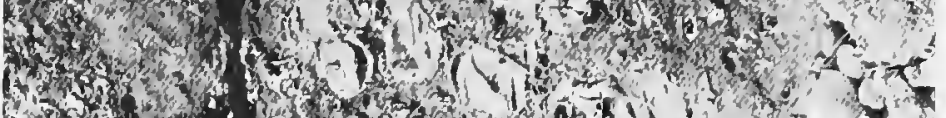

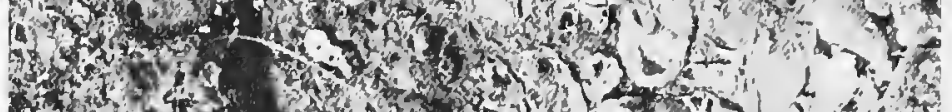

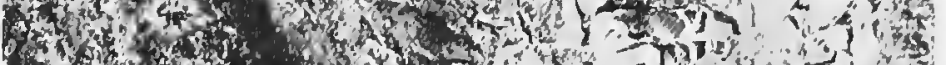

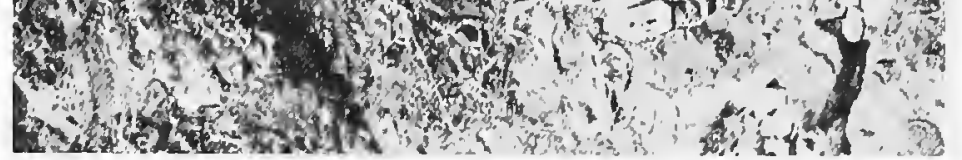

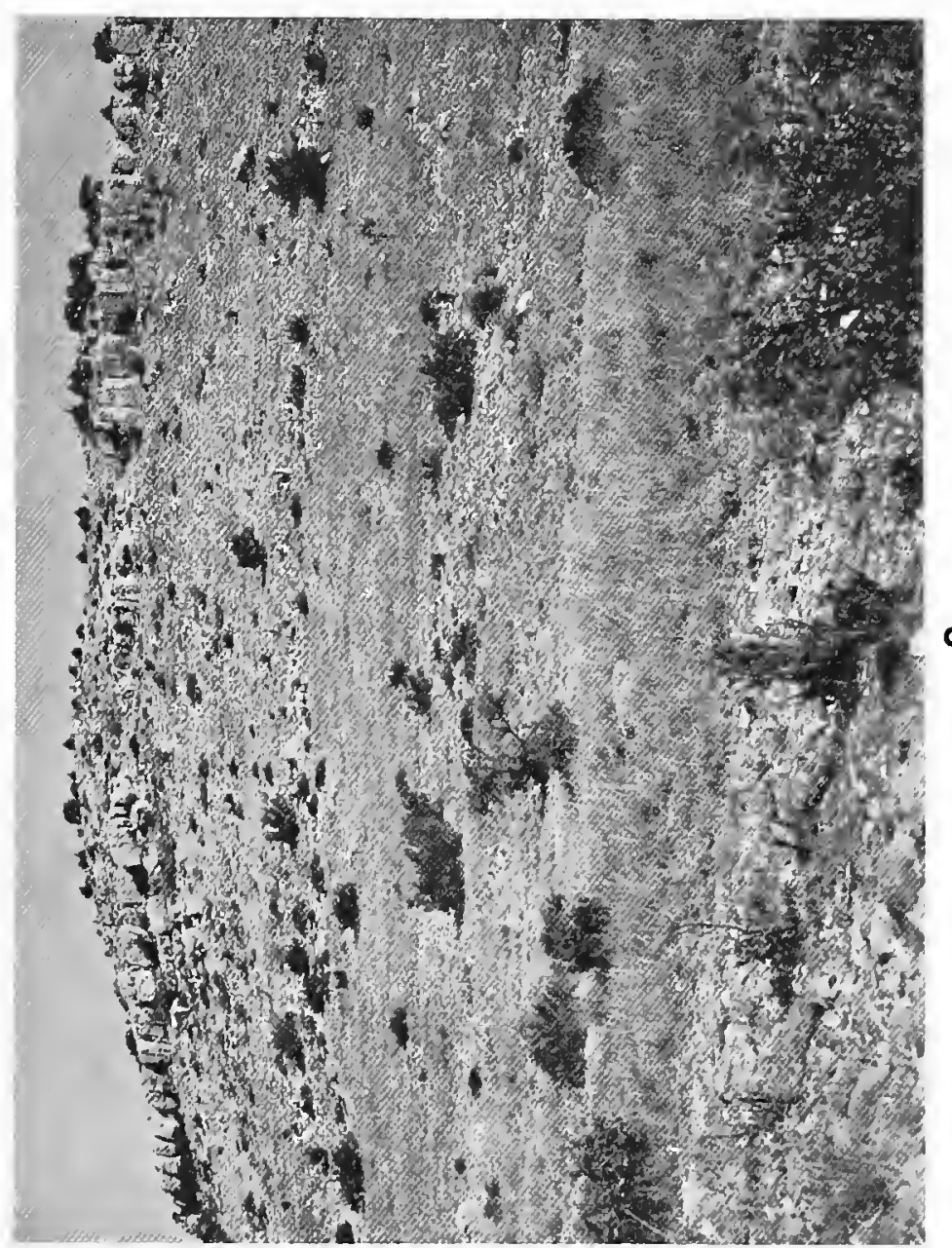




\section{PLATE 20}

1. Low knob of hill at USNM 702c with biohermal beds on the crest in the Road Canyon Formation: Another small bioherm appears on the right side of the picture in the Cathedral Mountain Formation, about 4 miles, by road, northeast of Hess Ranch house. (Hess Canyon quadrangle.)

2. Small biohermal mass in the Lenox Hills Formation on Leonard Mountain at elevation of 5425 feet, containing Scacchinella, Tropidelasma, and Parenteletes (USNM 705k). (Hess Canyon quadrangle.)

3. Biohermal limestone (USNM 702al), containing a mass of Collemataria, 0.5 mile east of Split Tank. (Hess Canyon quadrangle.)

4. On the right, light gray biohermal limestone and, on the left, siliceous shaly rock of the Cathedral Mountain Formation: Cooper stands near the contact of the two, which lie at the same level, 1 mile southwest of the site of the Old Word Ranch. (Hess Canyon quadrangle.) 

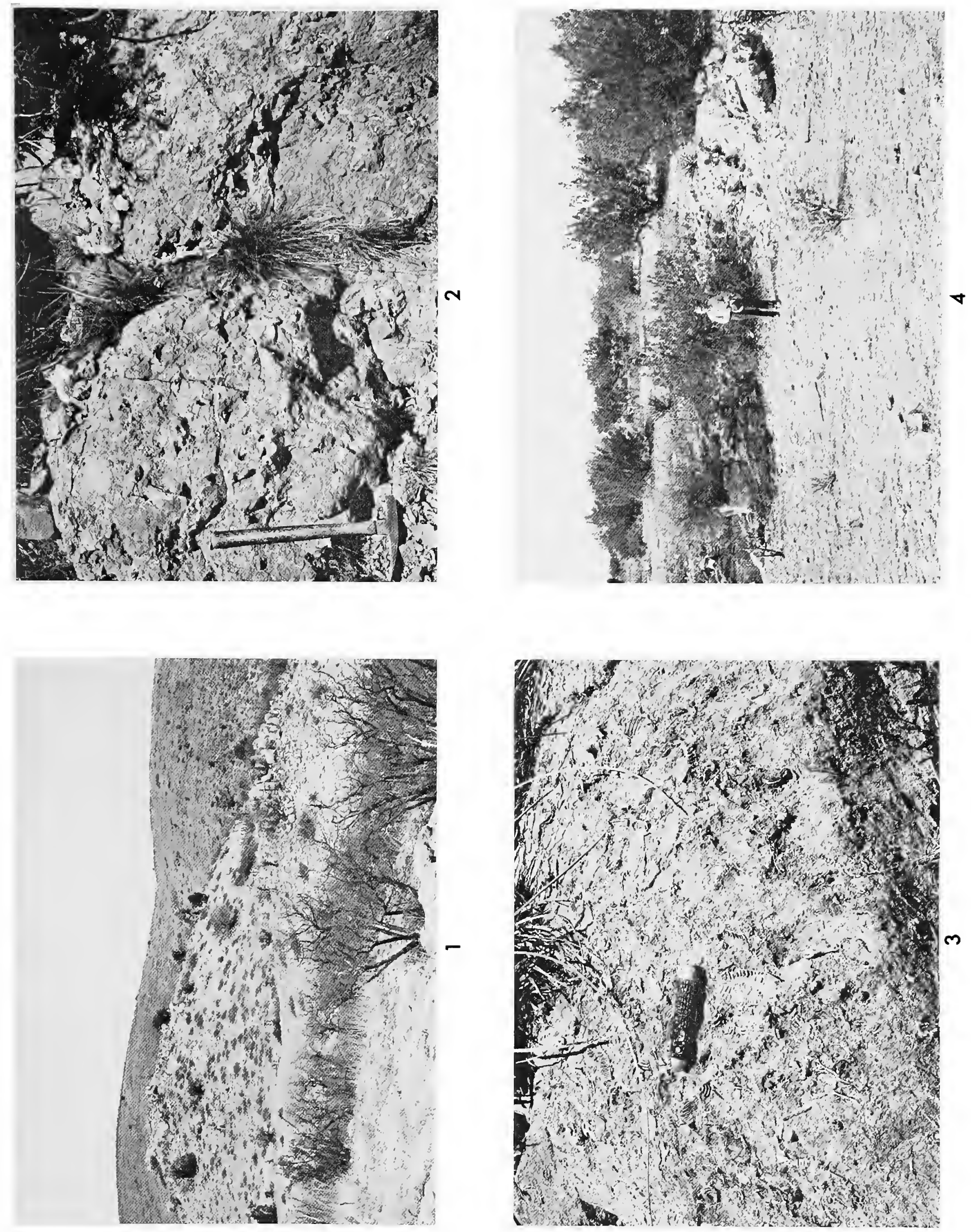


\section{PLATE 21}

1. Detail of the surface of a bioherm at USNM 703a in the lower part of the Road Canyon Formation: Photograph shows a section of the brachiopod Edriosteges multispinosus MuirWood and Cooper partially filled with matrix but with mineralized cavity above. The line of junction is at the regional dip as shown by the Brunton Compass. Such geopctal structure indicates that the bioherm is in place and undisturbed. (Hess Canyon quadranglc.)

2. Bioherm near the contact of the Poplar Tank and Sullivan Peak Members, USNM 708e, in hill 5300. (Altuda quadrangle.)

3. Profile of the Lenox Hills from the southwest, showing the regional dip of about $10^{\circ}$ : The conical knob on the skyline near the center is hill 5300 in the upper Cathedral Mountain Formation. (Monument Spring and Altuda quadrangles.)

4. Dugout Mountain from the northcast, showing the long dip slope: The highest point on the right is held up by the Sullivan Peak Member of the Skinner Ranch Formation. The small knob on the right is hill 4811, which contains limestonc of the Dugout Mountain Member of the Skinner Ranch Formation. (Monument Spring quadrangle.)

5. Hess Ranch Horst from the south: On the extreme lower left, just above the road leading to Old Word Ranch site, is the igneous plug that extends up the ravine to its end. The face of the hill on the left side of the ravine is Lenox Hills Formation with beds of limestone conglomerate overlying shale of the Neal Ranch Formation, which forms much of the ravine. The conical hill on the right side of the ravine is upper Skinner Ranch Member in fault contact with the Neal Ranch Shale. The Skinner Ranch is overlain by lower Cathedral Mountain Formation with Institella, and this extends across the road on the right, about 3 miles northeast of Hess Ranch. (Hess Canyon quadrangle.) 

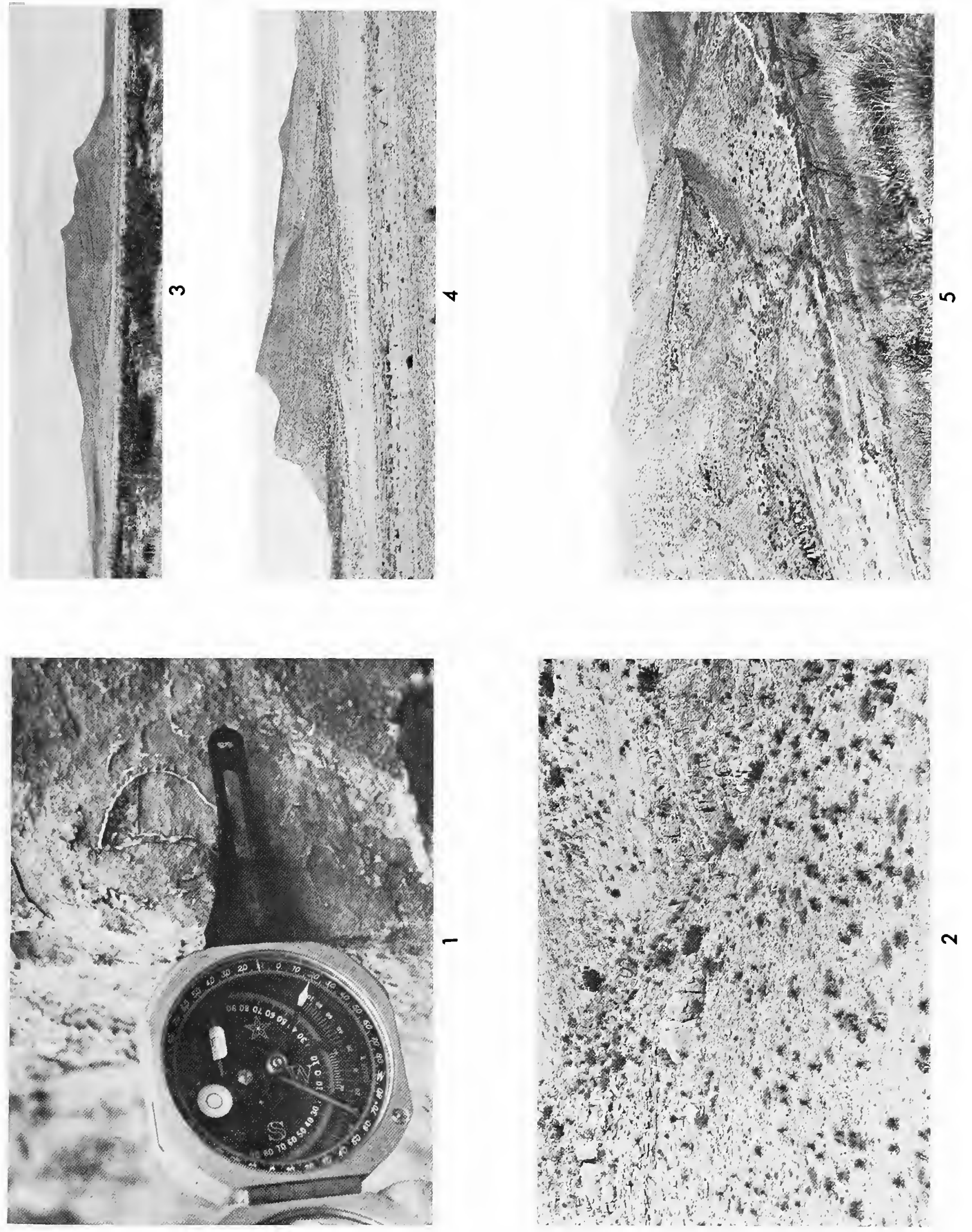


\section{PLATE 22}

1. Bold face of El Capitan, composed of the Capitan Limestone Formation resting on Delaware Mountain Sandstone. (Guadalupe Peak quadrangle.)

2. Small conical hill with elevation of $5130 \mathrm{feet}$, about 1 mile south of Pinyon Tank, capped by Bell Canyon Formation (Hegler Member) and overlying fine-grained yellowish sandstone: USNM 731 is on the nose of the hill facing the viewer. (Guadalupe Peak quadrangle.)

3. Capping ledge of Bell Canyon Formation (Lamar Member), forming a small butte: This is the site of USNM 728p, and the fossilferous ledge is about 12 feet above the base of the limestone. The view is about 0.25 mile south of the junction of $D$-Ranch headquarters road and U. S. Highway 62-180, 3.25 miles northeast of Hegler (=Ligon) Ranch, Culberson County.

4. Biohermal limestone (USNM 728-1) in the Cibolo Formation (Brecciated Zone of Udden), on the south bank of Sierra Alta Creek, about 1 mile east of Cibolo Ranch house, Presidio County. (Chinati Peak quadrangle.) 

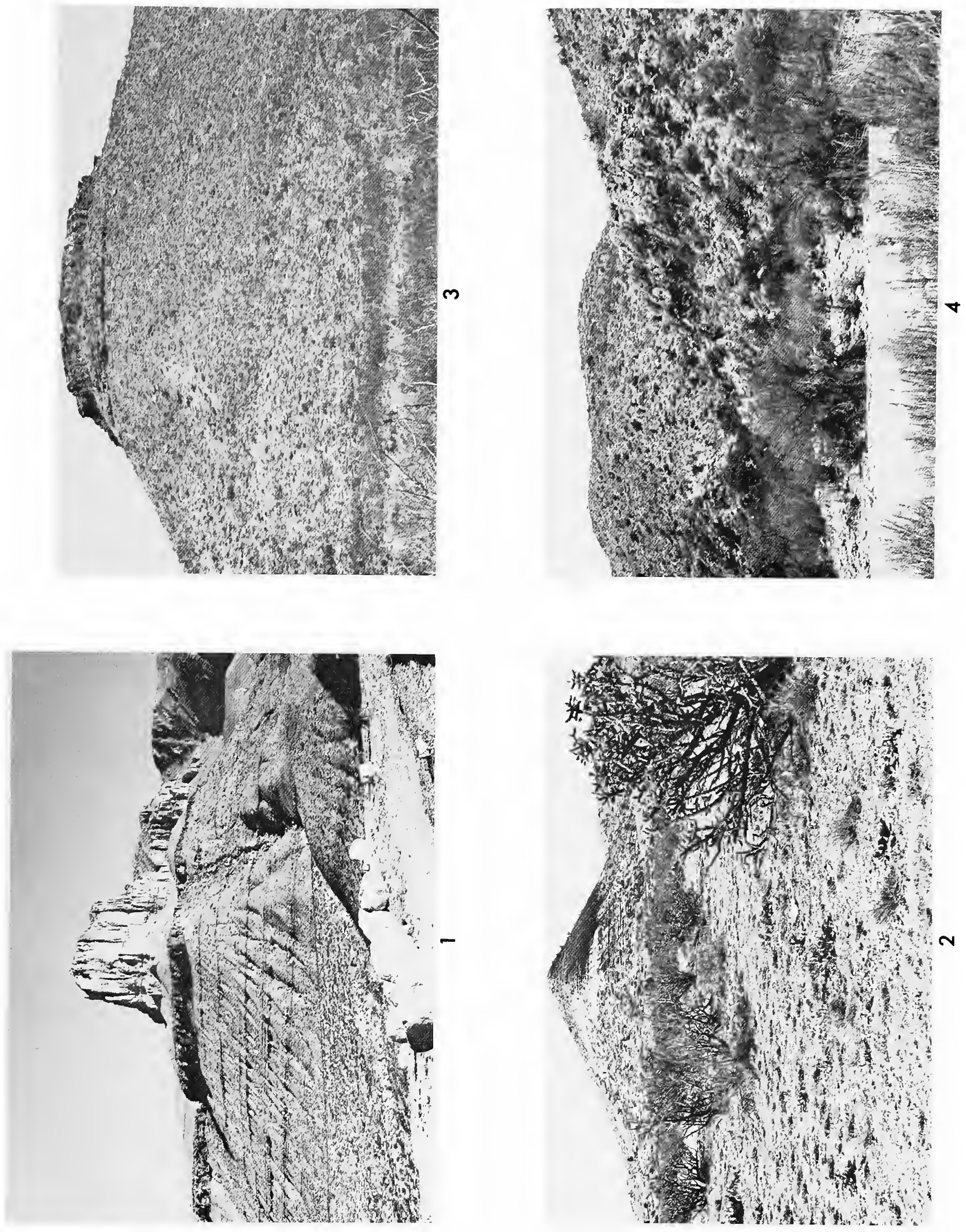


\section{PLATE 23}

1. View toward northeast up Sierra Alta Creek, showing an igneous plug on the extreme left and low hills capped by massive limestones of the Brecciated Zone (of Udden), in the Cibolo Formation: These consist of biohermal limestone masses with Scacchinella and interbiohermal conglomerates. They rest on shale and thin limestone of the Cibolo Formation (Transition Zone of Udden), about 1.5 miles northeast of Cibolo Ranch house, Presidio County. (Chinati Peak quadrangle.)

2. Loose block of massive biohermal or reef limestone, containing abundant cross-sections of Scacchinella (calcite filled and white) in the bed of Sierra Alta Creek, detached from the bioherms of the Cibolo (Brecciated Zone) masses, about 1 mile northeast of Cibolo Ranch house, Presidio County. (Chinati Peak quadrangle.)

3. Bluff on the south side of Sierra Alta Creek about 1 mile northeast of Cibolo Ranch house, Presidio County, showing thick mass of Udden's "Breccia Zone" with bioherms of Scacchinella and interbiohermal conglomerate overlying Udclen's "Transition Zone" with large scachinella but containing Wolfcampian fusulinids, (Chinati Peak quadrangle.)

4. Rader Ridge just west of Hegler (= Ligon) Ranch, with massive reefy Capitan Limestone Formation in the background and the Rader Ridge in the foreground composed of Bell Canyon Formation, which consists of Rader and lower members. (Guadalupe Peak quadrangle; USNM 725f.) 

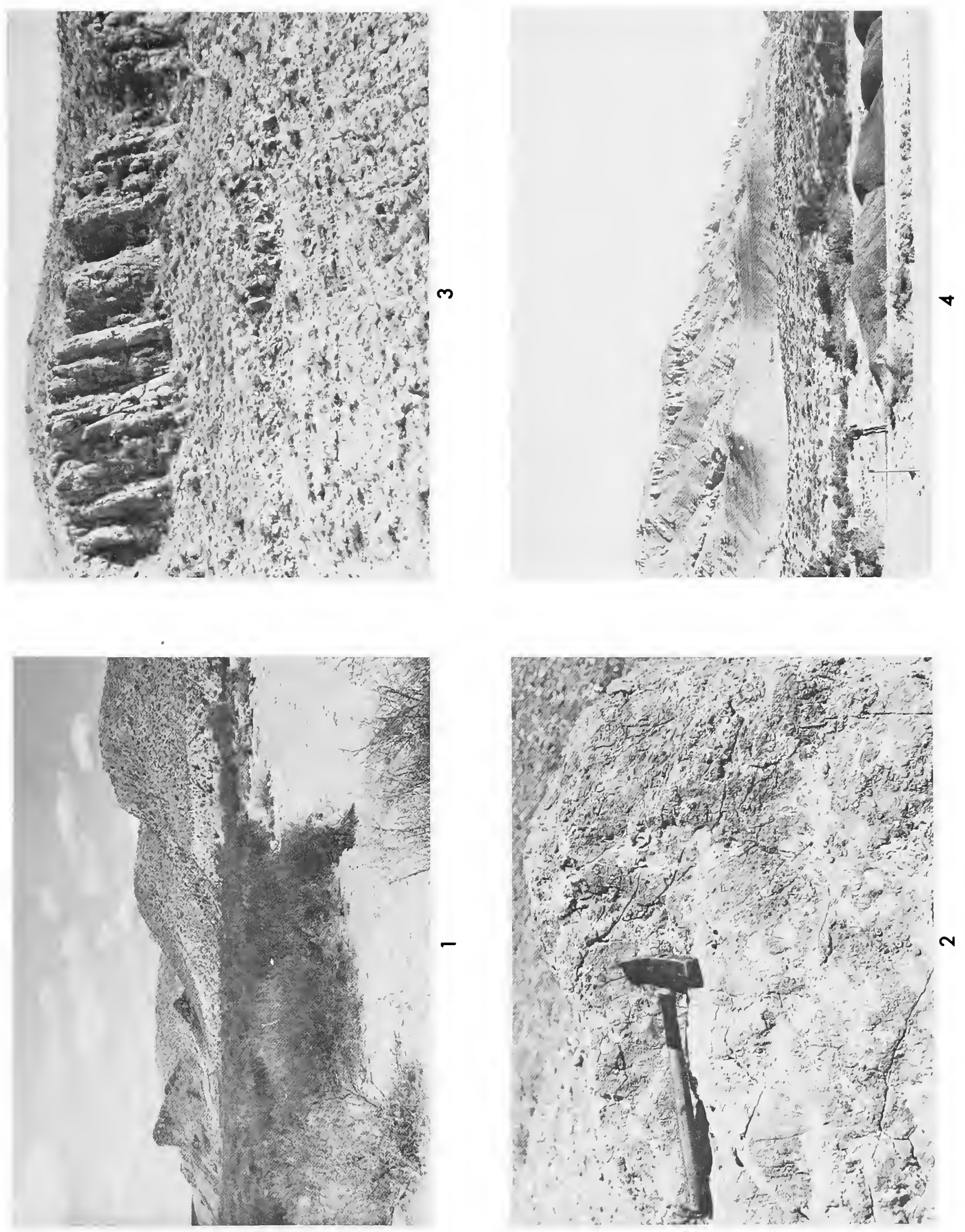

。 



\section{Publication in Smithsonian Contributions to Paleobiology}

Manuscripts for serial publications are accepted by the Smithsonian Institution Press, subject to substantive review, only through departments of the various Smithsonian museums. Non-Smithsonian authors should address inquiries to the appropriate department. If submission is invited, the following format requirements of the Press will govern the preparation of copy.

Copy must be typewritten, double-spaced, on one side of standard white bond paper, with $11 / 2$ " top and left margin, submitted in ribbon copy with a carbon or duplicate, and accompanied by the original artwork. Duplicate copies of all material, including illustrations, should be retained by the author. There may be several paragraphs to a page, but each page should begin with a new paragraph. Number consecutively all pages, including title page, abstract, text, literature cited, legends, and tables. The minimum length is 30 pages, including typescript and illustrations.

The title should be complete and clear for easy indexing by abstracting services. Taxonomic titles will carry a final line indicating the higher categories to which the taxon is referable: "(Ammonoidea: Goniatitidae)." Include an abstract as an introductory part of the text. Identify the author on the first page of text with an unnumbered footnote that includes his professional mailing address. A table of contents is optional. An index, if required, may be supplied by the author when he returns page proof.

Two headings are used: (1) text heads (boldface in print) for major sections and chapters and (2) paragraph sideheads (caps and small caps in print) for subdivisions. Further headings may be worked out with the editor.

In taxonomic keys, number only the first item of each couplet; if there is only one couplet, omit the number. For easy reference, number also the taxa and their corresponding headings throughout the text; do not incorporate page references in the key.

In synonymy, use the short form (taxon, author, date:page) with a full reference at the end of the paper under "Literature Cited." Begin each taxon at the left margin with subsequent lines indented about three spaces. Within an entry, use a period-dash (.-) to separate each reference. Enclose with square brackets any annotation in, or at the end of, the entry. For references within the text, use the author-date system: "(Jones, 1910)" and "Jones (1910)." If the reference is expanded, abbreviate the data: "Jones (1910:122, pl. 20: fig. 1)."

Simple tabulations in the text (e.g., columns of data) may carry headings or not, but they should not contain rules. Formal tables must be submitted as pages separate from the text, and each table, no matter how large, should be pasted up as a single sheet of copy.

Use the metric system instead of, or in addition to, the English system.

Illustrations (line drawings, maps, photographs, shaded drawings) can be intermixed throughout the printed text. They will be termed Figures and should be numbered consecutively; however, if a group of figures is treated as a single figure, the components should be indicated by lowercase italic letters on the illustration, in the legend, and in text references: "Figure 9b." If illustrations (usually tone photographs) are printed separately from the text as full pages on a different stock of paper, they will be termed Plates, and individual components should be lettered (Plate $9 b$ ) but may be numbered (Plate 9: figure 2). Never combine the numbering system of text illustrations with that of plate illustrations. Submit all legends on pages separate from the text and not attached to the artwork. An instruction booklet for the preparation of illustrations is available from the Press on request.

In the bibliography (usually called "Literature Cited"), spell out book, journal, and article titles, using initial caps with all words except minor terms such as "and, of, the." For capitalization of titles in foreign languages, follow the national practice of each language. Underscore (for italics) book and journal titles. Use the colon-parentheses system for volume, number, and page citations: "10(2):5-9." Spell out such words as "figures," "plates," "pages."

For free copies of his own paper, a Smithsonian author should indicate his requirements on "Form 36" (submitted to the Press with the manuscript). A non-Smithsonian author will receive 50 free copies; order forms for quantities above this amount with instructions for payment will be supplied when page proof is forwarded. 
